TWW WWISRZZR JOONMAL
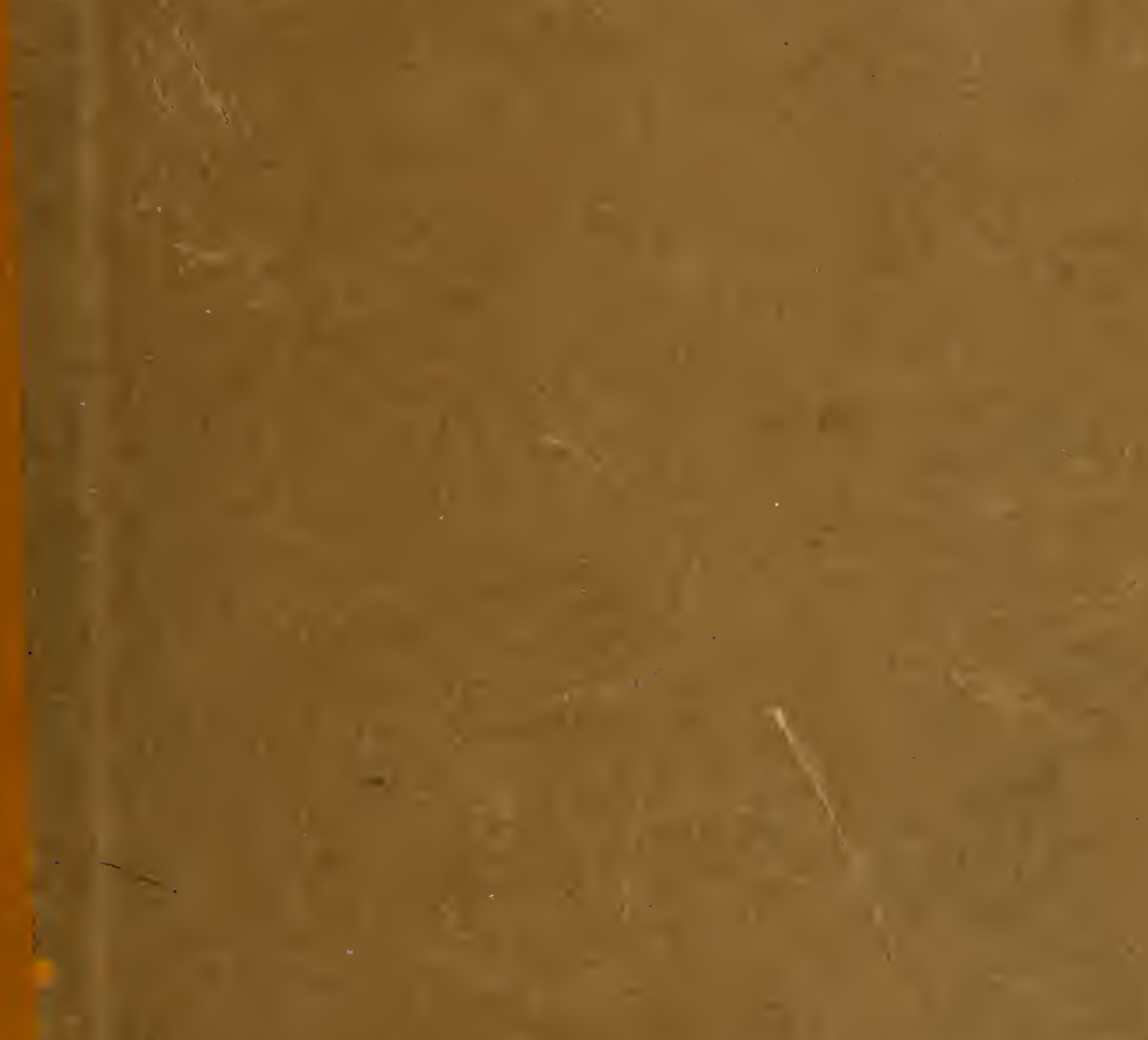

1

1.

$\frac{25}{20}$

1

(1)

1)

i.

12 
, 
THE WHISTLER JOURNAL 
JAMES McNEILL WHISTLER

BY ELIZABETH ROBINS PENNELL

AND JOSEPH PENNELL

Sixth and Revised Edition

ROME-VENICE

NIGHTS

In the Esthetic Eighties BY ELIZABETH ROBINS PENNELL

Large Crown 8vo, 16 illustrations.

THE LOVERS

BY ELIZABETH ROBINS PENNELL

Small I 2 mo. Frontpiece

JOSEPH PENNELL'S PICTURES OF

WAR WORK IN AMERICA 36 Plates. Octavo.

JOSEPH PENNELL'S PICTURES OF WAR WORK IN ENGLAND

Introduction by H. G. Wells. 5I Plates. Octavo.

JOSEPH PENNELL'S PICTURES OF

THE WONDER OF WORK

33 Plates. Octavo.

JOSEPH PENNELL'S PICTURES IN

THE LAND OF TEMPLES

40 Plates. Octavo.

JOSEPH PENNELL'S PICTURES OF

THE PANAMA CANAL

28 Plates. Octavo.

JOSEPH PENNELL'S LIBERTY

LOAN POSTER

Illustrated. Octavo.

OUR PHILADELPHIA

Br ELIZABETH ROBINS PENNELL

ILLUSTRATED BY JOSEPH PENNELL

Quarto, $71 / 2 \times 1$ Io ins. xiv $+55^{2}$ pages.

J. B. LIPPINCOTT COMPANY

PHILADELPHIA 



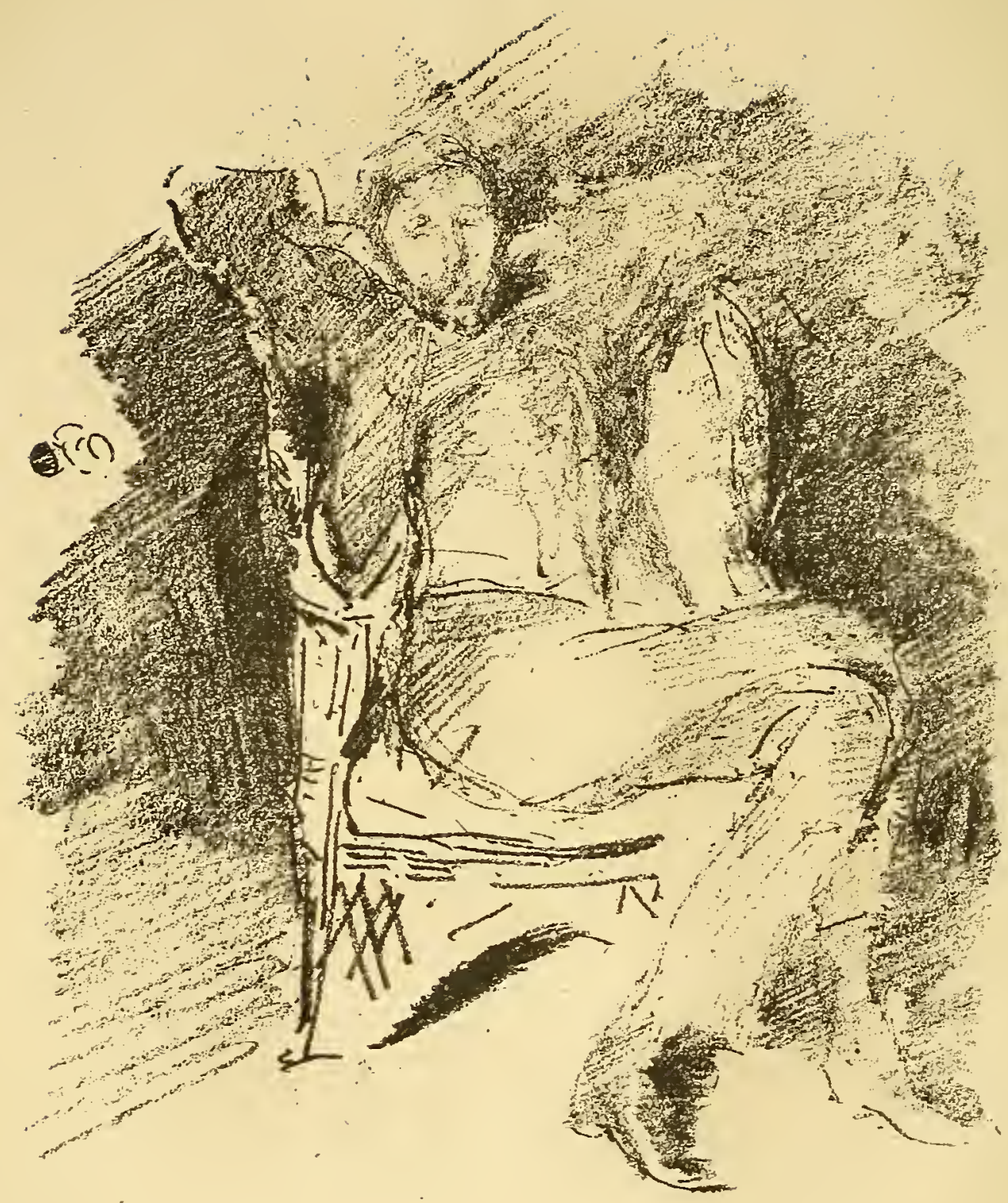




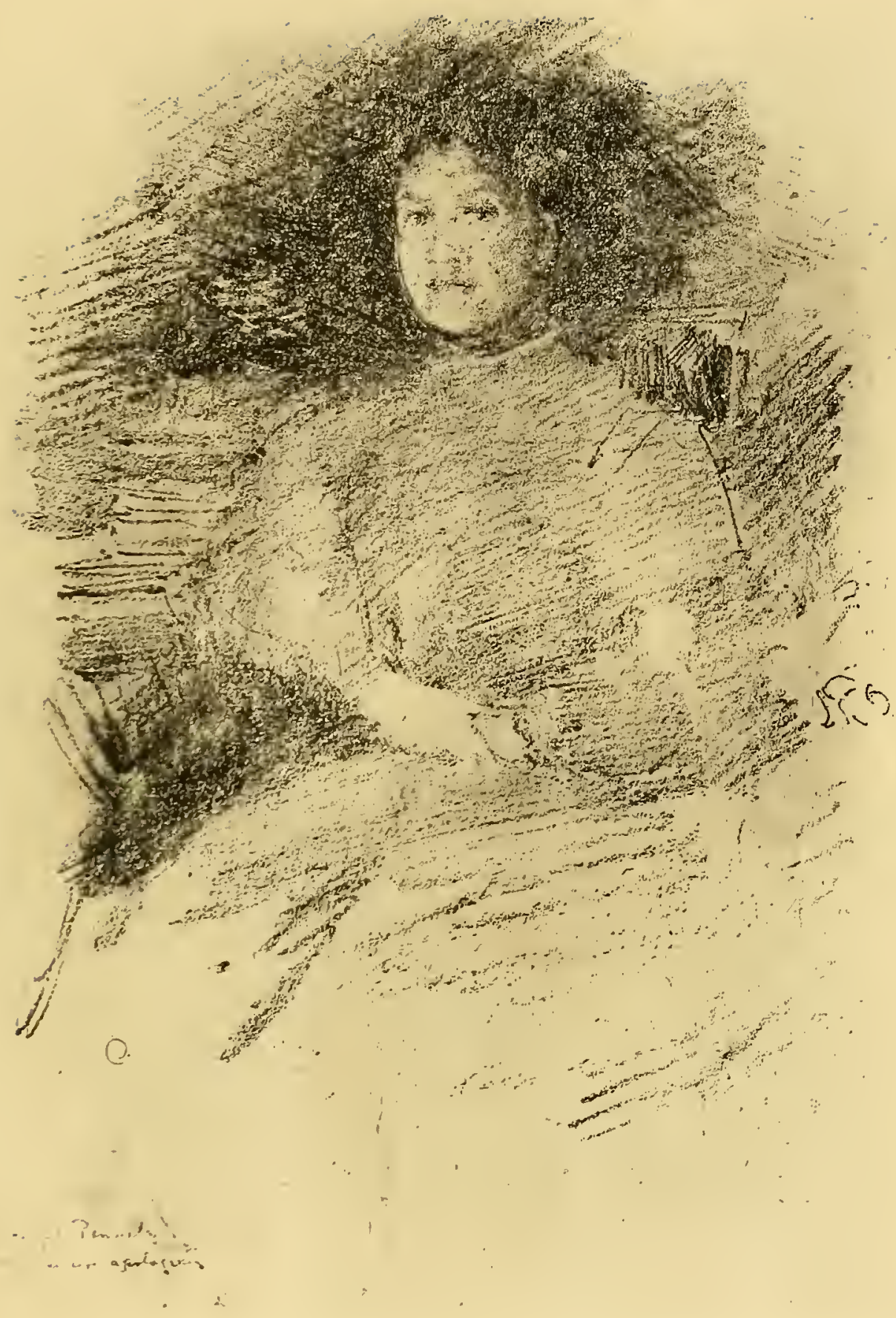




\section{THE WHISTLER JOURNAL}

BY

E. R. \& J. PEN N E L L

A U THORS OF THE

AUTHORIZED LIFE OF

JAMES McN. WHISTLER

ILLUSTRATED

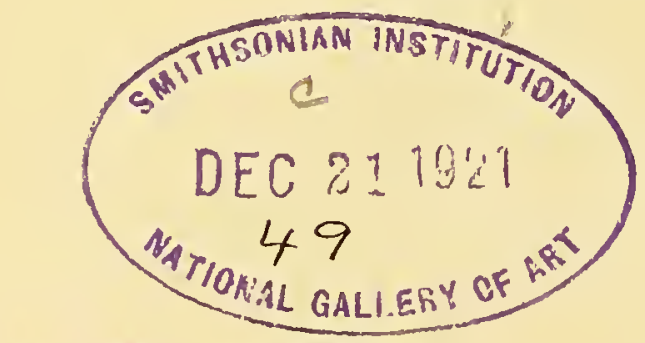

NATIONAL COLLCTION OF FINE ARI:

PHILADELPHIA

J. B. LIPPINCOTT COMPANY

I 92 I 
WNAAINPG LIBHAFY Recatalogued OCT 1; MyU

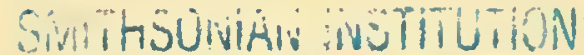

PRINTED BY J. B. LIPPINCOTT COMPANY AT THE WASHINGTON SQUARE PRESS PHILADELPHIA, U. S. A. 


\section{PREFACE}

This book needs no preface or apology or explanation. Each will be found in it. It is the story of the life Whistler lived with us during the three years after he asked us to write it, and the story he told us of the sixty-six previous years of his troubled, triumphal career-the foundation upon which the biography was built up. But in a biography the intimate tone of a journal is not appropriate and only certain portions could be used. We have had both pleasure and pain in recording what he gave us and also what we learned of him from others. For, when we were writing the Authorized Life, we received aid and assistance from every one except his wife's family who had nothing they could have given us save the documents and letters they may possess, if they preserved them. Mr. Freer was the other exception. Now, however, Mr. Lodge, Curator of the Freer Collection, has granted us the permissions we have asked and, with - we hope-the early opening of that Gallery, a large amount of information about Whistler, as well as many of his important works, will be available.

Whistler's fame has vastly increased, the commercial value of his work-now the artistic standard-has also vastly increased, and we have done what we could to increase the world's knowledge of Whistler as we knew him. Miss Philip has given her interpretation of him and his wishes. When his Society proposed to honour his memory by a Memorial Exhibition, she was at first willing to help. Then she became sure he did not wish his work in an English Gallery, but not till she had shown it in the International. Later on, there seemed no question that his wishes could not be opposed to her contributing to a small Whistler exhibition at the Tate Gallery, or to her making a special exhibition from her own collection of his paintings and pastels at Obach's. She, and Arthur Studd, who supported her, and who afterwards bequeathed his Whistlers to the British nation, leave us in doubt therefore as to "the master's wishes." Nor is the information, attributed to Miss Philip this year, concerning the printing of the lithographs exhibited at Obach's in London and Keppel's in New York exactly what one would have expected from Whistler.

Many besides Freer are dead-saddest to us, William Heinemann, Whistler's true friend and our true friend, killed like so many good men by the war. Richard Canfield is gone and his collection scattered, all save the lithographs which are preserved in the Brooklyn Museum. And Arthur Jerome Eddy who, like Canfield, will live by his portrait. And the Hadens, and Mrs. William Whistler, and 


\section{The Whistler Journal}

Rodin, and William Michael Rossetti, and Swinburne. Indeed, so many have gone, that we realize how soon the time will come when none will remain who knew Whistler, knew the facts of his life. It is for this reason we have thought it wise to publish information as it was given us, by those who did know him in days when we did not, even their opinions and impressions which we do not always share. We wish to say now much that was left unsaid, or halfsaid, in the Life, to give many details that could wait then, but can wait no longer. For there have been too many examples of whitewashing by contemporaries too cowardly to tell the truth, too many examples of the eagerness of posterity when freed from all responsible witnesses, to distort and play with incidents and adventures in the lives of the great dead, finding scandals in mean hints and idle gossip, the delight of the ignorantly inquisitive who sit in biographic judgment. We would spare Whistler, if we could, the fate of figuring in the future as "the true Whistler," subjected to the dissection, the misrepresentation of busy-bodies, from which too many great men have suffered. Nothing in Whistler's life needs to be concealed. He was human. Who is not? But the truth cannot detract from his fame as the most striking personality, the most distinguished artist of his time.

Our record of his life is not only in our Whistler biography and our Whistler Journal but in the collection of Whistleriana that we have presented to the Library of Congress, which Mr. Herbert Putnam, the Librarian, says "has, as a record, a completeness probably unparalleled by that of any other artist or writer." It is also a record of the story of modern art from all sides as well as from Whistler's.

The opening of this exhibition of a fraction, though it includes over 600 items, of our Whistleriana in Washington at the Library of Congress has proved to us conclusively, however, that if there ever was an artless age and an artless race it is this. No people talk so much around art and care so little for it. When the Whistler Memorial Exhibition was held in London it was visited by thousands daily. The King and Queen asked to come. It was opened by Ambassadors and supported by the press. Here, in the first weeks, not a thousand people visited the exhibition. But one Ambassador has come near it-naturally M. Jusserand, the French Ambassador; but one Minister, M. Peter, the Swiss Minister; not a congressman, not a senator that we know of has entered the Gallery set apart for it in their Library. So far as we can find out, not a director of a Washington Art Gallery has visited it. And, with a single exception, not a Washington paper has had an adequate notice of it vi 


\section{Preface}

or even one to compare with those in the papers of the far West. Most of the journals of the Capitol have ignored it.

Though so many of Whistler's friends have gone a few are left. Duret still lives, Kennedy, Lavery, Guthrie, Walton, Sauter, are still here, though the International-Whistler's International-is dead, or become British, with a Knight and an Academician for its President. Truly, again the artists have gone out and the British remain, and history repeats itself. But Whistler's fame grows.

If this book is appreciated, we will continue to publish The Journal kept till this day. Anyway, it will be preserved in the Library of Congress with our other Whistleriana, even if it is not now appreciated, waiting that future when the world shall emerge from its orgy of vulgarity, sport, commercialism, and the hypocrisy it has been made safe for. But art will triumph and the name and fame of Whistler will endure. He is with the Immortals.

There are again many people to thank, many things for which to congratulate ourselves: one of the principal, our obtaining the papers in the Whistler v. Ruskin libel action. After being rejected and refused by several collectors and museums of America, the Whistler papers came to us and now with other Whistleriana, are in the Library of Congress--priceless documents which will be valued in the future though they were spurned today. What would we give for a record of Rembrandt's bankruptcy? And the record of Whistler's is ours. His Honour Judge Parry, son of Mr. Serjeant Parry, Whistler's barrister in the Whistler v. Ruskin case, has more recently obtained for us, to be deposited in the Library of Congress with our Whistleriana, the Ruskin papers from Messrs. Walker, Martineau and Co., Ruskin's solicitors, so that the documents are complete and the record is intactforfuture reference. Not only our thanks but the thanks of our country are due to Judge Parry and to Messrs. Walker, Martineau and Co., especially Mr. J. A. Hammett, one of the firm, for this important gift to the Library and therefore to the nation. There are many others who possess papers and documents about Whistler, and it is our hope that they may add them and make perfect the unrivalled collection which the United States Government now owns. We have also in the Washington Collection the entire Whistler Memorial correspondence and the photographs of the properly rejected design by Rodin, rejected rightly by artists - and Rodin was their President. We must here again thank Mr. Putnam, Librarian of Congress, for allowing us to exhibit so admirably a selection of our Whistleriana, which has grown with and out of this book, and the various officials of the Library, especially Professor Rice, Mr. 


\section{The Whistler Journal}

Roberts and Mr. Bier, who helped us to install it in the Print Division, and Miss Wright and Miss Bier for much work. It has been the American public alone which has shown no interest. The American public of the present will not last, or the country will not last. But the name and fame of Whistler will endure.

Messrs. Knoedler have greatly aided us by furnishing us with many photographs and much information about works in their possession. Messrs. Rosenbach supplied us with the Greaves portraits in abundance, and we have shown and told the performances of the Brothers Greaves for the first time. Mrs. Eddy has given us the portrait of her husband which, during his lifetime, he refused to publish even in his own book on Whistler. Messrs. Keppel have, as usual, helped in many ways, and Messrs. Kennedy and Co. especially, permitting us to use the illustrations in their catalogue of the lithographs; and so have other dealers who know and understand. They have also shown us, and consulted us about, the endless fakes with which the country is flooded, and are a delightful contrast to those amateur collectors who know everything about Whistler and cannot-some of them-tell his signature from Harper Pennington's to say nothing of a good work from a bad imitation; a contrast also to the amateur amateurs and the business men who, if they employed the same methods in collecting cash as they do in collecting art, would find themselves in the bankruptcy court in six months-and occasionally they do. The restorer too is abroad and works have been utterly ruined, notably The Lange Leizen in the Johnson Collection, all the skin cleaned, scraped, scrubbed off it.

We have been helped by Mr. J. P. Heseltine; Mr. Sydney Pawling; greatly by Mr. Mitchell Kennerley; Mr. Kent of the Metropolitan Museum; the Milch Gallery; Mr. E. G. Kennedy; Miss Alice Roullier; Mr. Weitenkampf of the New York Public Library; Mr. W. H. Fox of the Brooklyn Museum; Mr. George Stevens of the Toledo Gallery; Mr. J. E. Lodge, Curator of the Freer Gallery; Mr. Lucas; Mr. Bement of the Maryland Institute, who, under the excellent guidance of Mr. C. Lewis Hind, the Editor of The Studio, and Mr. Fitz Roy Carrington, Lecturer on Prints at Harvard, discovered forty water-colours, two pen drawings, and twenty some wash-drawings which turned out to be two water-colours, one pen drawing and one rejected wash drawing in black-and-white. Recently we have been assured by the editors of an art paper that "So much has been written about Whistler, a certain weariness is making itself felt." It is this desire for some new thing that has made the Isms so popular in a world of ignorant amateurs. With viii 
such people and in the art schools, so-called, of the country, Whistler is not the fashion-he requires too much knowledge to understand, too much ability to follow. So they all go the easier way, and art in America today is dormant. Artlessness and $\mathrm{Cu}-$ bism and other Isms are the fashion, and fashion rules art here, not tradition. But art will live and Whistler is among the Artists.

Joseph Pennell

BRooklyn, September I, I92I 


\section{CONTENTS}

AN INTRODUCTION AND AN EXPLANATION. THE YEAR NINETEEN HUNDRED

CHAPTER I: THE BEGINNING. HOW WE GOT TO KNOW WHISTLER. THE YEARS EIGHTEEN EIGHTY TO EIGHTEEN EIGHTY-FIVE

CHAPTER II: THE BEGINNING CONTINUED. GETTING TO KNOW IVHISTLER BETTER. THE YEARS EIGHTEEN EIGHTYFIVE TO EIGHTEEN NINETY-SEVEN

CHAPTER III: THE FIRST IDEA OF THE JOURNAL. THE PRE-RAPHAELITES AND OTHERS. THE YEARS EIGHTEEN NINETY-SEVEN AND EIGHTEEN NINETY-EIGHT

CHAPTER IV: THE WHISTLER SCHOOL. THE YEARS EIGH. TEEN EIGHTY-NINE TO NINETEEN HUNDRED

CHAPTER V: THE COMMENCEMENT OF THE WHISTLER JOURNAL. THE YEAR NINETEEN HUNDRED

CHAPTER VI: CHARLES AUGUSTUS HOWELL, HIS FRIENDS AND HIS ENEMIES. THE YEAR NINETEEN HUNDRED CONTINUED

CHAPTER VII: EARLY PARIS MEMORIES. THE YEAR NINETEEN HUNDRED CONTINUED

CHAPTER VIII: THE LEYLANDS, THEIR CIRCLE, AND THE PEACOCK ROOM. THE YEAR NINETEEN HUNDRED CONTINUED

CHAPTER IX: THE GREAVES. THE YEAR NINETEEN HUNDRED CONTINUED

CHAPTER X: JO AND MAUD. THE YEAR NINETEEN HUNDRED CONTINUED

CHAPTER XI: WHISTLER'S AMERICA AND OTHER THINGS OF EARLY DAYS. THE YEAR NINETEEN HUNDRED CONTINUED

CHAPTER XII: FAILING HEALTH AND HIS WANDERINGS. THE YEAR NINETEEN HUNDRED CONTINUED

CHAPTER XIII: THE RETURN FROM CORSICA AND WHISTLER'S LIFE IN ENGLAND. THE YEAR NINETEEN HUNDRED AND ONE 


\section{Contents}

PAGE

CHAPTER XIV: FROM CHELSEA TO THE HAGUE. THE YEAR NINETEEN HUNDRED AND TWO

CHAPTER XV: THE INVALID IN THE STUDIO AFTER THE RETURN TO LONDON. THE YEAR NINETEEN HUNDRED AND TWO CONTINUED

CHAPTER XVI: THE LAST MONTHS. THE YEAR NINETEEN HUNDRED AND THREE

CHAPTER XVII: THE LAST DAYS. THE YEAR NINETEEN HUNDRED AND THREE CONTINUED

APPENDIX I: WHISTLER AS A DECORATOR, FROM THE CENTURY MAGAZINE FOR FEBRUARY 1912, BY PERMISSION OF THE CENTURY COMPANY

APPENDIX II: THE WHISTLER MEMORIAL

APPENDIX III: THE PAPERS IN THE WHISTLER-RUSKIN LIBEL CASE 


\section{LIST OF ILLUSTRATIONS}

G., after an etching, refers to the Grolier Club Catalogue of Whistler's Etchings

M., refers to the Caxton Club Catalogue

W., after a lithograph, refers to Way's and Kennedy's Catalogues of

Whistler's Lithographs

Firelight - Joseph Pennell (Lithograph. $W$. 104 )

Frontispiece

Portrait of E. R. Pennell (Lithograph. $W$. Ioz)

Frontispiece

Autographed Proofs by Whistler from the Pennell Collection, Library of Congress, Washington

Photogravures by Messrs. F. A. Ringler Co., Printed by Messrs. Peters Brothers

Tablet and Brass to Members of the Whistler Family in the Church

To face page at Goring-on-Thames, England

Rubbings in Pennell Collection, Library of Congress, Washington

Whistler's House at Chelsea (By Sir F. Seymour Haden) (Etching)

Whistler's House at Chelsea (By Joseph Pennell) (Etching) 2

The White House (Photograph by $W$. E. Gray) 3

Lady Meux Triplex-Caricature of Whistler Painting the Three Portraits of Lady Meux at once (Unknown)

In the possession of the Rosenbach Co.

Whistler About the Time of His Return from Venice (Photograph by Mendelsohn)

Loaned by Burton Mansfield, Esq.

Portrait by Carlo Pellegrini, "Ape" (Dry-Point)

Poster of the Sale at the White House (Proof)

"On the premises of Mr. Whistler" omitted from poster used.

Pennell Collection, Library of Congress, Washington

2i Cheyne Walk (By Joseph Pennell) (Etching)

In the Garden of SAMe (Lithograph. W. 38 )

By permission of Messrs. Kennedy and Co.

W. E. Henley (Lithograph. W. I27)

By permission of Messrs. Kennedy and Co.

Poster for Exhibition of Nocturnes, Marines and Chevalet Pieces io

Pennell Collection, Library of Congress, Washington

Late Piquette (Lithograph. W. 57)

Io

By permission of Messrs. Kennedy and Co. 
Stephane Mallarme (Lithograph. $W .66$ )

By permission of Messrs. Kennedy and Co.

THE Duet (Lithograph. Undescribed)

In the possession of Messrs. Knoedler and Co.

Miss Mildred Howells (Lithograph. W. 75 )

By permission of Messrs. Kennedy and Co.

Mother and Daughter (Lithograph. Undescribed)

In the possession of Messrs. Knoedler and Co.

Study Portrait of Josepir Pennell (Lithograph. W. im

Pennell Collection, Library of Congress, Washington

The Russian Schube (Lithograph. W. II2)

Pennell Collection, Library of Congress, Washington

Nelson Boarded at Last

Reproduction from The Daily Chronicle

Not Known at the Royal Academy

Reproduction from The Daily Mail. Originals in Pennell Collection,

Library of Congress, Washington

Whistler Making a Lithograpi at Way's (By T. R. Way) (Lithograph)

In the possession of Mrs. T. R. Way

Portrait of Thomas Way (Lithograph. W. IO7)

By permission of Messrs. Kennedy and Co.

Portrait of Whistler (By J. Boldini) (Oil)

Brooklyn Museum

Portrait Made While Whistler Posed to Boldini (By Paul Helleu) (Dry-Point)

Pennell Collection, Library of Congress, Washington

Whistler Sleeping (By J. Boldini) (Dry-Point)

Done between poses in Boldini's Studio. In the possession of E. G. Kennedy, Esq.

Whistler in His Paris Studio (By Dornac) (Photograph)

I8

Showing the screen with Battersea Bridge made for Leyland

Fruitiere, Rue De Grenelle (Lithograph. W. 70 )

By permission of Messrs. Kennedy and Co.

St. GILES-IN-THE-FIELdS (Lithograph. W. I20)

By permission of Messrs. Kennedy and Co.

Swinburne (Dry-Point. M. I36)

Portrait, Attributed to Whistler (Oil)

Portrait by Fantin Latour (Oil)

Freer Collection, National Museum, Washington xiv 


\section{List of Illustrations}

Whistler in the Big Hat-Hat Worn in Paris and on Journey to Alsace (Etching. M. 54)

Proof of Destroyfd Plate

Pennell Collection, Library of Congress, Washington

Whistler Smoking (Oil)

Attributed to Whistler. By permission of A. E. Gallatin, Esq.

Whistler in the Big Hat (Oil)

Freer Collection, National Museum, Washington

Lindsfy Row (By Joseph Pennell) (Etching)

Whistler lived in the houses at each end of the Row

Millbank (Etching. $M .7 I$ )

Used as invitation card to Thomas's Exhibition of Etchings

Dr. Whistler (Lithograph. W. 78 )

By permission of Messrs. Kennedy and Co.

Sketch from the Portrait in the 1900 Paris Exhibition (Pen-and-Ink) 40

Pennell Collection, Library of Congress, Washington

Portrait of Whistler from Title to the French Set (Etching. $M .25$ )

Unpublished Title to French Set (Etching)

Grolier Club Supplement. By permission of the Grolier Club

Drouet (Etching. $M .55$ )

Riault (Etching. M. 65)

Speke Hall (Dry-Point. M. 96 )

Lyme Regis (Water-Colour)

In the possession of Mrs. Innowles

C. A. Howell (By H. T. Dunn) (Pen-and-Ink)

In the possession of the Estate of W. M. Rossetti

Chelsea Embankment (Oil)

Freer Collection, National Museum, Washington

Rosa Corder (Pen and Wash)

In the possession of Alan S. Cole, C. B.

Selsey Bill (Water-Colour)

In the possession of Mrs. Knowles

Chinese Cabinet Subject of the Owl and the Cabinet (Photo)

62

Pennell Collection, Library of Congress, Washington

Designs for Blue and White China (Wash)

The Murray Marks Collection

Drawing for Sir Henry Thompson's Catalogue of a Collection of Blue and White Nankin Porcelain (Wash)

In the possession of Pickford R. Waller, Esq. 


\section{List of Illustrations}

Cover of the Unique Large Paper Copy of the Book

Pennell Collection, Library of Congress, Washington

The Purple Cap (Pastel)

Freer Collection, National Museum, Washington

Little Nude (Pastel)

Formerly in the Canfield Collection

Boulevard Poissoniere (Etching. M. 423)

Balustrade, Luxembours, (Etching. $M .427$ )

Grolier Club Catalogue

La Mere Gerard (Etching. $M . I I$ )

REAding By Lamplight (Etching. $M .33$ )

Seymour Haden, left; Traer, centre; Lady Haden, right

Delatre (Etching. M. 26)

Fumette Crouching (Etching. M. I3)

Bibi Lalouette (Etching. M. $5 I$ )

Becquet (Etching. $M .52$ )

FinetTe (Etching. M. $5^{8}$ )

Axenffld (Etching. M. 64)

Astruc (Etching. M. 53)

F. R. LeYland (Etching. M. IOZ)

96

SkETCh of LeYLand (Oil)

In the possession of the Estate of F. R. Leyland

Florence Leyland (Dry-Point. M. IIo)

Elinor Leyland (Dry-Point. M. IOg)

The Peacock Room-From a Photograph Made While It Was in Place at Princes Gate, Showing Blue and White on the Walls (Photograph) 100

Pennell Collection, Library of Congress, Washington

Ricil and Poor Peacocks

Peacock Room. Freer Collection, National Museum, Washington

Mrs. Leyland. The Velvet Dress (Dry-Point. M. Io5)

100

Studies of Mrs. Leyland's Dress. (Black and White Chalk)

IOI

In the possession of Walter S. Brewster, Esq. and Mrs. Knowles

Sketch of Detail of Peacock Room (Pen-and-Ink)

IOI

Sketch of Stairway at Leyland's House-Partially Decorated by Whistler (Pen and Pencil)

In the possession of the Estate of Mrs. Leyland

Sketchies of Peacock Room (Pen-and-Ink)

In the possession of Mrs. J. C. Gardner svi 
Chelsea Embankment (Water-Colour)

Note for Nocturne (Black and White Chalk)

In the possession of Mrs. T. R. Way

Nocturne (By Wa'ter Greaves) (Oil)

120

In the possession of the Rosenbach Co.

Nocturne (By Whistler) (Oil)

120

In the possession of the Estate of Mrs. Leyland

Lord Wolseley (Dry-Point. M. I64)

Whistler's Etching Needle-Actual Size Given By Whistler to Joseph Pennell

Pennell Collection, Library of Congress, Washington

The Table Palette-Used in Fulham Studio (By G. P. Jacomb-Hood) (Wash)

Mr. Eldon (Oil)

Once in the possession of Mr. Walter Sickert and attributed by him to Whistler

Interior of the Studio, Fulham ( $B y$ G. P. Jacomb-Hood) (Wash)

Tinnie Greaves (Dry-Point. M. I4I.)

Study of Carlyle on Back of Canvas (Signed by Greaves) (Oil)

In the possession of Messrs. Dowdeswell and Dowdeswell

Head of CarlyLe (By Whistler) (Oil)

In the possession of Burton Mansfield, Esq.

White Grrl. No. IV. (Oil)

In the possession of John F. Braun, Esq.

Sketch of Same (Chalk)

Attributed to Whistler. The Way Collection

Mrs. A. J. Cassatt (Pen-and-Ink)

In the possesssion of Alan S. Cole, C. B.

Battersea Bridge (Oil)

Tate Gallery, London

Passing Under Old Battersea Bridge (By Walter Greaves) (Oil)

From The N. Y. Herald

Portraits of James McNeill Whistler (By Walter Greaves) (Oils)

In the possession of the Rosenbach Co.

Spy's Caricature of Whistler (Lithagraph)

Published in Vanity Fair

A Portrait of Whistler (By Walter Greaves) (Oil)

In the possession of the Rosenbach Co. 
Jo-Print from the Destroyed Plate (Dry-Point. M. 77)

Pennell Collection, Library of Congress, Washington

Wali of the First International Exhibition at Knightsbridge (Photograph)

The centre group of works arranged by Whistler

Wall of the Whistler Exhibition at Bradford (Photograph)

Arranged by Joseph Pennell. Oils, Water-Colours and Prints hung together

Sketches by Whistler-For the Seal of the International Society of Sculptors, Painters and Gravers, and the Final Design used by THE Society (Pen-and-Ink)

I5I

Interior of Room in Whistier's First House in Lindsey Row Showing the Mantelpiece before with the Little White Girl was Painted (Contemporary Photograph)

Loaned by Mr. Chambers

Dining-Room in Whistlen's First House in Lindsey Row (Contemporary Photograph)

Loaned by Mr. Chambers

Fireplace, Dining-Room in Whistler's First House in Lindsey Row (Contemporary Photograph).

Loaned by Mr. Chambers

InTERIOR OF THE Lindsey Row Studio (By Walter Greaves) (Oil)

In the possession of the Rosenbach Co.

Note Blanche-Portrait of Jo (Oil)

In the possession of Mrs. Cobden Sanderson

Sketcifes of MaUd (Pen-and-Ink)

152

152

152

Weary-Portrait of Jo (Dry-Point. M. 92)

157

SkETch of MAUd (Pen-and-Ink)

154

156

Formerly in the possession of S. P. Avery

SKetch of MAUd (Pen-and-Ink)

From Arrangement in White and Black No. r., afterward called

L'Américaine

Casa Jankovitz, Winere Whistler Lived Most of the Time in Venice (By Joseph Pennell) (Pastel)

Whistlen's House in the Vale, Ciielsea ( $B y W . E$. Gray) (Photograph) 166

The Dyre at Domburg (Water-Colour) 167

Shore. Near Dublin (Oil)

167

Freer Collection, National Museum, Washington

Enlargement of Etching Black Lion Wharf Published in The Daily Chronicle

$\mathrm{xviii}$ 
Illustration to Little Johannes (Drawing on Wood)

The Quadri, Venice (By Joseph Pennell) (Pastel)

I 71

Pennell Collection, Library of Congress, Washington

Portrait of Carlyle (Oil)

Glasgow Art Gallery

Sketch of the Portrait (Pen-and-Ink)

In the possession of Alan S. Cole, C. B.

Lion-Designed for the British Artists (Pen-and-Ink) 176

First Page of the Memorial to Queen Victoria from the British 176 Artists (Water-Colour)

Royal Collection, Windsor

Interior of Galiery of the British Artists Sitowing Velarium and Arrangement of Pictures (Pen-and-Ink)

Formerly in the possession of G. R. Halkett

Page of Sketches of British Artists Exhibition, 1886 (By Bernard Partridge) (Pen-and-Ink)

Under a BRIDGe (Pastel)

178

The Rrva (Black Chalk)

182

In the possession of Mitchell Kennerley, Esq.

Venice Pastels

In the possession of J. P. Heseltine, Esq.

Tine Gold Girl, Connie Gilchrist, Sketches of the Picture (Penand-Ink)

In the possession of Alan S. Cole, C. B. and Henry Blackburne

The Dancing Gird (Pen-and-Ink)

In the possession of Messrs. Knoedler and Co.

The Quadri at Venice, Whistlen's Cafe (By Joseph Pennell) (Pastel)

Pennell Collection, Library of Congress, Washington

Sketch of Whistler (By Phil May) (Pen-and-Ink)

182

Portrait of Whistler (Wood-Block in Colour)

182

Drawn and cut by William Nicholson, Esq.

Sketch of Whistler (Pen-and-Ink)

By Harper Pennington and Evolution of His Signature

Sketch of Harper Pennington (By Whistler) (Pen-and-Ink)

182

CAFE, Corsica (Pen-and-Ink)

183

The Forge (Pen-and-Ink)

188

189

200

202

In the possession of Messrs. Knoedler and Co.

203

206

206

xix 


\section{List of Illustrations}

Whistler Seetching in Corsica (By William Heinemann) (Photograph) 208

A Street in Corsica (Pen-and-Pencil)

In the possession of Messrs. Knoedler and Co.

Smiths, Ajaccio (Chalk)

In the possession of Messrs. Knoedler and Co.

Phryne (Oil)

International Exhibition, 1901

The Forge, Ajaccio (Chalk)

220

In the possession of Messrs. Knoedler and Co.

Richard A. Canfield (Oil)

234

In the possession of Messrs. Knoedler and Co.

Arthur J. Eddy (Oil)

In the possession of Mrs. Arthur J. Eddy

La Napolitaine, Rose et Or. Portrait of Carmen Rossi (Oil)

In the possession of Messrs. Knoedler and Co.

Little Evelyn, Daughter oe D. C. Thomson, Ese. (Lithograph. W. IIO)

By permission of Kennedy and Co.

Robert, Comte De Montesquiou-Fezenzac $\left(\mathrm{O}_{2} l\right)$

In the Frick collection

The Mother (Dry-Point. M. 97)

272

Henry Irving (Dry-Point. M. I7o)

272

From destroyed plates. Pennell Collection, Library of Congress,

Washington

Whistler, About i 878 (Photograph)

Pennell Collection, Library of Congress, Washington

House Where Whistler Died and Chelsea Church from Which $\mathrm{He}$ was Buried (By J. Pennell) (Etching)

Corrected Copy of "Who's Who"

Pennell Collection, Library of Congress, Washington

Cabinet Decorated with Painted Panels (By Whistler)

Owned by P. R. Waller, Esq.

Sketch for Sideboard (Pen Drawing)

Pennell Collection, Library of Congress, Washington

Sketch for Rosettes (Chalk)

302

Pennell Collection, Library of Congress, Washington

Seetch for Matting (Chalk)

Pennell Collection, Library of Congress, Washington 


\section{List of Illustrations}

Design for Silk Butterfies Worn at Private View ( $W a s h$ ) In the possession of Mrs. Wickham Flower

The Evolution of the Butterfly (Pen-and-Ink) 304 Pall Mall Magazine

Rodin's Rejected Memorial to Whistier (Photographs) 308

Pennell Collection, Library of Congress, Washington

Letter from Rodin to Joseph Penneli

Pennell Ccllection, Library of Congress, Washington

Cover of Mr. Serjeant Parry's Brief for Whistler

Pennell Collection, Library of Congress, Washington

Trial. Caricatures of Trial (By M. Bryan in "Judy") (Pen-and-Ink) 
H.

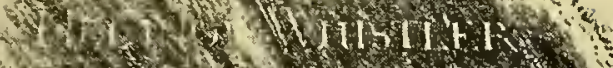

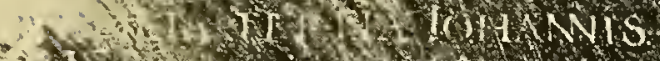

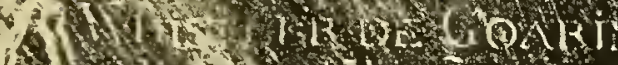

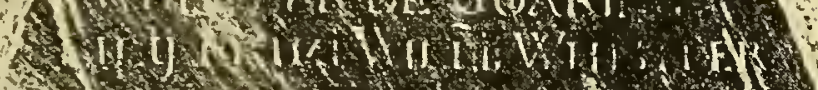
6. B s.

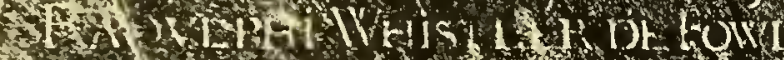

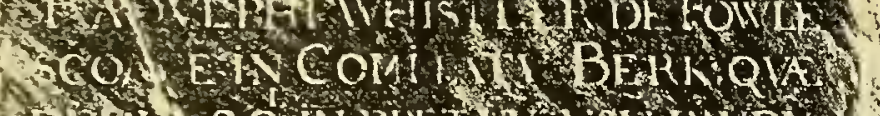

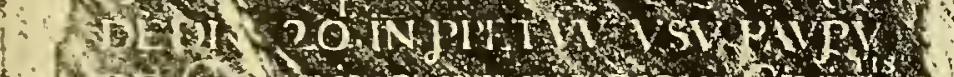

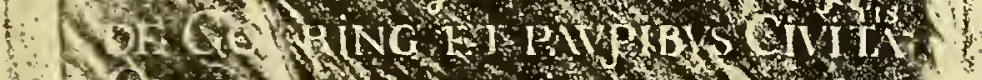

$10 \times 0$.

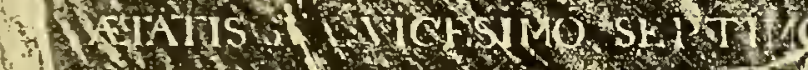
M 1 (x)

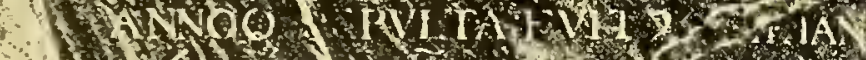

1.6 $10 \mathrm{H}$.

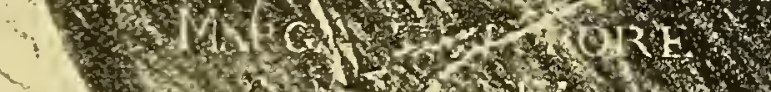

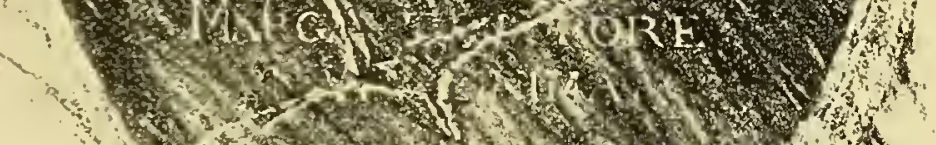

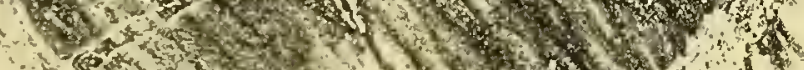

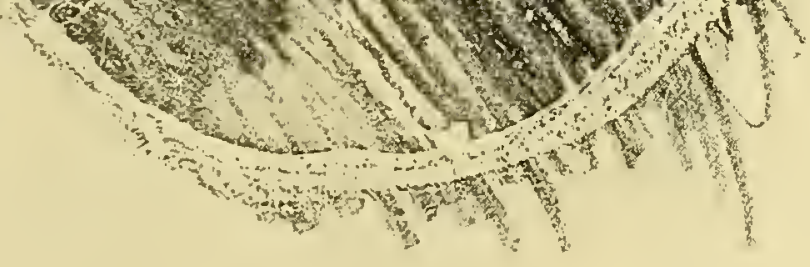

Whs

HERE LYATHOVRTED THFBODY OF HVGH - WHISTER THE SONNE OE MSTIR ITON

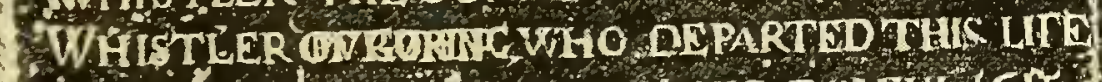
4THE, DAY OF ANVA CO AYNO DOMINI IGB

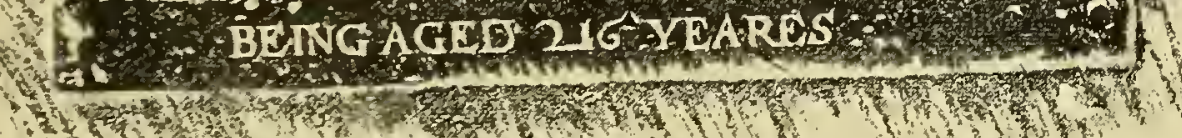

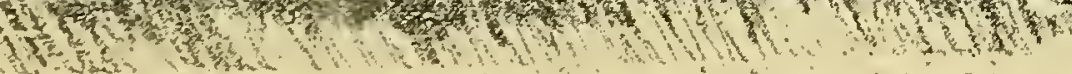

TABLET AND BRASS TO MEMBERS OF THE WHISTLER FAMILY IN THE

CHURCH AT GORING-ON-THAMES, ENGLAND. RUBBINGS IN PENNELL COLLECTION, LIBRARY OF CONGRESS. WASHINGTON 



\section{AN INTRODUCTION AND AN EXPLANATION. THE YEAR NINETEEN HUNDRED}

"2I Bedford Street, London, W. C., May 28th, 1900.

Dear Penneli,

I have at last got Whistler to consent that you shall write, if you will (and I know you will only too gladly) a book on him, illustrated with his pictures, his etchings and his drawings. Here is a magnificent opportunity.

Yours very sincerely, Wm. Heinemann."

When J. received this letter he went at once to see Heinemann, who explained that he had long wanted to publish a Life of Whistler, that he had first suggested it should be written by W. E. Henley, but Whistler objected, next by Charles Whibley, but Whistler protested, and then by J. and Whistler agreed. He would write it, J. told Heinemann, but on one condition: that E. should write it with him. Heinemann was willing. Would Whistler be willing? It did not take J. long to find out. From Heinemann's he went to Whistler's studio at 8 Fitzroy Street. He told Whistler what had happened. Whistler consented, and said he would help us in every way. There should be two volumes, one his life, the other his work, and he gave his permission to have his work photographed, and he promised to tell us things about himself just as they occurred to him, as he talked, whenever and wherever we met, and E. should put down what he said, and he would correct it. And so after our next meeting with him on Whit-Sunday, June $3 \mathrm{rd}$, I900, E. began The Whistler Journal which has been kept up ever since.

J. had known Whistler sixteen years, we both had known his work long before that, and many of our most delightful memories are of days when there was no thought of a biography. We made few notes, we kept no journal during those years, but we remember better some things we did not make notes of than others of which notes were made. There was no reason to make notes until he asked us, though we were foolish not to, for we were far more intimate with him than any one else. But then, there are many other things in our lives that we should have done that we have left undone, and when Whistler did ask us to make notes, we began to make them with all diligence.

1900] 
CHAPTER I. THE BEGINNING. HOW WE GOT TO KNOW WHISTLER. THE YEARS EIGHTEEN-EIGHTY TO EIGHTEEN EIGHTY-FIVE

T., a Quaker boy in Philadelphia, a student of the Pennsylvania Academy schools, first saw Whistler's work at the house of the President of the Academy, James L. Claghorn, in Logan Square, Philadelphia. Claghorn was glad to show his prints, and many were the First Day afternoons that J. spent looking them over at one end of the room with Harry Poore and Gerome Ferris-fellow students in the Academy Schools who cared-Claghorn with Peter Moran and Stephen J. Ferris-artists who also cared-sitting at the other; Claghorn encouraging young artists instead of patronizing them. The prints that appealed most to $\mathrm{J}$. and that he studied oftenest and with greatest interest were Whistler's and Haden's.

His next chance was at exhibitions. In 188I, Ernest G. Brown of the Fine Art Society, brought over from London the first Venice Set of twelve and showed them in one of the little galleries in the Academy, decorated in white and gold as Whistler had decorated his gallery in London. The show was a failure. It wasn't even made fun of. Philadelphians then were Americans and didn't ape the English as they do now. Nobody in Philadelphia, except Claghorn, wanted Whistlers at that time, though $\mathrm{J}$. revelled in them, and though in New York Wunderlich, with whom Mr. E. G. Kennedy then was, bought six sets, Mr. Avery one, and Mr. Andrews another, while Mr. Howard Mansfield had already begun his fine collection, and Doctor Darrach of Philadelphia, a friend of Doctor Whistler's, had The Thames Set, though this later was burned or lost. In I 882 the first International Exhibition of Etchings of any importance in the United States was given in the Academy by the Philadelphia Society of Etchers of which J., a mere boy, was Secretary, and a large number of Whistlers were hung. The same year J. heard Seymour Haden lecture on etching in Philadelphia, and this lecture helped to draw the attention of American artists and American art lovers to the art of etching. $\mathrm{He}$ still remembers the supper after the lecture, given by Claghorn to Haden at the Union League. The exhibition, lecture, supper, even the brand of champagne,-O, that dear dead past! - had all been arranged by Frederick Keppel who, about the same time, began to publish J's. Own prints, so that he was often at Keppel's print shop in New York where he was always sure to find more 


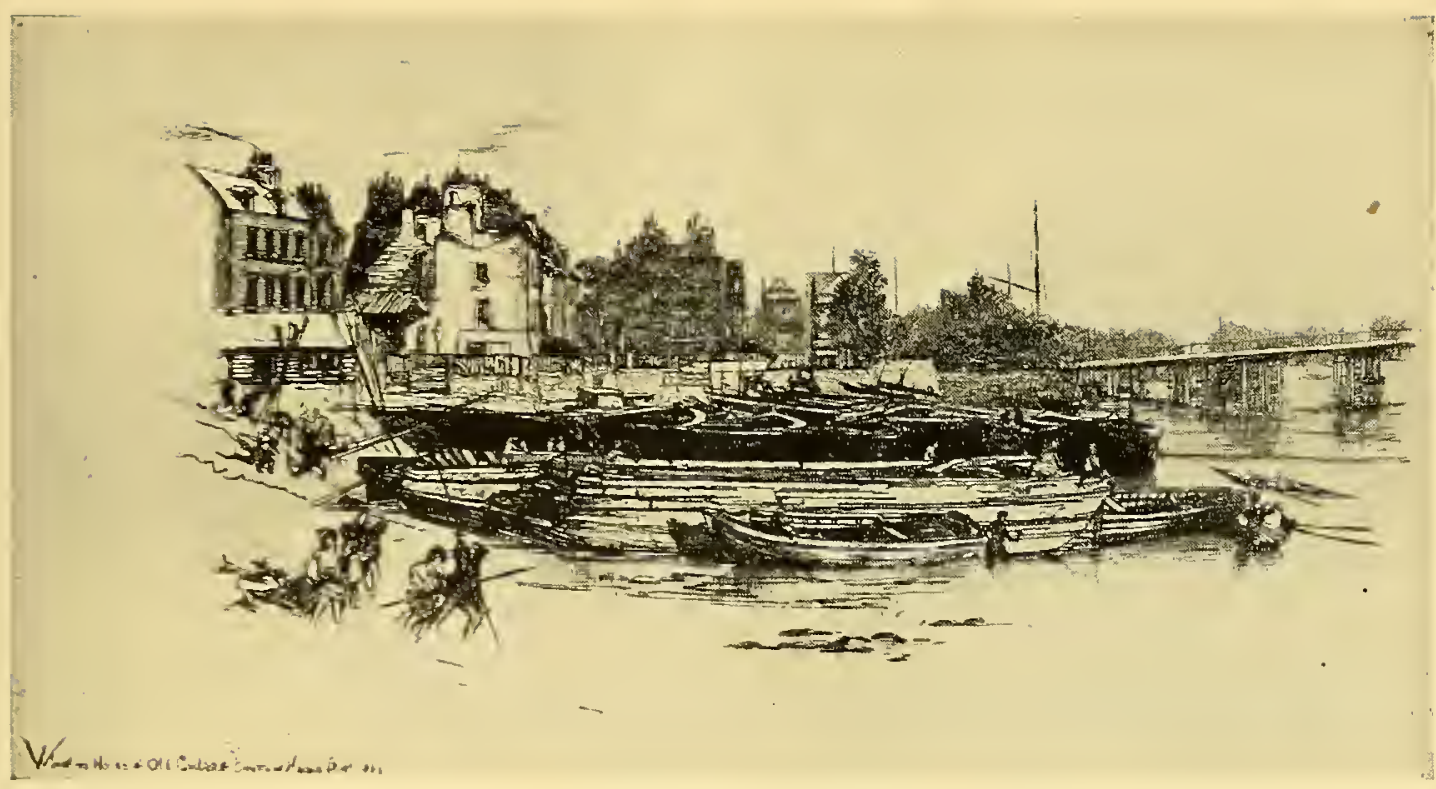

WHISTLER'S HOUSE AT CHELSEA

ETCHING

By Sir F. Seymour Haden

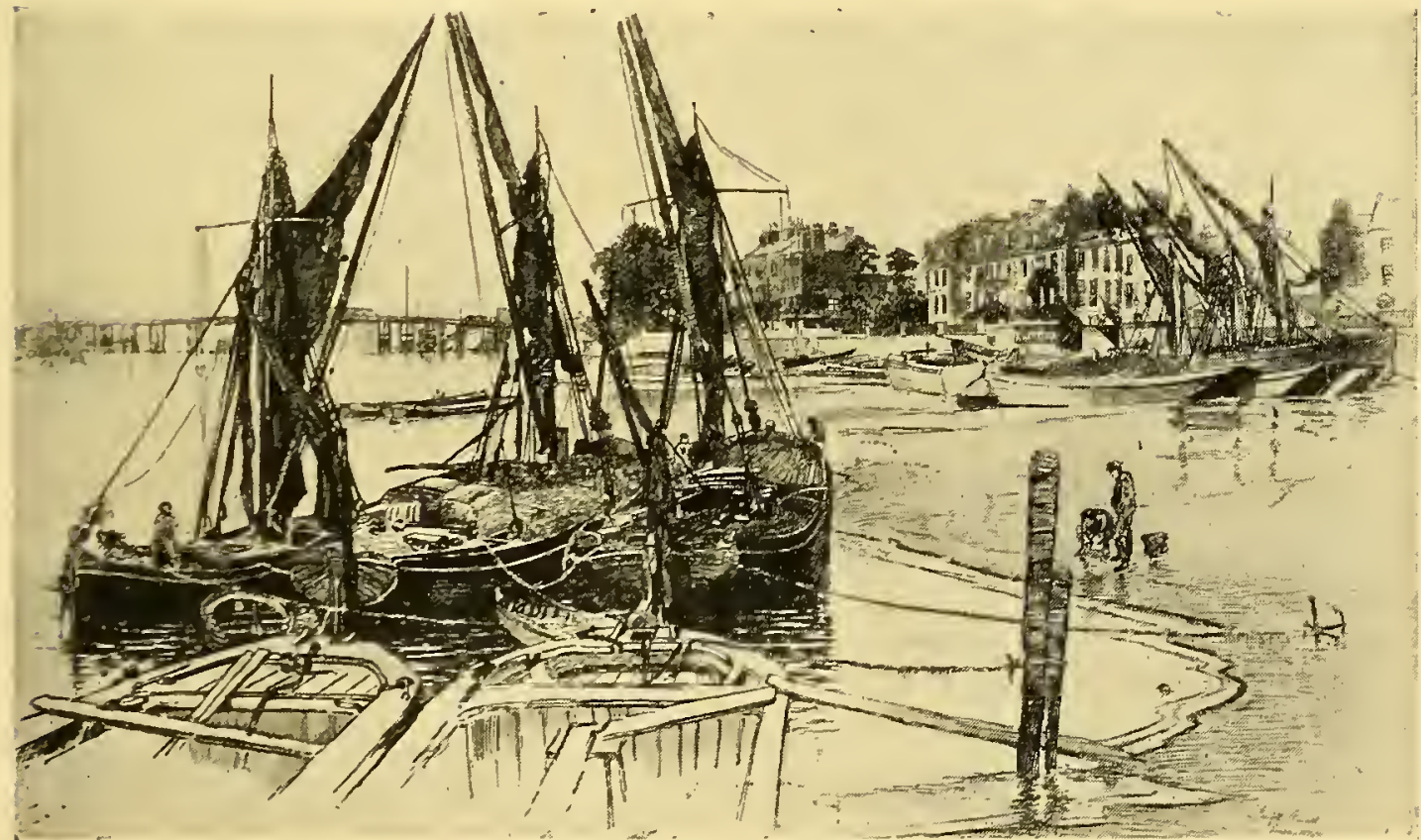

WHISTLER'S HOUSE AT CHELSEA

ETCHING

By Joseph Pennell

(See page 7) 


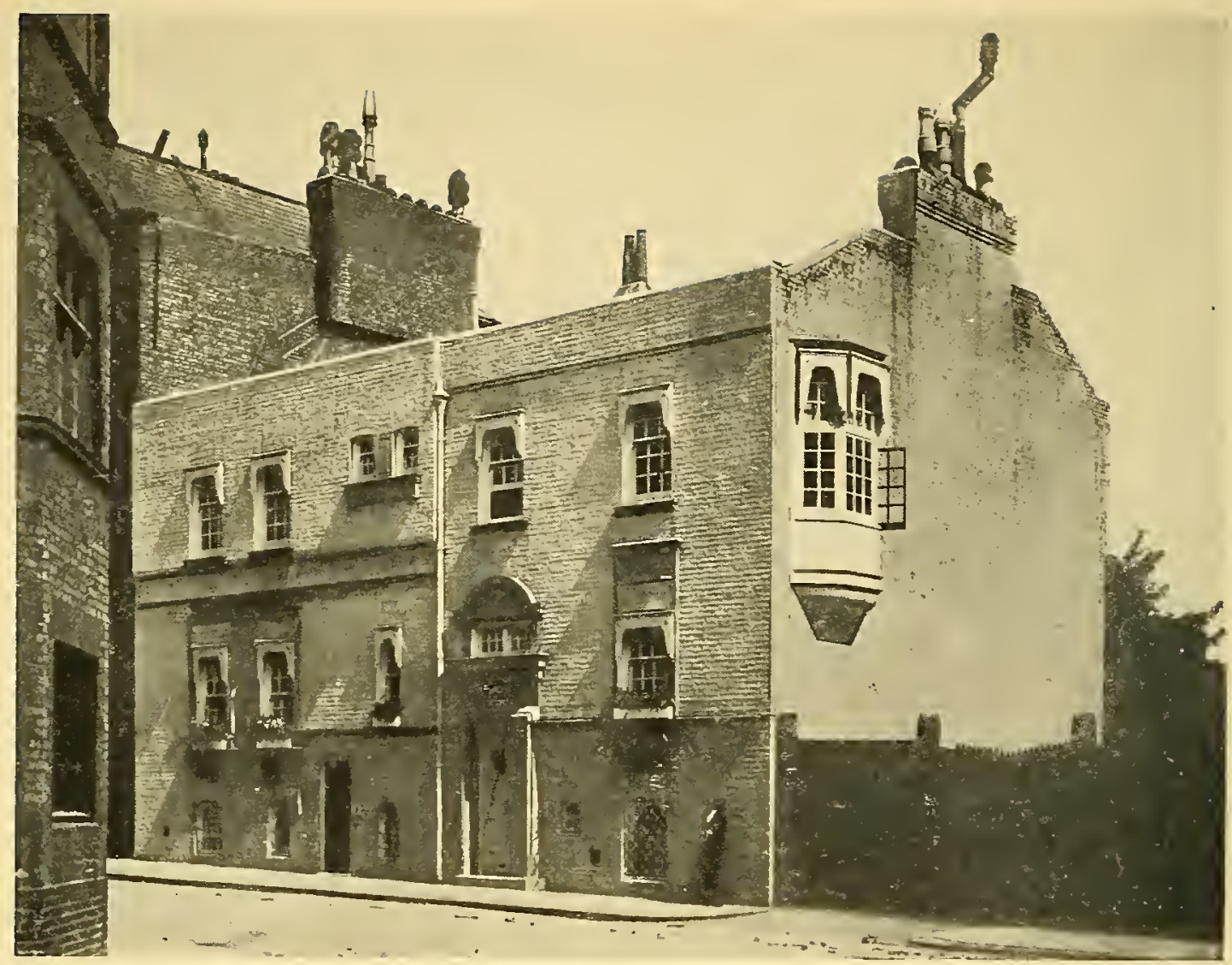

THE WHITE HOUSE

(See page 7)

Photograph by W. E. Gray

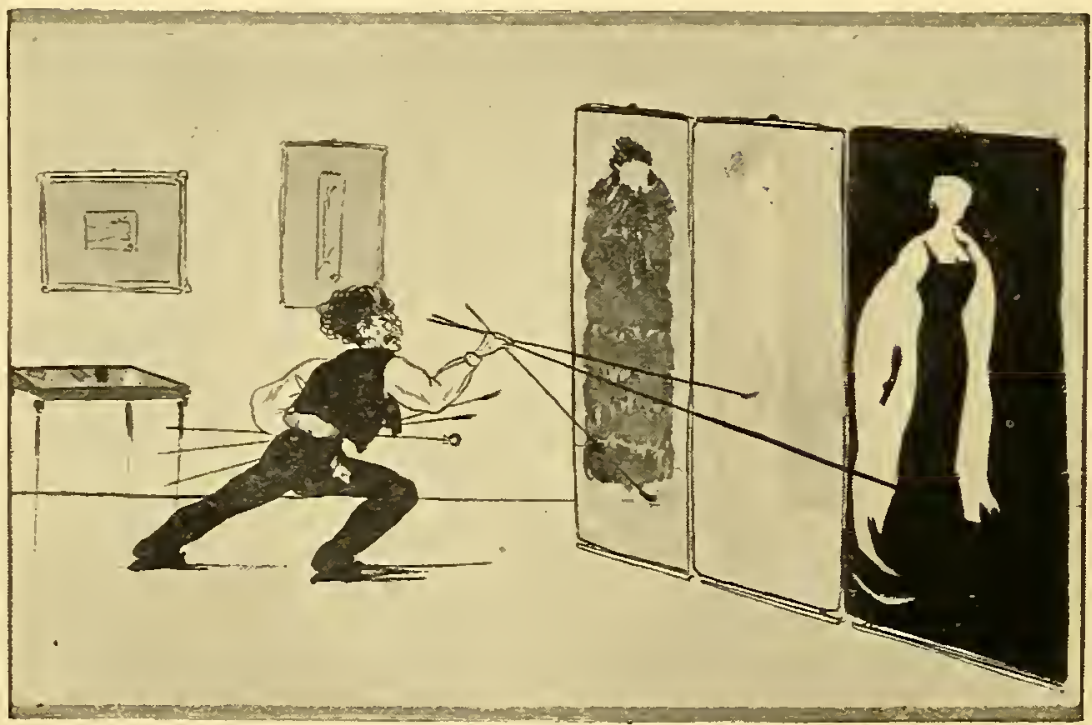

LADY MEUX TRIPLEX

CARICATURE OF WHISTLER PAINTING THE THREE PORTRAITS OF LADY MEUX AT ONCE

ORIGINALS PAINTED IN THE WHITE HOUSE

In the possession of the Rosenbach Co. 


\section{The Beginning}

Whistlers to see and to study, and where he remembers copying in pen-and-ink Haden's print of Whistler's House at Chelsea. He remembers also Haden's praise of Whistler's work. On one occasion Haden said that if he had to sell his Rembrants or his Whistlers, he would sell the Rembrants first. He sold both, but he sold the Whistlers first.

E.'s interest in Whistler was first roused at much the same moment, by Oscar Wilde whom she not only heard lecture during his American lecture tour, but met while he was in Philadelphia. Her Uncle, Charles Godfrey Leland, had shortly before come home from England where Wilde had known him, admired him, looked up to him as the youth will to the older man in his profession. Leland was living-or camping out-in the big Broad Street boardinghouse where the Philadelphia so-called Art Club now stands, and Wilde often dropped in for a talk. His enthusiasm had not been wholly swallowed up in his affectations. It had survived even the mockery of imitation-the velvet knickerbockers, the lilies and sunflowers of the American college boys who flocked to his lectures arrayed in all his own æsthetic glory. Besides, there would have been no use posing for Leland, who posed himself and would stand no rivals. In Leland's rooms, Wilde was natural even when he returned from the West in cowboy hat and flowing cloak, or came back from Camden and Walt Whitman. His talk was extraordinary to a girl who had never been further from Philadelphia than Richmond in Virginia. Like his lectures, it was mostly around art, and he had no more to say about anyone than Whistler. He had not then outgrown his deference nor the acknowledgment of his debt. He was a worshipper at Whistler's shrine, he said.

But most important to both of us was the fact that at the Pennsylvania Academy in I 881, Whistler's portrait of his Mother was hung: not in the place of honour, but in the narrow North Corridor beside the staircase. To Mrs. Anna Lea Merritt belongs the credit of getting Whistler to allow the picture to be sent over, in the hope that it might be purchased by the Academy. The price was one thousand dollars and, since writing the Life, we have heard that it could have been had for five hundred-we might recall the fact that the French Government gave Whistler six hundred and twenty dollars for it. After the painting had unsuccessfully tou red America, it returned to Chelsea, and the Pennsylvania Academy of the Fine Arts, having lost a golden opportunity, has now bought and hung upon its walls one of the innumerable Greaves portraits of Whistler. True, the Academy did bestow its medals upon Whistler. The 1880-I 885] 


\section{The Whistler Journal}

Carnegie Art Institute, fifteen years afterwards (1896), bought for five thousand dollars the Sarasate, the first picture Whistler sold to a public gallery in America, though the Wilstach Collection in Philadelphia purchased The Yellow Buskin from a dealer in 1894 . Mr. Harrison S. Morris, who was Director of the Pennsylvania Academy at the time, has told us how it came about. The picture was at the Chicago Exposition in 1893 with the Princesse $d u$ Pays de la Porcelaine and The Fur Jacket, and, at the close he brought the three to Philadelphia, showed them in the Academy in I894, and persuaded John G. Johnson to buy The Yellow Buskin, for the Wilstach Collection. Alexander Reid, the Glasgow dealer from whom it was obtained, asked fifteen thousand dollars for it, Johnson offered seven thousand five hundred, and his offer was accepted. We also remember seeing in those earlier days The White Girl in the Metropolitan Museum, New York, where Tom Whistler, he told J., sent it to escape paying insurance, and where, later, Mrs. Untermeyer's Falling Rocket was hung. But the Metropolitan Museum only waked up to an appreciation of Whistler under its present Director Mr. Robinson, his predecessor Sir Charles Purdon Clark having calmly announced that he "did not understand Whistler and did not want to."

In I884, after we were married, we went together to England, with much work to do for The Century. One commission was to illustrate articles on Old Chelsea by Dr. Benjamin Ellis Martin, who knew not only Old Chelsea but much of the rest of Old London, and who, from that summer until the day of his death, had for us the further charm of being as American as Americans used to be and are no longer, seeming all the more so against his English background. The scheme was to get Whistler to make drawings or etchings for the articles and J. went to see him about this in his studio at No. I3 Tite Street. At the time E. had undertaken to keep a diary which we wish she had succeeded in doing. The record of the work in Chelsea went no further than " J. to Chelsea" until Monday, July I3th, I884, when a few details were added in the first Whistler note she ever made:

Monday, July I3th, I884. J. to Chelsea, and called on Whistler about The Century work. Whistler was at lunch in a blue and yellow room-asked J. to stay. J. asked him about the Thames plates which Whistler said were all done out of doors. Talked for two hours-mostly about himself and his work. Pointed to a 4

[I880-I 885 
nocturne of Fireworks at Vauxhall-said it was the finest thing that had ever been done, that critics pitched into it, but that any tot knew it was fireworks - then showed a pastel of a girl with an umbrella_"a classic"-asked J. to come again.

J. remembers most distinctly other details of that visit. He remembers there was a curry for lunch because it was the first he ever tasted. He remembers that when he asked Whistler to do the drawings, Whistler said, "I can't, but"-turning to Mortimer Menpes, who until then had lingered unseen in a corner-"here"s a chance for you. You will do these things." "No," said J., "if you cannot, why, I'll do them myself." And from that moment they began to get on terms. We know now it was because of this speaking up to Whistler that we got on with him always-also because we were, as he was, real Americans. And J. remembers it was on that day he first saw the Sarasate, in the studio, looming up at the end of a long dark passage which led to it, looking just as Whistler wanted it to look, as if the violinist were standing on the darkened stage. Like the Meniñas, the Sarasate should be shown alone in a properly lighted room. J. remembers also that Whistler sent him that afternoon to an old photographer in a by-street who had photographs of some of his pictures and also views of Old Chelsea. Then Whistler asked him to come to his show being held at Dowdeswell's in Bond Street-it was the show of Notes, Harmonies, Nocturnes, 1884, in which were many of his Cornish sketches-but J's. memories of that first summer in London, so crowded with new adventures and new impressions, are all confused. One, however, stands out with greater vividness, the memory of the day when, going into Charing Cross Station, he saw Whistler at the book-stall, the only time he ever saw him in his long frock coat, white trousers, and top hat, carrying his long cane, and $\mathrm{J}$. did not like his looks and avoided him.

At this period, and during the greater part of his life, when he was in the studio at work, Whistler looked not unlike an old-fashioned American barkeeper because he wore a white waistcoat with sleeves which all bar-keepers used to wear, and also because he had the thick curly hair which many of them cultivated. They juggled with glasses, a lost art in this home of hypocrites; he mastered paint, as every artist thinks he has in this land of artless imitation. We have seen an oil portrait of him by himself in this costume. But after his wife's death he added a black coat over the white jacket. I880-1885] 
Out of the studio and in the street he dressed for some years as J. saw him at Charing Cross. If he changed, it was probably for something more exaggerated. G. A. Holmes, a Chelsea artist, is one among many from whom we have heard of this side of Whistler and of the variations in dress he invented. He remembered "the day I sauntered up Pall Mall with Whistler who wore a flatbrimmed top hat, long black frock coat, white waistcoat and white trousers, and carried the long stick, and-well-some people did observe him." Frederick Jameson, with whom Whistler shared a studio for almost a year, put these exaggerations down to Whistler's gaiety and fun which gave him a new idea of life, he said, of what life might be. It was this sense of fun above all that made Whistler do the astonishing things he did, and Jameson delighted in the memory of him walking out with two umbrellas, one white and one black, and his explanation that the black was in case it rained, and the white in case the sun shone. The joy was malicious when he returned from Venice wearing the coat with a cape he had bought there: as great a sensation in Bond Street galleries as among Sackville Street tailors. He posed in it to photographers and to $\mathrm{Mr}$. Menpes, as if bent on handing down the joy to future generations. But when convention required it he could be as conventional as anyone. In these matters he had a sense of appropriateness. Circumstances made the difference in his dress just as he felt age did in the appearance of Napoleon who, he said, "was quite right when young and struggling for success to have long wild hair and thin haggard face, and equally right, when older and success had come, to be smooth and sleek and develop a corporation."

This Whistler of the strange costumes was the man the world got to know through Ape's and Spy's cartoons and later, in a garbled version, through the numerous caricatures of Mortimer Menpes and Walter Greaves, too exaggerated to be authentic; also from the Chase portrait, now in the Metropolitan Museum, painted the summer after we came to London. The impression Whistler's dress made on those who did not know him was "startling." We have heard from Emil Claus how it struck Constantin Meunier. Claus, with other Belgian artists, was in London during the War which he tried to forget by recalling the past. Dining with us one evening, he began to talk of Meunier whom he described as simple in manner and dress and every other way. He had gone once to Paris with Meunier for the Salons, but, he happened to be alone at the Champ-de-Mars when he saw a curious figure with flat-brimmed hat-chapeau calicot-and monocle and of many 


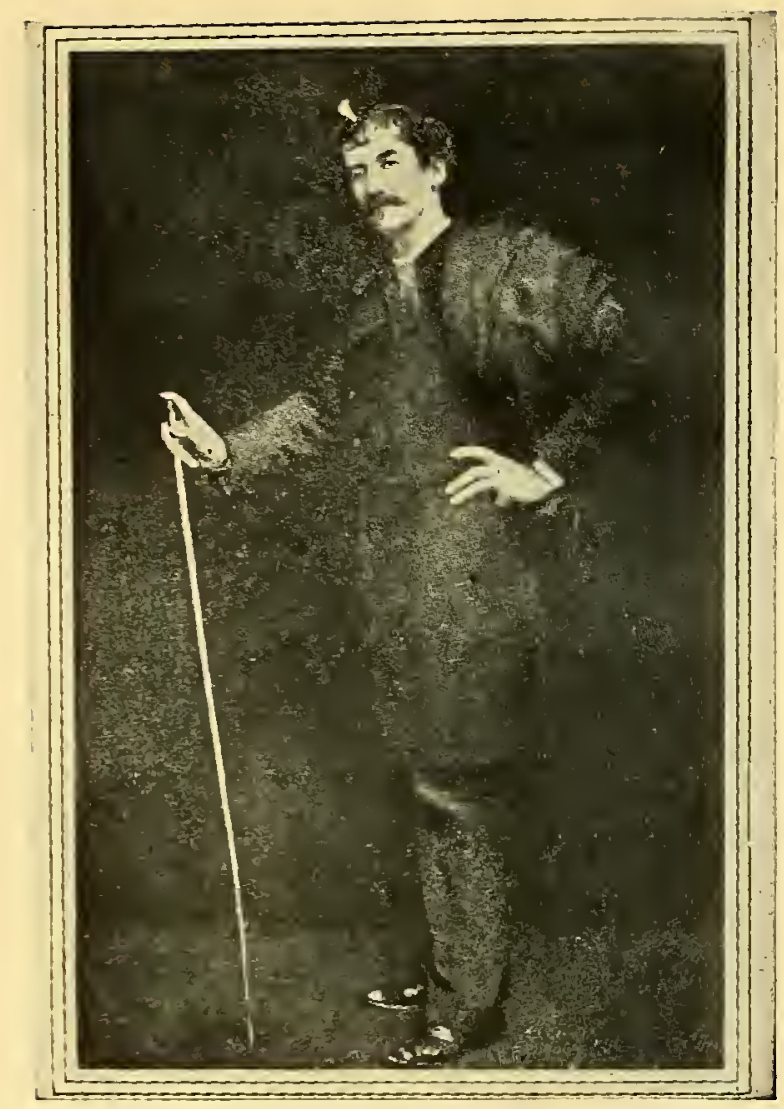

WHISTLER ABOUT THE TIME OF HIS RETURN FROM VENICE

Photograph by Mendelsohn

Loaned by Burton Mansfield, Esq.

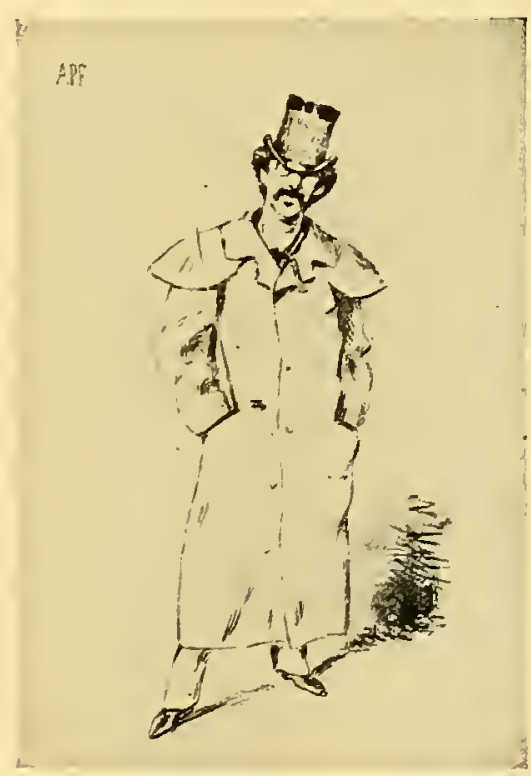

PORTRAIT BY CARLO PELLEGRINI. "APE"

DRY-POINT 


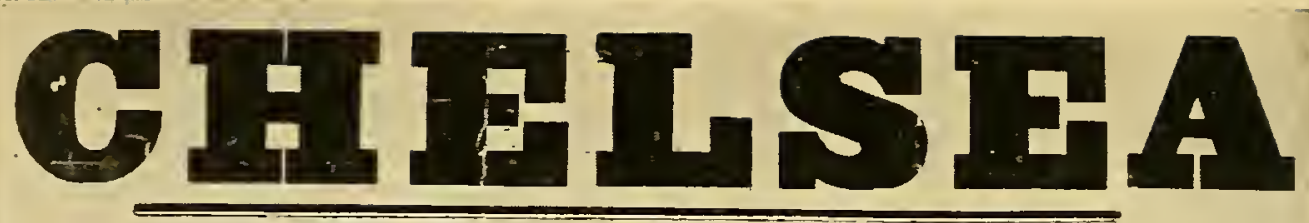

Ebonized \& gilt Drawing Room Suite 3-Ft. LAC JAPAN CABINM, JAPANESE SCREEN,

COTHAGP PIANOFORTE

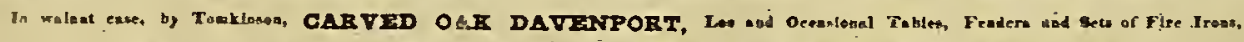

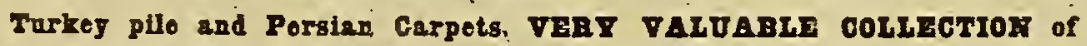

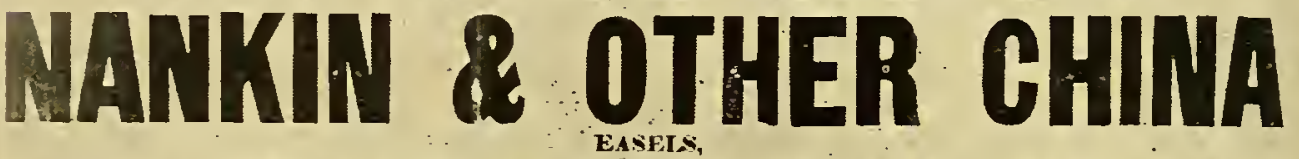

Fittings of Dining Koom, Japanese Camphorwood Cabinet,

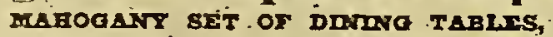

VALU ABLE COLLECTION DF

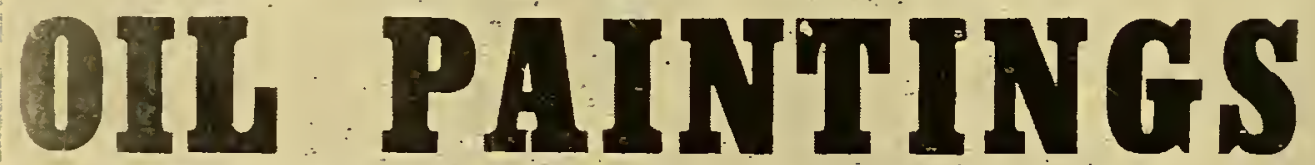
Alchings and Drawings,

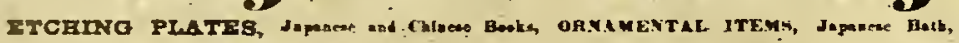

THE APPENDAGES OF BED CHAMBERS

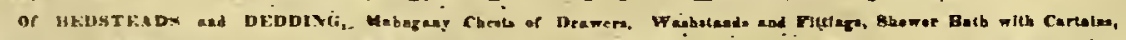
100 Dzs. Nilver Plated Articles

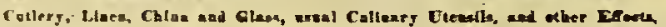
. HICH WILL, HF SOLD BY AUCTION, BY MESSRS.

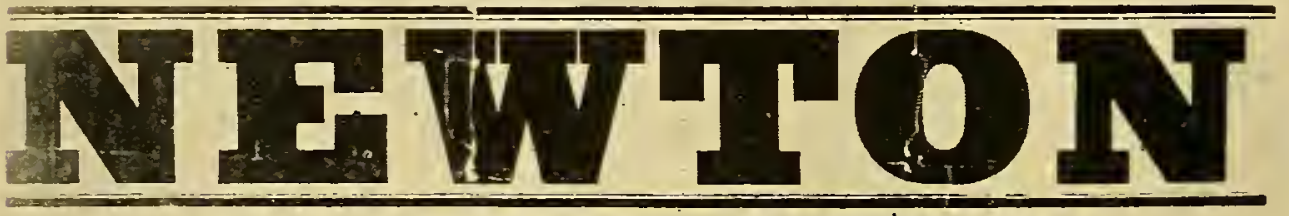

On the Premises of Mr. Wrarstrin, "THE WHITE HOUSE," TITE STREET, CHELSEA, On TEDITSSDAY, MASY 7th, 1879 69. CEANCERT LANE

POSTER OF THE SALE AT THE WHITE HOUSE

PROOF

On the premises of $M r$. Whisller omitted from poster used. Pennell Collection, Library of Congress, Washington 
poses. He asked who it was, and was told, "Vistlaire." That evening he and Meunier were at the Café Napolitain. The same curious figure appeared, stood a minute at the door, the flatbrimmed hat down over his eyes, in his hand a tall slender stick. Everyone stared. To Meunier, who was staring with the rest, Claus whispered "Vistlaire!" Meunier said "C'est dommage!" and that was all. Had Whistler sat down and talked, Meunier would have forgotten the flat-brimmed hat and the long stick and the pose, and been conscious only of the artist. That was always the way with those who could understand. But we wonder whether, that evening, Meunier was wearing his sweater and his béret in which he also liked to pose for the photographer? Both were artists, and that is all there is about it.

Confused as J's. memories are of our first year in London, we have nothing else to depend on and, at least, they are fuller than that earliest of all the note-books, in which there is but one other reference to Whistler, and it is vaguer still:-

Monday, August IIth, I884. After lunch at the Holborn, went to Chelsea. J. P. made a sketch from the bridge. I wandered and watched a boat-race which had crowded the Embankment. After it was over, walked about Chelsea. Saw Rossetti's house and Turner's and the one Whistler used to live in. Then home by the steamboat.

"The one Whistler used to live in" was the White House where his stay six years before had been cut tragically short by the Ruskin case and the bankruptcy. An empty, bare little note this, not a word in it as to the look, the condition of the house, only interesting for the reference to the penny steamboat on the Thames, one of the London joys of those old days gone forever.

There is no mention of Whistler after this until several months had passed and we were in Venice where Whistler was the hero of the cafés and trattorias Duveneck introduced us to. It was little more than four years since Whistler, in his wide-brimmed hat and flowing tie, penniless and waiting for payment, watched over by Maud, tireless, working from dawn to dusk, had become a rival of Duveneck with the "Boys," and created the Whistler Legend. But the Venetian note-book has disappeared for the moment, gone astray in the chaos of breaking-up our Adelphi Terrace flat and ending our thirty-four years' life in London-another of the little horrors of the great useless war.

I880-I885] 


\section{The Whistler Journal}

This brings us to our return to England in the late spring of $\mathrm{I} 885-$ shortly after Whistler delivered the Ten O'Clock which we never heard-and to our settling down in London, and the days when we not only listened to Whistler stories and looked at his work, but got to know him, the knowing gradually growing with the years into friendship and intimacy.

CHAPTER II. THE BEGINNING CONTINUED. GETTING TO KNOW WHISTLER BETTER. THE YEARS EIGHTEEN EIGHTY-FIVE TO EIGHTEEN NINETY-SEVEN

WE have no notes of Whistler for $\mathbf{I} 885$, the summer of our $W$ return to London, but many memories. It was the summer that Whistler and Chase were painting each other: Whistler making Chase "beautiful on canvas, the Masher of the Avenues," but the portrait never seen since; Chase making the weak caricature now at the Metropolitan which could so much more easily have been spared. As time went on, J. began to run across Whistler occasionally at private views and galleries and functions, but it was not until Henley and The Scots, changed to National, Observer, came up to London in $\mathbf{I} 892$ that he saw much of Whistler and learned to understand him.

Before this, however, an incident in connection with The Scots Observer had been the cause of a second meeting, and a very friendly one. Sir Hubert von Herkomer published the libretto and music of his play $A n I d y l$, and he illustrated it with pen drawings, reproduced by photogravure and faked up with a little dry point, which he tried to sell as etchings. J. wrote an open letter to the eminent professor, in The Scots Observer saying frankly what he thought of the professor's proceedings. In doing so he was supported not only by Henley, the editor, who was keenly sympathetic, but by Seymour Haden, though, naturally, Haden went back on him as soon as he heard that Whistler also was supporting J. Whistler's support was active. He wrote a letter to The Scots Observer condemning Herkomer, who there upon, or shortly after, retired from the Slade Professorship, as Ruskin had previously retired when Whistler annihilated him, and Herkomer disappeared as an etcher. This took J. to Whistler's at 2I Cheyne Walk, the only time he was there. He remembers that the house down stairs, which was all he saw of it, looked as if it was just being moved into or out of. There were no pictures, only packing cases about, and little furni8

[1885-I 897 


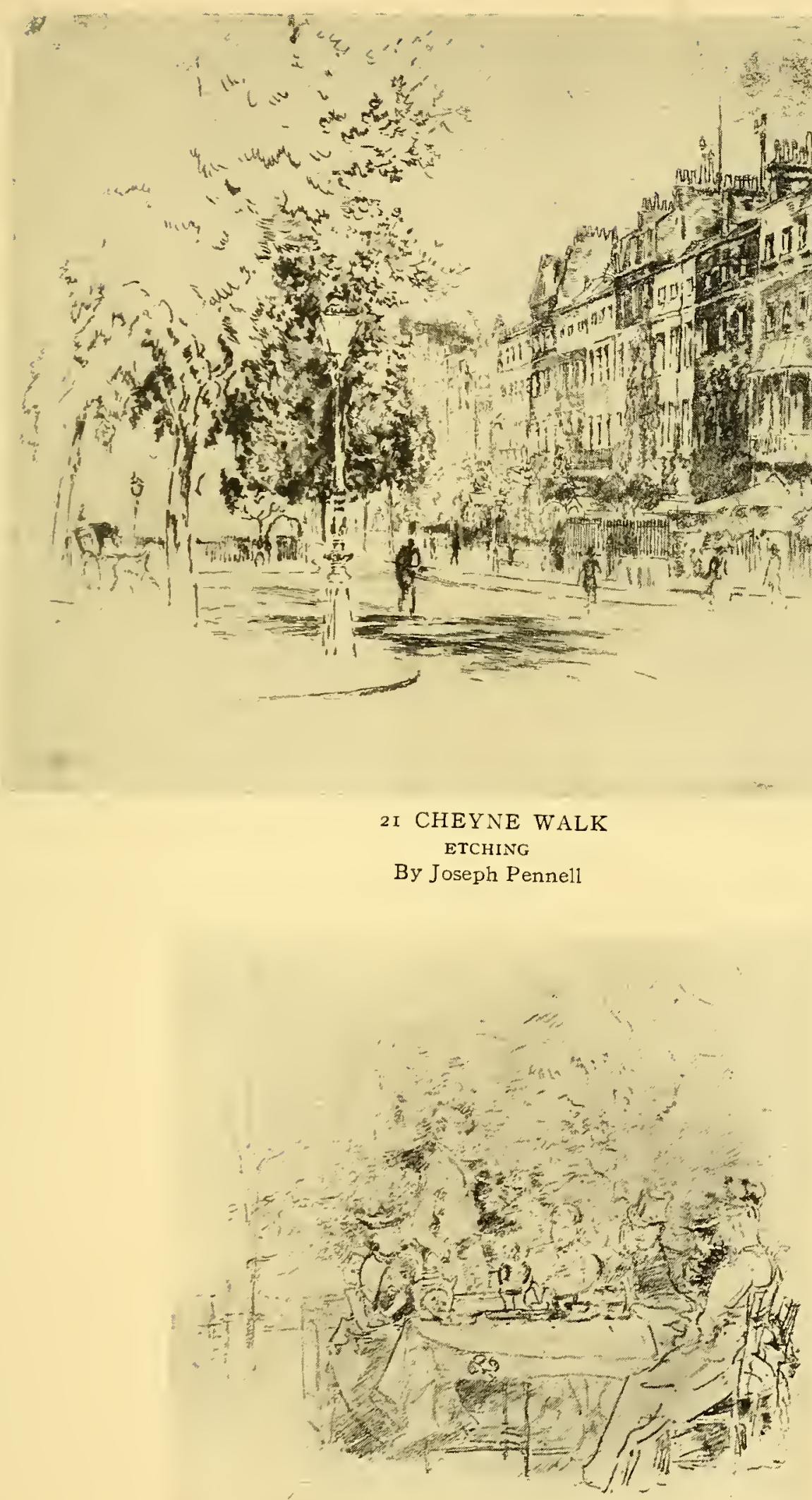

IN THE GARDEN OF SAME

LITHOGRAPH. W. 38

The print contains portraits of Walter Sickert standing, Brandon Thomas in top hat, Charles Whibley, Mrs Whistler, $M$ iss Ethel Birnie Philip and others

By permission of Messrs. Kennedy and Co. 


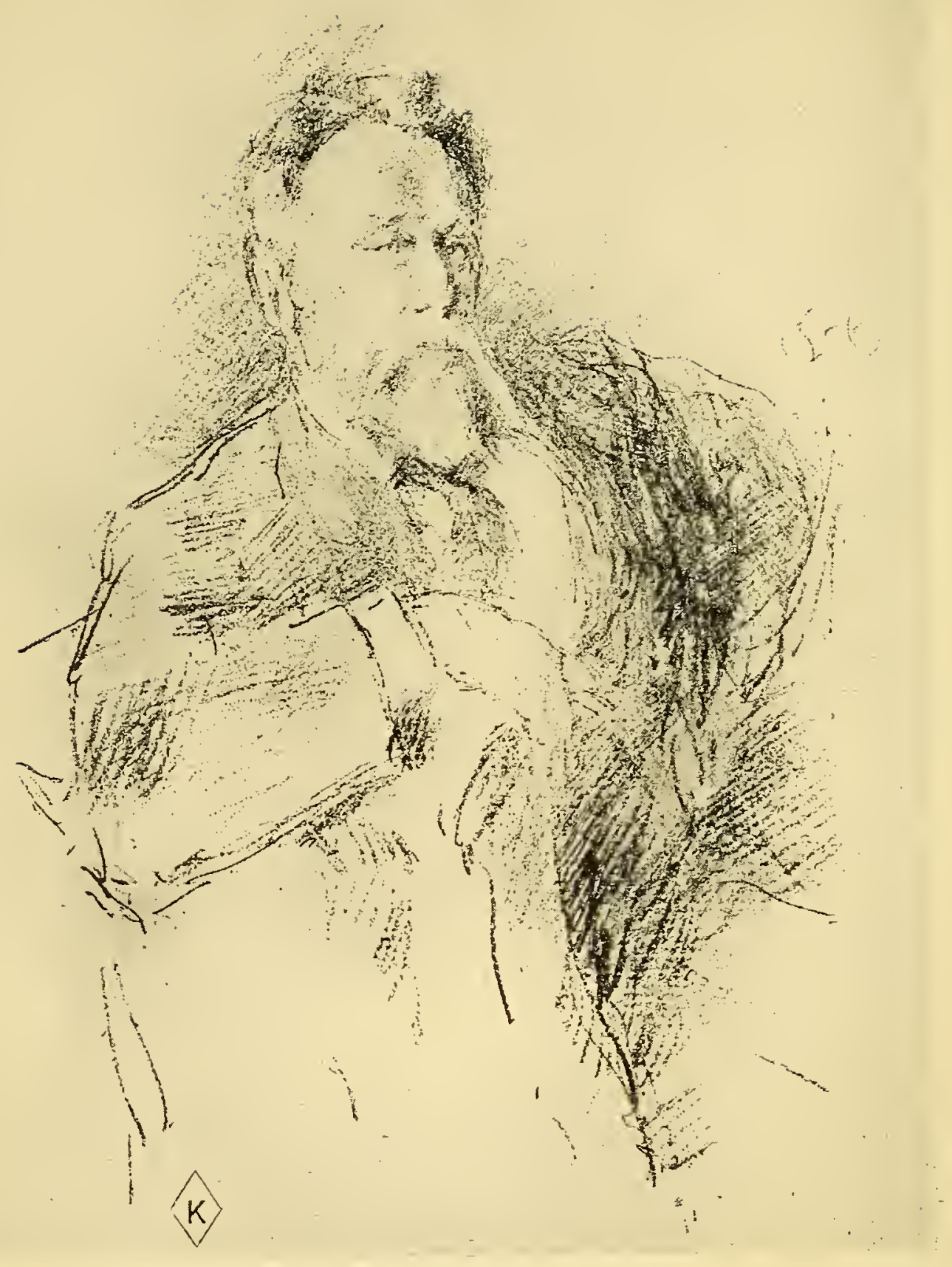

W. E. HENLEY

LITHOGRAPH W. I 27

By permission of Messrs. Kennedy and Co. 
ture. He also remembers Mr. Walter Sickert coming in and being promptly sent out to post a letter, for in those days Mr. Sickert was still one of "the Followers."

Later, when we were all mixed up with The National Observer and The Pall Mall Gazette, J. used to find Whistler in Henley's rooms and Charles Whibley's flat-delightful evenings spent in both places-and also at Solferino's, the little restaurant in Rupert Street, where The National Observer staff and The Pall Mall crowd would meet and Whistler would drop in. Presently The National Observer men began to give themselves dinners in an upstairs room, Henley at the head of the table, on one side Harry Cust, editor of The Pall Mall, on the other Hamilton Bruce, proprietor of The National Observer, and up and down both sides, J., Arthur Morrison, George Steevens, Bob Stevenson, Charles Whibley, Charles Furse, J. M. Barrie, Harold Frederic. And once in a while some one, Barrie probably, would bring Conan Doyle, though what he was doing there it would be hard to say, unless it was that after a certain hour in the evening the diners would make bets as to which was Frederic and which was Doyle. Sometimes Whistler would appear and, as he became more intimate with Whibley, he would go oftener to Whibley's rooms, now on the Embankment at Millbank. There was brilliant talk and some of the things we have related in the Life occurred at Whibley's and at Solferino's and at the Hogarth Club where also Whistler occasionally went. But all this is vague. J. recalls with less vagueness the night Whistler had promised to come to a dinner at Solferino's and did not come on time. The others would not wait. Instead, his empty chair was solemnly asked, "Mr. Whistler, will you have some of this?" And he was served with everything from the soup, one course piled in the plates upon another, and his glasses were filled. At last he arrived-with dessert-was shown his place, took it all in, and, without a word, ate his cold dinner backward. Not one of them dared to make any comments, nor did he. He could take a joke among friends who were really his friends.

During this period J. began to write a column on art signed "Artist Unknown," for The Star, succeeding George Bernard Shaw who gave it up for music, or socialism, or something or other, and at the same time Bob Stevenson, whom we had got to know through Henley and Whibley, did the art criticism for The Pall Mall Gazette. D. S. MacColl had just come up to London and George Moore was trying to chip in, writing on art for The Speaker. MacColl became the mouthpiece, first in The Spectator and then in The Saturday, for the New English Art Club and, as Whistler I 885-I 897] 
had occasionally shown with the New English, "D.S.M." reluctantly stood by him. George Moore praised and then qualified the praise and never understood, as Modern Painting amply proves. But J. believed, and Stevenson believed in Whistler's art always, and they wrote about it always, and soon the triumph came with the exhibition of Nocturnes, Marines and Chevalet Pieces arranged by D. Croal Thomson in I892 at the Goupil Gallery. Mr. Thomson told us years later how he brought it about. The Carlyle had been bought for Glasgow, and shown at Goupil's where all London crowded to see it. Thomson, rejoicing in its success, said to Whistler that the time had come to make really an exhibition. "Of what?" asked Whistler. "You know what I mean," was Thomson's answer, "we can't do anything with pastels and water colours. We have got beyond etchings and lithographs which have been often exhibited. It must be pictures." And pictures it was, and, the decision reached, Whistler spared no pains to get together a representative series. It began with early paintings, The Blue Wave, Old Battersea Bridge, The Music Room. It included the Japanese subjects. It gloried in portraits of many periods, from the Miss Alexander to the Lady Meux. It found a place for some of the most beautiful nocturnes. Never before had there been so magnificent a proof of Whistler's mastery and variety. Whistler looked in for a minute at the press view. The room was crowded with the critics who had come to laugh and remained to try to toady. There they were, Humphry Ward of The Times; Sala or Claude Phillips of The Telegraph-it was only a change of names; Wedmore of The Standard, whose critical record will remain in Whistler's brown-paper-covered catalogues; Walter Sickert who ceased to be a "Follower" to become one of the "Enemies"; Stephens of The Athenaum; and all the rest. The enthusiasm was great, but Whistler never forgot, and the almost universal praise next day in the papers could not wipe out the past and the old empty ridicule. But on private view day Whistler, taking Bob Stevenson and J. away into Mr. Croal Thomson's little curtained-off room, said nothing about what they had done for the exhibition but told them that he had just heard of the death of the Duke of Marlborough, who had wanted to be painted by him and had invited him and Mrs. Whistler to Blenheim, where, the Duke wrote, they would "all work like niggers." "Well, you know," Whistler said, "I accepted the commission, the first of that sort I ever had, and I wrote him so-one of my charming letters-and now I shall never know whether my letter killed him, or whether he died before he got it. Well, they all want to be painted now, 


\section{SMALL COLLECTION \\ of \\ NOCTURNES \\ MARINES \& CHEVALET PIECES \\ MR. WHISTLER \\ - THE GOUPIL GALLERIES \\ FOR \\ THREE WEEKS ONLY

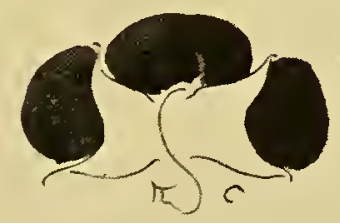

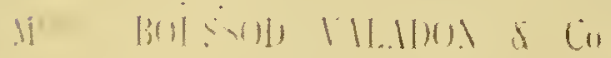 \\ Wf $\mathcal{E} 117$ VIV BOMD STREET \\ March 2I to April 9}

POSTER FOR EXHIBITION OF NOCTURNES, MARINES AND CHEVALET PIECES

Pennell Collection, Library of Congress, Washington 


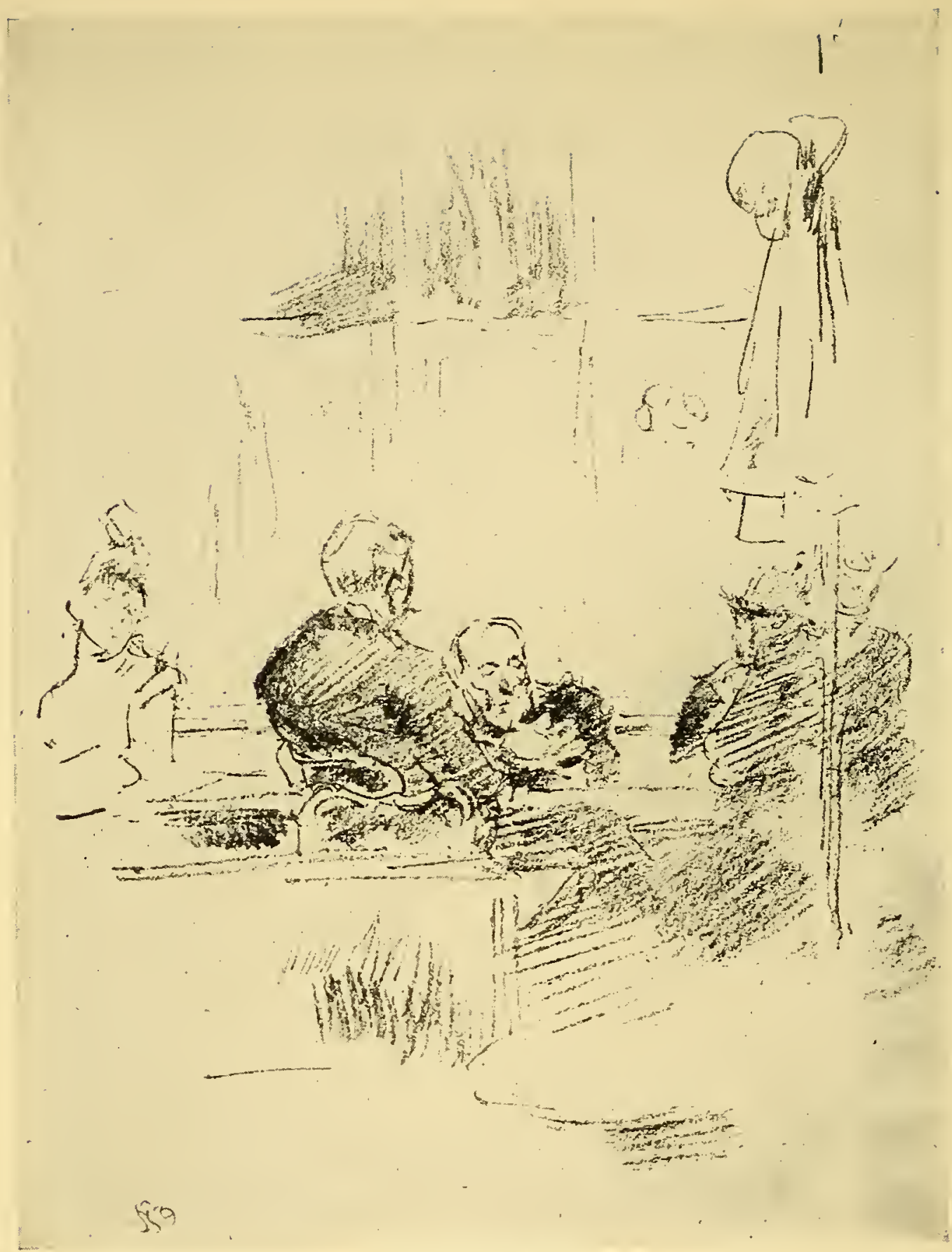

LATE PIQUETTE

LITHOGRAPH. W. 57

By permission of Messrs. Kennedy and Co. 


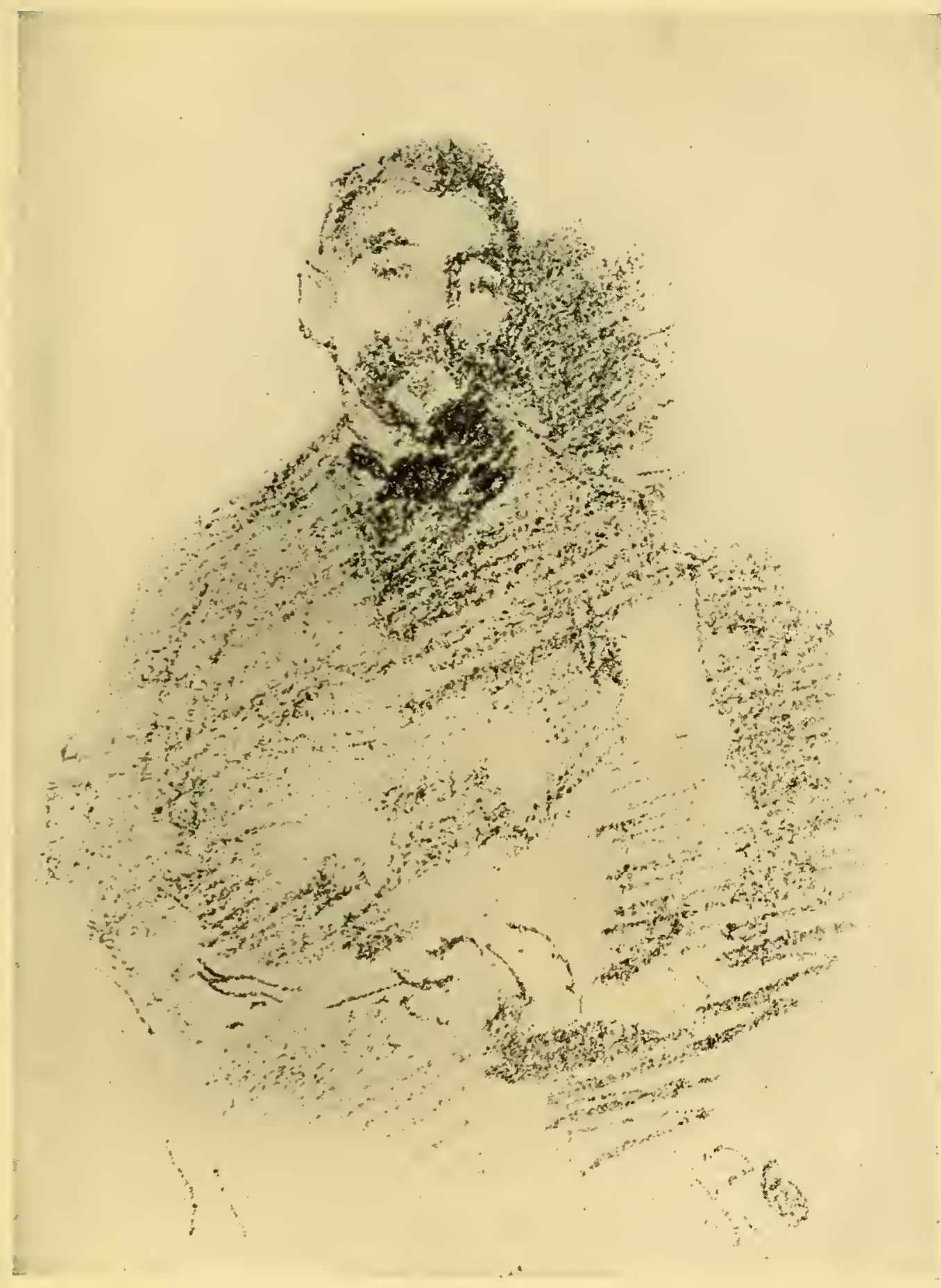

STÉPHANE MALLARME

LITHOGRAPH. W. 66

By permission of Messrs. Kennedy and Co. 


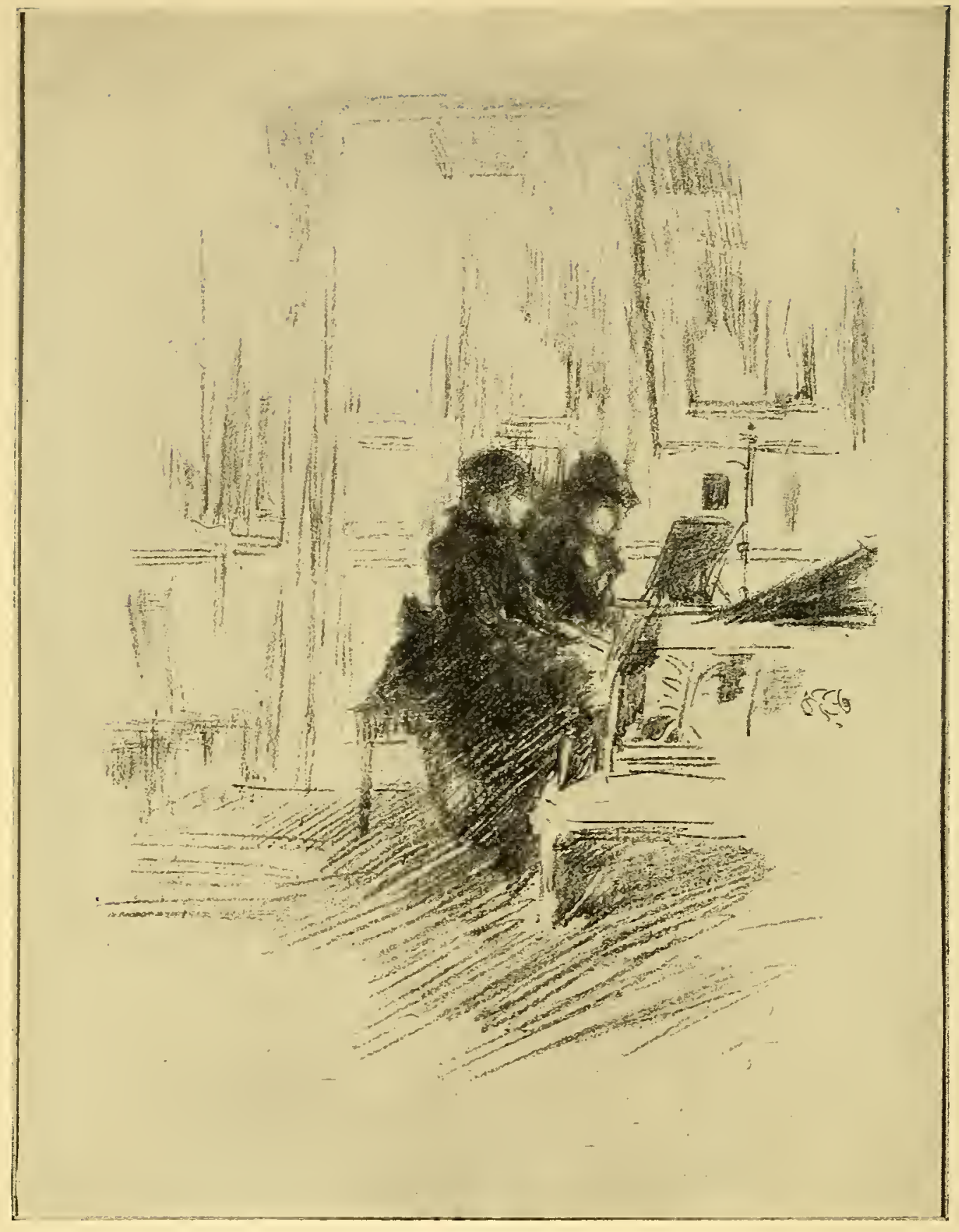

THE DUET

LITHOGRAPH (UNDESCRIBED)

In the possession of Messrs. Knoedler and Co.

(See page I 2) 


\section{Getting to Know Whistler}

but why wouldn't they be painted years ago when I wanted to paint them and could have painted them just as well?" Whistler's comment upon the Duke's death is not unlike his complaint when, after one of his "most amazing letters" to Sergeant Thomas, his publisher, "What did Thomas do but die by return of post!" It is worth noting that the Duke was to have given Whistler two thousand guineas for the portrait which, it was agreed, would be a large full-length, or, if Whistler would also paint the Duchess, three thousand pounds for the two portraits:- the new prices that the turn in the tide of his fortunes brought with it. This shows that the Duke of Marlborough had courage, especially as he seems to have shared the popular idea of Whistler, the man. "You must stick to painting and give up writing letters about R.A's. and A.R.A's.," is the condescending advice with which the letter ends. From the Goupil Gallery J. went on with Whistler and Bob Stevenson to the Arts Club, to which Whistler then belonged, to Solferino's to dinner, then to the Savile Club of which Stevenson was a member, and very late they sent Whistler home in a hansom, wondering if he had money enough to pay for it. J. does not remember what he talked about all evening save that much was said of the new flat in Paris to which he was moving. He was serious, for it was a serious occasion-this moment of triumph or, rather, the beginning of his triumph-and he took it seriously. It was too serious for talk. But he knew perfectly well and proved that he knew, who were the two men who had helped to bring it about by making evident what he had done. And that afternoon J's. intimacy with Whistler began.

Some months later, J. was going somewhere on the Continent and stopped in Paris. Whistler had not got into the flat but was staying at the Hotel du Bon Lafontaine- "inhabited by the nobility. and clergy," he used to say-and there J. found him drawing the portrait of Mallarme for the frontispiece of Vers et Prose. This little drawing marked a new departure in the art of lithography. Instead of using the sticky brittle German transfer paper, he laid a sheet of thin Japanese tracing paper on a rough book cover and drew on it, shifting the paper as he drew to get a varying grain. But before he got the result he wanted, he made many drawings. Lithographers have usually discussed the difficulties of their art, Whistler overcame them before he spoke of them. J. thinks it was that evening, when Mallarmé was tired posing, that Whistler, gayer than ever, took J. to the little restaurant, more like an English chop-house with its sort of boxes, in the Passage des Panoramas, much haunted by Duret, Drouet, Beurdeley, VieléI885-I897] 


\section{The Whistler Journal}

Griffin, the last of whom alone was there that evening and it was the only time J. ever met the New Orleans French poet. The next day Whistler showed J. the new flat in the Rue du Bac. And then they went their ways.

The following spring-I893-J. returned to Paris to make drawings of Notre-Dame for our book on The French Cathedrals. To the top of the tower Whistler toiled to find him one morning after he had climbed in vain to the top of the house on the Quai-des-GrandsAugustins, where J. was staying, drawing out of the windows, and where, in the café downstairs, Whistler wrote his disappointment at not finding him to J., one of his earliest letters to either of us. Over lunch, under the shadow of Notre-Dame, he explained that he wanted J. to help with his printing-he was biting and printing the last Paris plates which no one had seen. This was arranged, though only after endless postponements and after J. finally said that he knew Whistler could teach him just what he wanted to know, but he could not afford to spend his time running about Paris, lunching and dining instead, even with Whistler. At once the printing began and the friendship became more intimate and its terms better understood.

For weeks in the summer of $\mathbf{I} 893$, either at the printing press in the Rue Notre-Dame-des-Champs or at the Rue du Bac, J. was with Whistler almost daily. Work stopped on the Sunday afternoons, when sometimes all the world came to Whistler's and sometimes no one came. And there were excursions to all sorts of places, from St. Denis to Fontainebleau. It was the summer of the Sarah Brown row when the whole of Paris was upset by the students' rising over which everybody went mad, except Whistler who thought it absurd. It was the summer when Whistler signed his will and J.witnessed it.* And it was the summer when Beardsley was in Paris getting the backgrounds for The Rape of the Lock, and when one night, coming away from Tristan and Isolde at the Opera, which gave him his motive for The Wagnerites, and crossing the street to the Café de la Paix, he and J. found Whistler there and J. had Beardsley asked to the Rue du Bac. But this was before The Rape drawings were published, and Whistler's feeling for him was anything rather than friendly. "Why do you go with him?" Whistler said. "He has hairs on his hands, hairs on his finger ends, hairs in his ears, hairs on his toes, hairs all over him." Yet Whistler asked Beardsley for the next Sunday afternoon, promised to dine with him and never turned up.

* Note-He later made another will, a copy of which is in the Pennell Collection, Library of Congress, which I did not sign. 


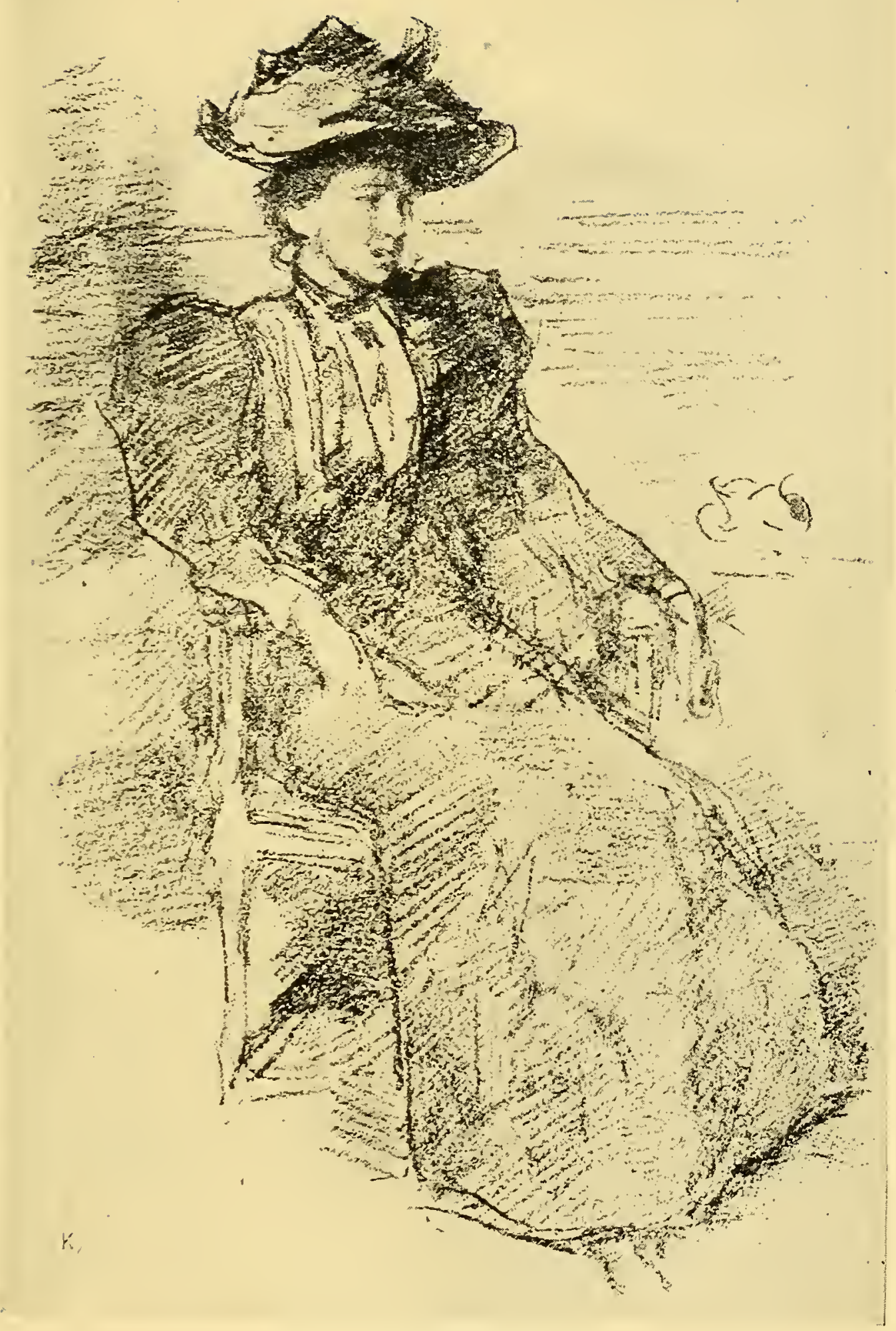

MISS MILDRED HOWELLS

LITHOGRAPH. W. 75

By permission of Messrs. Kennedy and Co. 


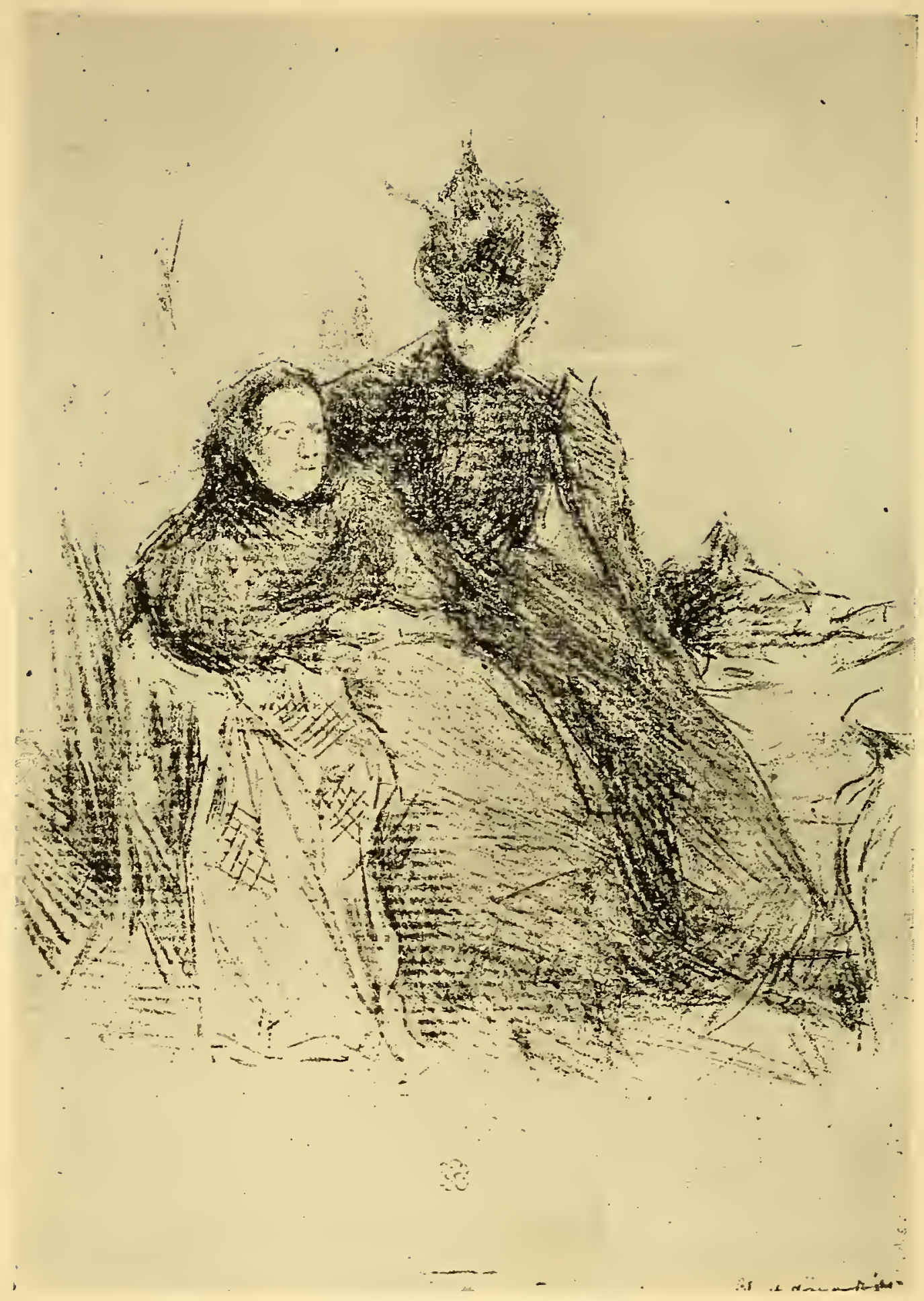

MOTHER AND DAUGHTER

LITHOGRAPH (UNDESCRIBED)

In the possession of Messrs. Knoedler and Co. 


\section{Getting to Know Whistler}

In the beginning of May E. also was in Paris, doing the two Salons. She has no memories of Whistler, even vague, during the years between I 885 and I 893 when J. was of ten seeing him, and she has no notes, her diary having long since been given up as impossible to fit into her busy life. It still seems strange to her why she never met Whistler, never so much as saw him, for she too did more than one weekly column on art and was much at exhibitions, galleries and art functions. But her first meeting was in May 1893, when Whistler, learning that we were in Paris, asked us both to Sunday breakfast in the Rue du Bac. She remembers the walk with J. and MacColl across the Seine and up the long street in the May sunshine, finding the big porte-cochère of No. IIO and the dark passage that led to the bright little courtyard, and the blue and white door in the sunlight at the end, and the welcome they received from Whistler. The breakfast was gay. Mrs. Whistler presided and, besides ourselves and MacColl, Mr. and Mrs. Edwin Abbey were there. It was the day he told us the story of the babies at Liverpool-which we have told in the Life-and the breakfast was something to remember: the beautiful blue-andwhite, the good wine from some Abbe's cellar, the Argenteuil asparagus, the strawberries in a little silver basket at each guest's place.

After this, E. saw Whistler often. She was never in Paris that she did not breakfast or dine at the Rue du Bac. She recalls delightfully an autumn when she arrived after two nights and a day in the train from Madrid, travel-worn, travel-soiled, her baggage on its way to England, and she was taken in as if she were spick and span and could treat dinner as the formal event Whistler always made it. And this time there was a new flat to see, in the Rue Garancière, just being decorated for Mrs. Whistler's sister, Ethel Birnie Philip who was shortly to marry Charles Whibley. This was in the autumn of I894. J. had been all spring and summer, first in Italy and then in Spain and for him there were no meetings with Whistler, who was indignant because, on his return from Spain, he rushed through Paris "in such improper haste." Whistler wanted to hear about his feelings when he looked at Velasquez "whom we have, you know, never seen." This statement of Whistler's in a letter to us demolishes all the ridiculous stories of his mysterious appearances in Madrid where he never went.

J. was home again by the end of October, and Whistler, whenever in London, began to come to us in our Buckingham Street chambers. But he was not in London often until the tragedy of Mrs. I885-I897] 


\section{The Whistler Journal}

Whistler's illness compelled him to be there. The day of her first consultation with her English doctor, late in 1894, E. must always remember, for Whistler kept her to lunch with them at Long's Hotel in Bond Street, where they were staying, and, in his nervousness, would not let her go afterwards while the Doctor was with Mrs. Whistler-would have had her still with him when the Doctor gave his report.

We have already told in the Life how much he was in our place from this time on, when he and Mrs. Whistler were coming and going between London and Paris, to Lyme Regis, back again to London, and from one hotel to another. Almost every afternoon or evening he spent with us during the last months of her illness. It was then, when, tired from a night of watching and hardly refreshed by a morning of sleeping, he would come to Buckingham Street in the waning afternoon, that he lithographed our portraits by the flickering firelight. The afternoon he was making the lithograph of The Russian Schube, he told J. he had taken a studio in Fitzroy Street that he might paint the same subject. He said nothing to $\mathrm{J}$. about this until the studio was taken, and then $J$. had to tell Whistler that he must leave for Italy. Sadly, Whistler said, "Well, I thought some gallery-the Pennsylvania Academy, what?-would have bought it and you and I might have been remembered by it."

J. was somewhere in France when Mrs. Whistler died, on May Ioth, I896, and E. was in Paris, at the Salons. On the Saturday following the funeral E. returned and more than sad is her memory of the next day, Sunday, when in the afternoon Whistler appeared in Buckingham Street, and asked her to come with him to the National Gallery. And sad are many of our memories of the years that followed, though, little by little as they passed, Whistler's sadness lifted. Gradually, we had the people we knew would amuse him to dine with him, and wonderful were the long evenings and the long talks.

His days were full not only of work, but of many schemes. For these were the years of the founding of the International Society of Sculptors, Painters and Gravers, out of which some of the English members tried to keep J. until Whistler made it a condition that either J. should be on the Council, or he would go. And so this time it was the British who went out and Whistler and J. remained, backed by the Scotch, the Irish, the German, the Scandinavian, and the French-Guthrie, Lavery, Sauter, Thaulow, Blanche. The Society really was International, and they brought it off. And these were the years when we were all busy over the 


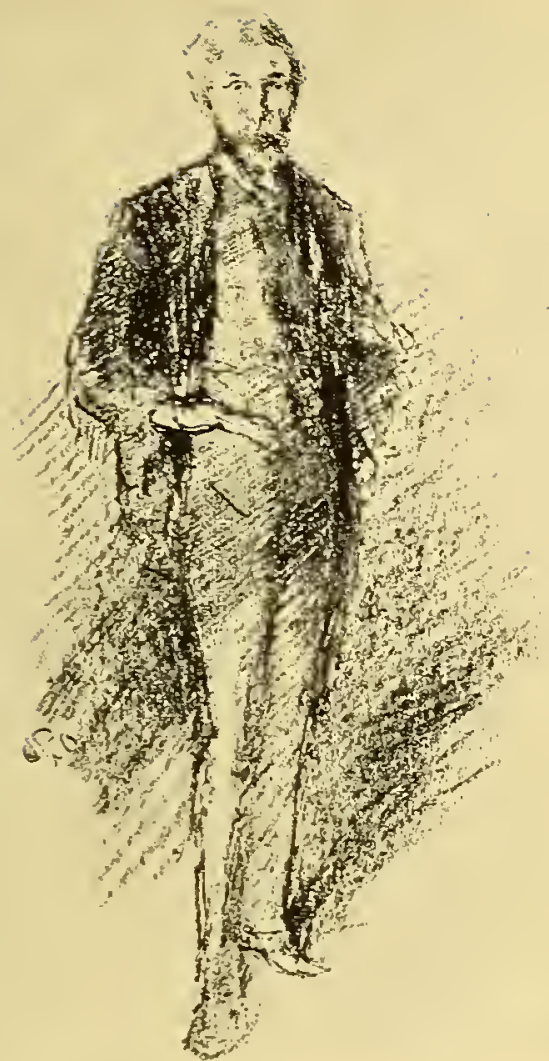

STUDY PORTRAIT OF JOSEPH PENNELL LITHOGRAPH. W. II I

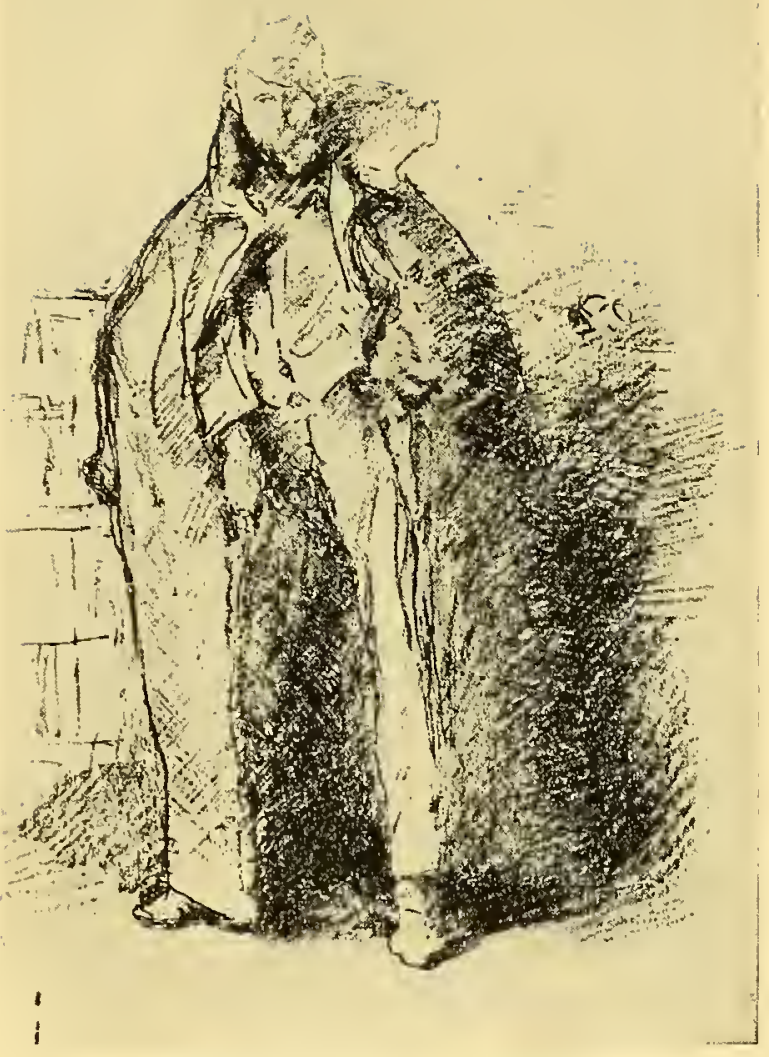

THE RUSSIAN SCHUBE LITHOGRAPH. W. II 2

Pennell Collection, Library of Congress, Washington 


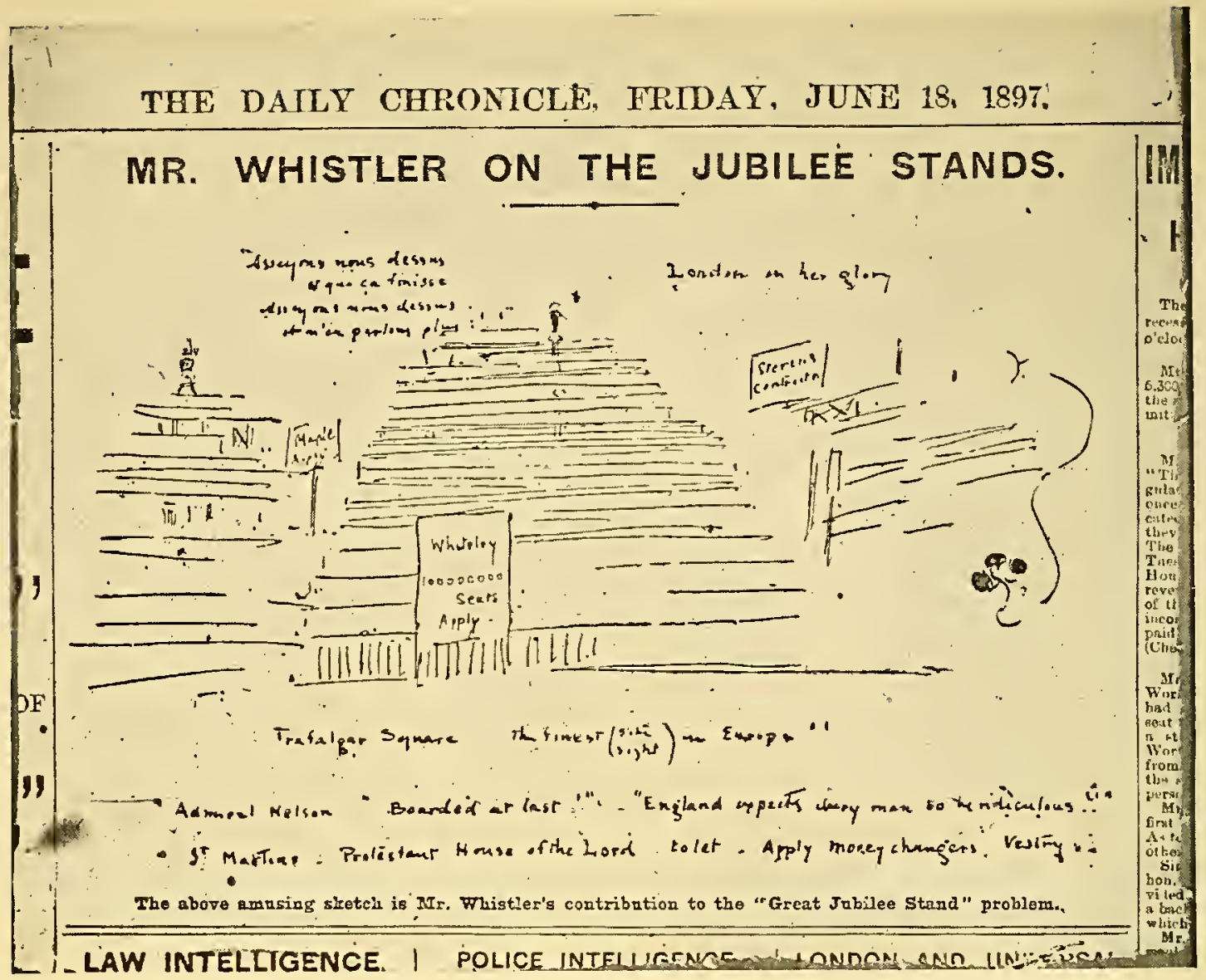

NELSON BOARDED AT LAST

Reproduction from The Daily Chronicle

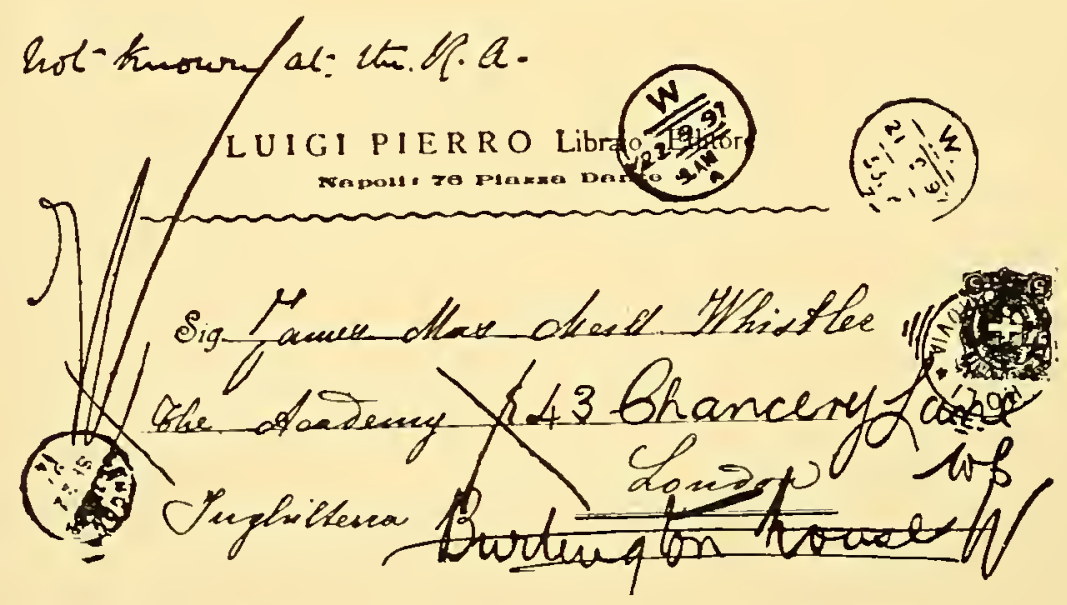

NOT KNOWN AT THE ROYAL ACADEMY

Reproduction from The Daily Mail.

Originals in Pennell Collection, Library of Congress, Washington 


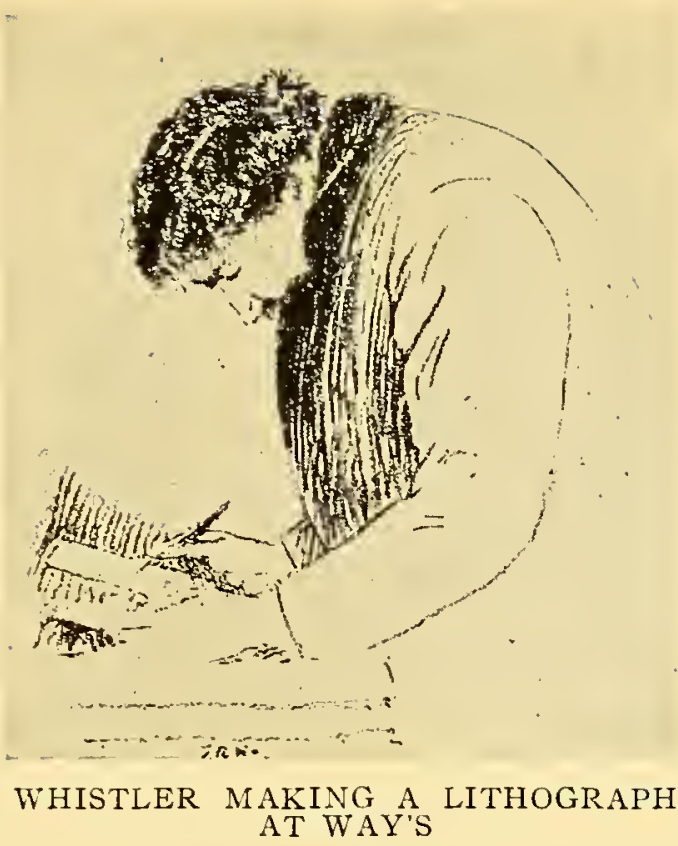

LITHOGRAPH BY T. R. WAY

In the possession of Mrs. T. R. Way

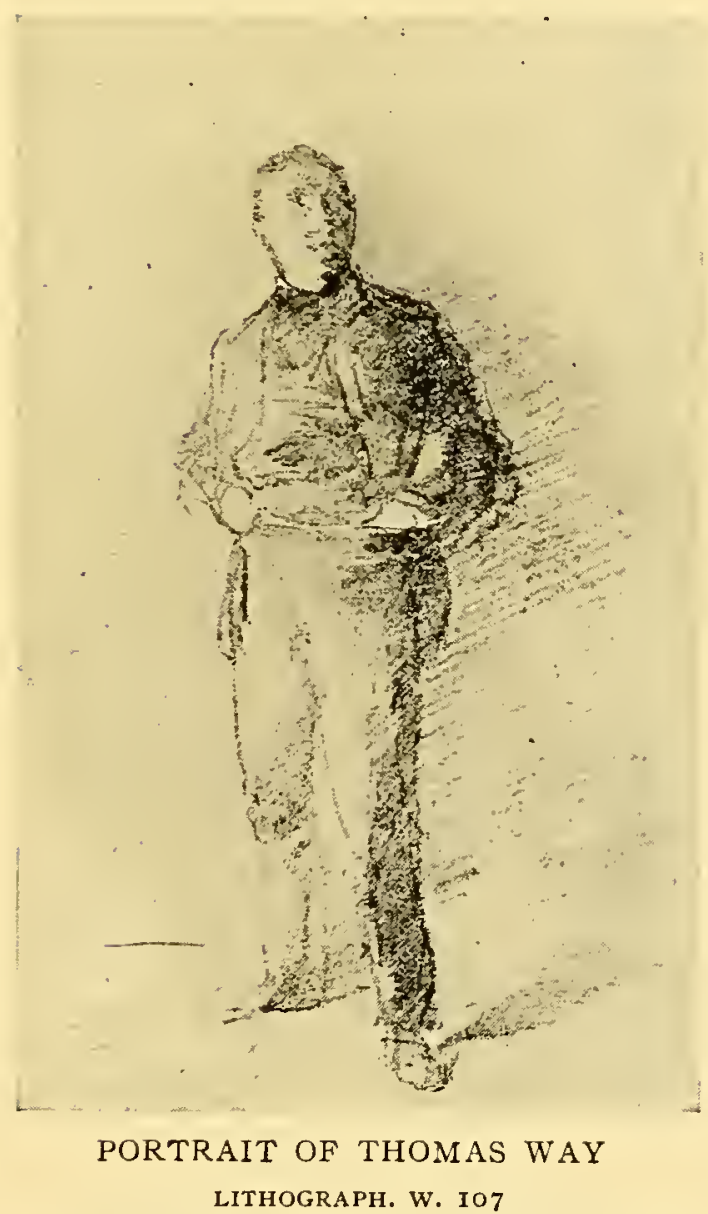

By permission of Messrs. Kennedy and Co. 



\section{Getting to Know Whistler}

Lithograph Case, caused by Walter Sickert and an article he wrote in The Saturday Review, to injure not so much J. as Whistler. Although Whistler was more eager for it than J., he, like the rest of us, was sick of it long before the trial, so sick that the morning before he came to say he would not attend as a witness. "The caśe is as much yours as mine, and you must come," J. said. "Your reputation is involved. There will be an end to your lithography if we lose. You must fight." And he came, and we won. And time was still left in these years for afternoons of working at Way's, lingering to give a last touch to a drawing, or to drink a last glass of Way's rare old liqueurs-"All very delightful," Way would grumble, "but hardly business;" time for making lithographs round London, when he would go out in his flatbrimmed hat and long overcoat, and on the London sidewalk seat himself on his tiny three-legged sketching stool and work away on his little sheets of paper; time too for starting the school in Paris, the Académie Carmen, and to establish in London the Company of the Butterfly, which was to be his own incubator for his own golden eggs, but which succeeded chiefly in proving to him that dealers have their use. It was a nuisance to him almost to the end of his life, his landlord pursuing him to Corsica with bills for rent and complaints of the condition of the outside doorplate-the scheme perfect in theory, he thought, but the trouble was, he had no time for it.

One of these years-I897-was the year of the Jubilee, when Whistler went with the Vanderbilts on their yacht to the Naval Review and delighted all London with his drawing of Nelson Boarded at Last for The Daily Chronicle.

He had begun to go out again, his first appearance in public being the occasion of his last encounter with Haden at a dinner given by the Society of Illustrators, in celebration of the publication of a volume illustrated by the Society, which brought them neither the fame nor the fortune they hoped for. It was called The London Garland and was edited by W. E. Henley. Both Whistler and Haden were Vice-Presidents of the Society, of which Sir James Linton was President. J. induced Whistler, then staying at Heinemann's, to go to the dinner, which was at the Holborn and, being on the Committee, he went to the restaurant early to see about the seats. What was his horror when Haden suddenly arrived, though not expected. There was nothing to do but to put him on Linton's right at the high table where he belonged. But what was to be done with Whistler? The two had not met for probably half a century. A small table was arranged in the middle of the 1885-1897] 
room and at the head of it, with his back to Haden, J. placed Whistler, Heinemann and ourselves on either side. Whistler's reception pleased him enormously, and J. kept Haden safely out of the way until dinner was announced. But both seemed to feel that something was happening, though at first neither saw the other. As Whistler sat down, he produced two or three eye-glasses from his pocket. Still, neither saw the other. The soup came. Some one said something to Whistler and there was a "Ha! ha!". Haden stopped, his spoon in his hand, dropped it in his plate, and fled, followed by another "Ha! ha!" and J. had to explain to Haden that the Committee had no idea he was coming, or he would have been warned. But Haden, too furious to protest, rushed away without a word. Whistler, even then, gave no sign that he saw Haden. But Haden knew the restaurant was no place for him. Later, that same evening, in Heinemann's rooms, when Whistler was brewing his wonderful grog in Heinemann's wonderful old glass, J. described Haden's flight and it rounded out the triumph of the evening. The dinner was long remembered by the illustrators who could appreciate the difference between the two men- "Haden running and Whistler staying and enjoying it," was the way E. J. Sullivan put it years afterwards, and he recalled Whistler's speech which kept us all in a state of expectation for he seemed ever on the point of referring to the incident, only to steer delicately away from it.*

People who did not know Whistler were sometimes bewildered by the many glasses he produced at times from his pocket, and they invented ingenious reasons-none more ingenious than that of Armand-Dayot, Inspecteur Générale des Beaux-Arts. $\mathrm{He}$ and Albert Belleroche were breakfasting with us one day when the talk turned upon Whistler, whom Armand-Dayot met but once, at a dinner given by Mrs. Potter Palmer. He sat on her right, Whistler on her left, and he saw Whistler put up one eye-glass after another, dropping each off in turn into his right hand, as was his habit, and laying it on the table by his place, until there was quite a little pile on the cloth. He supposed, seeing this, that Whistler was bothered by the steam which, rising from his plate, clouded his glass and he preferred putting up a fresh one to wiping it off.

During Whistler's frequent and long visits to Heinemann at this period there were other strange encounters-with Beerbohm, Frank Harris, Shorter, Rothenstein-how he hated Jews! En-

* Note. - For the beginning of Whistler's quarrel with Haden, see the authorized Life of Whistler, sixth edition, page 75 and seq.

I6

[1885-1897 


\section{Getting to Know Whistler}

counters too with friends when he proved his wonderful mastery of the art of making cocktails and toddies. And there were as many encounters in our flat, few more memorable than those with Timothy Cole, at work then in the National Gallery, his talk of art a challenge to Whistler, his fads and fancies a continual amusement, his gaiety a stimulant until it culminated one night in Cole's masquerading as his grandfather, a misunderstanding at the front door, and confusion and regrets for us all. We remember J's. distress as host, fearing an offence to Cole, and in contrast to it Whistler's irresponsibility as guest, delighting in the jest and the mistake and J's. scruples, improvising out of it an Oratorio motive: "How is the old man his grandfather-the old man-the old manthe old man-the old man-his grandfather-his grandfather-his grandfather" - chanting it over and over, keeping it up until J. had to laugh and forget his worries.

These were the years also of endless meetings at Garlant's Hotel or in our own place with Whistler and Mr. E. G. Kennedy, then the head of Wunderlich's-now Kennedy and Co.-and Whistler's agent and good friend, who had bought his etchings as far back as the Seventies when scarcely anybody else thought of buying them. The meetings in London were broken by little journeys; the gayest in memory to Dieppe when Boldini was with us and revealed himself a genius in practical jokes and a boy in the fun he got out of them: whispering it about the Hotel that we were Royalty, though in cycling clothes J. and E. must have looked curiously un-Royal; letting us in for apartments far beyond our means; appearing and disappearing from our side with remarkable agility, and profiting by his disappearances to make our beds pie-fashion, hide our combs and brushes, scatter our belongings; getting up in the night to knock madly at our doors and frighten us out of sleep; down stairs at dawn and away to Paris before our wrath over our bill, and his which he left Whistler to pay, could fall upon him. And Whistler, through all his nonsense, shrugged his shoulders, and Kennedy paid.

But during these full years there were no Whistler notes, great as was our opportunity. 
CHAPTER III: THE FIRST IDEA OF THE JOURNAL. THE PRE-RAPHAELITES AND OTHERS. THE YEARS EIGHTEEN NINETY-SEVEN TO EIGHTEEN NINETYEIGHT

THAT there were any notes before our Whistler Journal was 1 begun we owe to Robert Underwood Johnson, at the time Associate Editor of The Century. In the late summer of 1897 Mr. and Mrs. Johnson passed through London and we asked Whistler to meet them at dinner. Our dinner-table was small, six the number it limited us to. But six is the best number for talk, and there must have been good talk that night. For Mr. Johnson remembered it so well that, on his return to New York a few months later, he wrote us from The Century Office:

Dear Mrs. Pennell,

"December 6th, 1897.

... And now we want to stake out another claim on your territory. We have obtained the right to engrave Boldini's wonderful picture of Whistler, and we wish from you an article on him which shall be in the nature of a record of such of his table talk as may be of public interest, with all sorts of picturesque incidents of him, such as may not be undignified either on his part or on ours. Outside of the range of his whimsicality and the objectionable side of his career, there is a substantial and vital body of artistic thought and criticism which it would be useful to make known. It is not necessary that this article should appear during his lifetime, and we particularly wish that the matter should not be mentioned to him-at least until the article is completed; but you are in a position, without any violation of hospitality, to make record of a great deal that is interesting and properly publishable about his artistic life. You remember his saying the evening we were with you that it took the nouveaux riches a long time 'to grow up to the portraits we make of them.'

Will you turn this over in your mind and let us know your attitude toward it? What we want to feel is that anything you may have to write, now or hereafter, will come to us. . . .

Very sincerely yours, R. U. Johnson." [ $1897^{-1} 89 \mathrm{~S}$ 


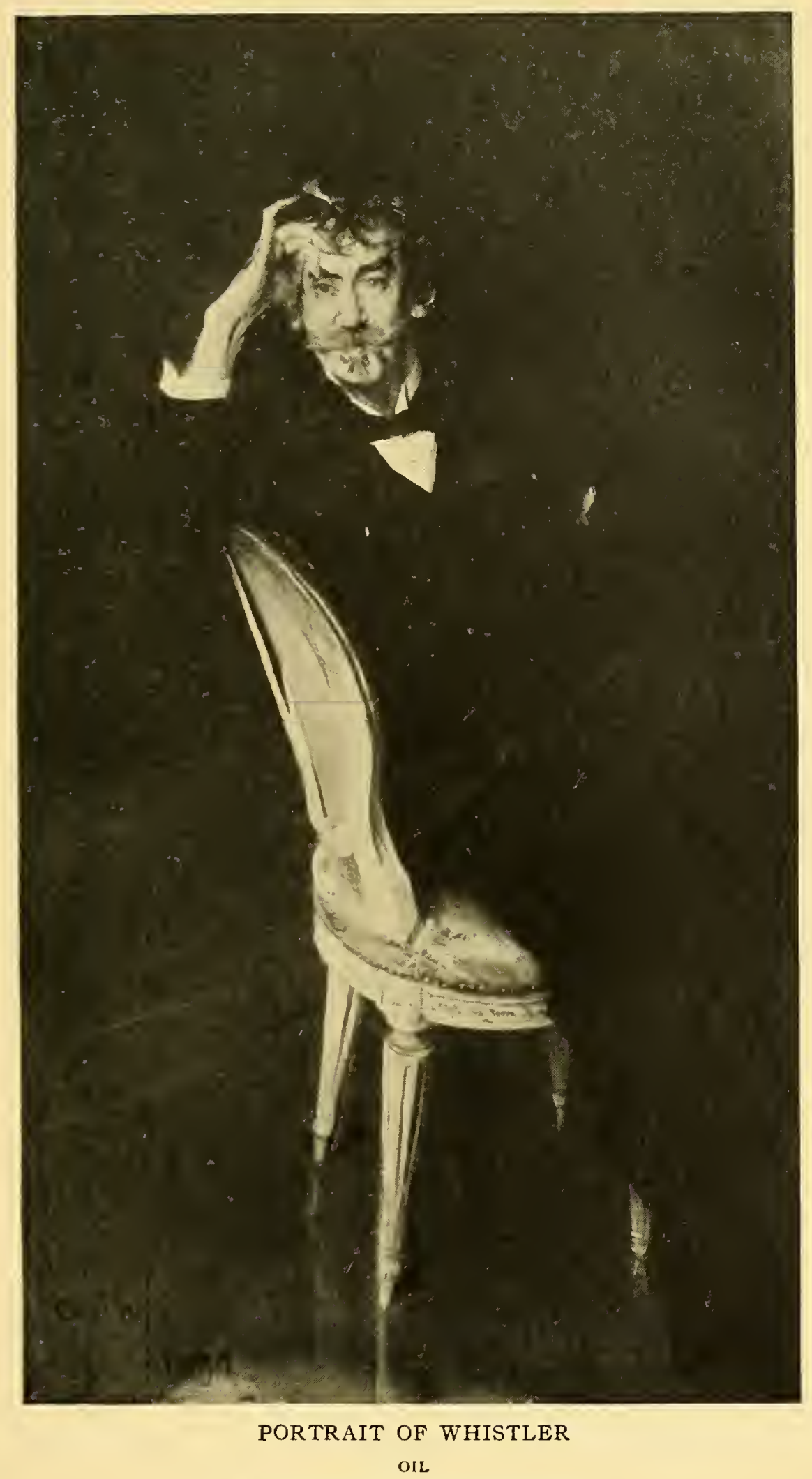

By J. Boldini, Brooklyn Museum 


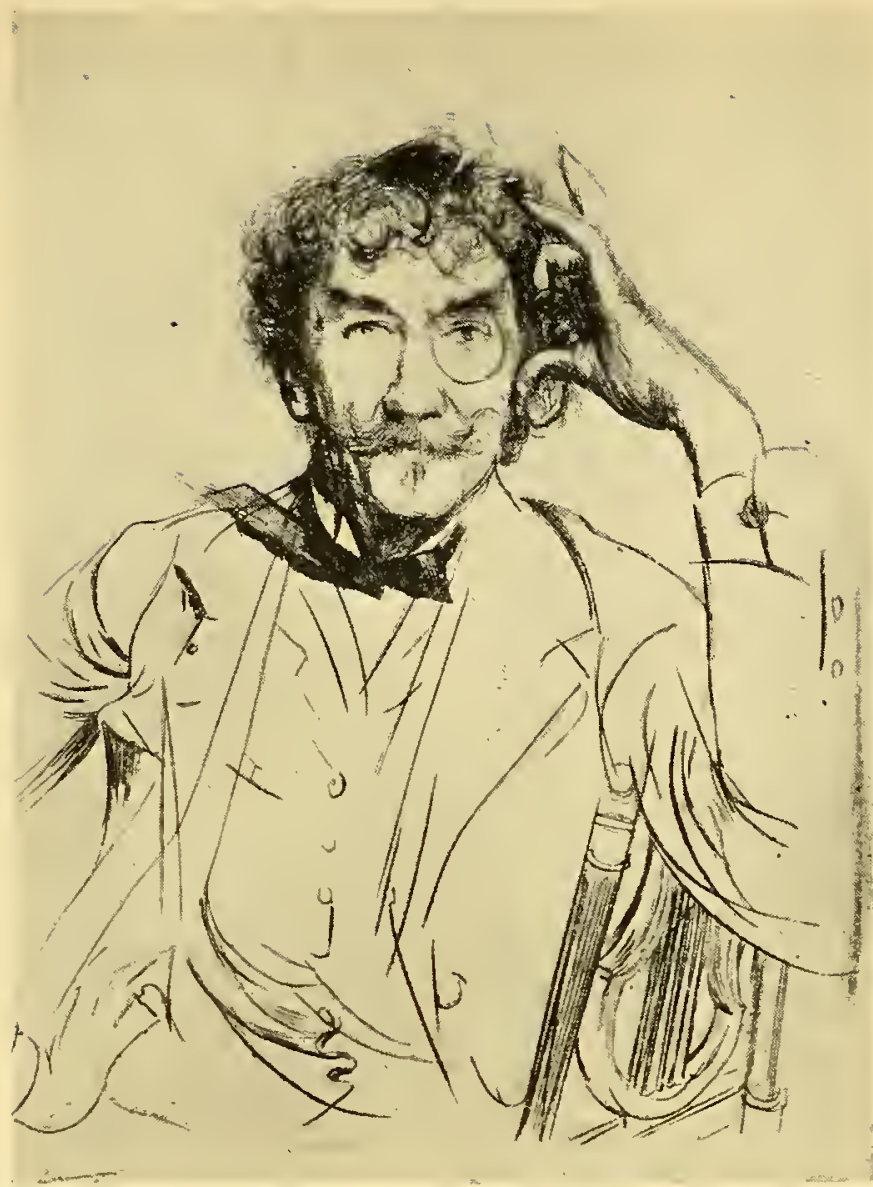

PORTRAIT MADE WHILE WHISTLER POSED TO BOLDINI DRY-POINT

By Paul Helleu. Pennell Collection, Library of Congress, Washington

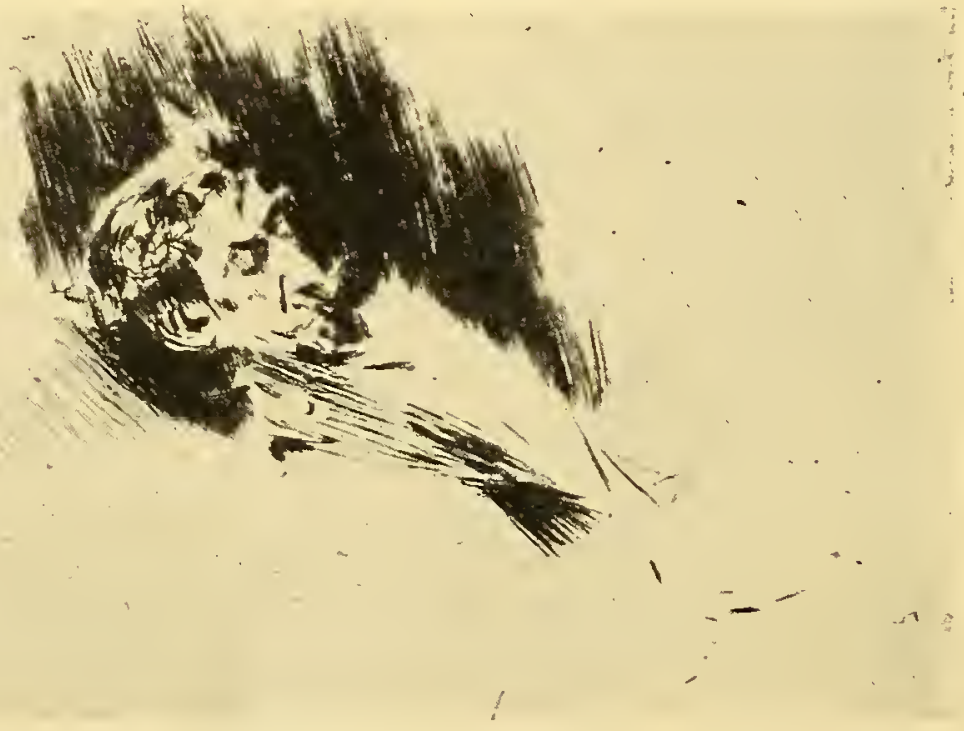

WHISTLER SLEEPING

DRY-POINT

Done between poses in Boldini's studio. By J. Boldini.

In the possession of E. G. Kennedy, Esq. 


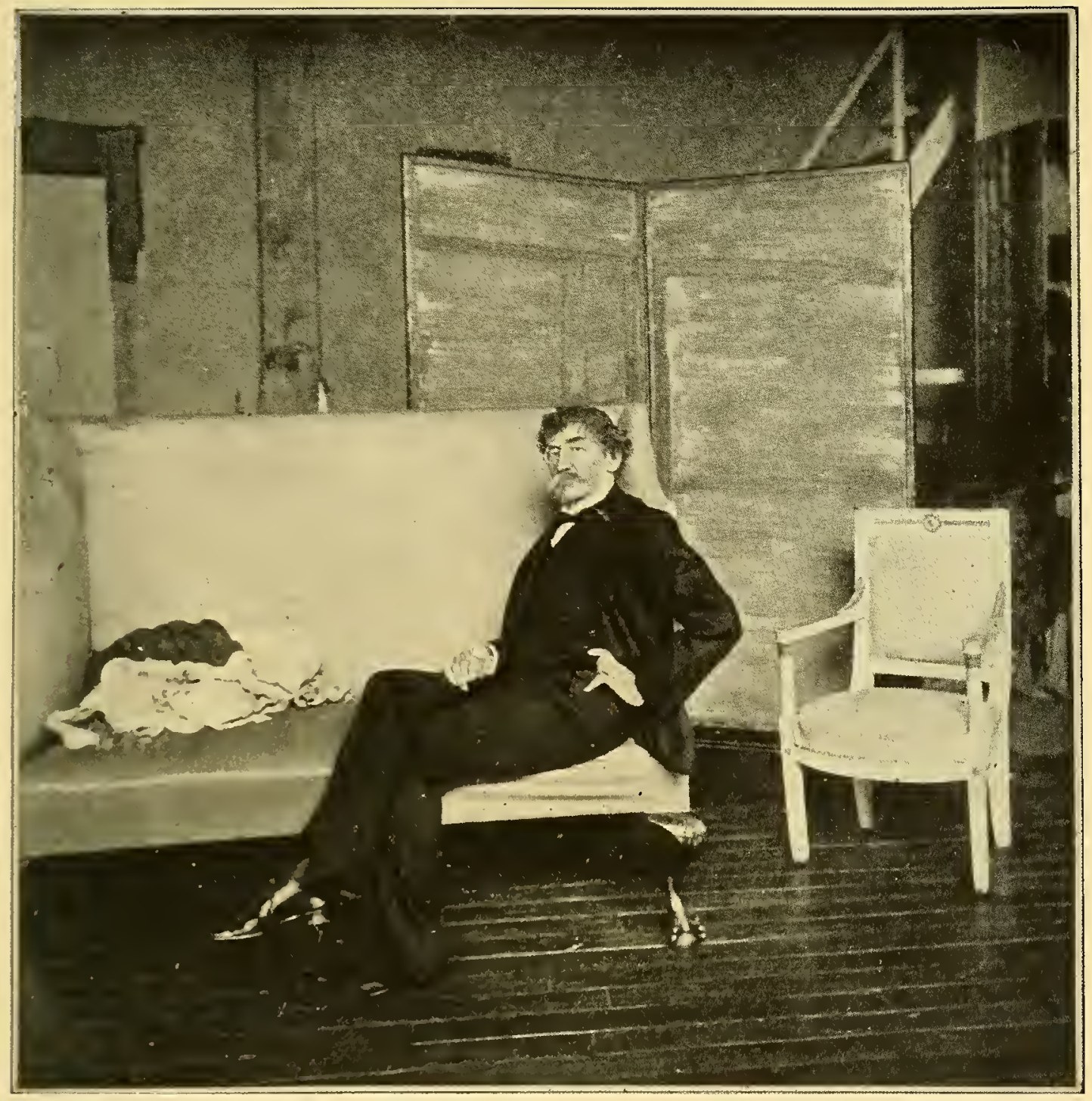

WHISTLER IN HIS PARIS STUDIO

Showing the screen with Battersea Bridge made for Leyland PHOTOGRAPH

(See pages 12 and 302)

By Dornac. 

Mr. Johnson's letter reveals better than he could have realized what the American cultured public's feeling about Whistler still was, much as it had been obliged to modify its opinion about his work-though the American public has no opinion of its own any longer, thinking and saying only what it is taught or told to. To those who did not know him he had not ceased to be "whimsical," "of objectionable career," his "want of dignity" making it questionable if reputable publications like The Century could print anything about him without loss of their dignity-or, more important, their subscribers. But meeting Whistler impressed upon Mr. Johnson, as it was impressed upon everyone who met him, that the whimsicality was mythical. Mr. Johnson was struck with him and with all he said, and felt that the right impression had not been given of his personality. We agreed to do the work, and to make notes of the talk and we did begin to make them, though in halting fashion. In our affection for Whistler we hardly liked doing it without his knowing it. This is why these notes are so few.

The first was not made until late in I898. It is dated:

September 25th, 1898 . A visit from Whistler early, just as we were settling down to work. He is depressed ever since his return to town, wonders that he can take no more pleasure in work, no more interest in the absurdities of the art critic, he will not even be bothered to arrange to send his lithographs to the coming show at South Kensington. But he at least is gay enough to report about the new book [The Baronet and the Butterfly] and to tell us two stories. The book is stupendous- "Well, you know there was the toad I was to get as a model for the 'toad in the belly' to decorate the Dedication. I was to apply for one to the Zoölogical Gardens, Wimbush was to find one, but in the meanwhile Teddy Godwin brought one and made a drawing of it. But the thing died. You know, they say I starved it. They had put it in a paper box. Well, it must have caught a fly or two. And I thought toads lived in stone or amber or something for hundreds of years. Perhaps it was because I hadn't the amber."

One of his stories was of Lady Donoughmore: "Well, she was staying with Mrs. Bradley Martin and she told it to me herself as an instance of American bad manners rather than in enjoyment 1897-1898] 


\section{The Whistler Journal}

of the superb humour of it. Mrs. Bradley Martin, having come over here and married her daughter to a title and studied the Red Book, had rather sized things up. And so, when Lady Donoughmore, in a room the Duchess of something occupied the week-end before, found her mattress shockingly hard and complained to the maid and asked for another, Mrs. Bradley Martin, at her toilet when the maid brought the message, waved her aside with supreme indifference. 'What has done for a Duchess to sleep on,' she said, 'is good enough for a Countess to rough it on!'" This recalled to him the other story of the typical "Aoh ah" Englishman coming for the first time to a Pullman car. "Aoh!" he called out, "Aoh, I say, how do you get in heah?" Strowbridge, the Pullman manager in England, was passing. "Well," he said, "the common-sense man walks in at the door, but for the God damned fool we keep a ladder and he crawls in through the roof. John, fetch the ladder."

These are the stories that Whistler loved, enjoying them in a way the Briton cannot grasp. The country-house week-end parties were an inexhaustible source of fun. About a scandal that was making much talk in London, his comment was, "Well, you know, for week-ends the rule should be to ring a loud bell at five in the morning, after which guests are expected to be found in no rooms save their own. What?" He told the story of Lady Donoughmore in no unkindness, for he liked her, even if her sense of humour sometimes failed. He met her and Lord Donoughmore often at Heinemann's, and we have seen the letter he wrote her after her husband's death, as tender a letter of condolence as we have ever read. "I never forget your own sweet sympathy in my deep sorrow," he told her, "and Donoughmore's kind hand upon my shoulder when again we met."

The exhibition at South Kensington was the Centenary Exhibition of Lithography organized by the British Government, and J., who was on the Royal Committee, was anxious for Whistler to make a fine showing.

The Baronet and the Butterfly was dedicated to those members of the New English Art Club who were too afraid to lose favour with Sir William Eden, the rich man and the art patron, to back Whistler in his second fight for art for the artists' sake. He did not let them off lightly. For months they dreaded to go to their usual haunts. where Whistler had a way of turning up unexpectedly 


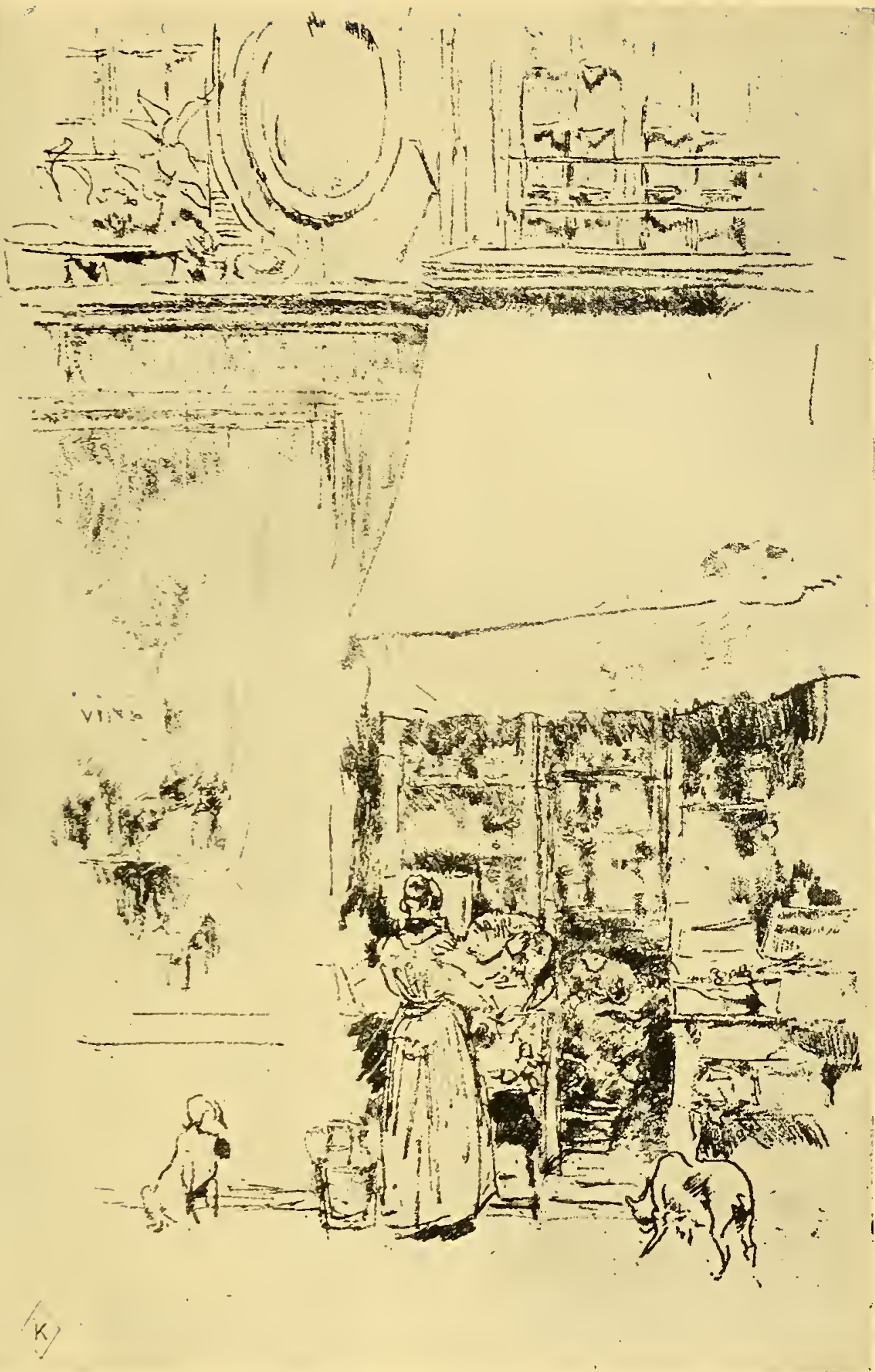

FRUITIERE, RUE DE GRENELLE

LITHOGRAPH. W. 70

By permission of Messrs. Kennedy and Co. 


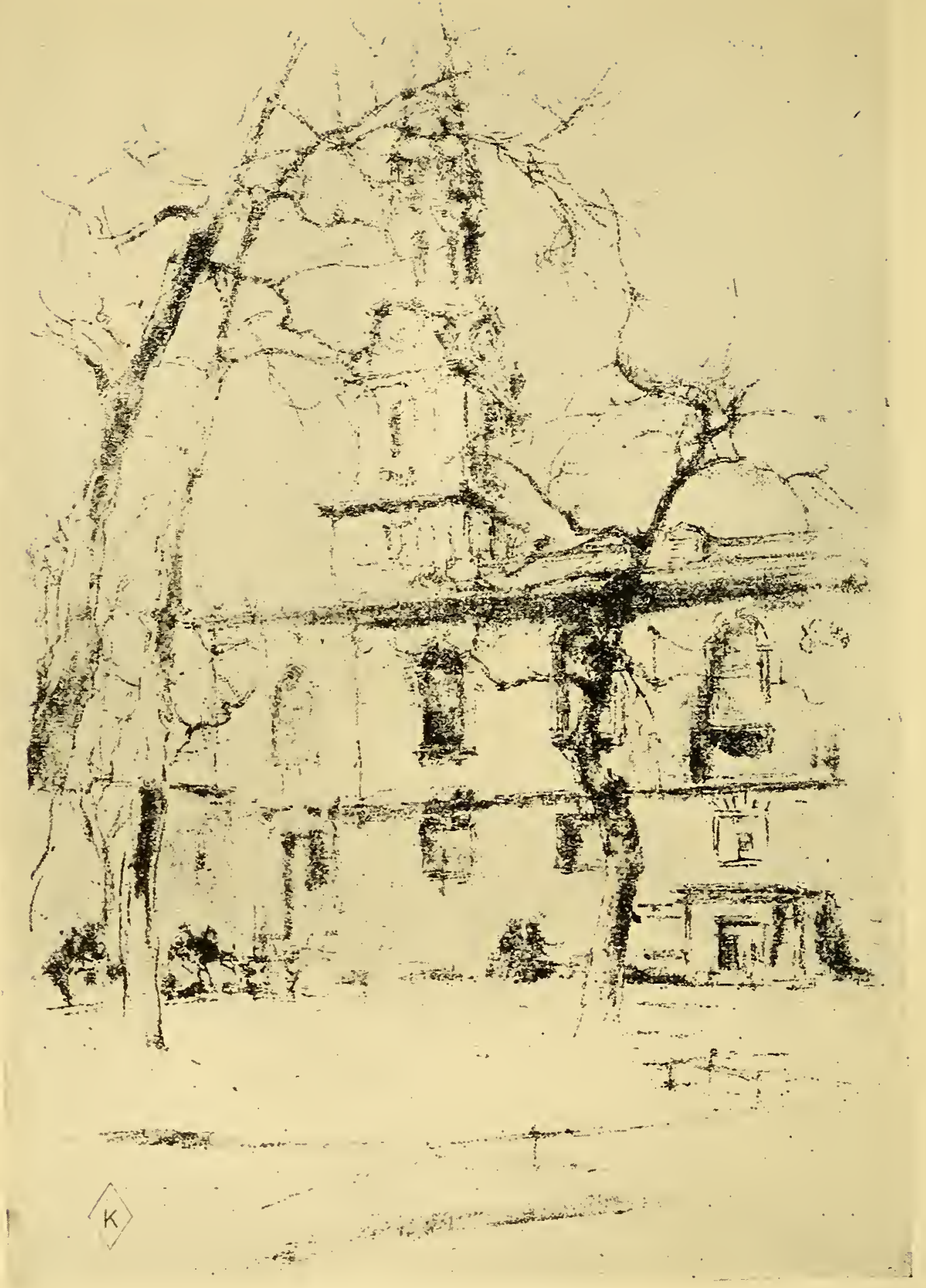

ST. GILES-IN-THE-FIELDS

LITHOGRAPH. W. I 29

By permission of Messrs. Kennedy and Co. 


\section{The First Idea of the Journal}

and taunting them with the toad in their belly and the throes of indigestion that came of it. Teddy Godwin who found the model for the toad was his step-son. E. J. Sullivan, talking over the affair some years afterwards, recalled Whistler's sending a wire to the Chelsea Club when he won the Eden case, asking them how they liked the toad, which Sullivan thought rubbing it in, considering that Whistler used to come down there often and empty the place. J. remembers Wilson Steer one day saying what was the use of coming to the Club any longer to get kicked. Sullivan also recalled an occasion when MacColl tackled Whistler, who was in his best form, and every time MacColl would try and get in a word, Whistler would put an eyeglass on the table and say "And"-and this would come out with such mock strenuousness that MacColl never got a chance to say anything, and Whistler had it all his own way. Nor was it only the artists who feasted on the toad. When he asked us to collect certain facts from dealers as evidence in the Eden Case, he warned us of one dealer because "You know-well-I believe the Baronet sends him game." One evening just after Whistler's death, Lavery told us the end of Whistler's membership in the Chelsea Arts Club.

July Igth, I903. Lavery said that a couple of years ago, when the Chelsea Club moved into their new house, and he made himself largely responsible financially for it, the question of Whistler's membership came up. Whistler had not paid his subscription for some years, but at the Council (or Committee?) meeting, Lavery urged that such a distinguished artist; moreover an original member of the Club, without whom, indeed, the Chelsea Club would not have been, should be made an Honorary Member. But he was told it would be the ruin of the Club; Steer and others would resign-they did not want him about the Club. After the meeting, Lavery went to Steer and asked him point blank, if it was soSteer blushed, was confused, said there was a mistake. However, Whistler was not elected, and Lavery, having taken over so much responsibility, did not resign at once, as he wanted to. The men would have said he was taking advantage of the dispute over the Honorary Membership to shirk it.

It is hard to explain why, but having started to make notes of Whistler, a few days later E. was making one of a visit from Frederick Sandys, the great illustrator of the Sixties, friend and enemy 1897-1898] 


\section{The Whistler Journal}

of the Pre-Raphaelites, her only note of his many visits to us at this period. We would give much now had we written at the time an account of how he and Whistler met one afternoon in Buckingham Street after years of not meeting anywhere. The trouble between them, Sandys said afterwards to Mr. Kyllman (of Constable's), was that he remonstrated with Whistler about The Peacock Room, and that Whistler resented it, which is more than likely. He then went on to describe their meeting. When, as he sat with us, he heard the knock, "no one but Whistler would knock like that," he said to himself, and he grew nervous-as we well remember. But Whistler, he added, was charming, so charming that that same year he invited Sandys to dine with him, "and we will get Joe Pennell," he wrote. We give E's. note as it is, for he told us many things we had never heard before and have never heard since, and they concern a group of Whistler's earliest friends in London. We must not be held responsible for Sandy's facts or criticisms. For all his dignity of demeanor and suave solemnity of speech, he was suspected of being a bit of a Munchausen. That was why he was amusing.

October $3 r d, 1898$. Sandys came in early in the afternoon, a little after two. J. had to leave almost at once for a Committee Meeting at South Kensington for the Lithograph Show. But Sandys stayed on until half past six, and talked steadily the whole afternoon. It was like listening to, instead of reading, a book of memoirs. He told one story after another, so that it would be hopeless to try and remember them all. J's. connection with the coming Exhibition of Lithographs at South Kensington and the fact that Sandys' Nightmare [the parody of Millais' Sir Isumbras at the Ford] is to be shown started him talking about it. He thought our impression was one of ten printed on India paper, but, looking at it more closely, he found it was not. He hardly knew whether it could be called a lithograph. It was done partly with a brush, partly with a pen, on zinc with some sort of ink brought to him by a man who patented the method. It was out five days after the Academy opened [the Royal Academy of 1857 in which Millais showed his Sir Isumbras] and three hundred were sold the first week and then the man disappeared with the plate and has never been heard of since. Naturally, Sandys had not much time. The 


\section{The First Idea of the Journal}

only way he got a glimpse of Rossetti, whom he did not then know, was by asking for an introduction from a friend and going with it to Chatham Place to see Rossetti's pictures. Rossetti came to the door, said he was sorry but he was busy with a man who was buying things-would Sandys come again?-and Sandys, from that one glimpse, made the portrait. The drawing won him Rossetti's friendship. Millais did not mind it. Holman Hunt was indignant. But the furious person was Ruskin's father who wanted to prosecute him. However, the print had been published anonymously and for a long while no one knew who did it. Old Ruskin, breakfasting with Smith, the publisher, offered him five hundred pounds if he would find out the author of the caricature. Millais, he describes as beautiful as a god in his youth. Sandys had won a Silver Medal at the Society of Arts for water-colours of birds, and then had to come up to London and, at their place in John Street, make drawings of the same kind to prove they were his work. He was left in a room with Millais, who had won a Gold Medal and was also being put to the test. People who came in looked at Millais" painting and went away whispering "astounding genius," but never looked at Sandys who was copying a pigeon brought from a near market. Sandys was awfully nervous. Millais was full of confidence in himself-not conceit, but certainty of what he could do. He encouraged Sandys- "that's all right," he said of the drawing of the feathers, "it's the feet you have to look out for," which Sandys thought showed wonderful insight for a youth of Millais' age-the feet being the difficult thing. Later on, he tried to reunite Millais and Rossetti, who did not see each other because Rossetti was hurt at Millais' not having suggested his name for the Royal Academy when there was the chance. Sandys asked Rossetti to dinner, saying Millais was to be there, and Rossetti would not come. Then Sandys asked him without telling him, and Rossetti came, and the two were friends again at once. Millais begged to be asked to the studio to see Rossetti's pictures and asked Rossetti to come and see his children - he had some very pretty children, he said. But Rossetti never went and never asked Millais to come to him and so they lost 1897-1898] 


\section{The Whistler Journal}

sight of each other again-Rossetti was cruelly misrepresented by William Michael Rossetti, Sandys thought, for he was really the most abstemious of men-knew so little of wine that, having tasted a "bishop" of ordinary claret warmed with spices, wanted to make one of fine old Madeira worth about two or three pounds a bottle that some one had given him. Sandys was shocked and would not allow it.

Sandys went once with Rossetti, Swinburne and George Meredith to Hampton Court, and between Waterloo and Hampton Court Station each one of the three wrote a poem. He remembered Swinburne's in particular because it was Faustine written to see how many rhymes he could find to the name. He also was with Swinburne and Meredith when they had their final quarrel. They had just been reconciled after another quarrel and were dining amiably at the Garrick Club. It was when Meredith was editing The Fortnightly Review for John Morley, then in America. Meredith had recently sent Swinburne ten pounds for a poem. After dinner, Swinburne asked Meredith why he sent ten pounds? Meredith explained he was paying all contributors during Morley's absence. "Yes," said Swinburne, "but why ten?" Meredith explained it was what he usually got for his own poems. "Yes, for yours," said Swinburne, "but for mine?" Meredith tried to point out the justice of it: what was enough for him was enough for Swinburne. Swinburne got up, came over to him, and slapped his face. That was the end of their friendship. Sandys defended Swinburne and said he was not half so drunken as his reputation. His strong intellect kept him from showing, or perhaps feeling, the effect of drink as others did. As an example-one evening, while living with Rossetti, he was very drunk, at the stage when he saw two candles where there was really but one. After dinner William Michael Rossetti came in with Walt Whitman's Leaves of Grass, the first copy brought to England. Swinburne was eager to read it, but when he opened the volume he saw two Leaves of Grass. He just clapped a hand over one eye, and with the other eye saw distinctly and then read easily.

Loud in praise of Meredith as a brilliant talker. He was wonderful, 


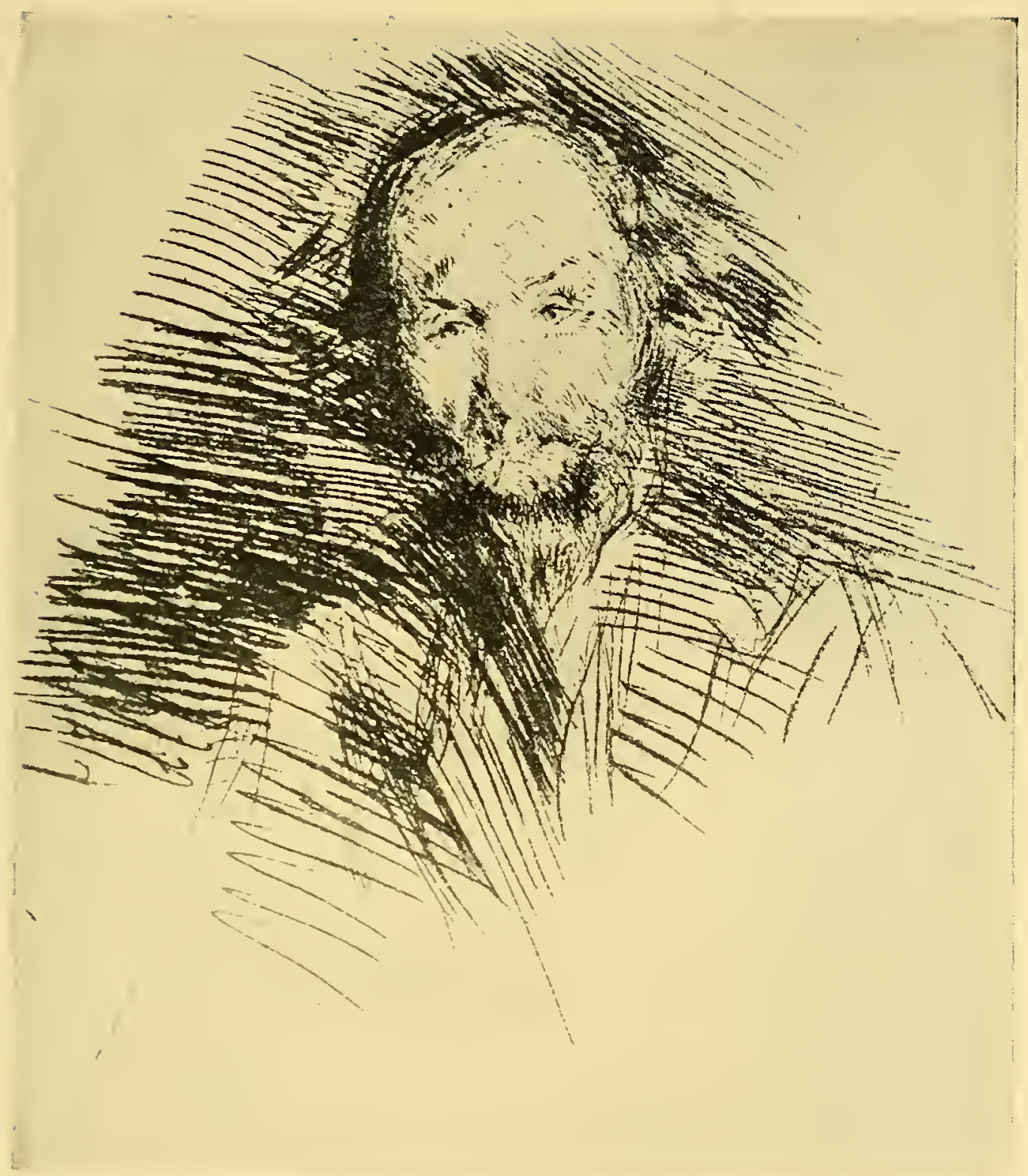

SWINBURNE

DRY-POINT、M. I36 


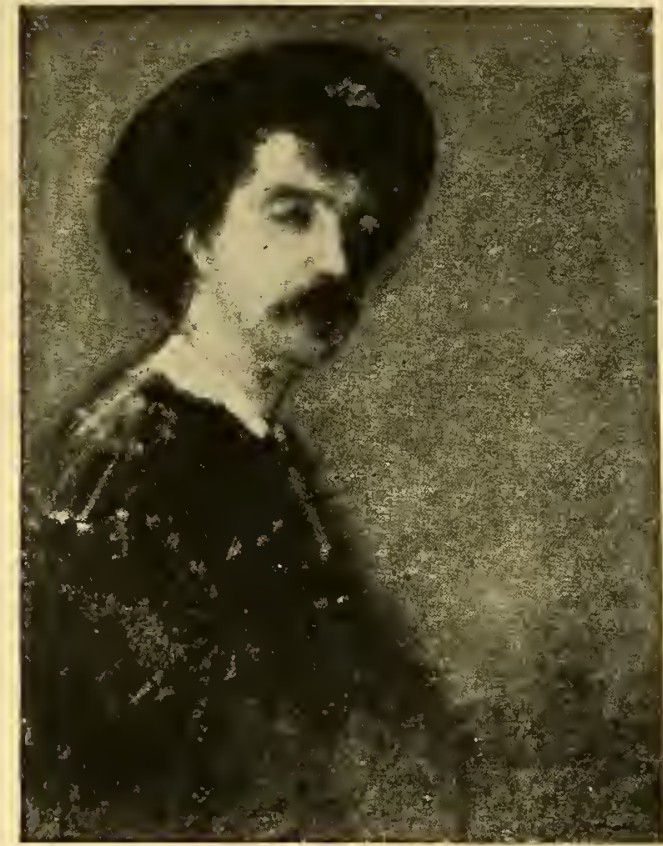

PORTRAIT ATTRIBUTED TO WHISTLER

OIL

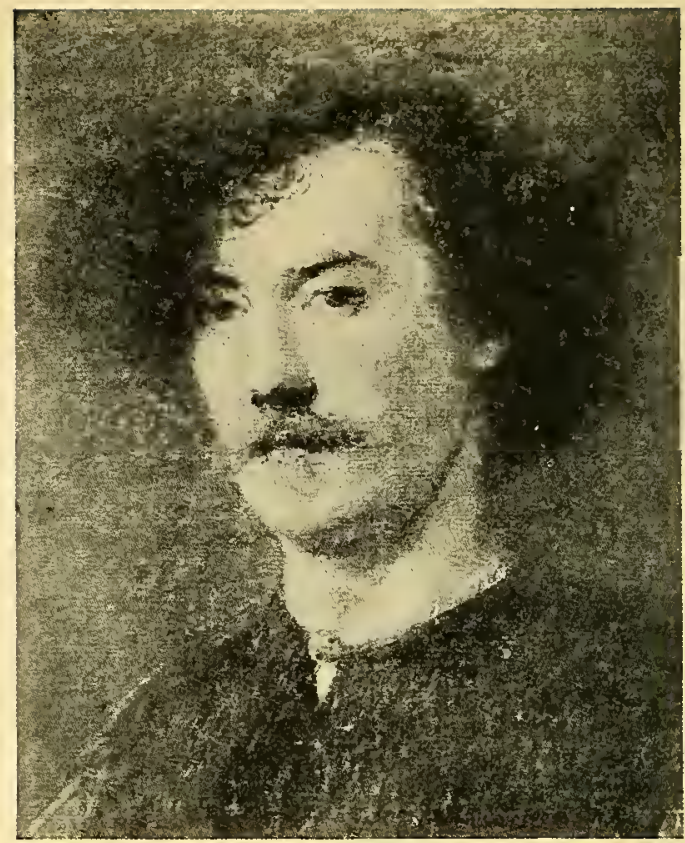

PORTRAIT BY FANTIN LATOUR OIL

Head cut from the large painting, The Toast, destroyed

Freer Collection, National Museum, Washington 


\section{The First Idea of the Journal}

though at the expense of his friends. Often had three or four friends dining with him on Sunday and, if the humour seized him, would select one of the company and dissect him for the benefit of the others. It was like taking a butterfly, pinning it, still alive, to the wall and examining every quivering detail. This lost him many friends, was the reason for his quarrel with Rossetti. $\mathrm{He}$ was living in the Chelsea house. Some of Rossetti's patrons had come to dinner and Meredith chose this occasion to make sport of Rossetti. The result was Rossetti turned him out.

The first quarrel with Swinburne was because Meredith put him unmistakably, as a red-haired poet, into one of his novels. Swinburne did not appreciate it. The novel was Emilia in England, or something of the sort, and now has another name [Sandra Belloni]. Meredith was always going through different philosophical or social or religious phases. One day he announced he was a socialist. Sandys asked him if he followed Morris or Crane? Neither, Meredith said. All men who thought must, at one time or another, pass through a stage of socialism; of course, it was impossible to say how long he would remain a socialist. He had been, he added, everything in his time save, lowering his voice, a curate. Lowell, after lunching with Meredith at the house of Mrs. Lawrence, where Meredith as usual talked in a loud, vibrant voice, said he had been thinking all through lunch of the Bible. "But why?" asked Sandys. "Because," Lowell explained, "in the Bible we read of the still, small voice of God." Sandys once took two Americans down to see Meredith. They arrived in the morning, Meredith met them, and from the moment they were on the platform until he drove them back at ten o'clock at night, he never once stopped talking.

Ruskin, Sandys said, treated Lady Millais when she was Mrs. Ruskin abominably. He was not brutal, he never reproved her. But he kept a diary, and every Monday morning he had her up before him and read her a list of all her misdemeanors for every day in the past week.

Sandys' caricature of Millais' picture is now well known. It was forgotten for a while-as, indeed, was Sandys-but when, in the 1897-I 898] 
Nineties, interest was revived by J. in the work of the Sixties, which he called "The Golden Age of Illustration," the title soon borrowed by Gleeson White and others both here and abroad for their own use, the print re-appeared and was reproduced in many articles. For long it hung on our Buckingham Street walls. The Ruskin family objected to it because Ruskin was drawn as an ass with $J$. $R$. Oxon branded on his rump. He carried a great big Millais in armour on his back, a little Rossetti in his arms, a smaller Holman Hunt hanging on behind, and a still smaller Titian and Michael Angelo chanting Ora pro nobis on the further shore.

Holman Hunt, of whom at one time we saw a good deal, as we met all the Pre-Raphaelites except Rossetti, was most interesting when you got him away from his work to talk about himself. When he talked about anybody else or about his paintings, he was an awful old bore. J. remembers going down to the studio, in Fulham to see The Shadow of the Cross being fixed up, and Holman Hunt's saying that it took him three weeks or three days to paint one of the shavings on the floor. "H'm," Whistler laughed when J. told him later, "some people could have done it better in three minutes, and then wouldn't have said anything about it!"

Except in Sandys' story, we know of no medal won by Millais at the Society of Arts except a Silver Medal awarded him when he was nine years old. No wonder Sandys was struck by the insight of so youthful a critic. In the Life of Millais by his son, the reason for his quarrel with Rossetti is not given. Only the discreet fact is stated that after I 852 Millais seldom saw Rossetti.

If we are not mistaken, Swinburne's account of how Faustine came to be written is rather different from Sandys'. And we can hardly believe that Swinburne could have been much annoyed by "Tracy Runningbrook," the poet in Sandra Belloni. The parody upon his name is not offensive as Dr. Furnival's "Pigsbrook" was, and the poet, with hair red as a blown flame and a way of coining words, is as unobjectionable as, his name. But Meredith's letters show there was friction between Swinburne and himself over The Fortnightly rate of payment during Meredith's editorship, and certainly the two men did not see each other for years. Sandys' story, so far as this goes, may be true.

His version of Meredith's quarrel with Rossetti is virtually the same we had from Whistler, according to whom it occurred the evening Swinburne was reading Leaves of Grass and the wombat was devouring Rossetti's cigars - altogether an eventful evening. Whistler gave Mrs. Clifford Addams other details which we do not remember hearing from him. There had been a disagreement between Meredith 26

[I $897-$ I 898 
and Rossetti, and Meredith had gossipped about it to a cabman at the corner, and this came to Rossetti who was furious. They were all dining together that evening, Whistler and Howell too. The meat was served and Rossetti began-he was the more indignant because, so Whistler told Mrs. Addams, the others had no money at the time and were living there practically as his guests. He declared that people who could talk that way to cabmen were no gentlemen, and in his rage he brought down his spoon hard into the dish, and the gravy squirted right into Whistler's eye. And Meredith got up and left the house and the table and never came back. But it made no difference in his friendliness to Whistler. Almost half a century later, after reading our Life, he wrote to Heinemann, "It shows him as I knew him, a perfectly genial soul."

It is a pity that Edmund Gosse, William Michael Rossetti and William Meredith never consulted Sandys, a greater pity that E. did not make more notes of his talk. It was this sort of thing we used to listen to daily and rarely put down. Those who pretended to write about the Pre-Raphaelites may have heard it, but they never dared to print it. These big men, as we saw them or heard of them, were perfectly human. Their biographers have mostly made them into pompous prigs. Mr. Luke Ionides could tell, and did tell us in 1906 and I907, almost as many stories as Sandys, for the house of his father, Constantine Ionides, was a meeting place for them all. One of his stories was of Burne-Jones and himself going to a country fair and wandering into a side show to see a tattooed lady,

September 27th, I906-with he was afraid to say how many subjects tattooed on her-on one knee the American Eagle, on the other the Union Jack, to symbolize the understanding there should be among nations, and on her back, Leonardo's Last Supper. And she really was amazing and they enjoyed it hugely. Some four or five years afterwards, in London, Burne-Jones burst in upon Ionides and told him the same tattooed lady was at the Aquarium and they must go and see her again. And they went, and she had grown very stout in the meanwhile and when they looked at the Last Supper, all the apostles wore a broad grin. Another story was of Rossetti and William Morris. Rossetti was never in sympathy with Morris' Norse studies and sagas, and once when Morris was reciting the adventures of one of his Norse heroes, Rossetti interrupted to say he didn't think much of a man who had a dragon or a serpent for a brother. "I had a great deal rather have a dragon for a brother," Morris I897-I 898] 


\section{The Whistler Journal}

roared, "than a damned fool!" A third story was of Swinburne at his Club on one of those evenings of which his biographers prefer not to write. As he stumbled out he lifted up his cane and knocked down all the hats hanging up in the hall-or, in a variation of the tale, tried on each hat in turn and when it did not fit, threw it on the floor and jumped on it. The Club expelled him and many felt it an outrage that the author of Laus Veneris and Atalanta should be so treated. Whistler, and several members with him, resigned. Other authorities say that Whistler did not resign but allowed his membership to lapse, forgot all about it, came back the next evening, ordered something to drink, and paid for it. The following morning the Secretary returned the money, regretting that no one not a member could order and pay for anything. Excellence in billiards rather than distinction in art was then the chief qualification for membership in the art clubs of London.

A characteristic story of Sandys himself, we had from Mr. Hartrick:July 20th, 1903. Whistler at Sandys' studio met Sandys' fathercurled, white-waistcoated, and wonderful in every way. Sandys asked the old gentleman, "Will you have a glass of port, father?" "Well, Fred, I don't mind if I do!" and Sandys searched elaborately in a cupboard, "Strange, there does not seem to be any port, will you have some brandy, father?" "Well, Fred, I don't mind if I do!" Another search, "Strange, I can't find the brandy. Will gin do father?" "Why, yes, Fred." And Sandys called the slavey. "Run and get a pen'orth of gin." Then the father, as elaborately, got out a cigar case with two cigars in it, offered it to Whistler who refused, then to Sandys who took one. The old gentleman put the other back in his pocket elaborately, got out his knife and handed it to Sandys, "Do you know which end to cut off, Fred?"

We insert here a much later note by $\mathrm{E}$., because it relates to one of this group of artists, giving a pleasant glimpse of the friendly side of Millais.

January 2Ist, 1905. Lunching with Mrs. John Lane. I sat next to Miss Millais, who said she had one or two letters Whistler wrote to 28

[1897-1898 


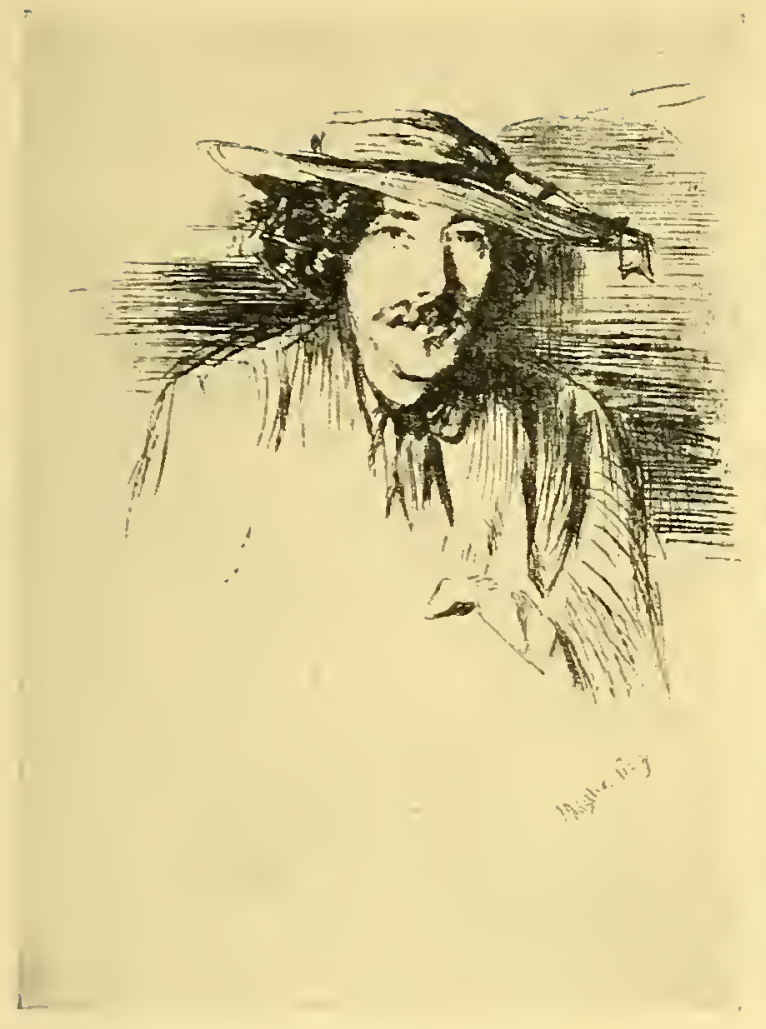

WHISTLER IN THE BIG HAT ETCHISG. M. 54

Whistler's Hat, worn in Paris and on journey to Alsace

Pennell Collection, Library of Congress, Washington

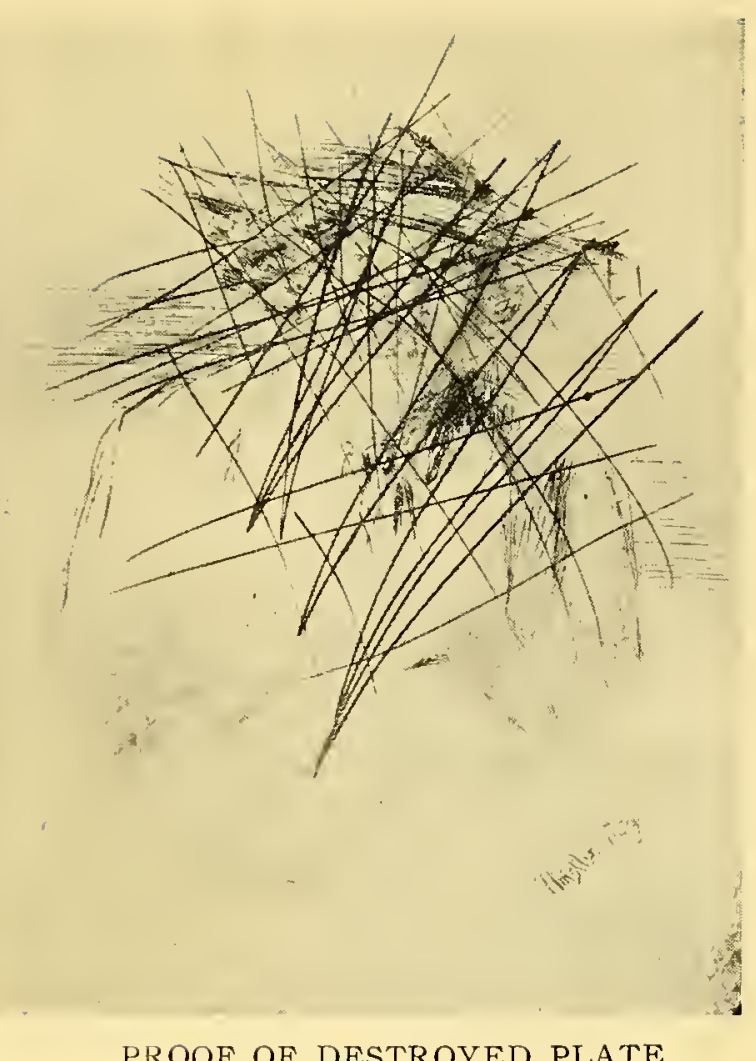

PROOF OF DESTROYED PLATE

(See page 4g) 


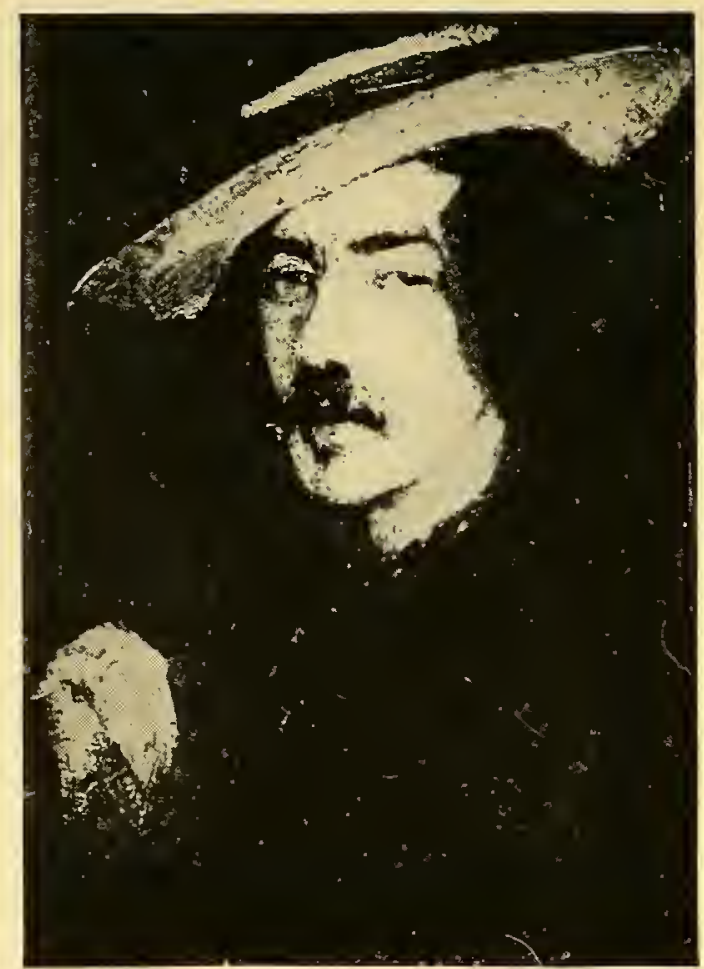

WHISTLER SMOKING

OIL

Attributed to Whistler. By permission of A. E. Gallatin, Esq.

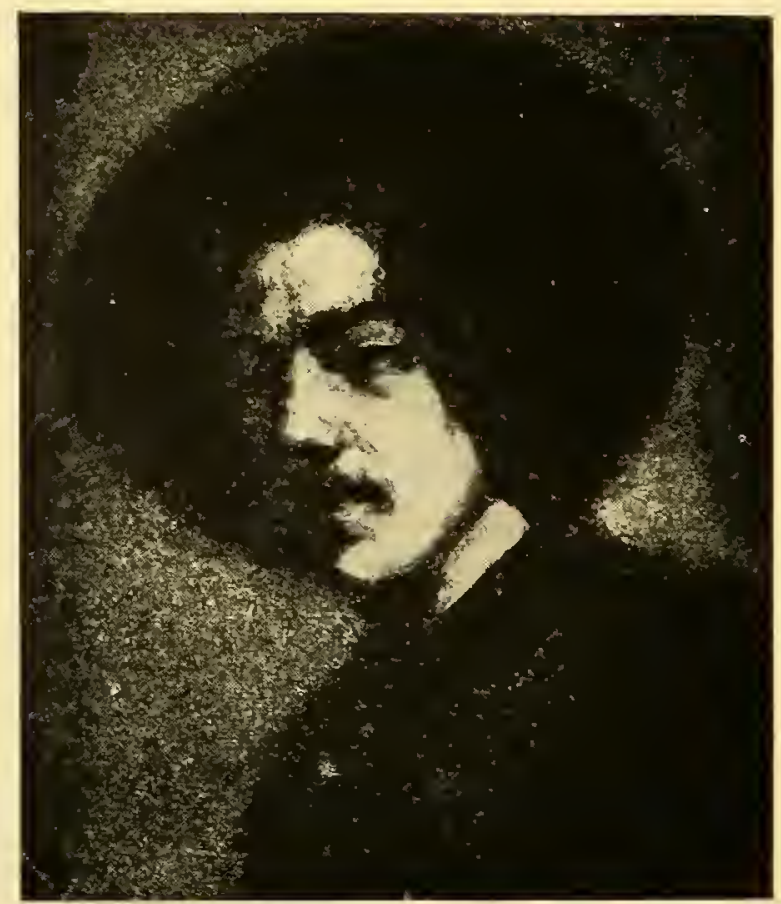

WHISTLER IN THE BIG HAT OIL

Freer Collection National Museum, Washington 
her aunt which she would let us see. She was not sure if those to her father were preserved, but she would find out. Her father had been fond of Whistler whom he was often able to help when Whistler got into trouble from lending money to his friends, or from other things. She went with him once to call on Whistler in the White House. It was a moment of difficulties, and when they rang the door was on the chain and cautiously opened. No one could come in, they were told. But Millais said he was a friend of Whistler's-it made no difference-the door was closed. However, they walked up and down the street in front of the house and, after a while, they saw Whistler peeping out of a window. Then they were let in. They saw nothing of Whistler after he was married. Somehow, her mother never called on Mrs. Whistler and so they never met. But Whistler came to inquire after her father during his illness.

There are only two more Whistler notes in $\mathbf{1} 898$. The first is dated: Tuesday, October IIth, I898. Mr. Armstrong of Bristol was to dine with us. A few minutes to seven Payne arrives from Whitehall Court, saying Mr. Whistler wants to know, are we at home? and may he come and dine? I send word, yes, we shall be delighted-butwe are expecting a friend, we have said seven is the hour, and dinner will be ready then, and I do not want to keep it waiting, though we may be a little late as $\mathrm{J}$. has been detained. At half past seven, a note saying letters to Paris will keep him, cannot possibly get here till eight, and so will not come to dinner, but will look in later. I write that we are only just sitting down, won't he come? As we are eating our fish, messenger returns to say he will be with us in a quarter of an hour. He comes with the coffee, eats his warmed-updinner without a murmur, finds out that Mr. Armstrong belongs to the British Artists-he is enchanted-it was most delightful for him, he tells us afterwards, but not sure how Mr. Armstrong felt, sitting face to face with him.

He tells us how he happened to join the Society . . . Mr. Armstrong told the story of the Carlyle portrait, which Whistler said was founded more or less on fact. . . . He talked to us again about the AmericanSpanish war. ...

I 897-r898] 


\section{The Whistler Journal}

Whistler was staying that autumn with Heinemann at Whitehall Court only a few minutes from Buckingham Street, and when he was there Payne, Heinemann's valet, often appeared with just such a message. It must be said for Whistler that if he was late to dinner, and our hour of seven was distasteful to him, he gave no trouble when he came. He was fastidious about his dinner, but when he knew the fault was his, he ate his warmed-up dishes as if he liked them. His friends-friends to whom he went intimately and informally-understood this. Mrs. Alan S. Cole has often laughed with us over the way she managed to please him. Her cook got to know that if he had sardines and an egg done in a little casserole and, above all, plenty of bread and butter directly in front of him, he was content. The details of the talk which make this an unusually long note we have not given because we used them in the Life. The British Artists, Carlyle, the Spanish-American War, were subjects he never tired of.

Thursday, October 13th, I898. Edgar Wilson and Fernald-The Cat and the Cherub-were dining with us. Whistler had said vaguely he might come. I had a place put for him, but I expected him so little that I did not wait a minute after dinner was ready. At twenty minutes past eight, in he walked, just as we were finishing, smiling, imperturbable, eating as leisurely as if five people were not waiting for him. Again he told us of the magnificence of the war, and the chivalry. And to Edgar Wilson, whom he had never met before, he was as kind as it seems to me he is above all to young artists starting out in life. The talk of the evening was chiefly upon the fact that there can be no progress in art though there may be in the knowledge of art. It was the old discussion of many evenings, especially the evening Iwan Muller and Van Dyke were dining with us: "Art," Whistler declared, "is as exact as science."

The evening referred to was in the earlier noteless days. Van Dyke is Mr. John C. Van Dyke, whom Whistler was always glad to meet, and Iwan Muller was a journalist, assistant editor of The Pall Mall Gazette in the first years of Astor's proprietorship, afterwards leading writer on The Daily Telegraph, and approved of by Whistler because of his Russian father, though in everything but looks he was as English as if he were trying to live down his Russian ancestry. Mr. Van Dyke has recorded in a chapter on 30

[1897-1898 


\section{The Whistler School}

Whistler, in American Painting and Its Tradition, one event of the evening, but not its most memorable: Iwan Muller's description of the brilliancy of Northern colour, his own desire to listen, and Whistler's hopeless boredom with it, only waking up when the subject was changed to art as a science, which engrossed him more and more as time went on and often kept us hours round the table in the Buckingham Street dining-room.

Mr. Fernald, dining with us about a fortnight after Whistler's death, spoke to us of his meeting with Whistler on this occasion. He said as many have said, that he owed his one glimpse of Whistler to us, and a wonderful glimpse it was. For Whistler talked of art. Art was always the same; there could be no change; art was eternal; a theory he only half understood until now that he was reading the Ten O'Clock. And again four years later, again dining with us, he recalled the day he met Whistler in our flat as one of the days that stand out in his life. He spoke to Whistler of Japanese art and its influence on Western art, and Whistler explained that this influence meant the carrying on of tradition, not a revolution in Western art, for art is unchangeable. Whistler was the first to admit its influence upon his work. Not that his work had been changed by it; always, he insisted, his work was the same, in the beginning as in the end.

CHAPTER IV: THE WHISTLER SCHOOL. THE YEARS EIGHTEEN NINETY-NINE TO NINETEEN HUNDRED

Friday, July I4th, I899. About half an hour before dinner, to which we had asked Kennedy and young Irving Clark, Kennedy arrived to say that Whistler was in town and would we dine with him instead? It was too late-we suggested their both coming here to dinner or coming in afterwards. But they put in no appearance.

Mr. E. G. Kennedy, when in Lundon stayed at Garlant's where Whistler stayed, and was much with him as will be seen. O'K., Whistler mostly called him, we never knew why until Mr. Kennedy explained a few months ago. He had been talking of his name and its variations to Mrs. Whistler, and of the O'Kennedys who had vanished because they didn't owe anyone anything any more. But Mrs. Whistler said if that was true he was an O'Kennedy, he always owed them something, and " $\mathrm{O}$ 'K. it shall be from now on." I899-I900] 
The Whistler Journal

And so, it became his familiar name, not only for Mrs. Whistler, but for us all, and as O'K. he will often appear in these pages.

Irving Clark is our cousin who was in London on his way home from exciting adventures in the Balkans.

Saturday, July 15th. Whistler arrived early, just after J. had gone out: gay, alert, in an irreproachable new suit, with a "dandy" straw hat. He was astonished to find himself here. How, indeed, was it possible to consider a relative when there was question of going to him?

His talk was chiefly of the school. "It is amazing. It grows more amazing with every day. No one knows what is being done there. Really, I am amazed myself when I see it all. And, you know, this is the proper moment to make the world see what is going on, and you surely are the person to do it. I have been thinking it over. I would not care to have it come from me-it would not answer. But it has occurred to me that Miss Bate is just now in London on her way from Paris, why should there not be a talk with Miss Bate? What more appropriate? Miss Bate, the Massière, whose painting has already astonished the world at the International?" I told him I knew nothing of interviewing. But he thought "Something charming can be done, without its being necessarily in the form of an interview." -

About four o'clock he reappeared, beaming. He was on the way to the station, to go to the Heinemann's at Weybridge, but he had stopped to tell us. "Really, it has been beautiful. I know you will enjoy it-it occurred to me in the morning-the Baronet's sale to-day. ..."

The Baronet was Sir William Eden. The story of the sale, as Whistler gave it, is in the Life.

Though E. told Whistler that she knew nothing of interviewing, she did eventually write something about the Académie Carmen. But she put it off too long and the article never appeared. When she was in Paris, Whistler arranged for her to visit the school, and she has memories of its seclusion in the Passage Stanislas and of its calm. She had never seen anything like the absorption in their work of the women in the life class, and the model, posing for the 32

[1899-1900 


\section{The Whistler School}

nude on the throne against quiet grey draperies, was exactly like a Whistler, needing but a frame to complete the illusion. It helped her to understand better Whistler's Propositions which, in Duret's translation, hung upon the wall. Miss Inez Bate, now Mrs. Clifford Addams, wrote, at Whistler's request, the record of his school and his methods and allowed us to print it in the Life. The world would be the richer if the students of other great masters had written so authentic a report of their schools and systems. Hers is more valuable than any interview by $\mathrm{E}$. could have been. But after it was published it was criticised by some of Mrs. Addams' fellow students-by the few who remained faithful for, as always, there were exceptions. Mrs. Graham Shaw, Miss Halliday, and one or two others objected that Mrs. Addams was too sweeping in her version of the closing of the school and the dwindling of the students. They were loyal and thought their loyalty too should have recognition. Out of the school came two or three who distinguished themselves, a good record for any art school that runs so short a time; the average art student goes to a master only to acquire his knowledge of a lifetime in ten minutes. Therefore it cannot be said that the Académie Carmen was altogether a failure. But the exceptions were few, the majority of students were disappointed for the reason that they ought never to have been students. As Miss Dixon who was there said, it was astonishing how many women came at first simply because they had heard so much about Whistler and wanted to see him. An English woman, who crossed the Channel purposely to have a look at him, lived in the Champs-Elysées, drove to the studio in her carriage, and stayed for three weeks though she had paid for three months. Women journalists hoped to make good copy out of the classes. It was a distress to Whistler to have to consider the work of such people, and they were gradually weeded out. His health interfered with his attendance. And in the end only the loyal stayed on until they were dismissed. The notes for the spring of 1899 reveal the activity of his interest in the school and his high ambitions for it as long as he was well.

Sunday, July I6th. Whistler came to supper. Harry Wilson and Irving Clark here and later Kennedy. Whistler at first inclined to be quiet and grumpy. He had gone to Heinemann's. "Some one said, 'Have a hot bath before dinner.' The very thing, I thought, and then, after dinner, we sat out on the lawn, and I have come back to town with a cold, and now I am going to be ill." But he I899-1900] 
forgot his cold when he found that Wilson the night before had dined with Mr. Sydney Morse, and that Mr. Morse was the unknown or unremembered friend upon whose arm yesterday he entered Christie's in triumph. He told the story of the Eden sale again. . . He said he met Sargent at the station, going to Weybridge, Sargent on his way to Sir George Lewis'. They had a compartment to themselves, to Sargent's intense discomfiture. "I told him the whole story, you know, interspersing it with ' of course, you understand!' and 'of course, you sympathize!' and Sargent looked hopelessly at door and window. Not that Sargent is not charming and all that-only, a sepulchre of dulness and propriety." Later, some one was talking of Rossetti. "Rossetti," he said, "well, you know, not a painter, but a gentleman and a poet. As for the others dangling after him, with them it was all incapacity and crime." After supper Wilson and J. sat with him on one side of the room and held a sort of impromptu Committee Meeting on International affairs.

Harry Wilson is the distinguished English artist-architect, painter, jeweler, sculptor, manager, author-a man of many sides-now President of the Arts and Crafts Exhibition Society. Sydney Morse is his brother-in-law, a well-known solicitor, who in the old days rented No. 2 Lindsey Row when Whistler moved out of it into the White House. The coincidence of meeting Wilson the day after the Eden sale and getting from him the effect of his presence there was precisely one of the little things that, as he said, Providence sometimes sent him, and the imprudent bath at Heinemann's was forgotten and the illness cured before it came. Morse is also the owner of the Cabinet of the Owl and the Cabinet episode. All that summer and the next too, Sargent was much in Whistler's talk. He had no dislike for Sargent. On the contrary he held him in great friendliness. We have seen letters in which he wrote with unmistakable feeling of his admiration and gratitude when Sargent went out of his way for him in connection with the decoration of the Boston Library-" "rare and noble camaraderie" were his words. But the excessive praise of Sargent, then the fashion, got on his nerves, just as the unintelligent criticism of Louis Stevenson got on Henley's. How he felt can be gathered from something he said to Clifford Addams, from whom we heard 


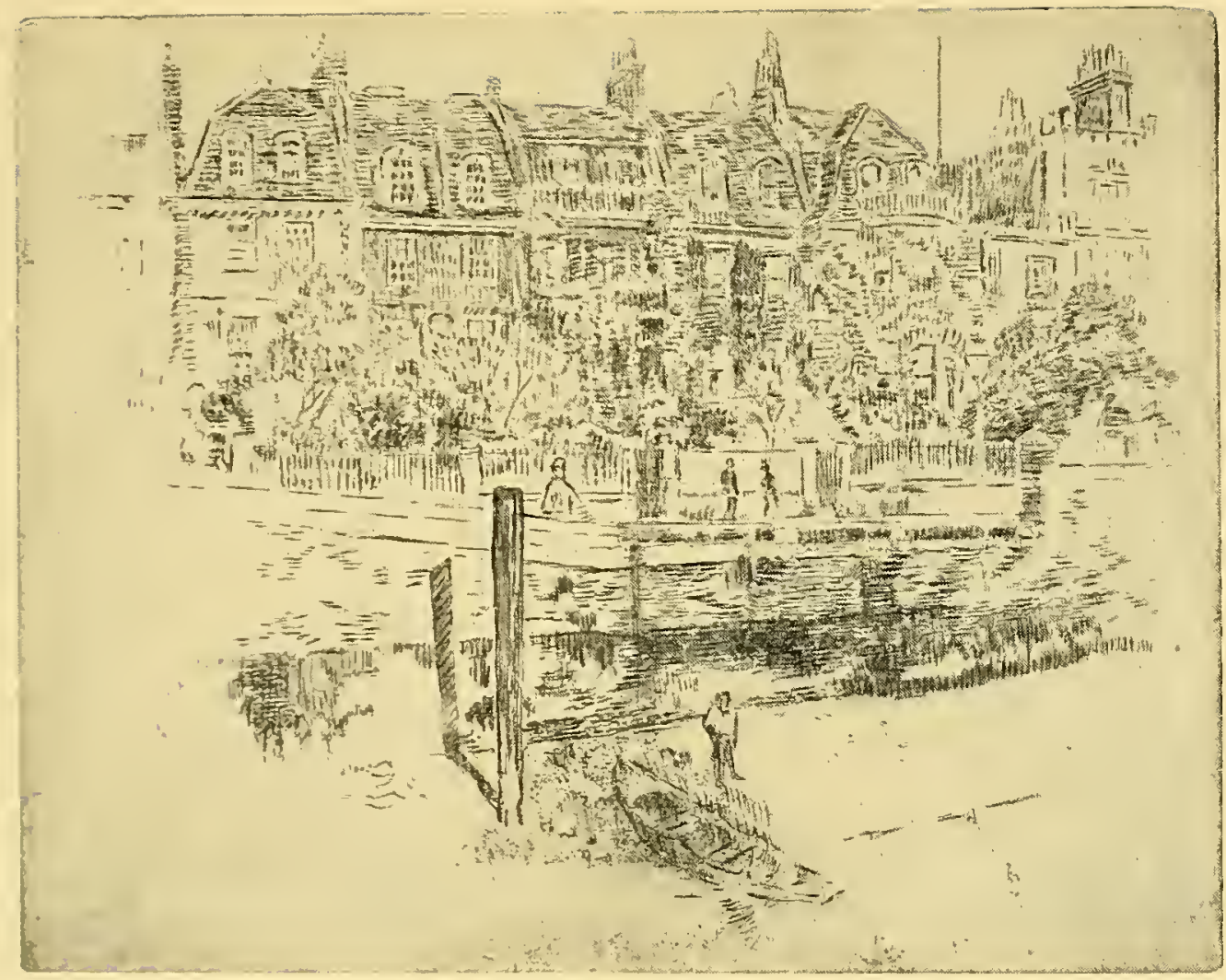

LINDSEY ROW

ETCHING

By Joseph Pennell

Whistler lived in the houses at each end of the Row.

(See page 59) 


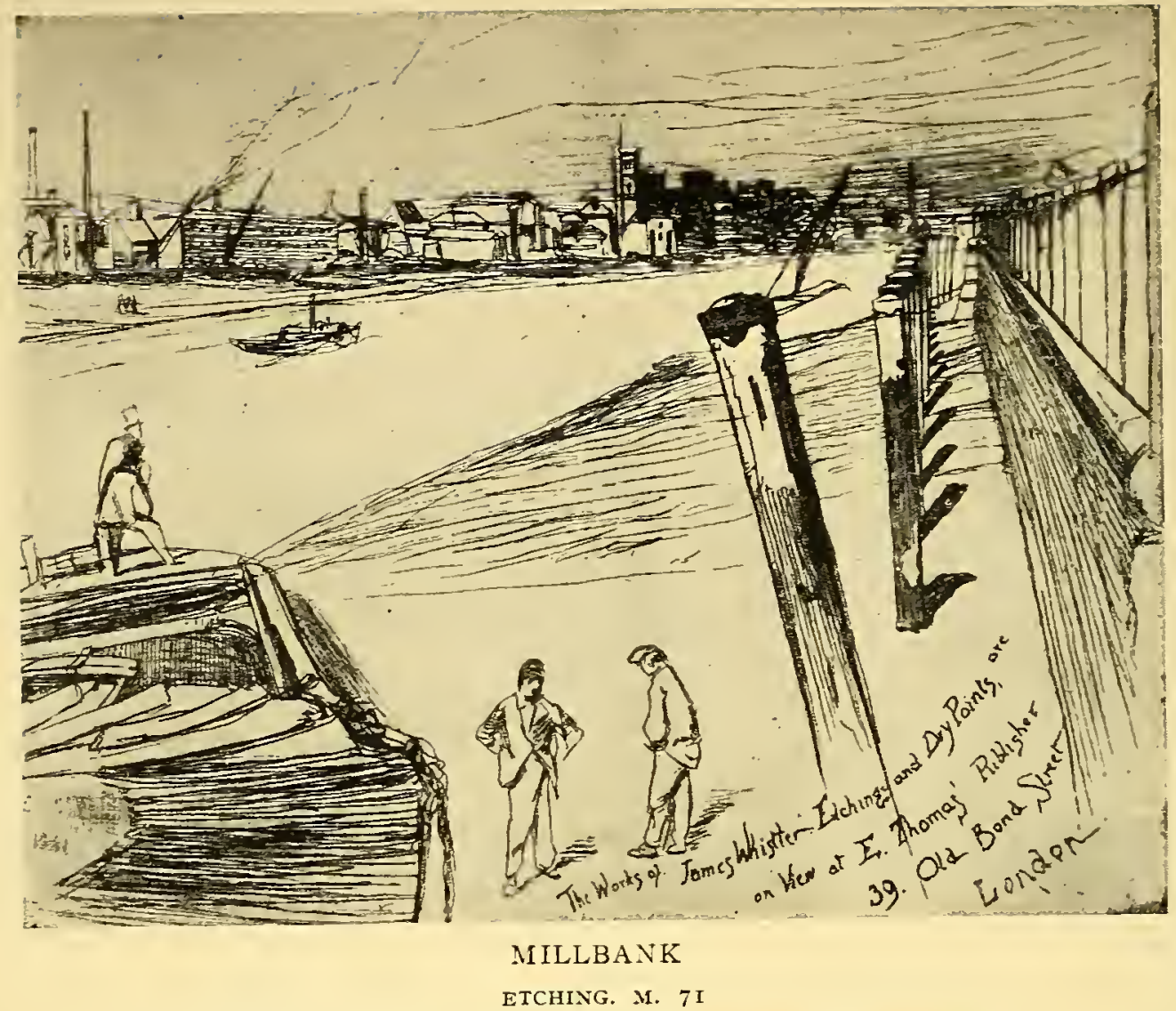

Used as invitation card to Thomas's Exhibition of Etchings 


\section{The Whistler School}

it later. Addams had been admiring the realistic painting of diamonds in one of Sargent's portraits. "Yes," Whistler said, "and the loaf of bread and bottle of wine on the restaurant sign you could recognize for what they are half a square away, but you do not praise them for all that-before the smallest thing ever done by Hals (to whose lesser work Addams had compared Sargent's) you could take off your hat and bow the knee." Whistler praised Sargent's work when he thought it good. An example of this we had another day from Mrs. Clifford Addams, whom he told that when he saw Sargent's painted and modelled Crucifixion for the Boston Library at the Royal Academy, he wrote immediately to Sargent to say how fine it was. Sargent understood. He is reported to have said that there was more talent in Whistler's little finger than in his whole body, and to us he wrote of a letter from Whistler which he regretted not having kept because it was "a generous recognition of something he considered friendly on my part and would have been a record of feelings that he is not often credited with."

Monday, July I 7 th. Whistler came to arrange to bring Miss Bate to tea on Tuesday afternoon that we might have the talk. $\mathrm{He}$ asked who the youth last night was. "Well, entirely too appreciative, you know. Why, he laughed as if he were in it all and understood."

Tuesday, July I8th. Whistler came with Miss Bate to tea, then left us to talk, which Miss Bate did exhaustively. It was interesting to find how absorbed she is in Whistler. She can see nothing outside of Whistler. Even the Old Masters do not count for much to the student. One enjoys them, one does not need them. Before she went to Whistler she learned nothing. She studied with Cormon. She was in despair. As soon as she heard that Whistler was to visit the Académie Carmen, she rushed back to Paris from Belgium. At once, it was another thing. He taught her to see-he taught her that to create something beautiful was the end and object of art. It was a revelation. She saw things differently. There was no question of her enthusiasm. All the students did not understand him-they thought they were learning nothing because he never bothered about composition in the usual way. I899-I900] 
These students left and went back to other studios. But those who were serious and in earnest stayed on.

Wednesday, July, Ioth. Whistler sent word he was ill in bed. J. went at noon. Then he sent and asked me to come later-he wanted to hear about the talk. He was sprightly for an invalid. "Everything," he said, "is to prove that Art is the Science of the Beautiful-the Science, as I have always insisted. It was Knowledge the Old Masters had, exact Knowledge. The modern painter has a few tricks, a few fads; these give out and nothing is left. But knowledge is inexhaustible, and Titian was painting in as masterly a manner in his last years as in his youth." He gave me the last set of Propositions as he has issued them for his pupils, re-printed from The Gentle Art, those in which it is explained that flesh should be low in tone. And he hinted at some wonderful departure in his school-some wonderful apprentice system. It was like him that, though on Monday he declared he would not go to the International Meeting, yesterday when he came to tea he was wavering. He had half a mind to go towards the end of the meeting. "Do you think Joseph would like it if I did?" And he went, and heard so much of the financial difficulties and misunderstandings that, when $\mathrm{J}$. was with him to-day, he wrote a long letter to the Committee, summing up the difficulties and suggesting a way out of them.

Thursday, July 20th. Whistler appeared in the morning in white trousers and waistcoat, jaunty black sack coat, straw hat-very "dandy"-on his way to see Miss Bate. "Well, you know, you'll be hearing wonderful things shortly, pupils articled, what? Why should I bring my pupils to a certain point, and then have them go back to other studios?"

Friday, July 2Ist. Whistler in bed again and we did not see him. But Miss Bate came to show us the wonderful legal document which apprentices her to him for five years in the old fashion. She is not to show or sell any work without his permission; she is to help him in his work if he wants; she is to be in all things sub36

[1899-1900 
missive; while he binds himself to teach and to train her. It was the old legal form; the only clause left out was one that forbade the apprentice to marry during her years of apprenticeship. The whole document was charmingly expressed-just the stately language to please Whistler, and with next to no punctuation from beginning to end. Miss Bate was impressed. She felt the distinction of her position, especially as I think she fancies, though she does not say so, that there will be no other student found to consent to the same terms. Later, Mrs. Whibley came to read over the letter to the International Committee.

Whether there were any female apprentices in the past, we are not sure. But at the Académie Carmen, Miss Bate had no rival except Mr. Clifford Addams, whom she married. Talking of the apprenticeship several years after Whistler's death, her memories were of his pleasure in it. The day the papers were drawn up, they celebrated the occasion by a lunch at the Cafe Royal, when he told her he would make her the greatest woman artist there had ever been-Rosa Bonheur had seen things curiously, with dulness, Madame Vigée le Brun had not known how to draw-but if she left herself in his hands and did as he said, he would make her greater than any. His enthusiasm was wonderful. He always said the thing he could not teach students was how to see. That must be in the student-it could not be taught. It was like Whistler that he always spoke of Mrs. Addams as an Irishwoman, as we supposed she must be, until she explained it was only that Whistler decided she must be Irish because he could not have her English. She went often to Ireland because her sister lived there, and she was married there, so Whistler said she must be Irish, just as he said he wouldn't be born in Lowell.

Mrs. Whibley is Mrs. Charles Whibley who was Miss Ethel Birnie Philip, one of Whistler's sisters-in-law. His portraits of her are many, in oils and in lithography.

Saturday, July 22nd. Whistler left in the morning train for Dieppe, J. going to the station to see him off.

Monday, August 7th. Bank Holiday. Kennedy came to ask us to dine with him. We arranged to meet him at the Cavour at seven. At half past five, he was back to say a telegram had just come from Whistler-was to arrive at seven.

I899-1900] 


\section{The Whistler Journal}

Almost a year passed before another note was added. When we look back and consider how full our life was of work and many interests, the wonder is there were any notes at all. Besides, most of the following winter (1899-1900) Whistler was in Paris, living at the Hotel Chatham, sending us frequent bulletins of the Boer War in the cartoons of Caran D'Ache, saddened by the death of his brother, Dr. Whistler, whom he dearly loved. J., going through Paris, as he was always doing, would stop at the Hotel Chatham and see him there, and there were always experiences. If they came in together, Whistler would invariably walk rapidly upstairs -his rooms were little and dark on the first floor-because, he said, he never knew who might be waiting to entrap him. One day J.remembers coming back and people jumping up, and Whistler running upstairs as fast as he could, and then cards coming up, and then his saying, "I knew it, the damned Pea-Shooters asking me to dinner, thinking they can eat their way in. Because he paints, he thinks he can know me." If Whistler was pursued in Paris, he was probably lonelier there than he cared to admit. $\mathrm{He}$ laughed at "the Islanders," but his laugh was gayest when he was in their midst.

At the beginning of May, I900, he returned to London and stayed with Mr. and Mrs. Heinemann who had moved from Whitehall Court to Norfolk Street, Mayfair. They asked us to dine the evening after his arrival. J. was away, as he often was at this time of the year, but E. had her usual pleasure in going to one of the pleasantest houses in London, especially when Whistler was of the company: All, all are gone.

Friday, May 4th, Igoo. To the Heinemanns to dinner, Whistler having just come to town and staying with them. Mrs. Chalmers Mitchell, a Marchesa something-an Englishwoman-Arthur Symons and Walter Armstrong there. At dinner, Armstrong full of official swagger-you could see how accustomed he is to playing the Director at the dinner table as in his Gallery, and telling people all about art generally. He began to tell Whistler. There never was such a thing as an artistic country or period. "Dear me," said Whistler, "it's very flattering to find that I have made you see it at last, but, really, you know, I think I shall have to copyright my little things after this!" Armstrong was furious, lost his temper completely. "Oh, but you mean it one way, and I 38

[I899-I900 


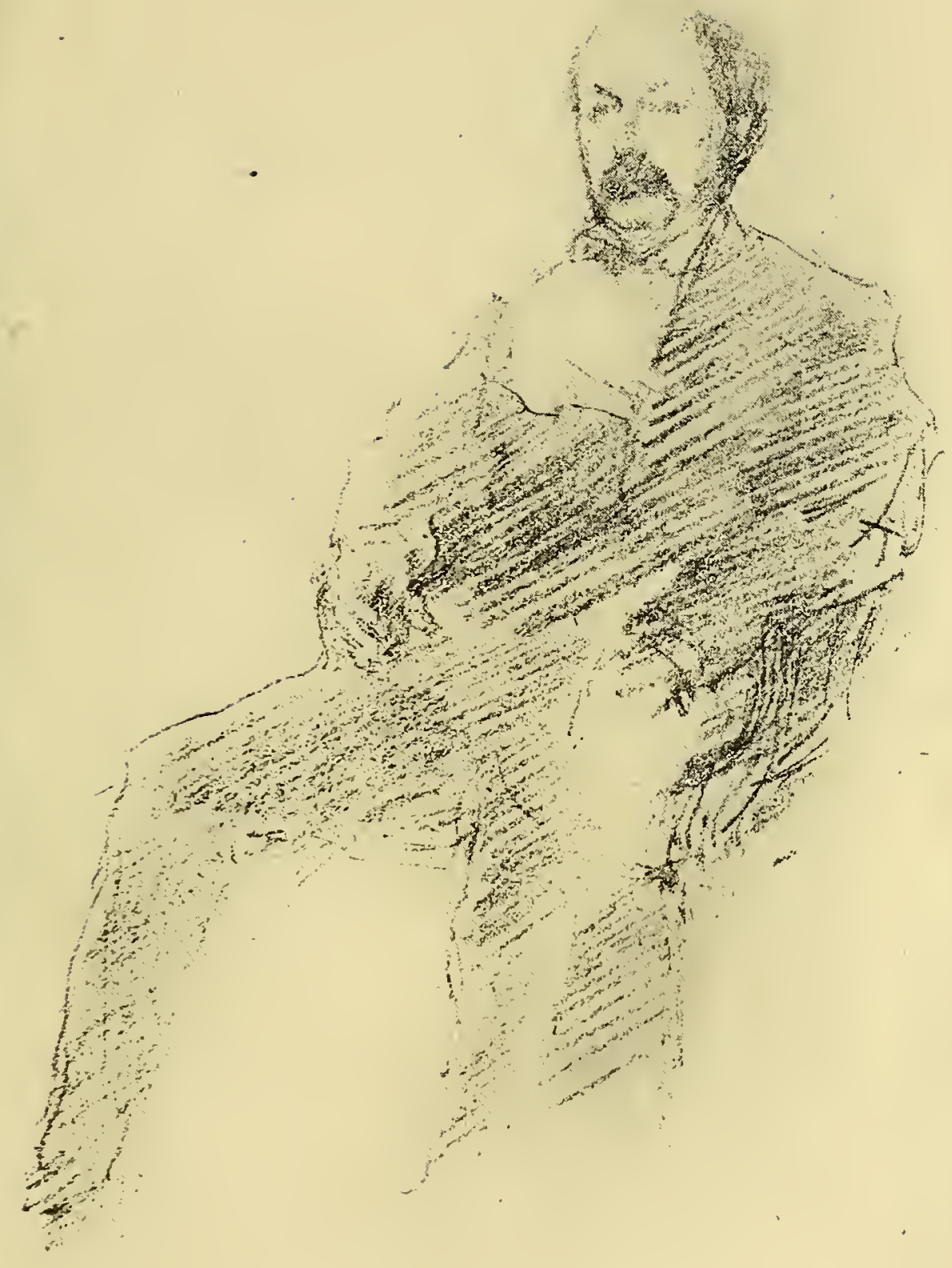

DR. WHISTLER

LITHOGRAPH. W. 78

By permission of Messrs. Kennedy and Co. 

quite another," he said. The Marchesa, who professed contempt for everybody but the English, said that, after all, the manners of the Italians and French were all on the surface. "Well, you know, a very good place to have them!" said Whistler.

Chalmers Mitchell is the Secretary of the Zoölogical Society, London, and he and his wife are old friends of Mr. Heinemann's. Arthur Symons is the poet, and there is a reference to this evening in his essay on Whistler. Sir Walter Armstrong, after many years of art criticism in London, was then Director of the Irish National Gallery in Dublin.

Monday, May 7th. Whistler, the Heinemanns and Kennedy to dinner. Whistler had been to the Royal Academy, had seen the much talked-about Sargents. "Really, you know, it is incomprehensible, all this talk about masterpieces. The big picture is nothing more than the usual game-nothing more than the Ouless or Fildes or Herkomer portrait: just the same thing, only perhaps a little more so. Sargent is a good fellow, I like him extremelybut-really-that is not great painting, what? A smudge for a nose, a great brown shadow a nywhere, anything at all that happened to be on his palette, even to pure white squeezed out of his tube. It is preposterous. And the little picture-smudge everywhere. Think of the finish, the delicacy, the elegance, the repose of a little Terborgh or Metsu-these were masters who could paint chandeliers and the rest, and what a difference! There is nothing in the Academy, nothing, and Sargent is on a level with the others. And it is the same with his pictures in Paris, the one that made such excitement here-the man and the dog with a tongue-or what was it? And so with Cecilia Beaux and all of them-even Boldini. The French, it is true, have a certain sense of things and can draw, and their work gains in dignity by their respect for tradition. But, no. Sargent is a good fellow, yes, but, as a painter, no better than the rest."

Sargent's big picture in the Academy this year was the portrait group of Lady Elcho, Mrs. Adeane and Mrs. Tennant, and the small picture $A$ Venetian Interior, Sargent's Diploma Work. The porI 899-1900] 


\section{The Whistler Journal}

trait in Paris was $M r$. Asher Wertheimer with his poodle before which the British critics had hovered in crowds at the Academy press view of $\mathbf{I} 898$.

Wednesday, May gth. J. back and Whistler, coming in, stayed on to lunch and we sent for Miss Philip.

Miss Philip is Miss Rosalind Birnie Philip, another sister-in-law whom, immediately after the death of his wife, he adopted as his ward and, in a new will, made his heiress and executrix.

Thursday, May Ioth. Whistler and Miss Philip to dinner. Again talk of Sargent. Whistler all satisfaction with the way his pictures are hung in Paris, though J. thinks they might have been treated with more deference. But Whistler wishes he had not sent his own portrait. "It was not ready, the colour has sunk in, you cannot see it, and really it is very swagger."

This was a three-quarters length in a long overcoat. The painting has disappeared, but he made the drawing of it.

Tuesday, May 22nd. Whistler and Ludovici to dinner.

The notes were growing more and more brief, May always being for $J$. the beginning of out-of-door weather and journeys of work, for $\mathrm{E}$. innumerable exhibitions in London and Paris and as many articles to write. I 1900 was the year of the last Paris International Exposition, in which Whistler won two Grands Prix, and E. was busier than usual. The note for May 22nd, brief because the next day E. started for one of her many visits to Paris during the spring and summer, was the last before the letter from Mr. Heinemann printed at the beginning, asking us to write the Life. 


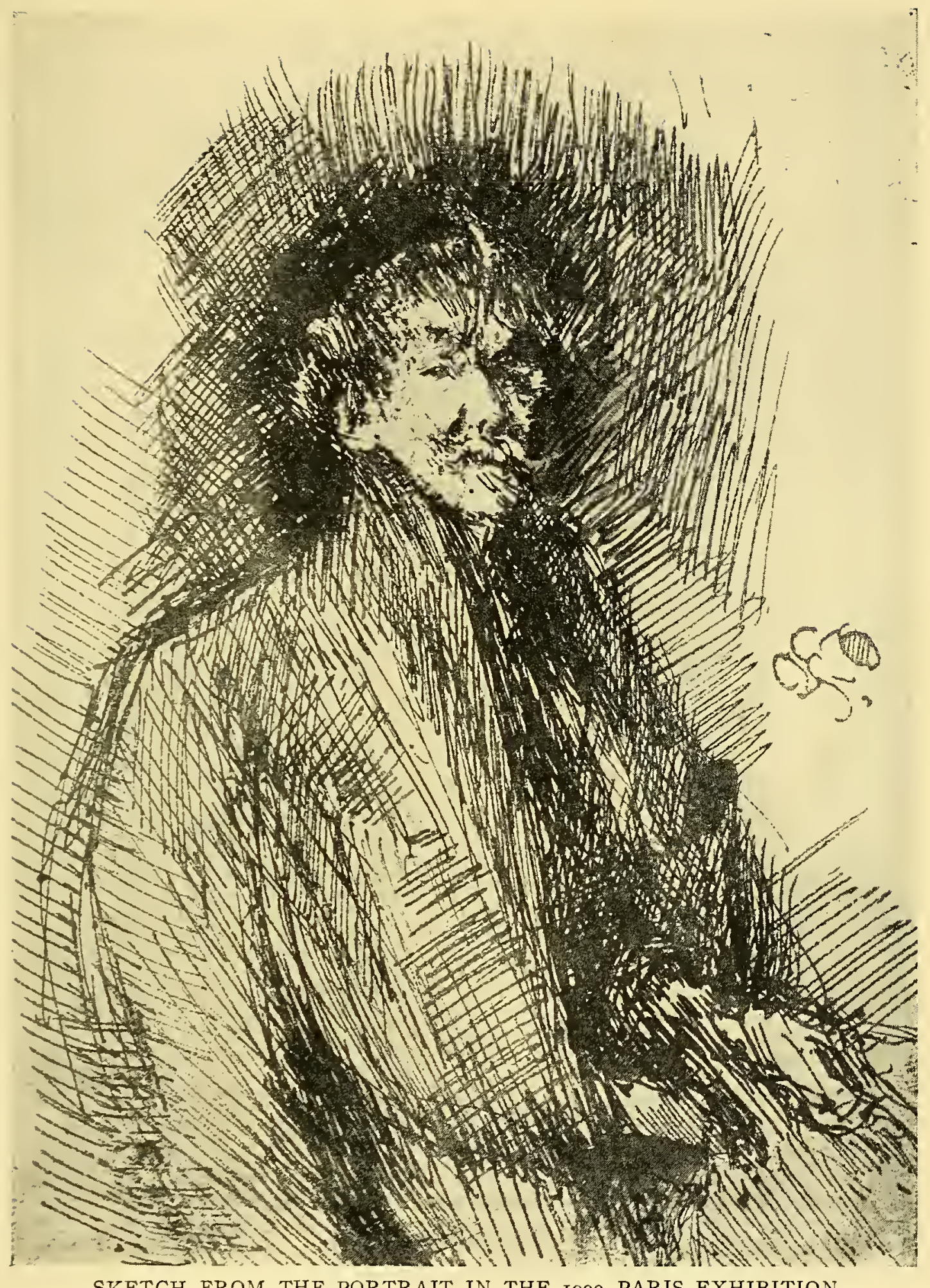

SKETCH FROM THE PORTRAIT IN THE I900 PARIS EXHIBITION

PEN-AND-INK

Pennell Collection, Library of Congress, Washington 


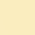


CHAPTER V: THE COMMENCEMENT OF THE WHISTLER JOURNAL. THE YEAR NINETEEN HUNDRED

WE have quoted Mr. Heinemann's letter in the Introduction to this book, and we have tried to explain how we got to know Whistler and what happened in the intervening years. As soon as it was arranged that we were to write his Life, Whistler asked us to dine with him, and The Whistler Journal begins with this dinner. Whit-Sunday, June 3rd, I9oo. Dined at Garlant's with Whistler and Kennedy. We arrived promptly at the hour, a quarter to eight. At the stroke of eight, the waiter turned on the electric light and Whistler appeared: "most dramatir," he said.

The talk turned, somehow, on Rome and he told us more of his two or three days there last year with Heinemann than ever before. "Well, you know, I found St. Peter's fine with its great yellow walls, the interior too big, perhaps, but you had only to go inside to know where Wren got his ideas-how he, well, you know, robbed Peter's to build Paul's! And I liked the Vatican, the Swiss Guards, great big fellows, lolling about as in Dumas; they made you think of D'Artagnan, Aramis and the others. And Michael Angelo? A tremendous fellow, yes; the frescoes in the Sistine Chapel, interesting as pictures, but, with all the legs and arms of the figures sprawling everywhere, I could not see the decoration. There can be no decoration without repose; a tremendous fellow, but, not so much in the David and other things I was shown in Rome and Florence, as in that one unfinished picture at the National Gallery. There is often elegance in the Loggie of Raphael, but the big frescoes of the Stanze did not interest me. And Rome was awfula hard, blue sky all the time, a glaring sun, and a strong wind. And it was the same in Florence-a sky as cold and hard and blue, and a wind blowing."

Later Whistler, when Kennedy asked him if he had had enough, said, "Well, you know, I have already had too much, and too much is enough!"

But it was still later, after he had had his ten minutes' nap and waked up for the evening, that he was most wonderful. He told us the story of Valparaiso more fully than we had ever heard it. I900] 


\section{The Whistler Journal}

It happened when he was living in Chelsea. "It was a time when many of the adventurers the war had made of many Southerners were knocking about London, hunting for something to do, and, I hardly know how, but the something resolved itself into an expedition to go out to help the Chileans, and, I cannot say why, the Peruvians too. Anyhow, there were South Americans to be helped against the Spaniards. Some of these people came to me as a West Point man, and asked me to join, and it was all done in an afternoon. I was off at once in a steamer from Southampton to Panama. We crossed the Isthmus, and it was all very awfulearthquakes and things-and I vowed, once I got home, nothing would ever bring me back again. I found myself at Valparaiso, and in Santiago, and I called on the President or whoever the person in authority was. After that, came the bombardment. There was the beautiful bay with its curving shores, the town of Valparaiso on one side, on the other the long line of hills. And there, just at the entrance of the bay, was the Spanish fleet, and, in between, the English fleet and the French fleet and the American fleet and the Russian fleet, and all the other fleets. And when the morning came, with great circles and sweeps, they sailed out into the open sea, until the Spanish fleet alone remained. It drew up right in front of the town, and bang went a shell, and the bombardment began. The Chileans didn't pretend to defend themselves. The people all got out of the way, and I and the officials rode to the opposite hills where we could look on. The Spaniards conducted the performance in the most gentlemanly fashion; they just set fire to a few of the houses, and once, with some sense of fun, sent a shell whizzing over toward our hills. And then, I knew what a panic was. I and the officials turned and rode as hard as we could, anyhow, anywhere. The riding was splendid and I, as a West Point man, was head of the procession. By noon the performance was over. The Spanish fleet sailed again into position, the other fleets sailed in, sailors landed to help put out the fires, and I and the officials rode back into Valparaiso. All the little girls of the town had turned out, waiting for us, and, as we rode in, called us Cowards! The Henriquetta, the ship fitted 42

[ 1900 


\section{The Commencement of the Whistler Journal}

up in London, did not appear till long after, and then we breakfasted, and that was the end of it. But I made good use of the time, I painted the three Valparaiso pictures that are knownand two others that have disappeared. I gave them to a steward or purser to bring home and the purser kept them. They were seen once in his house or rooms in London by some one who knew me and my work. As soon as he saw them, he said, 'Why these must be by Whistler.' 'Who's Whistler?' said the purser. 'An artist,' said the other. 'Oh no,' said the purser, 'they were painted by a gentleman.' Then the purser started back for South America and took them with him. And, you know, a tidal wave met the ship and swept off purser, cabin, and Whistlers." The return journey was vaguer than the journey out. Out of the general vagueness, looms one figure, the Marquis de Marmalade, "a nigger from Hayti, who made himself-wellobnoxious to me, by nothing in particular except his swagger and his colour. And, one day, I kicked him across the deck to the top of the companion way and there sat a lady who proved an obstacle for a moment. But I just picked up the Marquis de Marmalade, dropped him down on the steps below her, and finished kicking him down stairs." After that we believe he spent the rest of the journey chiefly in his cabin. "And when I got back to London I settled down in Chelsea again, but in another housethe house next to the one where Studd now lives."

Then we got back to earlier days still: the famous journey to Cologne with his friend Ernest: "I had made a little money and we started out gloriously to Nancy and Strasbourg, and we were coming back by way of Cologne and Amsterdam. When we got to Cologne, the money gave out. 'What is to be done?' asked Ernest, who having nothing at all in prospect anywhere, took the situation gloomily. 'Order breakfast!' I said, which we did. Then I wrote for money to everybody-to a fellow student, a Chilean I had asked to look after my letters in Paris--to Seymour Hadento Amsterdam where I thought letters had been forwarded by mistake. We waited. Every day, we went to the Post Office, and every day the officials said, 'Nichts, Nichts!' until finally we got 1900] 


\section{The Whistler Journal}

to be known, I with my long hair, Ernest with his brown holland suit and straw hat now fearfully out of season. The boys of the town would be in wait to follow us to the Post Office, and hardly would we get to the door before the official would shake his head and cry out 'Nichts, Nichts!' and all the crowd would yell 'Nichts! Nichts." At last, to escape attention we spent the day sitting on the ramparts outside the town. When things were looking desperate I went back to the hotel, put the copper plates in my knapsack and called the landlord. I told him we hadn't a sou, but here were my copper plates in a knapsack upon which he would put his seal. 'But what is to be done with copper plates?' asked the landlord. They were to be kept with the greatest care as the work of a distinguished artist-once back in Paris, I would send money to pay the bill, and the landlord would then immediately send the knapsack. He was a good sort, for he agreed, and even gave us the last breakfast I asked for, and Lina the maid slipped her last groschen into my hand. Then, with a supply of paper and pencils, we started off for Paris on foot. It was the time of the autumn fairs and we paid our way by making portraits for a few sous. We even joined a lady who played the violin and a gentleman who played the harp, and we gave entertainments in all the villages we passed through, sleeping in the straw, and tramping it on off days. My little patent leather shoes were all in bits and had to be patched together in the evening at every town or village. And one day when it rained, and I saw Ernest tramping solemnly before me through the mud, the water dripping from his hat and his coat a wet rag, I shrieked with laughter. 'But what would you have?' said Ernest, 'les saisons m'ont toujours devancé.' When we got to Aix-la-Chapelle, it was all right again. I went to see the American Consul, got some money, and did the rest of the journey in comfort. And the landlord was paid, and the knapsack of etchings returned, and, you know, some years later when I was passing through Cologne with my mother and had left her in her hotel in the evening, I went off to find the old hotel and the landlord. And the daughter of the house, who had grown up in the meanwhile, recognized me at once, and many bottles were opened." 


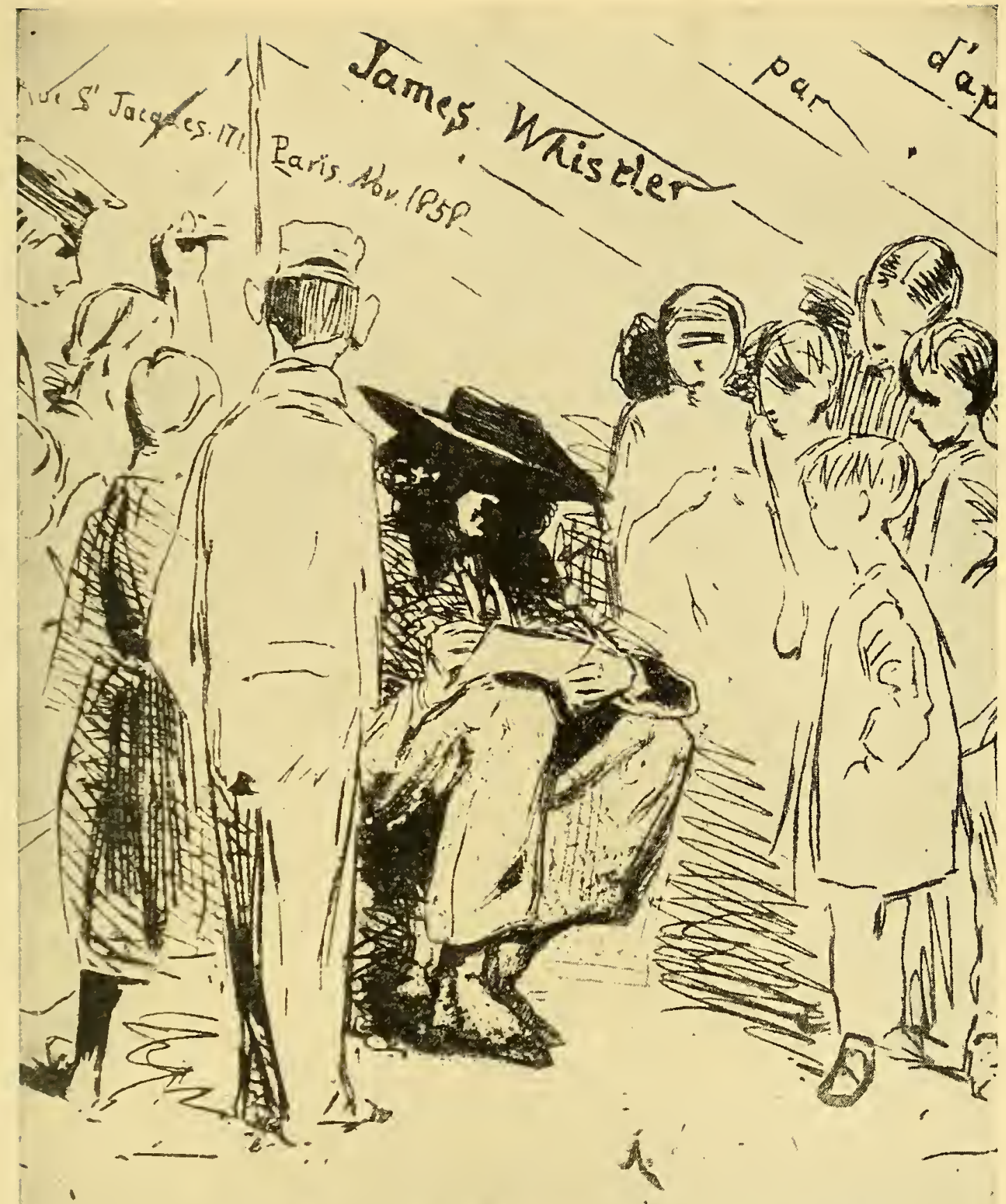

Mon viel Ami Seymour Faden. PORTRAIT OF WHISTLER FROM TITLE TO THE FRENCH SET ETCHING. M. 25 


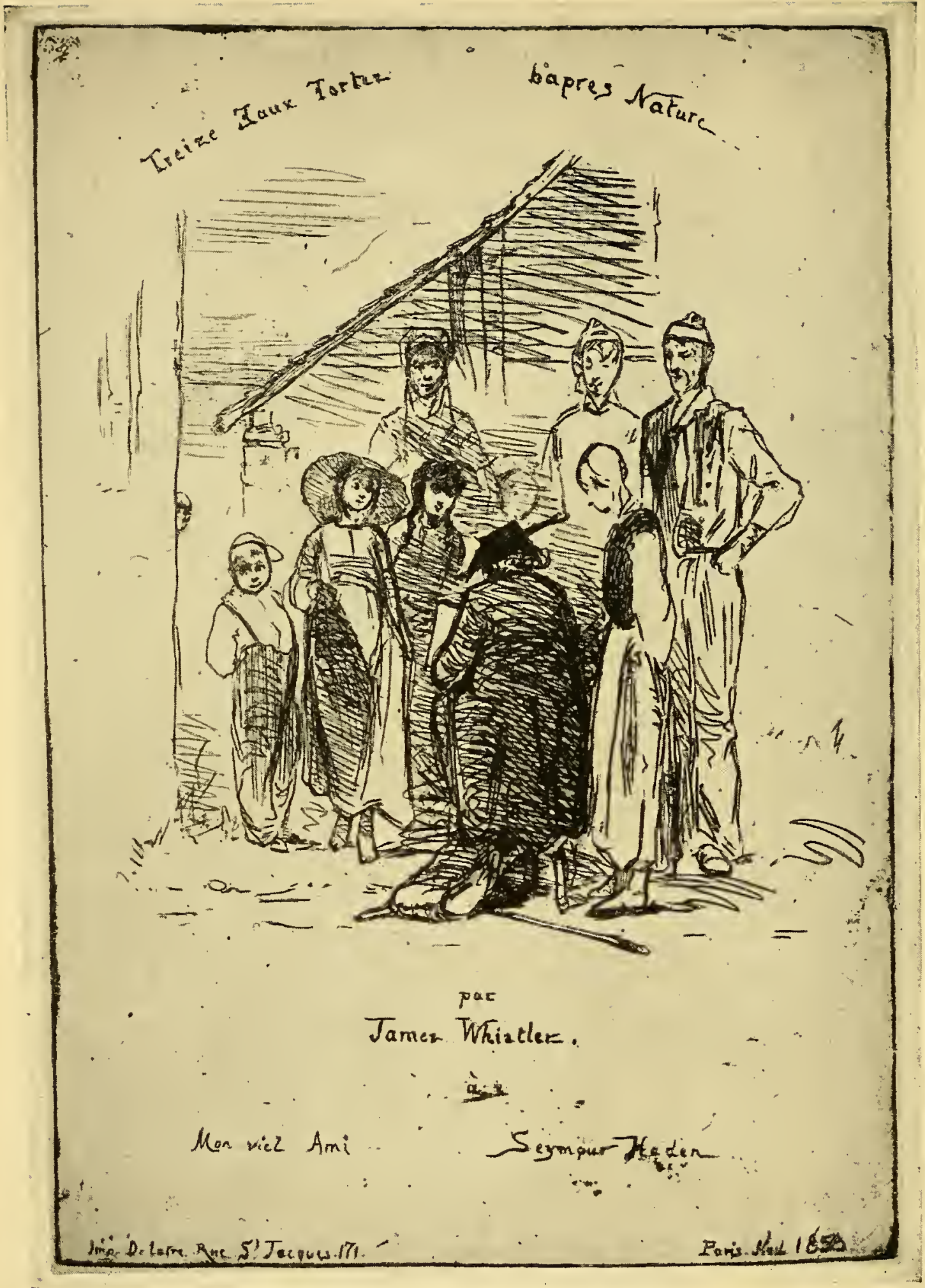

UNPUBLISHED TITLE TO FRENCH SET ETCHING

Grolier Club Supplement. By permission of the Grolier Club 
The Commencement of the Whistler Journal

We had another story of a delightful creature, always without a sou, he knew in those days, the Count de Montezuma. "This was the sort of thing he would do-amazing! He started one day for Charenton on the steamboat, his pockets as usual empty and he was there for as long as he could stay. The boat broke down, a sergent de ville came on board and ordered everybody off except the Captain and his family who happened to be with him. The Montezuma paid no attention. With arms crossed he walked up and down, looking at no one. They waited, but he walked on, up and down, up and down, looking at no one. The sergent de ville repeated 'tout le monde à terre.' The Montezuma gave no sign. 'Et vous?' the sergent de ville asked at last. 'Je suis de la famille!' said the Montezuma. Opposite, staring at him, stood the captain with his wife and children. 'You see,' said the sergent de ville, "the captain does not know you, he says you are not of the family. You must go.' ' $M o i$ ' and the Montezuma drew himself up proudly, 'Moi, Je suis le bâtard!'”'

Garlant's, where we dined, is the hotel in Suffolk Street, Pall Mall, to which at this period Whistler went when in London, unless he stopped at Mr. Heinemann's-" keeping house with Heinemann," he said. It was amusing to us that he chose Garlant's, for close by, in the same street, is the gallery of the British Artists whom he therefore exposed to the constant risk of an embarrassing meetting with their former President, while the hotel was Sir Seymour Haden's London headquarters and the brothers-in-law had not been on speaking terms for years.

The talk often turned on Rome after the winter of 1899 when Whistler was there for the first time on his way to Heinemann's wedding at Porto D'Anzio, the home of Mrs. Heinemann-Magda Sindici before her marriage-and Rome, though disappointing, made a strong impression. Mr. J. Kerr-Lawson's account of his stay in Florence we printed in the Life. Together, they visited the Uffizi, and its gallery of artists' portraits painted by themselves. His would be there one day, Lawson told him; the day never came. After his death some one in Florence realized the mistake of not having invited him and Herbert Horne wrote to J., asking if a portrait of Whistler might be obtained, but it was too late. J. suggested that they apply to Miss Philip, but no portrait of Whistler is I900] 
The Whistler Journal

yet in the Uffizi. If the present owner would send the McCulloch portrait, which Freer had not the sense to buy, he might stand a better chance of being remembered as the intelligent patron of Whistler. One or two incidents of the stay in Florence, Lawson omitted from the account sent us, though not in talking it over. Among other things, he told us of the meeting between Ricci, the Director of the Uffizi, and Herbert Horne at an evening reception.

April 28th, I906. Ricci asked Horne who were the living English painters whose portraits of themselves he ought to have for the gallery. Horne said he must think it over. And he did. And he suggested Holman Hunt, Sargent, and Wilson Steer who, naturally, were willing. Then Horne told Kerr-Lawson what he had done. "And Whistler?" Lawson said, and he advised Horne to write to J. and ask if the McCulloch portrait or any other as good was to be had, but Horne did not follow his advice at the time. Shortly after, Lavery came to Florence and suddenly everyone was saying what a great man he was, and why was not his portrait of himself in the Uffizi, and in the midst of the excitement he was asked for it. Extraordinary, was Lawson's comment, the way Lavery on the Continent seemed to reap Whistler's laurels. Whistler passed through Florence unnoticed; Lavery was fêted, asked to paint his portrait for the Uffizi, given banquets-getting commissions, borrowing easels, using packing boxes for thrones, altogether making a tremendous success. And it was the same everywhere. The fault, Lawson suggested, was Whistler's. Whistler irritated by foolish talk of Sargent, thought to belittle him by praise of Lavery - to pull down the great man by putting up the little. We said it was not like Whistler. But Lawson insisted that it was soWhistler told him, at a moment when praise of Sargent was in every man's mouth, that Sargent was a mediocre painter-any one of the Glasgow School was better, there was-giving the first name that occurred to him-Lavery, for example. The chances were Whistler had only just heard of Lavery, but he served his purpose as well as another. If, however, Whistler repeated this to half a dozen or more people, it was enough to make Lavery's reputation. 


\section{The Commencement of the Whistler Journal}

The whole story is an absurd misconception of the character of Whistler, who was not vindictive over the success of other artists. But it is typical of the sort of thing said of him even by men supposed to appreciate him. As a matter of fact he had known Lavery for years, and Guthrie too and always, as they have told us, they admired him. Of the beginning of their friendliness, Lavery has given us an account. He had only seen Whistler once or twice, rather formally, when one day he met him about four in the afternoon at Piccadilly Circus. "Come," said Whistler, "and have a cocktail," and they went to the Criterion and sat there for two or three hours. From there they went to Lavery's hotel and dined, and Whistler talked and talked and never left until four o'clock in the morning, fresh as ever, but leaving Lavery exhausted.

Another incident, recalled another day by Lawson, is as typical of the persistency with which the English, even as far away as Florence, kept up the old Whistler tradition.

September Ist, rgo6. Lawson, wanting to arrange something pleasant for the day Whistler was in Florence, asked Mrs. Janet Ross if she would not like him to bring Whistler to lunch at her house near Settignano, a visit to her being one of the things the "Loiterer" in Florence was supposed to want most to do after seeing the Bargello and the Uffizi. "Oh," Mrs. Ross said, "he's a dreadful little cad, but bring him," and she rather made a point that he should be brought-she had known him in London, had been to his breakfasts. The next day, toward lunch time, Lawson said to Whistler, "why not go out to Mrs. Ross's house and lunch with her?" "Who's that?" Whistler asked, "Mrs. Ross, that dreadful old bore?" and he wouldn't hear of it. Lawson remembers that he was amusing about Loeser and Berenson-one of them, he said, had strayed into the studio and bought things and carried them off, but the other-Berenson-never ventured.

$\mathrm{J}$. remembers one of the tribe turning up in the Rue du Bac and describing to Whistler his own pictures and Whistler's comment after he had gone. "Well, you know, he knows a great deal more about my things than I do, but then he don't know enough to know that everything he does know is wrong!" When you reflect that these are the people who know everything about the artists of the past, you do not wonder at their ignorance of everything I900] 
going on about them. This was Whistler's only visit to Florence and Rome.

Why Whistler went to Chile, he never explained to us or, as far as we can find out, to anybody else; just as he never explained why he did not go home during the Civil War, though it would have seemed more in accord with the West Point traditions to which he held all his life, and though his brother, Dr. William Whistler, was a Surgeon in the Southern Army. The true explanation probably is that, as Whistler knew, Art is a jealous, no less than "a whimsical goddess," and demands the undivided time and service of the artist. But it is curious, because during the Boer and Spanish wars he worked himself up into the greatest excitement, endlessly discussing them, and yet in the Civil War and the FrancoGerman war he took no personal part. By the grace of God, he did not live through the world-ruining war that we have not yet seen the end of. Mr. McQueen, a young Oxford undergraduate when we knew him, told us that his father was in Valparaiso when Whistler was there, that he put Whistler up at his Club, and that it was from the Club windows that the beautiful upright Valparaiso was painted.

Studd, to whose house in Lindsey Row Whistler referred, was Arthur Studd, for some unknown reason called Peter by his friends. His admiration for Whistler was great. In the end it led him far astray in his interpretation of "the Master's wishes," but a proof of his sincerity is shown in his purchase of The Little White Girl, one of the Cremorne series, and a very beautiful nocturne. He left the three pictures to the British nation on the wise condition that they should be hung at once in the National Gallery, Trafalgar Square. And yet, when the International gave the Whistler Memorial Exhibition in 1905, Studd protested in The Times and other papers that Whistler did not wish an exhibition of any of his works in London, and Whistler told J. and Heinemann that he did not wish any of them hung in an English public gallery. Studd also opposed the scheme of the London Memorial for London, but with no success, for Whistler's friends, with very few exceptions, supported it. The money was obtained. The failure was Rodin's. His design was rejected. We are sorry the pictures remain in London, where Whistler certainly did not want them, though it may at the present time be the safest place for them. More than once he said that no "eccentricity" of his was to go into the National Gallery, that the Louvre was good enough for him. We have seen a letter from him in which he refers to one he wrote to Studd to beg him, if The Little White Girl ever left the 


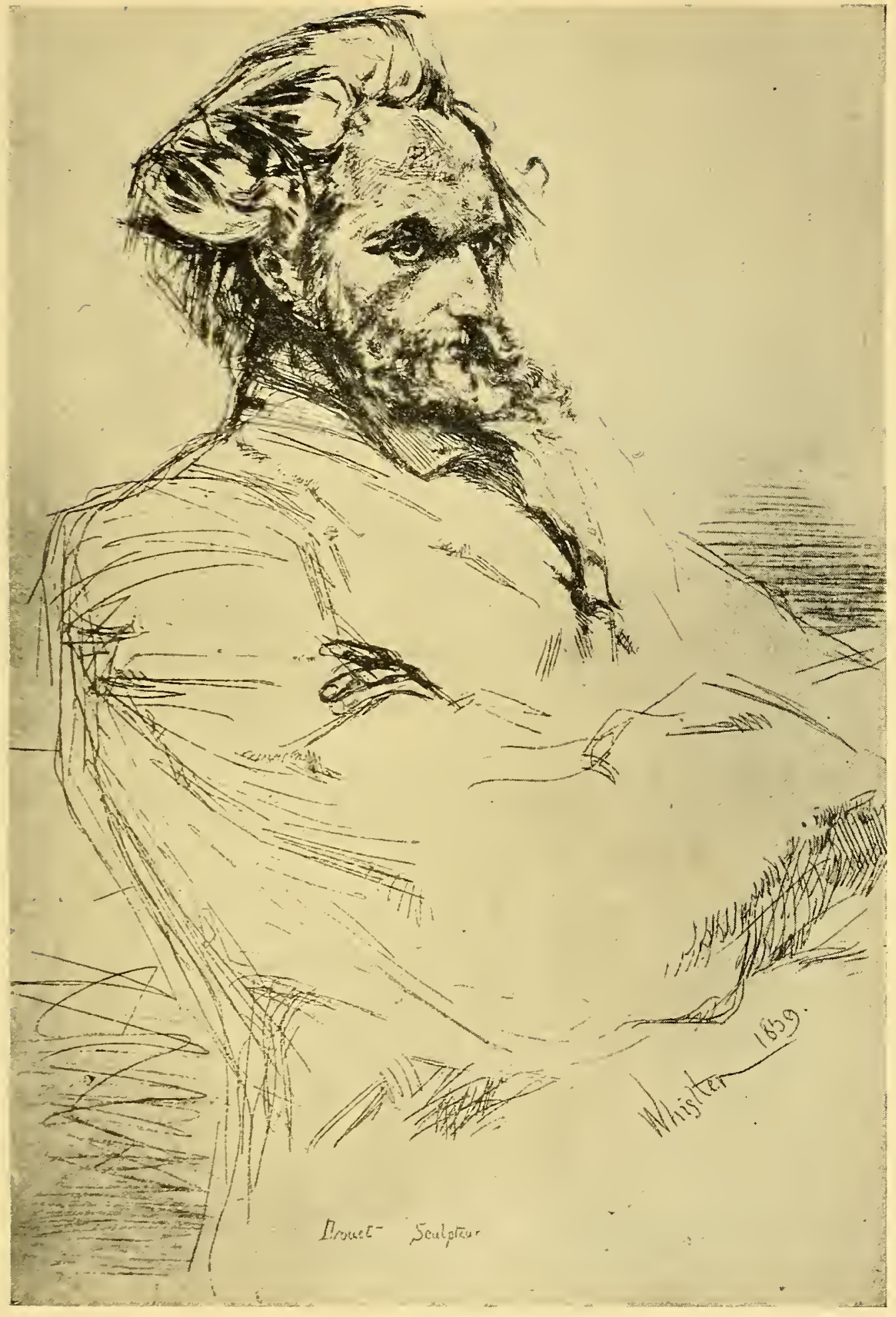

DROUET

ETCHING, M. 55 


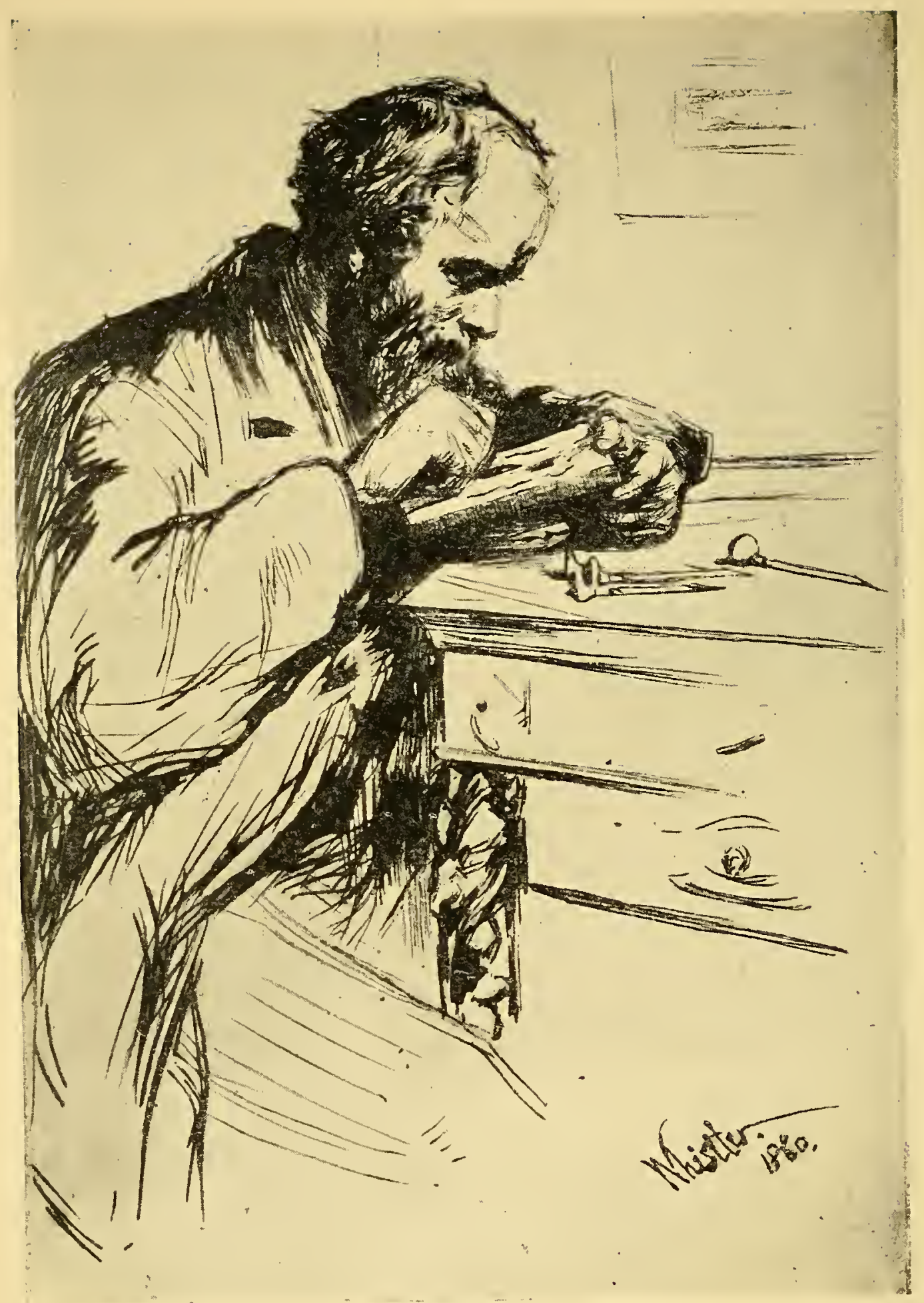

RIAULT

ETCHING. M. 65 
family, to promise not to leave it to any gallery in England. He did not want his pictures to go even into private English collections. They might be sold to Scotchmen, Irishmen, Americans, Frenchmen, but never to an Englishman. However, if, as it has turned out, Studd's pictures-and the same is true of Mr. Alexander's-had to remain in London, we are glad they are the property of the British nation. And so, Studd, in defiance of Whistler, did great good. We have not seen The Little White Girl and the Nocturnes in the National Gallery and we like to remember them as they hung - the only pictures on the wall-in Studd's drawingroom in the old Lindsey Row house looking out on the river, near where they had been painted and where they seemed to belong.

Ernest was Ernest Delannoy, a nephew of Benjamin-Constant, the statesman. The story of his life was finished for us a few years later by Drouet, the sculptor, Whistler's friend to whom we owe many facts of Whistler's student days in Paris. There is a note of our first visit to him.

May 9th, 1907. Drouet asked us to come and see him in the Rue de Seine; a little court, an old stairway, and two or three small rooms, crammed with pictures and drawings, from floor to ceiling, on easels, stacked in corners, and almost all copies or fakes. In the largest room, a bed in one corner and a table with old velvet as cover, hardly space for two or three chairs; in the adjoining room, the washstand. As he told the story, Ernest and Whistler both wore the same sort of linen suits for their journey, and so Ernest was able to pose for the portrait, all but the face, in the title to The French Set of etchings. Ernest could not stand London, where he went to stay with Whistler, it was trop triste. But he was in misery after he came back to Paris: he could get no work. He had not money for sufficient food. In the end, he went mad and died in a lunatic asylum.

Whistler's adventures in Alsace, as he recalled them, gave us one of many glimpses of his gaiety as a student-the gaiety so bewildering to the solemn Britons, his fellow students, that Sir Edward Poynter brought back to London the myth he never ceased to believe in of Whistler-the Idle Apprentice. It was the one impression he gave in his speech at the Royal Academy banquet the year following Whistler's death; his usual suggestion in private as, when 1900] 
The Whistler Journal

looking over some Whistlers at the Fine Art Society's that same spring, "A genius," he said to Mr. Langton Douglas, "but the devil wouldn't work!" Whistler, never a member of the Royal Academy, was worth a sneer from Poynter after his death-but he was not elected because the American members did not want him. If sometimes, as on this Third of June, Whistler spent the evening recalling his early life, on other evenings he told us nothing of the past. But, as we agreed, he was to talk when he felt like it, and we were to listen. We had the sense not to bother him as most people did. Had we bothered him, we would have heard nothing at all.

Tuesday, June 5th, I9oo. Mr. and Mrs. Janvier to dinner, and about half past nine Whistler and Kennedy came in. I was vexed to see that Whistler's most gallant manners lavished in an opening remark to Mrs. Janvier, who was sitting nearest to him, were lost upon her as she is rather deaf and did not hear. And his gallantry is too charming to lose. He consented to Gray's going up to the studio to-morrow to begin photographing the pictures there for the book. Kennedy asked us to dinner at Garlant's, but it was decided they should both come to us to-morrow- "we shall have a so much better dinner with you," Whistler said, "and then, you know, they never have any sweet things round there"- !

On Sunday evening, the first note shows, Whistler began at once to give us facts of his life in the course of his talk, as he had promised. It was a greater proof of his interest in the book when, two evenings later, he came to our flat to see about having his pictures photographed. Nobody knew better than Whistler that to photograph pictures successfully takes long and calls for special arrangements of light, and that, while it was going on, his studio would be disorganized. We wondered, therefore, how he would feel when it was time to begin, but he accepted all the arrangements $\mathrm{Mr}$. Gray proposed. Gray was W. E. Gray, one of the best photographers for this kind of work in London. He had already made photographs for Whistler of which Whistler approved. Later, at the trial which Miss Philip brought against us and Heinemann to prevent the publication of our book, and which she lost, these photographs done for us were produced by her in court for some unknown reason, as they proved we had been authorized to have them made. Not content with this, Miss Philip in the witness box 50

[I900 
The Commencement of the Whistler Journal

stated that it was Whistler's wish that J. should go round Europe and America on a bicycle making snapshots of his pictures wherever $\mathrm{J}$. found them. But her statements were so amazing that nobody thought it worth while to cross-examine her.

Mr. Janvier was Thomas A. Janvier. He and Mrs. Janvier were living in London at the time, and we saw much of them.

Wednesday, June 6th. Whistler and Kennedy to dinner. A quiet dinner. Joseph had been up in the studio most of the day, superintending the photographing, and Whistler seemed satisfied with what Gray was doing. He slept more than usual, and Kennedy, ruthlessly carried him off, just when he really waked up and was in the humour to talk.

Sunday, June Ioth. Miss Philip, Whistler and Kennedy to dinner to celebrate Whistler's Grands Prix and J's. Gold Medals, Whistler, of course, treating the occasion with all solemnity and distinction-arriving with Miss Philip, both in evening dress-we were not, which he evidently thought a slight on our part. "Shocking! Shocking!-your want of ceremony," he said. Just before we sat down to dinner, Cole came in most unexpectedly; as the other Gold Medallist, it was appropriate, but things did not go quite as they ought to have gone to begin with. Cole was still full of the diet question. He now lives chiefly on rhubarb topsthey have such a "foody" taste, his son thinks. "Dear me! Poor fellow!" Whistler told him, "it sounds as if once long, long ago he had really eaten, and still has a dim memory of what food is!" "And spinach," Cole added, "it's fine. We eat it raw. It's wonderful, the things it does for you!" "But what does it do for you?" Whistler asked. And Cole began a dissertation on the juices of the stomach. But that was enough. Whistler would have no more. "Well, you know, when you begin to talk about the stomach and its juices it's time to stop dining." As he talked Cole was eating meat and drinking wine quite heartily. The evening was not over successful.

Whistler, like all true artists, hated awards at exhibitions, especially if he did not get the first one. For long, second-and-third-class I900] 
honours usually came his way, as in Munich when he arranged a show for the British Artists, in which they did not play up, and he received a second-class medal and thanked the Directors for their second-hand compliment. In Paris he got only one thirdclass medal, and in the first Venice International a third-class prize. But his objections came less from the fact that he was badly treated for many years by international jurors with no understanding of his art, than from his realization that money prizes for works of art were simply an incentive to graft and dishonesty. In no land has this system been carried to such an extreme as in the United States, where large cash prizes are annually awarded in large numbers of American exhibitions to American artists only. As far as we are aware, not a single one of these cash prizes was ever awarded to Whistler, and the majority of the men and women who have won them are unknown internationally. Further, Whistler was never made a member of the National Academy of Design and he belonged to the Society of American Artists only for a year or so. The consequence was that, in the few societies in which he had any controlling voice, he absolutely opposed money prizes, and in the International would not allow even medals to be given. And in these matters he was right.

However, when awards were given at an exhibition and the highest were bestowed upon him, he accepted them as practical signs of the appreciation of his work. This was why he was pleased when, at the Paris Exposition of 1900 , he was awarded a Grand Prix for Painting and another for Etching, and he did not conceal his pleasure. He was the more pleased perhaps because he had passed through a moment of doubt, of which we have a note:-

January I8th, 1908. Mr. Charles Prince tells us of the morning he went to see Whistler off for London at the Gare du Nord and found him on the platform in great agitation. "O," he said, "if only you had come five minutes sooner!" And explained that he had just read in one of the Paris papers a notice of the Exposition and his pictures were criticised in a way that convinced him something must have happened to them or that they had been badly hung, and he wanted to see to make sure. But his trunk was registered and in the luggage van, and it was too late. Mr. Prince got his trunk and a porter to carry it to a cab, and they drove away and left it at the Hotel. Then they breakfasted well, and drove on to the Exposition and went straight to his picture. He looked at it $5^{2}$ 
The Commencement of the Whistler Journal

in silence for a few minutes, hid his face in his hands-just like a girl, was Mr. Prince's description-and said "Why it's all right!" Afterwards, he was looking at other things, and one of the attendants, an American-most of them were students who had got the post for the summer-came up to Prince to ask who Whistler was. Prince told him. The man's eyes opened. "What! He's the biggest man we've ever had and we've had Kings!"

J. received Gold Medals for Etching and Drawing, and when the news came of the honours they both had won, we celebrated the events, as we celebrated all things in those days, with a little dinner. The announcement of the awards had been officially received while we were still in Paris. Then Heinemann gave Whistler a dinner, and they crowned him with laurel-or sprays from a plant in the dining-room-and Whistler was delighted. Now it was our turn to celebrate.

Cole is Timothy Cole, to whom a Gold Medal was awarded for his Wood Engravings. He is a remarkable man as well as a remarkable engraver, and Whistler enjoyed meeting him at our dinner table two or three years before when he was in London engraving the series of English Masterpieces for The Century. He had been away from London for some time, the mistake over the practical joke of which we have written had been forgotten, and nothing could have been more unexpected and appropriate than his sudden appearance. He was then, as we hope for his sake he is not now, an ardent vegetarian, though not a bigot. He ate no meat at home, for long he lived chiefly on apples and nuts, but we never knew him to refuse meat when he came to us.

Monday, June IIth, 19oo. Whistler alone to dinner. I had written that it was Joseph's last dinner, and that Joseph would be out all afternoon but would be home at eight. Whistler's answer was that he would come at eight, which, of course, meant dinner. When he came, "Well you know," was his greeting, "you will feel about me, as I did in the old days about the man I could never ask to dinner, because he was always there! I couldn't ask him to sit down, because there he always was already in his chair!" He was much pleased because he heard that when the International jury were voting for the American Medals of Honour, his were voted for unanimously and were read out the first of the list to I900] 


\section{The Whistler Journal}

unanimous applause. He read us an amusing letter from the Manager of the Hotel Chatham congratulating him on the award, which he, of all men, so well deserved. He promises to let Gray finish photographing. The South African position enchanted him: Mrs. Kruger receiving the British Army, while the Boers retired with all they wanted, and went on capturing the British soldiers wholesale-for the news has just come of the surrender of six hundred of a Derbyshire Regiment. He liked too The Star's suggestion that Buller might yet have to march to the relief of Roberts at Pretoria. A quiet evening, but delightful.

Tuesday, June Igth. Whistler called in the evening, but only for a few minutes. He thought Joseph was back. He had been out of town with Wimbush, who took him to Amersham, beyond Pinner, where he had meant to stay. "Well, I could see that towards twilight, it might be pretty in a curious way, but it was not really pretty, and so I came back. I want to go somewhere, for I have promised to paint two landscapes." He says he will come on Sunday when Mrs. Custer and the Lungrens are to be here.

From the earliest days Whistler was bored in the country and made a jest of his boredom. He never stayed long in it anywhere except at Speke Hall, the Leylands' place near Liverpool, and there the sea was close by and his chief work was painting or etching his many portraits of Mr. and Mrs. Leyland and their children. At first, when he was young and trying everything, he sometimes went to week-end parties and shooting parties. Sir Frederick Milner wrote us a story of Whistler's visit to his place. The first morning he started off with the rest to shoot, in little light shoes more appropriate to a drawing-room. Sir Frederick, a much larger man, lent him a pair of shooting boots in which he was the most comic sight imaginable. A hare suddenly sat up and looked at him. Whistler fired and shot it dead. Then he threw down the gun-he had had enough-he had never shot anything before-he wanted the experience and it was enough. It must have been before this that he tried his luck at the Leylands' when his own report was, "I rather fancied I shot part of a hare for I thought I saw the fluff of its fur flying. I know I hit a dog for I saw the keeper taking out the shot!" Sport amused him no more than the week-end. We know of his attempting no other variety save cycling, and then, 


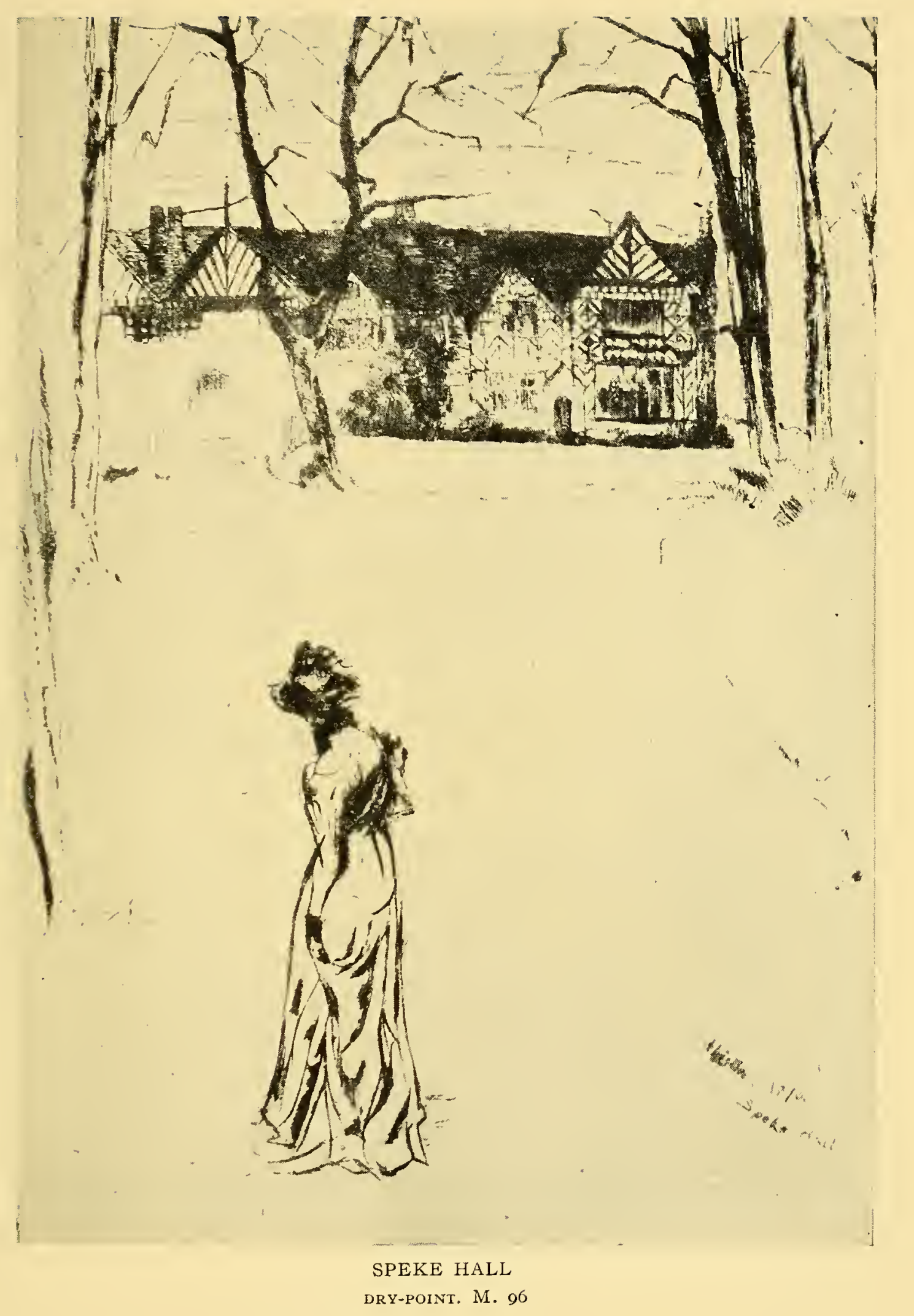




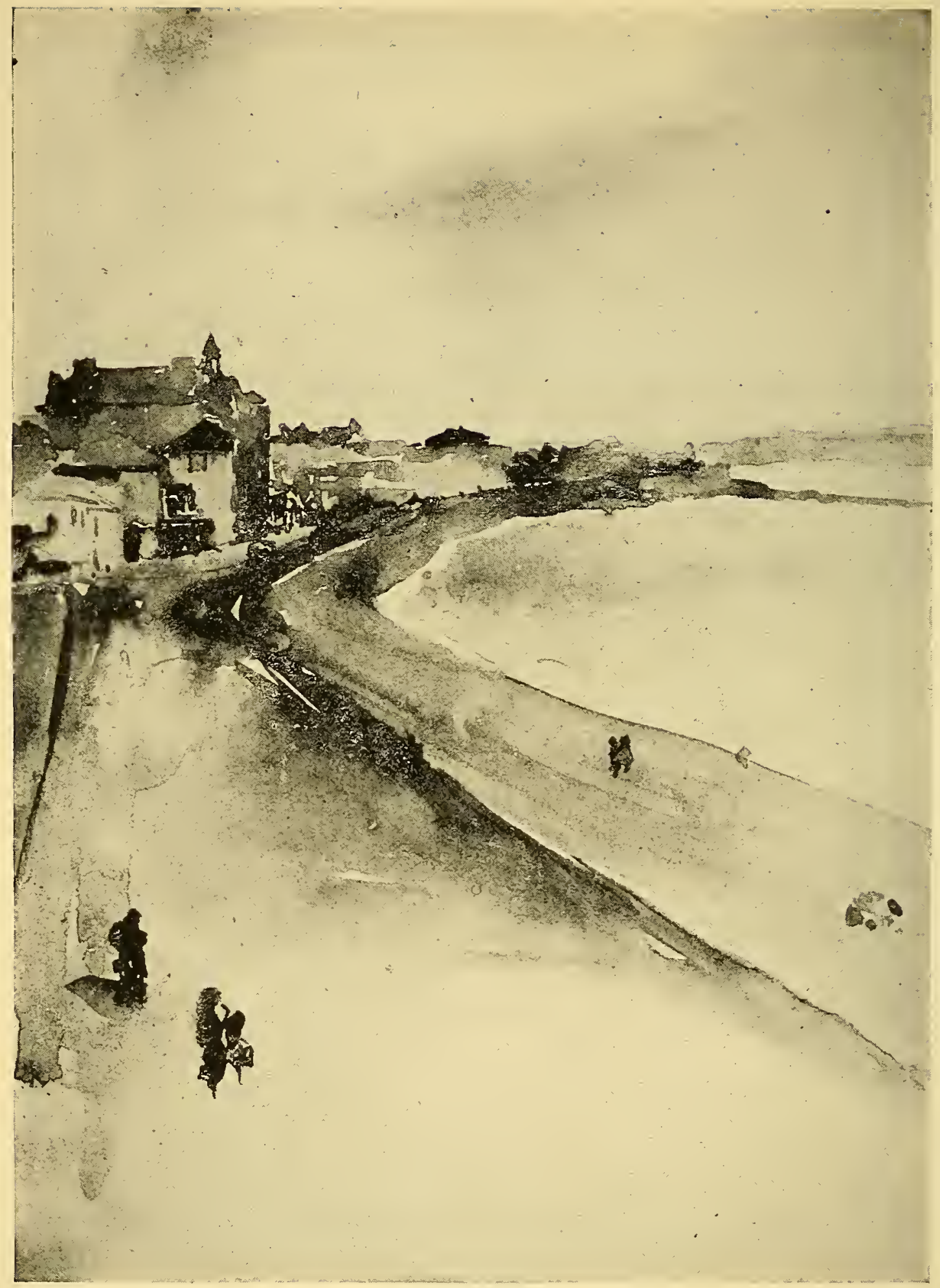

LYME REGIS

WATER-COLOUR

In the possession of Mrs. Knowles

(See page 14) 


\section{The Commencement of the Whistler Journal}

as we wrote in the Life, he fell off his wheel and was consoled only because the fall was in a rose bush. But the truth is, he soon wearied when away from town, and even the ocean he could exhaust, as he laughed in a letter to Mrs. Dr. Whistler from St. Ives. If his friends were in the country he would urge them to come up to town for a breath of fresh air, for which he would promptly run up himself if he was the unfortunate exile. He hoped the country would do her no harm, he wrote to Lady Colin Campbell-it could not make her more beautiful. Altogether, the grasshopper was a burden! He, or rather the world, lost by this prejudice, for it was the cause of canvases left unfinished, landscapes, marines, portraits thrown aside because he could not resist the call of the town. An unfortunate example is a small, practically unknown portrait of Mr. George Lucas which it would be doubly interesting to have, now that Mr. Lucas' collection of Whistler prints, letters and papers-a valuable collection-is in the Maryland Institute in Baltimore. He was an old friend of the Whistler family, a most affectionate and useful friend of Whistler himself in the early days and until the end, though they saw less of each other after Whistler's marriage. He was another of the remarkable old men our search for Whistler material introduced us to. E. has vivid memories of the winter morning in Paris, when M. Duret took her to see him in his apartment.

February IIth, I904. He was then eighty-like a prophet with his white beard, and in his long grey soft flannel coat and grey skull cap, sitting in a fairly small room, delightfully littered with his collections; the walls hung as close as possible with pictures-two Corots, a Daumier, a beautiful little Fantin like a Diaz, a Daubigny, a Hervier and more than I had time to look at, against the walls, two or three little cabinets covered with small bronzes by Barye and a few low cases filled with portfolios, labelled, Whistler, Manet, Jacque. He had just got the news of the great fire in Baltimore. It was the business part of the city which had been burnt down, the old part, and his house, the house where he was born, was almost in the middle of it and therefore must have been destroyed. He showed me a map of Baltimore to explain, and for a while could talk of nothing else.

At last, he began to talk about Whistler, and brought out etchings and water-colours and the portrait of himself in oils which Whistler I900] 


\section{The Whistler Journal}

had done, or rather begun once, he said, when staying with him in his place in the country. There had been only two sittings and then Whistler, unable to stand the country any longer, rushed back to London. It is a small portrait-anticipating the Holloway, Hannay, Kennedy, Crockett portraits. A label, stating that it is the result of two sittings, with the date, is on the back, and the date is I886. Mr. Lucas was therefore almost twenty years younger, but it was still like him. He stands facing you, in a loose blue-black coat and trousers, cane in hand, against a brown background, charming in colour, full of character. Mr. Lucas said it was characteristic that, as he heard afterwards, Whistler should be much concerned about it-asking some one who had seen it whether it was really beautiful, really his best-he did not want anything that was not to remain.

It was over the discoveries in this collection that the critics of America made such fools of themselves. If Whistler had no use for the country, he delighted in little country towns and villages, leaving in oils and water-colours and prints many records of his wanderings through them in France and Belgium, Holland and England. Lannion, Paimpol, Pourville, Domburg, Lyme Regis are names that occur to one at once. In some, if he carried away his impression of the place, he left an impression of himself hardly less strong. One evening during the war Muirhead Bone had dropped in to see us:-

July I8th, I9I6. He gave an amusing account of how Whistler is remembered at Lyme Regis, where Mr. Bone and his family spent the summer of I9I4. When he took his house he asked the house agent if he had known Whistler. The house agent said he had rented Whistler a studio, the first time we ever heard Whistler had a studio there. It was a sort of big house-painter's shop with plenty of light. The house agent was also a coal merchant, and Whistler's French servant used to come and buy coal by the pound, and take it home, which astonished the house agent who had never seen such a thing done before. No doubt he put it down to the queer ways of the foreigner. After this, Muirhead Bone made a Whistler pilgrimage through the town. He found the Blacksmith who looked like the lithograph and painting and who is as hand56

[ 1900 


\section{The Commencement of the Whistler Journal}

some as ever. He also found Little Rose. She is the daughter of the grocer he dealt with, she has married away from Lyme Regis, but she came in once while he was in the shop, big and buxom, with very red cheeks.

Friday, June 22nd, I9oo. Whistler called in the morning to say he would dine on Sunday. He seemed to be quite hurt that J. would stay away while he is here, and he was sure if he went down to join J. in Norfolk, illustrating articles on the Norfolk Broads for The Century, J. would at once be moving on somewhere else.

Sunday, June 24th. Dinner: Mr. and Mrs. Lungren, Mrs. Custer, Mrs. Ohl, and Whistler-the latter in great form. As we sat down, Mrs. Custer said something about the annoyance of having too many friends - "Ah," he said, "you should do as I did—get rid of them all at the start!" Rome, he described as "a bit of an old ruin along side of a brand-new railway station, where I saw Mrs. Potter Palmer." The talk was chiefly of the Boers. He had a sympathetic audience, and so went over it all again ... "Well, you know, Bismarck said South Africa would prove the grave of the British Empire, and that the day will come when the blundering of the British army will surprise the world. And there was a kind of a professional prophet who predicted a July that would bring destruction to the British, and I-well-for my part, I am waiting to see what this July of $\mathbf{1} 900$ has in store for the Island-What?" Then, the inexhaustible subject of British cleanliness-"Paris is and always has been full of baths-you can see them, beautiful Louis XV and Louis XVI baths on the Seine. In London, until a few years ago, there was none, except one in Argyll Street, to which Britons came with a furtive air, afraid of being caught. And the French, having the habit of the bath, think and say nothing of it; while the British-well-they're so astonished now they have learned to bathe they can't talk of anything but their tub: that is the difference."

The little party of Sunday, the 24th, was in every way to Whistler's fancy. Mrs. Custer is the widow of General Custer, and so he was 1900] 


\section{The Whistler Journal.}

sure she could understand the situation in South Africa. Mrs. Iungren was her niece, young and pretty. Lungren is Fernand Lungren, the artist, who was an influence in raising American illustration to the high level it reached in the Eighties and Nineties. Mrs. Ohl, wife of a well-known American journalist, is from Georgia and Whistler dearly loved a Southerner. Besides, he had already met her in Paris where she had an apartment for a year or two, and a young friend, another Southerner, who shared it with her, was a student at the Académie Carmen. There was no jarring element.

Monday, June 25th. Dined at the Maurice Macmillans, and while I was there Whistler called at Buckingham Street.

\section{CHAPTER VI: CHARLES AUGUSTUS HOWELL, HIS FRIENDS AND HIS ENEMIES. THE YEAR NINETEEN HUNDRED CONTINUED}

Tuesday, June 26th, Igoo. To make up for missing Whistler yesterday, asked him to dine with me alone. He came about a quarter past eight. "You know, I meant to send an answer by the boy, but somehow the boy had gone before I knew it, and then, somehow, the day had gone before I knew it, and there was nothing to do but come and make my apologies." He brought with him all the choice clippings from the papers of the two last days, reporting the news, with comments, of the early days of the month, which so far had not been sent in detail. . . . These, with his own additional comments, he was preparing to send to Kennedy, who ventures to sympathize with the English ... .

But the talk of the evening was on Howell, "the wonderful man, the genius, the superb liar, the Gil-Blas, Robinson-Crusoe hero out of his proper time, the creature of top-boots and plumes-splendidly flamboyant. Rossetti made a famous limerick of him:

There's a Portuguee person called Howell,

Who lays on his lies with a trowel.

When I goggle my eyes

And start with surprise

'Tis at the monstrous big lies told by Howell. 
?.1879 3110 His is Shells pro. Sad costume he his teen having $\sigma$

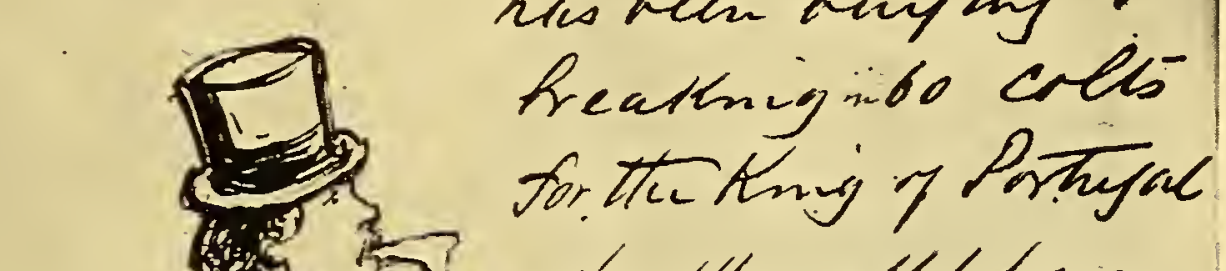
ste Itrovell/ has. Lint creed. tar. claseol a mem n a card en envy clive r litter, to you

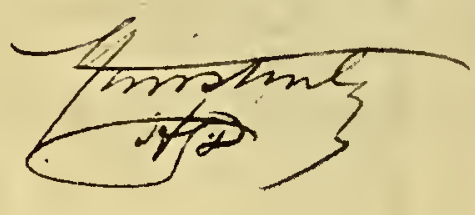

C. A. HOWELL

PEN-AND-INK

By H. T. Dunn

In the possession of the Estate of W. M. Rossetti 


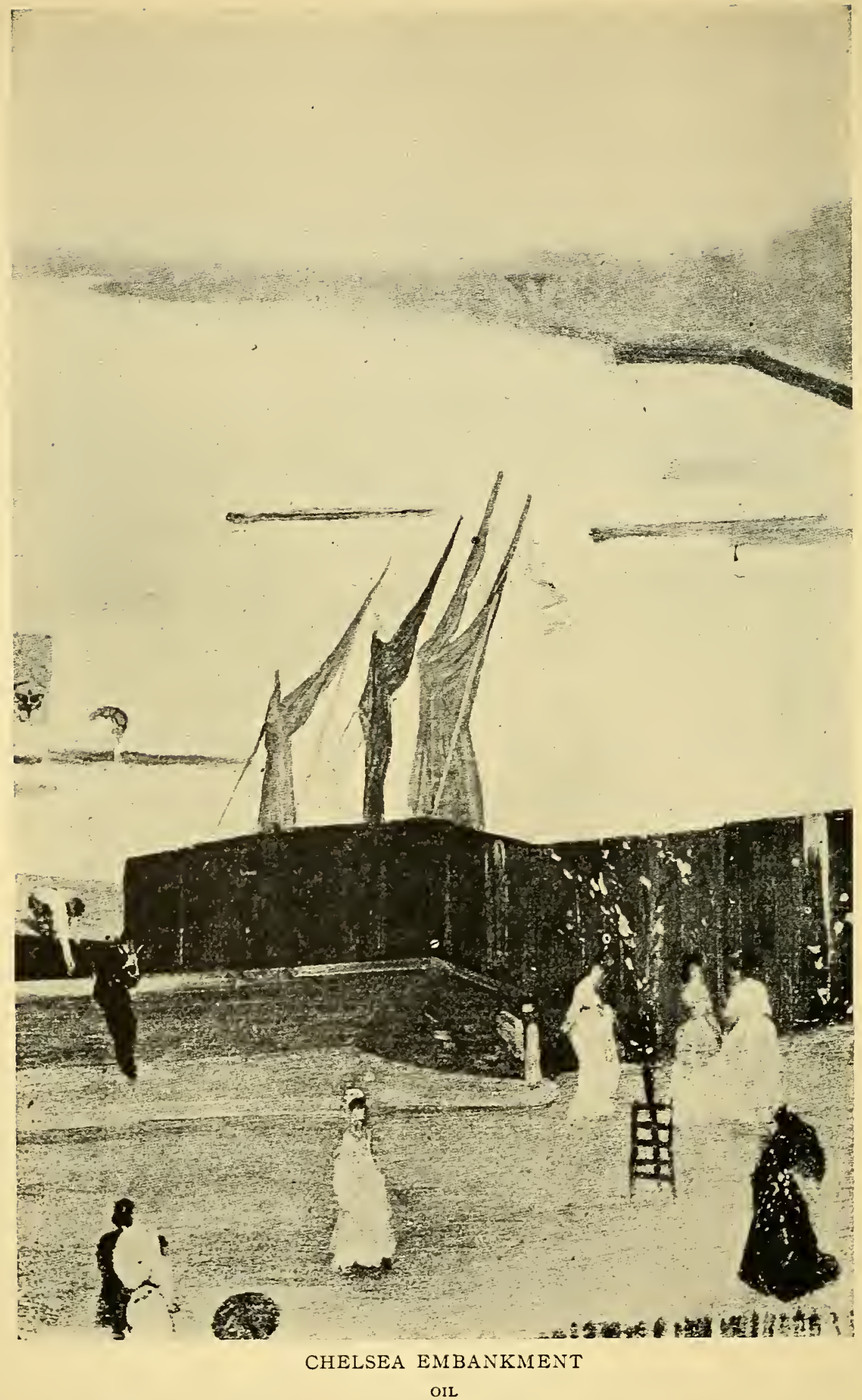

Freer Collection, National Museum, Washington 


\section{Charles Augustus Howeli}

He was the real hero of the Picaresque Novel, forced by modern conditions into other adventures and along other roads. He had the instinct for beautiful things. He knew them and made himself indispensable by knowing them. He was of the greatest service to Rossetti; he helped Watts to sell his pictures and raise his prices; he acted as artistic adviser to Mr. Howard [Lord Carlisle]. He had the gift of intimacy; he was at once a friend, on closest terms of confidence. He introduced everybody to everybody, he entangled everybody with everybody, and it was easier to get involved with Howell than to get rid of him."

Whistler could afford to remain friendly after everyone else had withdrawn because, as he once told a man who threatened his private life, "I have no private life!' I called after him as he growled threats down the stairs. It was a summer I was living in Chelsea, in Lindsey Row, in the house next to where Peter Studd is now, and my mother was with me. There always was real summer in those days-I was doing the nocturnes-and life was wonderful-if I rang, always a boy seemed to appear with a bunch of mint! Well, you know, it happened one evening I was sitting looking out of my window, and there was Howell passing, and Rosa Corder was with him. And I called out to them and they came in. It was astounding with Howell, he was like a great Portuguese cock of the poultry yard: hens were always clucking about himhis wife 'Kitty', and Miss Alice Chambers, and Rosa Corder. Well they came in and I rang, and tea and ice and all sorts of wonderful things came up-and Howell said, 'Why you have etched many plates, haven't you? You must get them out, you must print them, you must let me see to them-there's gold waiting. And you have the press.' And so I had in a room upstairs, only it was rusty, it hadn't been used for so long. But Howell wouldn't listen to an objection. He said he would fix up the press, he would pull it. And there was no escape. And the next morning, there we all were, Rosa Corder too, and Howell pulling at the wheel, and there were basins of water and paper being damped, and prints being dried, and then Howell was grinding more ink, and with the plates under my fingers, I felt all the old love for it come I900] 


\section{The Whistler Journal}

back. In the afternoons Howell would go and see Graves the printsellers in Pall-Mall, and there were orders flying about, and cheques-it was all amazing, you know! Howell profited, of course. But he was so superb. One evening we left a pile of eleven prints just pulled, and the next morning only five were there. 'It's very strange,' Howell said, 'we must have a search. No one could have taken them but me, and that you know is impossible!' And then Howell said I must paint the portrait of Rosa Corder, and there would be engravings and he would arrange with the Graves, and, naturally he couldn't pay much but he would want the picture for himself, and he would give me a hundred pounds. I said I would paint it for him and the engraving would pay me. But no, Howell said, I must have my hundred pounds-and the work began. In the middle of it he suggested a portrait of Disraeli, and the Graves agreed; they would give me a thousand pounds for picture and copyright, and it would be a companion for the Carlyle. Howell made all the arrangements. Then came the afternoon at Disraeli's place near Beaconsfield-a story to be told another time-when everything was most wonderful, and we were the two artists together, recognizing each other at a glance just as $I$ and Augustine know and understand each other. When I got back to town I reported to Howell at Southampton Row, where Rosa Corder was established. At supper, Howell was in a most sentimental mood-'You have never believed me in all this, you have never had the least confidence, you did not think I was going to pay you, but here!' and he threw down a role of bank notes. All surprised, I found seventy of the hundred pounds and pocketed them bewildered.

Next came the Ruskin trial, and general collapse, and my journey to Venice. When I got back to town, passing by the Graves picture shop I stopped in one day. The old man was glad to see me, fact of the matter was he wanted to know when I proposed to pay back the two hundred pounds? 'What two hundred pounds?' I asked. Why, the money he advanced at Mr. Howell's request on the Disraeli portrait that was never painted. He gave it the day I went down to Beaconsfield! - the seventy pounds were 60 


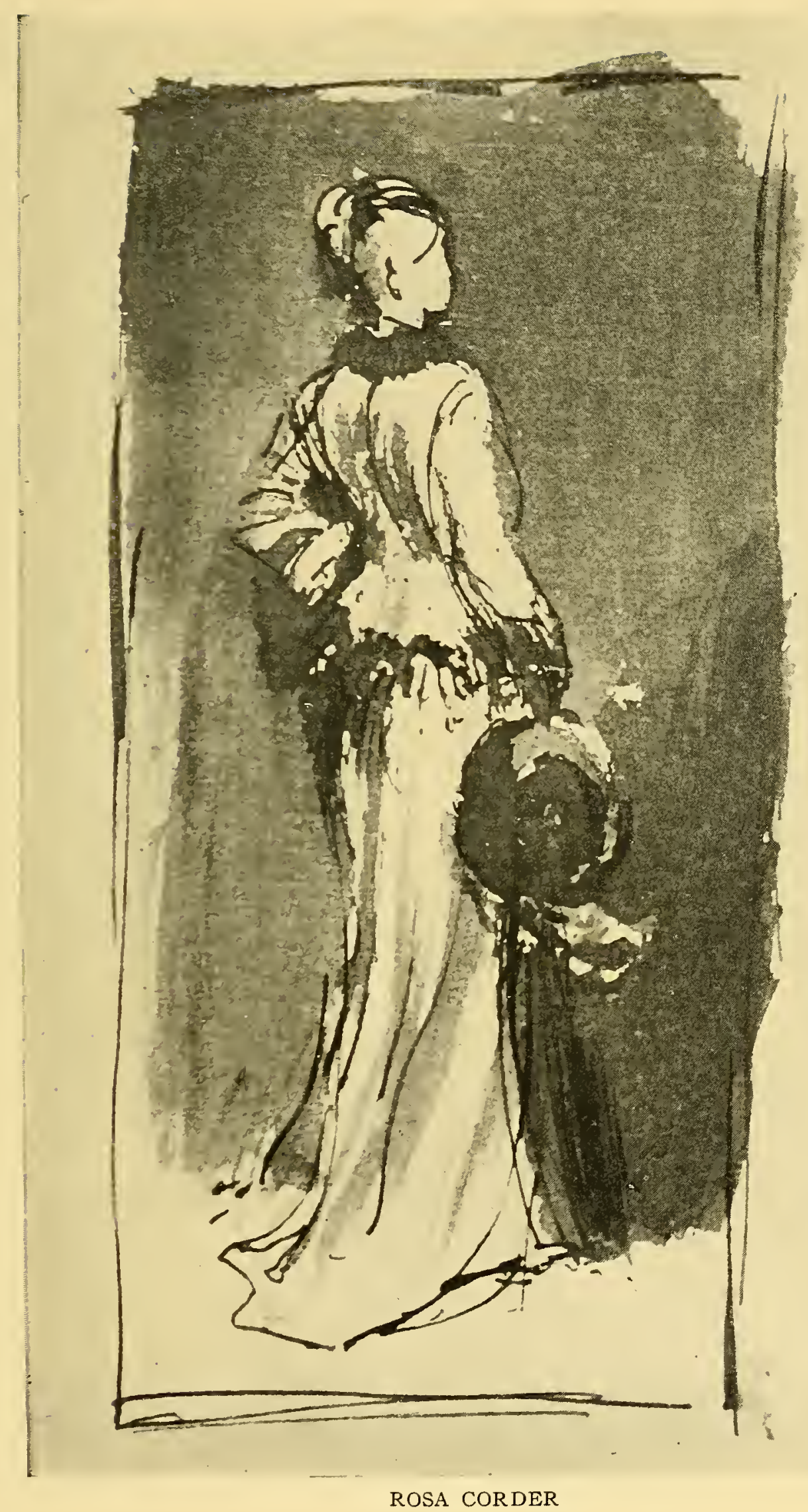

PEN AND WASH

In the possession of Alan S. Cole, C. B. 


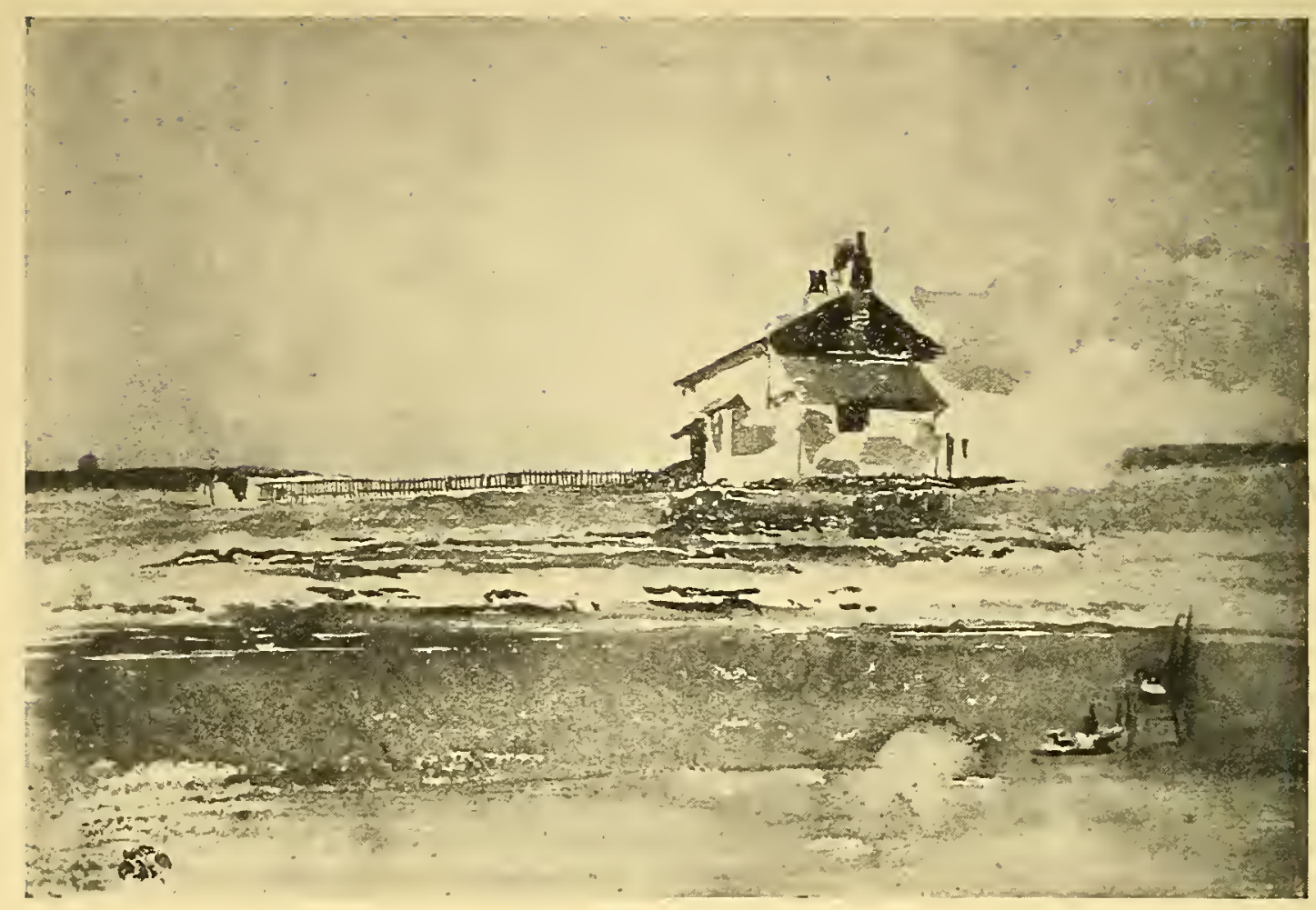

SELSEY BILL

WATER-COLOUR

In the possession of Mrs. Knowles 


\section{Charles Augustus Howell}

explained. Had he no security? I asked. Why, yes, there was the portrait of my Mother-so that, after all, but for Howell, the portrait would have gone to the creditors!"

And then there were the stories of Howell's house in Fulham, full of beautiful things, the hens all there clucking, and a child-no one knew who was its mother-and an old Italian, Brugiani, a Neapolitan who had had a fine villa and things in it near Florence, all of which passed somewhere through the fingers of Howell, and Brugiani, by way of claiming interest, had settled down on Howell, sleeping much under an old fur coat, playing checkers with "Kitty" and going to some unknown business every morning. And then Howell's days spent in four wheelers full of all sorts of things-he was known to and loved by all the pawnbrokers of London-and his appearance in court when the railway ran through his place and he claimed damages-spending the day before the inspectors came pulling up the weeds in the carriage drive to the front door, and pleading his case so well that the Judge complimented him and awarded him heavy damages, Howell afterwards carrying off the mantel pieces and the lead from the roof and putting any old rubbish in their place. This was followed by a flight to the seashore, to Selsey Bill, and his establishment in three houses by the sea, and his swaggering in the village as a great person, and on profitable terms for himself with a wine merchant, and finding occupation in getting off the copper from an old wreck in front of his houses, there for years, but never before touched. The end was the Paddon affair-Paddon, a diamond merchant who entrusted him with his cheque book and orders generally to furnish and decorate-probably half the shops of the kind in town coming in for the plunder with Howell. But the end was the famous black pots-Chinese, very rare, costing thousands-and then Paddon discovered rows of the same pots in an Oxford Street shop-mere fakes. And that was the end of Howell.

Howell disappeared for a while, but not so long after was seen at the house of a Lady Somebody in Mayfair, and is supposed to have died at Rosa Corder's in Southampton Row. He is said to have left his daughter as her fortune a huge box of letters and 1900] 


\section{The Whistler Journal}

papers good for blackmail. Whistler never broke off with him really, though he did not let Howell attend to things in the endbut went with him and stayed at Paddon's, laughing at him and his adventures to his face, much to his discomfiture. There was another famous adventure. "Some Mr. Gerald Lee had filled his house with Old Masters bought from a Jew dealer, and died before paying for them all. A claim was brought against the estate, but Mrs. Lee, who somehow doubted their genuineness, refused to pay. Howell, posing as professional expert and having in his cleverness managed to get a government position, was sent down to report. He made out a most wonderful catalogue, written with his inevitable neatness and elegance, all in favour of Mrs. Lee. There was, for instance, say a Sassoferato-which he described eloquently as a picture he would not be willing to see in the house with him. But to everybody's surprise on the day of the trial he turned completely round. Fletcher Moulton, the Jew's Counsel, had despaired and now found the case going for him-and Howell was superb. When he was asked to explain what he meant about the Sassoferato paragraph-there was no hesitation. Sassoferato was a painter with whom he had absolutely no sympathy-he was too sincere an admirer of this great master and that to stoop to Sassoferato. But it only showed what a fine, unquestionably authentic Sassoferato it was that it should have excited him to so strong an expression of opinion. And again he was complimented!

"When Rossetti was painting Mrs. William Morris, she was at work embroidering a design of Rossetti's on some hangings. And there she sat, day after day, embroidering, until, at last, the curtain was finished and Howell-the Owl, as they called him-hung it up between Mrs. Morris' bed and Morris'. But it was too short, about a foot from the floor and Howell came to tell Rossetti. What was to be done? It was a foot from the floor, and some night Morris would crawl under! 'He would not dare!' Rossetti declared, bringing his fist down on the table with a bang. Rossetti," Whistler added, "was a prince among parasites."

Burne-Jones was painting and drawing and sketching one of the Greek colony and there were dreadful times. But Howell managed 62 


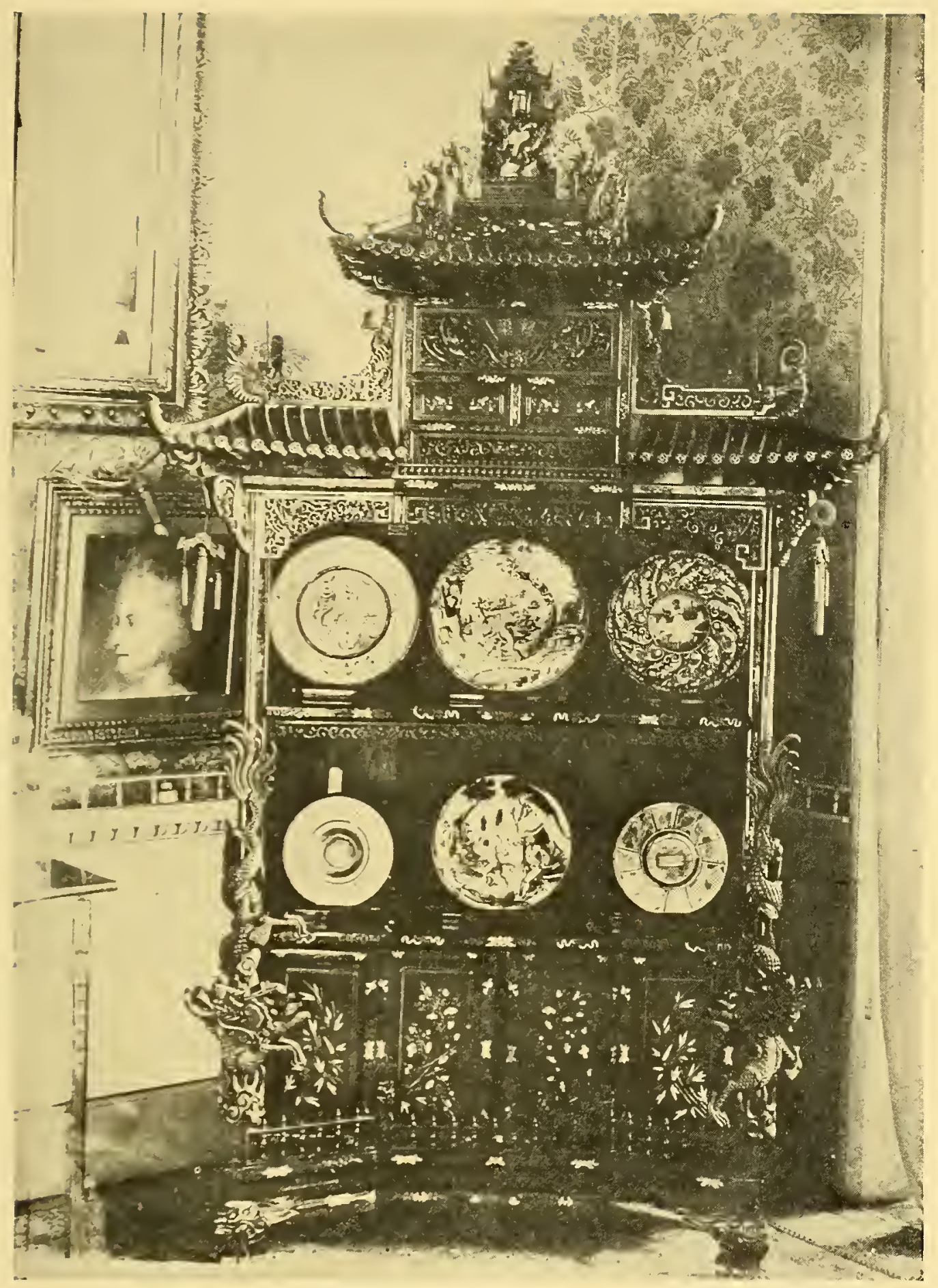

CHINESE CABINET SUBJECT OF THE OWL AND THE CABINET Рното

Pennell Collection, Library of Congress, Washington

(See pages 34 and 295) 

to bring her and Mrs. Burne-Jones together, and they were friendly, and all was pleasant. But the first time 'Ned' saw the two together, he fainted, and in falling struck his forehead against the mantel. 'And,' said Howell, with his last convincing touch-the touch of realism only he could have invented-'whenever it's damp, he feels it here,' pointing to his temples.

Whistler this evening was absorbed in Howell and Howell's friends, and so perhaps, before going further we had better explain one casual reference and say that Augustine, whom he honoured by bracketing her with Disraeli, was for twenty years our hou sekeeper, cook, and general guardian. She is the only person we know who was not afraid to scold Whistler when he was late for dinner or whenever it seemed to her he deserved it. And Whistler never resented her scolding. He thought her as a cook an artist, as a Frenchwoman he understood her. There was always a little talk with her in the hall before he was ushered in to us.

Howell needs no explanation-Charles Augustus Howell who figures in the letters, and affairs of Swinburne, Rossetti, Ruskin, Burne-Jones, as well as of Whistler, who has been much written about of recent years in the general raking-up of Pre-Raphaelite gossip, most recently of all by Dr. G. C. Williamson who devotes a long chapter to his adventures in Murray Marks and His Friends. Howell is said to have penetrated even into the Bishop of London's palace at Fulham to improve the Bishop's taste in furniture and things, and there, on the Episcopal grounds, to have introduced Menpes to Whistler - which is, at least, an amazing tale. Even Whistler did not exhaust the inexhaustible stories told of him. One we remember is of complications as to the ownership of forty blue pots and a demand from the courts that they should be produced. Howell arrived, leading a procession of forty four-wheelers, each containing one of the precious pots, and he won his case and was complimented as usual by the judge, given back the pots, and awarded damages, including the cost of the four-wheelers. Howell was proud of his success in court. After the Ruskin trial, he said he thought he could really have won the case had he been subpœnaed as witness. "Yes," said Whistler, "had you been a witness you would have won and we would all have been in Newgate!" Another story we had from Robert Ross:

October 22nd, Igo6. Whistler, one day when the talk was of the Oratory and what it ought to be, made a sketch of his idea for it. 1900] 


\section{The Whistler Journal}

The sketch was thrown aside and thought of no more. Then a fearfully hard-up moment came for all the group, no money to be had anywhere. Howell said he would see what he could do, the sketch suddenly reappeared, he carried it to Attenborough, the pawn-broker, returning with more money than any of them had ever yet pawned their work for. Time went on, the sketch was not redeemed, was altogether forgotten, until Whistler, passing Attenborough's, discovered it in the window, described as Michael Angelo's first drawing for St. Peter's, with a huge price tagged on to it. Howell's success was explained.

Of what time will do for a story, we had an amusing example when this one returned to us, Robert Ross quoted as authority, though the drawing had become one of the Louvre by Whistler which Jo tried to sell to Sir Sidney Colvin for the British Museum as a sketch of the Parthenon by Michael Angelo.

Whistler always spoke of Howell in a kindly way, despite his games, for Whistler loved the fantastic, the picturesque in people, and he found Howell vastly diverting. "I think that, criminally speaking, the Portuguee is an artist," is the opinion he published in The Paddon Papers, and, as this pamphlet is little known and is so rare that it is not likely to be better known, we quote from it another of his reasons for gratitude. Howell, he said, was the inspiration of "one of my most brilliant things-at least I am told so." Mitford [Lord Redesdale] rebuked Whistler for going about recklessly with Howell, for being seen walking down Bond Street with him: "My dear Whistler, even you cannot brave the people longer. Howell, you know, is a robber." "Well, my dear Mitford," Whistler said, "so was Barabbas!"

In a package of letters, out of the same shop from which so many sensational discoveries and unknown masterpieces emerged a few years ago, were testimonials to Howell's talents and ability signed by Rossetti, Millais, Whistler, and others of the group, and Whistler's we have seen. In it he testified to Howell's qualifications as a man of business and his practical knowledge of art. This was dated I 872 , but Howell was of most use to Whistler during the difficulties that ended in the bankruptcy, taking debts upon his own shoulders, signing notes, accepting responsibilities. We suspected that his success in his railway case, though Whistler seemed to credit it - "gained with thousands," he wrote to Lazenby Liberty-was part of Howell's flamboyant invention, until the bankruptcy papers 64

$[1900$ 
came into our possession. It is only fair to say that they show Howell in a more favourable light than that in which he is usually seen. He was deep in difficulties of his own- "It's all the devil as I am worried to death," he wrote to Anderson Rose, Whistler's solicitor. He had to leave his Fulham house, with nowhere to go, and one shilling to every ten everybody required, "still I am most anxious to see Jimmie out of the mess and will do all I can." One thing he did do is in another letter to Rosehe met a bill given to the irrepressible Mr. Nightingale, builder of the White House and one of Whistler's most importunate creditors "with the money out of my railway verdict now about to be paid." One of the humours of the bankruptcy, we might add, is Nightingale's entreaty to Anderson Rose, through his own solicitor, to be informed what this Mr. Charles Augustus Howell was, anyhow, which most people who had anything to do with Howell were apt to want to know. But despite an occasional flash of humour, the correspondence, which came into our hands after the sixth edition of the Life had gone to press, is so tragic that it has made us wonder more than ever how Whistler survived the anxiety and endless interruptions of writs and bailiffs and complicated bankruptcy proceedings.

Of course Howell was not wholly disinterested. His trouble was not without its reward. He made money by pawning some of Whistler's pictures, by selling others. There were times when Whistler, hard up, sold them to him for a song, times when they came into his possession by accident. Once when Mr. Croal Thomson asked Whistler to sign a painting of Selsey Bill Sands, Whistler refused-he painted it when Nature was in a shocking state-it was a scrap he left at Howell's who ought to have thrown it in the fire instead of keeping it. This was when he was staying with Howell at Selsey Bill where we know he made an etching and at least one water-colour. Howell must also have been repaid by Josey's three mezzotint reproductions, for the circulars are in his name and his Fulham house is the address given to subscribers. The etchings acquired in one way or another, were a further source of profit. One firm of dealers told us of plates he sold them when Whistler was in Venice and of the "terrible row" when Whistler was written to. At the press view of the Menpes collection, in the Leicester Galleries, I903, Ernest G. Brown said to E. that the collection was mainly Howell's, yet no one knew how. Howell realized its value even in days when the prints sold for little. Brown wished to buy some of them, but Howell said no; only when the United States Government was willing to pay three I900] 


\section{The Whistler Journal}

thousand pounds for the entire collection, would he part with them. It might be well to recall that in England, in 1920, at Christie's, The Second Venice Set alone sold for over three thousand pounds. Howell, in Menpes' debt, left the prints with Menpes as security, he died while they were still there, Menpes kept them in settlement of the debt, and Brown thought Menpes would make five or six thousand pounds-they were selling for enormous prices-the Mother for two hundred and fifty pounds. Before the exhibition closed, in another moment of confidence, Brown said he had made about ten thousand pounds for Menpes, so that had the United States Government bought at Howell's price, it would not have made so bad a bargain.

Among the Menpes prints were a few lithographs, probably only part of Howell's collection, according to T. R. Way:-

September 25th, Igo6. Howell used to come to Wellington Street with Whistler almost always for a while and, watching the proofs come off the press, would say, "This is for me, Whistler, and this, and this-" and Whistler never objected. And Way seemed to think it was not much in return for all Howell did for Whistler. The Ways stood around also, and Howell advised them to keep proofs of the lithographs. "See that you keep them all, Tom, and some day you will be glad enough." And Tom did, he thought his must be the only complete set, but it probably was not complete. $\mathrm{He}$ had not the French ones, though these Whistler was decent enough to try and get for him in Paris. His father too kept proofs and gave those he had to the British Museum. Others of the family and employés had numbers of them. And prints were always turning up in the shop. Whistler's letters were turned into money by Howell. Way assured us that not only his father was interested in Whistler, but also his father-in-law, a Mr. Cox, a stock-broker. Howell had a wonderful collection of letters from the various artists with whom he was intimately associated, and almost all of these, except Whistler's, passed into the hands of Fairfax Murray. Whistler's did not, for this reason-Way's father-in-law found in an old second-hand shop two albums full of Whistler's letters to Howell, carefully arranged and pasted in, a few sketches and other things with them, even dishonored 66

[1900 
cheques and letters written as a child to his Mother. Mr. Cox said this would never do. Such things should not be wandering about. He bought the two volumes for fourteen pounds, and wrote and told Whistler, who immediately asked him to bring them to the studio, just as they were, that together they might choose sketches or destroy letters. Mr. Cox removed some of the sketches before going, but gave him the books, and was given etchings for them. One paper showed that Leyland was paid after the bankruptcy five shillings in the pound and Mr. Cox thought Whistler would not care to have that seen. But Whistler said, on the contrary, it showed that the creditors were paid! These documents, therefore, unless they were destroyed, must be in Miss Philip's possession. Another thing Mr. Cox found in the pawn shop, bought, and told Whistler about, was the Gold Medal awarded to Whistler in Amsterdam. Walter Sickert was in the studio and Whistler turned to him and asked why he had neglected to pay the interest, or whatever it is called. And Sickert shrugged his shoulders as only answer, for how could he? - there was no money. The Medal went into Mr. Morrison's collection.

We asked Miss Chambers, mentioned by Whistler in the same evening's talk, an artist, one of Howell's executors, if she knew anything of this album and the documents in it. "Howell," was her answer, "sometimes borrowed money upon letters and other manuscripts from a bookseller called Coalford, whose shop disappeared some years ago from the Strand, a little west of Drury Lane." She could not say if any of Whistler's letters were among them. But the fact that Howell at times pawned letters helps to explain how Whistler's got into the pawnshop, especially as some of them were to Howell.

Altogether, after everything that can be has been said for Howell, he does not strike us as blameless in his relations with Whistler and probably nobody was more conscious of it than himself. Another of Ernest G. Brown's recollections was of Howell's discomfort in Whistler's presence after the Paddon affair. He took Howell to have a drink at a bar near the Gallery, where Howell confessed his fear of Whistler, saying he would be sure to show it if they met. As he spoke, his face turned white, and Brown heard a loud "Ha! ha!" and saw Whistler coming in at the door.

I900] 


\section{The Whistler Journal}

Howell had a few friends who never ceased to believe in him. Miss Chambers never wavered in her admiration and confidence. When we were preparing the Life and she consulted his diary for us, she spoke of him with enthusiasm and swept aside every charge against him. It is in Howell's favour that whatever his rogueries, he was a pleasant rogue capable of inspiring in some people a confidence unshaken by his shadiest transaction. E. can quote another of his enthusiastic admirers:-

February 8th, I907. Calling on Mrs. [afterwards Lady] Donkin, met there Mrs. Jenner, who said she had just been to the Old Masters Show at the Royal Academy with her oldest friend, Miss Chambers, and Miss Chambers had been talking to her about our Life of Whistler. This led her to speak of Howell whom she and her husband knew well, liked and believed in. He was the soul of honour, generosity itself, the most amusing of men. Because of some entanglement with a woman-he swore never to tell the story - he got into all his troubles. It was the reason of his misunderstanding with Ruskin. Honour forbade him to tell the story and he left Ruskin with his honesty in question. A bad name sticks to a man and so he got the reputation for dishonesty, until in the end he might, possibly with business men, have not been, strictly speaking, straight in his transactions. But he always was with artists and his friends. There were tales of him in connection with a society and its funds, and he was examined by a doctor, a barrister, and a parson, and came out "without a stain on his character." Though he wouldn't give the facts of his entanglement to Ruskin to clear himself, he confided them to Mr. and Mrs. Jenner, who cannot break confidence. No doubt, when he told a story, he had some sense of artistic finish, but that was why he was delightful. Anyway, while Whistler was treating him shockingly, Howell was keeping Whistler's illegitimate son from starvation-Howell's version this. He may, in Whistler's penniless moments, have advanced money to pay for the son whom we know Whistler looked out for as a child and launched in life.

The talk with Miss Chambers was of such interest that we give it as it is in E's. note of the time, simply omitting facts and details used elsewhere:

68 
January I2th, I907. Went to see Miss Chambers, Howell's executrix. I found her a woman of about fifty, stout, pleasantly ugly, with no endeavor to dress so as to improve matters. She seemed a trifle nervous at first, or I may have imagined it. She showed me loose pages of an account of money received by Whistler and Maud and, in one or two cases, "Mrs. Abbott," from Howell . . . and a diary ... It is clear from the diary that in the late summer and autumn of 1877 Howell was again printing with Whistler. $\mathrm{He}$ was constantly going and coming with prints ... On February 22, I878, Howell bought from Whistler for fifty pounds a large picture of apple blossoms, a sketch for Miss Alexander, one for a portrait of Greaves, a Nocturne-winter scene in Chelsea-a small framed Nocturne, Battersea-and eight frames. The journal gives an idea of Whistler living from hand to mouth, in a generally impecunious condition, from about the time of the quarrel with Leyland until the bankruptcy and the journey to Venice. Entries show Howell borrowing twenty shillings from "Alice," [Miss Chambers], to lend immediately fifteen to Whistler, or Whistler borrowing from Howell, who, to lend, had to borrow from Anderson Rose, who, in turn, had to borrow from his head clerk. Things were pawned-sometimes there are comments, as "lent ten pounds to Whistler, eight pounds to Maud, good girl Maud." On another occasion, he took twenty shillings out of his pocket to give Whistler, a half crown came with it, and Whistler said he might as well have that too. Howell finishes, "I walked home, damn him." Another time after an affair of the same kind, "selfish fellow Whistler,"-and again, he took gold out of his pocket, and "My God!" Whistler said. Miss Chambers regrets Howell's want of capital - had he only had capital, he might have done anything ... ... Among the pictures Howell had was one of Whistler in the studio, and it was left with eight or nine drawings, as security with a lawyer. While it was there, stuck up against the wall in the office, Whistler came in; "Why," he said, "there's the portrait I did of myself." After Howell's death the picture, with the drawings, came to Miss Chambers. Two years before Whistler died, she took it to Robinson and Fisher's to be sold, and the drawings 1900] 


\section{The Whistler Journal}

too, putting a reserve price on them. In the middle of the sale, Whistler came in, declared the picture and the drawings were not by him, and the result was they did not sell. After Whistler's death the lawyer made a statutory declaration that Whistler said the picture was his work, it was sent again to Robinson and Fisher's and was sold for a comparatively small sum. [This is the story of the Dublin In the Studio that Sir Hugh Lane vowed was the original. And this is the first time the story has been told. The picture, owned by Douglas Freshfield and now in Chicago, is the original.] The drawings Miss Chambers left with the auctioneers for a few days after that first attempt, and when she went to get them, two or three had disappeared. She had also owned "The Pacific." When it was sold at auction, Whistler bought it. She saw a good deal of Whistler in those old days. He was constantly at Howell's. She never felt his charm particularly, he seemed to her tiresomely selfish and vain, but she always thought him what he called Howell, "an amusing cuss."

Everybody knows Rosa Corder so well in Whistler's portrait as to forget she existed out of it. She was an artist, studied with Felix Moscheles, devoted herself chiefly to painting race horses, and is said to have aided Howell in copying old paintings and drawings. We remember seeing an excellent copy by her of Millais' $V$ ale of Rest hanging in Mrs. Warr's drawing-room in Earl's Terrace, London. But her claim to fame rests upon the fact that she posed to Whistler for one of his most beautiful portraits.

CHAPTER VII: EARLY PARIS MEMORIES. THE YEAR NINETEEN HUNDRED CONTINUED

Sunday, July Ist, Igoo. Whistler called in the morning to see J. who got back on Friday, unexpectedly. In good form and eager to look at the drawings which $\mathrm{J}$. refused to show. Uncertain whether he could come and dine in the evening or not, with the result that we got back from the Muras, where we had gone for the afternoon and were expected to stay to supper-as soon as possible. But about eight, came a note from O'K. saying he was too tired, but might come later. Toward ten both appeared, 70

[ I 900 

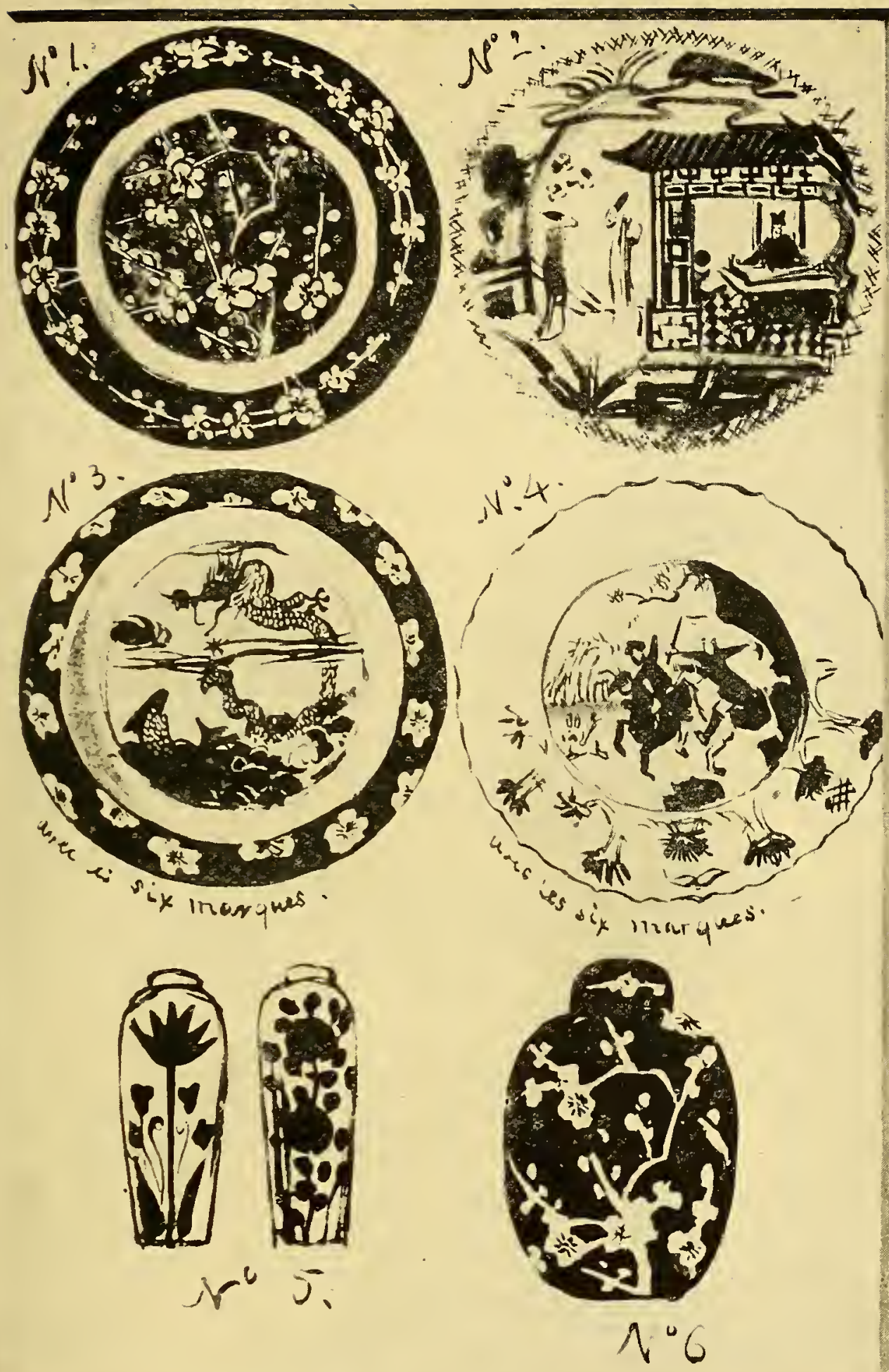

DESIGNS FOR BLUE AND WHITE CHINA

WASH

The Murray Marks Collection

(See Appendix I, page 302) 


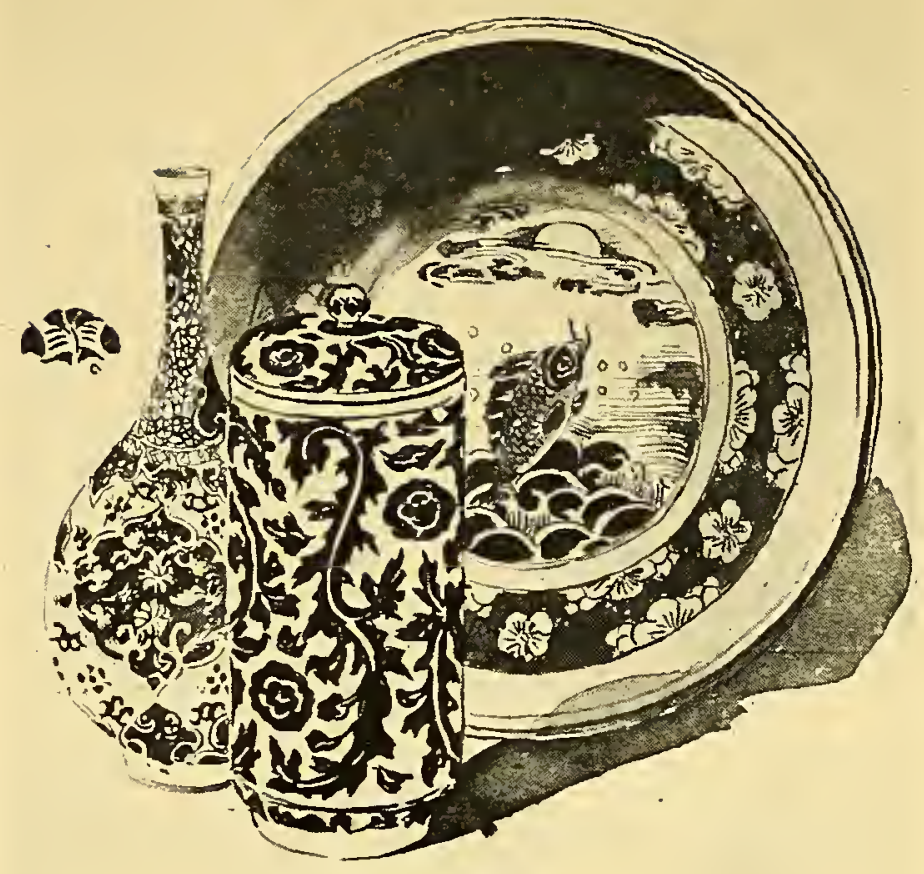

DRAWING FOR SIR HENRY THOMPSON'S CATALOGUE OF A COLLECTION OF BLUE AND WHITE NANKIN PORCELAIN

WASH

In the possession of Pickford R. Waller, Esq.

(See page 306)

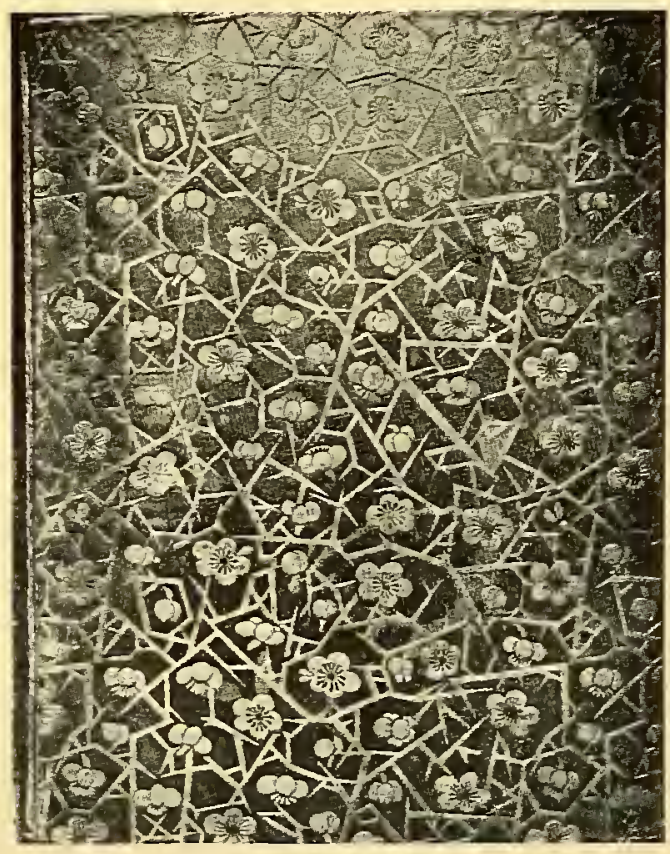

COVER OF THE UNIOUE LARGE PAPER COPY OF THE BOOK IN THE PENNELL COLLECTION

Library of Congress, Washington

(See Appendix I, page 306) 


\section{EARLy Paris Memories}

Herbert Gilchrist, who had been at the school in Paris, having called in the meanwhile. This was, evidently, an element Whistler found antagonistic, and he slept part of the time, and said little the rest.

The Muras are Mr. Frank Mura, the distinguished American painter, and his wife who died a few years since. They were then living in Greenwich. We remember their disappointment for they counted on our staying. Our hurrying back shows how unwilling we were to miss any chance of the usual talk with Whistler-no talk at all this evening, as it turned out.

Herbert Gilchrist was the son of Mr. and Mrs. Alexander Gilchrist, authors of the Life of Blake. He was rather old for a student when he went to the Académie Carmen, several years having passed since he studied in the Royal Academy Schools. He also studied with Chase in America, where he went with his mother on her extraordinary journey to offer herself in marriage to Walt Whitman, only to be refused and to remain his friend. Gilchrist objected to the methods of the Académie Carmen, his manner had all the English pomposity carried to an extreme, and it is easy to understand why Whistler was little in sympathy with him.

Wednesday, July 4th. Wrote and asked Whistler and O'K. to dinner to celebrate J's. birthday and the Glorious Fourth. But, as J. was obliged to go to a meeting of the Society of Illustrators at half past eight, must ask them for seven. They came, but, of course, not at seven. Whistler was full chiefly of The Architectural Review which has not yet paid him and of a fine letter he wrote to Wilson. Could it be the same Mr. Wilson who was on the Committee of the International? Hardly possible! Indignant with J. who, even on an occasion of this kind, with Madame everything that was charming, would not make himself beautiful.

$\mathrm{J}$. left to his great indignation, and later, John Lambert came in. Delighted with Lambert's story of Carolus. The Jury at the Paris Exposition decided that the First Medals for Painting should not be announced until all the other Medals were awarded. But somehow, some leaked out, and the names got into the papers. Carolus, who had been coming to the meetings in gorgeous clothes, appeared one morning just after this resplendent in a flowered I900] 


\section{The Whistler Journal}

waistcoat. When the Jury met, he took the chair, and with his eye on the American jurors said there had been indiscretions among some of the members. Harrison was up like a shot: "Apropos des indiscrétions, Messieurs, regardez le gilet de Carolus!" Whistler was delighted, but had not known Harrison was so equal to an occasion.

O'K. said something about Millet, whose early work was good, but he married a wife and had to manage to make both ends meet. Whistler was indignaut. "The artist's work is never better, never worse, it must be always good, in the end as in the beginning, if it is in him to do anything at all, and he would not be influenced by the chance of a wife or anything of that kind."

It was not one of his brilliant evenings. Lambert, evidently prepared to worship, was a trifle ponderous and serious, with depressing effect, and the party broke up early.

Whistler's habit was to dress for dinner. We can recall but few instances when he was willing to come to us, informal though we were, straight from the studio or wherever he might happen to be: one reason he was always late. We were less formal and he resented it, or pretended to, especially when the occasion for a dinner, as on the Fourth of July, which is also J's. patriotic birthday, suggested formality.

The Architectural Review, started shortly before, was a monthly founded by a Mr. Abram whose ambitions were great. He wanted to publish only the best, or he would not have wanted Whistler, whose fine lithograph of St. Anne's, Soho appeared in his Review. At times its finances did not keep pace with his ambitions, and payment was not always prompt, and promptness was a condition upon which Whistler insisted. Harry Wilson was then editor of The Architectural Review and a member of the Council of the International.

John Lambert was a Philadelphia artist of promise who died too young to have made a name outside of Philadelphia. We need hardly say that the Carolus of his story was Carolus Duran, and the Harrison, Alexander Harrison. If Lambert was ponderous, we have been told since by one of his friends, it was because he worshipped in fear and trembling. He was overcome by meeting the man who to him was supreme among modern artists. He turned white and half the time had not a word to say. 


\section{Early Paris Memories}

Nothing could be more characteristic than Whistler's answer to Mr. Kennedy about Millet. His theory, his belief, his ardent conviction, was that the quality of an artist's work could not change. There might be degrees in this quality, but the quality itself must be always there from his first painting or print to his last. He was quick to pounce upon friend or enemy who ventured to hold or suggest the opposite opinion, and the subject roused him often to eloquence, often to wrath. We have not forgotten his indignation when he asked J. to go and look at his Carmen at the exhibition of the Portrait Painters' Society in $\mathbf{1} 895$, and J., in his enthusiasm, declared he had never seen anything like it. What did he mean? Whistler wanted to know. The Miss Alexander was like it, so was the Nocturne $\mathrm{J}$. was reproducing for $A$ London Garland, so was the Mother at the Luxembourg. People might be a long time in finding it out, but all his paintings were alike-only, the Carmen was finer. This was one of the times when he said he was "mortally offended," but was as prompt to make his peace with $J$. as to take offence. Lavery offended no less once when, talking, of L'Art Nouveau, the precursor of the Isms and Ists, he ventured to define it. Whistler would hear of no definition- "There is-there can be-no Art Nouveau-there is only Art!"

Thursday, July 5th. To Mrs. Ohl's to dinner. No one else there but Whistler, who was fairly prompt. A grey evening, the sky heavy as lead, no air anywhere, a suggestion of thunder, and we were all exhausted. Whistler fell back on the papers, eager about the Chinese business, rejoicing in the turn affairs were taking. As for the report of the massacre of the Ministers in Pekin "Well, it is the Chinese way of doing things and there is nothing to redress. Better to lose whole armies of Europeans than harm one blue pot!" J. toild of Zug's performance as instructor' of art in Paris, a sort of Cook to conduct personally parties through the Grand Palais des Beaux-Arts, and his request that $\mathrm{J}$. would allow his name to be used on the circular. "When a man writes and tells me that my name will be useful to him," Whistler said, "why then I write and say it's time for me to change it!"

Zug is Mr. George B. Zug who has now become a great Professor of Art in a small college in the United States.

1900] 
Sunday, July 8th. Dined with Kennedy and Whistler at Garlant's. Whistler late and when he came in, it was clear something was wrong. He seemed suddenly to have grown old. His hair lay flat, his forehead was a network of wrinkles, his cheeks had fallen and were flabby and pale, and when he talked, all life and gaiety and fun had gone. He was interested when we told him of the United States officer-Captain Hunter-fresh from West Point, who had called on us in the afternoon. West Point was the standard. But it was like the shadow of his talk. The one rally was when he talked of Fagan, whom he had not seen for a long while. There was some little discussion as to who Fagan was-a Jew? No, because his father, of course, was Panizzi of the British Museum-or rather his uncle. Whistler's Secretary Grimaldi, he said, had been to the British Museum to see to something for him and had difficulty about getting his ticket. He should have got it without asking, Grimaldi said, was he not the nephew of Panizzi? "Clearly," was Whistler's comment, "the twin of Fagan."

Later on, J. talked to him about the book, but of this talk I heard little. He said, when Kennedy regretted that he did not seem up to the mark, that he was not and for this once we must bear with him. He followed us down when we left and stood on the steps, looking as if he had forgotten why he was there, or, indeed, that he was there. And I carried away such an impression of him as I have never had before-of Whistler suddenly grown old and thin and shrunken and sad.

On this evening at Garlant's dinner was served in a dining-room upstairs, on the second floor, where we had never dined before. We learned afterwards that it was Whistler's sitting-room once when he stayed at Garlant's with Mrs. Whistler. He had not been in it since, and no doubt this fact accounts for his extreme melancholy. We remember evenings when he came to us sad and depressed, especially during the first year after Mrs. Whistler's death, but never another evening when nothing could lift the depression or make him forget the sadness.

Fagan was Louis Fagan, an official in the Print Room of the British Museum. Panizzi probably did more than any other Librarian to make the Library of the British Museum what it is. Grimaldi 


\section{Early Paris Memories}

Was one of the several secretaries Whistler picked up during these years. The wonder was where he found them and why he employed them, of so little use did they seem to him.

Wednesday, July IIth. An early visit from Whistler, who says he will come this evening to meet our West Point man, Captain Charles M. Hunter, and his wife, who are fresh from the Academy, after a four years' term and are over here on a holiday before going to San Francisco.

When they came in the evening-before him, of course-they were delighted at the chance of meeting him. He has become a tradition at West Point, where on a certain stairway, hung with the work of cadets, his drawings hold a place of honour. He was a little late, and was more than usually cordial and distinguished and elegant -the West Point officer in perfection. At dinner, naturally, the first talk was of the Chinese. "Here are these people, thousands of years older in civilization than we, with a religion thousands of years older than ours, and our missionaries go out there and tell them who God is! It is simply preposterous, you know, that for what Europe and America consider a question of honour, one blue pot should be risked."

There were two moments when West Point failed him. He asked Captain Hunter of what branch he had been professor "Artillery Tactics, no doubt?"- - he is in the Third U. S. Artillery-and Captain Hunter said, "No, French and English." We rather gasped at that, but as Whistler said afterwards, it was better not to pursue the matter. The other moment: talking of the Boers, and after he quoted the instances he loves about Buller, Roberts and the rest, some one asked Captain Hunter what West Point thought of the blunders at the opening campaign. "Oh," he said, "it was what always happened with Generals who had not had that sort of experience for years, what happened at Santiago when two divisions of the U. S. Army were drawn up so that, if they had fired, they must have shot each other down." This, Whistler passed over, and was on safer ground when he asked about West Point and the changes that had been made. He seemed to remember the buildings in every possible detail. He was disgusted when 1900] 
he heard that the cadets now play football. "They should hold themselves apart and not allow the other colleges and universities to dispute with them for a ball kicked round the field-it is beneath the dignity of officers of the United States." The Hunters were certainly appreciative and understood enough to be appreciative in the right places. But there was another shock when the Captain explained that his wound at Porto Rico was the result of his going out with some other officers to dinner one evening and putting on white trousers when the army weren't wearing them, and being shot in consequence, by the American sentry when he came back to camp. But, on the whole, it seemed to me that just as we are more American than the Americans who stay at home, so Whistler is more West Point, according to his notion of it, than the men who have never come out of it.

We remember that the next day Captain Hunter was suddenly ordered off to China. He had no uniform, as he was in Europe on leave, and he was forced to get one at once in London. He went for it to the Army and Navy Stores. His delight was great, and he refused to make any change, when it was sent to him with the bronze letters S. U., instead of U.S., on the collar. Whistler, when we told him, was even more pleased with the ignorance and invention of the Islanders.

Thursday, July I2th. Dined at the Fisher Unwins. Whistler, Mr. and Mrs. Hilaire Belloc, and Mrs. Maurice Hewlett there. Whistler was quite away from where I sat, so that I saw nothing of him during dinner, but Mrs. Hewlett said afterwards he had been telling her extraordinary things about niggers and Boers, and Belloc was insisting that at every house he went to he met only Pro-Boers, that everybody really was Pro-Boer, and he, because of his disgust for the English outburst over the Dreyfus case, was in sympathy with the Boers; and so was Mrs. Belloc, who despite an extraordinary gown of blue silk and white sort of cloak that hung loose and shapeless, and made her back view suggest a High Priest of some strange Oriental sect, was as sensible. Mrs. Hewlett, in Empire dress, said she was frankly out of it, but she thought 76

[1900 
she ought to be just a little offended at being made to feel by Whistler-I don't know how, for I did not hear the talk-that she was just a plain, bourgeois, middle-class person, when everybody else thought she was just the other thing.

We stayed on after the others. Whistler admitted to a passing shock when he heard of the French and English professorship at West Point, but it was only passing. The Captain was, after all, West Point. He was pleased at their telling him how he was remembered there and how the old officers who had been at West Point at the same time often spoke of him, but liked less well the reminder that his was the class of ' 54 . He and J. and I started home together, but could find no four-wheeler, and so had to break up into two hansoms.

Saturday, July I4th. Went to tea in Whistler's studio, Fitzroy Street. Mrs. Ohl and her little girl, Mr. and Mrs. Louis Fagan, Miss Philip, Kennedy, and an American artist, Elwell, there. "We have been having splendid news," was his greeting to me, and he began to read the leader in Thursday's Star, about the taking of an Irish squadron and the Lincolns, by the Boers at a kopje comparatively near Pretoria.

Mr. Fagan had a story of a drawing brought to him by some one who declared it to be by Frith. He saw at once that, though immature and boyish, it was something of importance, and he wrote to Frith that he had something to show him, and Frith came promptly the next morning, and explained that it was a drawing he made when he was six years old! "It must have been then he tossed up!" Whistler suggested.

He showed us some of the things he has been doing lately-his portrait of Miss Philip in hat and boa close round her throatthe Little Lady Sophie that he has worked on since the International last year, giving it finer colour and tone, the Lillie in Our Alley, pastels of the nude, and then some of the marines-water colours he did at Dieppe. I left them all there, to find later that the contrast between Mrs. Ohl, the Southern woman, and Mrs. Fagan, the British matron, delighted him enormously. 


\section{The Whistler Journal}

The present generation may have forgotten not Frith, for it is said that the British art lovers at the National Gallery continue to pass Whistler's Little White Girl to stare at Frith's Derby Day, but Frith's explanation of the "toss-up" it had been whether or no he was to become an artist, his father wanting him to be an auctioneer. Whistler made use of this in the report of the Ruskin trial published in Art and Art Critics. But his personal opinion of Frith for testifying against him did not extend to all of Frith's art. For one day, walking through the National Gallery with J.,Whistler stopped before the Derby Day, then hung in a Modern British Room, and pointing to the Grand Stand and the distant crowd, he said "How did he do it? It's as good as Manet." And when J. told it to Frith, Frith was nearly paralyzed, though we doubt if he knew who Manet was.

Sunday, July 15th. Dined at Garlant's Hotel with Whistler, the last little dinner of four before Kennedy's departure, he having put off going for a day, so we could have the parting celebration. Of course, it was about half past eight when we sat down. Whistler was in fine form. J. asked him how he got on at Short's on Friday, where he went to print some of his Paris plates. "Well, I pulled nineteen prints. Once I started, all the joy in it came back again, and I got through by lunch time." J. thought he would have been at it all day, and, indeed, when Short did not turn up at the Art Workers' Guild on Friday evening, supposed the printing was still going on. "H'm, h'm," Whistler said, "well, you know, my consideration for others quite equals my own energy."

He was in a reminiscent mood. Told the story of The Piano Picture. "It was the second picture I painted. The first was the Mère Gérard, done in Paris, which I gave to Swinburne. In The Piano Picture my sister, then Mrs. Haden, is sitting at the piano, her little girl standing by it, and I gave it to Haden-in a way. Well, you know, it was hanging there but I had no particular satisfaction in that. Haden just then was playing the authority on art and he could never look at it without pointing out its faults-and telling me it would never get into the Academy-that was certain. But after it had been for awhile on Haden's walls I did send it to the Academy and it was hung, and Phillip, the R. A., back from 78

[1900 


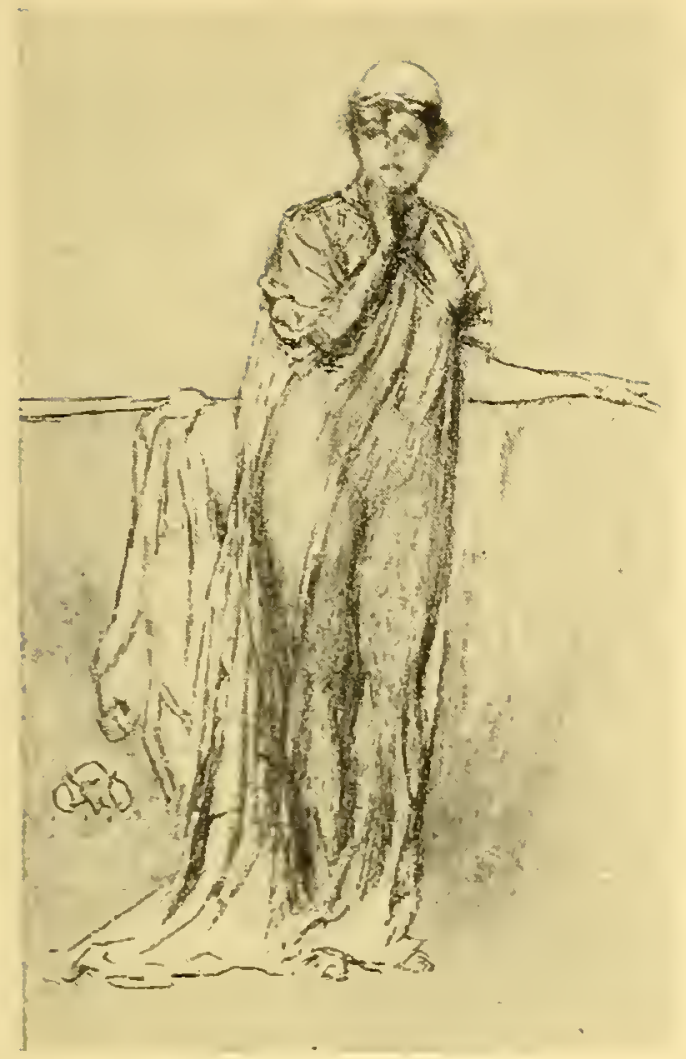

THE PURPLE CAP

$$
\text { PASTEL }
$$

Freer Collection, National Museum (See page 235)

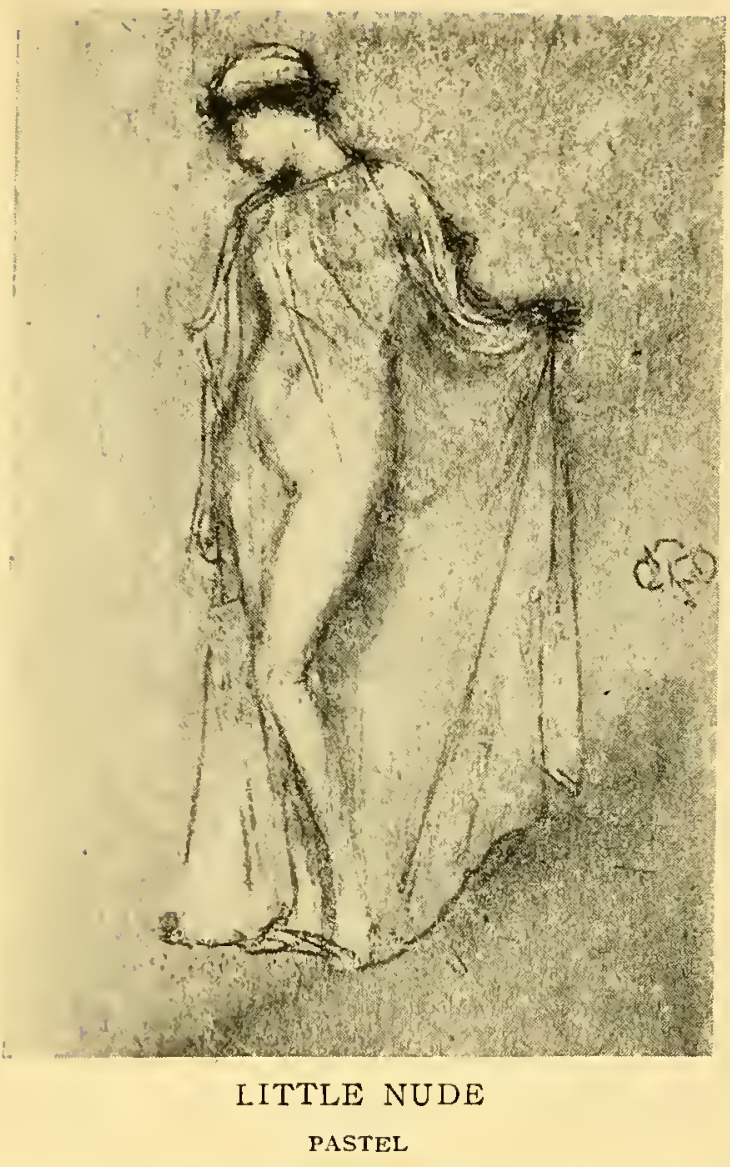

Formerly in the Canfield Collection 


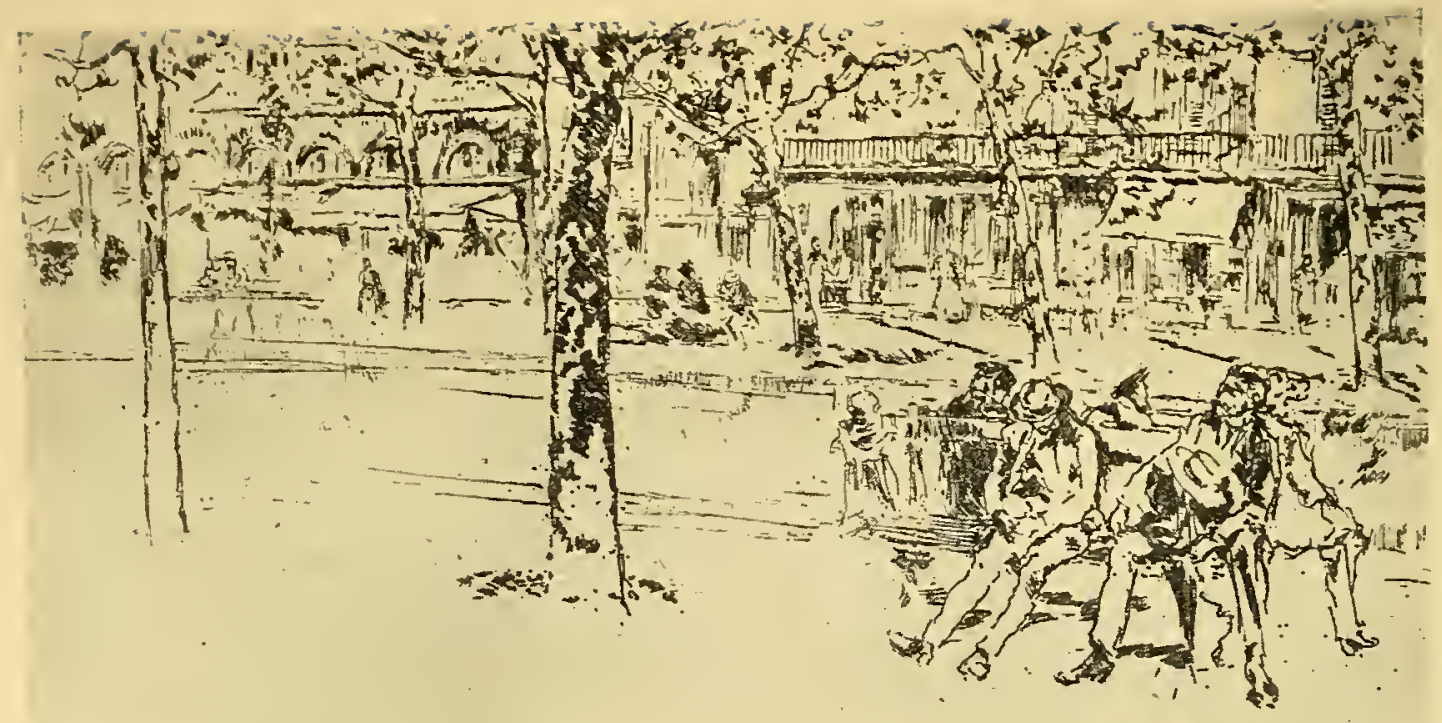

BOULEVARD POISSONIERE

ETCHING. M. 423

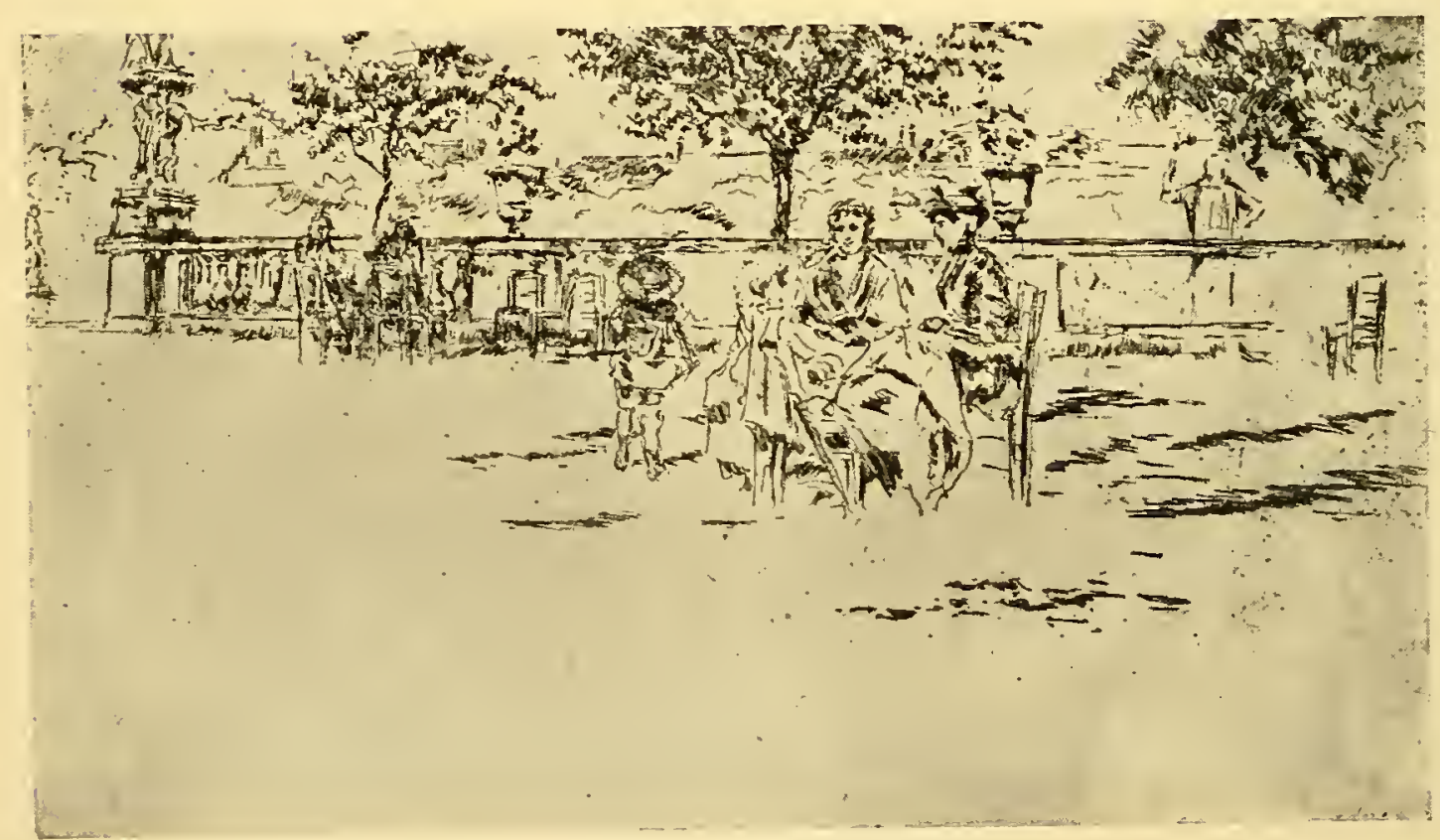

BALUSTRADE, LUYEMBOURG

ETCHING. M. 427

Freer Collection, National Museum, Washington 


\section{Early Paris Memories}

Spain with, well, you know, Spanish notions about things, asked who painted the picture, and they told him a youth no one knew about, who had appeared from no one knew where. Phillip looked up my address in the Catalogue and wrote to me at once to say he would like to buy it, and what was its price? I answered in a letter which I am sure must have been very beautiful. I said that in my youth and inexperience $I$ did not know about these things and would leave to him the question of price. Phillip sent me thirty pounds. [When the picture was last sold, to Edmund Davis, it brought two thousand, eight hundred.] Haden did sometimes buy my work, you know, my dear sister was in the house and women have their ideas about things, and so I did what she wanted to please her-and for the Ice picture-The Thames in Ice, The Twenty-Fifth of December-Haden gave me ten pounds." But there came a time, when notwithstanding his sister in the house, things could not go on as they were.

He lingered over the Chelsea days, Rossetti, Legros, all the wonderful things! "Legros, I came upon in Paris, where, as a surprising youth suddenly appearing in the group of French students from no one knew where, with my Mère Gérard and The Piano Picture for introduction, I made friends with Fantin and Legros, men who had already arrived, and Courbet, whom they were all raving about, and who was very kind to me. I came upon Legros at one moment in so deplorable a condition that it needed, well, you know, God or a lesser person to pull him out of it. And so, I brought him over to London, and for awhile he worked in my studio. He had before coming sold a church interior to Haden, a little interior of a church with kneeling figures of women. It was when Haden was etching and used to lock himself up in his room at the top of the house, glorying in the artist who let the surgery business slide. He liked Legros' picture, though he found the floor out of perspective. One day he took it to the room upstairs where he did his etching and turned the key. When it reappeared, the floor was in perspective, according to Haden. A gorgeous frame was bought, and the picture was hung conspicuously in the drawing room, and left there, though Haden was just a bit restive when I900] 


\section{The Whistler Journal}

he heard that Legros was in London. When Legros came with me to Haden's the first time, he was fearfully impressed with the frame, having been used to see himself in any shabby old frame that came his way. But gradually Haden's work dawned upon him. That he could not stand. What was he to do? Run off with it, I suggested. We got it down, called a four-wheeler, and carried it away to the studio-to our own little kopje-[for Whistler told the story in the days of the Boer warl-cleaned off Haden's work. Haden, in a rage when he discovered it had gone, hurried after us to the studio, but when he saw it on the easel, Legros repainting the perspective, well there was nothing to say."

J. referred to the other piano picture Keppel told us about, the boy Haden at the piano, with head turned, still at Haden's, but Whistler knew nothing of it. The White Girl-the big one-was painted in Paris, and gave him a place among the Indépendants. In the portrait group by Fantin he is in the centre at the table, in front of Delacroix, holding a bunch of flowers-The Hommage a Delacroix in the Moreau Nelaton Collection in the Louvre. The Mère Gérard, he said, "I must have back from Swinburne. Time has changed the conditions of the gift, and therefore of course, as will be understood among gentlemen, the gift must be returned."

Whistler went to Sir Frank Short, whom he rightly regarded as an eminent technician, to get proofs of his Paris plates. These were the plates that he bit and printed in Paris with J. But the ground, which he laid, was bad and came off, and the prints he pulled, after he bit them as far as he could, were in many places weak. Curiously, Whistler was afraid to re-ground them, or to allow Lamour, the old etching material maker in Paris, to do it, though Lamour offered to and sent Whistler and J. re-grounding rollers for the purpose. This was in I893, and it was not until I 900 that he did anything with the plates and then, as we have said, he went to Short, whom he trusted and who had a good press, rather than to Goulding, whose "little tricks" and "dodges" he thought of "the cheapest kind," while Sir Frank Short is the best technician in Great Britain. And these prints by Short, as far as we know, are the last that were pulled from Whistler's Paris plates. Short offered to re-ground them, but we do n,t think that Whistler let 80 


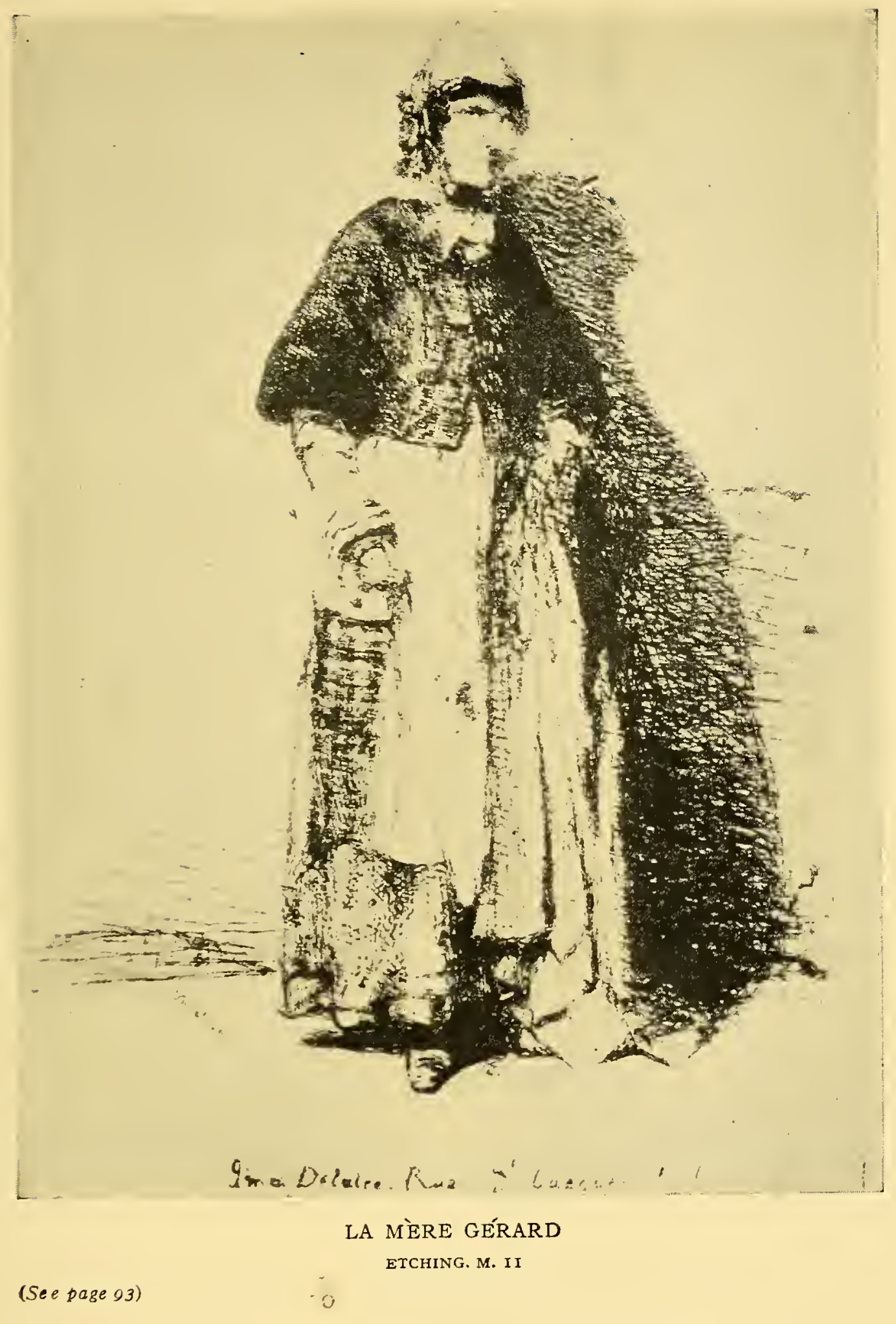




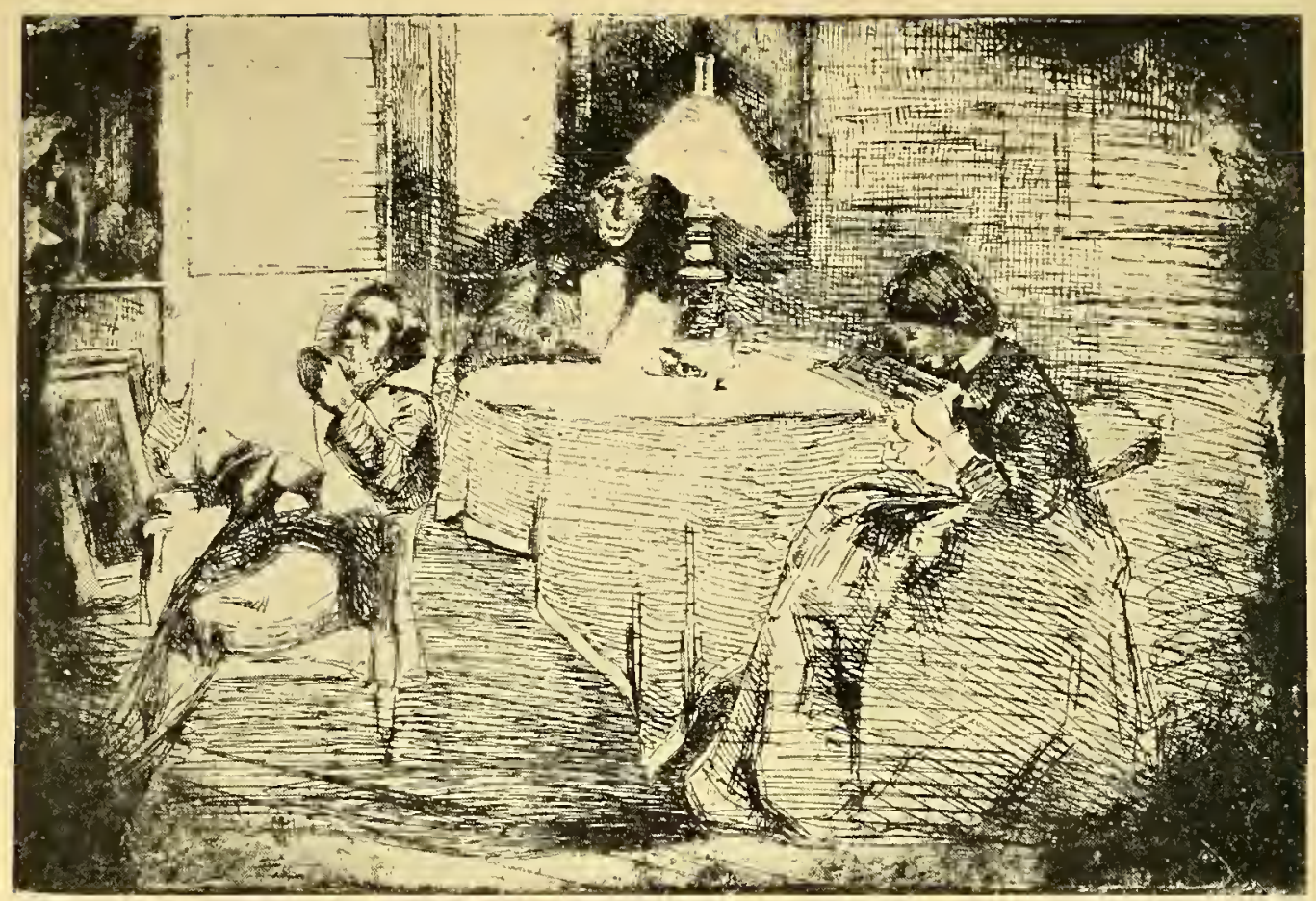

READING BY LAMPLIGHT

Seymour Haden, left; Traer, centre; Lady Haden, right ETCHING. M. 33 


\section{Early Paris Memories}

him do so. He did, however, after Whistler's death, bite a plate which mysteriously came into Way's or Walter Sickert's possession and which was later published. Mr. Mansfield has described it among the Attributions. Short, some years later, referred to this printing in a lecture on etching at South Kensington to which we went:-

November 27th, I9I3. He dragged in Whistler with measured praise, though in the end he told how Whistler came to him to print his plates and how, when Short asked him about wiping the plates, Whistler said, "Wipe them as clean as you can-what was good enough for Rembrandt is good enough for me." The impression given was that, at the last, this was the sort of printing Whistler wanted when, as J. said after the lecture, Whistler was just trying the plates to see what was in them-he never printed them after that or, no doubt, the results would have been different. Short is not the only Academician who can praise Whistler's work. Indeed, their praise sometimes makes one wonder why they did not show their appreciation practically and make him a member of their Academy.

As for the Art Workers' Guild, their knowledge of Whistler was so slight that when, less than a year after Whistler's death, Way gave a talk about him, it was announced in the Guild's circular as a talk about "John McNeill Whistler and his Work." As Whistler said on another occasion, "the gentlemen might have asked." What Delâtre in the early Paris days thought of Whistler's printing, he probably never let Whistler know, though he did not hesitate to tell others. Frederick Keppel had many amusing stories of Delâtre who, he said, could not help what some people might think stealing and, as printer, kept his finest proofs for himself. Whistler knew this and determined to take his plates from Delâtre. He brought them to Goupil's in Paris and made an arrangement to sell them the prints at a certain price. He had hardly gone when Delâtre brought them prints of the same plates and asked about twice as much. They told him his price was far higher than Whistler's. "Yes," said Delâtre, "but then my prints are far finer than his." To our regret, Delâtre left no records or reminiscences with his son, also a printer. E. went to see the younger Delâtre in search of information:-

1900] 


\section{The Whistler Journal}

May I4th, Igog. Though he was charming and friendly, he had nothing to tell me and apparently knew less about his father's printing for Whistler than we do. He said his father's old place was opposite to where I found him in the Rue Lepic, but up almost at the top of Montmartre and he had never heard of the printing house in the Rue St. Jacques described by the De Goncourts, of whose description he knew as little. In the later days he met Whistler who once or twice came en ami to shake the hand of an old friend. He could find only two letters from Whistler to his father, one written at Speke Hall, the other at the Hotel du Bon Lafontaine. He had never seen Whistler's etching of his father who, he feared, was careless in such matters and had not kept proofs of the plates he pulled. He was so amiable and so willing to tell anything and everything, it was the more provoking that he had nothing to tell.

To go back to the rest of Whistler's long talk on the evening of July I 5 th. Colonel Hecker of Detroit now owns The Piano Picture. The Thames in Ice is in the National Collection at Washington. Both were bought by Mr. J. J. Cowan for two thousand pounds from Sir Seymour Haden. Mr. Croal Thomson, when giving us the information, thought Haden had bought back The Piano Picture at the Phillip sale after Phillip's death. McLure Hamilton in a long talk on the subject, pointed out to us a detail in The Piano Picture with an explanation that we believe has not occurred to most artists:-

March 5th, 19og. Whistler's treatment of perspective in it-his giving a curve to a straight line so as to carry the eye into the room. The wainscot, behind the piano and the pictures, curves downward and Mr. Hamilton was sure Whistler did this on purpose to take away from the austerity of the straight lines of the pictures above, and also because, after this gentle curving towards the centre, the lines of the wainscot lead one's eyes far into the room from either side and so express the size or space. I was particularly interested because, at the Whistler Memorial Exhibition shortly before this talk with Mr. Hamilton, Humphry Ward tried to prove to me that the wainscot curved because Whistler could not 82

$[1900$ 


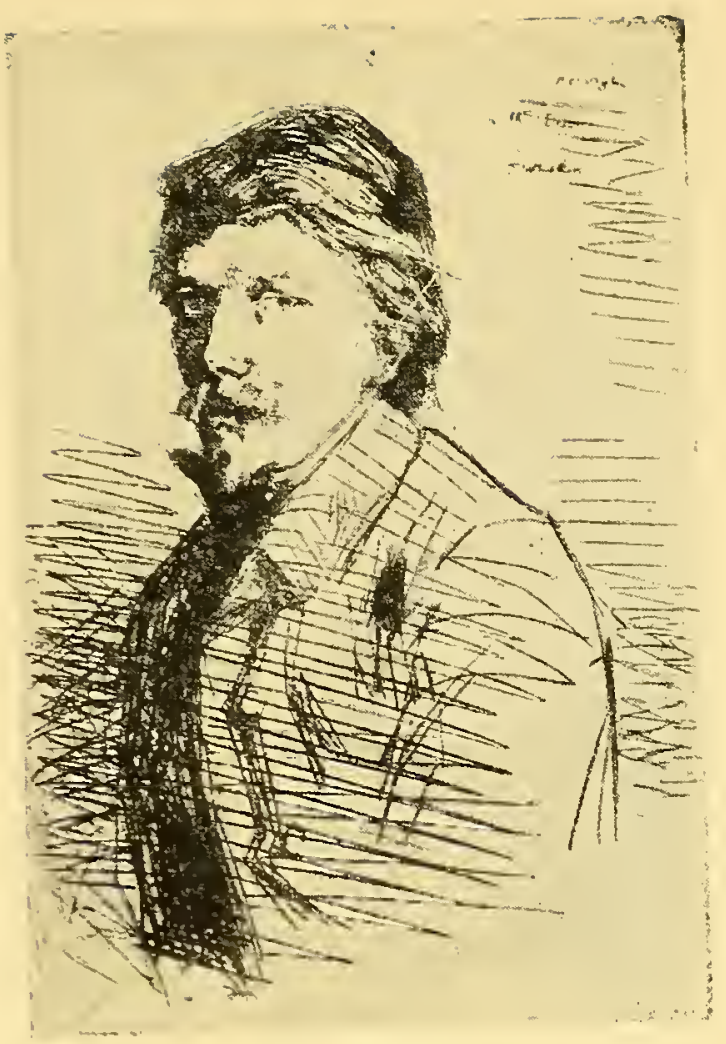

DELÂTRE

ETCHING. M. 26

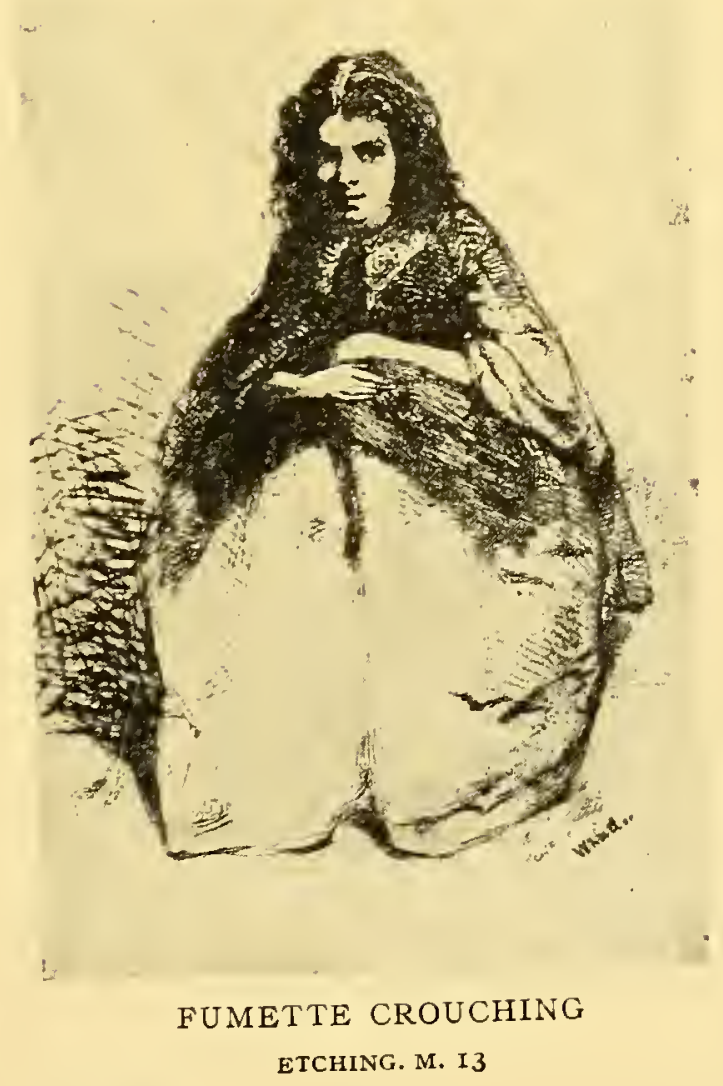

(See page 9I) 


\section{"}




\section{Early Paris Memories}

draw-the critic does not see with the eyes of the artist. All the same, the curve is a mistake. However explained, it hits you and therefore the picture is not finished according to Whistler's teaching that in the finished work all traces of how it is done must be obliterated. The use of this curve, whether designed or an accident, is not a success and we regret never having asked him about it.

Whistler's friendship with Legros and Fantin-their "Society of Three"-was one of the pleasantest episodes of his early years and his letters to Fantin, some of which M. Bénédite, Conservateur du Luxembourg, published in the Gazette des Beaux-Arts in 1905, are among his most interesting. His friendship was not all on paper. He was in a position to be of use to both and he turned it to the best account as Fantin always acknowledged. The clue to the deplorable condition in which he found Legros we had some years later from M. Oulevey, one of the little group of French students Whistler knew and loved. Legros' father had died leaving many debts and, according to French law, Legros was obliged to pay the creditors and he was without a sou. The creditors could have pursued him as a French citizen to London and, to protect himself, he was naturalized as promptly as possible, and not, as he himself used to say, "to be able to boast that he had gained the battle of Waterloo." Unfortunately, he and Whistler quarreled soon after he got to London. We wanted, naturally, to have Legros' memories and impressions for the Life, but it was impossible. We were assured that M. Lantéri had more influence with him than anybody. When we asked him if he could and would use it for us, he hesitated, was afraid if Legros could be induced to say anything it would be coloured by his bitterness. Still he did what he could. Legros, however, would not speak. He had not even then forgiven Whistler, many as were the years that had passed and whatever the cause of the quarrel may have been. William Michael Rossetti, a mine of information, informed us that the cause was women and that he thought the details, which he wrote out for us, were unfit for publication, and he was right. The crisis came in the office of Mr. Luke Ionides, from whom we had an account of it. Whistler and Legros by chance dropped into the office the same afternoon. They were talking together when, suddenly, Ionides heard Legros say to Whistler, "You lie!" That was enough. Whistler knocked him down. Ionides did what he could to get them to make it up, I900] 
reminding them what good friends they had been. It was no use. Legros had another grievance against Whistler. Some one who wanted copies of pictures at Bath House consulted Rossetti, and, through Whistler, gave the commission to Fantin, and Legros thought it should have come to him; he could do the work as well as $F$ antin. Ionides suggested to Whistler that he should apologize to Legros. So did Rossetti. Whistler regretted the liberty taken with Ionides' office but grew wrathful at the suggestion of an apology. "A man gives you the lie to your face and you naturally strike him." It was a simple chastisement of a gross insult and he could not understand why everybody was so disturbed. And from that day we doubt if the two men ever spoke to each other, even ever met. If all Whistler's letters to Fantin are eventually published, the truth may come out, but Madame Fantin, in whose possession they still were the last time we saw her, said passages in them were not over friendly to Legros and these she felt should not be seen by the public. She promised them to us, but $M$. Bénédite objected, saying she had promised them to him first and he intended publishing them, which he never has, and no use has yet been made of the letters. M. Bénédite, arriving in America during the autumn of this year, was heralded by puffs of himself as the man who first discovered Whistler, who managed the first exhibition of Whistler's work, who bought the portrait of Whistler's Mother in the name of the French Government. Whistler and Whistler's work were known in Paris long before M. Bénédite was heard of. Exhibitions were given by Whistler as early as 1874 when M. Bénédite must have been still a boy. M. Bénédite's name never appeared publicly in any of the transactions for the purchase of the Mother and we are not sure that he had any connection with the Luxembourg or even the French Government at the time. But M. Bénédite was responsible for the Paris Memorial Show, as he might not have been had not J. and Lavery handed over the London Memorial show to him. And the Paris exhibition was disgracefully hung, in unsuitable rooms. M. Jacque Blanche said of it that, while the London exhibition made Whistler look like a great man who now and again made a mistake, the Paris exhibition made him look like a little man who now and again did something good."

Finally, Whistler told George W. Smalley:

"The French Government took the initiative step and le Ministre de l'Instruction Publique et des Beaux-Arts wrote himself direct to me personally, asking if I would 'céder ce tableau au Gouvernement 84 


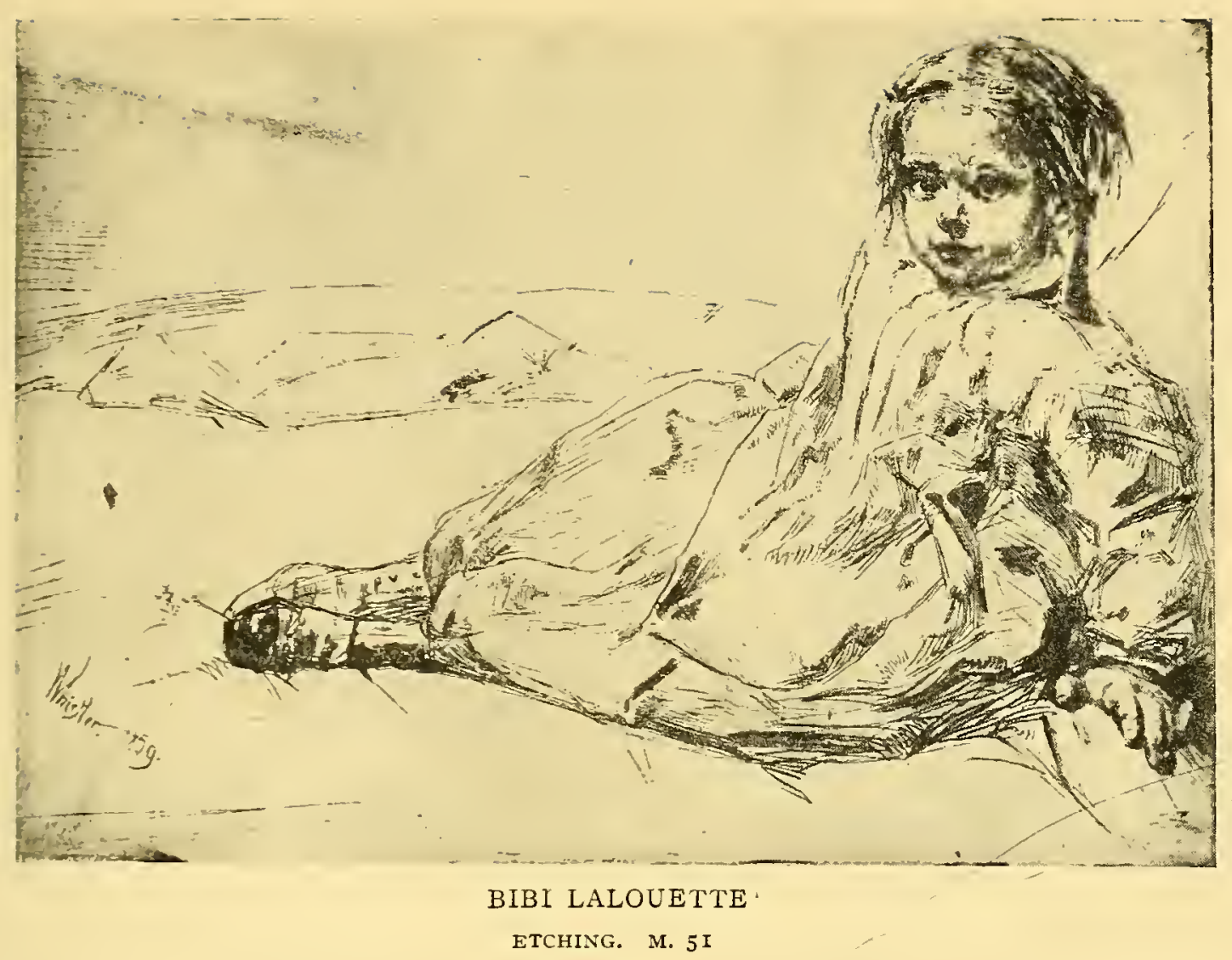




\section{Eariy Paris Memories}

Français'-and trusting that, in such case, my conditions might not prove an obstacle to its purchase.

Such a demarche on the part of the Government is openly acknowledged to be quite unheard of and is equivalent to and universally accepted as an official engagement that the picture goes to the Louvre!-this is simply the greatest honour that can possibly be conferred upon an Artist-and it occurs to me in my lifetime! You may therefore write and congratulate me."

And there is not one word of M. Bénédite.

There was no quarrel with Fantin who, after Whistler's death, wrote of him with real affection. Of Fantin's feelings as long as Whistler was alive, we have different versions. In the earlier years of their friendship he said in a letter to Mrs. Edwin Edwards that his love for Whistler was like that of a man for the mistress he adores despite the trouble she gives. But they drifted apart. Fantin was less often in London. When Whistler lived in the Rue du Bac he went occasionally to see Fantin, but Fantin never returned the visit, making the excuse that he had too much to do, he had no time for visits. This we heard from Madame Fantin, and M. Duret has confirmed it by describing Fantin's life to us as one of such complete retirement with his wife and her sister, that he probably would never have gone out at all had he not been something of a gourmet. It was to a shop where they kept the best Camembert cheese and another where they made the best patisserie that he took his daily walks. Once in the Eighties Whistler came to Fantin's with Maud, introducing her as the daughter of a friend whom he was seeing back to London. Then Madame Fantin said, they heard he behaved badly to her and it had made a difference with Mr. Lucas. But they knew nothing of it and Fantin was friendly and admired him to the end, which does not agree with another story we had from Keppel. After Whistler's death, Fantin could not understand why he did not hear again from Deschamps, at one time Durand Ruel's manager in London, who had written to him for us; he was willing to give all the information he could to Whistler's biographers - to us.

Keppel's introduction to Fantin was an article about his lithographs which Keppel wrote for The Century. Fantin was pleased and Keppel, the next time he was in Paris, called, bringing with him a portfolio of prints he thought would be of interest to Fantin, as they were, none more so than Whistler's Bibi Lalouette, with its I900] 
memories. Keppel gave it to him. Fantin placed it carefully in a cupboard where he kept his prints, locked the door, put the key in his pocket. Half way across the studio, he stopped, hesitated, went back, unlocked the cupboard, took out the print and handed it to Keppel. "No," he said, "I cannot keep the work of a man for whose character I have so little respect." Probably the truth is that the two men were friends when they most needed each other. Two other early Paris friends and fellow students, Drouet and Oulevey, we met a few years after Whistler's death. Our talks with them rounded out so well our talks on his student days with Whistler in 1900 that we think it appropriate to quote here, almost in full, a note from a later volume of The Journal which records our meeting. We were in Paris in May, 1907, as usual for the Salons, but no work was then as important as getting together Whistler material. This is the note:

Friday, May Ioth, I907. Went early to see Oulevey, whose address Drouet gave us with a card to him. Living in the Passage des Favorites, away at the other end of the Rue Vaugirard. Entrance through a gate into a garden. His apartment on the ground floor, immediately to the left. I was received by him, a little old man with wild, thin, long, white hair and straggling white beard and moustache, looking much older than Whistler, miserable and poor, but charming, with something in his manner that recalled Whistler. He spoke of Whistler with unmistakable affection. He was tout à fait un homme à part. Oulevey had been très lié with him, knew him first when he lived in a hotel in the Rue St. Sulpice. Then at No. I, Rue Bourbon-le-Château near St. Germain-des-Près, then at Rue Campagne-Première. They used to eat often at Lalouette's, also at Madame Bachimont's in the Place de la Sorbonne, a sort of cremerie. Whistler took the American Consul to dine there once, and on that occasion gave a new hat to the daughter of the house, known as "Canichon," who was to dine with them. When he was in the Hotel, Rue St. Sulpice, a little girl lived with him, Fumette, in whom he was much interested because she knew Musset by heart and could recite the verses to him. He thought something should be done for a woman with such a gift. It was she who, in a rage one day when he was out, tore up drawings he 86 


\section{Early Paris Memories}

had made; not etchings, but drawings, something in the manner of Gavarni, of all sorts of people and things in the Ouartier-des amoureux et des sujets presque enfantins. Whistler came home to find them torn to pieces and piled upon his table, and he was so unhappy Oulevey says he cried. In his unhappiness that evening, at the café, with Oulevey and Lambert, he drank too much Kirsch, and was quite tipsy. Whistler, by no means a buveur usually, became very gay and insisted that they should all go to supper in one of the open-all-night restaurants at the Halles. Oulevey represented the lateness of the hour and their penniless condition. But when Whistler took a thing into his head, he must do it-and Oulevey, seeing it was useless to argue, took two or three more glasses of Kirsch himself to be in the right frame of mind. Whistler said they must get money from Lucas. It was after one, but they went to where he lived, made the concierge open, and climbed up to his apartment. Oulevey and Lambert stayed in the shadows. Whistler knocked and knocked. After a long while, Lucas was heard shuffling to the door which he opened on the chain. There was an argument. Whistler said his concierge wouldn't give him his key to let him into his room until he paid his rent, and he hadn't a sou. Every now and then he threw a word back in French that they might know how things were going, and they were going badly. Lucas, no doubt, saw he had been drinking, and would give nothing. But they went on to the Halles and into one of the restaurants. They had twelve sous left. They ordered beer, and as they drank it, Whistler began complimenting the patron on his cuisine and its fame; they had come for un petit souper fin. The patron was delighted. But Whistler said it was not their habit to pay at the moment. The patron said it was not the habit of the house to be paid at any other time. So they went to another restaurant. Here, said Whistler, we shall say nothing about payment until we have eaten. And they ate their supper, all the while Whistler working himself up into a wild state of agitation about Lucas. He must challenge Lucas to a duel, and they must be his seconds. After their supper, he said as soon as le petit jour came, he would go and find money, and the three went to sleep. Oulevey woke up, and I900] 


\section{The Whistler Journal}

saw that le petit jour had come, but Whistler slept on. Then Oulevey woke up again, said le grand jour has come, and Whistler started to go. Oulevey again slept peacefully, for he had learned that when Whistler said he would do a thing he always did it. The next thing he knew, he was awake, it was late, and Whistler was sleeping at his side. "But you have not been," he said." "But" I have," said Whistler, and he showed his pockets full of money, some three or four hundred francs. He had got it from an American friend who, Whistler said, abused the situation, insisting on Whistler's stopping to look at his pictures! On the way home, they passed the Café de France, and Whistler said they must have a refreshing drink, and they sat down outside. Presently they discovered Lucas who was to be killed in the duel, drinking his chocolate in a corner inside. But there was no more talk of a challenge. Another time, Whistler wanted cool drinks in a café just opposite his rooms in Rue Bourbon-le-Château, where they wouldn't give credit. It was summer-he could find no one to lend him money at the moment-he pawned his coat, and went about in his shirt sleeves for the next two or three days.

Then there was a story of Drouet's heroic Géricault, intended for a certain town, but refused by the Mayor. A fellow student, Echery, a short, small man, had just died. "Tiens!" said Whistler, "erect it over Echery's grave." Drouet saw everything big. He designed a monument for a little girl, and the figure lying on the tomb was at least twelve feet long. When he was working on the Géricault, a moment came when there was no money to buy clay and it was all he could do to keep his huge monument covered with wet cloths while he waited. But at last money drifted in from somewhere, clay was bought, the cloths removed, and the monument had sprouted with mushrooms. What a chance, said Drouet. And he sold the mushrooms and gave them all a big dinner, and much wine was drunk and speeches made. Drouet has been for years doing a Joan of Arc and still is working on it in the studio, Oulevey said. Henri Martin was the son of the historian, a painter and a great deal with Whistler. In the Rue Campagne-Première, Whistler had a little hand press and pulled 88

$[1900$ 


\section{EARLy Paris Memories}

his own prints, sometimes before the people who bought them. A rich American friend wanted one and came to the studio, and Whistler asked a good price for it. He got to work, prepared his plate, pulled a print. It wasn't good enough, he said, and he crumpled it up, and threw it in the ashes in the fireplace, and the next three or four were thrown after it. At last, he pulled one that would do, and, with every care, put it in a flat box, and the American went off with it. No sooner had he gone than Whistler pounced upon the first print in the ashes, smoothed and pressed it. There, he said, is the best proof, and it is for me. It wasn't for the money he did this sort of thing, but he seemed to see the humour of it. When he had money, he flung it away. The story of his copying in the Louvre, Oulevey told with some new touches. Whistler helped himself to a box of colours. The owner discovered and claimed it, but what more natural than the surprise of Whistler who supposed the boxes of colours were for general use. He was a man with un coeur de femme and la volonté d'un homme. In the Alsace journey he bought a little iron, and ironed his shirt and collar at night-always must be perfect in his dress. It was not vanity, but taste, le gout, that he brought to everything: his talk, his work, everything. Legros went to England because his father died deeply in debt . . When Oulevey was in England about eight years ago, he wrote to tell Legros, an old friend. Legros no doubt thought, "here is an old comrade down on his luck who wants to come and sleep on my floor and live on me, and bohemianize as in the old days," and in a prompt answer he represented the impossibility for artists to sell anything in England, he himself sold everything in France, and regretted that he was just going away for an indefinite time. And Oulevey begged him in a polite letter: je vous prie de ne pas me laisser vous faire déménager-which enchanted Whistler. On that occasion Whistler furnished him with many letters and much advice. Oulevey lodged in a hotel with a cousin, where there were only merchants of meat, which Whistler told him would be disastrous-any small hotel in the French Quarter, Soho, would be a better address. Oulevey could remember nothing of the show at Bonvin's in 1859 . But he rememI900] 


\section{The Whistler Journal}

bered Whistler once going to see Courbet and coming back and saying, c'est un grand homme! C'est un grand homme! Whistler would go to the bookstalls and shops and look over the old books and quietly tear out the blank sheets at either end and carry them off to print his etchings on. He never worked at Gleyre's, nor in the Louvre, nor anywhere that Oulevey can remember, but he was always making the sort of drawings that Fumette tore up. In the evening, Duret, Drouet and Keppel dined with us at the hotel-the Saint Romain-alone in an upstairs room. A bad dinner, abominably served, but an evening of wonderful talk. Drouet's stories and reminiscences were endless. Becquet, whom Whistler etched, was a sculptor from Besançon who died two or three months ago. Drouet was in great distress about it, felt himself responsible. He had had Becquet to dinner and Becquet drank half a bottle of wine and some cognac; it was too much for him in his feeble state, he died two or three days after, and Drouet never heard of it until he saw an account of the funeral in the papers. Becquet was a man loved by his friends, the best and greatest Drouet ever knew, but he was unsuccessful, unrecognized. He lived in his studio where there was nothing but disorder and his 'cello, for he was a great musician. Whistler had not seen him since the etching was made in I859, and Drouet arranged a dinner a few years before Whistler's death. A wreath of laurel was prepared. During dinner, Drouet said that he had met many great men, but, pour la morale, none greater than Becquet. Becquet was moved to tears. Then Whistler said that they wanted to give him some little souvenir, and the laurel wreath, hitherto hidden, was brought out and presented to him by Whistler, and Becquet broke down, and said he would take it home and hang it on his wall where he could always see it. Drouet added a story of a rich young girl of about twenty-five who came to Becquet's studio and offered herself to him, but he, then fifty, refused out of consideration for her youth, though it was a chance any other man, in such terrible poverty, would have jumped at. Drouet gave him one of the three proofs of his own portrait presented to him by Whistler and Becquet said he would leave it on his death to the 90 


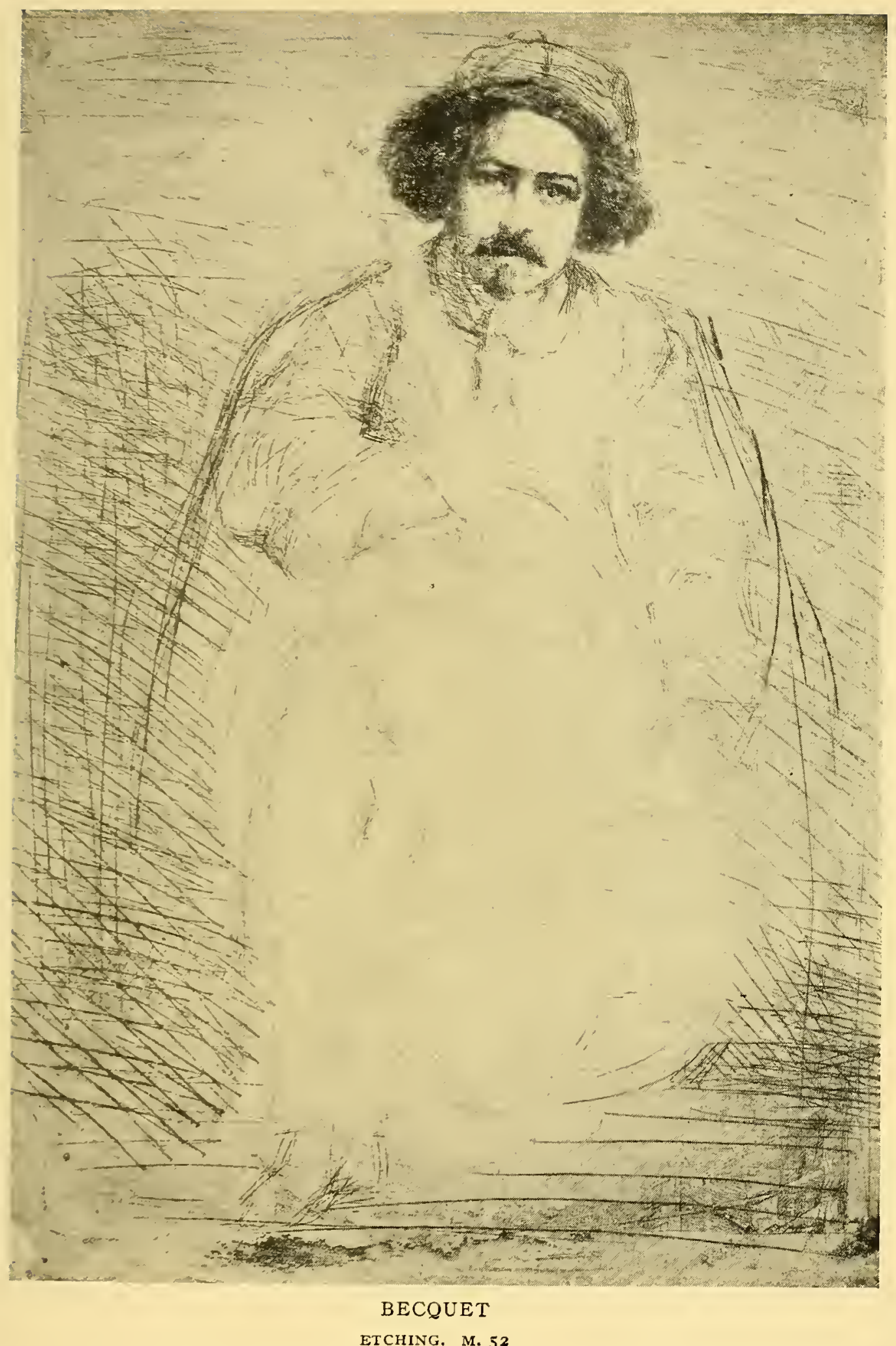




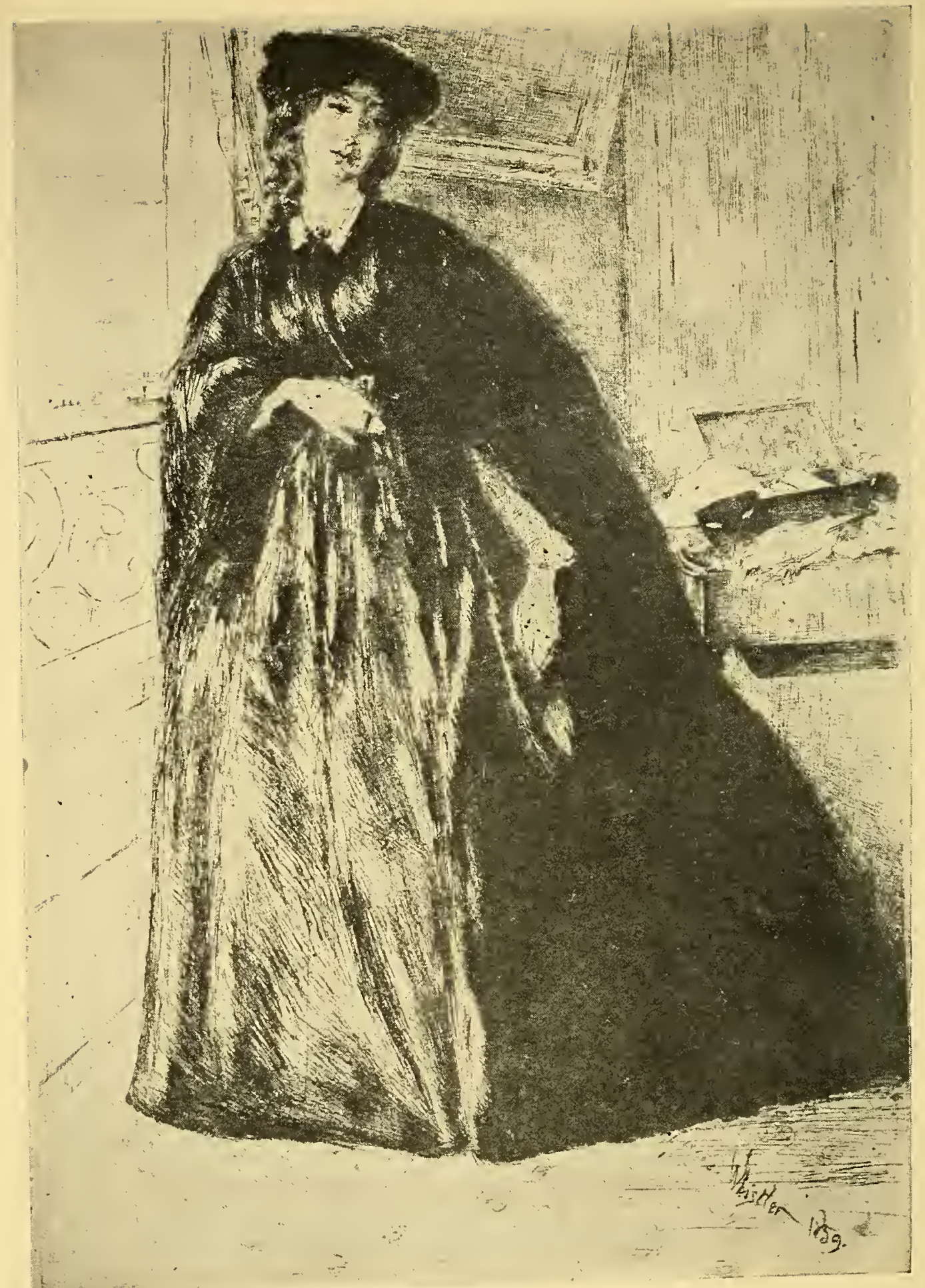

FINETTE

ETCHING. M. 58 


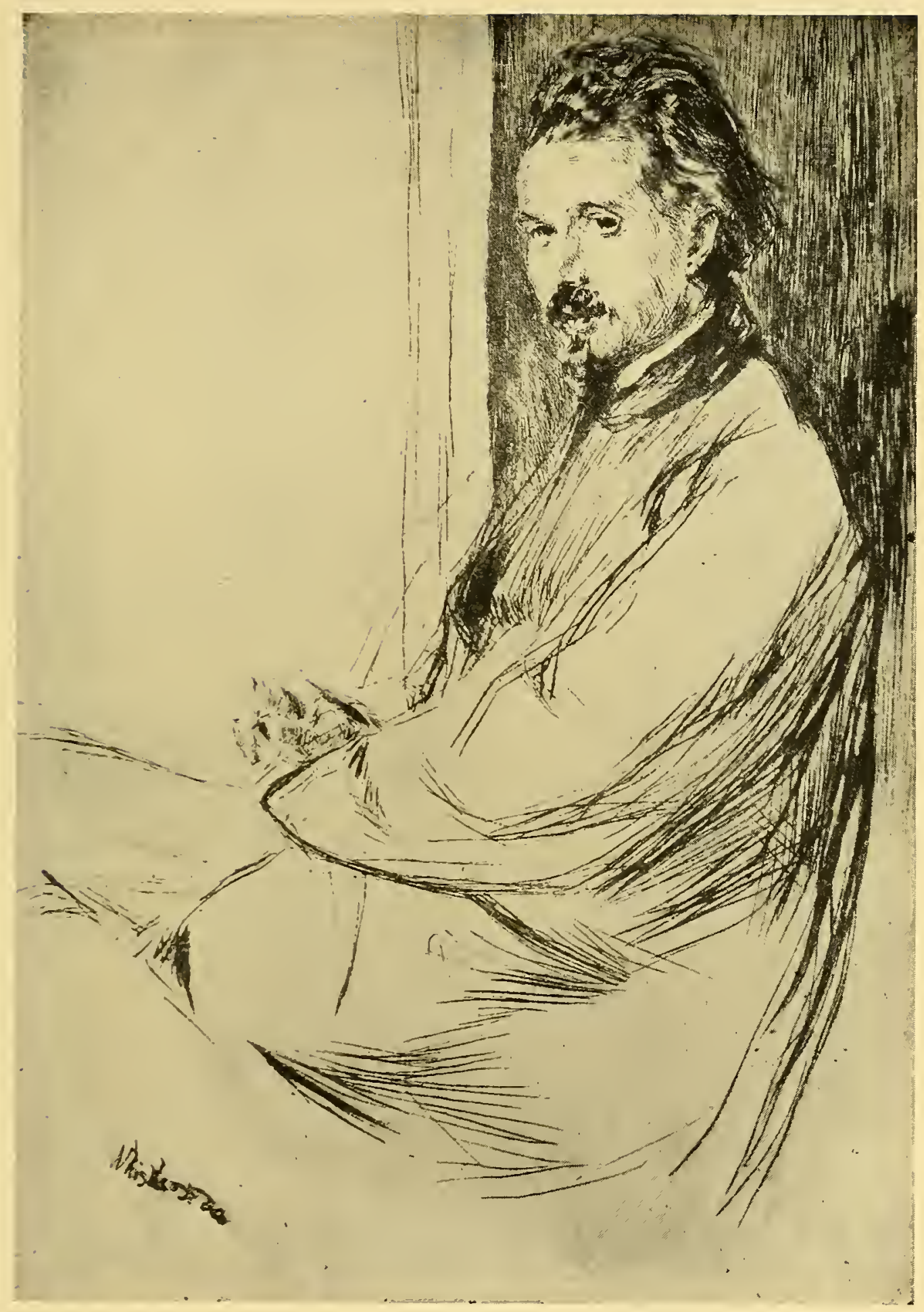

AXENFELD

ETCHING. M. 64 


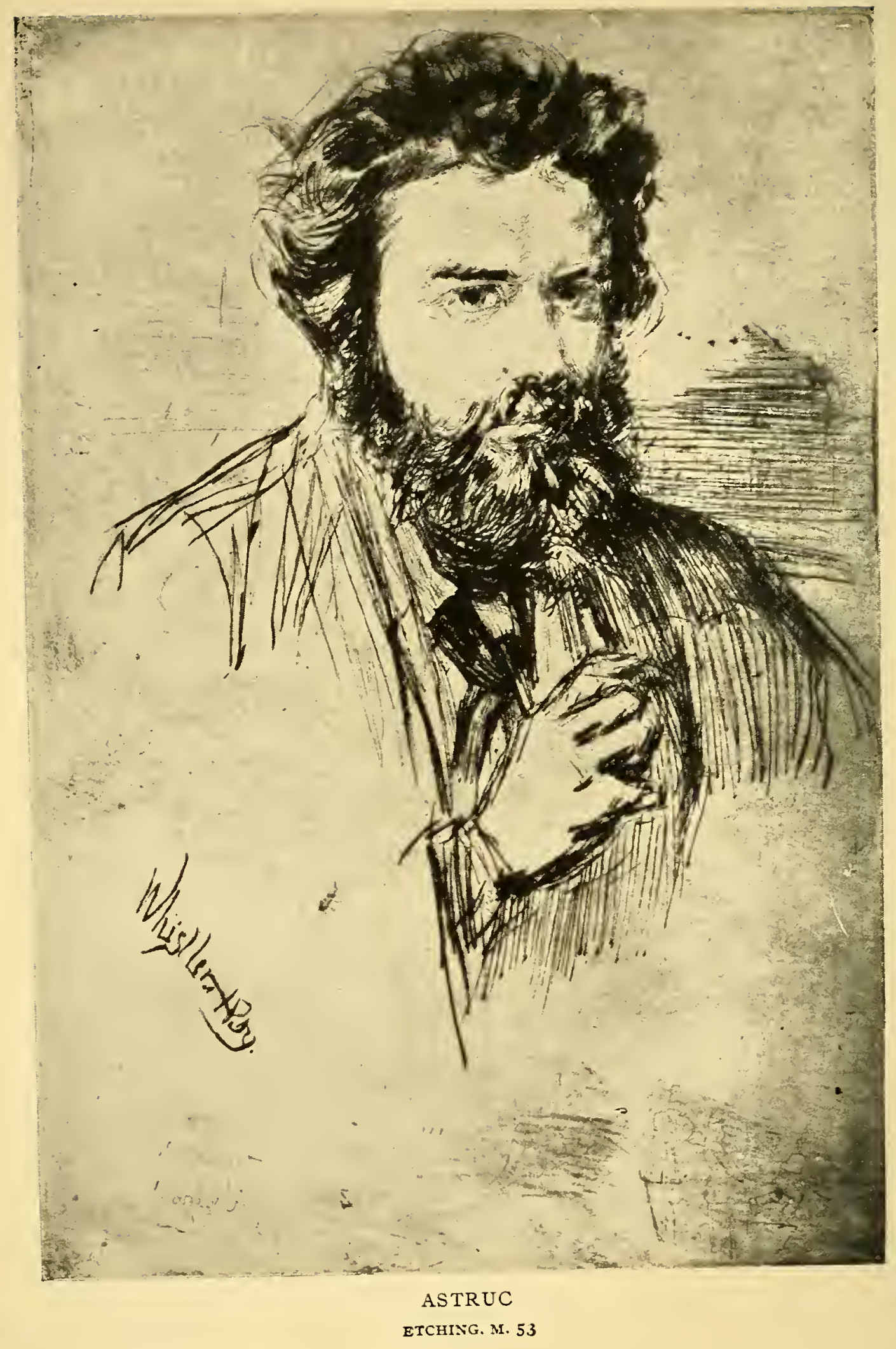




\section{Early Paris Memories}

Museum at Besançon. He lived by playing in an orchestra at some theatre. Sarah Bernhardt saw him once as he played, was struck by his beauty, asked who he was, and sent for him to come to her dressing-room. But he would not hear of it-he would have nothing to do with that! And there was a story of a composer who asked Becquet to play his music; at first Becquet said no, then he consented, and the composer wept as he listened, and the two embraced.

Valentin, the father of Bibi Valentin, was an engraver.

Drouet could not remember exactly what Axenfeld did, but his brother was a celebrated physician of the time.

Astruc was not only editor of $L$ 'Artiste, but he painted and sculped, made water-colours and wrote verses-in fact, did a little of everything, and his wife used to say he was the first artist since the Renaissance who had combined all the arts.

It was Eloise, La Fumette, who was with Whistler in the Rue St. Sulpice and tore up the drawings. She was a grisette who liked to live with men she thought distinguished, out of the common. She and Whistler were together in misery, for two years. He hadn't anything to give her. Later she was the mistress of a musician. Then she went to South America, thinking to find an opening as "modiste," but she was too old, and died there. Finette was a cocotte, very elegant, who sometimes danced the cancan in the dancing places. She went to London to dance in the Music Halls, and they announced her as Madame Finette in the Cancan, la Danse Nationale Française.

Sometimes they made the feast at Lalouette's restaurant and then they ordered cachet vert, a Burgundy at one franc or one franc twenty the bottle, but only on great occasions. This brought a question from Duret and the talk back to Becquet who, to the last, asked Drouet to dinner in the little restaurants where a plat cost two sous, where it was an event to spend a franc, and where forty sous would pay for a banquet with all the delicacies of the season. But they were seldom so extravagant, though often they would go on to the theatre afterwards. Aubert was the first man Whistler knew in Paris, the friend who helped him to find his I900] 
The Whistler Journal

first rooms. Henri Martin, he thinks, must be the son of the historian, who did a little painting. The man in Soupe a Trois Sous was another Martin, a soldier, given the cross of the Legion of Honour at sixteen for bravery in 1848 . He planted a flag on the top of a barricade. He was the youngest man who ever received the Cross. Afterwards it was taken from him for misconduct. Whistler was always ready for a quarrel, or rather to defend himself-as in the case of Legros-un petit rageur, even as a student. Then a story of another artist with a studio at the Rue CampagnePremière who came to Drouet one day about noon, looking miserable, wrapped in his coat, the collar turned up, and asked Drouet to help him out of a scrape. He had been to the Bal Bullier the night before, and there met with a wonderful creature, the model who posed for La Baigneuse of Courbet, a splendid creature, but enormous. And he was with her all evening and kept telling people she was La Baigneuse de Courbet, and he brought her home, and she spent the night with him. But in the morning, dégrisé, it was another matter, and he did not know how to get rid of her. She was in a most extraordinary costume, à L'Ecossaise, huge in her red and white stockings below her knees, her short skirts, and her absurd little hat perched on her head with a feather sticking up in the air, and he was ashamed to see her go across the court, or to be seen with her. At last he decided to fetch a cab into the court and drive her out of sight. But, as she waited for him she leaned out of his window, neighbors got wind of something unusual, when the cab rattled in, they were all at their windows, and her going was an enormous sensation.

Another story was of the old man whom Whistler painted with a pipe in his mouth, the picture Drouet has. Whistler picked him up in the Halles, un misérable without a sou to buy himself food, but with a curious hat and a face full of character, and Whistler told him if he would come to the studio and be painted, he could earn forty sous. And the old man said Bien, but first he must get his voiture, and Whistler wondered how a man who hadn't a sou for a dinner could keep a carriage. When they got outside, there it was: a push cart full of pots-de-chambre. And off they went, 92

[1900 


\section{Early Paris Memories}

and the voiture with its crockery was left in the court, and he sat for two or three hours, and he sang funny old songs to Whistler who began to sing them with him, and they were great friends. Freer wanted the painting, but would not give Drouet two thousand francs for it. Now no one shall have it for less than two thousand, five hundred. [Drouet left it to the Louvre.] Drouet sat twice for his etching-one day for two and a half hours, the next for one and a half. The Bibi Valentin was done in a couple of sittings also-about five hours in all. Another touch to the story of Mère Gérard. When she said encore une espèce de canaille de moins, Whistler laughed and then she recognized him though she couldn't see him-his laugh was known even then. When Whistler left Paris, he owed Lalouette three thousand francs. It was an awful business paying it, but he paid it in the end. A picture Drouet remembers his painting was the portrait of a big Englishman who was copying a picture of Angelica Kauffmann's in the Louvre. What has become of the portrait he cannot say.

The stories about Oulevey were inexhaustible. When he moved into new quarters, with no furniture except an easel and a chair or two, the landlord objected to a tenant without furniture. At that time, pianos could be hired for about seven francs a month. Oulevey hired one. It came, made a great effect in the house, and the landlord was reassured. [A piano later saved Whistler from his creditors. Nor was this merely a version of the Oulevey adventure with Whistler's name substituted. We have the piano people's bill presented for payment of rent to the bankruptcy commissioners.] Sometimes when Oulevey was two or three months behind in the rent, an old man and good friend, le Pere Perret, would come round, make some excuse to sit with the concierge, and presently begin to talk of Oulevey and what a talented fellow he was. "Yes, all very well, but he doesn't pay his rent which is much more important," the concierge thought. Bah! was the Perre Perret's answer, that was all right, he had an order for a five hundred francs picture, and would be less than a fortnight painting it. And the Père Perret would go up to see Oulevey and, on the stairs coming down would call out, "And now, mon gargon, you know you must I900] 


\section{The Whistler Journal}

get to work and paint your picture." And the concierge would tell the landlord, "Better let him stay on, he will have five hundred francs in a fortnight, and then he can pay. If we turn him out now, he can't." A time came when the landlord wouldn't keep him any longer, and everything was to be seized. Oulevey wanted to get his canvases away. He tore them off the stretchers and made a great roll of them. One day, when he was out, a friend came with a roll just like it on his shoulder, and Oulevey's key in his pocket, and lingered a moment with the concierge to make sure the roll on his shoulder was seen. He climbed to Oulevey's studio, changed the rolls, returned with the canvases on his shoulder, and again stopped to let the concierge know that he hadn't found M. Oulevey and couldn't get in to the studio. In the Louvre, it was the same. Oulevey was forever playing practical jokes. When a young lady, working next to him on a high scaffold copying a popular Murillo, had carefully prepared her palette and was about to begin to paint, he would give an accidental push to the steps of the scaffold, and the stroke would be made in the air. Or he brought carrots, turnips and potatoes, and while she was at lunch hid them on the steps so that when she came back, at the first touch, they rattled down all about her, rolled over the floor. One day she felt she couldn't stand it any longer and meeting him at the lunch hour in the Rue de Rivoli, she stopped him to say she must complain to the authorities. But pardon, he said, he did not understand what she was talking about, he did not paint in the Louvre - that must be his brother-then he tore back as fast as he could and was in his place, painting, when she got there. She had never seen such an extraordinary resemblance, she marvelled, and forgot to complain. He loved les charges-was a great blagueur. It was the day when artists still delighted in practical jokes-even Courbet played them.

Drouet remembers seeing Whistler in Paris in $\mathbf{I} 862$, breakfasting with him in his studio, and Whistler cooking the breakfast over a little stove in the middle of the studio. His impression is that Whistler did not work in the schools-did not work in Paris. $\mathrm{He}$ danced in the evening, went to bed late, never got up till towards 


\section{Early Paris Memories}

noon. But he would have done more had he stayed in Francewhere there were artists to rival: in England there was no one. However, all his great pictures, beginning with $A t$ the Piano, were done in England. He thinks Whistler soon lost his power-either from alcoholism or women-which is absurd. Thought he never did prints of any account after he went to Venice. He drew freely at first. But, whether from alcohol or not, his hand weakened, he had to rest his wrist on something while he worked, could only make a few strokes at a time. This was the reason of the change of method in the Venice plates. They had no real value. It was fictitious, made by dealers who couldn't get hold of the early ones. He ought to have stayed in Paris where there were painters he could compete with-there were none in London.

Whistler was always unwilling to tell his age-only two or three years before his death, once in Drouet's rooms, Drouet asked him how old he was. He fumbled with his eyeglass and said, about fifty-eight or fifty-nine, yes, that must be it, all the time looking out of the corner of his eye to see if Drouet took it in. He never gave anything much to Drouet, though Drouet gave him many things; he was un peu égoiste, un enfant gâté. He hated to be alone. Those last years in Paris he always drove everywhere, couldn't walk in his little, tight shoes. You would see him in cabs, fast asleep. One night he was going to dine with a friend. It was cold and he took a cab, with a chaufrette. Got in, couldn't find it anywhere. Then he saw that the cocher had it under his own feet. When Whistler got out, he paid his fare-it was before the taximetre-exactly thirty sous and no more, and the drive had been long. "And the pour-boire?" the cocher asked, and his language was awful. "Inside on the chaufrette," Whistler said, so pleased that he was in wonderful spirits all evening. The friend he dined with had never seen him so gay. Drouet said there were always histories with the cocher when Whistler came to see him. Whistler would never pay enough. At last Drouet said to his bonne, just to pay it always, and be done with it.

Drouet, unlike Oulevey, says that Whistler didn't print his etchings in Paris, Delâtre printed them all. Whistler stood by his side and I900] 
watched the printing of every one; that was how he learned to print. Drouet and he were looking over Rembrandt's etchings together once in Drouet's rooms, and Drouet told Whistler he was the first etcher since Rembrandt and pointed out where their work was alike. And Whistler was deeply moved-"si vous le pensez, mon cher," he said, "fa me donne grand plaisir."

Drouet's stories, not always exact and sometimes flamboyant, showed a tendency to greater flamboyancy as the evening went on. Whether or no they alarmed Keppel, after one more than usually lurid, he abruptly said good-night, the first of the party to go. Drouet and Duret, having complained of a courant d'air, we had pulled the table from the middle of the low room to one side, and Keppel was sitting directly under the electric light. He got up from his chair so suddenly that he struck his head hard against the sharp end of the bulb. Blood streamed down his face. For a moment it looked serious, a sensational tale for Drouet to add to his list. But the wound, when examined, proved a scratch. The blood was staunched and he was able to drive home alone, which was fortunate as our other two guests showed no signs of going. Duret stayed until midnight, Drouet an hour later. J. looked ready to drop. I was all but stifled from the atmosphere of the room so carefully protected from any courant d'air. Wonderful the old men of Whistler's generation, so much younger than the young of to-day.

CHAPTER VIII: THE LEYLANDS-THEIR CIRCLE, AND THE PEACOCK ROOM. THE YEAR NINETEEN HUNDRED CONTINUED

Monday, July I6th, Igoo. Whistler came to dinner. A fearfully hot evening - the heat quite American-and he arrived in a broadbrimmed grey felt hat on one side of his curls, a cross between the Rough Riders' and a Henry Heath hat.

He was in a reminiscent mood, though he had first to tell us of Kennedy. "I had not liked Kennedy's saying that my sending him clippings of the Irishmen's reverses in South Africa was in poor taste. And so, you know, I went to his room, while he was 96

$[1900$ 


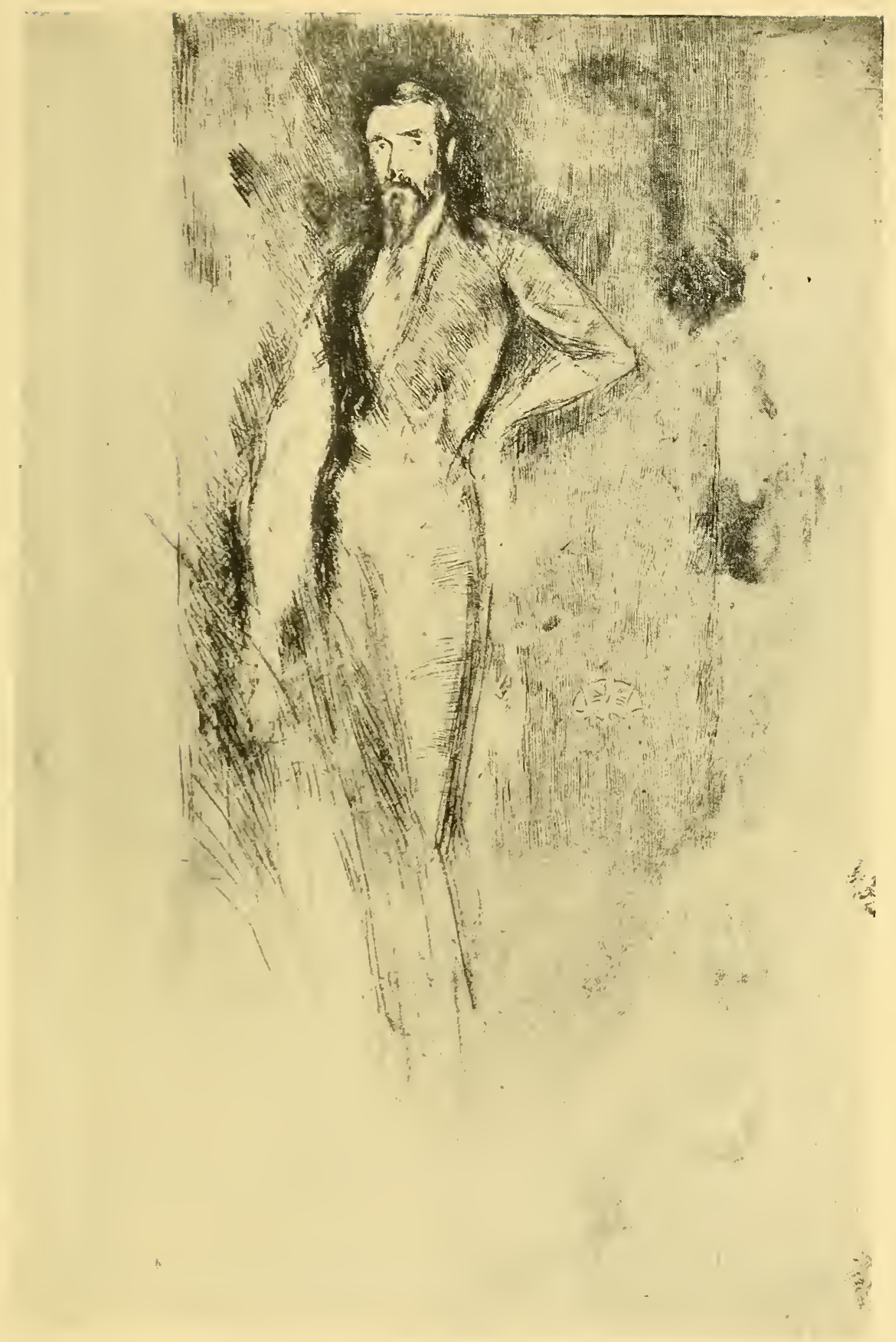

F. R. LEYLAND

ETCHING, M. $\mathrm{IO}_{2}$ 


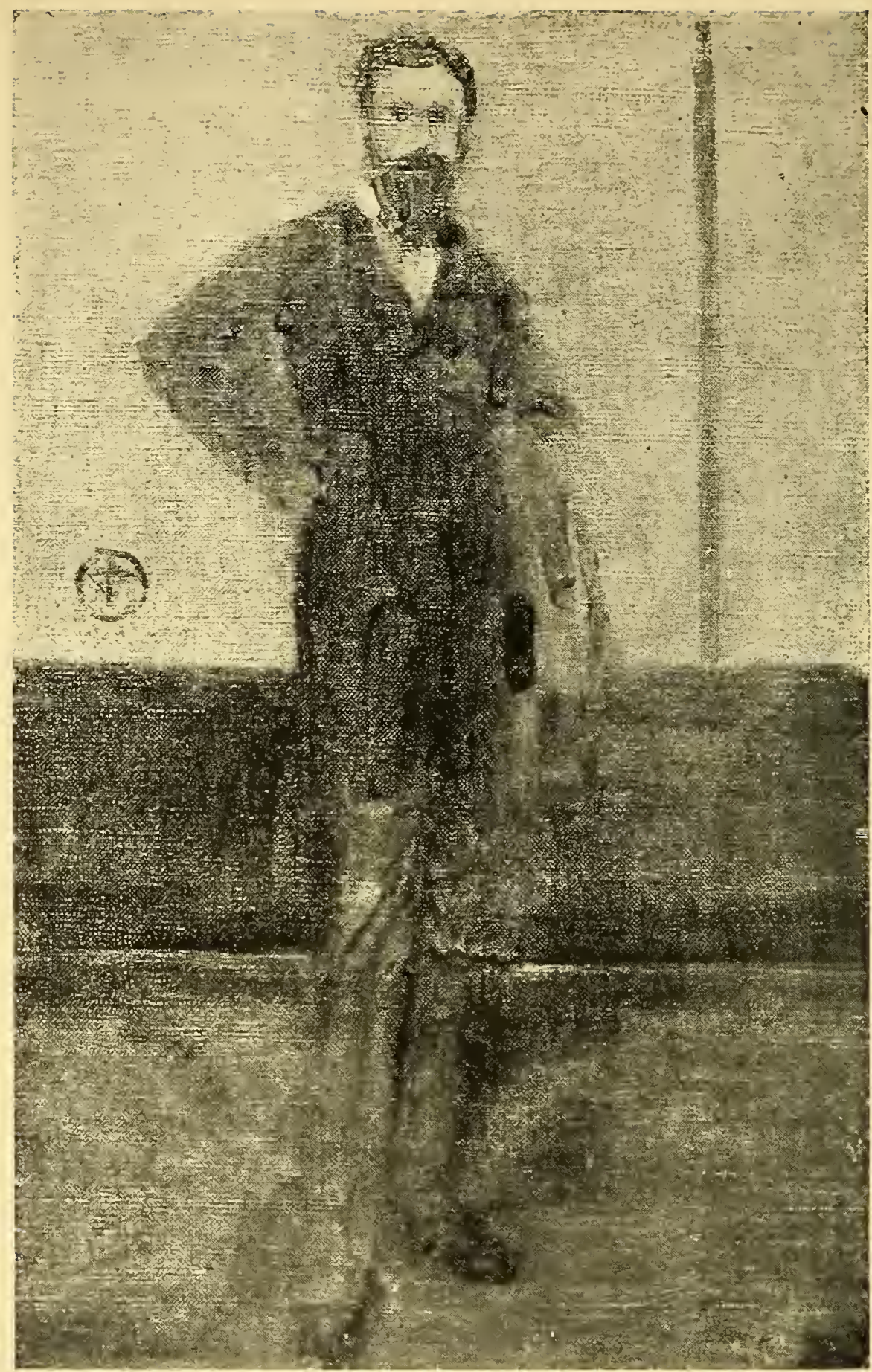

SKETCH OF LEYLAND

OIL

In the possession of the Estate of F. R. Leyland 


\section{The Leylands-Their Circle}

in the midst of his trunks and things this morning, and told him so. And Kennedy was splendid and said how much he regretted having offended me and that he would write and tell you, and we shook hands on it, and parted greater friends than ever." His reminiscences began with $\mathrm{X}$., who was asked once to stay over night in the house in Chelsea, because of rain, and stayed three years. "Well, you know, there he was, and that was the way he had always lived-the prince of parasites! I met him first at the Leylands-an extraordinary household. Leyland was playing the Liverpool Medicis - he was interested in art - he would come home from his office, go upstairs to his room without speaking to anyone, shut himself in, and play on the piano, practising and practising. Then, perhaps, he would go downstairs to the drawing-room where Mrs. Leyland was with $\mathrm{X}$. and his two sisters and other hangers-on, and he would make a scene with her-he was always making scenes with her, so that when he was away she was always having little parties and supper parties, and he would come home and catch her in the middle of supper sometimes. X. was the professional hanger-on, drifting from one house to another. He was a genius, a musician; that was why Leyland kept him for so long. He was supposed not to know his notes, and for that to be all the more wonderful. He was really the first of the Aesthetes, before the silly name was invented. He hadn't anything to do while he was with me, he didn't do anything but decorate the dinner table, arrange the flowers, then play the piano and talk. He hadn't any enthusiasms, that's why he was so restful. I never saw him until I came out of my studio in the afternoon, and there would be dinner, and there he was ready to talk and be amiable. He was always ready to go to Cremorne with me. At moments, my Mother, and you can just imagine the strict, correct old Southern lady, fresh from New England, objected to such a loafer about the house. And I would say to her, 'Well, but my dear Mummy, who else is there to whom one could say, Play, and he would play, and, Stop playing, and he would stop right away!' Part of the time X. spent with the Greaves, the boat people, a sort of Peggotty family, playing with Tinnie Greaves. The two brothers were my first pupils. 1900] 


\section{The Whistler Journal}

And that was about all he did, except drink my whiskey. I remonstrated once, but he said, What could he do? He belonged to a thirsty family, a family that needed whiskey. His mother was always thirsty too. Then, I was ill, and he was no use at all. He couldn't be trusted with a message to the doctor or the chemist, and he was only in the way. But he had the good sense to see it and to suggest it was time to be going, and he left for somebody else! And he drifted and drifted, until one day an old Polish lady saw him on the pier at Brighton, or some place, and took a fancy to him. And he went to live with her, and she made him her heir, and they went to Paris together. But his thirst was still strong, and he died before she did. His friends even dressed him half the time. When he was with me he pointed once to his shoes, all broken and cracked. I said, 'Yes, they are rather bad, but I don't mind.' 'No,' said X., 'but I think I should have another pair because of John,' my man servant. Yes, you know, the real parasite, and it never occurred to him that there was any reason why he should not live like that."

The Greaves brothers afterwards made a great excitement by painting the Town Hall at Streatham. Trixie went down to see it when we were staying at Long's Hotel and the walls were covered with nocturnes and things. Then he went on to The Peacock Room. "I had got to such a point in the work, putting in every touch with a freedom that was wonderful, so much so, that when I got round to the corner where I had started, I painted a bit of it over again that the difference should not be seen. I just painted it as I went on, without design or sketch."

The garden-the Embankment Gardens below our windowsstruck him especially. After all, why should we want to go away, with the river there, and the garden gay with people and with music, even if it was bad. And, for the first time, he complained of the heat. He liked it, but it made him restless.

Frederick Leyland was one of the rare modern collectors with the sense to collect modern work and the discrimination to commission the most distinguished artists of his time to decorate his house and to paint, draw and etch himself and his family. He and Mrs. 98 

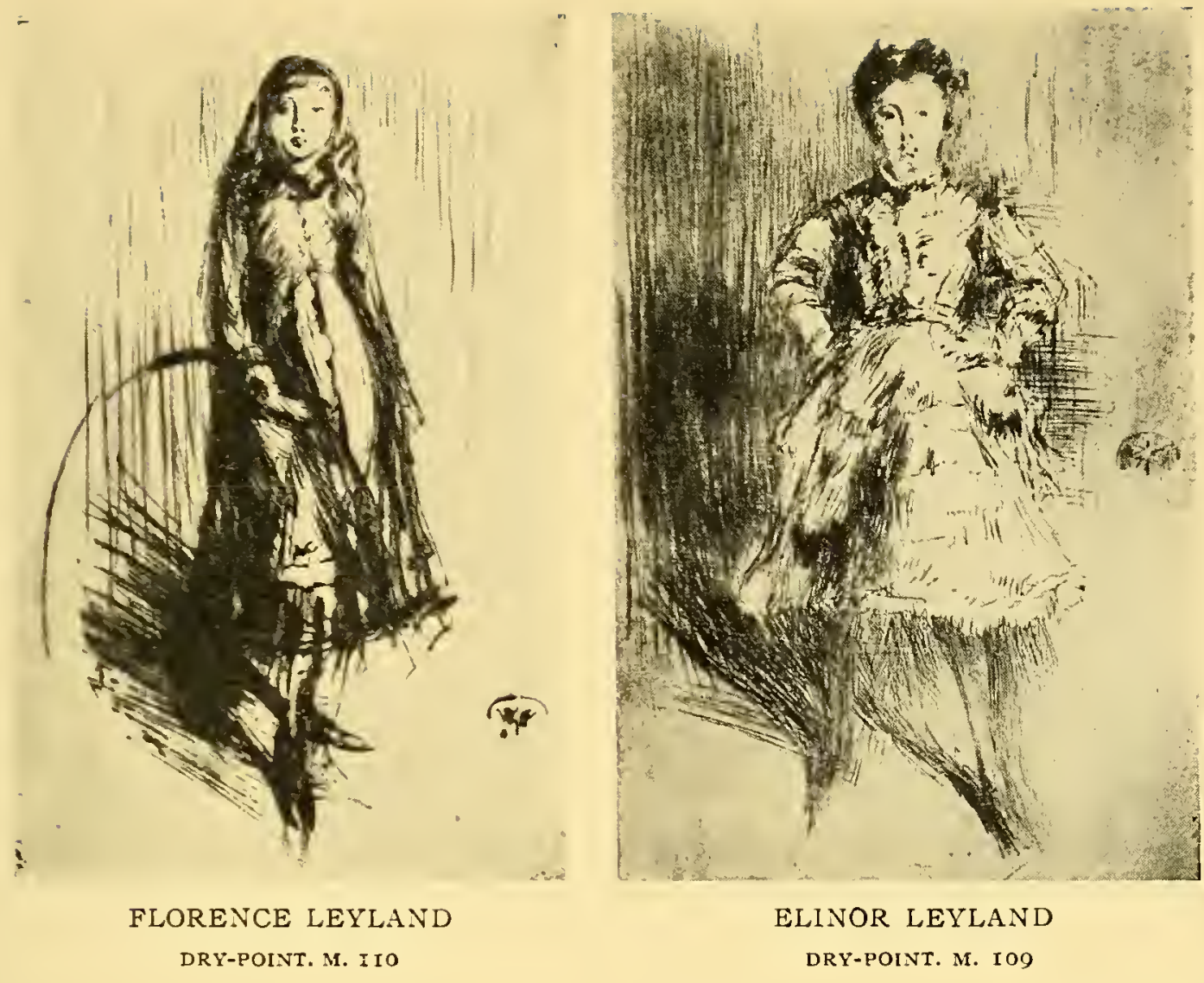

ELINOR LEYLAND

DRY-POINT. M. IO9 



\section{The Leylands-Their Circle}

Leyland, their three daughters and their son will live in Whistler's portraits as Philip IV and his family live in the portraits by Velasquez. Other contemporary collectors are forgotten but Leyland is remembered and he owes it to Whistler. The Fricks and the Johnsons and that type of collector may hope, by buying dealerboomed Old Masters at huge prices and ignoring the art of the present to buy immortality for themselves. But who to-day knows anything about the personality of Altman, or J. P. Morgan? In twenty years neither will be heard of because they bought only the things of the past, while the Six family and the Medicis family live because they collected the work of their contemporaries, though the Medicis could interest themselves too in the re-discovered treasures of earlier ages which, in their day, were becoming a collector's fad. The stupidity of the average American collector, however, is equalled only by his money, and before long his collections will be sold for the benefit of his family or dispersed by the proletariat, as is happening now in Europe. And before that even his name will be forgotten.

Leyland, the great shipowner, one of the wealthiest and most influential men in Liverpool, was as extraordinary as Whistler called him. He was entirely a self-made man. The career of many of our self-made magnates would seem commonplace in comparison to his. He began at the lowest rung of the ladder and not only climbed to the highest, but got there with a distinction and accomplishment seldom equalled by the University-made snob who looks down upon anyone not born and bred according to his standards. Mrs. W. J. Stillman, in a talk about Whistler with E., said:-

November I3th, I9o6. Leyland's mother was a poor woman who sold pies in the streets of Liverpool and Bibby, the rich shipping man, sometimes bought her pies and found them good. 'And he used to talk to her. Once he asked her what she was going to do with her son and, as her plans for him were vague, took the boy to sweep out his office and run his errands. That was the beginning and yet Leyland, like old Ionides, knew what was good in art and was, moreover, a fine musician.

With his talent for music we have nothing to do. Apparently it was a genuine talent, but it amused Whistler. He thought Leyland portentously solemn and serious over it and nothing pleased him more than the comment of a chance workman about the house who, hearing Leyland practising his scales for hours, thought "he must I900] 


\section{The Whistler Journal}

be such a light-hearted gentleman!" But in art Leyland knew well enough what was good to become Whistler's patron at a time when purchasers of Whistler's paintings and prints were few. From Leyland, Whistler received innumerable commissions to which the end was not in sight when he began the decoration of The Peacock Room, and the commissions brought about a close friendship between him and the Leyland family. Leyland approved of him as much as of his art; the children delighted in him; for a while he was engaged to Mrs. Leyland's sister; the gossip of the day was inclined to believe him in love with Mrs. Leyland. What with their friendship and what with the work that took him to Speke Hall and the London house in Princes Gate-- "a neverending guest" as he put it-he was so closely associated with them that the quarrel disorganized his life as disastrously as his finances. He said more than once that The Peacock Room was the reason of his bankruptcy- "Ever since, I've had no luck," or, in the face of another writ or bailiff, "All this annoyance is the result of that confounded Peacock Room where I had no 'business contract." Not many people are left who knew both Leyland and Whistler in the years of their friendship. We were just in time when we began the Life. Never again can the facts and contemporary rumours and opinions be collected, as we collected them, at first hand. Some we did not use, thinking them inappropriate in a biography, others we obtained only after the Life was published. But they should not be lost, and at this date we can write with greater freedom. Besides, they help to a fuller understanding of Whistler. Too much cannot be known of the world's great men. We never saw Leyland who died in the early Nineties. But E. met Mrs. Leyland as our work on the book progressed and she was keen to tell all she could, keen to talk of Whistler who, there is no doubt, then occupied as prominent a place in her memory as of old he had in her life. The notes made of E.'s three visits are of interest- "human documents" would have been the name for them in the Eighties and Nineties-and we therefore give them, with occasional omissions, as they are in The Whistler Journal. The first visit was on

October 26th, I906. Went by appointment to call on Mrs. Leyland. Found her sitting in her drawing-room with a cat on her lap; an old, much-wrinkled woman, short, slight, still pretty with a becoming white wig, in a tight-fitting black lace gown and many pearls and diamonds, her figure as slight and trig as a young girl's. She IOO 


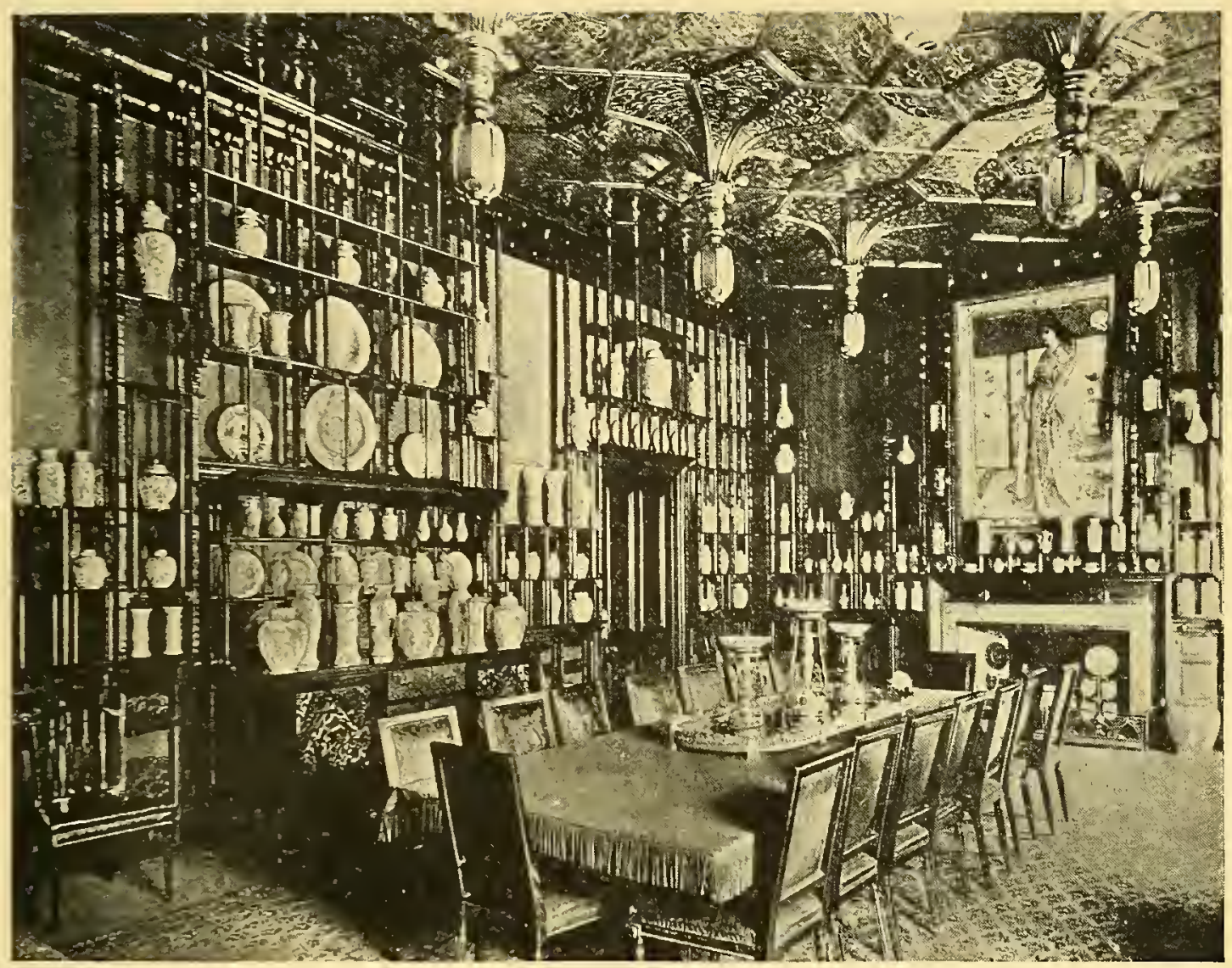

THE PEACOCK ROOM

From a photograph made while it was in place in Princes Gate, showing blue-and white on the walls Photograph in Pennell Collection, Library of Congress, Washington 


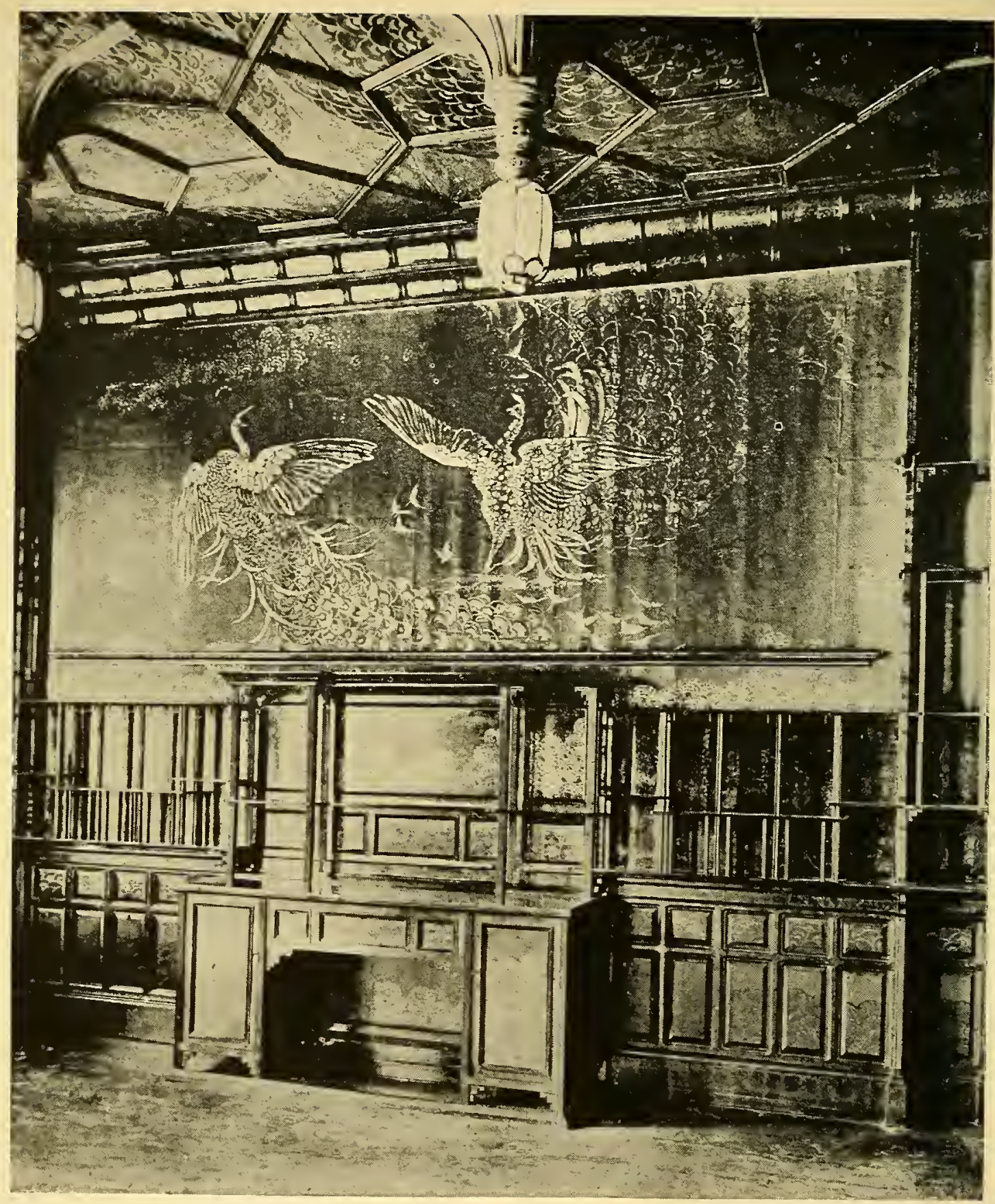

RICH AND POOR PEACOCKS

In Peacock Room. Freer Collection, National Museum, Washington (See page 108) 


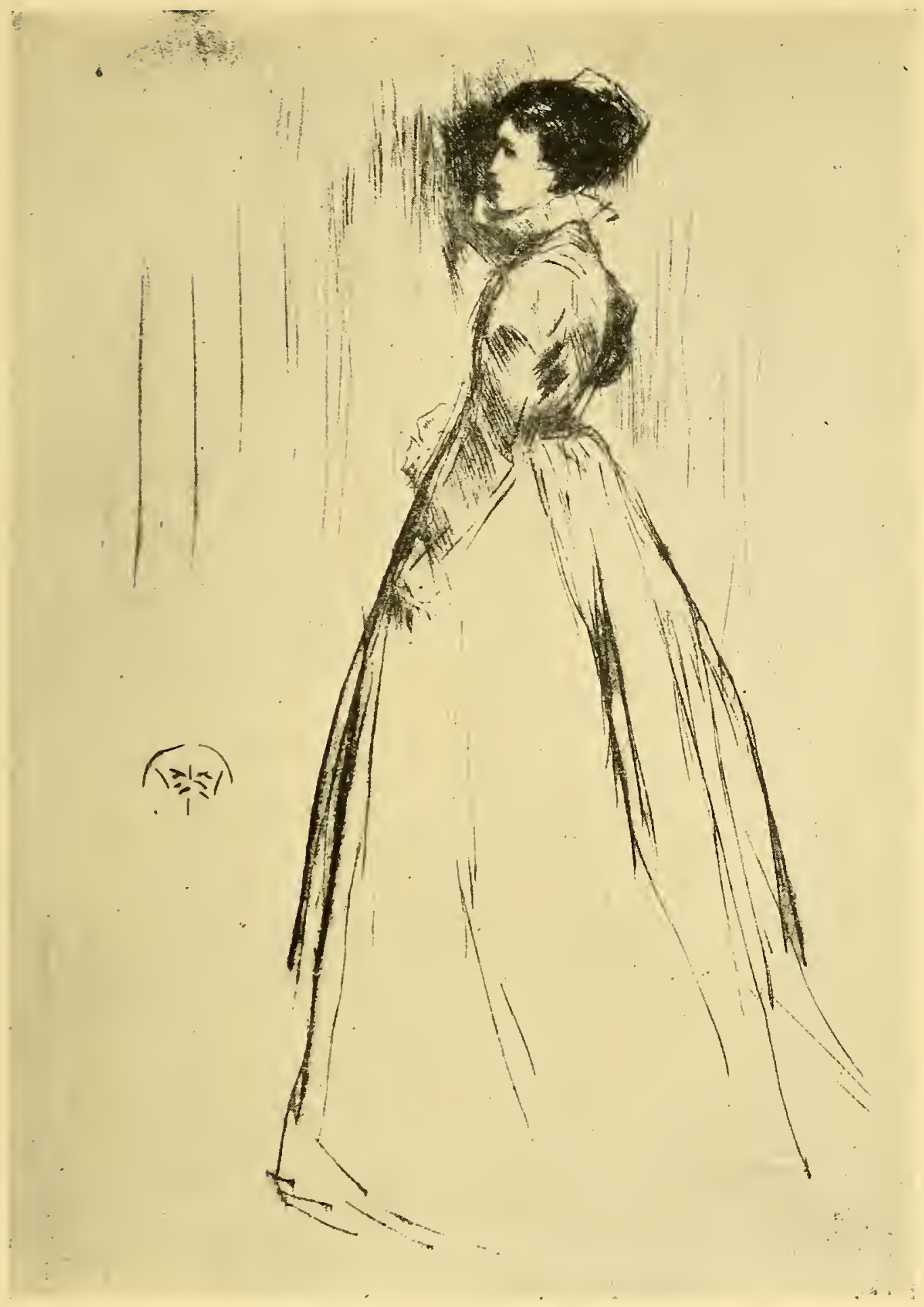

MRS. LEYLAND. THE VELVET DRESS

DRY-POINT. M. IO5

(See page 102) 

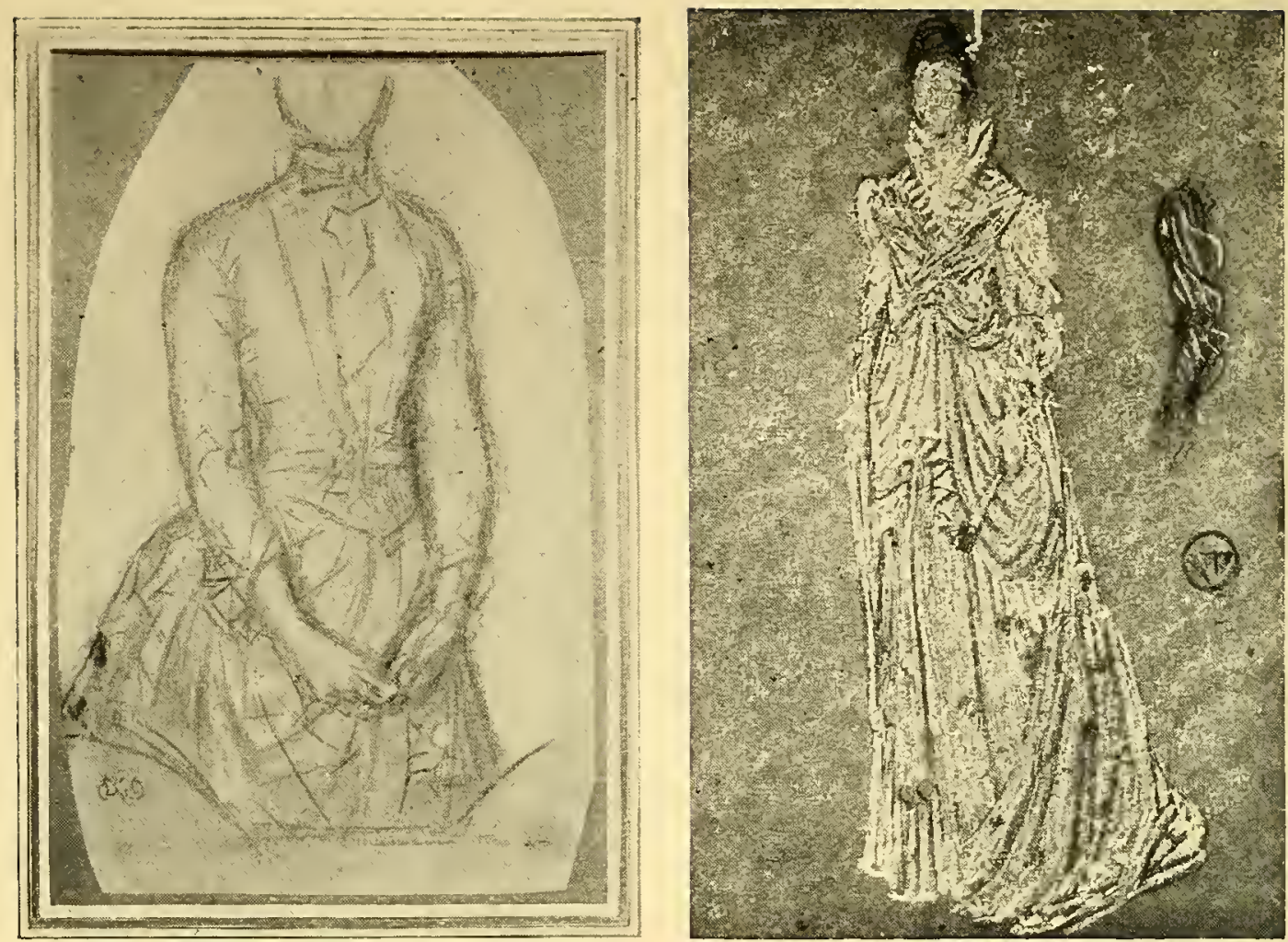

STUDIES OF MRS. LEYLAND'S DRESS. BLACK AND WHITE CHALK In the possession of Walter S. Brewster, Esq. and Mrs. Knowles

(See page 30I) 


\section{The Leylands-Their Circle}

talked for fifteen minutes or so about the cat, a quite homely, almost a gutter cat, and when I was wondering how I could bring in Whistler, she suddenly said that cats had such charm and were so graceful that they appealed to Whistler who always liked everything charming and graceful.

She told me it was through Rossetti they first knew him, Rossetti introduced him to Leyland who bought La Princesse du Pays de la Porcelaine, and they at once became great friends. In those days the Leylands had no house in London, they stayed at the Alexandra Hotel when they came to town, but Whistler and his mother used to spend months with them at Speke Hall. All the family sat for him: Leyland, herself, her three daughters, her son; Leyland paid him for all the portraits, but not one was completely finished. He would work on them in the Lindsey Row house and then take the canvases up to Speke Hall and work on them there. Her children were awfully good about it, though they got fearfully tired. The son, after three sittings, wouldn't sit again. She herself didn't mind, she didn't get tired, and she knew Whistler liked to have her stand because he always talked to her freely, told her all his troubles and looked for her sympathy. When she was in London, and Leyland had to stay in Liverpool, Whistler would come and take her about; one had to have a man when one went out in London. She remembered his going with her to her box at the Opera, and the attendant who opened the door and helped them with their wraps, when he took Whistler's hat, leaned over and said, "I beg your pardon, Sir, but there is a white feather in your hair, just on top." People talked about her and Whistler, went so far as to say she was going to elope with him, which was absurd, as if she would! Though she didn't say that if she had been a widow then she mightn't have married him. Whistler was engaged for a while to her youngest sister, who was pretty, but not the wife for him, and it was a good thing the engagement was broken, though she always thought that if he had married early the right sort of woman it would have made the difference.

$\mathrm{He}$ designed the dress in her portrait, white and rose chiffon with rosettes scattered here and there, and when she could not come, I900] 
sometimes Maud posed in it so he could paint the draperies. The pose was one natural to her, one she took unconsciously when she stood talking. She had never known an artist to be more conscientious - the picture was rubbed out again and again; there were times when after a day's work, it looked as if it were really all but finished and she thought not more than another sitting was needed, and the next morning she would come to find the whole thing rubbed down, and the work to begin all over. The portrait of Mrs. Huth was painted while she was sitting for hers in the Chelsea house, and she pretended to be indignant with him because she wanted to wear just such a black velvet dress as Mrs. Huth wore and he insisted on her wearing the one he designed. He began a big picture for Leyland, girls and flowers, but never finished it. When he gave his first dinner party at Lindsey Row, she lent him her butler and in the afternoon she and her sister went round to see if everything was in order, and they hung up white muslin curtains at the windows for him. It was a big dinner party and there were interesting people, and one absurd incident she remembered. A woman neither she nor Whistler liked came in a white muslin slip over a pink slip, and, being near sighted, mistook a sort of Japanese bath filled with water and water-lilies for a divan and was about to sit in it when Mrs. Leyland rescued her, and Whistler said afterwards, why did she? A daughter of Grisi's was there, and Whistler made Leyland take her in to dinner because he thought she must be musical, and the first thing she said when they sat down was, Did he like Ouida's novels? Of course they went to many of the breakfasts, but she had not much to say about them.

In the end, she thought Whistler behaved badly to Leyland. Leyland only meant him to decorate the shelves Jekyll designed to hold the blue-and-white china, and he passed over the loss of his old leather and being kept out of his house for so long. He was not only a generous, but a just man, and he thought Whistler asked him too much for the decoration. If she remembered it was three thousand guineas, something between two and three thousand. She herself never quarrelled with Whistler, though she IO2 
objected to something she heard him say in The Peacock Room about her husband. But she saw him afterwards, she went to his house and he came to see her. Her oldest daughter, however, seemed to think it was better not to, and so in the end, for some years before his marriage and until his death, they had not met. She sent him a message once, to come and bring his wife, through Mrs. Alan Cole, and Mrs. Whistler, who seemed a jealous person, resented it and asked Mrs. Cole how she could want to break up the peace of a happy home. She could not understand his will. She thought he ought to have left something to his son. He had taken her to see the son once when he was a small boy.

It was her nocturne that was brought into court in the place of Mrs. Wyndham's, which she insists was the one Ruskin wrote about. Mrs. Wyndham was away, and hers was sent down from Speke Hall, and she was furious because it was taken into court without the frame, and the frame was painted by Whistler-with blue waves, carrying out and completing the design. It got so battered afterwards she had it gilded over. It hangs in her drawing room: a beautiful blue night, a great wide stretch of river, the factory chimneys and church tower of Battersea on the far shore, and in the foreground a spray of foliage and the Butterfly in the long narrow Japanesish panel. She says it was Leyland who suggested to him the names Symphony and Harmony. There are dreadful pictures near it in the drawing-room and a lot of photographs of people, and one of a gravestone in a cemetery. Down stairs in the dining-room, where she took me, Whistler's portrait hangs side by side with a big full-length portrait of her by Phil Morris, a portrait of Mrs. Prinsep by Val Prinsep on one side, and opposite another of Prinsep's pictures. I could hardly see the Whistler in the late afternoon light, so I lost the colour. The pose is charming. The portrait belongs to her son, but she is to keep it as long as she lives. The Nocturne is hers and she will not part with it. An American had come to her anxious to buy both. In her bedroom are three pastels of the children: the boy with a wide-brimmed hat on the back of his head, his legs crossed and stretched out in a graceful pose; one little girl, Mrs. Prinsep, stand1900] 
The Whistler Journal

ing in old-fashioned dress, wearing hat and jacket; and the other, the youngest, lounging in a chair. In the back drawing-room and in the morning-room are etchings of The French Set and other early ones of that date, and of The Thames Set. She is willing to let us photograph anything she has, provided the pictures are not taken from the house. At the time of the sale of her husband's things, she says Whistler wrote her from Paris protesting against the sale of certain sketches of herself and the children, which he said were hers and not Leyland's. He had given them to her, Leyland had not bought them.

The second note is dated a month later the same year:-

December I2th. I called on Mrs. Leyland. She evidently likes to talk Whistler. She told me virtually the things she told me the last time I saw her, with a few additions. When she went to sit for her portrait in the Lindsey Row house, she used to meet Carlyle who was sitting for his. He was grumpy, in the end wouldn't come as often as Whistler wanted. Phil Morris' father had to sit for the coat. Then, it was Rossetti who told her of the report that she was about to elope with Whistler. Not only had she gone with him to see his son; then a small child in charge of some woman somewhere in the country, and Whistler seemed quite fond of him, taking him in his arms; but she saw him again when he was much older and Jo was taking care of him. He called her "Aunty," and sometimes he would come to the studio and say that "Aunty" wanted some money-she remembered him a little lad in a sailor suit. He was the son of another model. Whistler always said he was "an accident."

Mrs. Whistler, Whistler's mother, told her a most romantic story of her marrying Major Whistler. The Major's first wife had been her intimate friend, with whom she stayed a great deal in the few years of their married life. And all the while she was in love with Major Whistler, determined that she would marry no other man. And it seems that the first wife, dying, said to him that if he married a second time, it must be to Miss McNeill, that is, Whistler's mother. 


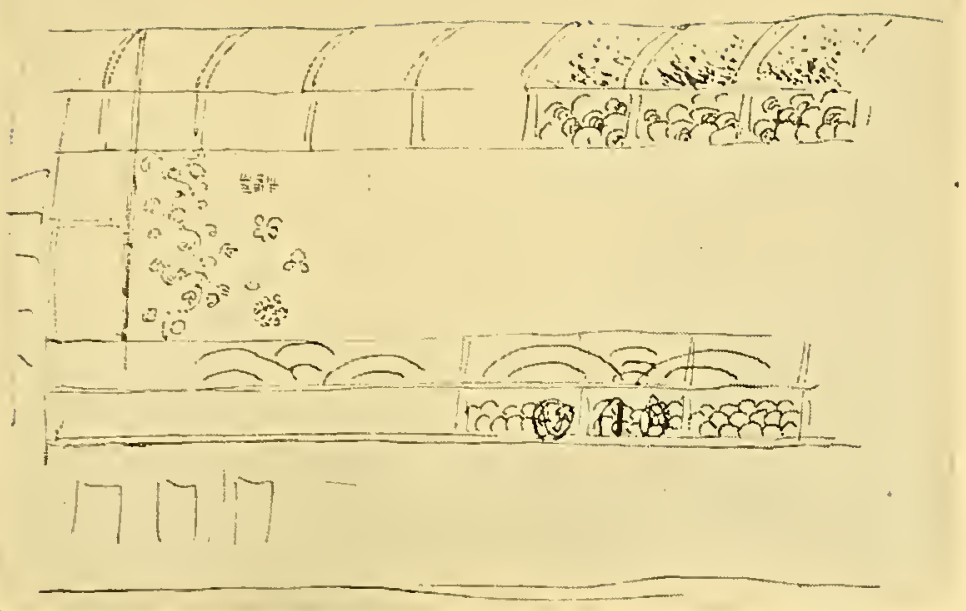

SKETCH OF DETAIL OF PEACOCK ROOM PEN-AND-INK

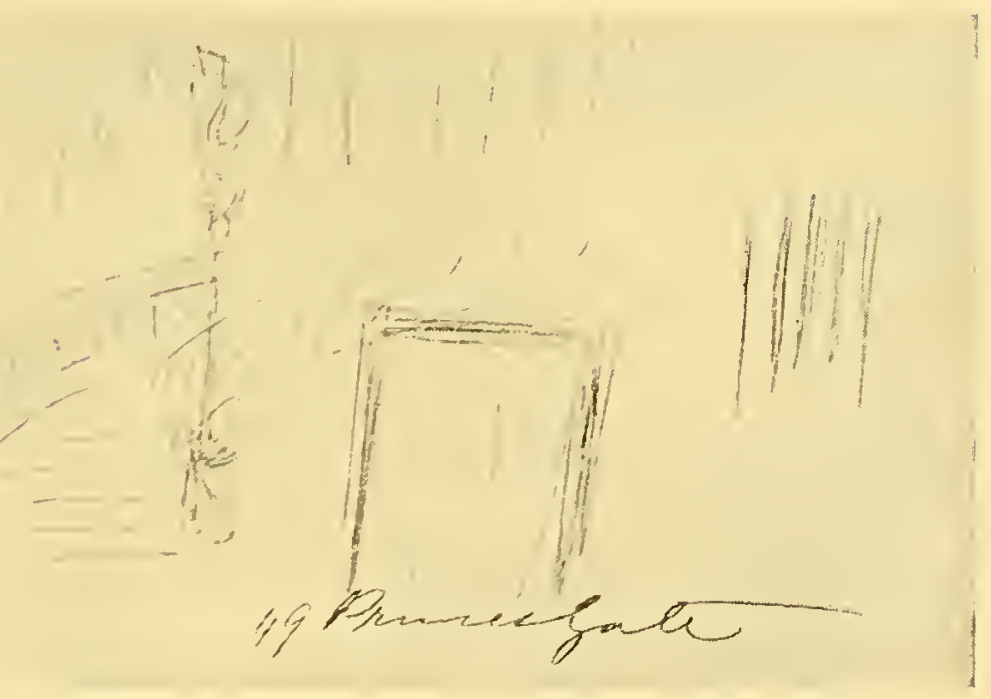

SKETCH OF STAIRWAY AT LEYLAND'S HOUSE

Partially decorated by Whistler PEN AND PENCIL

In the possession of the Estate of Mrs. Leyland 

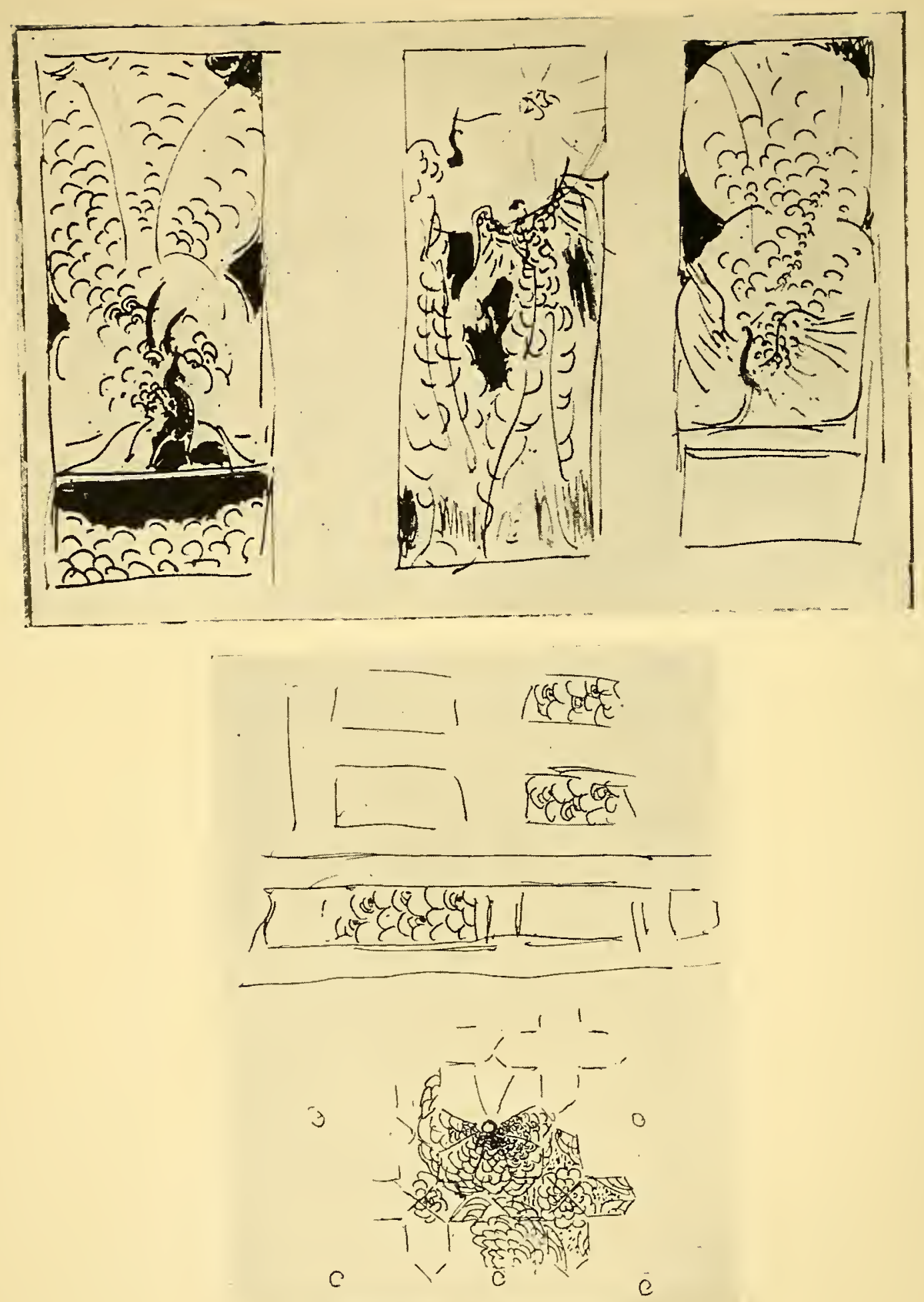

SKETCHES OF PEACOCK ROOM PEN-AND-INK

In the possession of Mrs. J. C. Gardner 


\section{The Leylands-Their Circle}

Mrs. Leyland thinks there could be no greater contrast than between Whistler and the Doctor. Whistler quick and alert, the Doctor slow and deliberate-he would take half an hour almost to write the simplest prescription; Whistler slight, the Doctor short and heavy. Whistler's voice disturbed some people. She remembers at an evening reception, Whistler coming in and being heard at once, and the man with her, not knowing who it was, grumbled that even genius could not excuse such a voice. She talked again of The Peacock Room and said nothing she had not said before, except that for a while, when he was doing it, Whistler lived at Princes Gate, Leyland hoping that if he did, he would get on faster. But it was Whistler's conscientiousness in work that made him slow. He never minded how much time or trouble he took in order to get what he wanted.

The third and last visit was just before the book came out-a hurried visit, for E. was on the point of sailing for New York:-

October 14th, 1908. Called on Mrs. Leyland. She has let Gray photograph her portrait again for Heinemann. I asked her especially about the picture in the Brooklyn Museum, which is catalogued as a portrait of Florence Leyland, and which Joseph, who has just seen it, thinks a portrait of Maud. She had forgotten it, thought that her children posed to Whistler only. when quite young. But she asked Mrs. Val Prinsep, who says it is her portrait. She stood for it when she was seventeen or eighteen, and Mrs. Leyland's description of the dress and details agrees exactly with Joseph's. $\mathrm{He}$ is anxious to let Mr. Goodyear, the Curator of the Museum, know about it. Mrs. Leyland went over the same reminiscences of Whistler, and regretted that he could not have married her-it would have been much better for him, she thinks.

That Whistler did one day say something which was overheard and considered offensive by Mrs. Leyland, she was not alone in telling us. We had the same story from T. R. Way, though he supposed that Mrs. Leyland also quarrelled with Whistler in consequence. The Ways had an excellent opportunity of hearing the gossip on the subject for it was work connected with The Peacock Room that introduced them to Whistler.

I900] 


\section{The Whistler Journal}

September 25th, 1906. Way said: They had printed catalogues for Deschamps, Durand-Ruel's London representative, and E. W. Godwin, knowing this and knowing Thomas Way personallyboth were members of the Hogarth Club-brought him to Whistler who wanted to issue a leaflet about his decorations. Way had bought a couple of Whistler's water colours and told him so, and Whistler asked him to the studio to see his etchings. After this, young Way too was sometimes there when Whistler was printing, and often in The Peacock Room on business about the leaflet which is now so rare a find for the collector. His impression was that Leyland did not mind anything Whistler did, not even the disappearance of the old leather on the dining-room walls, for he knew he was getting greater beauty in exchange. But one day Mrs. Leyland, who was out of town, came up unexpectedly to the house and let herself in by her own key. The dining-room door was open and Whistler was talking to a group of friends. Something was said of Leyland just as she passed. Whistler shrugged his shoulders, "Well, you know, what can you expect from a parvenu?" Mrs. Leyland went in and ordered him to leave the house. Until then, he had come and gone like one of the family, but when he returned after a day or two, the servants' instructions were not to admit him, and that was the end.

This is Way's version. From Mrs. Stillman also we heard of the indiscreet remark, though she did not attribute to it the beginning of the end:-

November I3th, Igo6. She remembered seeing Whistler in The Peacock Room at work with his pupils, the Greaves, and his giving her tea as if the house were his. She thought it was this, the way Whistler behaved as if the house belonged to him, issuing cards of admission, putting a bowl full of them in a prominent place at Liberty's, that, above all, infuriated Leyland. Then too while he was in possession of Leyland's house, Whistler abused Leyland and, by accident, the abuse was overheard by Mrs. Leyland.

On the other hand, Sir Thomas Sutherland assured us that Leyland knew nothing of the wholesale character of the work in his dining106

[1900 


\section{The Leylands-Their Circle}

room, and could not forgive Whistler when he discovered it. E.'s note of her talk with Sutherland goes further into detail:-

November Ist, Igo6. Sutherland knew Leyland well. Their business brought them into close relations, and he liked Leyland who was an upright man in affairs and he often visited the Liverpool house. Then Leyland took the house in London where he was at first a stranger and cared for few people except artists, in whom he was interested and whose work he bought. At Leyland's dinner table Sutherland met Whistler, then the "tame cat," the "cher ami" of the household, and also Rossetti, Howell, and various others. This was the story of The Peacock Room, he said, which he found few people gave correctly. When the blueand-white china was arranged on the shelves in the dining-room at Princes Gate, the beautiful old Spanish leather on the walls looked dull and dingy. To relieve this dulness, Whistler was to touch with gold or colour the flowers in the design and so bring them out again. The Leylands went back to Liverpool, and Whistler was left to finish, no one else there but a caretaker. The work was tedious and Whistler grew impatient, and, in his impatience, he covered the walls with blue and worked out a design of his own on the blue; this without consulting the Leylands. At last, Leyland returned. Whistler didn't say anything but rather kept out of the way. Leyland was furious. His Spanish leather was ruined, and, besides, he didn't like the idea of so much gold and gilding in the decorations; he felt it inappropriate, vain-glorious, for a man like himself who had made his own money. When he saw Whistler he told him that his diningroom was ruined and Whistler's time wasted, which was the more serious to Whistler who was then engaged-one of many times. What did he suppose all that was worth to him? And Whistler said two thousand guineas, and Leyland, who thought it extortionate anyway, paid him in pounds. And this was the end. Sutherland thought there was no question that Whistler behaved badly, for the Leylands had been good friends to him, their house had been his.

I900] 


\section{The Whistler Journal}

Lord Redesdale gave us his version which agreed with Sir Thomas Sutherland's that Leyland was kept in ignorance of what was going on in his house:-

August 20th, 1907. He remembered Whistler in The Peacock Room. He had been in Scotland and, coming back, called at Whistler's in Lindsey Row and was told that Whistler was at Princes Gate, and there he found him on top of a ladder, looking like a little evil imp, a gnome. "But what are you doing?" Redesdale asked. "I am doing the loveliest thing you ever saw," Whistler said. "But what of the beautiful old Spanish leather? And Leyland? Have you consulted him?" "Why should I? I am doing the most beautiful thing that has ever been done, you know, the most beautiful room!" Then Leyland returned and Leyland sent him a cheque for a thousand pounds, and Whistler was furious because it was not guineas. He painted in gold on the panels at the end of the room, the Rich Peacock and the Poor Peacock, and the shillings in silver under the Rich Peacock's claw.

Mr. Alan S. Cole, much with Whistler at this period, ascribed Leyland's irritation to the length of time Whistler took, the work seeming to drag on indefinitely, while he lost his temper outright when he heard of the unjustifiable use, as it appeared to him, of his house, and the publicity given to his dining-room, for, after all, it did not belong to Whistler if the decoration did. During several talks with Mr. Cole in 1906 and 1907, he told us among other things, on the evening of,

November 27th, Igo6-The leaflet on The Peacock Room was for the press and this more than anything, infuriated Leyland-the fact of Whistler, without consulting him, throwing open his house to people, inviting them there, and, indeed, all along, Whistler used the house in that way, bringing people in to see The Peacock Room, giving them tea, holding receptions. When the notices appeared in the papers, Leyland resented this turning of his house into a public gallery. He offered Jimmie the sum agreed upon to get out, but Jimmie wouldn't go, kept on asking people, said he would make Leyland a gift of the whole thing first. And, when it was complete, Leyland could sit at dinner with his back to the Princesse 108 


\section{The Leylands-Their Circle}

and see, at the opposite end of the room, the apotheosis of l'art et l'argent! To Theodore Child, invited to dine at the Leylands, Whistler wrote that he would have the rare pleasure of feasting on Roast Peacock. The leather was gradually covered, and, as it began to become Whistler's, it began to get on Leyland's nerves, but what got on them more than anything was the publicity. The crisis came with a notice in The Morning Post. It was the last straw for Leyland, and Whistler now did not seem to mind what he did, he was superb; carriages crowded Princes Gate. And Leyland was fine, keeping the Room and the Peacocks just as they were. There was no question Whistler was not in the right.

As some of the statements we have quoted are either not quite accurate, or else contradictory, perhaps, before going further, we had better give Murray Marks' description, as he gave it to J., of the original decoration in The Peacock Room, for which he was responsible, and the changes in it proposed by Whistler and gradually made. J. saw him at much the same period that we were having our talks with Mr. Cole and Sir Thomas Sutherland:-

December 9 th, 1908. Marks says he was responsible for The Peacock Room, or rather for having it decorated by Jekyll, whom he knew. He suggested and purchased the leather; Norwich leather, not Spanish; and it was painted, not embossed. He got the idea from Lord Battersea, then Cyril Flower, who had a room hung with Spanish leather in which there was Blue and White. Leyland bought the Princesse before there was any idea of Whistler's decorating the room, and on the floor was a rug, with a red centre and red lines. Whistler objected to the reds when the picture was hung because he said they killed the rose in the painting, and Leyland allowed the centre and the lines to be taken out of the carpet. In the centre of each panel of leather, however, was a red flower, which also offended Whistler, and he painted or gilded all the flowers over with yellow. The result, Whistler pronounced horrible, as the yellow paint or gilding wouldn't work with the yellow of the leather. And this was the reason why the peacock scheme, probably designed for Alexander's house, was commenced. I900] 


\section{The Whistler Journal}

Marks said further that, when Jekyll saw it, he hurried home, went mad, gilded his own floor and died.

We quote still another story, not because of its accuracy, which we question, but because it comes from Watts-Dunton. He told it one evening when Heinemann was dining with him and Swinburne at "The Pines" a few months before Whistler's death. Heinemann afterwards gave us the note he made of the evening's talk:-

Sunday, April 26th, I903. Watts told me the whole story of the Leyland row. Leyland had placed one of Whistler's Japanese pictures over the mantelpiece of his dining room, the decoration of which had been entrusted to some well-known artist, and the walls of which were covered with most expensive Spanish leather. Whistler considered that the Spanish leather entirely destroyed the effects of the picture, and he got Leyland's permission to modify the leather by painting on it. He began in Leyland's presence with only a few modifications in colour, but when Leyland went away, he began painting over practically the whole leather, a fact which drove the original artist mad (he died in an asylum). Whistler by degrees painted over the whole room, decorating the leather with peacocks, but Watts denies that at that time the portrait of Leyland was painted in the peacock's tail. When Leyland returned, Whistler took him into the room and said to Leyland: "Now I want a cheque for two thousand pounds." Leyland laughed at this and took no further notice of it. On the following Sunday morning Leyland happened to be at Rossetti's, and told Rossetti about Whistler's demand. Rossetti said that the whole thing was mad, that it was outrageous, but Leyland said that he would give Whistler a thousand pounds, which Rossetti said was far too much, and rather pooh-poohed the idea of the whole thing or that Leyland should give him anything at all. Leyland, however, saw Whistler and offered him a thousand pounds, saying that he would not give him another farthing. $\mathrm{He}$ had not commissioned the thing at all, and as he had done it simply to please himself, he considered the payment liberal and IIO 


\section{The Leylands-Their Circle}

handsome, one which nobody else in England would have made. Whistler took the thousand pounds in disgust, having first declined to take anything, but he reviled Leyland all over London, and presumably painted in Leyland's head later on.

This statement about Leyland's head painted in the peacock's tail we never heard from anyone else and we never could find the head.

It was interesting to collect these different versions, to fit them in together, and to work out from them the true story for the Life, comparing and sifting the evidence. The more we heard, the more we were convinced it was not the transformation of his dining room that incensed Leyland, who must have known from Whistler's letters to Mrs. Leyland, which we have seen, if not from letters to himself, something of the colossal scale on which Whistler was working. Otherwise, the decorations would not have extended over months, would not have kept him day after day from six in the morning until almost nine at night, would not have obliged Leyland to put him up at Princes Gate, would not have filled his eyes with sleep and peacock feathers, would not have led him to send a message, through Mrs. Leyland, warning "Freddie" of the price of his labour, large though barely enough to pay him. Leyland probably would have swallowed, if grumblingly, this large sum, along with the press and publicity and invitations scattered wholesale, and never quarrelled with Whistler. It was Whistler who quarreled with him. If there was one thing that enraged Whistler more than another it was to have his "golden guineas" reduced to pounds; to knock off the shillings he considered the height of meanness; it was "unbecoming in a transaction between gentlemen." When his Philosopher was sold to the Comtesse de Béarn and Petit, who arranged the sale, forgot the shillings in the French equivalent of the sum charged in English money, Whistler was prepared to take legal action had not M. Duret represented that it might seem strange for an American artist selling his work in France to demand payment in English guineas. Petit did add to the original sum, but some of the shillings were still missing, and again Whistler was quieted only by $M$. Duret's argument that the Comtesse knew no more about guineas and pounds than Petit, that she was charming, and that therefore it would be discourteous to insist. Mr. Fisher Unwin had a somewhat similar experience. For Whistler's lithograph of J., published as frontispiece to our Lithography and Lithographers, he sent Whistler a cheque for twenty 1900]

I I I 
pounds. Whistler returned it, saying "very nice-but-where are the shillings?" And then Mr. Unwin sent another cheque, this time for twenty guineas, and all was well. When Mr. Croal Thomson was guilty of the same crime, he was rebuked by Whistler for, like Leyland, "cutting the shillings off my pounds."

Leyland refused to pay two thousand guineas. Whistler suggested, he would contribute one thousand himself. When, on top of this the cheque came for pounds, Leyland had committed the unpardonable sin. Mrs. Dr. Whistler, Mr. Luke Ionides, the Alan Coles, dining with us on Thursday, December 19th, 1907, were all of the opinion that Leyland in doing this brought all relations between himself and Whistler to an end. They remembered an original agreement for five hundred pounds, though Whistler said there was no contract. It was probably not in writing and it was only for the touching up of the leather. The great thing is that Whistler knew the beauty he was creating too well to throw down his brushes over the disputes of a day, and that Leyland wisely preserved the masterpiece, though he let the master go. He was the custodian of one of the greatest modern decorations, he realized the responsibility, and, thanks to him, The Peacock Room exists to-day, caricature and all, as Whistler left it, and is now, by the bequest of Charles Freer, in the possession of the country of which Whistler was proud to be a citizen.

A curious characteristic of Freer's method of collecting is recalled by this reference. He had been collecting Whistlers since the early Eighties when his attention was drawn by Mr. Howard Mansfield, from the Palmers and Vans' Gravesandes he was buying, to Whistler's etchings. Then, a little later, at Messrs. Dowdeswell's advice he bought from Mr. H. S. Theobald, K. C., the pastels which, after the not too successful show of $\mathbf{I} 886$ in their galleries, the Dowdeswells had sold to Theobald. To Whistler Freer introduced himself. His account of it came to us through Chase, of whom he had asked a letter of introduction-probably after his purchase of the pastels. Chase suggested that an introduction from him would be of anything but use, that Freer would be better off without it, and so without it, Freer called. He sent up his name. The servant came back to say Whistler would see him in five minutes. Freer took out his watch and timed him. In exactly five minutes he appeared, a little dapper figure, with a monocle in his right eye. Freer said, "I'm an American, Mr. Whistler, just from America. I heard that you made an etching once and I would like to see it." Whistler took off his monocle, wiped it carefully put it up again, looked at Freer, asked him into the studio, made him stay to lunch. 


\section{The Leylands-Their Circle}

Freer explained that he tried to make himself as American as possible! - an amusing tale, but we rather wonder if Whistler could not have told it better. However, from the Nineties on, Freer never came to Europe without seeing Whistler in London or Paris, buying paintings, prints and drawings from him, or from owners willing to part with them. Nor did his collecting cease with Whistler's death. At the Whistler Memorial Exhibition in London, I905, he bought the portrait of Leyland, and what we want to point out as characteristic is the fact that, though he doubtless could have had the Mrs. Leyland, he never purchased it and it went to Mr. Frick. Freer also, for some unknown reason, refused to purchase the portrait of Whistler with the paint brushes, his best portrait of himself, which is now owned by Mr. Stevens of Detroit. It was offered to Freer by Mr. Coutts Michie, who married the widow of George McCulloch, the owner, and Freer took instead from the McCulloch collection, when it was being sold, another version of the Valparaiso nocturne which he already had. Freer also refused to purchase the portrait of Dr. Whistler which belonged to his widow, Mrs. William Whistler, and the study of Luke Ionides in that gentleman's collection, both of which were also offered to him. He did not buy the last two because he did not like their owners, and so Freer deprived himself and, more important, his country, of works, by Whistler because of his personal likes and dislikes.

Another painting Mr. Freer let slip from him is The Gold Scab. With the Mount Ararat and The Loves of the Lobsters which he did buy, it would have completed the history of The Peacock Room. All three are caricatures, as bitter as the peacocks on the walls. The Gold Scab is horrible in its strange beauty. The Dowdeswells, who bought it at Sotheby's sale after the bankruptcy, sold it to a Captain Hubbell. When they asked him what he wanted to do with it, he said he proposed to present it to Leyland's Club. But this did not come off, and the next thing heard of the painting was Jacomb-Hood's finding it in a pawnshop in the King's Road, Chelsea, though how it got there was, and still is, a mystery. From Jacomb-Hood, it passed to San Francisco, and is there now, we believe in Mrs. Spreckles' collection, though it ought to be in Washington, where Whistler would have wished it that, as he used to say, history might be made. 


\section{CHAPTER IX: THE GREAVES. THE YEAR NINETEEN HUNDRED CONTINUED}

T $T$ was in the note for July 16 th, given in the last chapter, that the names of the Greaves brothers first appear in The Whistler Journal. J. had met Walter Greaves a year or two before-Harry Greaves was dead. One day, walking with Whistler on the Chelsea Embankment, J. had been amazed to see approaching a strange faraway echo of Whistler, the chief difference being that the echo was shabby and wore a red necktie, and before he got over his amazement Whistler had introduced him. Walter Greaves seems always to have tried to get himself up like Whistler, and was still trying when we last saw him. It sometimes led to mistakes. One amusing story we had from Mr. Oliver Brown:-

Thursday, March 23rd, I913. He was dining with us and the talk turned on Greaves. He said his father, or some one who was there, told him of a dinner the Chelsea Arts Club gave to Whistler. A little while before the dinner hour, some of the Committee, who were attending to the last details and who had never met Whistler, saw an elderly man come in with long overcoat and straightbrimmed hat and white gloves, thought it must be Whistler, received him effusively, and fluttered about him, until some of the older members of the Committee arrived, said he wasn't Whistler, and asked him who he was. He said his name was Greaves and he was a pupil and a friend of Whistler's. And so, though he had not been asked, they gave him a good place at the table and insisted on his staying. Then Whistler came, presently saw him, put up his monocle, stared at him, said nothing, and Greaves faded away.

The next mention of Greaves in The Journal was after Whistler's death, on February 9th, I905, when J. was busy arranging the Whistler Memorial Exhibition at the New Gallery. An important letter came in his absence and E. hurried with it to the Gallery: "While I was there one of the Greaves brothers who figure in Whistler's early Chelsea days turned up. He also has lent things." One morning, a year later:-

May 5th, 1906. J. was working in Chelsea, making an etching of the old Church, and one of the Greaves brothers wandered up to 


\section{The Greaves}

talk to him. Probably no one living knows more of Whistler in the old Chelsea days, and he told J. he would be delighted to recall all he could, if J. would go to see him. His memory is still fresh of the "times" there had been in the evenings, of the people who came to the house and went out with Whistler on his father's boats. There had been noise. Whistler was always ready for it, he was always gay. But what affair was that of his? Why should he talk about that? The nights when Whistler worked, his usual method. was to make sketches on brown paper with black and white chalk. These were his notes. And as for his pictures, his nocturnes, it was all wrong what he said in court. They were usually done in about an hour and a half. But then, he probably destroyed many before he succeeded in getting just what he wanted. He used a quantity of McGilp or whatever was the medium, his paint was as fluid as water colour, and there were times when the canvas was so dripping, he had to put it down on the floor for a while. It was quite true that many of the nocturnes were painted on a red ground. But he told J. to come and see him and he could talk better and tell him more.

Whistler's method of making nocturnes has been more or less described by Way and Menpes. As Whistler told J., it was as hard as training for a foot race. He would note an evening effect and come back from dinner by the same spot night after night, and one night the nocturne would be there, the effect he wanted. And he would stand, leaning on the Embankment wall, looking. And when he had looked long, he would turn round with his back to the subject, and begin to recite the subject in a sort of chant. "The sky is lighter than the water, the houses darkest. There are eight houses, the second is the lowest, the fifth the highest. The tone of all is the same. The first has two lighted windows, one above the other; the second has four." "No," said Way. Then Whistler would wheel about, look, and correct his mistakes, turn his back and begin again. And so it would go on till he was right, then he would say "Good-night," go straight home to bed, and the next day paint his nocturne.

J. was away from London through the summer of 1906, but on . his return in the autumn he made three visits to Greaves and E. also called.

I900] 


\section{The Whistler Journal}

September 1oth, 1906. In the afternoon J. went to Fulham to look up Walter Greaves who has not answered his note. Greaves was away but Miss Greaves was at home and appeared, an elderly woman in yellow wig and much jewelry, low dress and many necklaces. She had a good deal to say about Whistler. She had posed for him, she was "Tinnie," she had sat for anything he wanted, there were the etchings of her. She knew J. had written, she had seen his note, she did not know why her brother had not answered, and it was arranged that $\mathrm{J}$. should call next Tuesday when he would be back.

Tuesday, September I8th, I9o6. In the afternoon J. went to see the Greaves in Fulham. As to Whistler's painting: he painted all the important pictures, the Mother, the Carlyle, Miss Alexander, the nocturnes which Greaves calls Moonlights in the second house from the east end of Lindsey Row as it was then, and not Cheyne Walk, one of the two houses which stand out. The studio was in the first floor back. The Mother was painted on the back of a canvas; the Miss Alexander, on an absorbent canvas, on a distemper ground. He also pointed out that the Mother was painted so thinly, especially her dress, that the black dado which evidently at one time had been painted all across the picture could be seen through her. J. suggested that it might have been at the start another picture but Greaves did not think so. The nocturnes, moonlights, were painted on this absorbent canvas on a red ground, or on mahogany which he got from Greaves-the red forcing up the blues laid on it. He also says that Whistler worked with linseed oil only on these nocturnes mixing his colour on a big flat table large quantities of it with a great deal of oil, calling it "sauce," washing it on like a water colour [this Whistler always said he did] and often having to put the canvas flat on the floor to keep the whole thing from running off. Greaves also said that it used to dry out like a wash of body colour. Whistler always told J. that this medium was made of McGilp, copal, turps or linseed oil. But Greaves says he never knew him to use anything but oil. Greaves also says that he and his brother painted the II6

[1900 


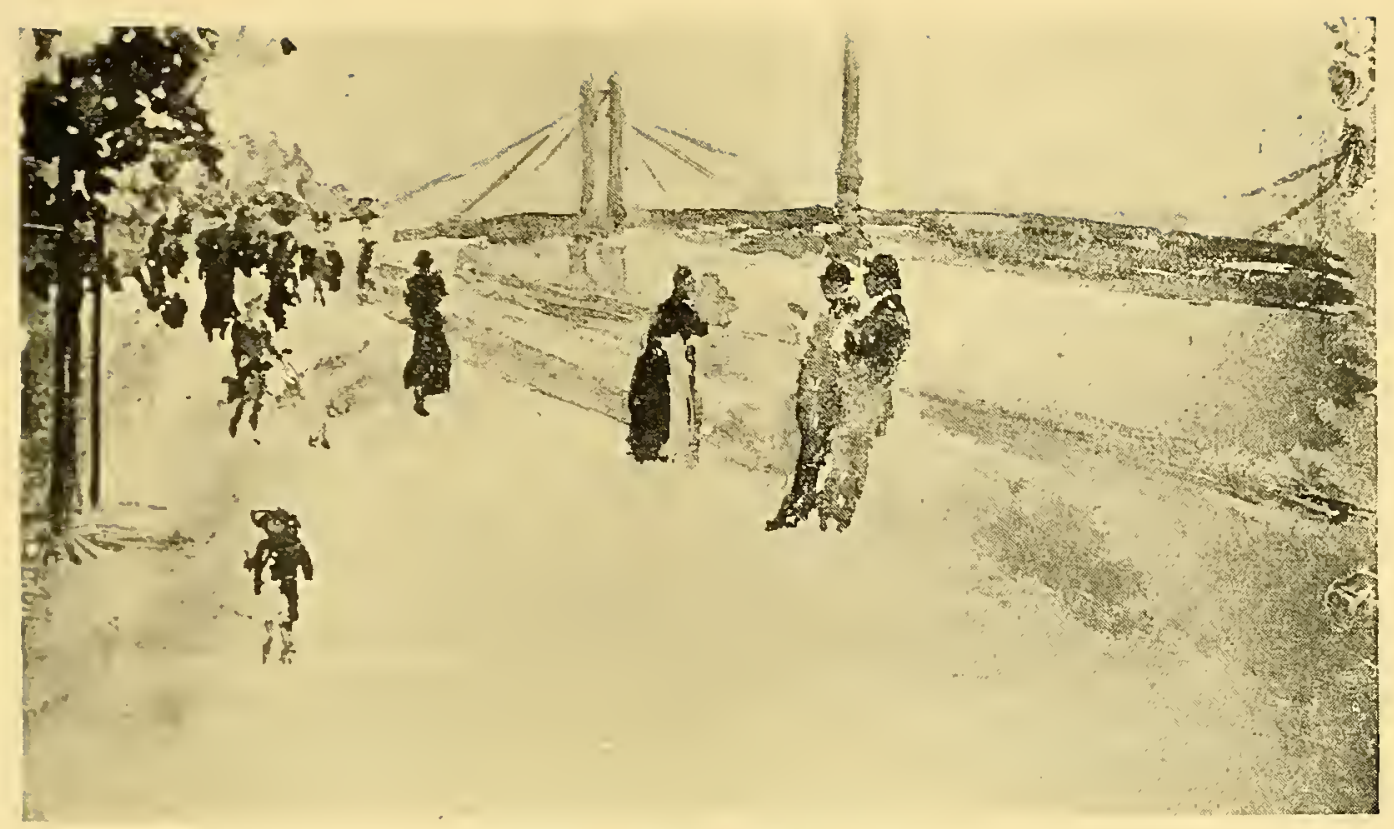

CHELSEA EMBANKMENT

WATER-COLOUR

(See page 59)

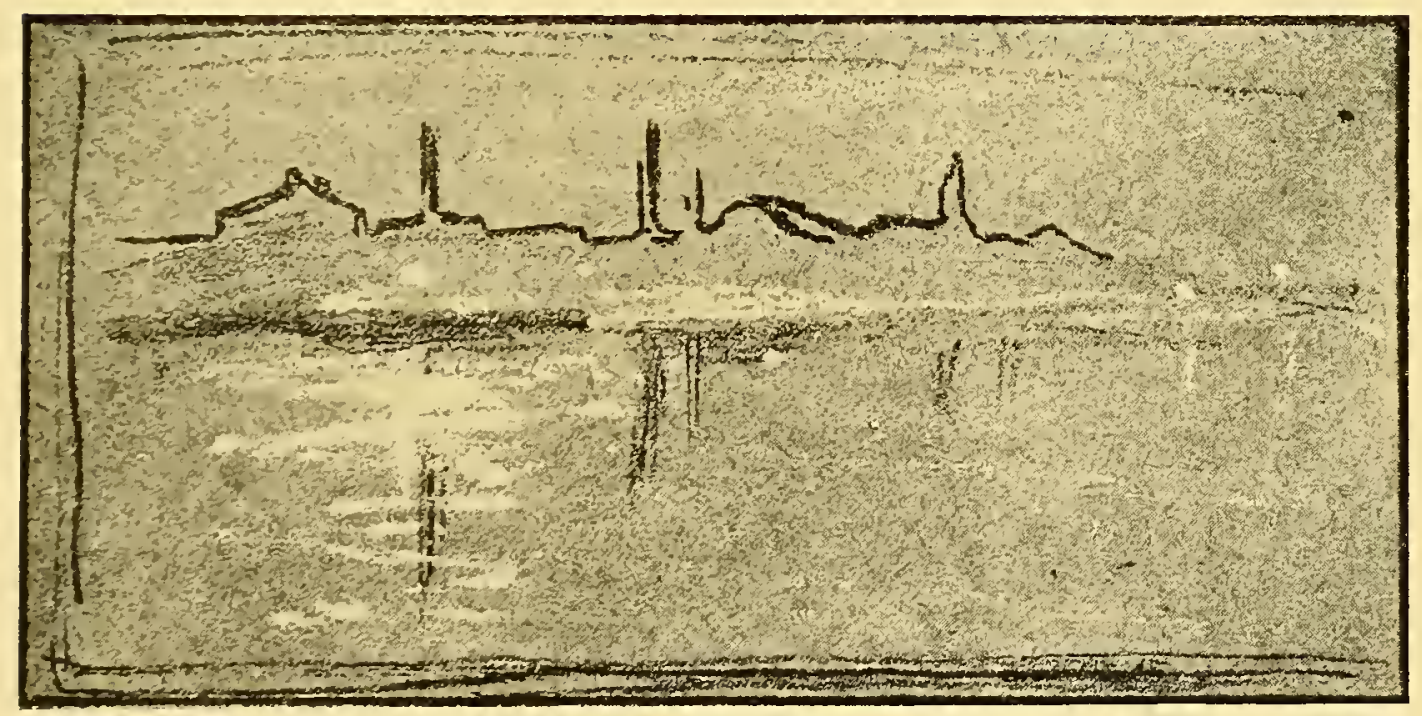

NOTE FOR NOCTURNE

BLACK AND WHITE CHALK

In the possession of Mrs. T. R. Way

(See page II $\mathbf{j}$ ) 



\section{The Greaves}

frames and that they worked on The Peacock Room which was first gilded all over and then the design painted on it in blue. Also he says he used to show the studio to people and remembers Tom Taylor coming there. In wiping his plates Whistler used three rags and then wiped with his hand and finally Greaves says pulled the ink out of the lines with a bit of muslin, really the retroussage he later objected to. The Greaves first met him in I859 or 60and he says we taught him to row and he taught us to paint, to row with what he calls the Waterman's Jerk. Frequently very early in the morning, sometimes at five, they would row up as far as Putney and get breakfast at Howell's when he was living there. Howell he described as all sorts of adjectives-Jew and liar. He apparently got etchings out of Greaves for next to nothing. Whistler seems to have been on the river a great deal and to have loved it, sometimes staying out all night when after his moonlights. He never tried to use colour at night or at Cremorne Gardens, but made notes on brown paper in black and white chalk. He lived in two places in Lindsey Row. The first was the third from the west end but Greaves says he did very little there. The Greaves themselves lived in the little white house which juts out at the far end of the row and shows very distinctly in Haden's etching and in J's. Greaves has several of Whistler's drawings of these houses. He says at the same time Brunel who built the Great Eastern lived in the easternmost house, and in the middle one with a balcony Martin the Scriptural painter lived. And on fine moonlight nights Greaves or his father when they were out late and there was a fine sky, at Martin's request, would knock at his door and the old man in his nightcap would appear on the balcony and go to work at the skies for hours. It was in the second house, however, that all the important pictures were painted. He also says that Whistler, he, and his brother went to a life school kept by Somebody Barthe in Lymmerson Street for one winter-that often after dinner he would come into their house sometimes sending in dessert and things and come along afterwards himself. And all the time he was sketching on brown paper in the evenings. They had a large number of these things, some were shown in the I900] 


\section{The Whistler Journal}

International Memorial Exhibition. He said in those early days things were extremely lively in the studio. There were always a lot of women hanging round and sometimes there were terrific rows, and they used to get into awful rows at Cremorne. Jo's name (he thinks she finally got married, she was the mother of Whistler's son Harry) was Mrs. Abbott, while Maud was Miss Franklin. Carlyle was very impatient, especially when Whistler worked with small brushes and to quiet him Whistler worked with big brushes or pretended to. When his own exhibition came off in Pall Mall, the Whistler and Greaves families wrote the cards of invitation and they all made Butterflies on them as hard as they could and filled the letter boxes in that part of Chelsea with them, but he didn't seem to think that many people went to the show. Whistler laughed all his troubles off. A grocer named Stevens to whom he owed, they say, a lot of money either seized or took in payment several pictures. Greaves says that the grocer's children are still in Fulham though he does not know where. But they came to him a year or so ago to ask as to the selling of these pictures. And there was a coal merchant or something of that sort who, Miss Greaves says, went mad because he couldn't get his money. Greaves used to buy all his colours and acids for him over in Battersea and apparently, as he said, finally got to do nothing but "fetching and carrying." They don't seem to have had any real row though apparently Whistler objected to the work done at Streatham Town Hall. He says he, Greaves, called at the house a few days before Whistler died but they wouldn't let him in. On the one hand he and his sister complained that nobody ever got paid and apparently they did not, yet on the other they were always praising his generosity, saying that the front door was literally wide open and that somebody was always in the studio. J. has an idea that this open door was taken great advantage of, and was one of the reasons that made him bitter about certain people. They corroborated the story about the bailiffs being made into waiters. Miss Greaves said that on one occasion he invited her and her sister to a Promenade Concert at Covent Garden, and took two hansoms and drove up to town. When they got to the II 8 


\section{The Greaves}

paper shop of an old woman near Drury Lane he stopped the cabs as he found no one in the party had any money, went in, borrowed two sovereigns of her, paid off the cabs and bought the tickets for the concert with the remainder. How they got back to Chelsea, J. forgot to ask. Miss Greaves insists the old woman never got her money back. But Miss Greaves is very positive he never paid anybody, which, of course, is not so. There is evidently something on the financial side that upsets Miss Greaves. They say there were two plays at least in which he was put on the stage. One was called The Grasshopper, the name of the other they don't remember. But they think it was in The Grasshopper that Whistler, Wilde and Frank Miles had a song and dance. He spoke of George Holmes who lives next door but one to old Chelsea Church, who knows a lot, and the parson Davies might too, but Davies never much approved of Whistler. Greaves never knew Rossetti and says that Rossetti never came to Whistler's. But Greaves was never invited to functions, he was in constantly in the evenings but does not seem to have been asked about by the others. Being a boat builder was, no doubt, against him. Miss Greaves also says that on one occasion at The Vale there was a terrible row between Maud and Mrs. Godwin, and that Jimmie threw them all into the street and shut the house. There was such a scene that Maud broke a blood vessel and Jimmie went off to the chemist and asked him to come and see her. But the chemist said he wasn't a doctor and refused. What the end of it was she did not seem to know. They all hated Mrs. Whistler whom Miss Greaves described as "a fat thing." Then came another Carlyle story: Greaves said that sometimes they would be together, Whistler and themselves, and other friends perhaps, leaning against or sitting on a wall by the river, and Carlyle would pass, and some one would say "It's a fine day, Mr. Carlyle,"-all Chelsea was like a village then-and Carlyle would say "Tell me something, mon, I dinna ken," and pass on without even looking at them. Greaves says that the man in a picture of the Thames that corresponds in the description to Mrs. Hutton's Wapping, is one of their boatmen. 
The Whistler Journal

Friday, September 2Ist, I906. J. went again to see the Greaves. As to Whistler and Velazquez, Greaves went with him to an Old Masters show at the Academy where they saw the Philip on horse back as Greaves called it-evidently the Olivarez or the Don Baltasar. Whistler was enthusiastic about the hunting picture in the National Gallery and the little head of Philip, and even then reviled the Turners. Greaves' father knew Turner and used to row him about just as the sons rowed Whistler. Turner used to walk about Chelsea with Mrs. Booth who was a big loud coarse Scotchwoman, and he would ask Greaves what kind of a day it would be. If he thought it would be fine they would go off, often being rowed over to Battersea church or the fields which are now Battersea Park. If it was not fine, he would say, "Well, Mrs. Booth, we won't go far." Turner wanted to buy the house from Mrs. Booth which Greaves says he had papered with drawings but apparently there were what he calls "private affairs" between her, Turner, and the other old woman from Queen Square and it never came off. Greaves does not remember Turner but he does remember Mrs. Booth of whom as a boy, he was much afraid. Whistler, always reviled Turner. He says that Whistler often put paintings out to bleach in the back yard and that that dried them thoroughly, taking the oil out of them and making them look like ivory. He remembers the first house was not the third but the fourth from the corner, and Whistler painted in it (though Greaves don't remember the date when he went to it) the Princesse; the second and the third Symphonies in White; the interior of the studio, a picture he calls Violet and Gold-a Japanese thing; the portrait, the full length, of Leyland; and the Battersea Bridge; also the studies of the river in ice (of course not The Thames in Ice) which he worked on his grey absorbent canvas in yellow ochre, black, red and white. Sometimes he got the whole of one of these effects in fifteen or twenty minutes and only just touched it up afterwards. He says some of the pictures were painted on bare brown Hollands sized and that on the portrait of his Mother there was scarcely any paint at all and that the canvas was simply rubbed over to get the dress, and that is the reason why the dado shows through, while the I 20

[1900 

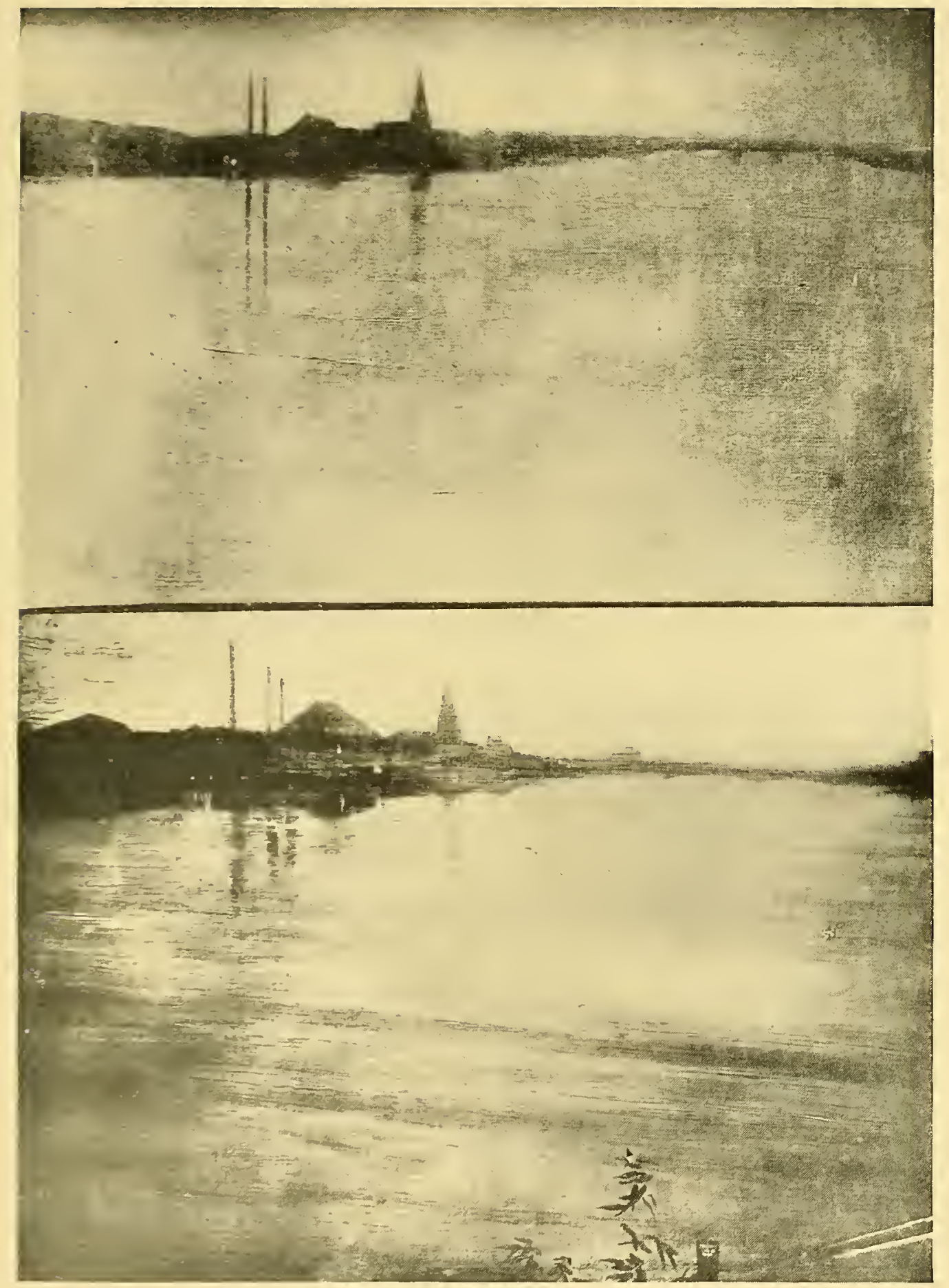

NOCTURNE

OIL

By Walter Greaves

In the possession of the Rosenbach Co.

\section{NOCTURNE}

OIL

By Whistler

In the possession of the Estate of Mrs. Leyland 


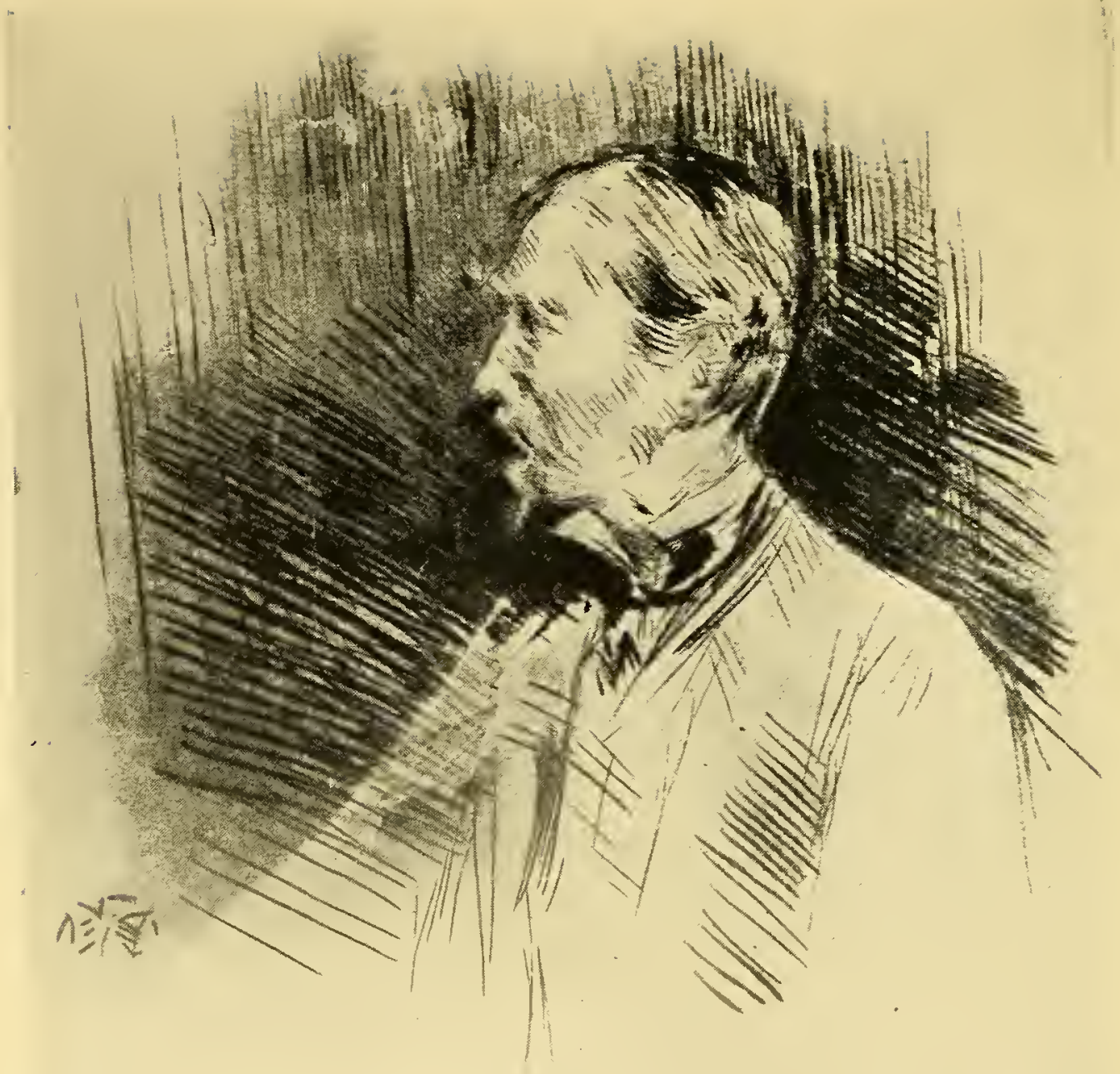

LORD WOLSELEY

DRY-POINT. M. I64 


\section{The Greaves}

handkerchief was nothing but a bit of white and oil. He now says Whistler mixed turps with the oil, probably he will at length get to the copal Whistler told J. was mixed with it. Not all the moonlights came off, and he painted, on some occasions, one on top of another. One only was painted on a white ground. But as Whistler said the day is grey, the sky is grey and the water is grey, therefore the canvas should be grey. The fireworks were painted on a lead ground. The dining room of the last house was blue with a darker blue dado and doors, and purple Japanese fans tacked on the walls and ceiling. The drawing-room, which was not finished until one afternoon when a big party was asked and they all worked like mad, was flesh colour. There were white-and-yellow doors and strips of Japanese tapestry about. The studio was grey with a black dado and doors as in the picture, and evidently the cretonne was there too as in the portrait of the Mother. He called the servants R. A.s and would ask Frith to bring this and Leighton to take that away. Even then, he was fond of mimicking things, saws and rockets, and loved American mechanical toys, and called himself the Pride of the Row. He bought the best brushes he could get and heated them over a candle to dissolve the glue, and then pushed them into whatever shape he wanted. The big table palette had the Butterfly in ivory in the corner of it. Greaves knew all these things because he passed days and weeks in the place standing beside him. He often put the coats of size on the canvas. Everybody came there. He remembers the Princess Louise and Wolseley and often there were strings of broughams and cabs before the door. He was ill once in the second house with some sort of fever, and ate ice which frightened Greaves. All the big canvases had to be oiled out, but, despite this, they all dried in again. He was drawing chimneys one day across the river and the other brother Greaves said, "But, Mr. Whistler, they are not straight." Whistler said, "But they are Whistler's." Another thing: Greaves says Howell came into the Lindsey Row house one day and saw a lot of plates kicking round under the press, Greaves thinks the London and some of the French ones, and Howell said, "Why, you have a gold mine here," and that's when it was Goulding was sent for, which 1900] 


\section{The Whistler Journal}

corresponds with Whistler's story to $\mathrm{E}$. In the beginning he used big etching needles, big double ended ones and later those in wood like a pencil which he gradually cut and sharpened down, and eventually gave all to Greaves, telling him to use them because they wouldn't slip. Goulding came down once or twice to prove plates. Haden wanted the Fine Art Society to get Goulding to print the Venice plates but Whistler said he wasn't running an aquarium or a music hall. Greaves says that most of the Chelsea plates were done at one sitting, that is that he worked on them in the house, he never went back again. He said the stairs of the house were covered with Dutch metal. J. forgot to ask if it was only the banisters, or the whole thing in which case it probably gave Alma-Tadema his brazen idea. Whistler painted ships at the end of the hall one Sunday morning after he had taken his mother to church and before she returned. The blue screen with the gold moon and bridge upon it, which always stood in the studios in Paris and Fitzroy Street, Greaves says was painted for Leyland. But, if so, either Leyland never had it, or else gave it back to Whistler. Greaves got to know him when he first came there because the brothers were trying to paint, and Whistler, finding this out asked them to come and see him. Greaves is forever talking about mysterious "private affairs" but J. can get nothing definite out of him, and it probably refers to the gay times in the studio. Greaves says also that in doing the full-length Leyland, he got into an awful mess over it, painting it out again and again until finally, he had a model in to pose for him nude, showing that the idea was suggested probably by Ary Scheffer or Leighton.

Thursday, January I7th, 1907. Walter Greaves came in unexpectedly while we were at lunch. He stayed quite a little while, repeating many things he had already told J., telling others in a disjointed fashion it is hard to follow. We showed him the photograph of Mrs. Hutton's Wapping and he was puzzled. It did not seem to him the picture he remembered, but then his memory may be at fault, for he was surprised at the Memorial Show to find the Westminster picture so much smaller than he remembered 
WHISTLER'S ETCHING NEEDLE

Actual size, given by Whistler to Joseph Pennell

Pennell Collection, Library of Congress, Washington

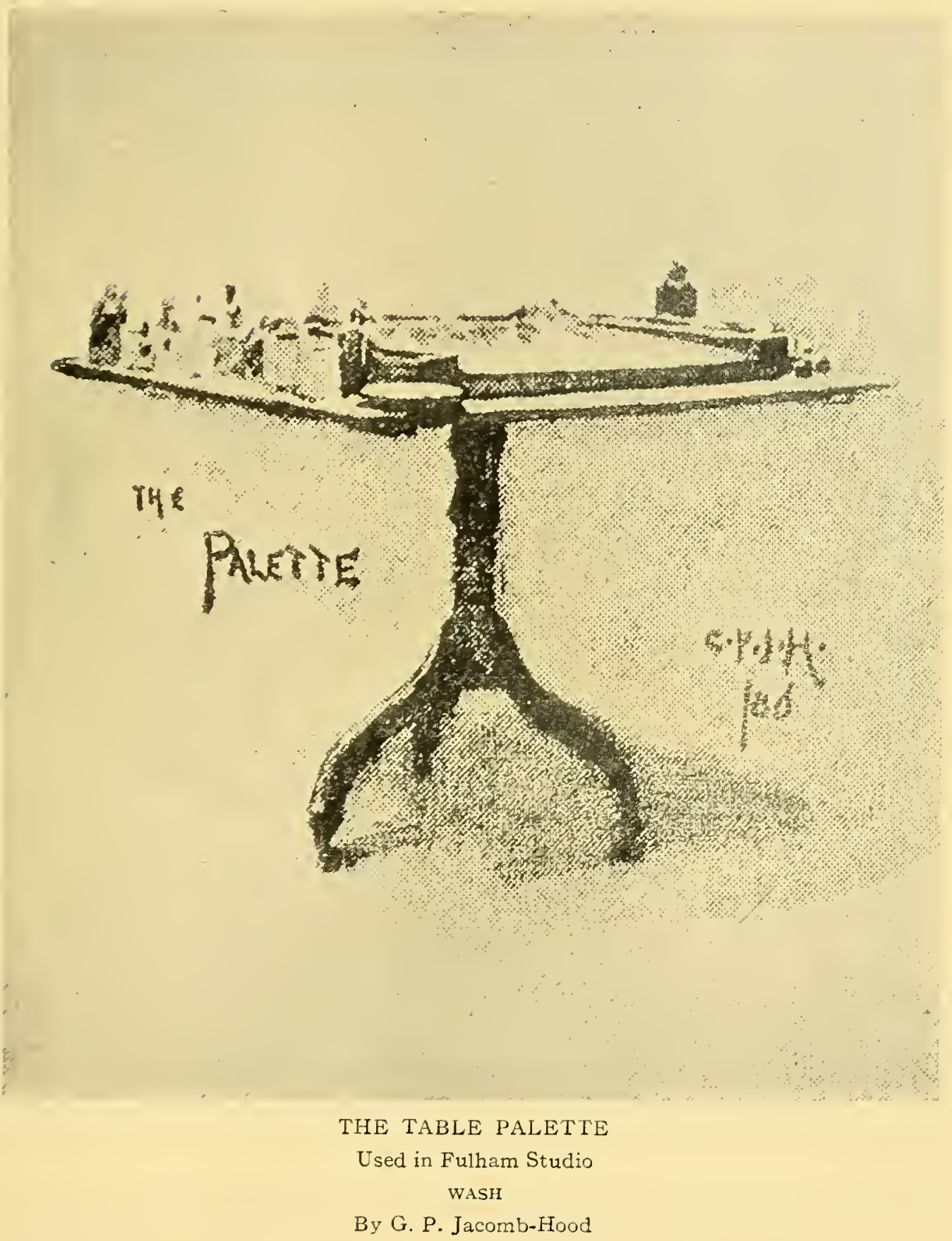




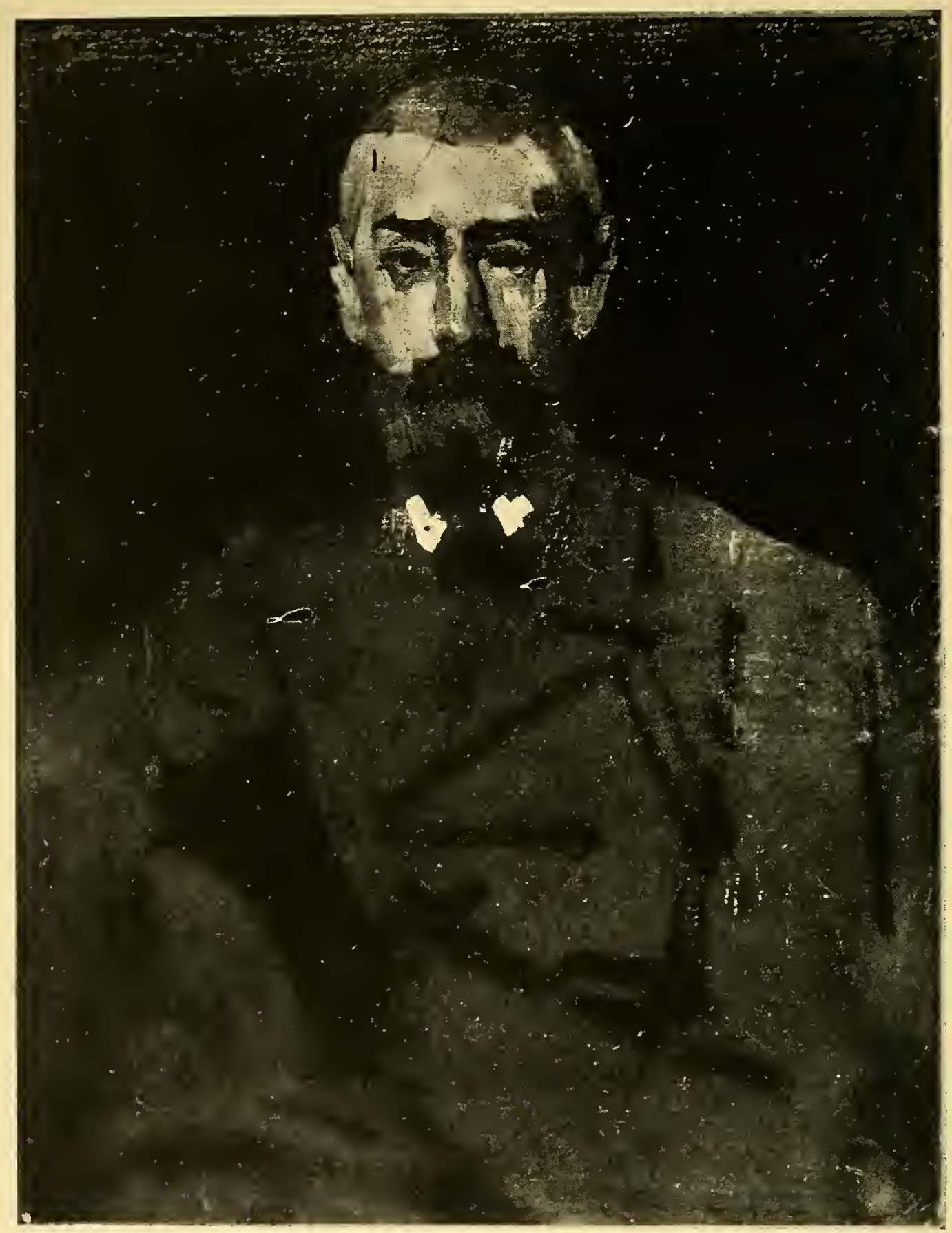

MR. ELDON

OIL

Once in the possession of Mr. Walter Sickert and attributed by him to Whistler 


\section{The Greaves}

it, and from his suggestion of measurements it was clear that, at the Show, it looked to him much smaller than it was. Then he recalled odd incidents: of Phil Morris whom Whistler liked, and when anyone wondered why, he would say, "He fights my battles"; of an irate Captain, who lived next door to Whistler and was usually tipsy and then violent beyond measure. His pigeons somehow became a nuisance to Whistler who wanted Greaves to tell him so. Greaves refused, said the Captain was too violent. "Then I'll go," said Whistler, who was never afraid of anything; he did, and almost at once came flying out of the door, the Captain, armed with a sword, at his heels, and Whistler was fortunate, for sometimes people came flying out of the first floor windows. And Greaves remembers how Whistler would have a passing hurdygurdy in the little garden in front of the house to play for a quarter of an hour or so, because he liked music. "He was a rare fellow for music," Greaves said, and he and his brother would play for hours in the evening while Whistler danced. And he was "a rare fellow," too, for round games of cards and for all sorts of fun. He would imitate a man sawing, and once, out in the hall, he imitated another man quarrelling with him so well, that when he came into the room, Mrs. Greaves couldn't understand why he was alone and unhurt.

There were times, of course, when Mrs. Whistler disapproved. She was indignant the Sunday she came home and found them painting the ships in the hall. Then more odd memories: of Albert Moore's going out sometimes in the boat with them at night; of pictures painted one on top of another, one of Harry Greaves on top of a moonlight, and, indeed, he always wondered that pictures like the Mother and Miss Alexander had lasted; of Eldon who lent him two hundred pounds and the indignation of Eldon's mother who came down upon Whistler for it; of Tinnie, who played so much better after $\mathrm{X}$. had been living with Whistler. And then of the way Whistler worked, "he was a wonderful fellow for working," endless sketches on paper for the Cremorne and all the other pictures. And then of the drawing-room he painted at the last moment, that is on the very day he was to have a dinner party. I900] 


\section{The Whistler Journal}

Greaves suggested that it would never dry in time, but Whistler said what matter, it would only mean a little paint on a coat or a dress. And then of that same dinner party when Whistler sent one of the Greaves' men to Madame Venturi's to borrow kettles and pots and pans, and the man came back covered all over with them. There was a testimonial got up, he couldn't remember why, to James Stansfield, an M. P., friend of Madame Venturi's, and she got the work of designing and making it for Whistler. But he didn't know anything about that sort of writing, and he handed it over to them. They had had practice in the heraldic marks on the Lord Mayor's and the City's barges, and they also were then making Whistler's frames for him, and they got it up, and Whistler paid them five pounds, and they made a tin box for it, and it was sent all over the world for the signatures of distinguished literary men. And it was travelling for six months.

Monday, October 14th, 1907. Went to see the Greaves at Fulham. Did not hear very much that we had not heard before, except that the brothers helped to fix the "Pink Palace" and studio in Fulham. The cottage where Whistler lived was almost directly opposite their house. It has been pulled down, and two little shops built there. A little further west is the gate leading to the group of studios where his was. It all looks shabby enough now. Miss Greaves talked chiefly of Whistler's gaiety, it was all wonderful, she told again how he used to come in to them in the evening. His son, she said, was Jo's and was born at No. 7. Jo's sister, got up like a French nurse, took care of him and would take him out walking, up and down the Row. Then a carriage came one day, and French nurse, baby and all, got in and went to Paris. She thought Whistler was jealous of other people. He would never let the two "boys" show anything. Their father did not like them working with him, leaving a business that paid good money. She said that No. 7 Lindsey Row and the two other houses west of it were not part of the palace, but stables and outhouses had stood there. Whistler, she said, used to give money to $\mathrm{X}$. to pay the weekly bills and $\mathrm{X}$. would call for her sister and take her out and 


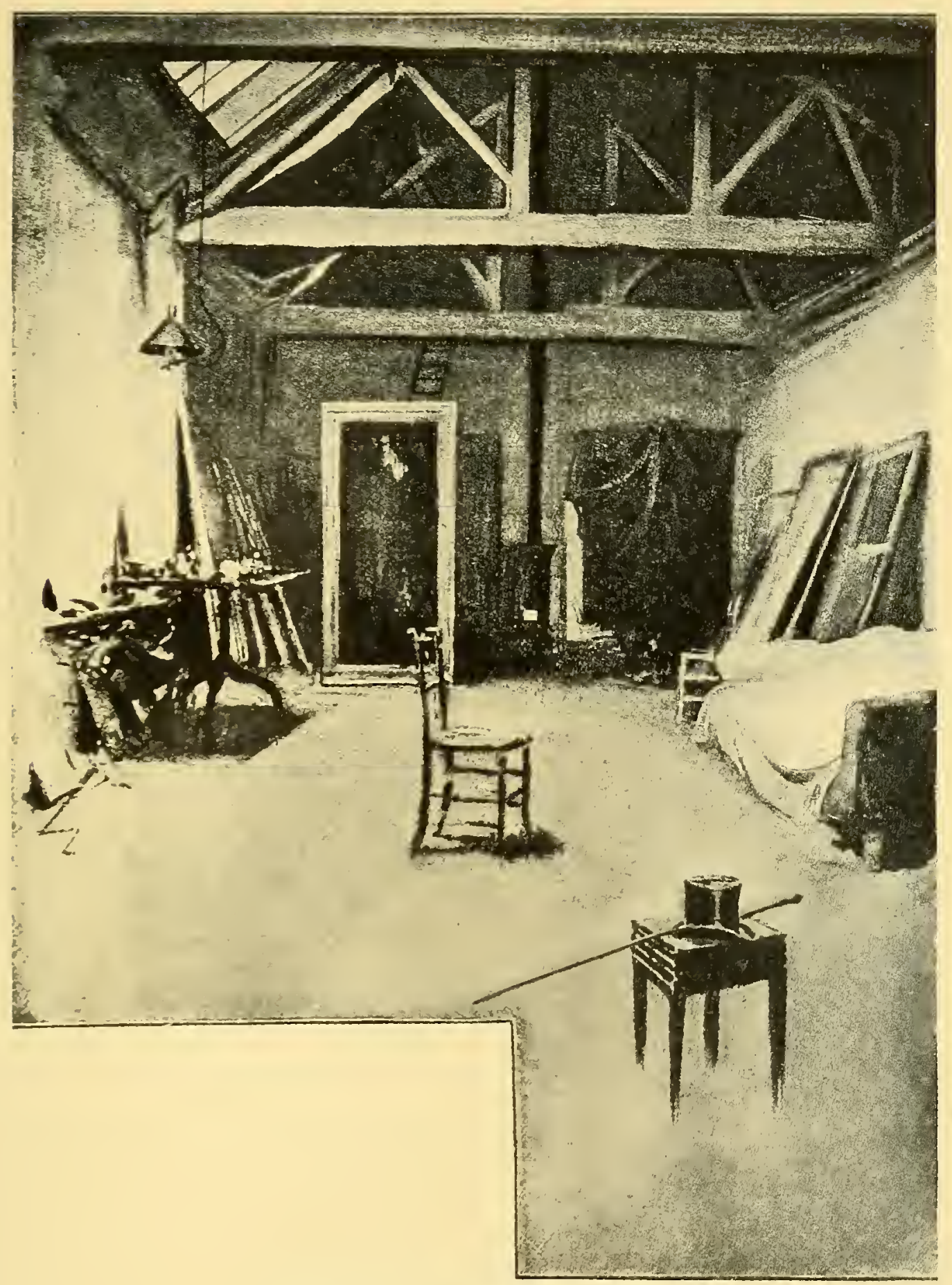

INTERIOR OF THE STUDIO, FULHAM

From a drawing by G. P. Jacomb-Hood 


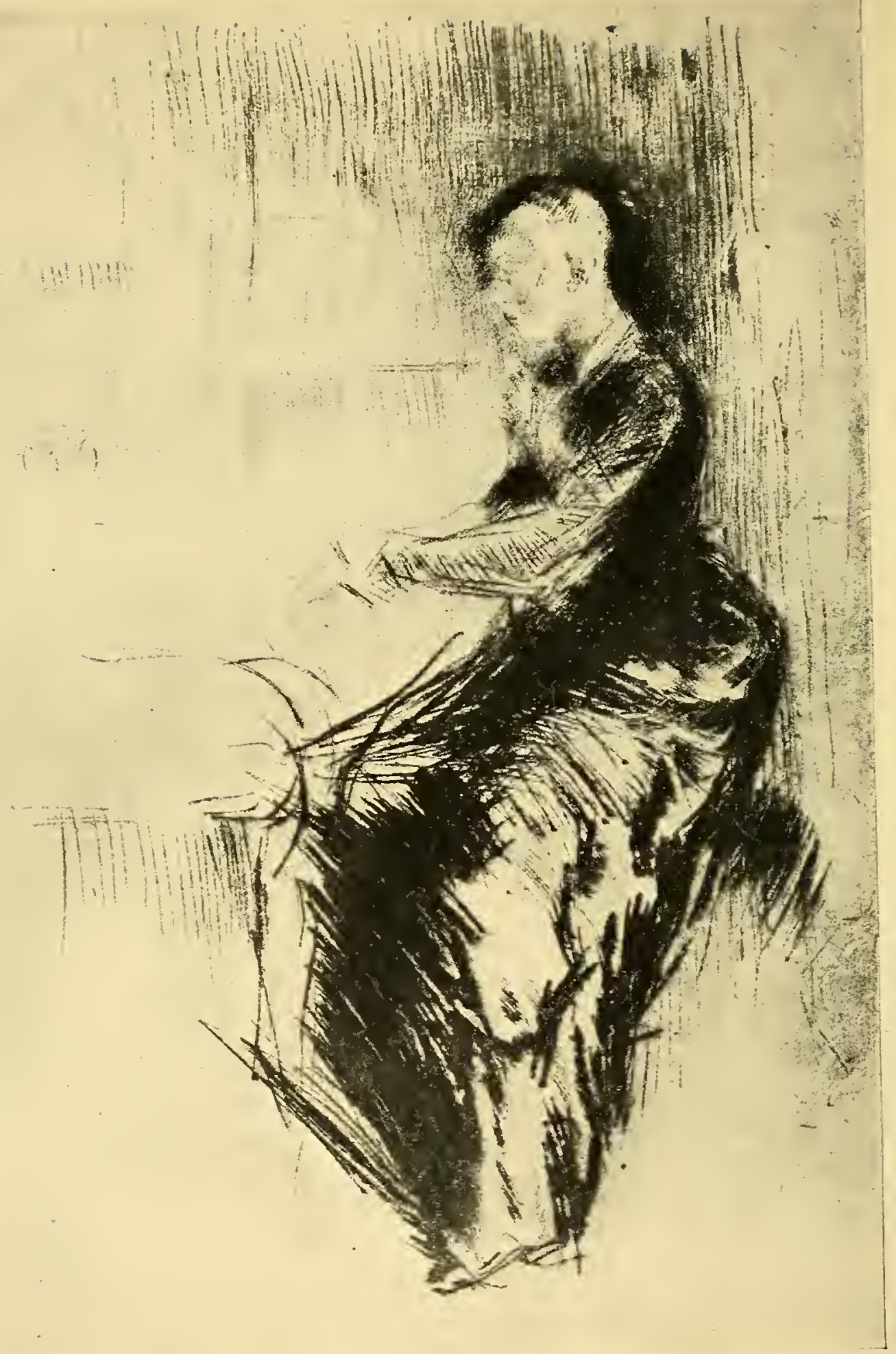

TINNIE GREAVES

DRY-POINT. M. I 4 I 
give her a wonderful lunch and send her home laden with flowers and chocolates, and the bills never got paid. Greaves said the door at No. 7 was literally open. And that was about all. except to repeat what we had already heard.

Two or three years after these visits, drawings and prints attributed to Whistler and found in Mr. Spencer's second-hand bookshop in New Oxford Street were brought to J. by more than one collector and bookseller for his opinion. He saw faint suggestions of Whistler in some of them, but that was all, and he did not hesitate to say positively that they were not Whistlers. His idea at the time was that they might be by Greaves from whom they were said to have come, together with a packet of Whistler's letters to him and his mother, and that the mistake might have arisen from careless cataloguing. Some were signed by a Butterfly which was not convincing enough in itself to stand against the evidence in the drawings. More astonishing were the paintings presently submitted to him.

Thursday, September I5th, IgIo. Walter Dowdeswell wrote to me on Tuesday that he had something of extraordinary interest to put before us, and would we be in town in two weeks' time. I wrote at once that J. was sailing for New York on Saturday, couldn't he put the something before us at once? Yesterday he telegraphed asking us to come to-day at noon; we said yes, but when noon came to-day, J. was so busy I went alone. Walter Dowdeswell took me upstairs into the front room on the first floor-told me he had something by way of a sensation for me-that in our Life of Whistler we referred to rolls of paintings carried off at the time of the bankruptcy; well, some of those had been brought to him, they had been in a cellar for years; a most romantic story altogether but he couldn't tell it yet. Then he took me into a part of the back room curtained off, where the window is, and there in a semicircle were some ten or twelve canvases he said were Whistlers, most of them nocturnes and in the centre a full length portrait of a small boy in blue sailor dress. The nocturnes were almost all of the Battersea shore, but there was one something like Mrs. Potter Palmer's, one with a few figures in the foreground, and one in a 1900] 


\section{The Whistler Journal}

gold, grey, and brown scheme. Several looked to me far too vivid and blue and hard for Whistler, but Dowdeswell said all had been in a shocking bad condition and had had to be cleaned and restored so that the vividness and hardness might be the restorer's. Then he brought in one after another, and these were finer: a Westminster; a large greenish-blue Battersea with wide foreground of water and the bridge in the distance to the right; another Battersea, apparently, with a big red-gold moon rising over the houses to the left; a grey stretch of river and banks with a little white yacht stranded in the foreground; there was also a little interior, a woman, with black hair done up high on her head, wearing a grey dress, standing in front of a Japanese screen, a mantelpiece not unlike the mantelpiece in The Little White Girl behind it, not particularly good but the skirt was absolutely the Whistler of The Six Projects: evidently a study of Miss Spartali for La Princesse du Pays de la Porcelaine. None of these were signed. There was also in the front room a full length of a lady in brown velvet, with white lace fichu and white lace collar, standing, her face in profile to the right, her golden hair in a coil with a gold band about it and in her hand, held a little out in front of her, a bit of fine linen embroidery in a long narrow piece hanging, and the hand beautifully drawn. If by Whistler, a perfect knock down for Kenyon Cox and all the other fools who said he couldn't draw a hand. A gold buckle fastens the dress at the side. The pose is like Whistler, the painting of lace and embroidery fine, but the head is too sharply cut out from the canvas to be like his work, though something like the Rosa Corder, and the treatment is still more unlike, though all this may be the restorer. On the left about the centre of the canvas is a little oblong panel with a W. in white sketched in like the beginning of a Butterfly, but so bright that it knocks the whole picture to pieces. Probably this too is the restorer. There was also a long ray of light, quite out of tone, apparently the fold of a screen, against which the model was standing. Old Dowdeswell and the other brother, Charles, joined us, in a great state of excitement. The old man-they say aged eighty - had come up to town on purpose. They felt that we ought to have the first chance to see I26

$[1900$ 
these things, our book was so wonderful, no one knew better than they the difficulty to write about such a man and we had given such a true impression of him. . . . I went back with J. at three. He agreed very much with me, didn't believe in the very clear vivid blue nocturnes, though the restorer might be to blame; he had no doubt of the Westminster, the green-blue Battersea, the bigger one with moon (there are two of this subject); the greybrown one; the one with figures; the one like Mrs. Potter Palmer's; and perhaps one or two others; was doubtful of the little sketch for the Princesse and Walter Dowdeswell admitted part of the screen had been repainted; was more sceptical about boy and lady in brown.

At last Walter Dowdeswell told the story. A lady who brings them things occasionally, told them of rolls which she had bought for nothing from a second-hand book-seller for the sake of one old English picture which she recognized for what it was and sold to somebody in Munich. The Dowdeswells looked over the rolls. The paintings were shockingly dirty but they saw passages that were unmistakably Whistler and they bought them and she brought more which they bought too; they have about fifty in all; and, really, it was difficult to know how to pay her for she didn't know the value and asked nothing, and they knew the value and felt they should pay her more than she asked, and the end was she felt as if they had made her fortune for her, though I gathered that her eyes were enough opened to make them pay more for the second than the first lot. When he had finished J. said he knew that second-hand dealer, his place was in Holborn. No, Dowdeswell said. Then New Oxford Street, he was not quite sure which. Yes, said Dowdeswell. Spencer, said J. Yes, said Dowdeswell. So it is the shop where Elmer Adler last summer found the Whistler charcoal drawings and spoke of rolls of things being there. It looks as if the whole business might come from Greaves. In the end Walter Dowdeswell took us to a man, in a remote part of Camden Town, who is restoring a few. There were so many they have been given to different restorers. It was like the house of a little cheap dressmaker with horrible pictures on the wall and orna[1900 


\section{The Whistler Journal}

ments that gave the man away, J. suggested afterwards, like Whistler's "little something on the mantelpiece." $\mathrm{He}$ had two full lengths: one of a woman, middle-aged with black hair drawn rather tightly back, in a white muslin gown, date I should say the Sixties, standing against a white background with at the bottom a low dado of blue-and-white (tiles or matting) with a long green stroke of the brush on one side and two touches of blue on the other, very Whistler, and not much tampered with by the restorer though he was thinking of cleaning away the strokes of green and blue. The other was a full-length of a lady in blue, carried much further. Her hair is golden, worn in a fringe on the forehead, the face characteristic of Whistler, though the restorer-the damned fool J. says-wanted to clean the character, which he called dirt, out. The dress has a quilted under petticoat in front, the basque is long and pointed, there is a little puff at the top of the sleeve, the hand, unfinished, hangs at the side (the figure is seen in profile) and there are soft white muslin frills at the neck. It seems that the bottom of the canvas was in tatters or "ribbons," Dowdeswell said. The restorer has not only mended it, but touched it with dabs of crude blue that knocks the whole thing out of tone, because he says there wasn't any paint there, and J. thinks he must have done a good deal of repainting to the gown. J. wonders if it possibly might be the remains of the portrait of Mrs. Mitford (Lady Redesdale) and Dowdeswell will find out. There was also a grey day, with figures and the plumbago works of Battersea on the opposite shore-the middle distance was absurd, and not Whistler. A Cremorne and a grey day with white blossoms were either not Whistler or entirely repainted by the fool restorer, and they suggested that those already at Dowdeswells may possibly be genuine and have passed through the same treatment. Altogether it was an interesting afternoon. There is no question that things did disappear at the time of the bankruptcy and auction, that there is comparatively little to represent some ten years or so of Whistler's work. and it is just possible that these rolls of paintings may be the explanation. They may have come from Greaves, from whom Spencer had letters and those charcoal drawings. From Spencer I 28

$[1900$ 


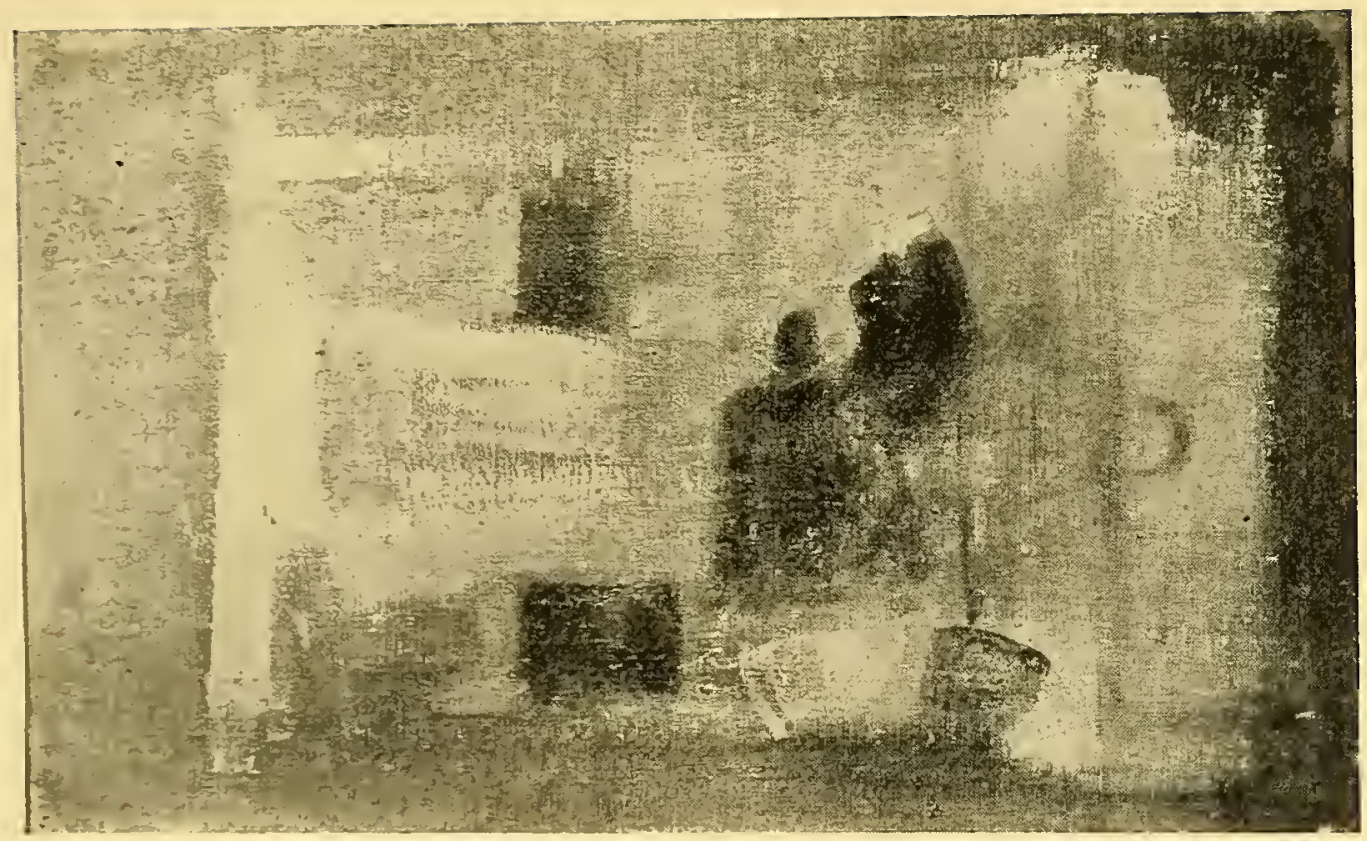

STUDY OF CARLYLE ON BACK OF CANVAS

OIL

Signed by Greaves

In the possession of Messrs. Dowdeswell and Dowdeswell

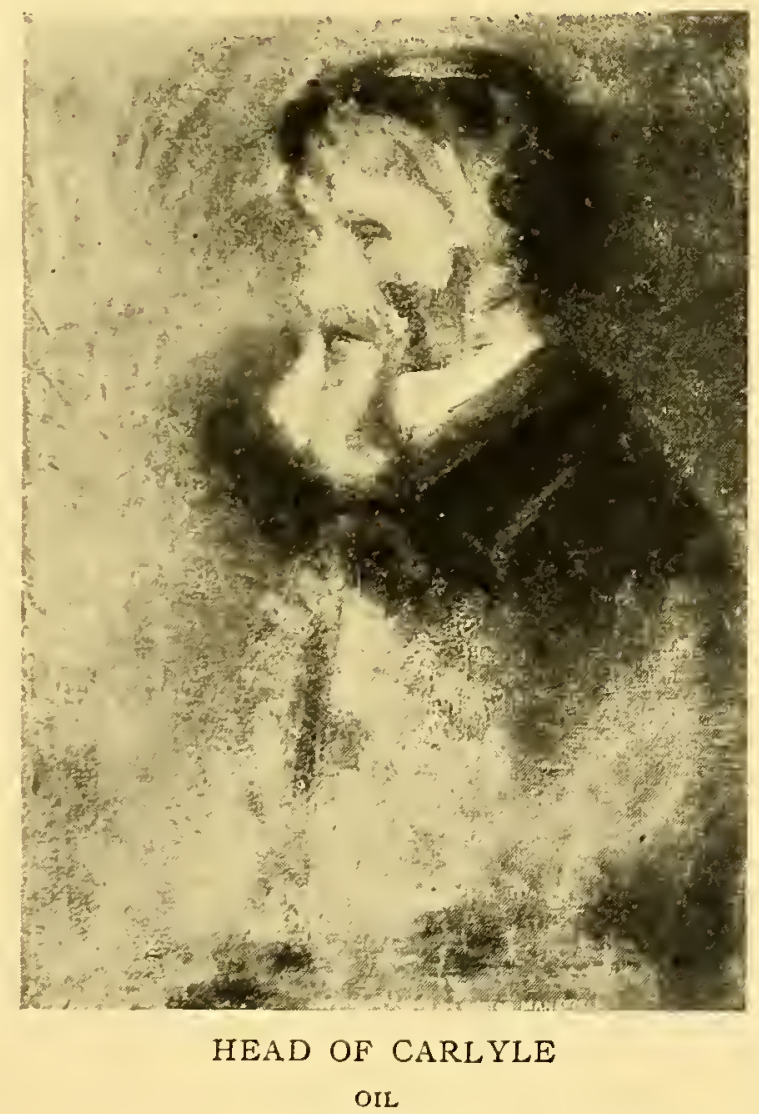

By Whistler

In the possession of Burton Mansfield, Esq. 
. 


\section{The Greaves}

direct, Dowdeswell had bought for twenty guineas a package of letters all written as testimonials for Howell: one signed by Whistler, one by Millais, one by Rossetti. I sent Dowdeswell the addresses of Alan Cole, Mrs. Thynne, and Greaves who, we told him, could identify the pictures better than anybody, as they must all date back to before 1879 and few remain who knew Whistler and his studio at that time, except Alexander, Rawlinson, and perhaps Mrs. Whistler. Among the other canvases being restored is a Carlyle, just sketched in, a little different from the picture, Carlyle wearing his hat. And I should have said that there is a sketch of Carlyle on the back of the gold-brown nocturne and a sketch of sails on the back of another. There is also at another restorer's a full length of a boy in white shirt. Dowdeswell says he is not paying Spencer for the letters until Spencer gives him some clue to the history of the pictures.

Friday, September I6th, IgIo. J. on his way to the Consulate taking out his papers on going to America, stopped at Spencer's where he encountered the clerk who had come down here with the signed etching that wasn't by Whistler. J. didn't know whether he knew him. He could get nothing out of the clerk who said he must wait for Mr. Spencer. In the meantime J. discovered the print of Drouet, which seemed all right, and a Fulham. When J. talked vaguely about there being piles of things in an upper story and an early English landscape some one wanted him to look at, Mr. Spencer knew nothing. And it now occurs to J. that when Adler was here and told him of the piles of stuff at Spencer's, very likely Dowdeswell's "find" was there, and that now even Spencer smells a rat. He said he was too busy to go in to things, he loved pictures but the place was a book warehouse, and he did not know what he had, which is terribly evident. But we must get at the bottom of this story. On looking in our Whistler this morning, at the reproduction of The Music Room, it struck me that Lady Haden, as you see her in the mirror, is like the portrait of the lady in white Dowdeswell showed us at the restorer's yesterday. Also the book recalls to us that Redesdale described Whistler as I900] 


\section{The Whistler Journal}

slashing the portrait of his wife and treating other pictures in the same way when threatened by bailiffs. At this period, Howell was much involved with Whistler, he was also on the Bankruptcy Committee. These things reappearing with the bundle of testimonials makes one wonder if, perhaps, all these pictures came, directly or indirectly, from Howell or his heirs. Miss Chambers would never say. In the afternoon J. dropped in at Dowdeswell's again, more particularly to represent what a mess the restorer is making of the lady in blue and to beg Dowdeswell not to have anything more done to the canvases. A number of others had come from the restorer's in the meanwhile-several nocturnes and one, evidently from his Lindsey Row window, of the shore with a man, as evidently Howell, walking with a group of women-unmistakably "The Cock and his Hiens," as Whistler used to describe Howell. They hope to have more before J. goes.

Saturday, September I7th. A telegram from Dowdeswell asking us to call before one and he could show us more pictures back from the liners. I was just off to Harpenden to see Mrs. Arthur Tomson and J. had to go alone. The Dowdeswells took him upstairs again into their front room and there were four or five more nocturnes which had just been lined, or rather two nocturnes and three grey days, small. One nocturne was probably an early one and first J. thought it was the railway bridge at Battersea with lights, but behind it there was something that looked like a hillside so it may have been somewhere else. The moon was outside of the picture but there were lights on the clouds at the top, on the hillside and a long reflection on the water which the imbeciles took for a crack and were on the point of filling up, and it took J. almost half an hour to convince them that they were fools and were doing their best to ruin the pictures. Another was old Battersea Bridge from his window, very like the one owned by Pope; in fact, it may be another canvas of the same subject which he never went on with; though as the houses in the background are different it might be Putney Bridge done in the same way. But it was blocked in in solid masses of red, evidently with 


\section{The Greaves}

the intention of painting the light through the piers afterwards. It was painted in a reddish-brown, really just rubbed in. Another was a steamboat coming up the river and leaving a white line of foam right along either shore. These two long lines of white made a curious composition. There were also one or two unfinished and of no importance. The Dowdeswells insisted on taking J. off to lunch at the Café Royal and talked for hours. Coming back after a long consultation they decided to show him another which they said they had been afraid to all along. Lunch seemed to give them courage. They produced a full-length canvas rolled up, and spread it out on the floor. It was ragged, having been pulled off the stretcher, and was the usual sort of Whistler early canvas or rather cloth. It represented a woman seated in a deep window seat holding her hands, very badly painted, and a book in her lap. All the details of the window and the wainscotting painted black agree with descriptions of the room. The woman had yellowish hair. J. thinks it is most likely Tinnie Greaves, at least it has a suggestion of Tinnie Greaves as she is to-day. She is dressed in white and the Dowdeswells raved over the painting of some of the lace. The work is full of brush marks, especially under the chin where there was a great swab of reflected high light. Through the window Battersea Church and the mills are seen, painted as hard as nails, though the water and sky are good. Of course the Greaves may have done this, and Whistler tinkered at it. On the back is another full-length of a woman standing, or two twisted figures: the first evidently wore a big brown hat and a brown cloak trimmed with fur, with a great swob of a hand just rubbed in hanging down in front. On top of this was the head of a woman with florid complexion and red hair, wearing a little round black hat: without doubt Jo. This is painted right over the head and hat of the other figure, or else the head is changed. The bust is absolutely gone, nothing but dirt and rags and the liner said it was impossible to do anything with it unless it was lined. J. suggested to put canvas round the edges, he said that would tear, and J. said then he had only to put it between glass. They will probably ruin the whole thing. The talk went on from twelve to five.

I900] 
The Whistler Journal

Monday, September Igth. To the restorer's with Dowdeswell. There we saw first a large full-length of a small boy, standing about the centre of the canvas, against a screen a little higher than himself with green frame and white panels. He is seen in profile, his hair is yellow and worn in a fringe over his forehead, he wears a white muslin shirt and white muslin breeches, low black shoes, and stockings with black and white horizontal stripes. The pose is childlike and simple and full of charm, the face delicate, the figure not carried as far as the screen. On the floor is black-and-white matting, there is a low wainscotting painted green, and in the upper part of the canvas, to the right and above the screen, is a print apparently of Battersea, with a wide white mount and a narrow black frame. It is one of the best of the things we have yet seen. The restorer said it was covered over with gum when it came to him, which certainly agrees with the description of Whistler's treatment of his pictures at the time of the bankruptcy. On a smaller canvas was a three-quarter length of a lady in white, the dress in the fashion of the Sixties. She is standing in the centre of the canvas, turned full face, she is dark, her short upper lip shows her teeth, and her black hair is rolled up on the top of her head somewhat in the fashion of the little figure in grey before the screen, the study for La Princesse, which Dowdeswell showed us the first day. Her arms hang at her sides and around the wrists are curious deep cuffs or wristbands of some thicker and heavier white muslin. She stands against a greenish-black curtain, rather elaborately finished in comparison with the figure which is not carried very far, and the face which is hardly more than rubbed in. This is much less interesting. It might be one of the Greek group of his friends, an Ionides or a Spartali. There was also a small, slight sketch of a woman in blue (oils) that might have been a study for the big portrait: there is the blue gown, the pointed basque, the puffed sleeves, only the figure seems to have a blue cloak over the left arm.

Tuesday, November, Ist IgIO. Dowdeswell showed me to-day a canvas, rather small, that was in too shocking a condition to be I32 


\section{The Greaves}

restored. It was the figure of a woman in blue drapery, standing, in the back-ground blue lines which might have been lines of the railing of a balcony or of a painted frieze. There were great dabs of paint, as if put on with a thick brush, across the figure, the whole canvas was dirty and grimy, and ragged at the edges where it had been torn from the stretcher.

These notes give our impressions at the time of the remarkable collection of canvases bought by the Dowdeswells from Madame Frida Strindberg, the lady of whom they spoke in their story of the transaction. Mrs. Dr. Whistler, Mr. Alan S. Cole, Mr. Heinemann, Robert Ross, Lord Redesdale, the Ways, to whom the canvases were submitted, were bewildered, certain that some were Whistler's, uncertain about others, struck as we were by the difference in quality, many of the paintings being as commonplace as many were masterly. The collection as a whole was fine enough for T. R. Way to write afterwards to the Dowdeswells to congratulate them on their Whistlers. Other rolls were sold to Mr. William Marchant, others offered to Ernest G. Brown, with letters accepting Whistler's invitations to his Sunday breakfasts. A canvas or two passed in to the hands of Messrs. Reinhardt. All came from the shop of Mr. Spencer who announced that he had also a bundle of Whistler's old brushes and had already sent Whistler relics to America. The condition of the canvases before the restorer had touched them naturally interested us, as it did the Dowdeswells, for they were exactly as T. R. Way had already, and now again, described the canvases bought by his father when he served with Howell and Leyland on the Committee of Examiners to settle up Whistler's affairs at the bankruptcy. For a guinea old Way purchased Whistler's unfinished canvases which were rubbish to the auctioneer. Way's story was that Whistler told him to take the rolls, Whistler's that he asked Way to purchase them and keep them for him. Years afterwards Whistler claimed them. Way refused to return them all. And that was the end. When Whistler thought his confidence had been abused, he could say things that hurt, and now he said it was only what was to be expected, his mistake had been to associate with tradesmen, and he would have nothing more to do with father or son. That Whistler in his difficulties asked people he thought he could trust to bring things from the White House, we know for we have seen his letter to Walter Greaves, telling Greaves to go to the White House and take for his own etchings any of the Japanese paper he liked, though some I900] 


\section{The Whistler Journal}

must be left. That other things disappeared, we also know, for we have also seen his letters from Venice to Mrs. Dr. Whistler begging her and the Doctor to hunt up missing canvases, especially the Lobsters and Mount Ararat caricatures of Leyland, a Blue Girl, a version of The Three Girls. He sent an urgent message to Way and to Eldon, then much in the studio, imploring them to trace these caricatures which he valued and which he feared Howell and Leyland had hatched a plot to destroy. Of much that went on during the bankruptcy proceedings, evidently he had no knowledge. At less agitated times Whistler, though usually over careful of his work, could be inexplicably careless, leaving his canvases here, there, and everywhere. After his death W. C. Alexander returned to Miss Philip paintings and drawings which had been in the Campden Hill house ever since Whistler stayed there to paint Miss May Alexander. We have spoken of the things that turned up at Howell's house in Selsey Bill. T. R. Way remembered beautiful seas painted in the Channel Islands- "most interesting and unlike anything else he had done"-which vanished. Towards the end, the disappearance of work from his Paris studio worried him to distraction when his health depended upon his not worrying at all. The bankruptcy was the opportunity for the greatest carelessness and, apparently, the greatest advantage was taken of it. Some years later on, Thomas Way gave him back one roll of large six-foot full-length portraits: the Sir Henry Cole, a Miss May Alexander, three Miss Leylands. One of these three is probably the painting in the Brooklyn Museum. Of another in riding habit, a drawing reproduced in M. Duret's Whistler, T. R. Way said was a sketch, though it looks to us more like the Mrs. Cassatt. Other rolls which Way had divided with his son, they refused to give up. Out of these came an unfinished Valparaiso now in the National Collection; a Cremorne now at the Metropolitan; a nude; a portrait of Miss Leyland, a Blue Girl, in such a state that only the flowers in one corner could be saved-a fragment Freer bought; the Lobsters and Mount Ararat which Thomas Way was asked to trace but apparently could not and we believe they too were sold to Freer. T.R. Way told us that Whistler, looking over the canvases, saw on one, emerging from the muck with which it was covered, two black slippers against a white ground, and recognized the feet of a White Girl shown in his 1874 exhibition in Pall Mall. That made Way set to work to clean and repaint it. For long this portrait, for which he thought Jo must have posed, hung in his father's house in Brunswick Square. Whistler saw it there after the repainting, objected, and Way cleaned off his own work. 


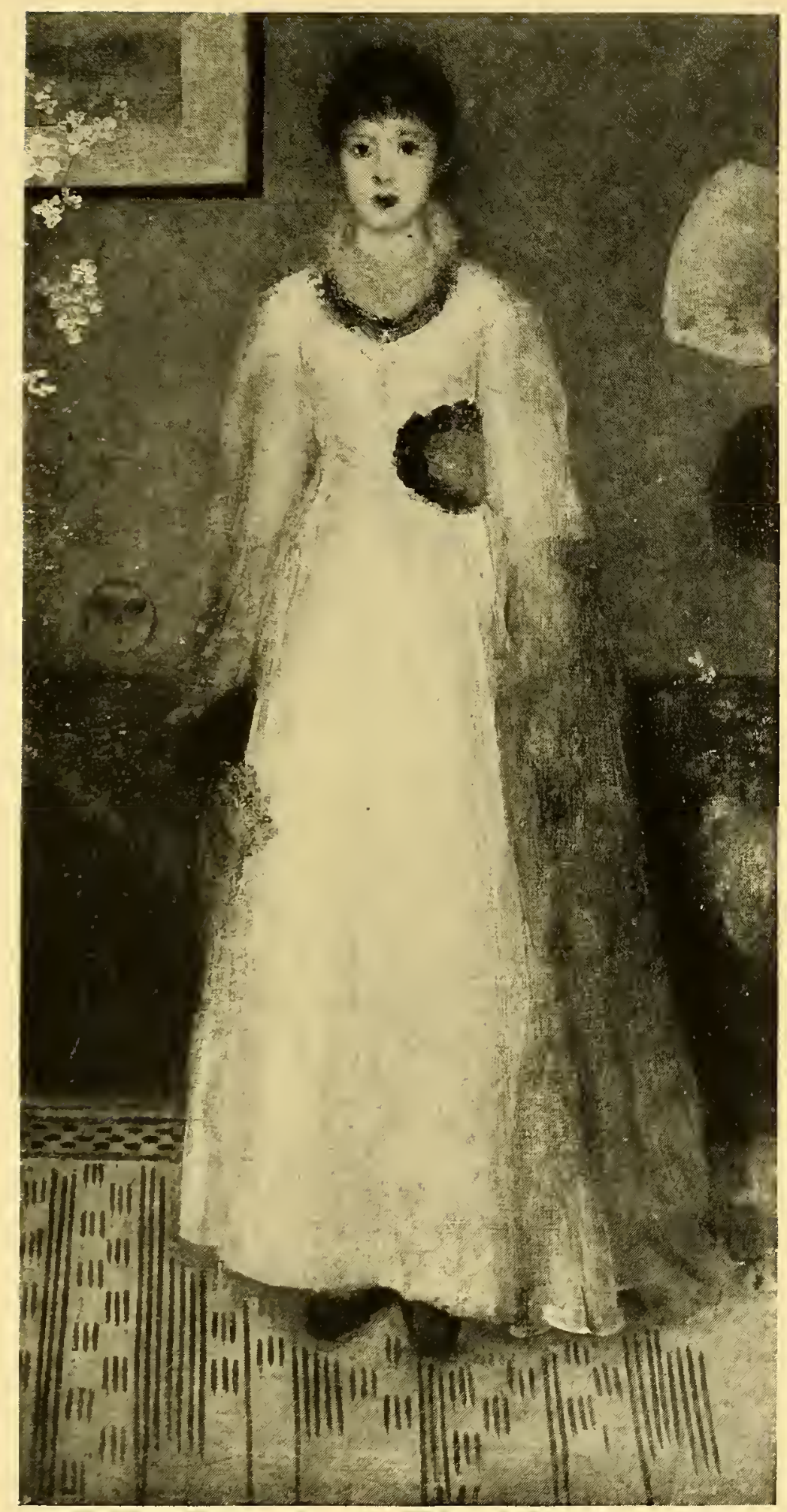

WHITE GIRL. NO IV.

OIL

In the possession of John F. Braun, Esq. 


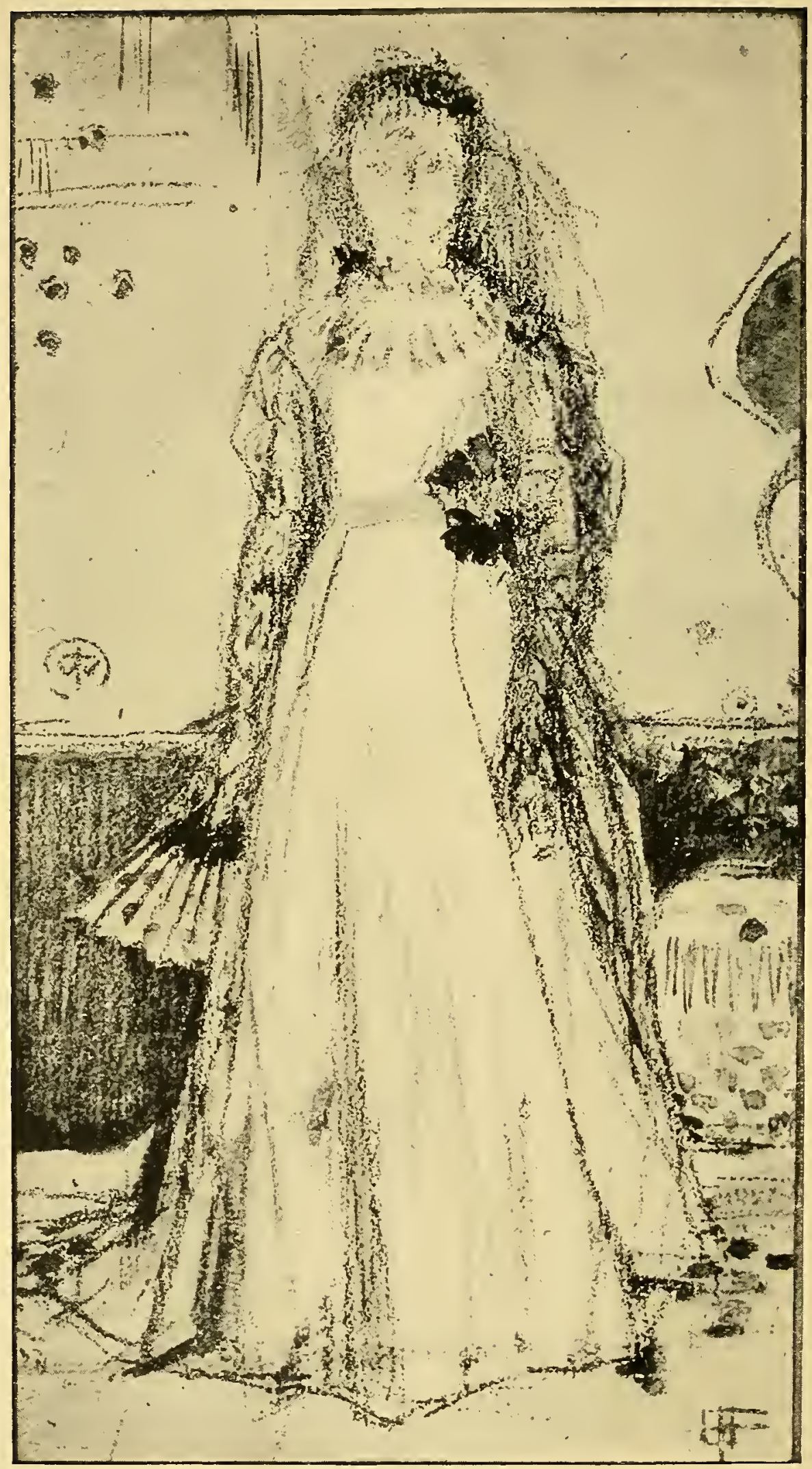

SKETCH OF SAME

Attributed to Whistler CHALK

The Way Collection 


\section{The Greaves}

"The over-painting was removed with the painter's knowledge," according to a note in the catalogue when Way sent it to the Fair Women show held in London in I9ro. "A sadly battered ghost of a Whistler," was E.'s impression; "a peculiarly poor Whistler, a shadow and not significant at that," was the prevailing opinion among the critics. It was again repainted by T. R. Way, sold by his sisters after old Way's death, brought to New York, bought by Mrs. Thaw, from whom the portrait, or what is left of it, passed into the possession of Mr. John F. Braun of Philadelphia.* That no Thames nocturnes were in his father's rolls had always been a wonder to T. R. Way, he wrote to a London paper after the discovery of the rolls at Spencer's. And it is astonishing, for during the years when these unfinished portraits were begun, Whistler gave as much time to the river as to his sitters.

The canvases in the Dowdeswell rolls were, many of them, in as desperate a state and were restored as thoroughly. Restoration usually means destruction. It is worse in America probably than anywhere else. The Lange Leizen in the Johnson Collection is a wreck. Almost every picture in many American collections has been, or will be, ruined by cleaning. Everything is reduced to a ruinous level of freshness by rubbing and scouring and scrubbing. The bloom of time is removed for the benefit of the American collector who cannot understand it-or art either-and if this is not enough the works are entirely repainted. It is not so long ago that $\mathrm{J}$. was dismayed by seeing an American restorer spit on his thumb and rub with all his might the glaze off a very old Master. It looked new enough in all conscience and perhaps, with further rubbing a picture by James Montgomery Flagg or Charles Dana Gibson appeared under it. On another occasion J. caught a dealer with a rough cloth endeavoring to rub the whole face in another portrait up to the high light on the chin, saying the rest of the face must be dirty. If in fifty years any old pictures are left in America, it will be because they have not been tampered with by dealers, restorers and collectors. A Whistler factory is working overtime as every American collector now has to have a Whistler and they are all signed, but scarce one is by the artist. In Chicago, in the autumn of I9I I, J. was shown a marine, one of the canvases bought by the Dowdeswells from Madame Strindberg and sold by them to another dealer. Everybody who saw it declared it a genuine Whistler. The fact coming to the knowledge of Madame Strindberg, led to trouble over the question of payment, and she demanded all the canvases back from the Dowdeswells * Note-Mr. Braun has had Way's and probably later painting cleaned off, and in this case the picture really has been restored.

I900] 
including this marine which had passed in to the possession of Messrs. Reinhardt. The Dowdeswells then withdrew their collection from exhibition and sale.

Up to this time we had heard the name of Walter Greaves only once in connection with the rolls-when Messrs. Dowdeswell told us of one roll offered them but refused, in which they came upon "strange things" signed Walter Greaves. Now, however, his name was to become a nine days' wonder. Mr. Marchant found the canvases he bought in the same deplorable condition, dirty and neglected, and certainly those he showed J. were about as bad as they could be. Mr. Spencer gave an ingenious explanation of the holes in some of them. Whistler, when he could not afford new canvases, bought old paintings, so old that they sometimes developed holes. Then he would tell Greaves to paint a tiny frame round the hole, and the device could be noticed in one of the portraits by Greaves. Ingenious but, we fancy, Mr. Spencer's own. Like the Dowdeswells, Mr. Marchant had the canvases restored. Then he looked up Greaves, arranged an exhibition in the Goupil Gallery in May, I9II, sent out cards for a show by "Walter Greaves. Pupil of Whistler," and published a catalogue. The card attracted small attention. The note of the private view in The Journal is:-

Thursday, May 4th, IgII. In the afternoon I went to the Goupil Gallery to see the Greaves show. It is given in the largest and smallest of the rooms on the first floor. In the small room are the etchings and one water-colour-the etchings reminiscent of Whistler. In the large room, the paintings; one of the first, a large full-length of Miss Alice Greaves- "Tinnie"-in blue gown. Opposite hangs another of "Tinnie" in the same sort of a gown only in black and white: white front quilted and black train. The Carlyle I saw in the Greaves' house is there, a portrait, small, of Walter Greaves, and a still smaller one of Harry Greaves. The rest are almost all of the river at Chelsea, streets in Chelsea, and Cremorne. It seemed to me easy to see at a glance which were the pictures Greaves painted for himself, and which under the influence of Whistler. One or two blue Nocturnes and one or two grey Battersea Bridges were obviously slavish attempts at imitation. The things that were entirely his own struck me as common in vision and treatment. I met first Hind, who wanted to know what it 136

[1900 


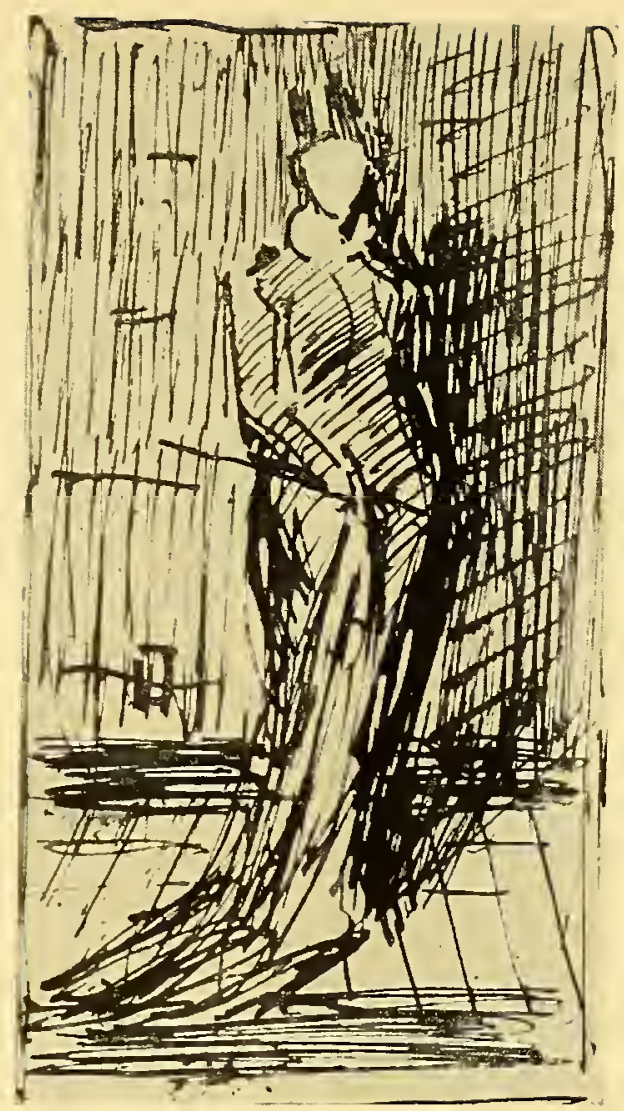

MRS. A. J. CASSATT

PEN-AND-INK

In the possession of Alan S. Cole, C. B. 


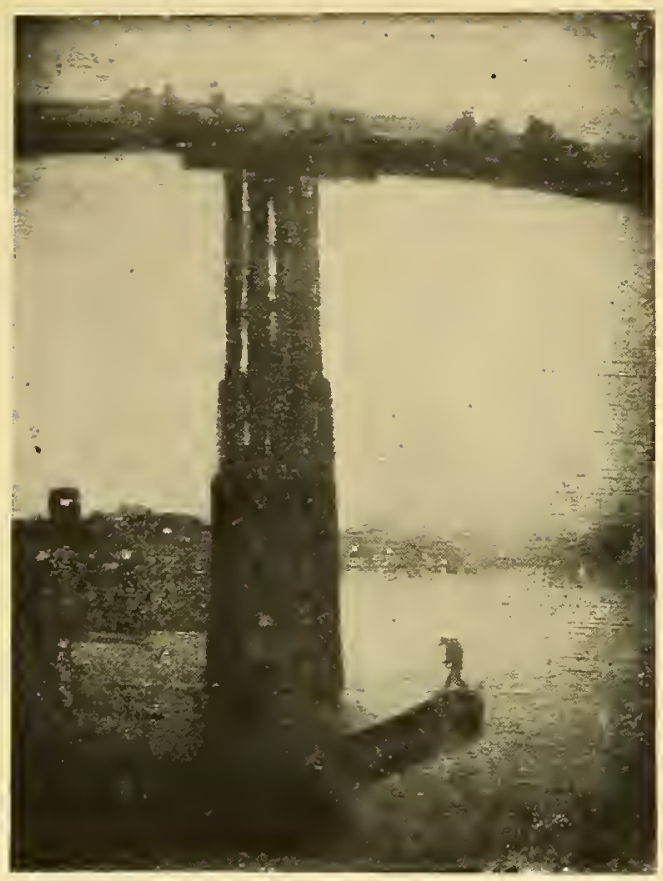

BATTERSEA BRIDGE

OIL

By Whistler

Tate Gallery, London

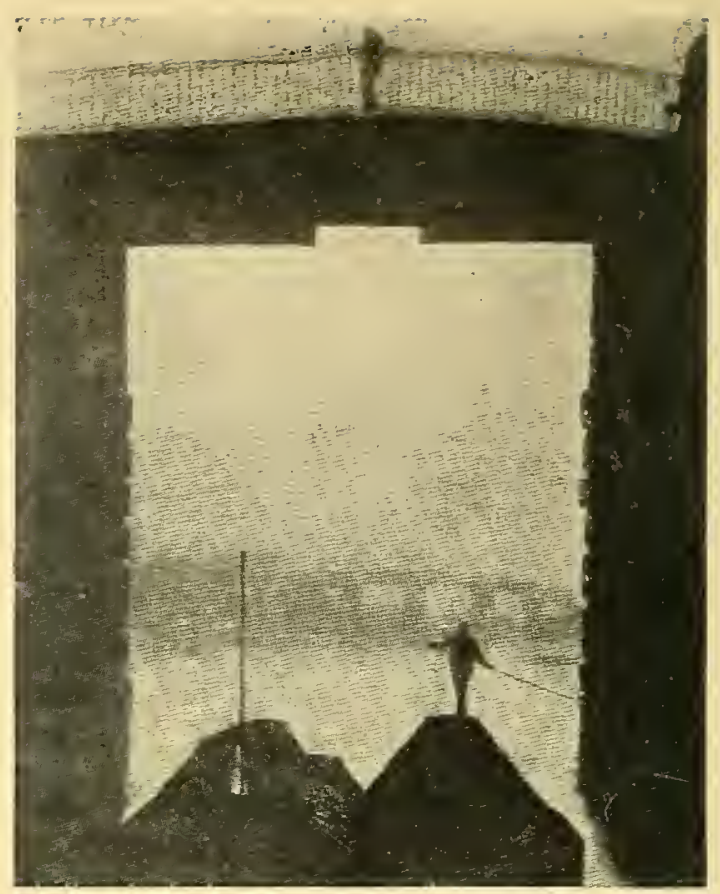

PASSING UNDER OLD BATTERSEA BRIDGE

oIL

By Walter Greaves

From the $N . Y$. Herald 
meant, and it was too direct a crib from Whistler. Then I talked to Marchant, who told me the whole thing was a most remarkable story. Rolls of canvases in the worst state he had ever seen canvases in were brought to him, he had one or two cleaned and began to see things in them, then found the name Greaves on one, hunted him up, found him in the most deplorable condition in the Fulham Road house, so deplorable that he sent down bits of furniture afterwards, and the result is the Exhibition. It is an extraordinary story and adds to the mystery of the Dowdeswell rolls. Then I saw Greaves, who was jumpy. He told me Whistler had worked on the Carlyle, had come in to see him and his brother while they were doing it and criticised their work. They had painted the mount of the print on the wall white and he said it would never do and then painted it grey in tone with the wall. He said also that The Balcony and one or two others were painted from Whistler's window, and they were always doing them, sometimes one on top of another. The one of Battersea Bridge, under the arch, to which he refers in his catalogue he said he and his brother had done and then Whistler saw it and said, "why, you boys have got something nice there," and after that he painted his Battersea at the Tate. It was private view, but nobody else there except two men and two women, and an old man and his wife with whom Greaves was talking. He introduced them as old Chelsea people, and the man said he was so glad to meet me, he was a great admirer of my husband's and my work, he knew it-from the illustrated catalogues!

The catalogue attracted more attention than the card. In the Preface, over Greaves' name, it was stated that he painted Passing Under Battersea Bridge, which was signed and dated, in 1862 and exhibited it the same year in the International Exhibition at South Kensington where for several years, International Exhibitions of paintings were held. This was proved a mistake, as no pictures by Greaves were shown there that year. Probably only a few people would have been interested, had not the press of Great Britain in the meanwhile broken out in praise of the unknown pupil whom Whistler suppressed-the pupil who was the master from whom Whistler learned everything. The Times started the ball I900] 
rolling with a notice, under the title "An Unknown Master"a master whose naïveté was so different from the "cosmopolitan cleverness" of Whistler, who was the British De Hoogh, whose drawing of boats had never been surpassed, whose work, indeed, bore the same relation to Whistler as the Giorgionesque Titian to Titian. This was printed on May 4th. It was enough. The floodgates opened. Two days later P. G. Konody of The Daily Mail was asking how much Whistler owed to his pupil, and on every side critics tumbled over each other in their eagerness to overthrow Whistler and set up Greaves in his place. Two or three kept their heads. Robert Ross in The Morning Post saw in Greaves a convenient "New Amico di Sandro." E. F. Strange in The Westminster Gazette pointed out the absurdity of it, especially so soon after the Whistler Memorial Exhibition. But they were exceptions. "Whistler Dethroned" was typical of the prevailing headline which, growing bolder in America, became "Art Tragedy Shows Vanity of Whistler," "Now Critics are Asking Which was the Master?" "Was this Artist Whistler's Ghost?" "The Crushed Genius," "The Other Whistler," "Casting Whistler in the Shade." British criticism decided that Whistler was artificial compared to Greaves, that Whistler exploited his obscure admirer, that Greaves was the first to paint nocturnes, that he accomplished what Whistler spent his life trying to do, that it looked bad for Whistler, that Whistler was at last exposed-and a jolly good thing too! The miserable Yankee. The question was whether a shred of Whistler's reputation would be left. As he was not alive to defend himself, there was the end of the Yankee.

Marchant's gallery now was crowded. Authorities urged the acquiring of at least one Greaves for the Tate, the voice of Sickert was heard crying "Au Louvre with Tinnie Greaves." Many paintings and, we believe, all the prints were sold. Among the purchasers were Sir Hugh Lane, John, Orpen, Nicholson, Northcliffe. Robert Ross, who gave us this list, suggested that Nicholson must have bought his just to prove his decency in not minding the way Greaves was overshadowing his own exhibition in another room, Northcliffe possibly to please Konody, his critic on The Daily Mail.

It was absurd and preposterous, and might have been ignored like all foolish criticism and discoveries. But the dates in the catalogue were used by the critics as a basis of fact upon which to build up their exaggerations, especially the date $\mathbf{1} 862$ on Under Battersea Bridge which, Greaves claimed, gave Whistler the idea for his Old Battersea Bridge now in the Tate Gallery. It was an extraordinary 


\section{The Greaves}

tale for this meant that Greaves' picture was painted before Whistler was settled in his first Lindsey Row house where the Greaves brothers began to work with him, and that Whistler borrowed the motive about ten years later. It was the more puzzling because few could look at the picture without seeing two distinct qualities of work in it, as if it were the work of two people or two periods. Mr. A. S. Hartrick assured us that, more curious still, if examined very carefully it looked as if a piece of canvas had been added where "Greaves, 62" was signed-as if the grain of the canvas below the piece ran quite differently, slanting, while the grain above ran almost horizontally. The matter was altogether too grave to be allowed to drop by those who cared for Whistler's reputation. This was why J., Heinemann, Mr. Cole, Robert Ross, and any number of artists began to make investigations. It was discovered not only that Greaves' dates were inaccurate but that the preface was prepared by Mr. Marchant and then signed by Greaves. J. wrote to The Times which refused to publish his letter. Then Heinemann wrote and his letter was published. The Times critic, ignoring the effect of his article, washed his hands of the whole business. He had praised Greaves for his unlikeness, not his likeness to Whistler, he said. But J., in the meanwhile, sent his letter to other papers which did print it. Critics began to waver. Those who had been eager to exalt Greaves began to talk of his inexperience, a painter technically not too well equipped. One went to the length of saying the Greaves Bubble had Burst, but threatened with a libel case explained it away. The preface, we think, was omitted when the error of date was pointed out and proved. Some of the pictures, it was said, were withdrawn from sale and the dates removed from some of the canvases and some of the entries in the catalogue. It was Alan S. Cole who exposed the statement in the Catalogue. $\mathrm{He}$ was referred to as an official of South Kensington. J. found him in the Athenæum Club, they visited Marchant's gallery, and they looked up a South Kensington Catalogue of that and other years. There was no picture by Greaves shown in 1862 and as Cole said, "my father thought me a genius, but even he would not have chosen me as art director at the age of sixteen." Marchant admitted that the Introduction to the Catalogue was not written by Greaves, only signed by him.

The collection later came to America, heralded by a pamphlet in which Mr. Marchant gave his statement of the Greaves affair, calling it $A$ reply to an attack on a pupil of Whistler. When the pictures were shown at the Cottier Galleries, New York, in the I900] 


\section{The Whistler Journal}

winter of 1912 , an equally misleading introduction or preface to the American Catalogue was concocted by Dr. Christian Brinton. It was a wonderful production, beginning in the G. P. R. James manner: "Shortly before noon on May 5th last there slipped quietly into the Goupil Gallery in Regent Street a timorous, unassuming little man," and so on for many pages in which Tinnie Greaves, "fresh as a flower," is seen going to Cremorne Gardens in Whistler's company, and, with her sister-" these wholesome, generous-hearted English girls"-helping Whistler, their "deft and willing hands" making the rugs upon which his models posed -altogether an appeal to the gallery for Dr. Brinton believed it was the life story of Greaves that had gone "straight to the big. responsive heart of the British public." It would have been only funny had not Dr. Brinton re-echoed the London critics, their statements and conclusions when the Greaves folly was at its height. Unfortunately for him and the owners of the galleries, J. happened to arrive in New York while the exhibition was being held and he exposed Dr. Brinton's mistakes. The pictures were disposed of at auction, fetching small prices, and Greaves has not often been heard of since.

Greaves, after the show in London, signed we believe all the paintings and those owned by Dowdeswell which, as we suggested, he was asked to examine. He claimed the canvases in the other rolls. But we have never heard that he explained the ragged edges or the smudges of black and the glue-like substance with which they were defaced. There was a reason in Whistler's case, but none in his that we know, unless the faithful pupil felt compelled to follow the master to this extreme of self-sacrifice. Nor did he explain to what extent the paintings had been further ruined or improved by the restorer. We saw what the restorer did to some of the canvases that came out of Messrs. Dowdeswell's rolls, and Mr. Kerr-Lawson (on September 9th, IOII) gave us an idea of the restorer's share in others out of Mr. Marchant's collection. At the Greaves show Lawson, pointing to one or two of the pictures, said they looked as if Whistler had begun but not finished them, had thrown them aside until the canvas was all cracked and dirty, when Greaves probably came along, cleaned them, filled up the cracks and repainted them. "O no!" said the assistant, "it wasn't Greaves who did that, it was the restorer!" At the International Exhibition in the new Grosvenor Gallery, in I9I2-J. was away at the timeone of the rooms, with its gorgeous rose brocade hangings, was devoted to nocturnes catalogued as Greaves that had not hitherto been seen-a curious tribute to the memory of Whistler. They 
made the same impression as the other Greaves collections, though no excitement this time in the press. The tendency was to dismiss them as "Whistlerian exercises." It was difficult to understand how a man who could paint some canvases of utter commonplace, could paint others so suggestive and beautiful that Whistler would not have been ashamed to sign them. At the private view they roused small interest save in artists who delighted in the beautiful nocturnes, full of rare Whistler qualities; while an official in the gallery, jesting at his friends' bewilderment, was heard to ask if they had been to "The Whistler Room." Portraits we had seen at Dowdeswell's were hung at other International Exhibitions, when The Times thought they were hung too high for faces and hands to be examined, that they were subjects rather for the archæologist and the historian, as if the critic were writing of an Old Master so long dead that only paintings remain as documentary evidence. Later a number of full-length, life-size portraits of Whistler and several small ones turned up, some of them bought by the Rosenbach Company of Philadelphia. One was sold to Toledo, one to the business-like directors of the Pennsylvania Academy of the Fine Arts. Before they left England, a small half-length was purchased for the gallery at Merthyr Tydvil, Wales. Had Whistler sat for them, it would have taken years of his life and almost all are in the supposed costume of the same period, even to the hat. But if one looks up the portraits of Whistler with Chase and Menpes in the Eighties, it will be seen that he was then still wearing a curly brim and Chase a straight one. According to Menpes, when Whistler first saw Chase's hat, he said, "Ha, ha! what have we here? This is good! I like the lines of this hat!" and in less than a week was wearing one like it: a story which gives the date, though some of Greaves' portraits are dated between sixty-nine and seventy-six. There is no evidence of Whistler ever having posed to Greaves at all. Whistler never referred to having posed, none of these pictures was ever shown or even heard of during his lifetime so far as we know, though Greaves told us that Whistler once painted Harry Greaves on top of a moonlight. Some of Greaves' portraits bear a striking resemblance to contemporary photographs and the caricatures by Spy and Ape. The portraits painted on the walls of the old Streatham Town Hall by the two brothers are similar in manner and treatment-the portraits that remain, that is. Some heads had been carefully scraped out when we were there, among them, we were told, a portrait of Whistler and another of Henry Irving. On the walls were also imitations of Chinese decorations, Albert Moore clasI 900$]$ 


\section{The Whistler Journal}

sicisms and numerous nocturnes, rank but artless imitations of Whistler. Whistler knew all about the decorations, was the first from whom we heard of them. A correspondence on the subject, published in the London Star, was sent to him by Mr. D. Croal Thomson, and in acknowledging it Whistler explained that the Greaves were his pupils-more his pupils than any others had ever been-this was in 1895; they were full of talent, he wrote, they had had no other master, for a time were always in the studio where they learnt everything they knew. The critics would have given the public the impression that Whistler had not allowed his pupils to exhibit during his lifetime- even Tinnie Greaves said sohad deliberately kept them in the background, as was written by one, "on the principle of the Turkish Sultans who killed off their brothers to avoid possible rivals for the throne." With his later pupils Whistler stipulated that they should not show without his permission, a condition they understood if critics make of it a crime. Also, he wished them to exhibit as his pupils, which is always done in France where students look upon it as an honour, not a hardship.

But the irony of this criticism is in the fact that the downtrodden pupils were commissioned to decorate a Town Hall, and did so during Whistler's lifetime, while the master never got a chance to decorate a public building-the Boston Library-until too late to avail himself of it. How then did Whistler hold back his pupils? Whistler had painted no nocturnes in I862, when Walter Greaves was at first said to have exhibited one, nor had Whistler influence in any exhibition or society at that date. Even the London Times, though at first it refused to admit that its critic would have ruined Whistler had his facts been correct, collapsed, and so did the rest of the British press, after Heinemann and J. exposed Mr. Clutton Brock's rhapsodies in The Times and the mistaken statements in the other papers, and made it clear it was a question not of relative quality but of fact. J. said at the time he had no quarrel with Greaves at whose success he was delighted, nor with Mr. Marchant whom he considered a clever dealer. He only wanted to point out the error in the dates and the use the critics made of it. But, certainly, had there been a scheme for the boosting of Greaves and the discrediting of Whistler, an attempt on the part of the critics to prove Greaves the real master and Whistler merely the pupil, the imitator, the pretender, it could not have been better arranged nor have failed more completely.

Mr. Marchant employed Greaves for a long while at a guinea or so a week which he paid him in cash, and J. has seen him do so, for 

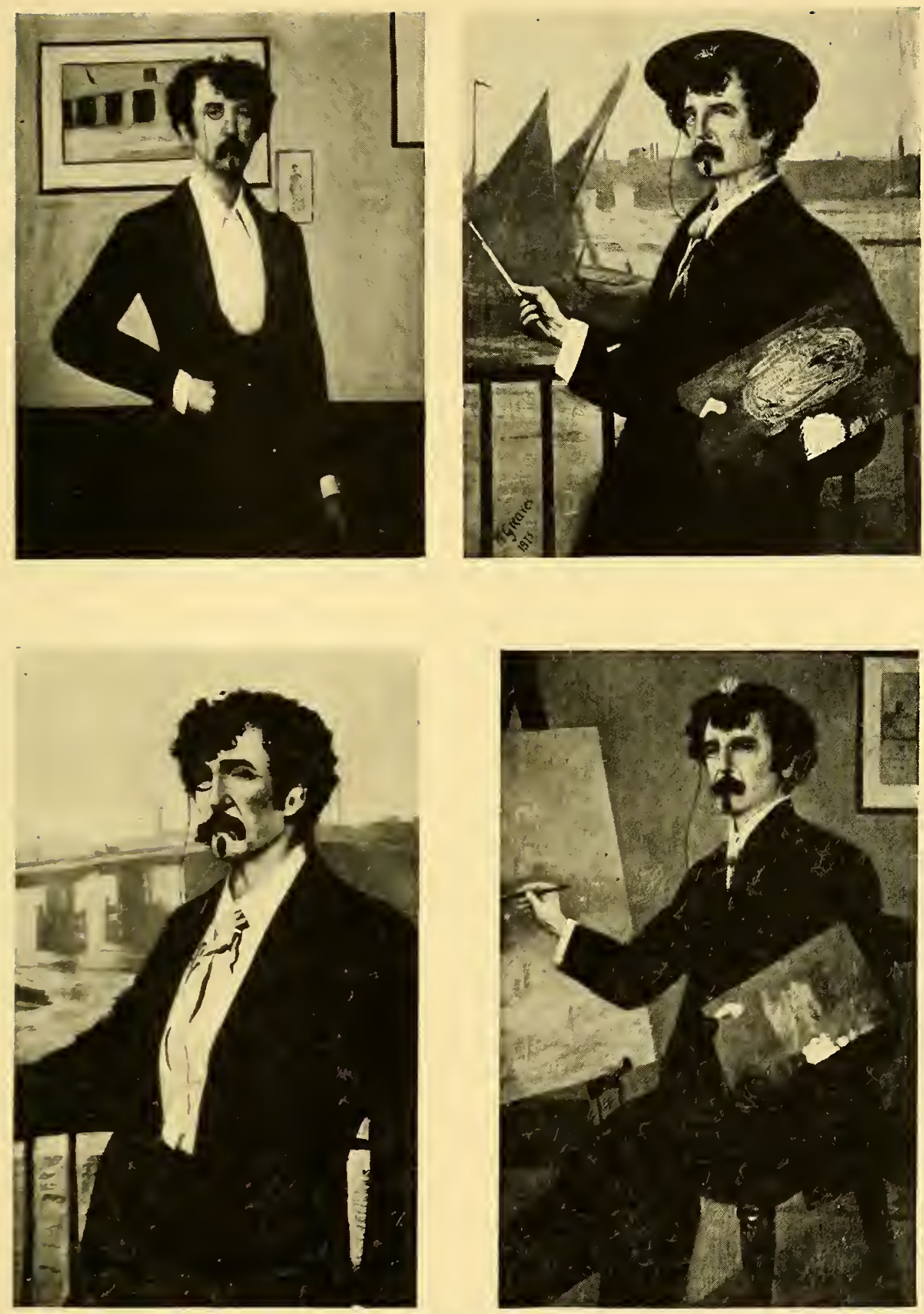

PORTRAITS OF JAMES MCNEILL WHISTLER

orls

By Walter Greaves. In the possession of the Rosenbach Co. 


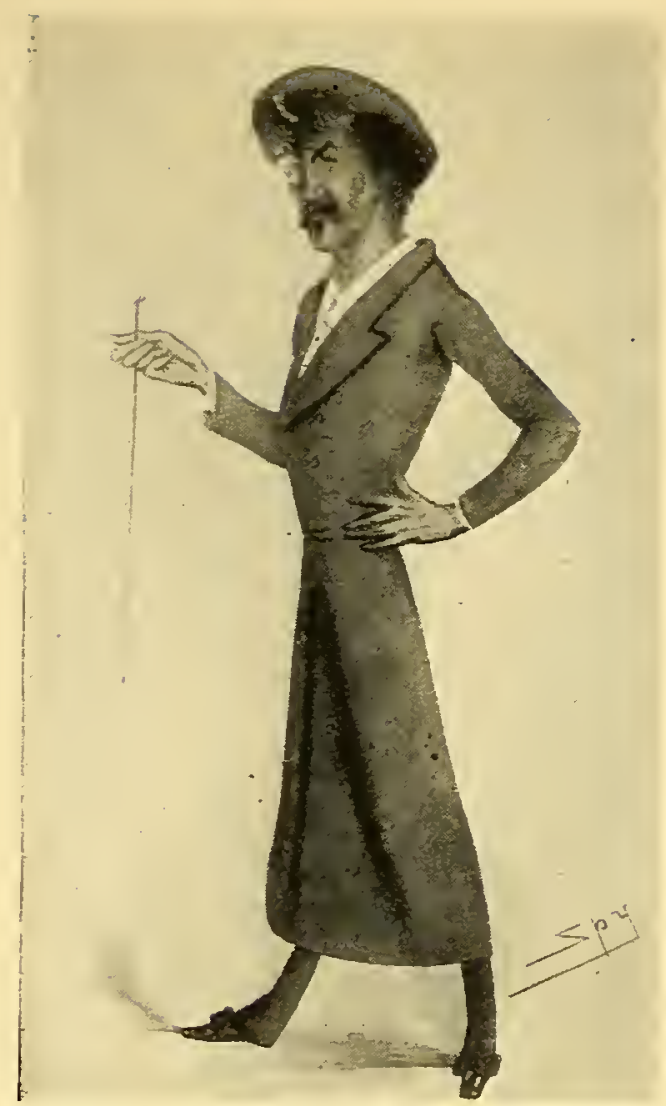

SPY'S CARICATURE OF WHISTLER LITHOGRAPH

Published in Vanity Fair

(See page 14I)

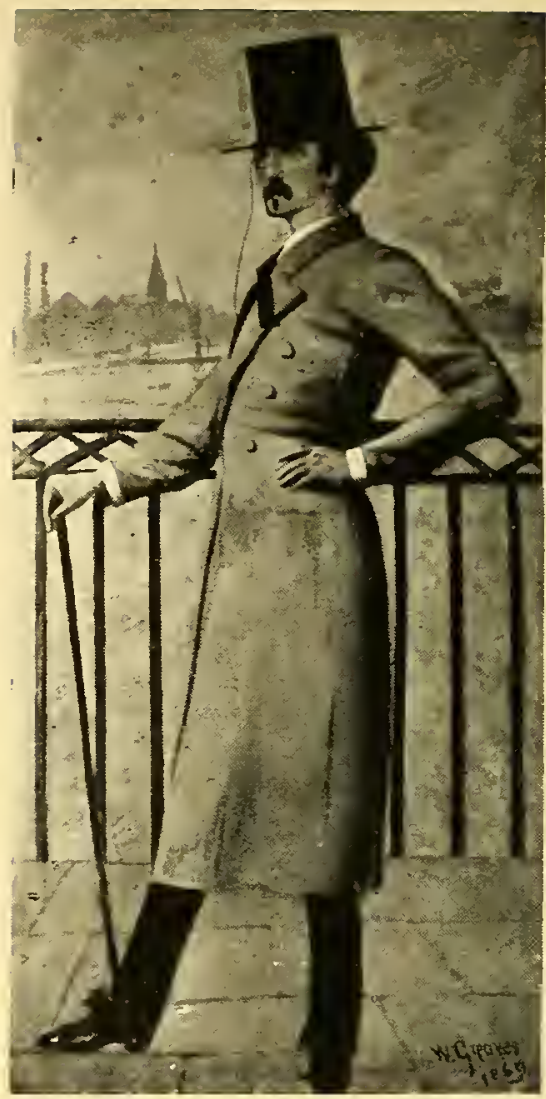

A PORTRAIT OF WHISTLER oIL

By Walter Greaves

(See page I4I) 
the poor man was in sore straits. Mr. Marchant also gave him a studio in the Howell and James building, and rumours went about of the work he was producing there to the wonder of some of Mr. Marchant's other artists who crowded about him to see him paint. Rothenstein was impressed by the rare passion and reverence of his work and the entirely new note running through all his pictures. Nicholson stood in awe of his marvellous powers as a technician. Walter Sickert proclaimed him a great master, and they all showed in the Goupil Gallery. It was to the credit of Sargent and Alfred East, among others, that, as Robert Ross reported, they were "on the right side." We never went to this studio, but we remember Mr. and Mrs. McLure Hamilton telling us that they strayed in by chance when looking for a studio advertised to let in the same building, and found Greaves, rather embarrassed by the interruption, a canvas on the easel, round the floor canvases with huge yellow stars and fireworks just put in, waiting they supposed for the glazes and scumbles that would turn them into masterpieces. As far as we know, no new works came out of the studio.

Among the early canvases signed by Greaves was one of striking merit and absolutely different from the rest. This was Boat Race Day, Hammersmith Bridge, fine as a Breughel, said to have been done by him at the age of sixteen. But never before, nor after, did he do, or at any rate show, anything like it, though another version of the race, devoid of merit, signed Greaves, was on the walls of the Streatham Town Hall. A study of a pond in Battersea Park was equally remarkable and equally different. Hung in a large group in New York, singly in London, were a number of water-colours signed by both Walter and Harry Greaves, while many prints - etchings and dry-points-not at all unlike unfinished and unsuccessful Whistlers-were in the Goupil Gallery exhibition. The water-colours were crude and amateurish. Before the Greaves excitement was completely over, one came up for sale at Robinson and Fisher's and Robert Ross thought it should be bought because of its date, for as this was $\mathbf{1 8 6 0}$, it must therefore prove, he said, what Greaves was doing before he met Whistler. He would have bought it himself for ten pounds but a reserve of twenty-five, which no bidder seemed disposed to go beyond, had been placed on it. As more of Greaves' work in various mediums was seen, the more readily the intelligent critic agreed with $G$. R. Halkett of The Pall Mall Gazette that when Greaves tried "a flight unaided by Whistler's genius" he went into another category altogether.

I900] 


\section{The Whistler Journal}

The Greaves episode, from beginning to end, is extraordinary. The critics based their claim for him as the master of Whistler on the Passing Under Battersea Bridge signed by him and said by him to have been exhibited at South Kensington in I862. When the mistake in the date was pointed out, the whole fabric of adulation of Greaves and depreciation of Whistler tottered and fell. Letters from Whistler to Greaves show plainly the relations between master and pupil. Whistler was willing to give the privilege of his studio to his pupils that they might learn in it everything they could; not, however, to imitate and borrow. Greaves, beginning a portrait of his sister, Mrs. Ranger, appropriated Whistler's arrangement of blue on blue. Whistler warned him of the danger of wandering, if unconsciously, into his symphonies. "Don't you see Walter, you know how I continually invent-and invention you know is the cream of the whole affair and so easy to destroy the freshness of it. And you know that all the whole system of arrangement and harmonies which I most certainly invented, I brought you up in, so that it is only natural that I should expect my pupil to perceive all harmony in the same way-he must do it -for I have shown him that everything outside of that is wrong. ... Suppose you were to see any other fellows doing my moonlights-how vexed you would be. Well, nothing more natural than that you two should do them and quite right that the traditions of the studio should go on through the pupils-but still for instance it would be absurd now to paint another White Girl. Don't you know what I mean?"

Whistler's attitude revealed by this letter throws a strong light on the Greaves affair. No master wants the flattery of abject and misleading imitation, no student with anything in him wants to pay that compliment when he begins to feel his own wings. The critic was right who, when the letter was published in a London paper, quoted it as proof of Whistler's unselfishness in his treatment of Greaves. That Whistler would have prevented Greaves, or any other pupil, from exhibiting good work is sheer nonsense. And we know that he did not, that indeed, he went out of his way to help Greaves to exhibit. In 1873 he asked Mr. Alan S. Cole, from whom we have the facts, to show a painting by Greaves in the South Kensington Exhibition and Harmony in Blue-Gray was hung. In 1874 he again asked that a Greaves might be taken in, and a Harmony in White and Gray by Harry Greaves was shown. Not at that or any other time in his life did he have the power to keep Greaves from showing either in a public exhibition or at a dealer's. It was Greaves' own choice or the decision of Selecting 


\section{Jo AND MAUD}

Committees if he rarely showed during Whistler's lifetime, or for some time after Whistler's death. The canvases unloaded on Spencer were never seen, were never heard of until Whistler was safe out of the way, and it may have been hoped his defenders were too. Until after the Whistler Memorial Exhibition not a single work by Greaves was ever sent to the International Exhibition, J. was on the jury the whole time.

Messrs. Dowdeswell sold the pictures first ascribed to Whistler at Christie's in 19I7, when they were catalogued as Greaves and, if we remember, signed by Greaves though originally his signature was not on them. Like the paintings sold in New York they fetched small prices-the average was from one to seven guineas-with the exception of the big lady in brown. The sale passed almost unnoticed. Every once in a while another Greaves appears and sometimes is hung in the Exhibitions of the International Society of Sculptors, Painters and Gravers, where none was seen while Whistler was alive. To the Whistler Memorial Exhibition he contributed one or two unimportant sketches and drawings which he said were by Whistler.

This is the first time the inner history of the Greaves affair has been written. But as criticisms which, had they been based upon fact, would have destroyed Whistler's reputation were made by the art critics of Great Britain, especially Clutton Brock and Paul Konody, and by Christian Brinton in America, it is well that a true statement should be put on record-and this is the truth.

\section{CHAPTER X: JO AND MAUD. THE YEAR NINETEEN HUNDRED CONTINUED}

Thursday, July Igth, I9oo. When we were both out in the afternoon Keppel called with Roul'ier, the Chicago print dealer. Keppel left a note to say he had a piece of news for us; the Caxton Club, with Mr. Roullier's assistance, were getting out a catalogue of Whistler's etchings, which would contain photogravures after everyone of his plates. It was to be published in a limited edition of two hundred and to be sold at twenty dollars a copy. This was a bombshell in our midst, for in the Life we have arranged with Heinemann to write, Whistler said he was not willing to have any of his etchings reproduced by photogravure. About ten, Whistler himself appeared, an extraordinary figure in white trousers, low I900] 


\section{The Whistler Journal}

white waistcoat, dinner-jacket and the same grey felt hat set jauntily on one side. He was rather cross. "I have dined badlycame home late from the studio, was banished to a dining-room I do not like at the hotel, and went to the Tivoli with some vague idea of German beer. But I had a bit of veal swimming in gravy intended for a schnitzel and a potato salad that was lukewarm, and a piece of cheese that was strong-a shocking dinner-and, you know, if you happen to have a piece of American cake, I could eat that," and, of course I hadn't any. Began by reading us the article in The Star about China, in a state of delight over De Wet's breaking through Buller's ranks. ... .

Then J. told him about the Catalogue. He was annoyed. He knew there was to be a catalogue, that was all right, they had come to him about it and were charming and polite. But the illustrations were evidently unexpected, though he gave me the impression of having committed himself unintentionally in some way, and so not having any redress. He began to write down on a bit of paper letters to Freer, to the Committee, to Eddy, and he must write them at once, though Joseph reminded him that the post did not go until Saturday and he had better see Roullier before writing anything. Keppel might possibly be mistaken in detail. Thereupon he began to make Keppel his scapegoat. What had he to do that he should be worrying about it? J. said that Keppel was surprised at the whole business, thought it scandalous if they had not Whistler's permission. He belonged to the Caxton Club himself once, but resigned, they were nothing but rich pork-packers. "And what right has Keppel to sneer at pork-packers?" Whistler wanted to know, "what is he but a dry-goods man?" Then Wedmore came in for his share. J. wondered if they had used Wedmore's Catalogue? "So much the better if they have, then I can write letters about Wedmore that I would like to have published." He was almost snappish with J. "Why repeat it?" he said, "when I know it all already." Altogether, clearly he was annoyed and when it was arranged that Roullier should come to his studio at four, he had an engagement with Mr. Russell at five, and J. suggested that he and Heinemann should come a little before Roullier, 146 


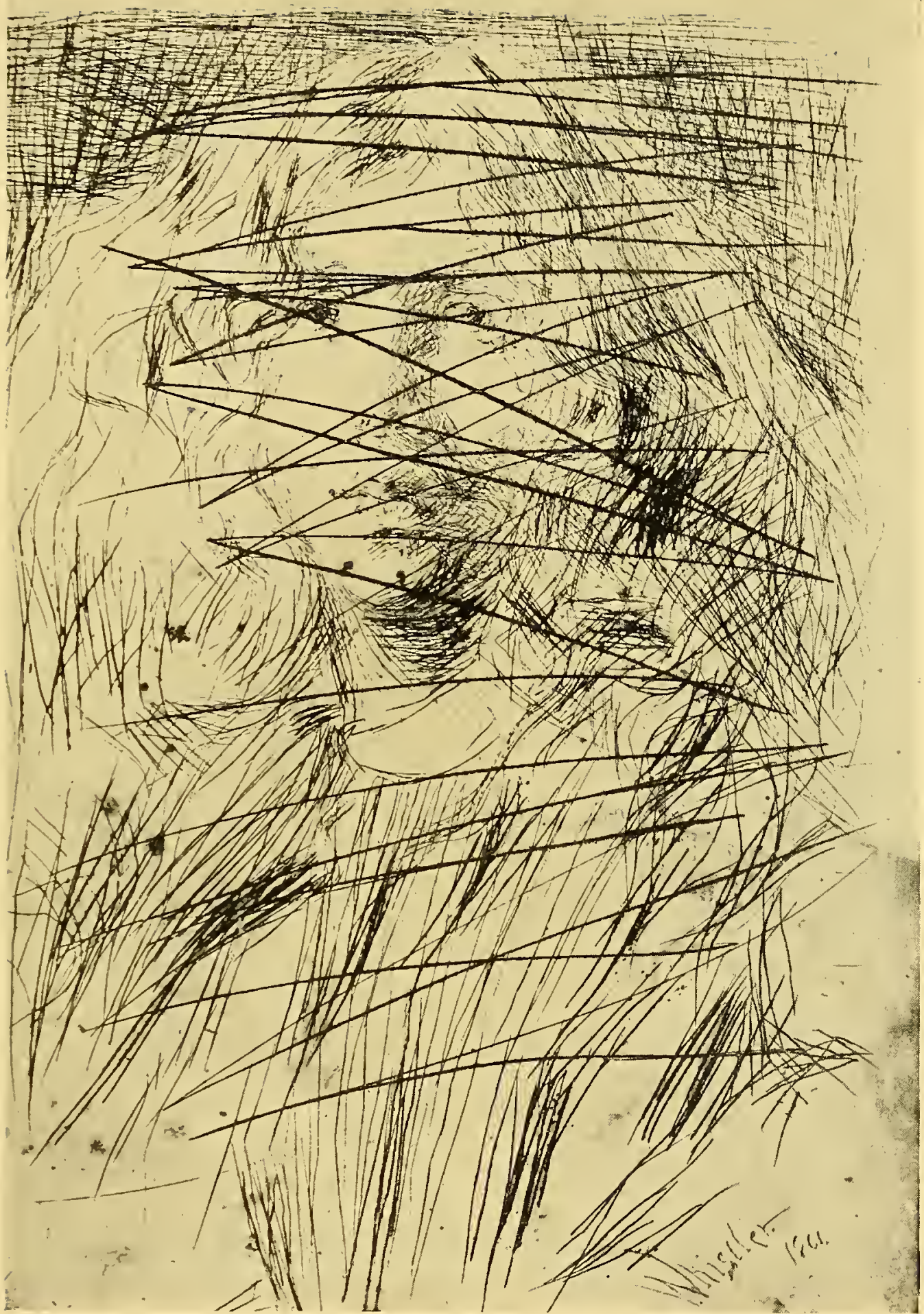

JO

DRY-POINT. M. 77 .

Print from the destroyed plate

(See page I $6 I$ )

Pennell Collection, Library of Congress, Washington 
he was furious "A regular invasion of my studio." But he saw the necessity and agreed.

Another step in The Architectural Review affair. His letter to Wilson brought an apology from Abram to Grimaldi, and a request that Grimaldi would call again on Tuesday. "And then, you know, the Lord interfered. Grimaldi had a sunstroke and went to bed-and I dictated a very Whistleresque letter from Grimaldi to Abram, his regrets and he was ill, and the cheque was the thing. There was nothing to talk over." And so, about twelve, he went off, J. walking to the hotel with him.

THIs note retains something of the excitement into which we were all thrown by the first news to reach us of the Catalogue planned by the Caxton Club. Mr. Keppel who brought the news was Frederick Keppel whom Whistler had unfortunately and mistakenly ranked with "the enemies," and Roullier was Albert Roullier of the Chicago firm of his name. The agitation was great while it lasted, for any disturbance of this kind was irritating to Whistler when it interfered with his work, while to Heinemann and ourselves the results might have been serious because of the use of the illustrations which we feared might take from the importance of ours. However, nothing worse came of it than much worry and time lost for a few days. The Catalogue, eventually, was published without illustrations. It was compiled by Mr. Howard Mansfield and is the only complete catalogue of Whistler's etchings, for Mr. Kennedy gave up the descriptions and trusted to illustrations, and for practical work one is compelled to use both. The Illustrated Grolier Catalogue, compiled by Mr. E. G. Kennedy and published much later, contains a complete set of reproductions of Whistler's etchings. But they are not done by photogravure and there is no danger of their being confused with the originals. What Whistler was afraid of was that reproductions in photogravure might be made, as some had already been made, of the same size as the originals, and that collectors might be deceived by them, as indeed they had been during his lifetime. Since his death many of his etchings have been reproduced by photogravure, including a number published by $\mathrm{J}$. in his Etchers and Etching, but as these were all signed by Ringler, the photo-engraver, and as they are a different size from the originals, there is no excuse for any collector being deceived by them, though they are remarkably good reproductions. Whistler was always worried about the publication of I 900 ] 
his prints and the minute we heard of the proposed Caxton Club venture, we realized what it would mean to him.

It is because we know how Whistler felt in this matter that we regret the more the action of his executrix which led to much confusion among collectors of his lithographs. She would not allow Way, who alone understood anything about the stones from which he had printed Whistler's work, to print them, though Whistler, after he gave up Way and took the stones from him, had been willing for him to print the portrait of J. for our Lithography and Lithographers, sure that no one else could print it so well. Instead, Miss Philip turned over such stones as she chose to Goulding who knew nothing about them and did not know how Whistler wanted the proofs pulled, and who used for the reprints not Whistler's good old paper, but modern O. W. paper. The water mark can be seen on the prints, a guide to the collector of intelligence. They were not signed as they were printed after Whistler's death. Many of his lithographs were printed during his lifetime without his knowledge and later issued unsigned, and these were, as a rule, printed on old paper by Way. They are genuine, but not signed by Whistler. Miss Philip, we believe, asked for the reprints, sold by Dunthorne and as we have said unsigned, the same price that Whistler asked for proofs printed by Way and signed by himself. There was nothing that was not correct in this proceeding, but Whistler never would have permitted it. The whole affair was a failure, or rather it failed because Goulding used his own modern paper, by which the reprints can be easily detected. It has also been stated that Goulding was furnished with transfers instead of the original stones. The Ways certainly printed many proofs, giving one set to the British Museum and at last selling more or less complete sets at auction, while for long it was possible to get proofs at their office. On one occasion stones were brought to the Art Workers' Guild, printed from, and the proofs given away. But the Ways only imitated the editors of The Whirlwind. So long as Way's Shop was in Gough Square there were prints by Whistler in the windows.

In January, I92I, Messrs. Frederick Keppel and Co. showed in their gallery in New York a collection of lithographs and, concerning them, Mr. David Keppel told a curious story which he said he had from Mr. G. Meyer of Messrs. Colnaghi and Obach, London: -that to Miss Birnie Philip, along with the lithographic stones, Whistler left "a small supply of the finest old paper which he had collected, with definite instructions that she take a tirage and then render it impossible for further proofs to be taken . . . by covering 


\section{Jo AND MAUd}

them with a sort of varnish which makes it impossible to print from them but leaves the stone itself with Whistler's drawing still visible." This statement of Mr. Keppel's is interesting and a surprise to us because, before these prints were exhibited in his gallery, we had only known of the prints pulled by Charles Goulding on O. W. paper. Mr. Keppel further says that Whistler left a certain number of proofs printed by Way, and that these impressions were signed in pencil with the Butterfly. In order that there might be no confusion, Miss Philip stamped every print on the back with her initials; those of Way's printing with a stamp having a square border and those of Goulding's with a round one. He further says that as the stock of old paper was soon exhausted, some of the stones were printed on $\mathrm{O}$. W. paper, bringing the number printed by Goulding to about thirty-five prints-not proofs as Mr. Keppel calls them-each. The whole story is confusing, though the prints are not, for Mr. Keppel further says that the number printed by Way and Goulding together was about sixty. As Way has most distinctly stated in his Catalogue that only six or seven of some of these stones were printed, it is not easy to make the numbers agree. Another thing, the lithographs were not printed by F. Goulding but by his brother Charles Goulding, and the use of the name Goulding is rather misleading as F. Goulding never printed lithographs, but turned them over to his brother who did. And the statement that they were printed under Miss Philip's directions hardly makes the matter clearer. Goulding told J. that she did come to his place while the printing was being done. The whole business, even down to the stones, as we have stated, is another Whistler mystery. The only genuine Whistler proofs upon which collectors can rely are those signed by the artist and printed during his lifetime.

Friday, July 20th. J. spent the day mostly between Heinemann's office, Keppel's rooms and Whistler's studio-with the result that a letter was written by Whistler to the Caxton Club to stop the publication of the photogravures after his etchings in the proposed Catalogue.

Dined at Sauter's; no one else there but Whistler. An oppressively hot evening. We found the road up just before Notting Hill, and had to make a great détour, and were a quarter of an hour late. But Whistler was half an hour later; he had been to Kew, he said, hunting for the house. The talk at dinner was largely of the Boers: Ig00] 


\section{The Whistler Journal}

the Sauters sympathizing, he could say what he wanted. After dinner, the men stayed in the dining room and talked about the International. When they joined us in the garden, he slept a little. But I was struck, when, afterwards we went up to the studio; with the interest he showed in Sauter's work, and the way he managed with a word to point out the defects or merits in it. There was a big more than life-size portrait of Prince Troubetzkoi on the easel-a sort of Sandow creature whose very size, as you looked, seemed to knock you down. Presently Sauter brought out a portrait he had done of himself, a half length, on a much smaller scale-a little less than life size. "There," said Whistler, "that is the way you saw yourself, isn't it, when you looked in the glass a few feet away? Then you must have seen Troubetzkoi like that too, and not like the giant you have painted." We all drove home together-but he slept most of the way.

Sauter is George Sauter, a Bavarian artist, who came to London to live and then married Miss Lilian Galsworthy, sister of Mr. John Galsworthy. They had a delightful house and studio in Holland Park Avenue, where Whistler was always glad, as we were, to go. The house now stands for tragedy-the life in it wrecked by the war as was the life in so many other houses not only in London, but the world over. Sauter was first interned, then sent back to Germany. It is his own country, true, but the best years of his life were spent in England which, therefore, is for him the land of many associations and friends. With the feeling as it is now, the chances are he can never return, though it might be recorded that the English, more generous than we showed ourselves, realized that an artist has nothing to do with military affairs and got up a petition for his release from the internment camp. But since then the British Government has made his life a burden. The petition was signed, among others, by Lavery, Guthrie, the directors of several galleries, and other prominent people. But nothing came of it, except Sauter's deportation to the land where he belonged by birth, exchanged with an English prisoner of war interned in Germany.

Two reminiscences connected with Sauter have an appropriate place here. Years before, there was to be an exhibition in Munich and Sauter was appointed Commissioner in England. Whistler was asked to meet Herr Paulus, the manager of the exhibition, I 50 


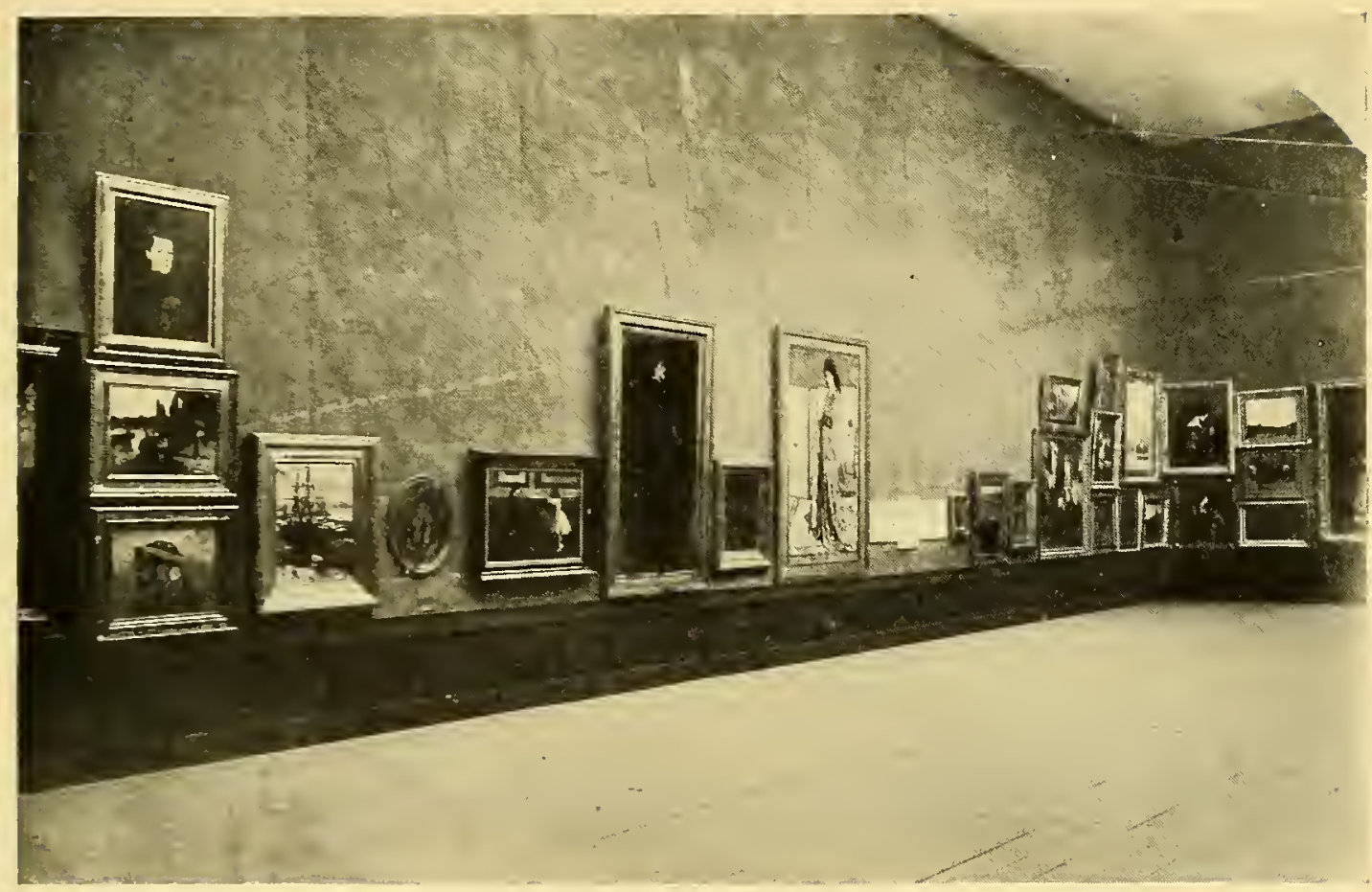

WALL OF THE FIRST INTERNATIONAL EXHIBITION AT KNIGHTSBRIDGE The Centre Group of Works arranged by Whistler. Photograph

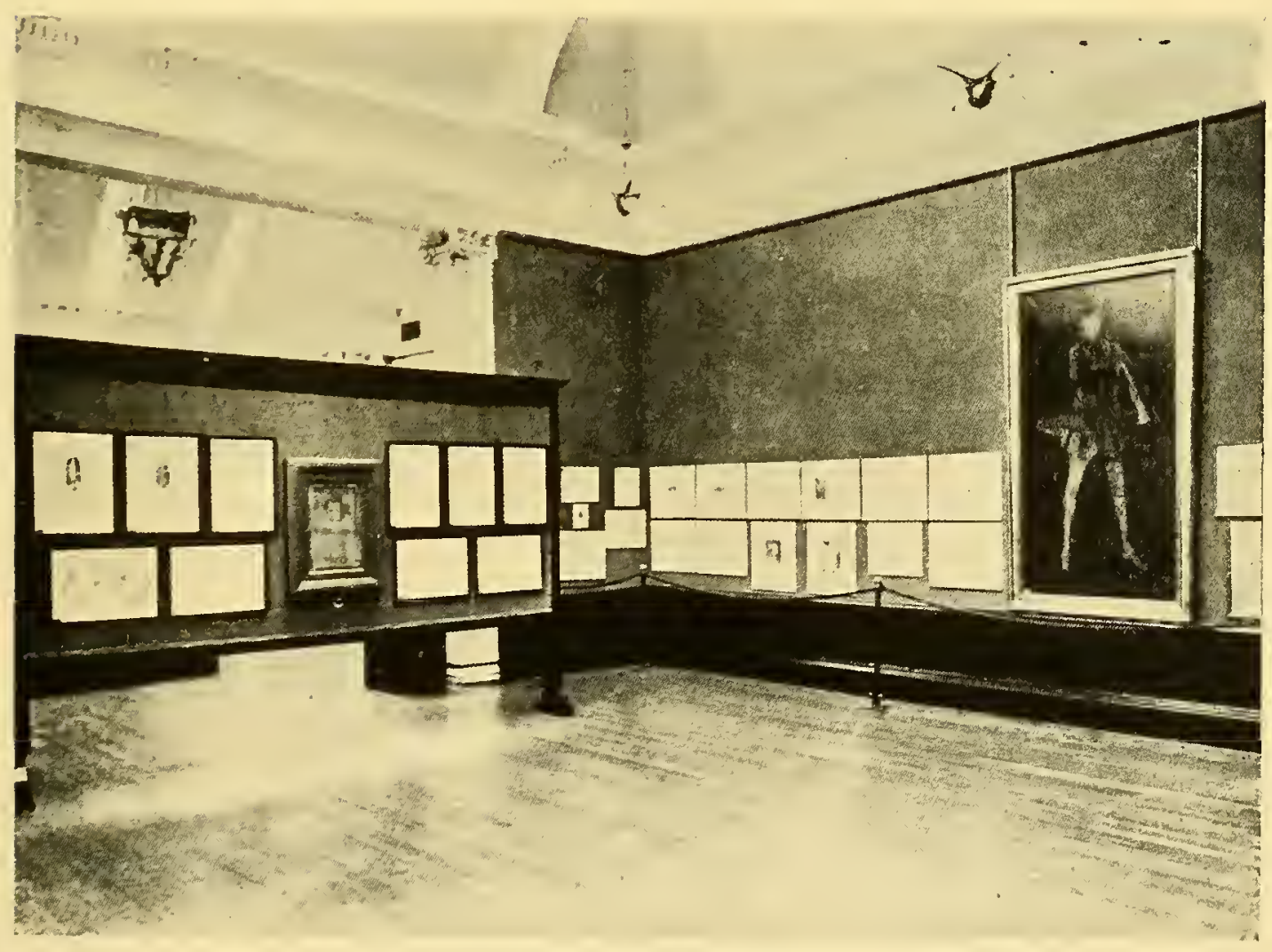

WALL OF THE WHISTLER EXHIBITION AT BRADFORD Arranged by Joseph Pennell OILS, WATER-COLOURS AND PRINTS HUNG TOGETHER Whistler's Scheme. Photograph 

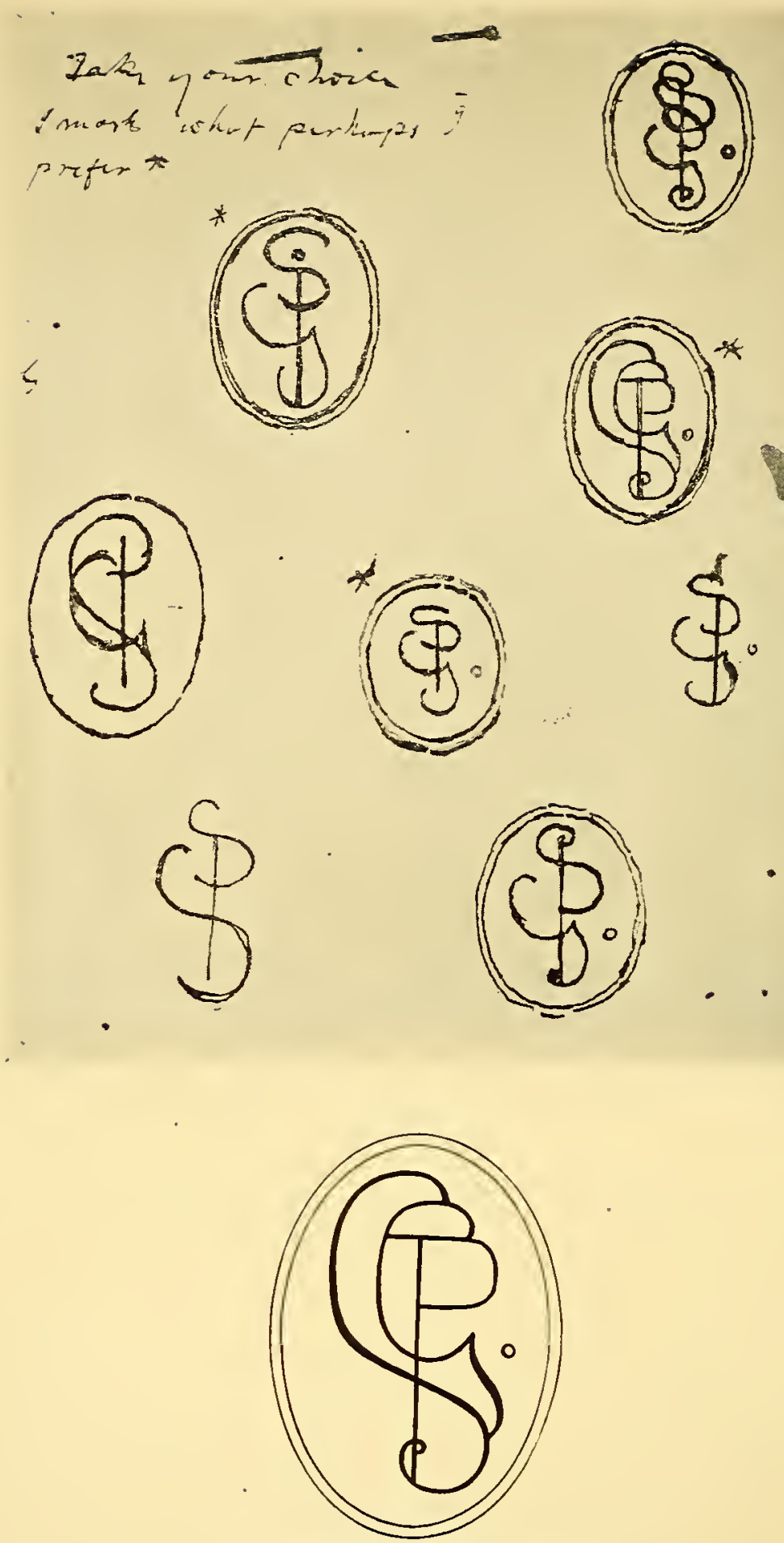

SKETCHES BY WHISTLER PEN-AND-INK

For the Seal of the International Society of Sculptors, Painters and Gravers and the Final Design Used by the Society

(See Appendix I, page 306) 


\section{Jo And Maud}

and a distinguished company, at Sauter's father-in-law, Mr. Galsworthy's. He came about an hour late, but they had waited for him, and the old gentleman, in a severe tone, greeted him with the remark: "We are all so hungry, Mr. Whistler." "What a good sign," said Whistler, and they went immediately to dinner. It was at Sauter's house another evening that Mrs. Sauter told Whistler of Felix Moscheles' experience in Trafalgar Square shortly before at a Peace Demonstration. A knife was thrown that just missed him. "Ha! ha!" laughed Whistler, "and so Moscheles just missed the knife. So like Moscheles. Always just missing something. Ha! ha! And he just missed the knife."

Sauter was for some time Honorary Secretary of the International Society, and a more faithful supporter and admirer Whistler never had. Whether Whistler was in London or Paris, if not at the meetings, which he always attended when he could, he had to receive a written copy of the Minutes with full explanations, brought or sent to him by the Honorary Secretary. He was not President in name merely, but he insisted on knowing everything that was done by the Society.

During the whole of his Presidency, which lasted to the day of his death, the members of the International Society of Sculptors, Painters and Gravers, the title of which even was Whistler's, were absolutely though not abjectly devoted to their President. It was he who made the Society, his influence and energy which made it a success. There were at first scarcely any English members in it. They were mostly Americans, Frenchmen, Germans, Scotchmen, Irishmen, Scandinavians-only one or two English. If a meeting of the Council was to be important, Sir James Guthrie would come up from Edinburgh, and Thaulow and Blanche from Dieppe, where they had been consorting and intriguing with the allies and the enemies-in art, not war.

One day, J. remembers, J. J. Shannon, a member of the Council, was elected to the Royal Academy. Whistler's abiding faith was that an artist should belong actively only to one society and always show in it, and, so far as he was concerned, that society was to be the International. The news of Shannon's election reached Paris and Whistler at once wrote, or wired, that Shannon must either decline his election to the Academy or resign from the Council of the International. If he did not, Whistler would resign himself. "It was no moment of half measures, peace was not their preoccupation. The Society was a fighting ship and carried the very best shots in Europe." A meeting was at once called. Shannon attended. He refused to resign from either. After a lengthy dis- 


\section{'The Whistler Journal}

cussion it was arranged that he should be made an Honorary Member of the International Society, as already one or two Royal Academicians held that rank. The Council were aware that no such information could be written to the President, and they deputed Lavery and J. to go to Paris and straighten things out, if they could.

They caught the nine o'clock train from Charing Cross. There were no cabins on the boat, no sleeping cars on the train, and, sad wrecks, they landed in Paris at dawn. They idled down the Boulevards, drinking as many cups of coffee as they could and eating as many brioches. They had wired they were coming, but they knew they could not see Whistler before ten or eleven, if even then, for he had answered they were to breakfast at noon in the studio. That was six hours away. Lavery had an idea. They would take a bath. They went into the well-known ark with the palm tree smoke stack that, from time immemorial, has stood in the Seine. They were given adjoining tubs, with a partition between and a little window in it. Lavery at once opened the window to ask J. if he had any soap, and of course he hadn't, soap never then being supplied in France. And so they ordered a piece, and after they had soaked and boiled themselves and passed it to each other, and read the papers, they went out to pay their bill, Lavery carefully carrying the soap. In the bill, it was five francs. The proprietor thought he had a couple of Englishmen. He soon found out that Sir John Lavery was very well acquainted with the artistic French of the Quarter. And, as a final piece of advice to the proprietor, he violently threw the cake of soap through the window into the river, only to remember that he had already paid for it.

The rest of the morning was spent in visiting the Luxembourg and calling on Mrs. Whistler in hopes that Whistler might be there. Finally, they got to the studio, there to be received by Carmen, who had been posing in her birthday robe, and she then got breakfast. And after this was finished and Mrs. Whistler came up, he showed them new things and his phonograph which was a new toy. And he talked of everything, except the Society, until it was almost time for them to go. And then he told them just what had got to be done, and they hurried back in the three o'clock train to do it. And at the meeting called for the next day, it was done, and Shannon was made an Honorary Member and severed all executive relations with the Society. And it might be mentioned also that the Council's devotion for the President and the President's devotion for the Society went to the extent of everybody paying I52 


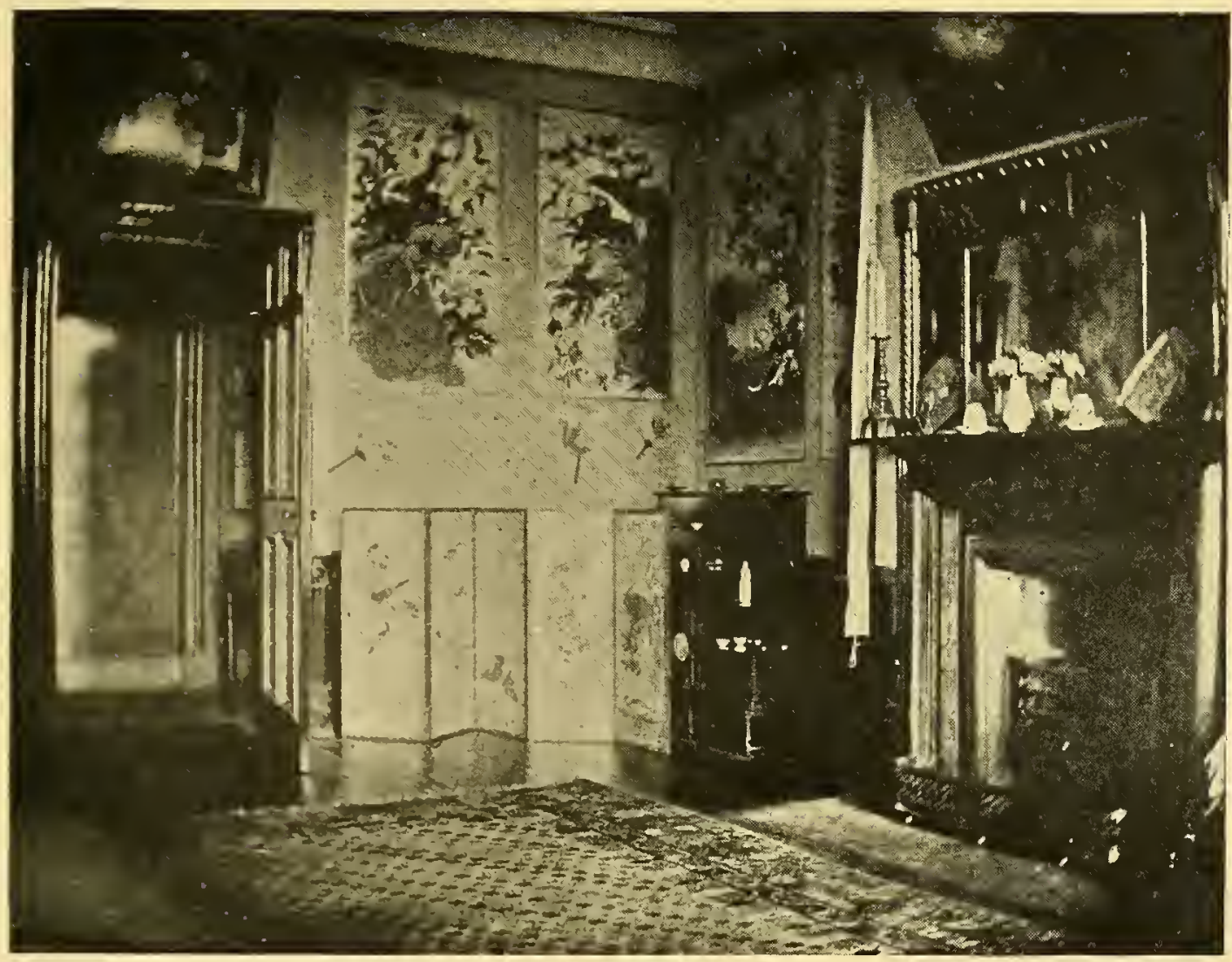

INTERIOR OF ROOM IN WHISTLER'S FIRST HOUSE IN LINDSEY ROW SHOWING THE MANTELPIECE BEFORE WHICH THE LITTLE WHITE GIRL WAS PAINTED CONTEMPORARY PHOTOGRAPH

Loaned by Mr. Chambers.

(See pages 117,161 and 300) 


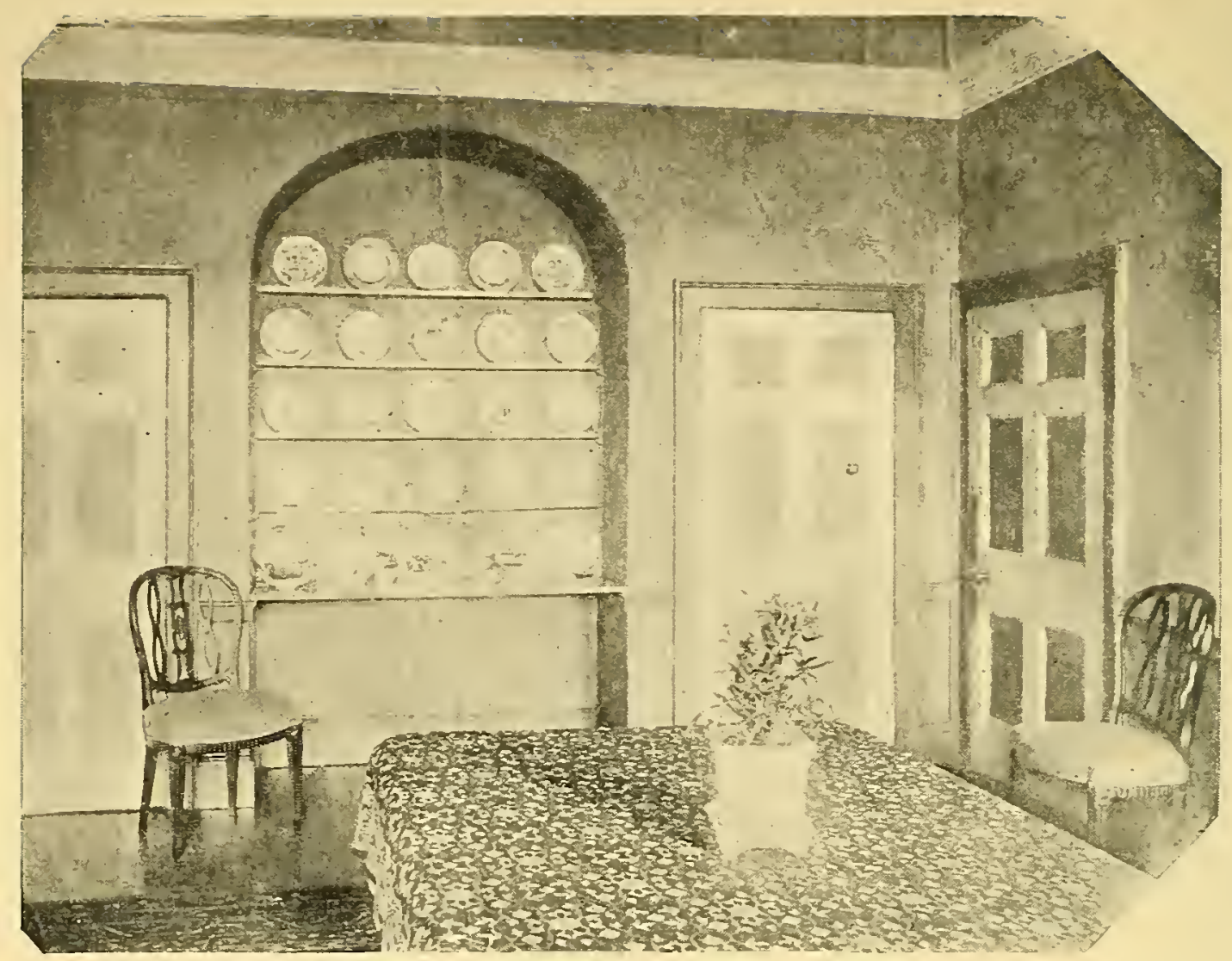

DINING-ROOM IN WHISTLER'S FIRST HOUSE IN LINDSEY ROW CONTEMPORARY PHOTOGRAPH

(See page II7)

Loaned by Mr. Chambers 


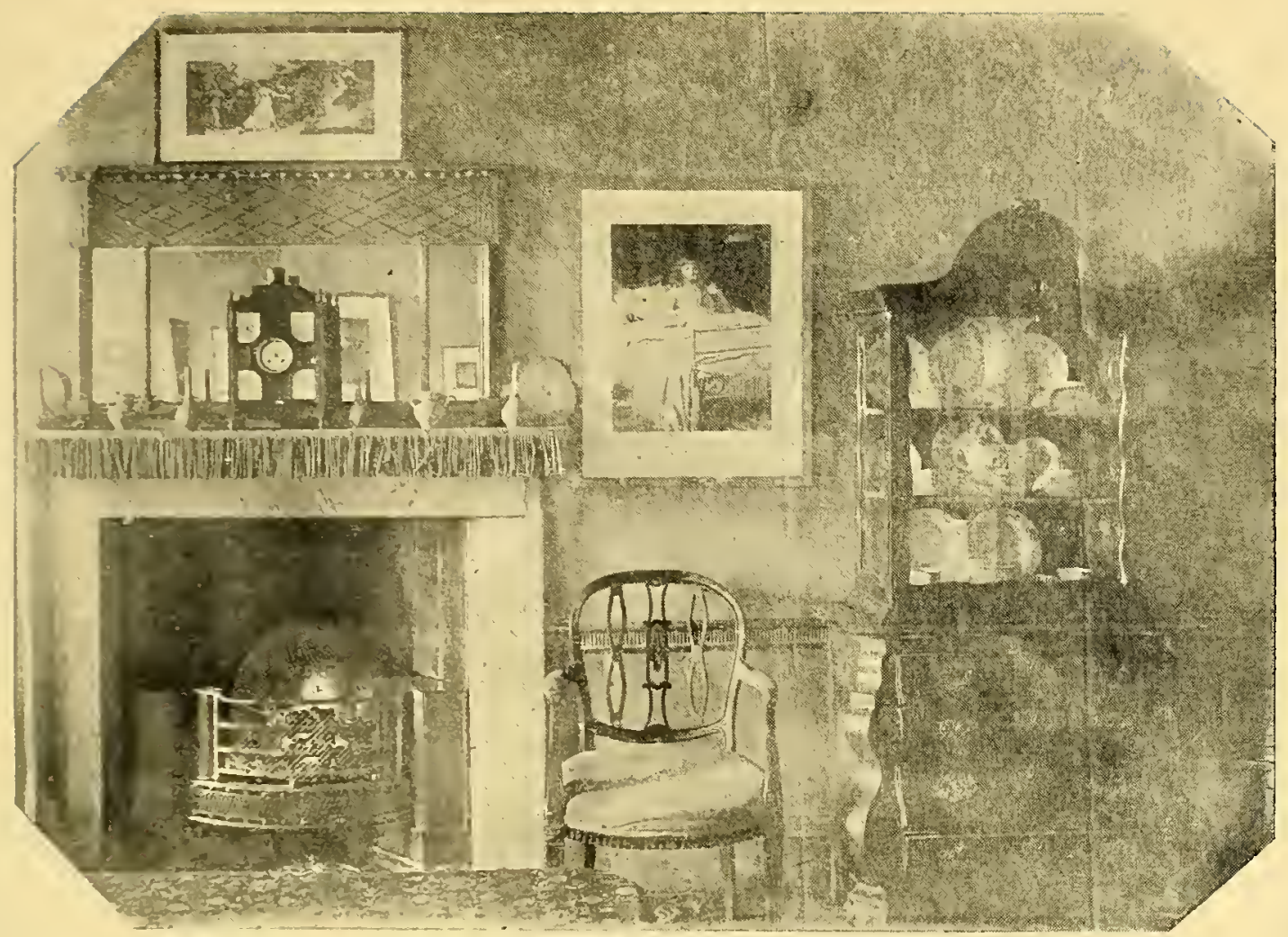

FIREPLACE, DINING-ROOM IN WHISTLER'S FIRST HOUSE IN LINDSEY ROW CONTEMPORARY PHOTOGRAPH

Loaned by Mr. Chambers

(See page II7) 
their own travelling expenses. There was a large amount of correspondence with Whistler when J. became Honorary Secretary for a time, but most of this has disappeared. It may, and it is to be hoped that it will turn up again some day, for, when the letters were read to the Council, they showed Whistler's intense interest in the Society, his practical suggestions for its success, a perfect contradiction to all those who say that he had no business ability. At any rate, it is probable that there are copies of these letters in the possession of the executrix, and they ought to be published. His private letters were as full of the subject. When ill and unable to preside at meetings, he insisted upon J. coming or writing to tell him all that had happened-" to the Captain in his berth everything must be reported." The Journal is a proof of thisso are his letters to us. He wrote from Paris to urge J. to go to all the Council Meetings, to see to the hanging of the exhibitions, not to forget to look out for Forain, or Milcendeau, or Thaulow, for one reason or another in anxiety about his work. Plans of the galleries were forwarded to him in Paris and returned with suggestions even to the placing of chairs and tables. No detail was too small, no scheme too large that could add to "the finish and intimacy and mystery and general richness and concentration of the exhibitions."

Thursday, July 26. Whistler came in for a few minutes early in the morning, about half past nine, a hansom waiting for him at the door, to say he would dine to-morrow evening to meet Mrs. Whitman. He wore his white waistcoat and trousers and his hammock hat, and, for the first time in my experience, seemed exhausted by the heat. He was too tired to say anything, except that he thought he would have to get out of it. Mrs. and Miss Philip are going over to Ireland on Monday or Tuesday, and will look for a house and then he probably will join them.

Friday, July 27th. Whistler and Mrs. Whitman came to dinner, and I left the conversation to them: Mrs. Whitman, the intelligent, emotional, "brainy" Boston woman, with a quotation, an anecdote, the right word for every occasion. Whistler appreciative of it all. Why did he not come home? Such a welcome was waiting. He had no idea of the respect and honour in which he was held. "They have a funny way of showing it," he said. "If I900] 


\section{The Whistler Journal}

ever anything particularly offensive reaches me, well, you know, it comes from America. If anything goes the rounds of the papers here, it is taken up, intensified a hundred fold in the American papers. When I go to America, I shall go straight to Baltimore, then to West Point, then sail for here." No, she said, they would come down upon him from Boston, seize him by main force and carry him off.

She had been to the Academy and seen the big Sargent. "It looked like a heap of women being poured out of a picture." Whistler repeated very much what he has already said of Sargent. "Well, you know, people tell me it is so clever. Has any one ever stopped in front of a Titian or a Tintoretto and called it clever? What? That sort of cleverness is infernal. I wouldn't, for a moment, have anyone think I was saying anything about Sargent, who is a good fellow, but as for his work it is neither better nor worse than that of the usual Academician."

Then the Boers followed. Buller making them respect his rear. I said that should remain in history in his words. After Mrs. Whitman had gone, he asked me what had he said that should "remain"? An evening, however, not easy to record.

Mrs. Sarah Whitman, as a painter and designer is known even outside Boston. She wrote to E. when she heard of Whistler's death, knowing what it meant to us both, and in her letter she spoke of her meetings with him in our flat, where he seemed happier than anywhere else after the loss of his wife:- "I cherish a long gratitude for those moments you gave me with him-the only really happy ones I ever saw him have after Mrs. Whistler died. The rest was sad and full of remembrance, and I like to think he is at peace." The Sargent Mrs. Whitman referred to is one of six in the Royal Academy of I900-the portrait group of the three sisters, Lady Elcho, Mrs. Adeane and Mrs. Tennant.

Whistler was bitter about the way he was treated in America, the more so because he never forgot that he was an American, ready as his countrymen were to forget it. He railed at the "cursed Yankees" to Mr. Lucas when he was badly hung in the Paris Exposition of 1867 , though it was in the American Section he preferred to show when he was decently treated. Again, he was furious with "these infernal American people" who are so horrid about 


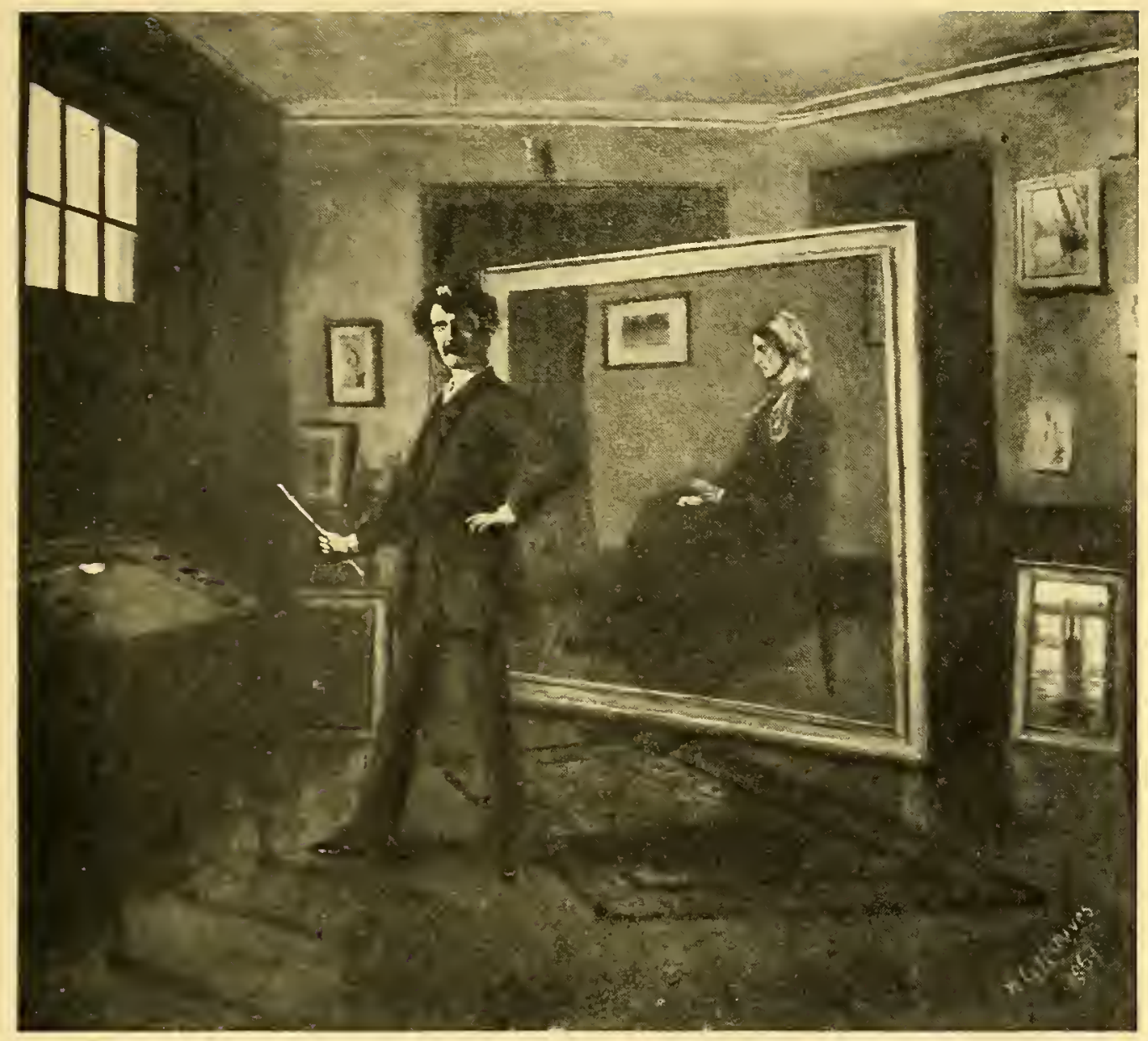

INTERIOR OF THE LINDSEY ROW STUDIO

Whistler Painting the Portrait of His Mother

OII,

By Walter Greaves

According to Walter Greaves the date 1869 is on this painting in Greaves' writing. The painting Ballersea Bridge is shown in it behind the portrait of the Molher, though it was not exhibited until 1877 -and the Molher was not shown until 1872. Besides which, at no time to our knowledge, did Whistler have a number of his paintings and prints on the wall. No! was the table palette on an angle like a desk. And we never saw any such shaped room in Chelsea

In the possession of the Rosenbach Co.

(See page $r(6)$ 



\section{Jo AND MAud}

the taxes for, as every American artist who has lived in London knows, the getting of a consular certificate when work is to be sent home is a nuisance as horrid as Whistler called it. And he resented his treatment by American papers-thought it, really, a curious thing to notice how offensive they always were to him when they got the chance. But it hurt him most that Americans misunderstood him as persistently as "the Islanders." We are still often astounded at the entire misconception of him and his art and his standard of conduct among some people in our own and his country. It grows stronger every day and little men are belauded by little critics that they may be shoved into his shoes. Of the sort of thing thought and said we had an instance two or three years after Whistler's death and made a note of it at the time.

February 15th, 1907. Dined with Mrs. Potter Palmer. She hadn't much to tell us about Whistler we had not heard except that Mrs. Farquhar (Miss Peck) never got back her portrait. Whistler returned the money. And the Pecks had talked about it and exaggerated it to themselves until now they are honestly under the impression that it was the most wonderful portrait he ever painted and that he wanted to keep it himself to show and exhibit as a contradiction to the reports of his falling-off, and then sell it for an enormous price.

This was repeated to J. when he was giving the Scammon lectures in April, I920, at Chicago, only the story had been carried so much further that he was assured Whistler stole the money. And J. had to explain that, as he knew for a fact, Whistler returned the money and never finished the picture. From the beginning, however, there were the exceptions who understood. American artists were in sympathy, if the American public was not, and we are glad to remember that La Farge was one of the exceptions. When we were in New York in the autumn of I908, we went on the morning of

November I2th, I9o8, with Mrs. Cadwalader Jones, to call on LaFarge in the old studio built by Hunt in Tenth Street. He told us that he never met Whistler until he went to Paris in 1895 , the year his South Sea sketches were in the Champ-de-Mars Salon. Whistler was charming and two things he then said were recalled I900] 


\section{The Whistler Journal}

by La Farge. One was, "Well, you know, when I first came to England I found I had to put my foot in it, and-well-I have kept it there ever since!" Another example of this sort was related to J. by Mrs. Paul Bartlett. One day, she said, he was pitching into some untortunate. "Why do you go for him? He has one foot in the grave," said Mrs. Bartlett. "Oh! that's not the foot I want to get hold of," said Whistler. La Farge's other story was of Whistler saying "I have always had such good luck. Somebody always has said something that gave me the chance to say something I wanted to say in reply." La Farge's comment was that this, like many of Whistler's sayings, sounded like a witticism but was really sound, brute common sense. Whistler sent a picture called Seule (The Coast of Brittany: Alone with the Tide) to the National Academy in New York and La Farge and St. Gaudens, who were on the Selecting Committee, at once accepted it. The Hanging Committee, of which they were not members, skied it, above a door. They were indignant, and La Farge said it was then, in their indignation, that they resolved upon their secession from the Academy, and founded the Society of American Artists.

This is La Farge's own story. He was an artist, not an amateur like many people who have told other stories. Over officious American friends sometimes made Whistler see an offence where none was intended, thus adding to his irritation. It was a grief to us when, in the last months of his life, he was worried and angered most unnecessarily by Freer's report of the shocking indifference with which his pictures were hung in that year's exhibition of the Pennsylvania Academy of the Fine Arts. Mr. Harrison Morris, who was in charge, has always assured us they could not have been better hung. So have Mr. Henry McCarter and Mr. McLure Hamilton who saw them and who explained the screen which was the chief offence to Freer. It was not the usual sort stuck up in the middle of the room but one placed at the end of the large gallery, making a centre, and the Whistlers on it formed the only group to which a panel was given.

Sunday, July 29th, Igoo. Whistler to dinner with me alone. J. still away. He brought Reynolds' newspaper with him, which he read with glee after dinner. But the chief talk was of spirits. He I56 


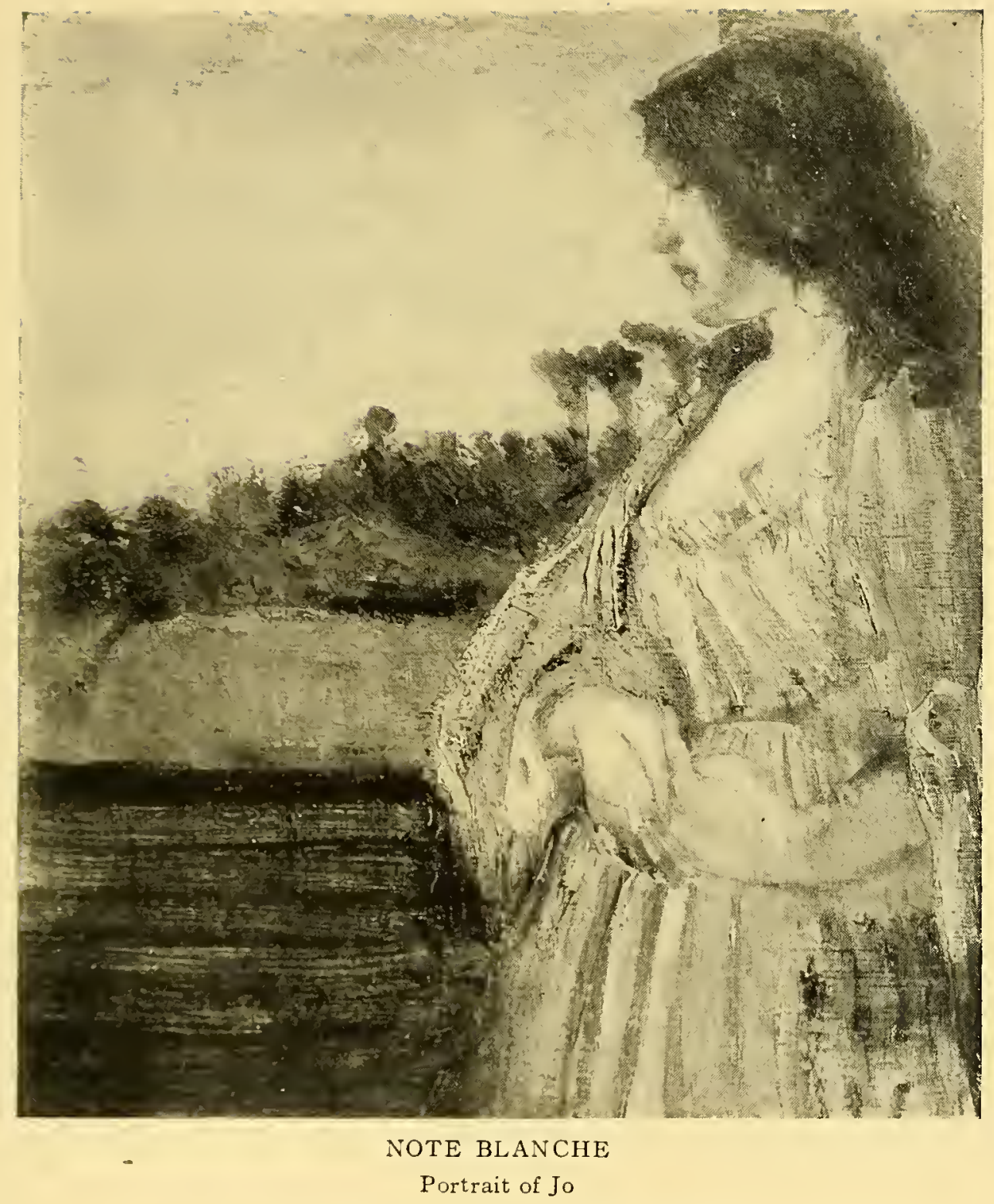

oll.

In the possession of Mrs. Cobden Sanderson

(See page ${ }_{1} \sigma_{1}$ ) 


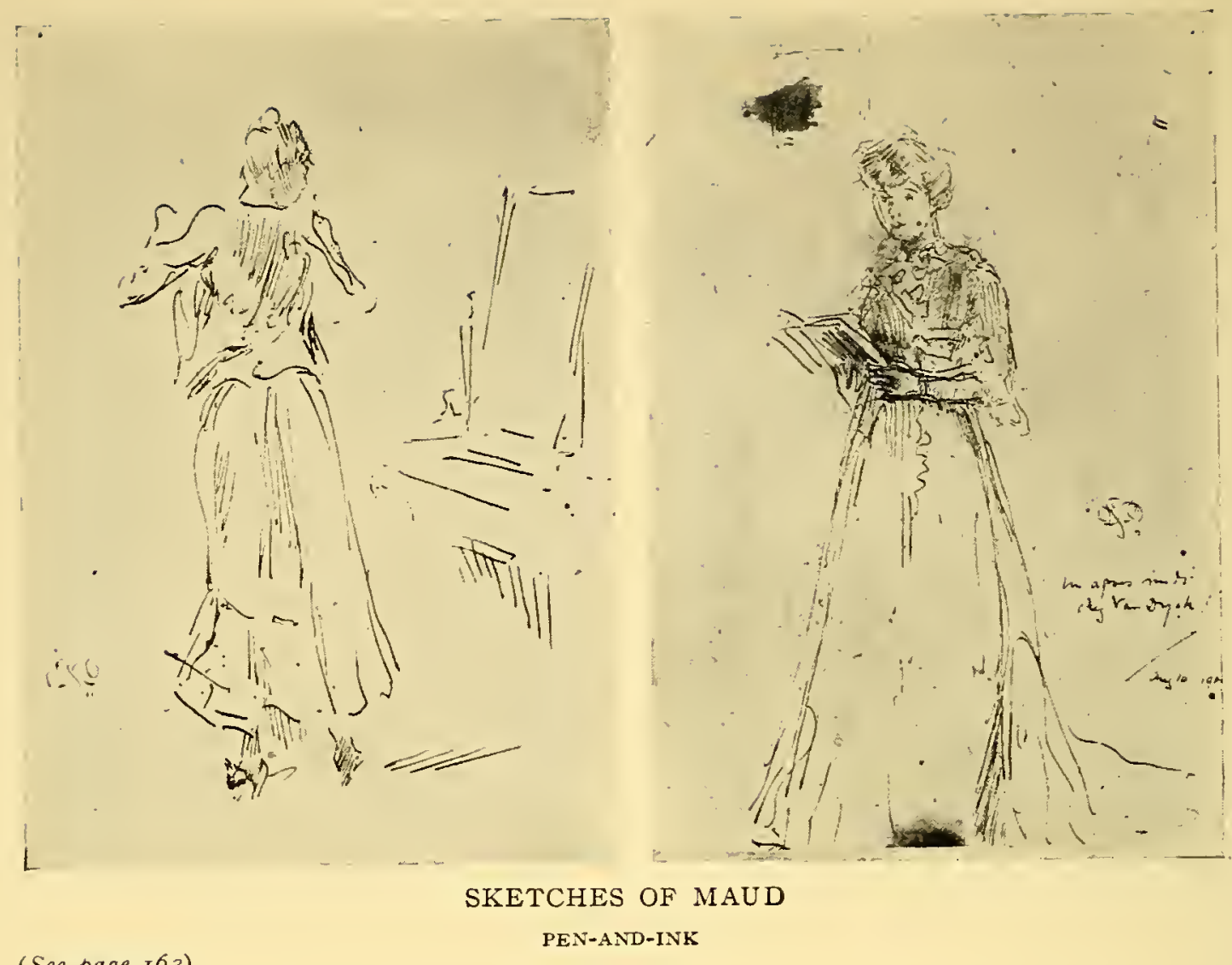

(See page I63) 
told me how, in the old days, he went to Rossetti's, the White Girl-"the Irish girl with red hair" - with him, and they all put their hands on the table, and wonderful things happened. "One day, I and the White Girl went into her room and just the two alone tried the same experiment, and a cousin from the South talked to me and told me the most wonderful things. Again by holding a lacquer box, a beautiful Japanese box, one of the many wonderful things in the Chelsea house, between us, we had the same sort of manifestations. But it is a study, really, that would engross a man's whole lifetime, and I have my painting to engross me. I believe? Yes." Every argument against it was disposed of. "The silliness, as a rule, of the spirit's performance? They may seem silly now, but wasn't the beginning of some of the wonderful electrical contrivances we have the mere dancing of little paper dolls on a table? The darkness that is always necessary? Why not? Everyone knows, there are certain chemicals that act only in the darkness. Why should it not be the same with the spirits? How can we understand the conditions that rule them? For myself, I have no doubt-the very fact that man, beginning with the savage, has always believed in them is proof enough." And in his interest, he stayed talking until half past eleven.

"The Irish girl with red hair" is Jo. He made experiments also with Maud: "could get only noises from sticky fingers on the table," was Mr. Cole's note afterwards of one of these experiments. The subject fascinated him. It may have been because of the Scotch, the McNeill, blood in him. He was evidently something of a medium while his brother, the Doctor, had curious warnings or presentiments-the Scotch second-sight-all his life, we were told by Mrs. Dr. Whistler who gave us two incidents. In Richmond, during the Civil War, suddenly one day he knew, though he did not know how, that a ship under a flag of truce was coming into a near port and that his mother, whom he had no reason to expect, was on board. On the strength of this, he got leave, started off for the port, and arrived just in time to meet her. Again, the day and hour E. W. Godwin died, he knew it, said so to his wife, though the actual news did not reach them until a few hours later when Whistler brought it. More than this once, Whistler spoke to us of spirits and his experiments with them. Probably nobody I900] 


\section{The Whistler Journal}

would have been more interested than he, could he have foreseen that his own spirit was to communicate with the most unlikely mediums, was even to dictate a book, Echoes of Whistler, to Dr. L. C. Alexander, whom Shakespeare had already honoured as the medium to take down his biography by dictation, revealing among other facts that his grandfather was a Jew. Whistler's communications were presented in such un-Whistler-like fashion that critics and public failed to see in Dr. Alexander simply the medium through whom Whistler was speaking. The critics cannot be blamed. We would never have imagined the book had not been written by Dr. Alexander had he not told us so himself. We first heard of him from Clarence B. McIlvaine, then London representative of Harpers. He was lunching with us to talk over our Life of Whistler which the Harpers wanted to publish in America:-

September Ioth, Igo6. . . . He told us of a Dr. L. C. Alexander-of whom he seemed to know nothing except that he lived at Putneywho had asked them to publish a volume of essays by Whistler which Alexander had prepared for publication. Naturally, this brought up the question of copyright, and it came out that he was a spiritualist and that the essays were communications received from Whistler after his death. It was arranged that Dr. Alexander should see Miss Philip at the Harpers' office, and after some correspondence, the meeting came off, but McIlvaine kept well out of the way. The upshot of it was that Miss Philip objected to the publication and McIlvaine had not heard from Dr. Alexander since.

We were therefore prepared when two or three weeks later Dr. Alexander wrote to $\mathrm{J}$. An appointment was made.

September 28th, J. to the National Liberal Club to meet Dr. L. C. Alexander. ... He neither knew nor saw Whistler during his lifetime, but since his death Whistler had communicated to him thirty essays, notes, and drawings. Dr. Alexander sits down, a pen in his hand, and his hand writes of itself, at times draws, the drawings always portraits, caricatures of Whistler. He promises to let us see essays and drawings. He declares himself no crank. He founded the Royal Historical Society and the Alexander Medal, he is a friend of Dr. Ginsberg and many men of repute. But here I 58

$[1900$ 


\section{Jo and Maud}

is a fact which he does not pretend to explain. If another man were to come and tell him the same story he would say that man was mad. But there it is, and he is the first to admit it extraordinary. His impression from these communications is that Whistler laughed because, if he hadn't, he must have cried.

He sent us a copy of his book when it was published. It fell flat, and we were not surprised. It is dull, the one thing Whistler never was, and we have not to this day been able to read it through. The drawings, which J. saw and which were not published, were characterless and beneath contempt, the whole thing a pathetic, if unconscious fake. There is not the slightest hint of Whistler's character in the book or the drawings. Whistler's next manifestations reported to us were to D. S. MacLaughlan, and from him too we had the story direct four years later.

March I3th, Igro. MacLaughlan's wife in Nashville, Tennessee, where she comes from, had got mixed up with spiritualists and people who held séances, to which he often went with her. Once, when they were trying to get knocks from a table, and only one or two of the party knew anything of MacLaughlan, a message came from a mysterious spirit whom nobody could understand at first. Finally they asked the spirit if it was German? Italian? French? At French, the table fairly danced. It explained that it was an artist, J. Herbert, and as it spoke in French, the MacLaughlans afterwards in talking of the affair naturally gave a French äccent to its name. It said it had a message from Whistler for MacLaughlan. Whistler wished MacLaughlan to go on with his etching, to devote himself to it. The French in which this was delivered was very bad indeed. Ever since they have been trying to find out if there was a French artist, Herbert, but without success. And then Joseph told MacLaughlan that J. R. Herbert, the English Royal Academician, who knew Whistler, had a fad of always talking in French which was bad, and the mystery seemed explained. In Florence, the MacLaughlans attended a séance, to which Whistler's own spirit came and told MacLaughlan that he must go on with his etching, and, after other spirits had spoken, announced his return by a curious knock that his spirit alone gave. 1900] 
He said good-night and made some little compliment to Mrs. MacLaughlan. But this, MacLaughlan admitted, might be suggestion. They had been reading the Life and had been struck by what we say in it about Whistler's charm of manner to women, and also about his unmistakable knock at the front door. Whatever the explanation, the story was one of the "amazing" things Whistler would have loved.

MacLaughlan's experiences fired us with a desire to repeat them. The Sauters were as excited, and a séance was arranged at their house of which E. made this note.

March 3Ist, I9IO. Mrs. Sauter had quite a crowd: Sauter and herself, ourselves, the MacLaughlans, the Withers, the Dulacs, Mrs. Craies, Miss Hullah, Mr. Kendall. The séance was held in the studio, round a large mahogany table on casters, lights out and silence. There was nothing for some time. Then the table trembled, moved about, raised itself on two legs, pushed us out of our chairs. At last it rapped, but in answer to no letter of the alphabet except W., when, however, excepting once or twice, it rapped vigorously. Occasionally it rapped yes or no to a question: No, it did not want to give a message to anybody. No, it did not want music. Yes, it did want something. What? A drink. MacLaughlan said an impish power was about, but a strong one. It was asked whether its name was William, Wilfred or Winifred, Sauter asked it in German whether it spoke Italian and Mrs. Sauter in Italian whether it spoke German, but no answer. The fire began to go out. The studio got cold. Sauter, Joseph, Withers and Dulac went downstairs. After that, no more "manifestations" except trembling and vibration, and at last everybody decided too to go down and "get a drink" with the spirit. As we were going, Mrs. Sauter suddenly regretted that nobody had thought of asking it if it was Whistler. And then we got down stairs to be told by J. that after the first tremblings and pushings, which he fancied came from one or another of the party, he decided to see whether this was so, or whether a power stronger than he was at work, and the rest of the manifestations came from his long legs! 160

$[1900$ 


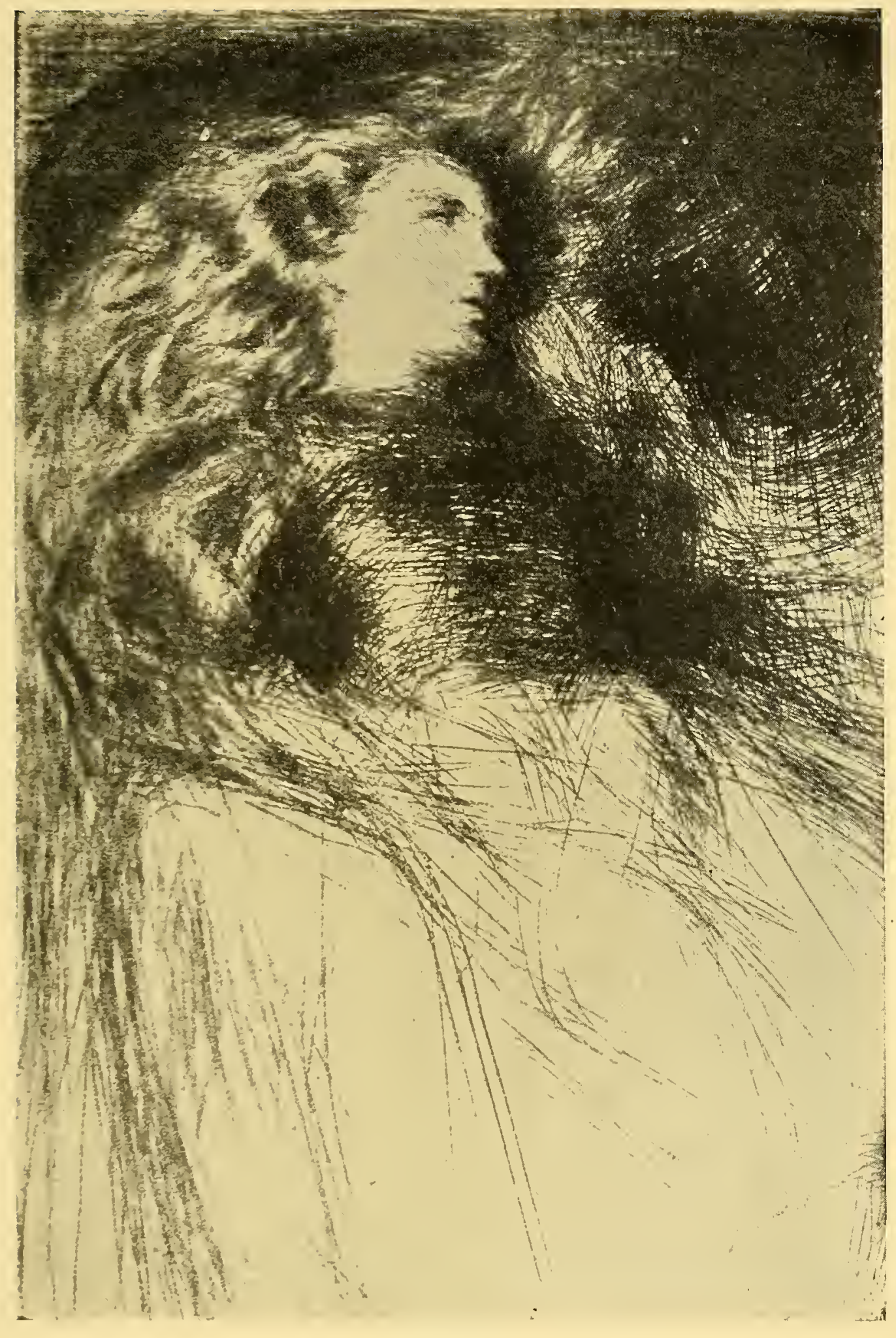

WEARY

Portrait of Jo

DRY-POINT. M. 92 
General dismay and disappointment. But for all that, experiments were tried with planchette. MacLaughlan, at a table by himself, with a clean sheet of paper before him, held a pencil in his hand making it passive for the "power" to write with. A message came: "Whistler is among you this evening. He wants your friends to try again." Of course we all, excepting Joseph and Sauter, hurried back to see the thing through. The table could not be induced to do anything but tremble. And we went home as unbelieving as we came.

Whistler had not spoken to us of the White Girl before this talk of spirits and his experiments with her, though already references to her and to Maud occur in more than one of our notes. It was not that he objected to talking of either. He often did, and of Tillie, and Gussie Jones who was Sandys' "little girl," and the other models who posed for him. It was simply because since The Journal was begun nothing as yet in the talk had recalled them. Jo-Joanna Heffernan-drifted into his studio and his life shortly after he settled in London, in the late Fifties or early Sixties. She was the daughter of an Irishman, Patrick Heffernan, described to us as a sort of Captain Costigan, "a teacher of polite chirography," who used to speak of Whistler as "me son-in-law." Her beauty was great, her gold-red hair a marvel. And she was not only beautiful. She was intelligent, she was sympathetic. She gave Whistler the constant companionship he could not do without, for he was more than most men dependent upon the presence and sympathy of women. Her beauty lives in The White Girl, The Little White Girl, the Note Blanche that belonged to Mrs. Walter Sickert and was at Knoedler's the last time we saw it. She is one of the two figures in the Symphony in White No. III and In the Studio, she reappears in the Japanese subjects and the almost unknown Six Projects which the public will soon be able to see in the Freer Collection, Washington. If the paintings were to perish, her loveliness would survive in two of the finest of Whistler's prints, the dry-points Jo and Weary. Her devotion kept her at his side in the studio and often took her with him on his little journeys from London. She was his companion in the old inn by the riverside where he stayed in 1859 or 1860 and painted $W$ apping, in it grouping her with Legros and a man said by Walter Greaves to be one of his father's boatmen, though Whistler had not then moved into his first Lindsey Row house and did not know the Greaves-and why should they have sent their man to Wapping? I900] 
This was the inn where the Englishmen and Greeks who had been Whistler's fellow students in Paris sometimes came to see and dine with him, and many were the stories told of Whistler there, none he liked better than the tale of the maid of all work who, when he asked her what she had for breakfast, said "Bloaters." "What are bloaters?" Whistler, still new to London, asked. "Why, 'errings, you bloomin' green'orn!"

Jo was again with Whistler in Brittany in the summer of $186 \mathbf{r}$, and the following winter in Paris when he had his studio in the Boulevard des Batignolles. Drouet remembered his pride in her beautiful hair and the way he drew it down over her shoulders to show to Courbet, who painted her as La Belle Irlandaise-the picture called, we cannot say why, The Fair Dutch-woman in John C. Vandyke's Modern French Masters. As La Belle Jo it was exhibited at the International Society's Exhibition of Fair Women in I9IO, and when the printer of the Catalogue changed this title to La Belle Io, the critics were prompt to accuse Whistler of borrowing even The White Girl's hair from Courbet, as a year later they proved him indebted to Greaves for his nocturnes. J. had to explain that La Belle Io was only La Belle Jo, Whistler's wellknown model, and that whatever borrowing may have been done was by Courbet. The next summer, I862, Jo and Whistler were together in the Pyrenees, stopping at Guéthary and Biarritz where he painted The Blue $W$ ave. He had been ordered to the Pyrenees for his health but his concern was for Jo, full of coughs, requiring the mild air of the South. Their plan was to go on to Madrid, to Velazquez, but that journey never came off, then or later, many as have been the false statements to the contrary. The autumn of I865 saw them both at Trouville with Courbet, Whistler painting Courbet on the Shore, and Jo posing to Courbet for Les Irlandaises and studies of Bathers, her hair a glorious note of colour in them all.

Jo shared not only the days of work in the studio and the journeys for work in the summer. She shared Whistler's troubles, she made them hers. She was first of all his model, but she was also his agent, his messenger, his go-between when his money difficulties grew pressing, as they did from the beginning. She was often seen in Bond Street, known there as Mrs. Abbott, the name she gave herself. To art dealers friendly to Whistler, she brought sometimes her own work to sell, for she drew and painted a little. Oftener she brought Whistler's and, if the crisis was acute, would accept as many shillings as at other times he was paid pounds. We have seen in one dealer's house drawings bought in these emergencies 


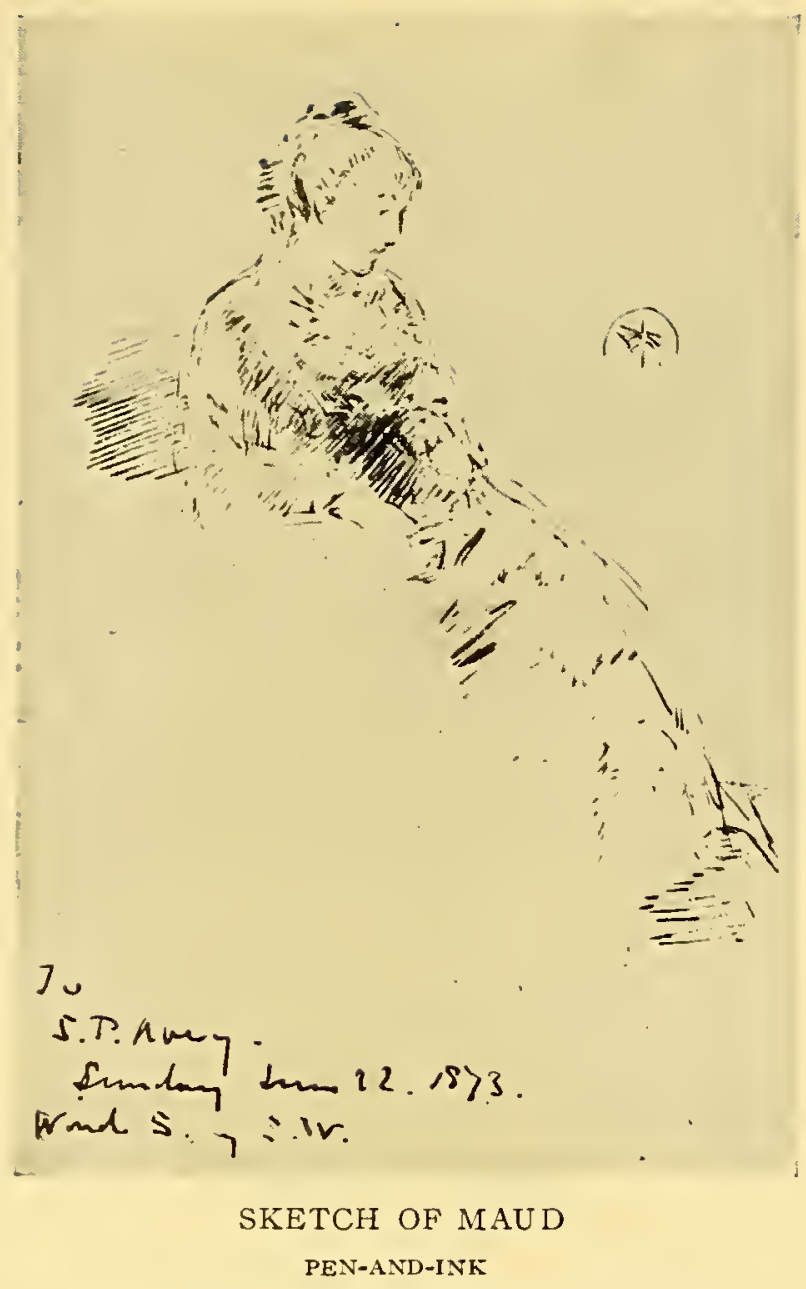

Formerly in the possession of S. P. Avery 


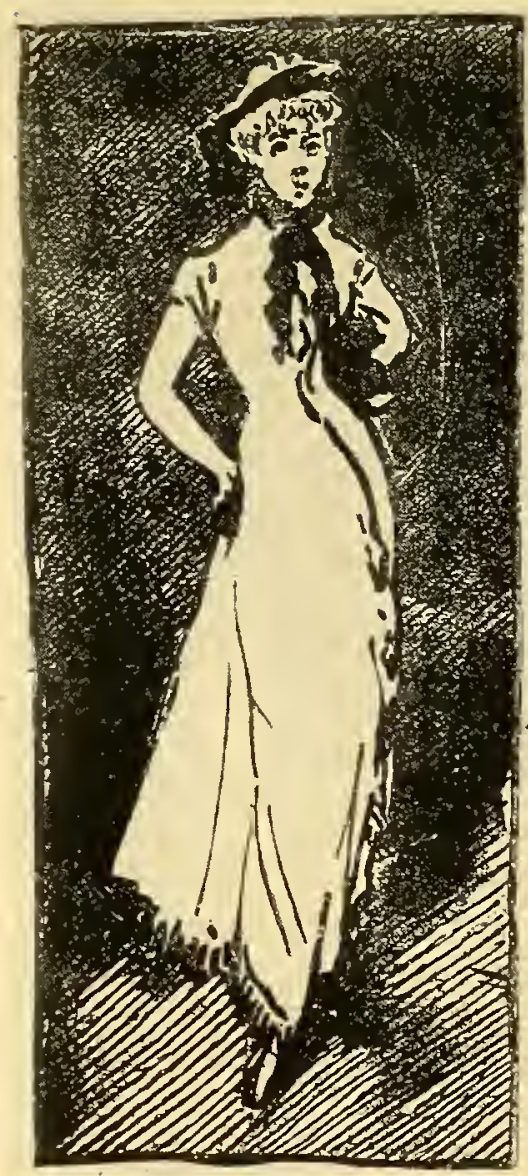

SKETCH OF MAUD

PEN-AND-INK

From Arrangement in White and

Black No., I, afterwards called 
from Jo. If a water-colour, or print, or drawing of too great importance slipped into Jo's package, a line would follow the next day from Whistler-"you know, an inadvertence and of course to be returned." And it was returned, for there were London dealers always who appreciated Whistler and showed him the consideration which was his due. Nor were these the only troubles. We have never heard, except from Walter Greaves and his sister, that Jo had a son, but we have heard from many that she adopted Whistler's son John, whom Whistler called "an infidelity to Jo." She watched over him, brought him up as carefully as if she had been his mother, and Whistler, who had gone to see him as a child, was glad to have his support as a man. For a while the son was Whistler's secretary, he took part in some of the historic events of Whistler's crowded life. Pellegrini, who lived across the street from the White House, standing at his window one night, saw Whistler come out with John, a ladder, a candle, paint and brushes, and write the famous inscription on the lintel of the door. During the exciting days of the British Artists, John attended to much of its important business. Dr. and Mrs. Whistler knew and liked him and he was often at their house in Wimpole Street. Mrs. Tom Whistler, when she came to see us with Mrs. Dr. Whistler, said:

Thursday, March 2d, IOII. She had just seen Whistler's son, they were staying for a little while in London and he came and dined with them. They found him "charming, a thorough Whistler, very like his father in appearance, only taller and with a better nose, extremely amusing and intelligent, and he stayed talking to Mr. Whistler until after midnight."

Also, he inherited the Whistler genius for engineering and made a good position for himself. The misfortune is that he has not inherited the Whistler name. People who knew them both say Jo and the son were at Whistler's funeral, her last tribute to the man who made her famous for all time. She is immortal because of the inspiration she was to him in his art. But her love helped him through dark moments as well as light, and was an inspiration in his life.

In the Seventies, Whistler's work shows a new model-a model with red hair, but not Jo. This new model was Maud-Maud Franklin who stood for The Fur Jacket, L'Américaine, Effe Deans, for many etchings, lithographs and water-colours, none more beautiful than a water-colour of her in bed reading which belonged I900] 


\section{The Whistler Journal}

to Mr. George A. Lucas. He showed it to E. when she saw him in Paris, saying "this for the lover of Whistler is perfect." It has vanished from the Lucas collection now in Baltimore. She was not in the usual sense a beautiful woman-" "not pretty, with prominent teeth, a real British type," was John Alexander's impression. But in paintings and prints her figure is slim and lithe and graceful, she had the grande dame air, dame du monde, according to M. Duret, and the colour, the splendour of her hair was like Jo's. Also like Jo's were her unusual intelligence, her rare power of sympathy and devotion, and Whistler's need of both was never so urgent. His fortunes were crumbling, he was building the White House and getting deeper and deeper into debt over it, he was plagued by the coming Ruskin trial, he was steering straight for the bankruptcy court and he knew it. She stuck to him through these evil days, not only posing for him, but lightening his burden of work and debt when she could, printing with him-for, in this too like Jo, she was something of an artist; writing his letters for him when "the show was so frightfully afire" that he had not time to write himself; getting entangled with writs and bailiffs; facing the irrepressible Nightingale, builder of the White House, whose name crops up in the bankruptcy papers, now in our possession, until we marvel that he alone was not the end of Whistler; dragged into the intricate money affairs with Howell, her name mentioned more than once in his journal and accounts. She was even involved in the intrigue from which Whistler's life was never free, and in Whistler's letters to Mr. Lucas now in the Maryland Institute, the world can read his elaborate arrangements for letters addressed to Miss Maud Franklin, enclosed in his and sent to Paris, to be posted back from that town to the White House-why no one alive to-day can tell. Whistler, bankrupt, left London for Venice; in a month Maud joined him. He was poorer than ever, so poor he was living on "cats' meat and cheese parings," he used to tell the artists there. But Maud fought his poverty with him, cooked for him, kept things in order for him, posed for him, posed for others. Even one day, Oliver Grover told J., when Whistler was biting a plate on top of his bureau in which were his shirts and the acid began to run off, instead of pulling the shirts out of the drawers or mopping up the acid, he stood perfectly still, shouting "Maud! Maud!" As she did not come, Grover had to rescue the contents of the bureau, while the acid ran to the floor and water had to be poured on that. Only love could have kept Maud with Whistler through these troubled days when with love alone could Whistler repay her. John Alexander said: 


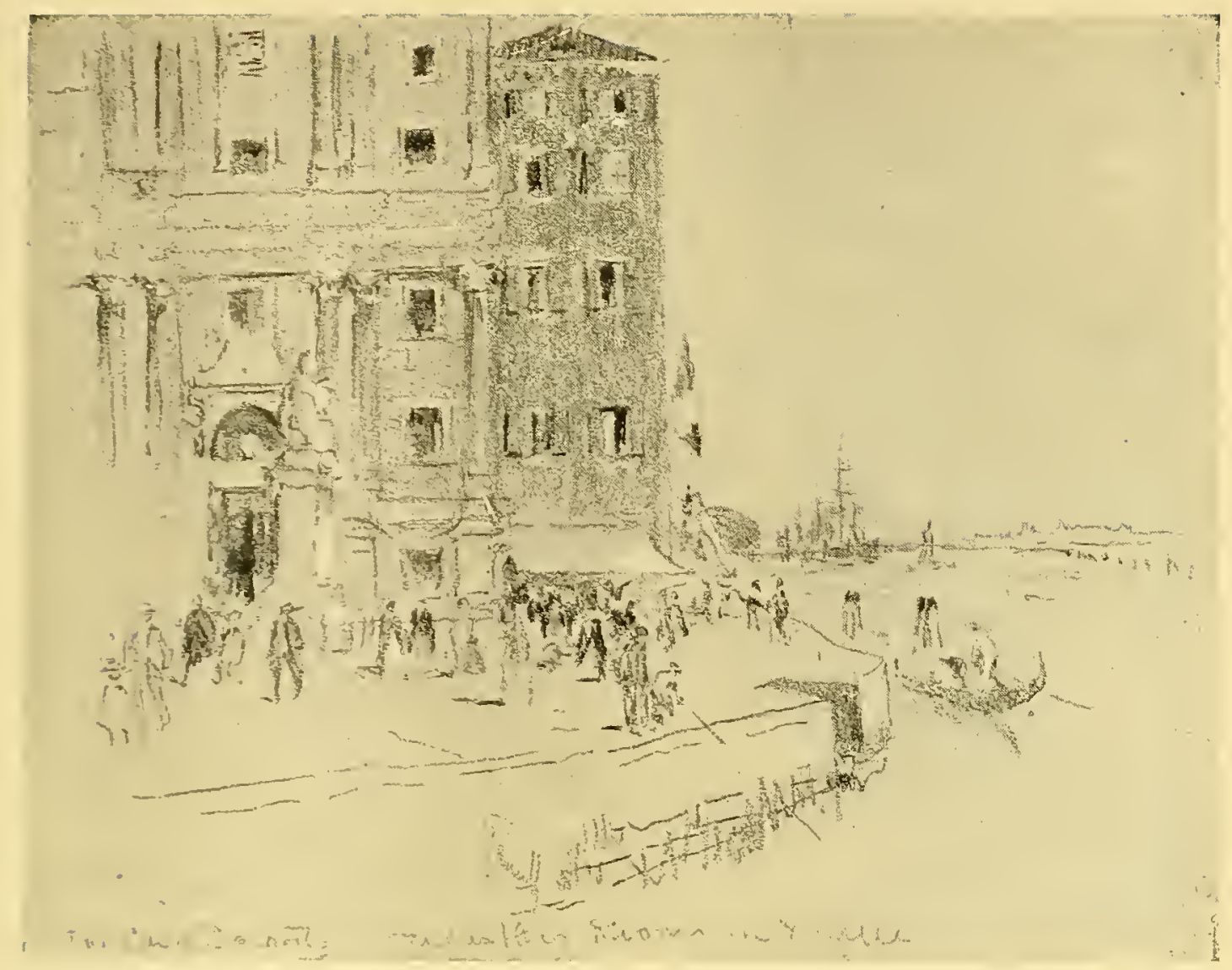

CASA JANKOVITZ, WHERE WHISTLER LIVED MOST OF THE TIME IN VENICE PASTEL

By Joseph Pennell

Pennell Collection, Library of Congress, Washington 

November 6th, 1908. "Her devotion was wonderful and made Whistler's later conduct to her unpardonable. That was one of the things those who loved him just had to forget, and they could for they understood. To those who do not understand, of course one does not even speak of the necessity of forgetting."

Perhaps because of this devotion, this daily life of self-sacrifice, the rumour went about of their marriage, the ceremony performed in a Venetian church. But it was only a rumour. It is certain that Whistler, who introduced her to artists and let her preside at the Venetian versions of his Chelsea breakfasts, did not take her with him to the Bronsons or the Curtises. When we were writing the Life, the American Consul in Venice looked up city archives and church records, but nothing was to be found.

These were the years when Whistler said he had no private life and Maud shared in the publicity. Back in London, they lived together. First in Alderney Street where, Miss Chambers told us, it was whispered at one moment that her figure looked rather queer and she went to Paris, or so she explained to friends, and stayed away two months. From others, we have heard of a daughter with her mother's wonderful hair. This daughter and John are Whistler's only children of whom we have a positive record, though from Mr. Percy Thomas, during a visit he paid us on October 4th, I906, we heard of four, a number unconfirmed by any one else. On her return, Whistler and Maud moved to the "Pink Palace" in Fulham, then to The Vale, Chelsea. Whistler, though he sold his etchings, could not sell his pictures, and was still miserably poor. Maud did everything for him, as in Venice, M. Duret says and he never went to share with them the dinner Maud cooked without a bottle of wine and some fruit or pastry in his pockets. All this while Maud called herself Mrs. Whistler, and was known as Mrs. Whistler to Chelsea tradesmen and cabmen. Mrs. Whistler was engraved on her cards, Maud Whistler was signed to her letters: two with this signature were published by Otto Bacher in his book about Whistler in 1908, the book suppressed by Whistler's executrix, though not because of Maud's letters. Some of Whistler's old friends say that he introduced her and spoke of her to them as Mrs. Whistler; others, that Madame was his name for her, though he might occasionally refer to her as "my pupil." She was seen in many places with him, paid week-end visits with him, was prominent at British Artists' functions with him, where M. Duret has told us that he, as foreigner and garcon, was ready to give her his I900] 


\section{The Whistler Journal}

arm if the respectable native hesitated. Always a few people accepted her, though the difficulty came after Whistler married. A friend was quoted to us as saying she could know one but not two Mrs. Whistlers. The situation was of a kind not likely to be ignored by gossip, and gossip made the most of it, as of everything connected with Whistler. It was an impossible state of affairs for them both. If the few accepted Maud, the many did not. Whistler loved society, and to most houses to which he was invited, Maud did not go. On the other hand, in the houses to which she did go she was often an embarrassment. She would stay hours, Miss Chambers explained, and if people came in, there was no knowing by what name to introduce her. Then Whistler would turn up and fetch her away and it was uncomfortable for everybody. Both had high tempers. Gossip rejoiced in tales of violent scenes in the "Pink Palace." Details are in Walter Greaves' talk with $J$. But it is useless to revive this unpleasantness of the past. All who knew them must have foreseen the end.

Whistler tired of so intolerable a life. Besides, his friendship with Mrs. Godwin was strengthening. He had known her before he went to Venice. Godwin was his friend, the architect of the White House, the first to praise his Venetian work and his decorative scheme for its exhibition, which was a joke to the average critic. Godwin died in I886. Mrs. Dr. Whistler told us (October Ist, I9o6) that he was buried in a corner of a field somewhere down in the country and Mrs. Godwin, Lady Archibald Campbell and Whistler had gone with the coffin, in some sort of an open cart, and they had covered up the coffin and made quite a picnic of it-perhaps what all funerals ought to be made if taken in the right way. Mrs. Godwin lived in Chelsea after her husband's death, and gradually came more and more often to the studio. Lady Colin Campbell, then sitting-or rather standing-for her portrait, was inclined to resent the daily interruption, Mrs. Godwin's arrival being the signal for work to stop. She chaffed Whistler about "the little widdie," but chaff could not reconcile her to the loss of her portrait which was never finished and disappeared after it was exhibited at the British Artists-destroyed by Whistler, Miss Philip informed her. Maud had not only a high temper, but the jealousy that goes with it. Her resentment had a more serious reason, than Lady Colin's, and the position grew strained beyond endurance. The crisis came with the exhibition of the British Artists in I887. William Stott of Oldham showed a Venus with red hair which gossip declared was Maud's. Her portrait by Whistler-the portrait in bonnet and furs owned by Mrs. Walter Sickert and by her returned to 


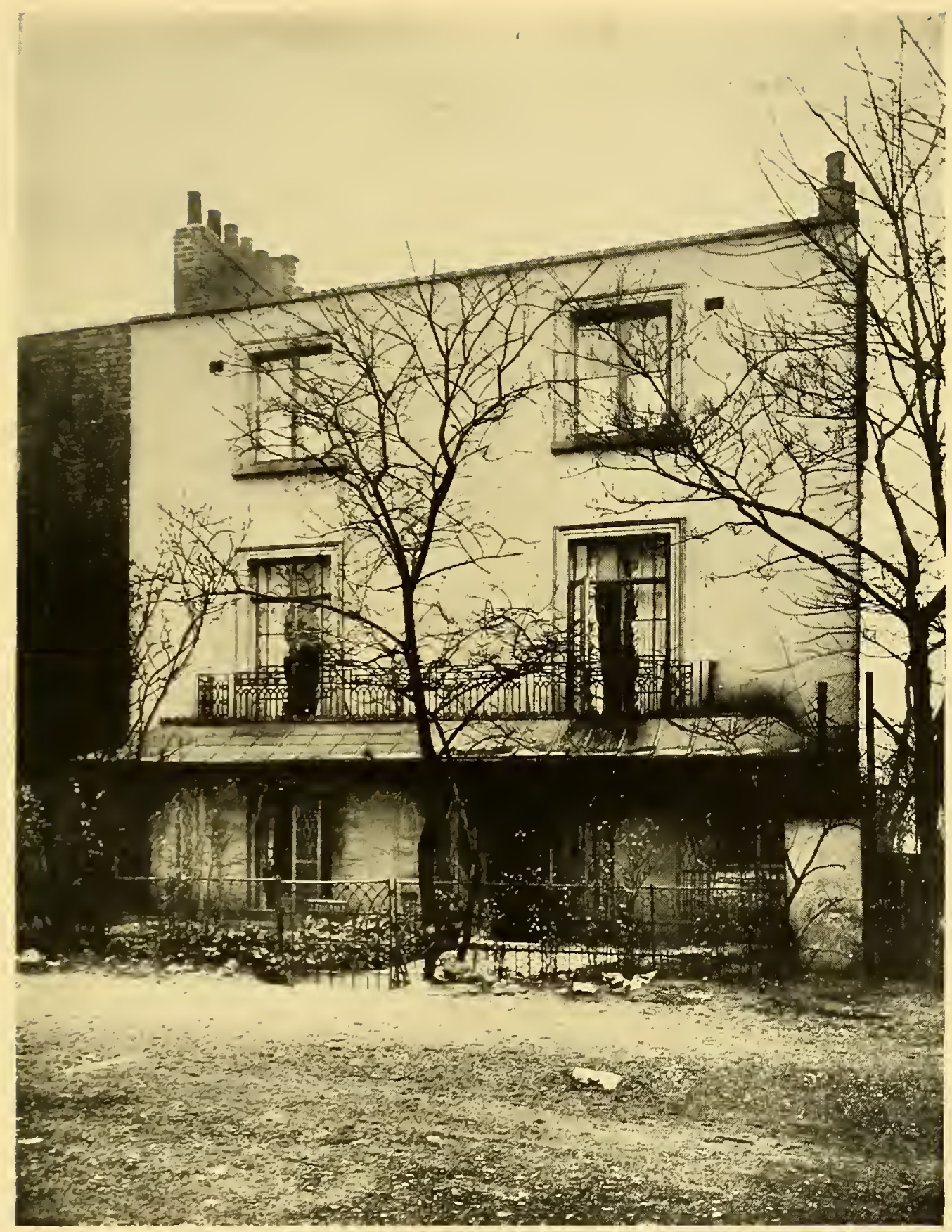

WHISTLER'S HOUSE IN THE VALE, CHELSEA

PHOTOGRAPH

(See page 165)

By W. E. Gray 


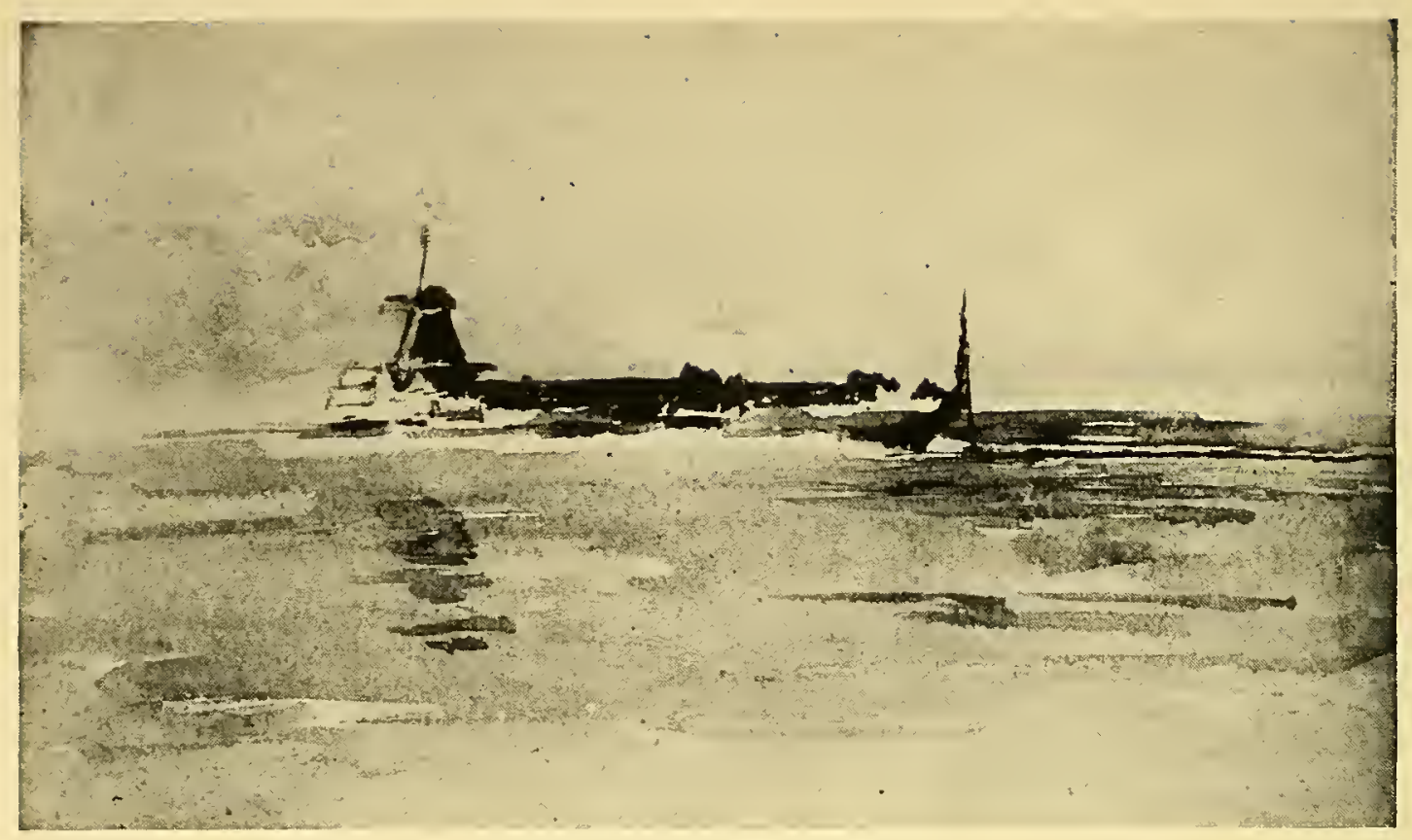

THE DYKE AT DOMBURG

WATER-COLOUR

(See page 179)

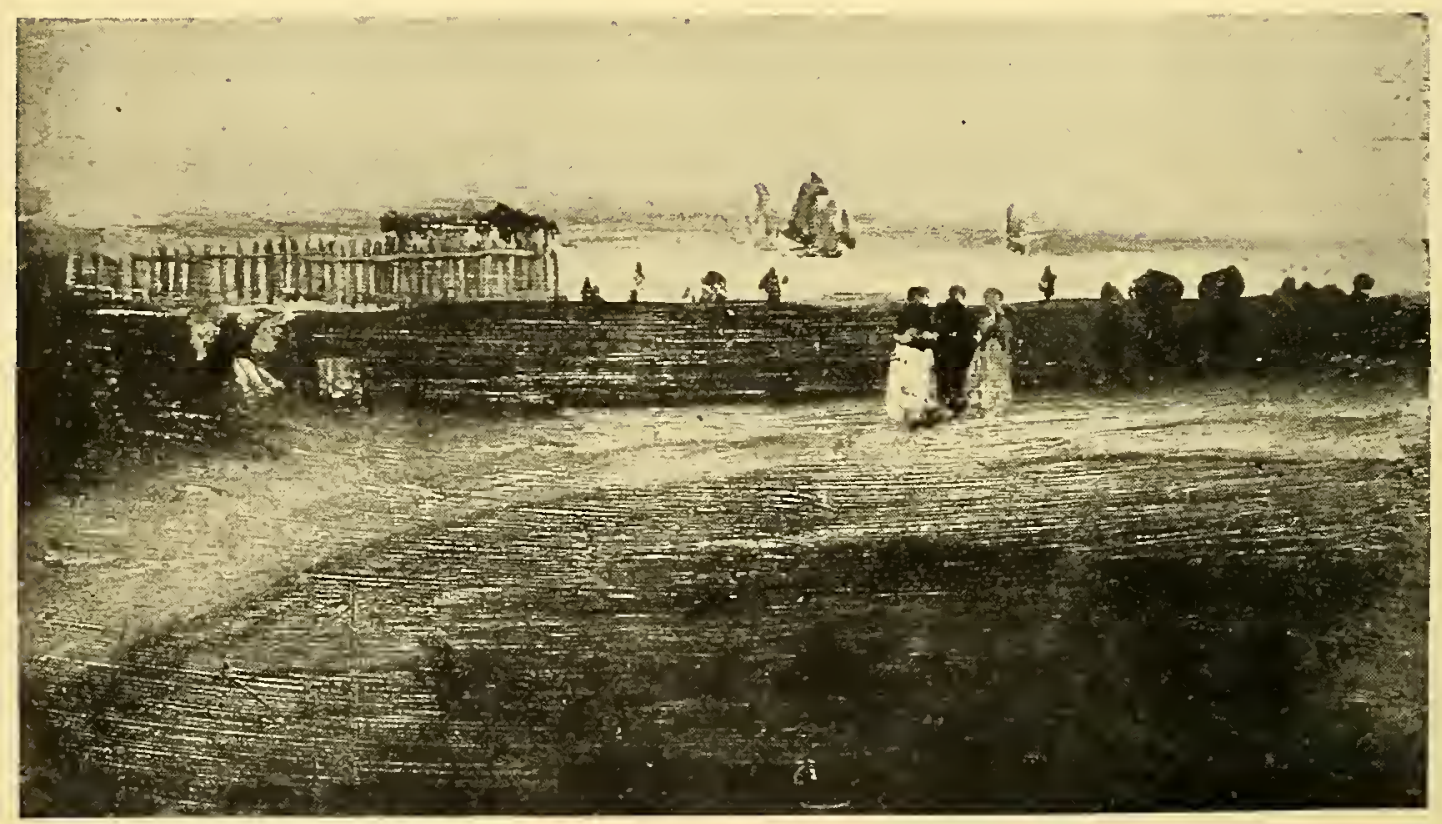

SHORE NEAR DUBLIN

OIL

Freer Collection, National Museum, Washington

(See page I8o) 


\section{Whistler's America of Early Days}

Whistler-was in another room: "the lady in her right clothing," the critics wrote. There was excitement, talk, and Whistler's indignation was natural, whether or no he believed the scandal. A little later Maud went to stay with the Stotts. While she was away, he left the house in The Vale, never to return. A tie so deliberately broken could not be mended. In I 888 Whistler married Mrs. Godwin. Mrs. Jopling-Rowe, who went with Mrs. Godwin to the church, thought Whistler was uneasy during the ceremony, he looked from side to side as if in fear that Maud might be there.

Maud did not accept the inevitable by amiably effacing herself. When the Whistlers took their apartment in the Rue du Bac, she arrived in Paris and rented an apartment in the neighborhood. She did not drop the Mrs. Whistler from her cards. It was not pleasant for Whistler. But then, it was not pleasant for her. She was poor and alone. She returned to her profession, trying through M. Duret, to pose, among others, to Miss Mary Cassatt. In the end, she married a rich South American. When we were writing the Life, E. called on her. The husband had died, she was a wealthy widow with her motor, her town house not far from l'Etoile, her country house. She was not home the day of E.'s visit, nor the next day when she was expected and E. had said she would return. Madame found the country in springtime too enchanting and was prolonging her stay, the bonne regretted, and all the time E. suspected that Madame was peeping through the blinds. Afterwards Maud wrote. She preferred to say nothing of the past. We cannot blame her. She had loved much, she had suffered much. It is something that her last years are quiet and untroubled. But her love and her suffering were for a great man, a genius, and therefore cannot be forgotten. She will live forever with Rembrandt's Hendrickje and Leonardo's Monna Lisa.

CHAPTER XI: WHISTLER'S AMERICA AND OTHER THINGS OF EARLY DAYS. THE YEAR NINETEEN HUNDRED CONTINUED

Sunday, August 4th, I9oo. Whistler came in the morning to see J. who got back from Scotland yesterday. He was worried, he looked tired and bothered. "Well, you know, Mrs. and Miss Philip have taken a house or part of a house on the seashore near Dublin and I suppose I ought to start to-morrow. And Elwell I900] 
wants me to go to a little place near Middleburg in Holland, and that seems nice and I would like it, but I am afraid it is not on the way to Ireland. Matters with Abram have come to a crisis. Abram said the last two drawings were printed with the text, and that makes the difference, and he suggested ten pounds a piece and I thought perhaps the whole thing might just as well be settled."

He came back to dinner in the evening. The Fisher Unwins were here. I was talking to Fisher and did not hear the beginning, but something started Whistler on the Eden question, and he told the story he had told me before of the sale at Christie's, and that led him back to the whole business of the valentine-and how he deliberately deposited the cheque, so the truth should be known, and the Baronet should not have the chance to go around, shaking his head, and saying "some little unpleasantness about money, you know." The Baronet won the first case, but when it came to the appeal and the Cour de Cassation, when the circumstances were understood, and the judge realized what an espece d'amateur, spéculateur and collectioneur, he was, why, then, there was no escape for him.

Sargent, again, was the subject. "Really," Whistler said, "his painting seems almost like the work of a bad boy, and I do not know whether he ought not to be taken out and whipped for it." I did not hear half the talk, but there was a wild argument with Mrs. Unwin about the negroes. "They never had had a chance," she declared. "Chance! Why there they all were starting out alike, white, black, brown, yellow and red men-what better chance could they have? What?" After the Unwins had gone, he said again as he did after Mrs. Whitman had gone home a week ago, that he ought not to talk about Sargent. "I like Sargent, and I am afraid if these things are repeated, people will get the idea that I am ill-natured and that is absurd. I may be wicked, butwhat?-never ill-natured!"

The subject of payment for his work reproduced in the papers often came up. Like most painters, except Royal Academicians and French professors, Whistler for many years-unless it was a question of publishing his etchings about which he was keen enough I68 


\section{Whistler's America of Early Days}

-allowed editors to use his work for nothing, he even made drawings of his pictures for them and charged no more. It was not until J. pointed out that he was throwing a fortune away when he might have been making one, with Alma-Tadema and Holman Hunt and Frith who grew rich on the prints after their pictures, that he demanded to be paid for his. But, alas! in most cases, as in the case of the Mother, the most popular picture of modern times, he had parted with the copyright, and from the endless reproductions published in all sorts of forms and all over the world, he never received a cent and was never offered one by the print publishers who owed so much to him. The royalties received by the publishers made their fortunes and would have made his. Josey's mezzotints, arranged for by Howell with the Greaves, were the exceptions. But by the time of which we write, he had begun to understand the value of royalties and fees for rights of reproduction.

Sunday, August 5th. J. had promised to go to Whistler's studio to-day, but did not feel up to it and I went to explain. I found Elwell sitting for his portrait, and tea on the table. "We must have tea at once, before it gets cold," Whistler said, and he went on painting. About ten minutes later, he said "we must have tea at once," and again he painted on. And we waited a good half hour before he could lay down his brush, and then it was to put the canvas in a frame under glass, and look at it for another ten minutes. Still worrying about his rashness in speaking of Sargent, "People might misunderstand-they are so oppressed now with the conviction of Sargent's cleverness, and it is cleverness which has nothing to do with art. It is the same sort of cleverness as that of the officer who cuts an orange into fancy shapes after dinner. My standard is the Louvre. What is not worthy to go in the Louvre has nothing to do with art." [And the Mother is there now.] Often and often he would work on into the dark till he really could not see-by the firelight over our portraits and when one tried to stop him he would say there is so much to do, so little time to do it.

Monday, August 6th. Whistler came to dinner-only half an hour late. He was grumbling at the cold and the rain, but, for all that was in u nu sually good form. No special news from the Boers except that Baden-Powell was still appearing in his usual rôle of the Besieged. 1900] 


\section{The Whistler Journal}

Then he read us one of Nevinson's letters from South Africa in The Daily Chronicle, with which he was much struck, Nevinson saying that it was a question of manners, and that the whole future relation of the two races down there would depend on the women-both points that specially appeal to him.

He was full of reminiscences, again of Rossetti and Howell-the Owl-and the house in Chelsea. Howell, he again compared to the people in Gil Blas or Robinson Crusoe-he was like the illustrations in Gil Blas-men in top-boots and feathers and magnificently flamboyant. He lied with splendour. He gave us again Rossetti's limerick-

There's a Portuguee person called Howell Who lays on his lies with a trowel.

"Once in a while, I would take my gaiety, my sunniness, to Ford Madox Brown's receptions. And there were always the most wonderful people-the Blinds, Swinburne, anarchists, poets, musicians, all kinds and sorts, and in an inner room Rossetti and Mrs. Morris sitting side by side, in state, being worshipped, and, fluttering around them, Howell with a broad red ribbon across his shirt front, a Portuguese decoration hereditary in his family."

It was at the time the large fair person Rossetti painted as Lilith, and called The Sumptuous, presided at Rossetti's, when Swinburne and Meredith and Sandys were living there, the time when the most wonderful birds and beasts were in Rossetti's collection: "the gazelle and peacock who fought, until the peacock was left standing desolate with its tail apart strewed upon the ground; and the bull-the bull of Bashan-Rossetti bought at Cremorne, brought home by two men, led through the hall, out in to the garden at the back, and its rope fastened to a stake. Rossetti used to come and talk to it. One day the bull got so excited it pulled up the stake and made for Rossetti, who went running round the garden, tearing round and round a tree, a little fat person with coat tails flying, until, at last he managed to rush up the garden stairs and slam the door in the face of the bull. Then he called his man and ordered him to go and tie up the bull, and the man, I70 


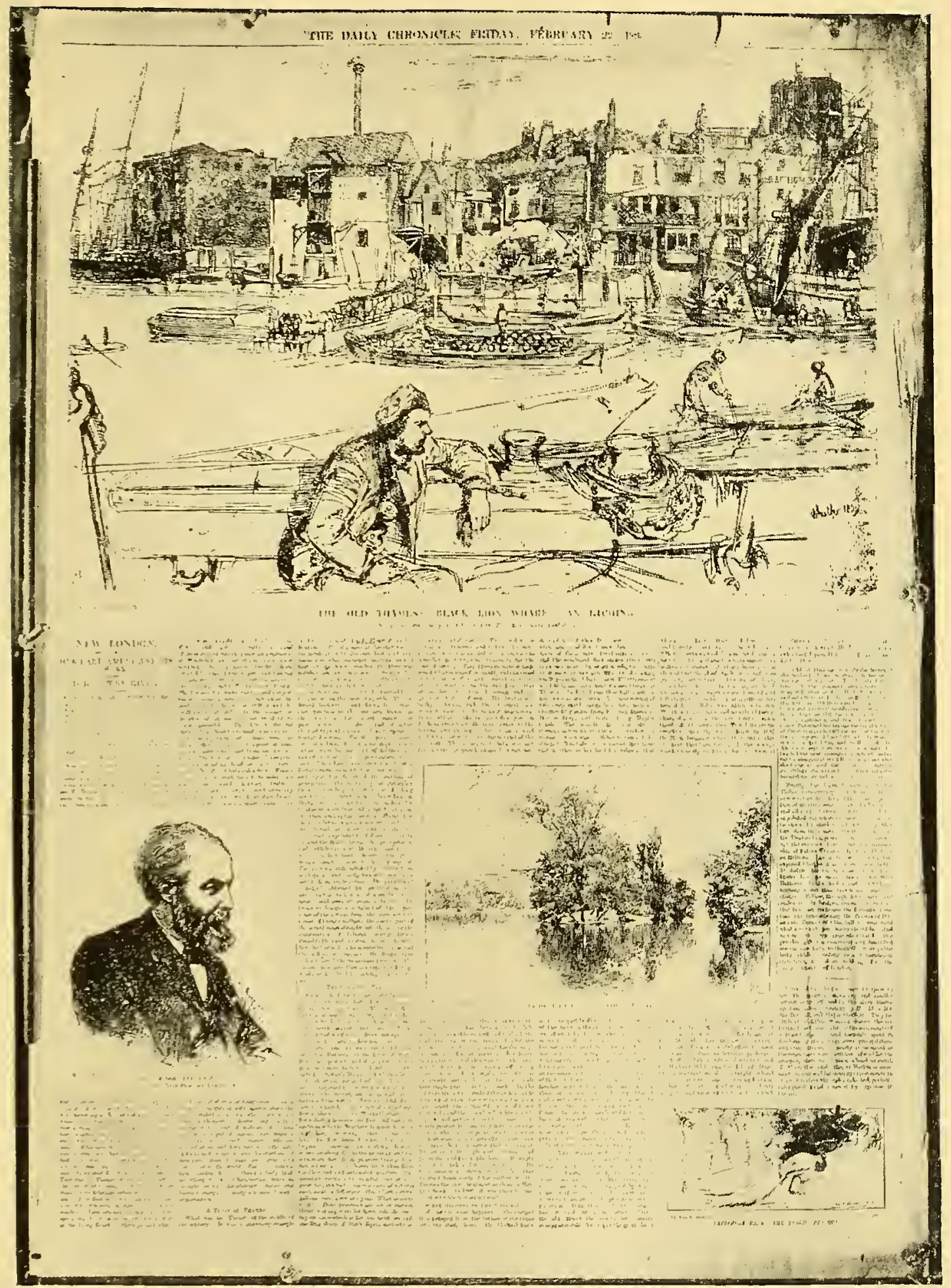

ENLARGEMENT OF ETCHING BLACK LION WHARF PUBLISHED IN THE DAILY CHRONICLE 


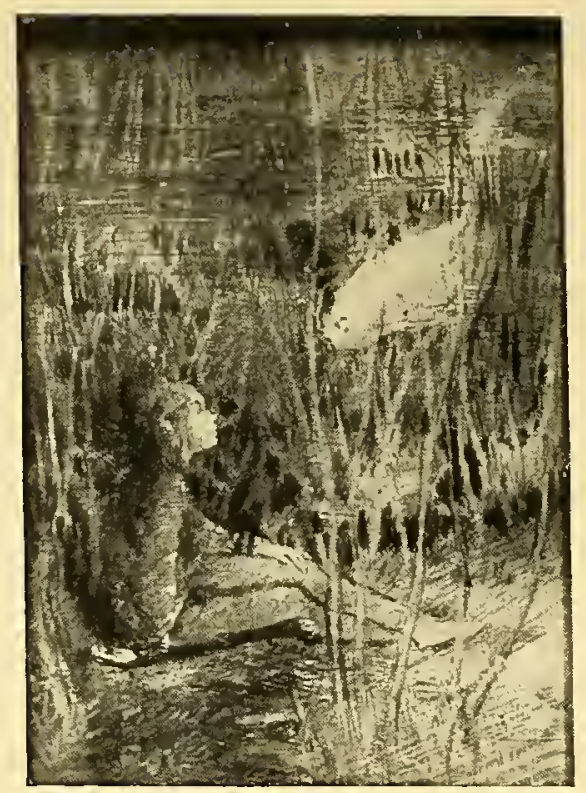

\section{ILLUSTRATION TO LITTLE JOHANNES \\ Drawing on Wood}

(See page 306) 
who had looked out for the rest of the menagerie, who had gone about the house with peacocks and other creatures under his arm, rescued armadilloes, captured monkeys from the tops of chimneys, struck when it came to tying up a Bull of Bashan on the rampage, and gave a month's warning. I told the story everywhere, and Rossetti never seemed quite to like my telling it."

Then there were reminiscences of Sandys and his love affairs: "the Gypsy"- "The little girl." Then reminiscences of himself. "Before I left America I painted portraits of Annie Denny, my cousin, and Tom Winans, and many pictures at Stonington. Then in Paris, when I was first studying, Captain Williams from Stonington; Stonington Bill they called him, got me to paint his portrait, and then gave me a commission to copy as many pictures as I chose for twenty-five dollars a piece, and I copied a picture, I cannot remember whom it was by, of a snow scene, with a horse and a soldier standing by it and another in the snow at his feet; a second of St. Luke, with his halo and draperies; a third of a woman holding up a child toward a barred window and a man seen looking through the bars; and a fourth of an inundation. I have no doubt I made something very interesting out of them. There were very wonderful things even then, the beginning of harmonies and purple schemes. I suppose it must have been intuitive. Then for another Stonington man, I painted-copiedIngres' Andromeda, chained to the rock. Probably all these are still at Stonington and are shown as wonderful things by Whistler! But I can remember, even before I went back to America, the wonderful things I did. In London, once, when I was given a hot foot bath, I remember how I sat looking at my foot and then got paper and colours and set to work to make a study of it. Even in Russia, I was always doing that sort of thing."

His friend Ernest died after the war. And there was another delightful story of him and his ingenuity in supplying himself with canvas and brushes and paints when he wanted to make a copy in the Louvre. He had finished a picture of the Marriage Feast at Cana on a large canvas, and he wanted to sell it. He and a friend started out one morning, carrying it between them very I900]

I7 I 
jauntily to find some one to buy it. They crossed the Seine first and offered it for five hundred francs to all the great dealers on the right side. Then they offered it for two hundred and fifty to the little dealers on the left. Then they went back and offered it for one hundred and twenty-five. Then they came across and offered it for seventy-five. And back again for twenty-five and over again for ten. And they had an awful day, getting very thirsty, stopping with it at cafés, leaning it up against chairs or tables. Until, at last, crossing once more to try and get rid of it for five, on the Pont-des-Arts they had an idea. They lifted it. " $U n$," they said, with a great swing-"deux-trois-Vlan!" and over it went into the water. There was a cry from the crowd, a rush to their side of the bridge, sergents-de-ville, boats on the river, an immense success and they were enchanted.

Another story of his own work. When he made his etchings in Venice and gave them to the Fine Art Society, little Brown showed them to old Mackay at Colnaghi's. But Mackay would not have them: he wanted the London etchings. But, Brown said, when the London etchings were offered to him he had not wanted them. No, Mackay said, then he wanted dogs by Landseer. "It was when I was doing my Venice etchings that I got in the habit, as I worked, of blowing away the little powder raised by the needle ploughing through the ground to the copper, and it got to be such a habit that I made the same blowing sound, even when I was painting or drawing and there was nothing to blow. But I was not conscious of it. After the school was started in Paris, Carmen told me that, one day, after I had been painting something before the students and had left the studio, there was suddenly heard in the silence a sound of blowing from one corner. Then another student began to blow away imaginary things as he worked, and so they kept it up one after the other. Tiens, they said, already we have la manière, and that is much! Since then, I have broken myself of the habit almost altogether."

J. asked him about Gleyre's studio, whether there was much of the usual tormenting of the nouveau? "No-very little. If a man was a decent fellow, and would sing his song and take a little chaff, I 72 


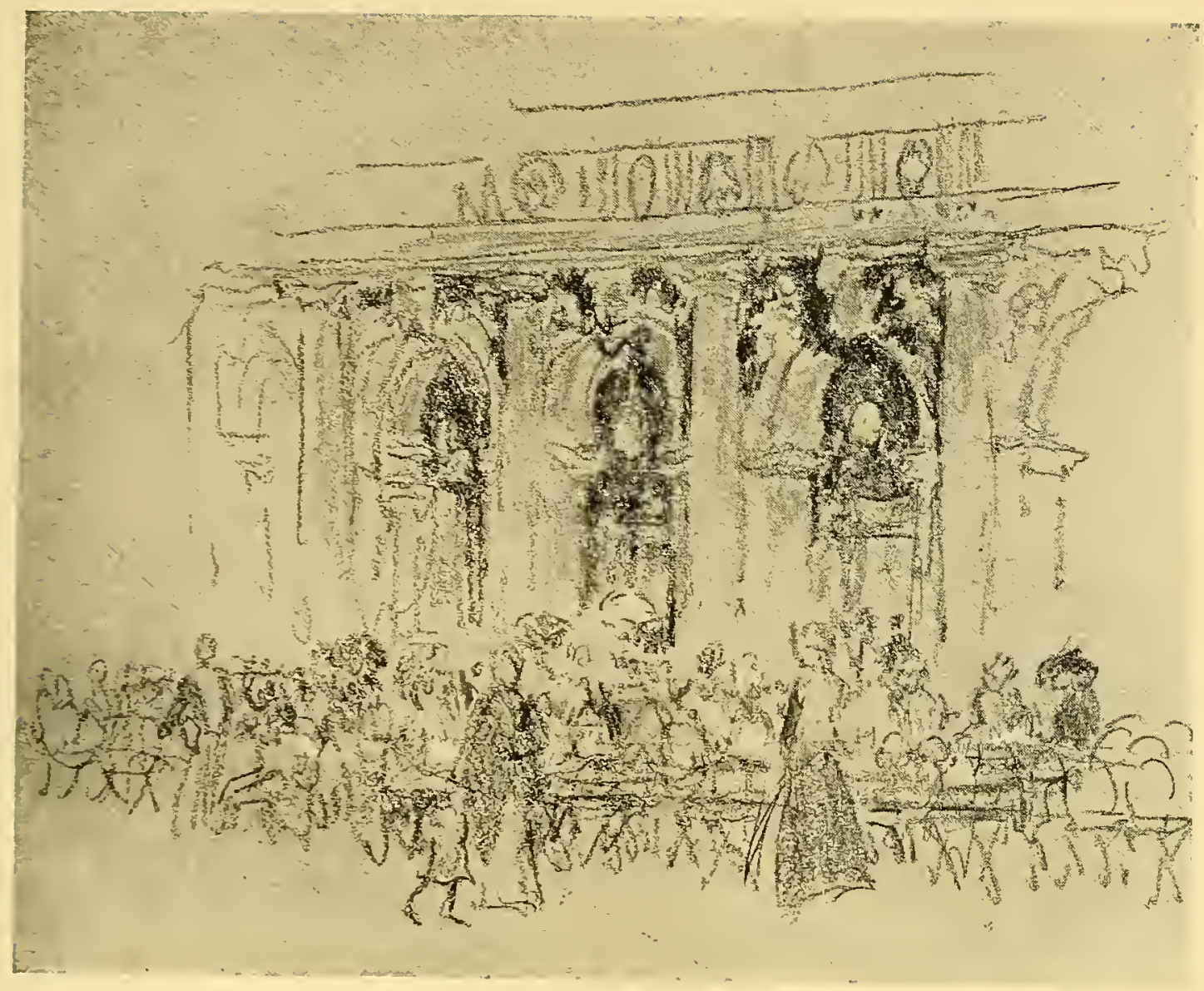

THE QUADRI, VENICE PASTEL

By Joseph Pennell

Pennell Collection, Library of Congress, Washington 



\section{Whistler's America of Early Days}

he had no trouble. I only remember one performance of the kind, and that was when a student, who had already been there some time, seemed too pleased with himself, too certain he was going to be made massier. And one morning when I came to the studio late, I found them all working very hard, the unpopular one among them, and there at the end of the room, on the model's stand was an enormous catafalque, a wonderful construction, the unpopular one's name on it in big letters. No one said a word. But that killed him. He was never again seen in the place."

Even when Whistler taught he was not taken up by the French Professors. One night at the American Club, after Wanamaker and the Professors and the Ambassador and all the lights had spoken, he was called on by somebody. He said he hesitated to follow such distinguished speakers, but he would like to say that in France they taught the student which end of the brush to put in his mouth, but in England it was all a matter of taste. "Little Brown" was Ernest G. Brown, first with the Fine Art Society, and later head of the firm of Ernest G. Brown and Phillips of the Leicester Galleries, Leicester Square. He died shortly before the war. Why everybody called him "little Brown" it would be hard to say, but everybody did-a term of endearment perhaps, for everybody liked him. He believed in Whistler from the first, and Whistler appreciated it. Pretty Nelly Brown who sat for one of Whistler's later portraits is Brown's daughter. Whistler in the Rue du Bac had not yet broken himself of the habit of blowing. Mrs. Whistler used to say that when he blew, it meant he was satisfied.

Thursday, August 9. Blaikie came to dinner, and also Whistler, bringing with him Elwell, the American artist whose portrait he is painting. First talk of Scotland, Whistler, as a McNeill of Barra, claiming Blaikie as a countryman, not a drop or touch of Sassenach in him, he said. Whistler is an Irish name, and the McNeill, of course, means Barra. Blaikie told the story of the time so many of the Barra Islanders emigrated to America. The McNeill did not like it at all, and he came down to the harbour to remonstrate with one of the clan. But the man was obstinate, until finally the McNeill in a fury struck him and knocked him down. Then, when the man got up, he was ashamed and told him he must strike him in return. I900] 
The Whistler Journal

"What, strike my chief?" the man said, "never, and, what is more I'll blow out the brains of anyone else who tries to." And yet he went away all the same, but it shows the feeling there is up there for the chief - a feeling which no one could appreciate better than Whistler.

Then it was Edinburgh and the Castle, and the wonder of it one day when Blaikie took St. Gaudens there. It was Sunday, "and they got in only by permission of the Governor, and there was no one else from outside, and the wonder of it in a thick mist, the figures of the Highlanders in their long overcoats, looming up through it like giants, and, everywhere, mystery when you leaned over the parapet and looked apparently into space. "That is just the sort of thing, the mystery of it all, that I have been trying to show people for years," Whistler said. "But people do not want it. What they like, is when the east wind blows and everything is sharp and hard and awful-they like the sort of a day when, if you look across the river, you can count the wires in the canary bird's cage on the other side. They talk about the blue skies of Italy; the skies of Italy are not blue, they are black. You do not see blue skies except in Holland, or here, or countries where you get great white clouds, and then the spaces between are blue."

$\mathrm{He}$, later, told the story of Carlyle and the painting of the portrait more completely than before, that is to us. "There were ladies in Chelsea-well-Madame Venturi, who was determined that I should paint it. I used to go often to Madame Venturi's. I met Mazzini there, and Mazzini was most charming. Madame Venturi often visited me, and one day she brought Carlyle. The Mother was there, and Carlyle saw it and seemed to feel in it a certain fitness of things as Madame Venturi meant he should. He liked the simplicity of it, the old lady sitting with her hands in her lap, and he said he would be painted. And he came one morning soon, and he sat down, and I had the canvas ready, and my brushes and palette, and Carlyle said, And now, mon, fire away! That wasn't my idea of how work should be done, and Carlyle realized it for he added, If ye're fighting battles or painting pictures, the only thing to do is to fire away. One day he told me of others who had 


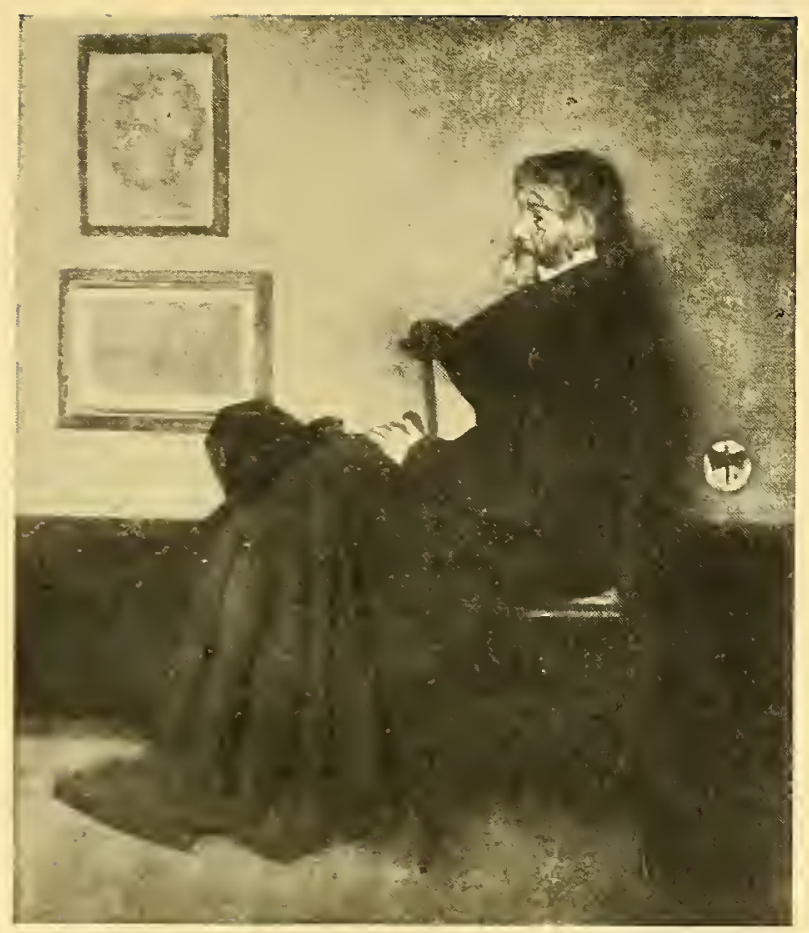

PORTRAIT OF CARLYLE OIL

Glasgow Art Gallery

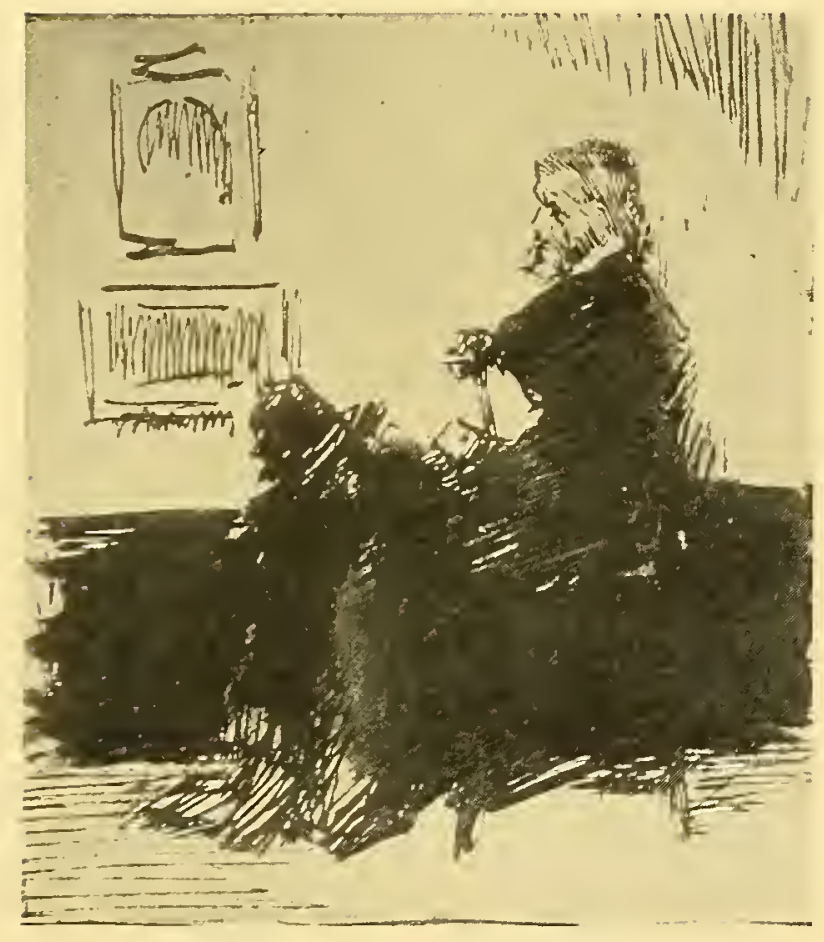

SKETCH OF THE PORTRAIT PEN-AND-INK

Owned by Alan S. Cole, C. B. 

painted his portrait. There was Mr. Watts, a mon of note. And I went to his studio, and there was much meestification, and screens were drawn round the easel, and curtains were drawn, and I was not allowed to see anything. And then at last, the screens were put aside, and there I was. And I looked. Mr. Watts, a great mon, he said to me, How do you like it? And I turned to $\mathrm{Mr}$. Watts, and I said, Mon, I would have ye know, I am in the hobit of wuring clean lunen. But Carlyle agreed that $I$ had given him clean linen and he liked the portrait-he told people afterward that he had been there, talking and talking, and that I had just gone on with my work, and had paid no attention to him whatever. Then I was ill, and Carlyle sent me one of the machines for making soda-water that he probably had used when he was ill himself; and then, afterwards I called and spent an evening with him, and our relations were always charming. Carlyle was really a very delightful person about whom delightful things were told. Allingham, at one time, was by way of being his Boswell and was always at his heels. They were walking in the Embankment Gardens, Chelsea, when Carlyle stopped suddenly: Have a care mon, have a care, for ye have a tur-r-rable faculty for developing into a bore. Carlyle had been reading about Michael Angelo and had had some idea of writing his life or an essay about him. But it was Michael Angelo, the engineer, who interested him. Another day, walking with Allingham, they passed South Kensington Museum. You had better go in, Allingham said. Why, mon, only fools go in there. Allingham explained that there was sculpture by Michael Angelo, and Carlyle should know something of his art before writing his life. No, Carlyle said, we need only glance at that!

A story of Blaikie's was interesting too. The students in Edinburgh elected Carlyle to the Rectorship, and he was pleased enough at the election. But he had to make a speech afterwards, and on the day of the ceremonies, he arrived in his official robes, trembling all over. First he threw off the gown and cap, but you could still see his hands tremble, and he could scarcely control his voice. But once he had started, he dropped his notes, and forgot himself entirely in what he had to say.

1900]. 
Then the talk drifted to the British Artists, and Whistler told again the story of the Prince of Wales, and of their coming to ask him to join the Society. Then he went on with the story of his relations to the Society. "There was the Jubilee. Well, you know, I found that the Academy and the Institute, and the rest of them were preparing addresses to the Queen, and so I went to work too, and I prepared a most wonderful address. Instead of the illuminated performances for such occasions, I took a dozen sheets of my old Dutch paper. I had them bound by Zaensdorf. Amazing! First came this beautiful binding in yellow morocco, and the inscription to Her Majesty, every word just in the right place, most wonderful. You opened it, and on the first page you found a beautiful little drawing of the royal arms that I made myself; the second page, an etching of Windsor, as though, 'here's where you live.' On the third page, the address began. I made decorations all round the text in water-colour-at the top, the towers of Windsor, down one side, a great battleship, plunging through the waves, and below the sun that never sets on the British Empire-What? The following pages were not decorated, just the most wonderful address, explaining the age and dignity of the Society, its devotion to Her Glorious, Gracious Majesty, and suggesting the honour it would be if this could be recognized by a title that would show the Society to belong especially to Her. Then the last page. Then you turned, and there was a little etching of my house at Chelsea'And now here's where I live!' And then you closed it, and on the back of the cover was the Butterfly. This was all done and was well on its way, and not a word was said to the Society, when the Committee wrote and asked me if I would come to a meeting as they wished to consult me. It was about an address to $\mathrm{Her}$ Majesty-all the other Societies were sending them and they thought they should too. I asked what they proposed spending, and they were aghast when I suggested that the guinea they mentioned might not meet a twentieth of the cost. But, you know, all the time my beautiful address was on its way to Windsor, and, finally came the Queen's acknowledgment and Her command that the Society should be called Royal. Well, I carried this to a meeting, and it was stormy. One member got up and protested against I 76

[1900 


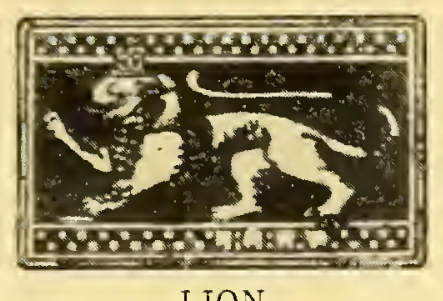

LION

PEN-AND-INK

Designed for the British Artists

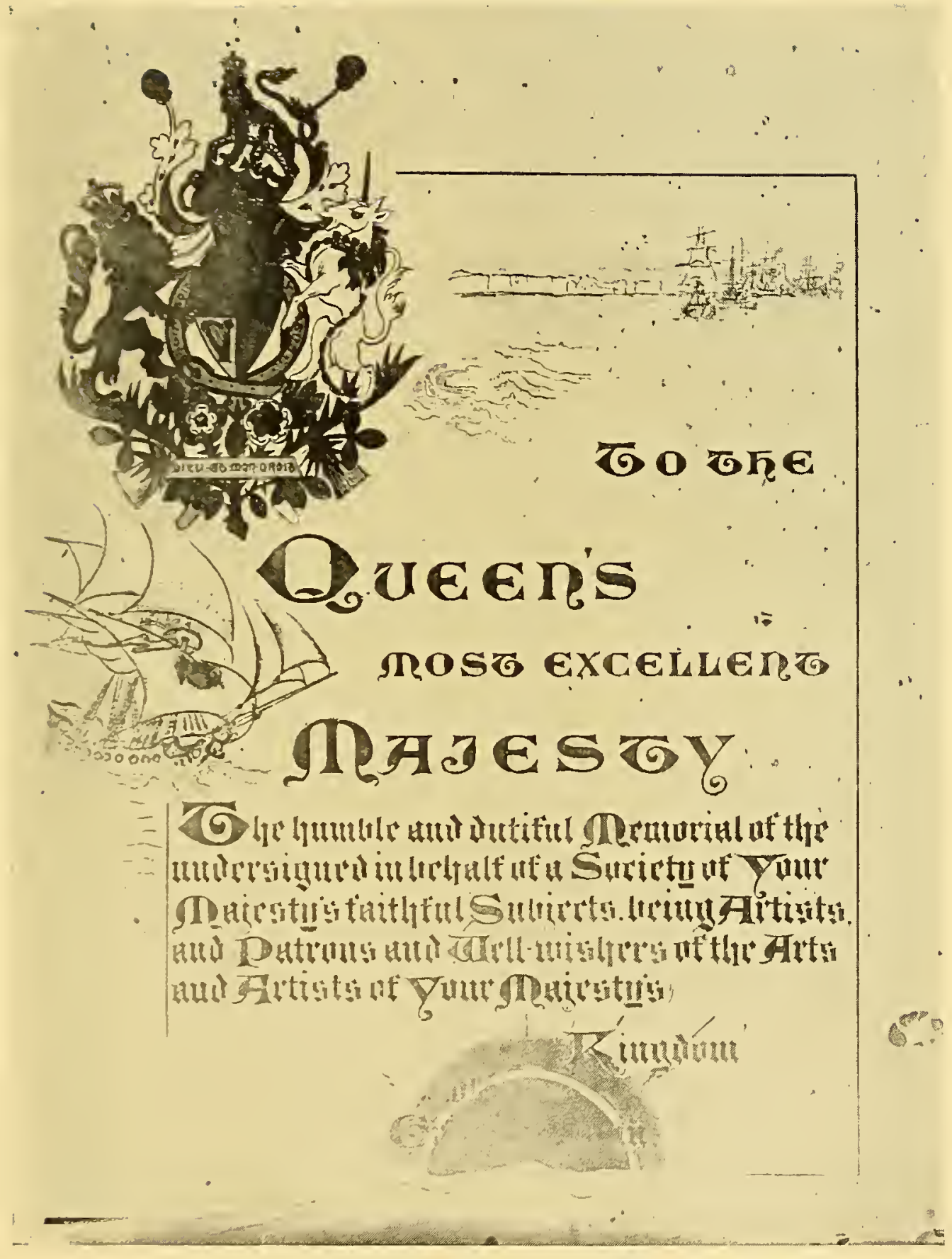

FIRST PAGE OF THE MEMORIAL TO QUEEN VICTORIA WATER-COLOUR

From the British Artists. Royal Collection, Windsor 


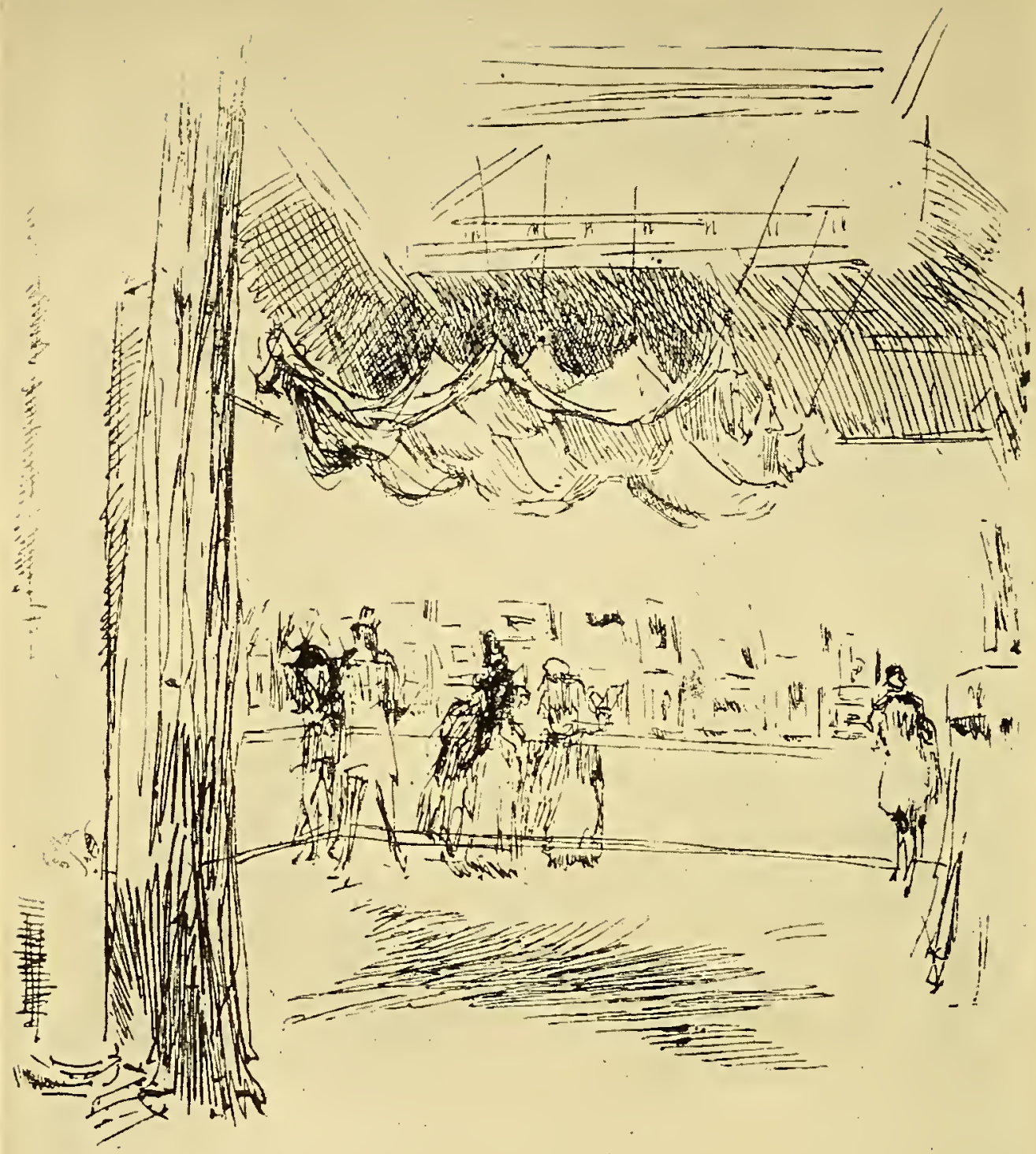

INTERIOR OF GALLERY OF THE BRITISH ARTISTS

SHOWING VELARIUM AND ARRANGEMENT OF PICTURES PEN-AND-INK

Formerly in the possession of G. R. Halkett

(See page 305) 


\section{Whistler's America of Early Days}

one thing or another and declared his intention of resigning. You had better make a note of it, Mr. Secretary, I said. And then I got up with great solemnity and I announced the honour conferred upon them by Her Gracious Majesty. They jumped up and rushed towards me with outstretched hands. But I waved them all back, and continued with the ceremonial to which they objected. For the ceremonial was one of their grievances. They were accustomed to meet in shirt-sleeves, free-and-easy fashion, which I would not stand. Nor would I consent to what was the rule and tradition of the Society. I would not, when I spoke, step down from the chair and stand up in the body of the meeting, but remained always where I was. But, the meeting over, I sent for champagne. Altogether when it came to the time of re-electing the President, usually as mere a form as at the Academy, they took advantage of it to get rid of me. Now, at last! I told them, you must be satisfied. You can no longer say you have the right man in the wrong place." Then wild talk of Burns, Elwell falling of a sudden upon Blaikie for Scotland's ill treatment of Burns during his lifetime, though Blaikie had said earlier in the evening that he might abuse things Scotch sometimes himself, but he could never allow anyone else to do it. Whistler, who tried to smooth things down for everybody, said, "after all, Burns was not Scotch: in the turning around of the world, he, the Genius, just happened to be born there." Then talk of the Davenport Brothers and of spirits, and again he described their séances, and the inexplicable things that were done, which, of course, were merely travestied in the later performances of Maskelyne and Cook and people of that kind. But one other thing about Burns. "The difference between the Scotch people's treatment of Burns and of Crockett, is that they slighted Burns during his lifetime and have been busy raising monuments ever since; but they read Crockett during his lifetime and will never raise a single monument to him after his death." And more talk and talk until one o'clock in the morning-Blaikie lingered-it was not often, he said, you heard such brilliant conversation.

Blaikie is Walter B. Blaikie, the head of Constables, the Edinburgh printers, and the friend of Henley, Stevenson, and all of us. CuriI900] 


\section{The Whistler Journal}

ously enough, whether or no something in the evenıng rankled afterwards in memory, that was the last time we ever saw Blaikie. Two absurd incidents in connection with the Carlyle portrait we take from later pages of The Journal, the first in a note dated

May 4th, I909. William De Morgan told Kerr-Lawson that, in Chelsea in the old days, they looked upon the portrait as a joke. He knew Carlyle, often walked with him in Chelsea; he was a lean, spare man with thin, clean-shaven face, not at all like Whistler's Carlyle. Lawson reminded him of Boehm's statue in the Chelsea Embankment Gardens, which he surely passed almost daily while in London: the face in the statue is the same as the face in Whistler's painting. De Morgan was astonished-he had never noticed it! But what was De Morgan save a pompous old bore, who wrote tiresome books that delight the middle classes. He described English life, and his power of observation was so small that he did not know what the man whose acquaintance he claimed looked like, and could not see a life-size statue directly in front of him.

The other incident comes from Mr. F. Ernest Jackson:-

Friday, February I 4 th, Igo8. Some few years ago, just back from studying in Paris, with less than he liked to do, he spent a good deal of time wandering about London. One late summer afternoon he was sitting on a bench in Hyde Park near the Marble Arch, watching the people pass, and an old man, not unlike Carlyle, came and sat on the same bench. Many bicycles were passing along Park Lane, and the old man made some opening remark about the wonderful inventions of the age, and Jackson answered something about the beauty that counted for more and was sacrificed to them. The old man asked him if he was an artist and he said he was. Then the old man spoke of Whistler, who had been his neighbour in Wellington Square (where to our knowledge Whistler never lived), and there the Carlyle was painted and there he sat for it sometimes. Then he went on to say that the Carlyle was not painted by Whistler, but by somebody else and there had been a bet that, if shown as a Whistler, nobody would know the difference, which was what happened and the truth has not been told $\mathbf{I} 78$

[1900 


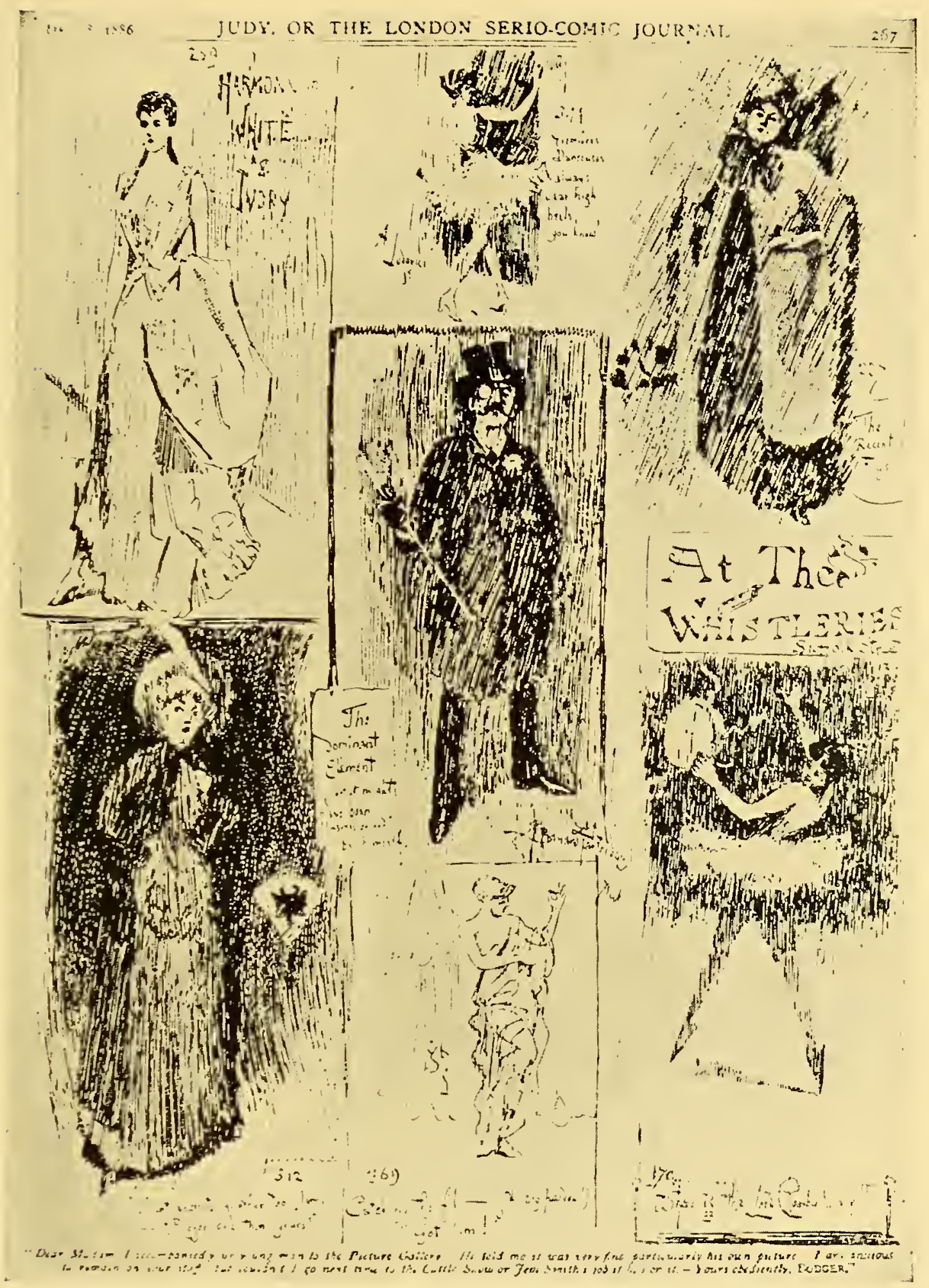

PAGE OF SKETCHES OF BRITISH ARTISTS EXHIBITION, I 886

PEN-AND-INK

By Bernard Partridge. Judy, showing Portraits of Lady Colin Campbell, destroyed, top left, and Mrs. Whistler, top right

(See page 176$)$ 



\section{Whistler's America of Early Days}

to this day. An extraordinary story, though we can see how it grew out of old Greaves sitting for Carlyle's coat and the two Greaves helping Whistler in the studio. One can see too how the history made to-day prepares the way for the attributions of to-morrow.

Whistler was right about Crockett. He is already forgotten, as are all the others of the once popular Kail-Yard. Ian Maclaren has gone. Barrie will go. Whistler's Crockett is one of the portraits that have vanished, though Whistler was pleased with it. When he asked E. to the studio to see it, he said that Crockett was delighted with it and he rather liked it himself.

Friday, August Ioth, Igoo. An early visit from Whistler, with timetables. He thinks of going to Middleburg with Elwell, he thinks of going to Ireland. He may start for either place, but cannot decide. "Well, you know, I wish there was some one just to take hold of me and tell me what to do and get me ready to do it."

Friday, August I 7 th. Again quite an early visit from Whistler; the announcement of his return from Holland, where he found Domburg a wonderful little place, just beginning to be known but not yet exploited, and he recommends a visit before it is ruined. He feels all the better for it, he says, and he looks it. And there was a merchant from Dordrecht, "a little reserved at first at the table d'hôte, but finally finding he was in safe company with me, he explained that I need have no fear about the Boers; the Dutch are financing them."

In the evening, as he promised, Whistler came to dinner, but he was unmistakably drowsy as the result of travelling the night before, and after dinner, he went fast asleep, not even waking when Lavery came in later.

Six summers afterwards, E. happening to be in Middleburg, in memory of Whistler went one afternoon to Domburg. It seemed still unspoiled - two or three long streets lined with trees meeting overhead, low red-roofed cottages, a small group of hotels, high dunes protecting the village. The sky forever cloud swept, the red roofs above the green, the lines of the dunes are in Whistler's water-colours. But how, she wondered, did he manage about the five o'clock dinner? I900] 
Friday, September 7 th. Back from Paris, and Whistler, too, back from Ireland. Came and dined, and the Sauters. Ireland evidently was not a great success-the house was on the wrong side of the Bay, the weather wasn't what it should be, and it was clear there was not, as in the case of Domburg, reason for enthusiasm. But Chester, on the way home, was charming-full of possibilities. The talk was altogether and entirely of the Boers-except once when he told us how, walking down Bond Street on the arm of little Brown, he saw Menpes. Brown was confused but Whistler was delighted and turned round for another look-"He's back from the front, then!" Whistler said to Brown.

Though he was on the wrong side of the Bay, he managed to do a few charming things in Ireland. One or two later went into Canfield's collection.

Saturday, September I 5th. To-day Joseph home from Switzerland, and I from Dorsetshire, find that Whistler called last evening and wanted to see J. urgently. J. went up to the studio to breakfast. Little Brown was there, and nothing seemed particularly urgent. Whistler came to dinner. His mood was retrospective. Talk, of course, began with the Boers. Kruger's flight, or removal to Laurenço Marquez led to comparisons with Jefferson Davis, and talk of Jefferson Davis reminded Whistler that it was through him he got his appointment to the Coast Survey. "It was after my little difference of opinion with the Professor of Chemistry at West Point. The Professor would not agree with me that silicon was a gas, but declared it was a metal, and as we could come to no agreement on the matter, it was suggested-all in the most courteous and correct West Point way-that perhaps I had better leave the Academy. Well, you know, it was not a moment for the return of the prodigal to his family or any slaying of fatted calves. I had to work and I went to Washington and called at once on Jefferson Davis, who was the Secretary of War, a West Point man like myself. He was most charming, and I-well-from my Russian cradle, I had an idea of things and the interview was in every way correct, conducted on both sides with the utmost dignity and 180 


\section{Whistler's America of Early Days}

elegance. I explained my unfortunate difference with the Professor of Chemistry, represented that the question was one of no vital importance, while on all really important questions, I had carried off more than the necessary marks. My explanation made, I suggested that I should be reinstated at West Point, in which case, as far as I was concerned, silicon should remain a metal. The Secretary, courteous to the end, promised to consider the matter, and named a day for a second interview. Before I went back to the Secretary, I called on the Secretary of the Navy, also a Southerner, James C. Dobbin of South Carolina, suggesting that I should have an appointment in the Navy. The Secretary objected that I was too old. In the confidence of youth, I suggested that age should be no objection. I could be entered at the Naval Academy and the three years at West Point could count at Annapolis. The Secretary was interested for he too had a sense of things. He regretted, with gravity, the impossibility. But something impressed him, for later he reserved one of six appointments he had to make in the Marines, and offered it to me. In the meantime I had returned to the Secretary of War who had decided that my wishes in the matter of West Point could not be met. West Point discipline had to be observed, and if one cadet were reinstated, a dozen others who had tumbled out after me, would have to be reinstated too. But if I would call on Captain Benham of the Coast Survey, a post might be waiting for me there. And so it was; Captain Benham had been my father's friend, and under him I became an official in the Coast Survey. I worked-yes-but with no great enthusiasm: I was apt to be late, I was so busy socially. I lived in a small room, but it was amazing how I was asked and went everywhere, to balls, to the Legations, to all that was going on. Labouchère, an Attaché at the British Embassy, has never ceased to talk of me, so gay, and when I had not a dress suit, pinning up the tails of my ordinary coat and turning it into a dress coat for the occasion. Shocking!

"But all the while, indeed ever since my Russian cradle, there had always been the thought of art, and when, at last, I told the family that I was going to Paris, they said nothing. There was I900] 
no difficulty; they just got me a ticket. I was to have three hundred and fifty dollars a year, which my half brother George, who was one of my guardians, sent to me after that every quarter, and so in Paris I was quite a swell-that is in the Quarter, of course. It was before this, when the Doctor and I were boys in Russia, that my sister [half-sister] married Seymour Haden. They had met when my sister was staying with an aunt, one of the McNeills, Eliza McNeill, who married for her second husband Winstanley in Stanley. I remember that my father came to England specially to see Seymour Haden, and I was with him, and, from the first, disliked him. Haden patted me on the shoulder and said it was high time the boy was going to school. Nor do I think my father approved. My mother came over and joined me towards the end of the war. She had been with the Doctor during the war, and she ran the blockade, to get to England."

The evening ended with a violent discussion about Labouchère, whom Whistler, liking, makes fit in to his standard and theory of conduct in every way. "People misjudge him about his political work, you know, as, for long, they misjudged me about my painting. When I gave my Venice show at the Fine Art Society's, I went there one day and met Sir George and Lady Beaumont face to face at the door as they were coming out. Both looked very much bored, but they couldn't escape me. So-well-the old man grasped my hand and chuckled-We have just been looking at your things, and have been so much amused! He had an idea that the drawings on the walls were drolleries of some sort, though he could not understand why, and that it was his duty to be amused. And I laughed with him. I always did with people of that kind, so they said I was not serious, and that is very much the world's attitude with Labouchère."

The story of Whistler's meeting with Captain Benham years after in Paris is in the Life. There was another occasion he must have told us about before we began our Journal, when he took the Russian Ambassador home with him, marketing on the way, doing the cooking himself, and serving the Ambassador the best dinner he ever ate. 


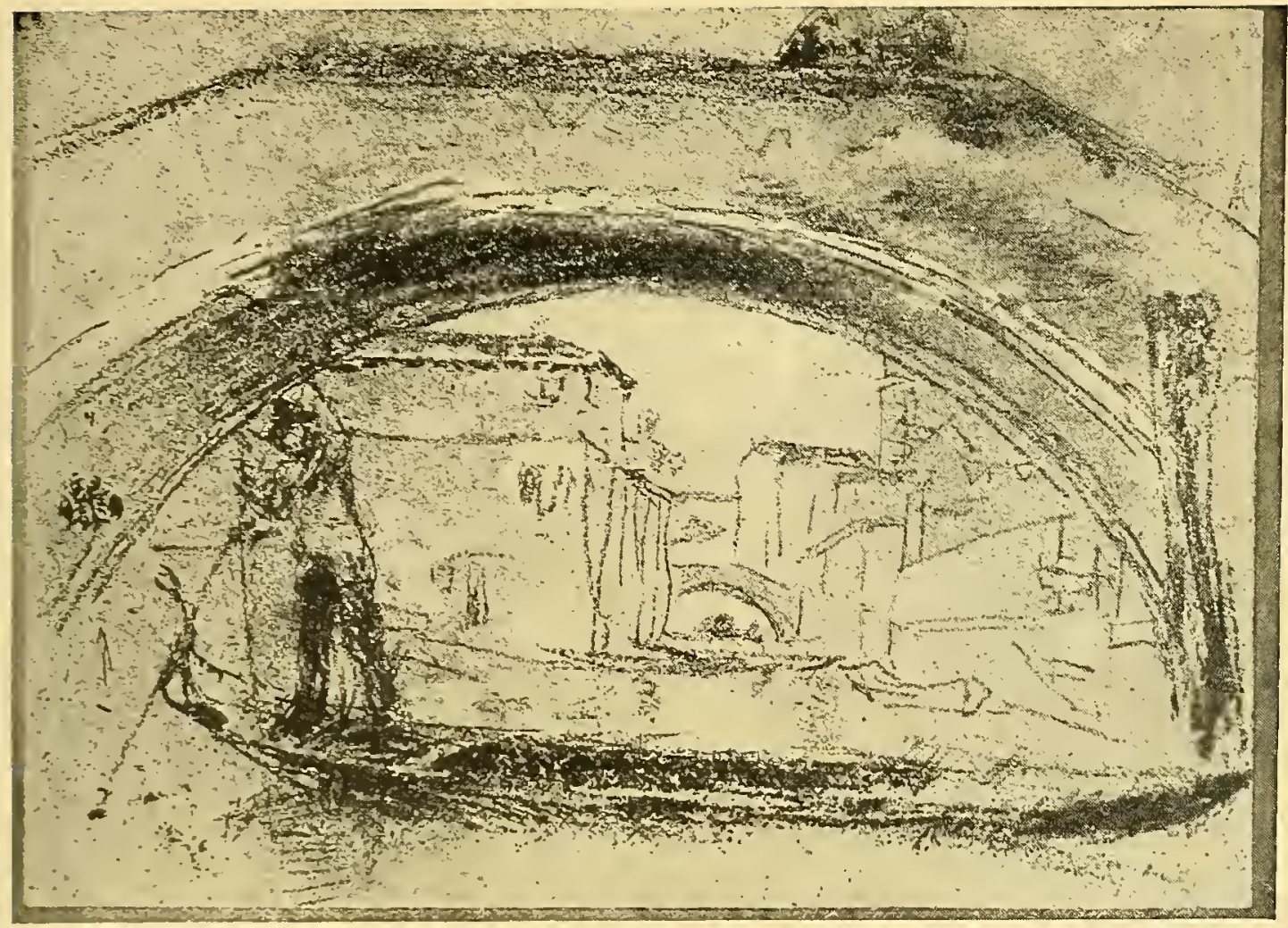

UNDER A BRIDGE

PASTEL

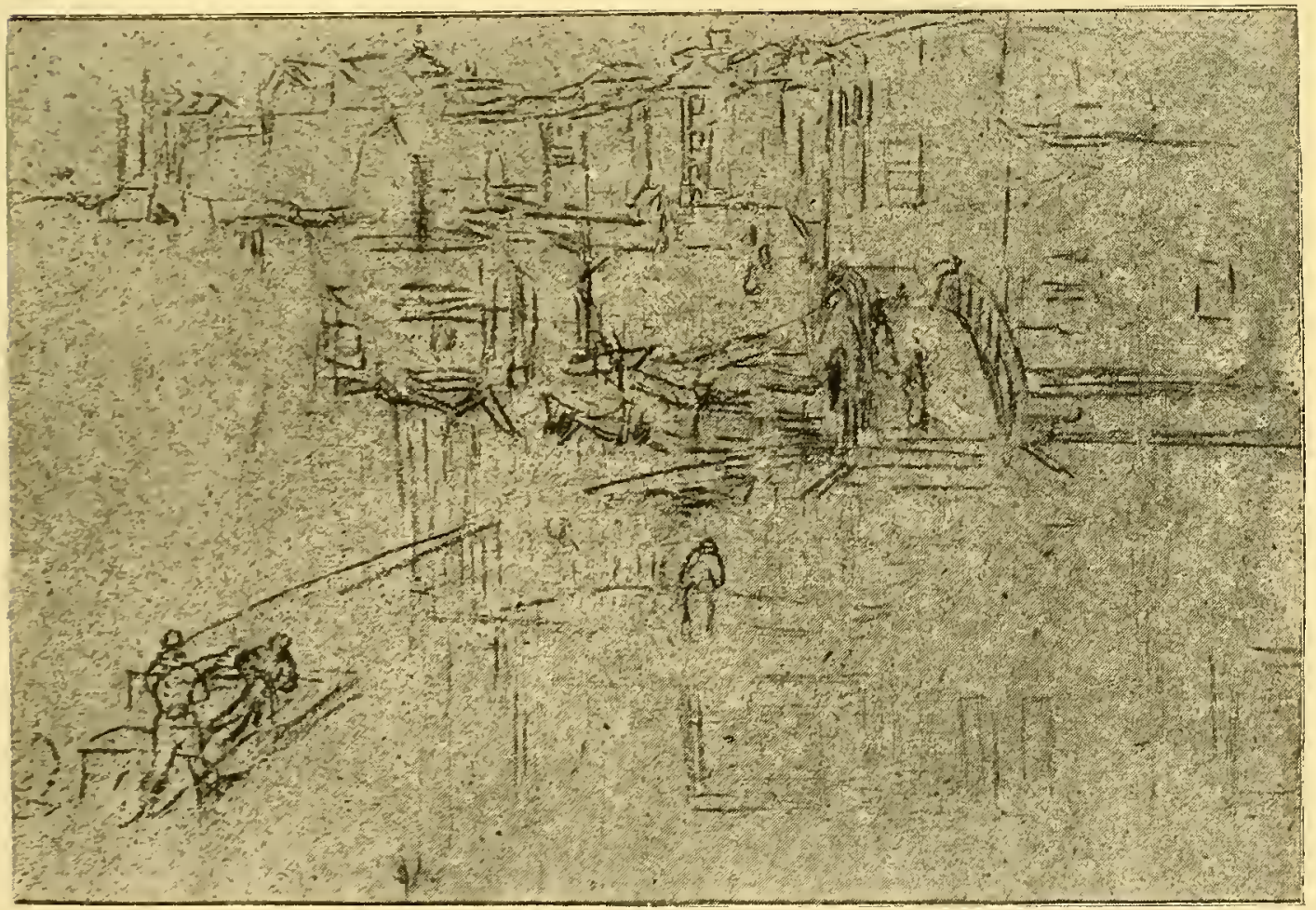

THE RIVA

BLACK CHALK

Commencement of pastel

In the possession of Mitchell Kennerley, Esq. 

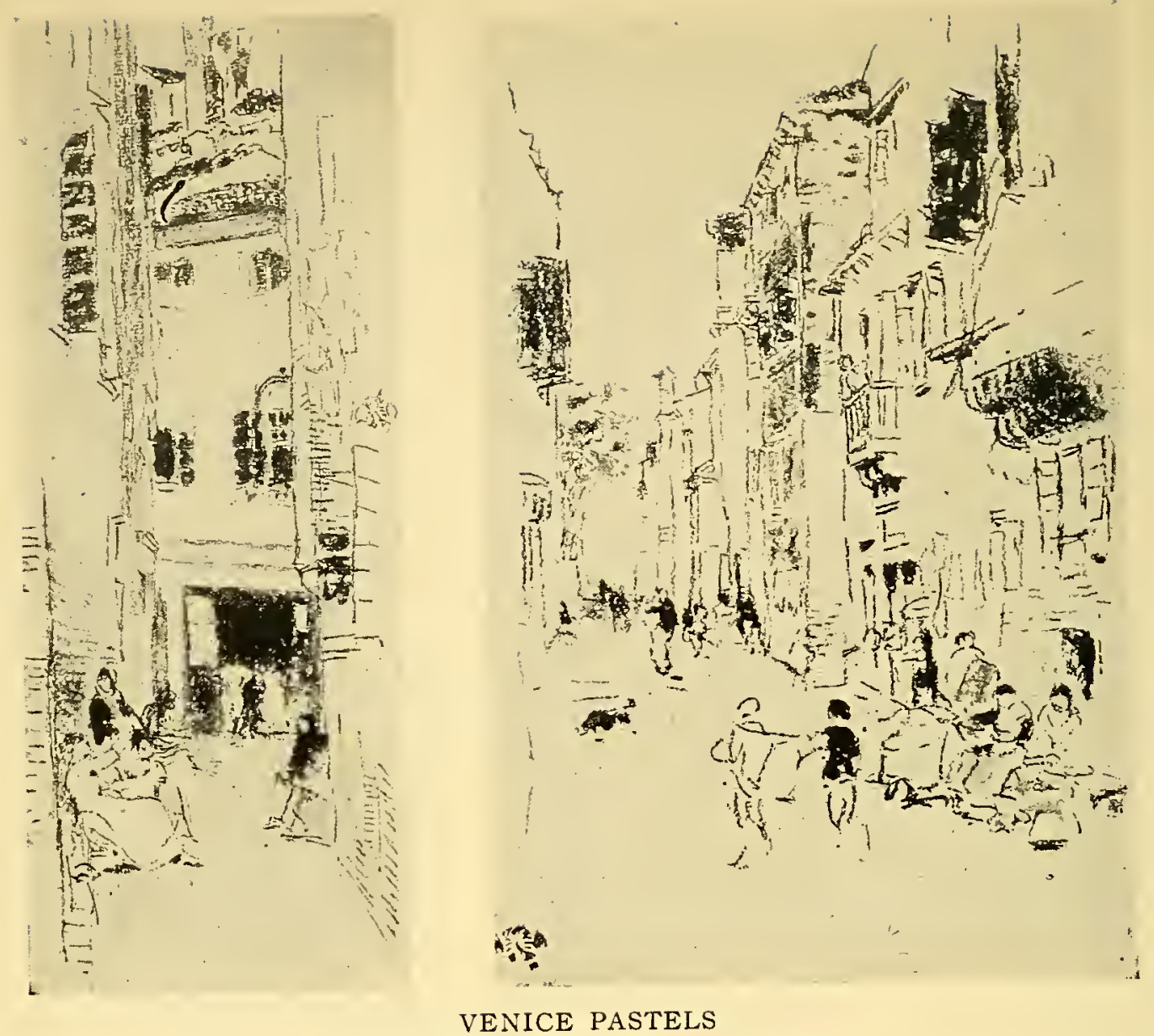

In the possession of J. P. Heseltine, Esq. 

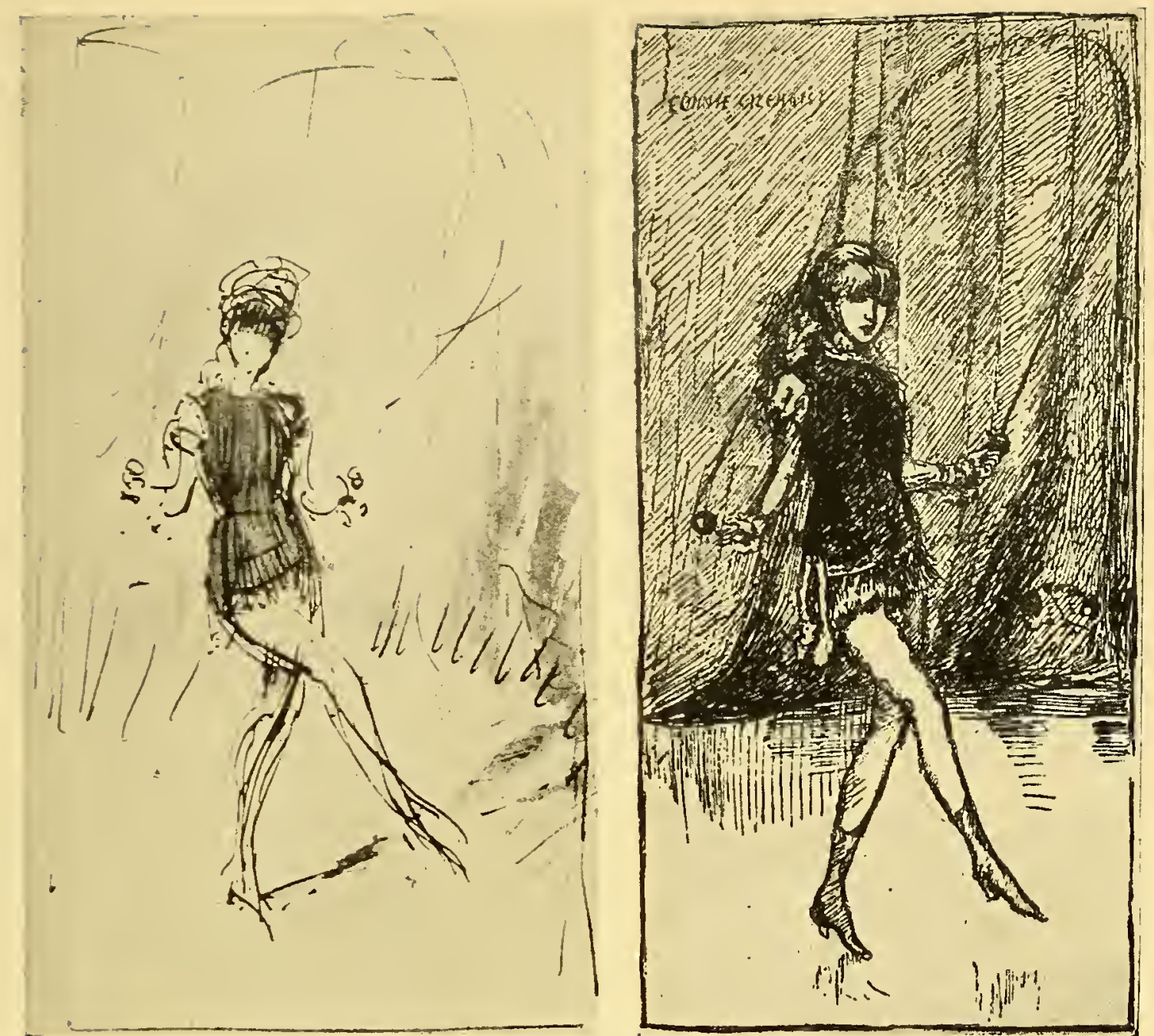

THE GOLD GIRL, CONNIE GILCHRIST, SKETCHES OF THE PICTURE PEN-AND-INK

In the possession of Alan S. Cole. C. B., and Henry Blackburne 


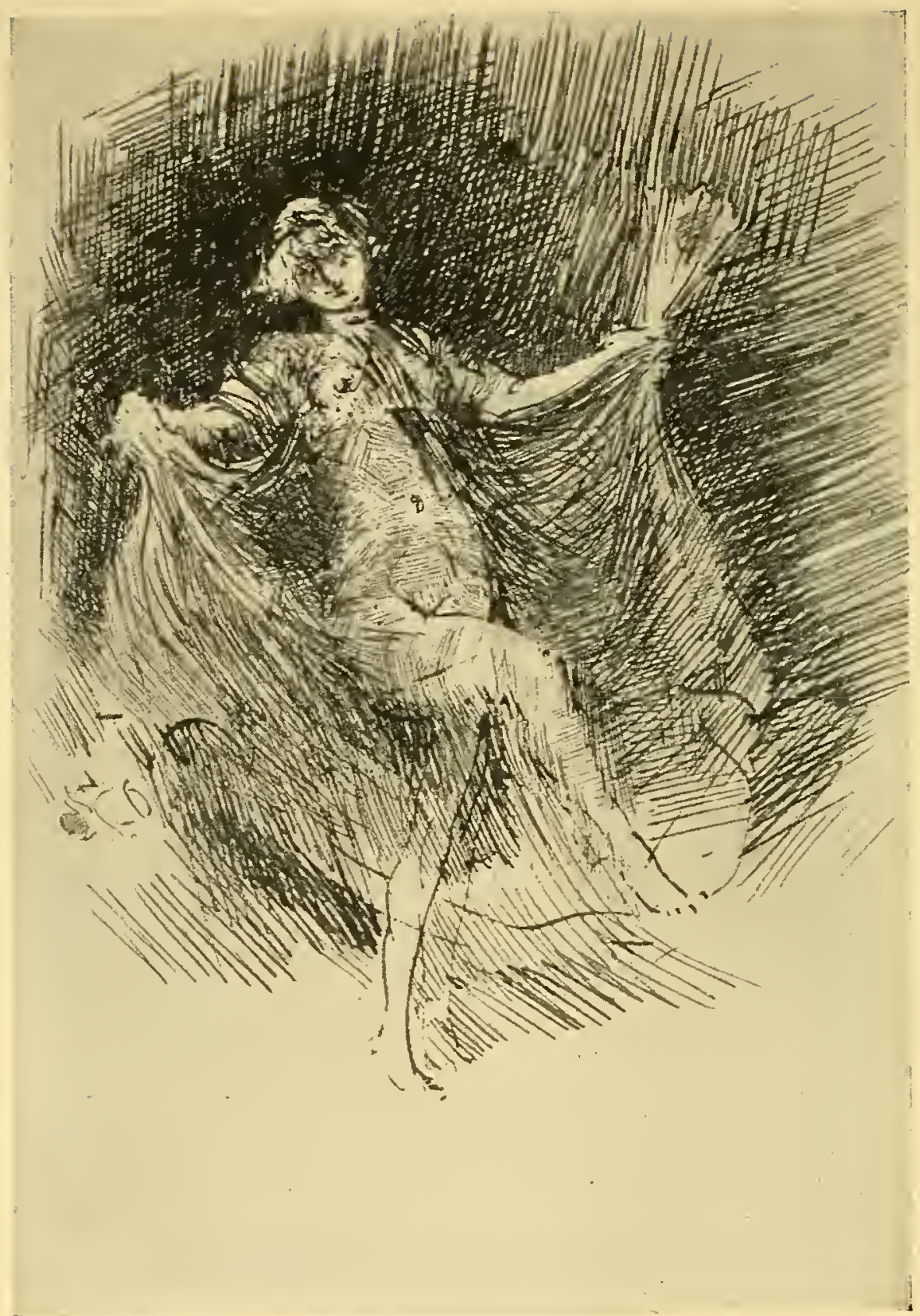

THE DANCING GIRL

PEN-AND-INK

In the possession of Messrs. Knoedler and Co. 
Whistler, for many years, gave undue importance to two men who did him great harm, though they gave him great publicity. One was Edmund Yates, the other was Henry Labouchère. Edmund Yates was supposed to be a wit and he owned and edited The World. Labouchère had the same reputation, and he owned and edited Truth. They were rivals and pretended enemies. Whistler saw a great deal of them at the Beefsteak Club. Edmund Yates published in his paper many of the most brilliant letters in The Gentle Art. These would be commented on in The World by Yates, who called himself "Atlas," and then contradicted by Henry Labouchère in Truth. This game of battledore-though not Whistler's letters-was badinage but the readers of the two papers, who were society people, politicians, sports and city gents, itook the papers and their contents deadly seriously; that is, they took everything seriously except Whistler who was serious. They regarded him as a joke. However, he found the papers useful, for they gave him the only publicity he could get at that time. Both Yates and Labouchère understood Whistler, and their papers were really clever, the contents vastly different from the drivel and blackguardism which disgrace the American society newspaper columns.

Both men also were collectors. Labouchère owned till his death the portrait of Connie Gilchrist Skipping-The Gold Girl-which is now, or what is left of it, in the Metropolitan Museum of New York. The year after Whistler's death, Labouchère sold the painting and it was handed over to the care of Robert Ross, then running the Carfax Gallery. He showed it to E. in his house in Sheffield Gardens, where it hung for a while, and told her that Labouchère let Whistler have it back to work on it. Whistler had not touched the canvas. The truth is, he was always trying to get the picture back to destroy it, not to work on it. It was in the studio when he died and the executrix, Robert Ross added, was obliged to give it up, though reluctantly. In the poor light of an upper room E. could not see it well, but, as well as she could see, the painting seemed flat and dead, and the regret is that Whistler left it in that condition. The picture was a failure, and Whistler knew it. For long, down the back of the figure, there ran a great black line of paint that showed the whole thing was to have been drawn again. Eventually it came into the possession of Mr. Hearn who carefully had the black line removed, and to-day, cleaned and smugged up, the Connie Gilchrist reposes in the Metropolitan, the butt of American critics who do not know enough to say nothing. The Metropolitan Museum is unfortunate in having some of the most I900] 
The Whistler Journal

unimportant and least desirable Whistlers of any collection in the world, when it might have had the best-the Mother, The White Girl, and a number of others. As it is, the Henry Irving is the one distinguished Whistler there. Truth and The World also printed so-called caricatures, mostly artless. In them Whistler appeared over and over, and they look as if they had been the foundation of more than one of the Greaves' portraits. One of Spy's may now be seen in the National Portrait Gallery, London. Through these caricatures Whistler became widely known to the British public, and it is thanks to The World and Truth and their illustrations that he came to be accepted as a joke. The shock to the British public was when it suddenly awoke to find he was a great artist and a great man-the American public has not found it out yet. Nor did that part of the British public of which Lord and Lady Beaumont were types ever wake up. More than. five years after Whistler's death, a month or so after the Life was published, at some afternoon reception, E. met Lady Dorothy Nevill who said she had read the book with the greatest interest because her friendship with Whistler dated so far back. She gushed to E. She had known Whistler, had gone to his breakfasts. He was a delightful creature, so amusing, he would show you a pair of boots on a canvas and you were expected to see in them a full-length life-size figure! And her laugh might have been the re-echo of Lord Beaumont's chuckle.

Those who did not laugh were afraid. An instance is in a delightful story little Brown told E. of Mr. Burrell who bought The Fur Jacket and other Whistlers, and has long since parted with them.

February roth, 1909. He was most anxious to meet Whistler, little Brown said he would arrange it, and Whistler invited them both to tea in the studio. On their way, in the hansom, Burrell, a great big Scotchman, a champion football player or something of that sort, sat very still at first, then, squaring his shoulders, said with a great air of determination, "No matter what he says or does, I will not retaliate!" Brown's comment was that his idea of Whistler was most people's idea of J., a man with one hand holding a pen ready to write disagreeable things, the other thrust in his pocket to draw his revolver.

To those who did not laugh, or arm for a fight, he was simply a mountebank. We were told by some one who heard it that after I 84 
his death he was called a "Charlatan" by the Princess Louise, the one member of the Royal Family credited with an intelligent interest in art. If this was her feeling, we wonder why the Whistler bust by Boehm remained so long in her possession. However, she succeeded in getting rid of it during the war at the big war charity sale held at Christie's in April, I9I5.

Sunday, September I6th, Igoo. Whistler dined and Agnes Repplier -not a successful combination. The dinner dragged until E. J. Sullivan happened to come in, and Whistler woke up, and, all of a sudden, I hardly know how, he was plunged into the midst of the Lake Country and a Church Congress, travelling third class with the clergy and their families, eating jam and strange meals with quantities of tea, and visiting the Rev. Mr. Green in his prison, shut up by his Bishop for burning candles and altogether the hero and important person he would never be on coming out. An amazing story, but what Whistler was doing in the Lakes, which had nothing about them but little round mountains with little round trees on top, and what he was doing with the clergy, he did not appear to know-the story was enough. Also, out of the talk of the evening, I have the memory of Whistler's picturesque description of the monastery adjoining his garden in the Rue du Bac; the music of the monks' hymns, and the mystery of it, heard in the twilight of summer evenings, and the glimpse of solemn processions through their garden on winter mornings-the beauty of ritual, he declared, is all with the Catholics. But the evening, on the whole, not one of our most successful.

If we remember, this was one of Whistler's very sleepy evenings. No doubt there had been a more than usually hard day's work in the studio. On another evening, he probably would have responded to Miss Repplier as joyfully as to Mrs. Whitman. As it was, his story of the Lakes and the clergy was as funny as it could be, though, as Miss Repplier said afterwards, enchantingly funny and witty as it seemed to her when he told it, when she tried to tell it herself afterwards, she could not succeed in even suggesting the fun or the wit, and her friends could not understand why she had laughed. It was not only the story with Whistler, but the amazing way he told it.

I900] 
The monastery next door at the Rue du Bac was one of missionary monks who are sent out to the French Colonies. They are the bearded priests one sometimes sees in Paris. Every afternoon in summer at the hour of the Angelus, or in the month of May for the May devotions of the Blessed Virgin, they gathered under the great trees which towered over the wall dividing the gardens of the two houses, and there sang their hymns. It was beautiful and impressive and, no matter who was with Whistler in his garden or what was the talk, every one became silent and listened. Whistler loved it, felt the beauty of it, and so did we all.

Monday, September I7th. Coming home about ten, we found Whistler waiting, established with The Star. 'Partly a Boer evening, Brown of the Fine Art Society-little Brown-had lunched with us and told us stories which Whistler confirmed. Brown began life in the Seeleys' office. It was in the days of The Portfolio, and he was sent to see Whistler on some matter relating to the Billingsgate plate, which Whistler sold to The Portfolio. He had no idea he was to see a man in any way extraordinary, and he can remember now the vivid impression Whistler's manner and appearance made on him. It was in the White House. Whistler took him to the window and showed him the river and the view of Battersea beyond. Then he put his hand on Brown's shoulder and said, "I am afraid I am going to lose my house!" This was not long before the sale. In the meanwhile Brown drifted to the Fine Art Society's, carrying with him the deep impression made by Whistler and his work. The result was, the Society bought two London plates. Then the crash came. Whistler wanted to go to Venice, and they arranged with him for a series of twelve plates, to be done in three months, and they advanced part of the money. Whistler went away, time passed, no plates came, but demands for more money. They were used to artists who if they said three months, kept to it, and they began to have their doubts, while he, naturally, was furious at their suggestion of doubt. This, Brown says, was the cause of the trouble. Indignant letters passed, a wonderful correspondence, and all the time Whistler, who had no resentment against Brown, whose fault it was not, was writing I 86

[1900 
Whistler's America of Early Days

him friendly letters which he still has. Fifteen months was the length of time Whistler stayed in Venice. But when he did come back, the etchings were a great success. Next came the pastel show. Nothing of the kind had been done before, the public knew nothing of pastels, but they made eighteen hundred pounds out of the show. This Brown quoted to prove that Whistler had never been neglected, in one sense of the word anyway. They wanted him to go on, to follow up the first with another exhibition of the kind. But he wouldn't. He would have made a fortune, if he had, according to Brown.

Whistler added to this a description of his first appearance at the Fine Art Society's after his return. "Well, you know, I was just home, nobody had seen me and I drove up in a hansom. Nobody expected me. In one hand I held my long cane; with the other, I led by a ribbon a beautiful little white Pomeranian dog-it too had turned up quite suddenly. As I walked in, I spoke to no one, but putting up my glass I looked at the prints on the walls: Dear me! Dear me! I said. Still the same old sad work! Dear me! And Haden was there talking hard to Brown and laying down the law, and as he said Rembrandt, I said Ha! ha! and he vanished. And then, when I was hanging my etchings, the consternation was great. On the ladder, I could hear whispers below me-no one would be able to see the etchings. Of course, I said, that's all right. In an exhibition of etchings, the etchings are the last things people come to see. The pastel show was a source of constant consternation on their part, and amusement on mine. There was the private view, when I had my box of wonderful little Butterflies, which I gave only to the select few, and, naturally, everybody was eager to be decorated. And when the crowd was greatest, Royalty appeared, quite unprecedented, you know, at a private view, and the crowd was hustled into another room, and the Prince and Princess went round the gallery looking at everything, the Prince roaring over the catalogue. I am afraid you are very malicious, Mr. Whistler, the Princess said. There were, well, you know, differences too about money. The Society would pay nothing in advance. It was against their rules to pay until the end of the 1900] 


\section{The Whistler Journal}

show. So the next Saturday afternoon, I came just when the crowd was thickest, and everything was going beautifully, Huish and Brown taking people round and showing them and explaining the pastels, on the point of selling many, and I stood in the little central gallery, and I said in a loud gay voice, Well, the Show's over. Huish and Brown rushed up and tried to quiet me. Everybody was in a fearful agitation. But I said again, The Show's over: Ha! ha! they will not give me any money and the Show's over. Finally, Huish promised to give me a cheque on MondayI had first asked for two hundred pounds; now I made it three hundred, and so I said, All right, the Show can go on. And on Monday I had my cheque. A little later I exhibited the other etchings I made in Venice at the Dowdeswells."

Ernest G. Brown was a very good friend to Whistler. "He used to say that he would lay the eggs," Brown told us, "but I must supply the incubator. But he seemed anxious not to give up the eggs-that was the trouble!" Financially, and it was only for financial reasons that Whistler was commissioned by the Fine Art Society, the first show of his etchings for which the Fine Art Society paid him twelve hundred pounds and some proofs, could scarcely be considered a success. The first Venice Sets were not disposed of for years. Nor was eighteen hundred pounds for the pastels a great success as these things go. The fact is, he could never get any one to publish a set of any of his etchings after the publication of the two Venetian series. There is a little confusion in this note about the Catalogue and the Butterflies, which we were able to correct before the Life was written. The Catalogue that contains the newspaper comments and the Butterflies distributed to friends were for the exhibition of the Second Series of Etchings and Dry Points. This is the Catalogue in which Whistler so neatly exposed Wedmore who, after this, was careful not to commit himself quite so freely. He was not the only critic who now hesitated. Whistler's catalogues showed them up too unmercifully. There was a four page leaflet, a list of the First Venice Series, issued by the Fine Art Society but no brown paper catalogue. The F,tchings, however, were in a brown paper portfolio. The Fine Art Society held probably one or more other exhibitions of Whistler's water-colours and pastels, but most of his exhibitions in these years were at Dowdeswells'. At any rate they had a number I 88 


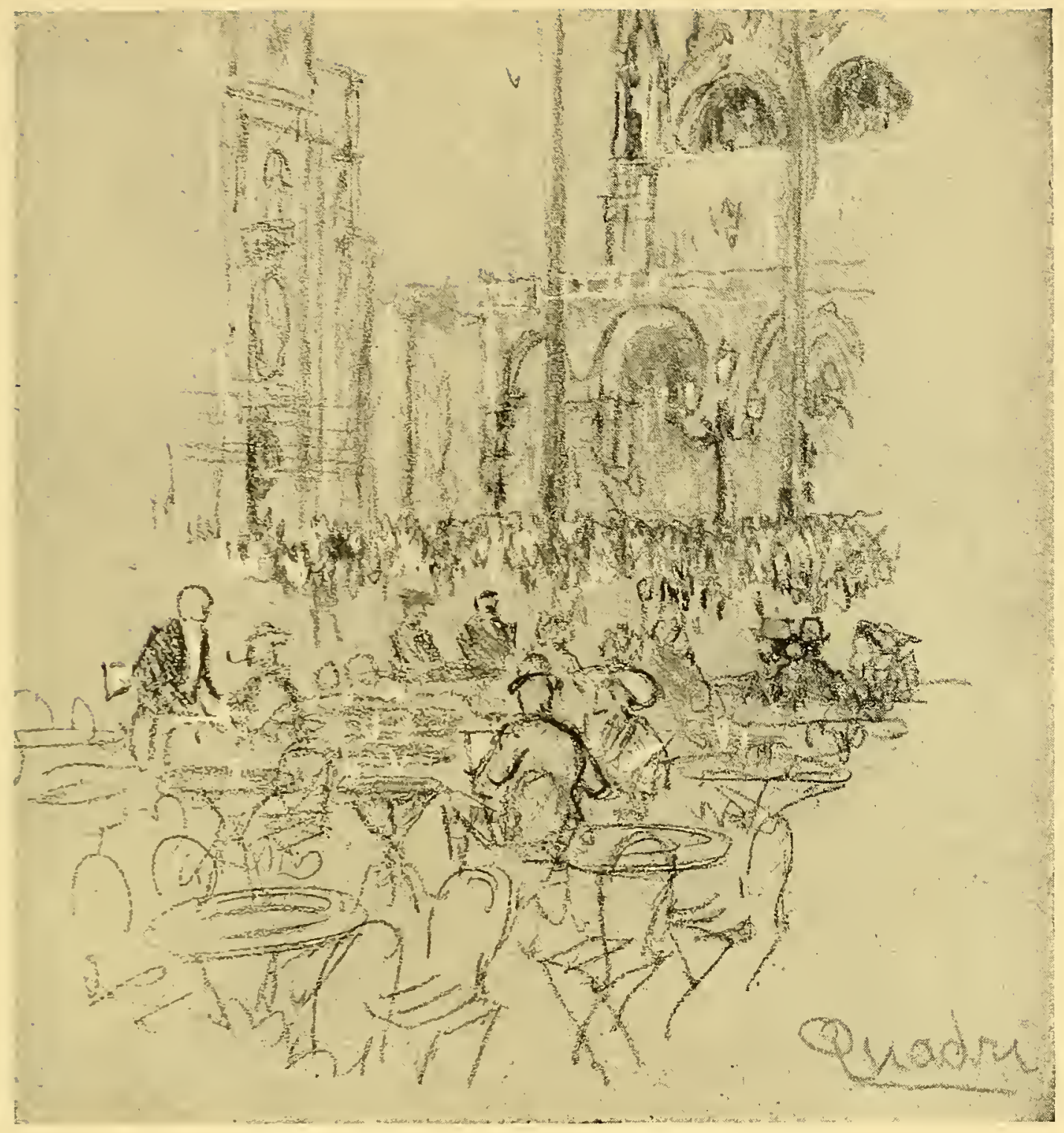

THE QUADRI AT VENICE, WHISTLER'S CAFÉ PASTEL

By Joseph Pennell

Pennell Collection, Library of Congress, Washington 


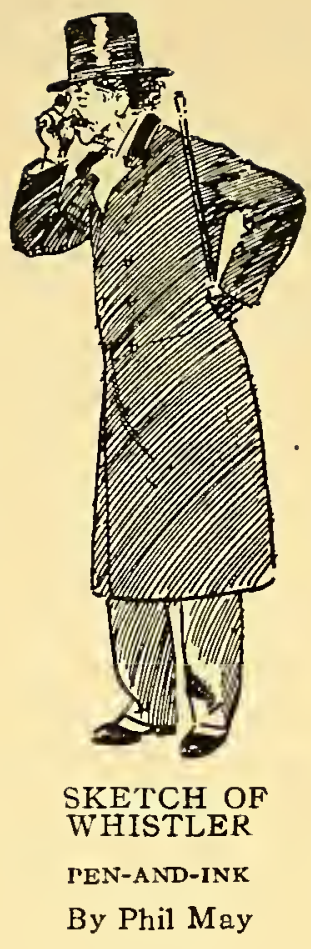


of water-colours and pastels in their possession which they eventually sold at Sotheby's. J. remembers going to the sale where they brought a mere nothing.

The Fine Art Society, however, arranged the first exhibition of his lithographs in London, in December, I895. For this, Whistler asked $J$. to write the Introduction to the Catalogue, the only time he ever asked any one to do so. The exhibition was far from a financial success, and no one save a few artists paid the least attention to it. The prices were mostly two and three guineas. But at the sale of the Jessop Collection at the New York Anderson Galleries in November, I9I9, for which also J. wrote an Introduction to the Catalogue one of these lithographs brought the sum of thirty-six hundred dollars and the total sales were about forty thousand, and the whole affair was thought of enough artistic importance to fill columns in the American papers and to be cabled to Europe. Yet these were the lithographs nobody wanted twentyfive years before.

The little white Pomeranian is the only dog we know of that figured publicly in Whistler's life. It went with the long stick and the cape of the overcoat, and all the gay extravagances of the Eighties, when it was conspicuous for a time. Mrs. Dr. Whistler said that he took it everywhere, to the theatre, in cabs, wherever he went. Once he left it for an evening by itself in the Air Street rooms, and when he came back it had eaten up a pair of his trousers, and that probably was the end, for he whipped it and called it a bad dog, and it disappeared as mysteriously as it appeared and was never replaced.

CHAPTER XII: FAILING HEALTH AND HIS WANDERINGS. THE YEAR NINETEEN HUNDRED CONTINUED

Tuesday, September I8th, I9oo. Whistler dined, to say goodbye to $\mathrm{J}$. on the point of starting for the Lakes. A Boer evening for he had come with a large supply of the evening papers. J. went back with him to the Hotel, and to the room of the Misses Hensman, the Managers, and drank whiskey and soda, and Whistler talked "Boer" until he made them white with rage, and then put them into a good humour by saying that, really, they ought to have been Boers themselves. And the end of it was that they brought out some peaches, and $\mathrm{J}$. did not get home until two in the morning. 1900] 
Sunday, September 23rd. Whistler called in the morning and he asked me to breakfast at the studio, but I couldn't go. He said he was doing some of the most wonderful things in pastel, nudes, they were really most marvellous, but, indeed, it was high time he did do something. More Boer and Chamberlain talk, his pockets as usual full of clippings. They will make, he says, an interesting history of the present condition of things in England.

Saturday, September 29th. Whistler and Miss Philip dined, and I invited the Greiffenhagens to meet them. First, the talk, was of the Paris Exhibition, the correctness and dignity of the French galleries, the naïvete of the English, the stateliness of the Grand Palais, the stairway, and a something elegant and true to tradition about it all. Then the talk veered to the country. Greiffenhagen said that he felt, more and more, as if he wanted to live in the country. Whistler asked "Why? The country is detestable. In Holland, it is different. There, I can see something." "But there is no country in Holland," Greiffenhagen said. "And that is just why I like it," was Whistler's answer, "no great full-blown shapeless trees as in England, but everything neat and trim, and the trunks of the trees painted white, the cows wear quilts, and it is all arranged, and charming." Then, some one said "Chamberlain," and the floodgates were opened. But the beautiful, kindly, intimate way in which Whistler said the most unpleasant things was stupendous. "Of course, you know, I do not speak as a stranger. I belong to London myself, have been here for years, and belong to it, and I understand, as you do"-he understands, that is, that Chamberlain is corrupt, that the English are hopelessly stupid, and many other things as pleasant. And in proof of their stupidity he tells of his dinner at Heinemann's, where he met Madame Sarah Grand, who started the evening by saying how delightful it was to be back in England. She had been in France for five or six weeks, and during all that time had seen no men, until one day on the Boulevards she met two Germans whom she could have embraced in welcome for they, at least, were men. And in France, the supposed-to-be men never could forget that Igo 
women are women-she liked to meet men as comrades-she did not want them always to be remembering her sex. And Whistler's comment was, "certainly the Englishwoman succeeds, as no others can, in obliging men to forget her sex." The other story was of a Lady Something, at Mrs. Curtis', in Venice, one afternoon meeting an Italian Princess who had just married a distinguished Roman Prince, a descendant of one of the oldest families in Rome. Ladycomplimented the Princess on her English. Oh, my grandfather was English, she explained. "I am so glad you're English," said Lady - "You know in England we don't think much of foreign Princesses." "And in Italy, we don't think much of English manners," was the answer. Mrs. Greiffenhagen wondered if England is in her decadence; thought not because art always marks the decadence of a country and there was none here yet. And she appealed to Whistler: didn't he think that the development of art in a country was a sign of its decadence? But he didn't know, "a good many countries manage to go to the dogs without it."

Maurice Greiffenhagen was an original member of the Council of the International. But he soon resigned. Later he went over to the Academic ranks.

Sunday, September 3oth. Breakfasted at one in the studio with Whistler and Miss Philip. He had just seen the reproduction of The Little White Girl in The Art Journal's Paris Exhibition, and Thomson's remark that it was for this he was given the Grand Prix. "He is playing into the hands of the many who like The Times man and D.S.M. are always passing over the recent work for the early masterpieces," Whistler said. "All are masterpieces; there is no better, no worse. The thing has always gone on and grown and the pictures I am painting now are full of qualities they cannot understand. D.S.M. cannot even get his facts straight. He spoke of The Little White Girl in the Salon des Refusés. It was never there. That was The White Girl, and The Little White Girl was painted some years after." He showed me two water-colours done in Holland-one of the sea rolling in to the low stretch of I900] 
sands, the other of Domburg nestling among the dunes-and a series of wonderful little pastels of the nude.

Thomson is David Croal Thomson who, at that time, was the editor of The Art Journal and who was issuing, in serial parts, a publication on the different art sections in the Paris Exposition of I900, and so important that Whistler did not care to ignore its mistakes. The Times man was T. Humphry Ward,- "the plain person Humphry," Whistler liked to call him. As will be seen, Whistler felt keenly and resented what seemed a deliberate attempt in England to deprive him of the honours awarded him in France. D. S. M. is D. S. MacColl, then art critic of The Saturday Review. His Scotch nonconformist conscience sometimes coloured his criticism in a manner incomprehensible and annoying to Whistler. For another specimen of it, we forget just what, earlier the same year, Whistler told $J$. there could be no sufficient punishment except to put D. S. M. in the Infantry that he might be marched into one of the Boer traps for the British and be shot, "that we hear him and read him no more." He tired of MacColl's championship of the New English Art Club which he described once as "only a raft."

Thursday, October 4th. Whistler came in late, about ten in the evening-for a few minutes-wants to ask J. to dinner, if J. gets back by Monday. Was afraid to stay longer, for he would certainly go to sleep. He laughed at what he calls my discretion. "You never have anything to tell me about people you see. Well, you know, the truth is, you have a cupboard full of skeletons and some day, when you are pulling the strings of one to put it back carefully in place, the whole lot will come rattling down about your ears." This was because Gosse and MacColl had been dining with me the night before. He had read MacColl's article in The Saturday, the first about the Paris Exhibition, devoted almost altogether to Manet, with just a passing mention of Whistler and Fantin and the others of the group. "It's all very well," Whistler said"Manet did good work, but he was always L'Ecolier."

Gosse is Edmund Gosse and MacColl, D. S. M. Whistler delighted in gossip and it was a disappointment to him when we had none to regale him with. He had ceased to be discreet himself, he would say, and did not expect discretion in others.

192 


\section{Failing Health and His Wanderings}

Sunday, October 7 th. Whistler called in the morning early to say "how do you do" to J. who came back last night. Said he would come to dinner, only he had arranged to dine with Jonathan Sturges at some little French restaurant. "Might I, perhaps, bring him?" We said, yes, of course, and they came at eight. He had been the night before dining in the Carlton Grill Room. "It is wonderful, I can go nowhere without meeting people I know. In the grill room was the manager of the Savoy. Upstairs, in the hall, a man bore down upon me, My dear Whistler, I am so glad to see you looking so well. You don't remember me? Chetwynd-Sir George Chetwynd. In the hall where I went for coffee, where the music is, at once General Arthur Collins, Princess Louise's Equerry, was at my side. So glad, I'm with some Americans, you must join us, nice simple Americans! Simple! Americans! Ha! ha! I laughed. But my dear Whistler, you must come, and I spent the evening with him. And here was this correct Equerry in the toils, why and what for, I do not know, of evidently an American millionaire, and so they are all being taken possession of in the Island!" $\mathrm{He}$ brought with him a beautiful Caran D'Ache-Le Départ du Maréchal Roberts-with the Boer popping up out of the box as the last handkerchief is waved and the boat steams off.

Jonathan Sturges was an American, a little dwarf, of whom Whistler said on one occasion when he had been on George Vanderbilt's yacht: "There we all were, you know-Philip-Velasquez-even the dwarves!" for Paul Leicester Ford was also in the party. Whistler was keen to keep on the right side of Vanderbilt and other patrons. J. will never forget one evening when Whistler was in bed and said he could not possibly get up. But a message or telegram from Vanderbilt asking him to dine brought him at once out of bed, and he went off in a hansom, and the next day, when we saw him, seemed the better for it.

Thursday, October IIth. We had already arranged to have $\mathrm{Mr}$. Radford, when Whistler wrote that he would dine with us. It was a curious combination, not sympathetic, but appreciated as everything of the kind must be by Whistler. He arrived, armed with Caran D'Ache's last cartoon in Le Journal; all the events of the I900] 


\section{The Whistler Journal}

day, seen from a balloon. The result was talk of the events of the day. I said I was glad the Americans had the sense, once they secured their Minister, to march out of China and Chinese complications. "But why shouldn't they?" Whistler asked. I suggested that after Manila and the Philippines one wasn't sure of American policy any longer. "Oh, but the Philippines," Whistler said, "that is quite different. Just a watering place!" Dinner dragged a bit, Radford being much engrossed with his own journalistic performances. After dinner I was alone for a minute with Whistler in the other room. Augustine made a descent upon us to ask who was the Monsieur who put us all to sleep? And Whistler just had time to say with pleasure, he had been dining with a type, a type he had fancied long since vanished. Of the rest of his talk I heard little, being obliged to entertain Radford while Whistler and J. talked over the International.

Mr. Radford was Ernest Radford, a minor poet and art critic. He died but a few months ago. We have referred to Whistler's liking for Augustine, upon whose intelligent sympathy, as on this occasion, he could invariably rely.

Sunday, October 14th. A funny dinner party: Whistler, Lavery, Miss Philip, and Mr. Harper, Professor of Assyrian at the Chicago University, whom J. picked up at the Whitefriars Club last night. He talked to me half through dinner, so that I only had scraps of Whistler. The first thing I had a chance to listen to was an account of the state of things in the studios when, as a youngster, he first came to London. "Well, you know, I was received graciously by the painters. Then there was coldness, and I could not understand. Artists locked themselves up in their studios, opened the door only on the chain; if they met each other on the street, they barely spoke. Models went round with an air of mystery. When I asked one where she had been posing, she said to Frith and Watts and Tadema. Golly, what a crew! I said. And that's just what they says when I told them I was a'posing to you. Then I found out the mystery; it was the moment of painting the Royal Academy picture. Each man was afraid his subject might be stolen. It 194 
was the era of the subject. And, at last, on Varnishing Day there was the subject in all its glory-wonderful!-The British subject! Like a flash the inspiration came-the Inventor! And in the Academy, there you saw him, the familiar model, the soldier or the Italian. And there he sat, hands on knees, head bent, brows knit, eyes staring; in a corner angels and cogwheels and things. Close to him, his wife, cold, ragged, the baby in her arms; he had failed. The story was told. It was clear as day-amazing!-The British subject-What?"

Then, one of his surprises. With all his West Point correctness and elegance, he now and then ventures on the last story you would expect from him, but always told, as he would say, charmingly. "A dandy about town, in the days when I was at Venice, went with a Lord Some One and a third man to the same hotel. They had heard much of mosquitoes and worse. The first morning, the dandy and the third man were bitter in the account of the misery they suffered during the night. 'But,' said the Lord-'I had no trouble, I saw no bugs.' The dandy stuttered a little. 'Even b-b-b-bugs,' he said, 'must draw the l-l-line somewhere!'" Lavery had a nice mosquito story. He had been warned of the American mosquito. In Philadelphia he stayed at a hotel at the corner of Broad and Walnut:- Just as he was going to sleep he heard a loud buzzing. He jumped up in agony. The ordinary mosquito poisoned him. This, he thought, meant death. He pulled down the windows, turned on the gas, looked all over the walls as well as he could for the pattern, found nothing, put out the light, but could not sleep for hours, lay there hot and cold. At last after a short, restless sleep, he woke with a start in the early morning, to the same loud, awful buzzing - another mosquito? It was the electric car round the corner. He had heard the last trolley car at night and been wakened by the first in the morning. After dinner Miss Philip and I sat together, while the men smoked, so that I had little more talk with Whistler.

Chase, dining with us one night in Buckingham Street, gave us another instance of Royal Academy methods that puzzled and at I900] 
the same time amused Whistler. Perhaps Chase published the story-he published most everything he knew about Whistler, but it will bear repetition. He went one day with Whistler to see George Boughton. The studio was flooded with light, no curtains, no blinds, no shades of any kind. Whistler's face screwed up in discomfort. "What's all this for?" "Why," said Boughton, "when I paint an outdoor picture in brilliant sunshine, I want to have all the real sunshine I can get in my studio." " $\mathrm{Hm}, \mathrm{hm}$," said Whistler. "And so, I suppose, if you were a musician and wanted to compose a blacksmith's chorus, you would go to the smithy's and put your ear close to the anvil, and get all the noise you could?"

Tuesday, October 16th. A meeting here of the International Committee was called for eight-and Whistler and Webb, his lawyer, dined with us first; Mr. Webb was late, so that dinner was hurried. The talk was chiefly of the International and the chances of an Exhibition, and the gallery where it might be held. Thomson's suggestion that the Society might claim the Royal Academy as a public building was discussed. Whistler evidently liked the suggestion, but Webb thought all the facts should be known before the proposition was made to the Committee. He was afraid there might be a reason against it somewhere; otherwise, why could not all societies of artists claim it? There was a probability, too, now that Admiral Maxse is dead, of making arrangements and better ones at the Skating Rink in Knightsbridge, where, after all, Whistler said, "the public now expect to find us." He recalled for Webb's benefit the evening Blaikie dined here when he told Blaikie he was one of the McNeills of Barra. His was the real Highland type, Blaikie said; that was why he looked so much like the present chief of the McNeills. "I am the chief," said Whistler. When the members of the Committee-only three-came, and after he had kept them waiting while he finished his dinner, it was funny to see how he got ready to be received by them, stopping a minute in the hall, straightening himself, giving a touch to his cravat, and another to his hair, just like a woman on her way to the drawing-room.

Webb is William Webb, Whistler's solicitor for many years. He was besides the solicitor for the International, and, finally, for 196 


\section{Failing Health and His Wanderings}

Miss Philip also, which led to endless complications. When the Whistler Memorial was started, he became its solicitor and treasurer. Mr. Webb certainly did an enormous amount for all these persons and bodies, and received in return little in cash, but a good deal in kudos, and more in blame. He is a very sporting person and loves the association with artists and actors, for many of whom he was the legal adviser. He was long Beerbohm Tree's solicitor. He is a curious type, not altogether extinct in England, whom Dickens might have used.

Whistler was fastidious about his personat appearance and was often misjudged for it. He was thought effeminate. Even artists failed to understand, with Mr. Walter MacEwen who gave us his first impression of Whistler at a big dinner in Paris a few years before Whistler's death. From the hall, MacEwen saw Whistler, as he lingered in the dressing-room, arranging his curls and necktie before the glass-"posing and prinking"-and MacEwen, after that, had no more use for him as a man, not appreciating the dandy -but not to appreciate the dandy in Whistler was not to know one very charming and characteristic side of him. He was neither vain nor effeminate. He simply sought perfection of finish in himself as in his art, in his writing-in everything that concerned him.

Saturday, October 2oth. Dined late at Heinemann's where Whistler is staying. Mrs. Heinemann was away. Dr. and Mrs. Chalmers Mitchell and Mrs. Ochs were the others. Somehow, not a brilliant dinner. I'sat next to Heinemann and Whistler was in the middle of the table between the other two women, on the opposite side, and I had little talk with him. He was telling Mrs. Mitchell the story of the entertainments given by Lewis of Lewis and Allenby, which I think I have written out already. His favourite memory is of the fancy dress party, to which Tadema came in full Roman costume, toga, sandals on his bare feet, crowned with flowers, and wearing eye-glasses. I do not remember how it started, but Heinemann began to confide to us what he does to keep the little hair still left to him. He did not think, as some one suggested, that it was the constant cutting or washing of their hair that made men lose it. Look at Whistler. "Yes, but give me time," said Whistler, hugely pleased with himself for saying it. Upstairs, again, I had no chance to talk with him, until just before I900] 


\section{The Whistler Journal}

leaving. "Dreadful," he said, "dreadful, you know, the way you drag me in. Here is Heinemann throwing down a letter on the table telling me I should read it, and here you are asking me peremptorily to settle finally and definitely about the publication of the book, and saying Heinemann told you I was back in town. Shocking, shocking! Why so excited?" And he complained to J. "you are bent on making an Old Master of me before my time."

Nothing in London amused Whistler so much as Alma-Tadema's performances. The golden stairs of his house Whistler always called "brazen cheap," and Tadema he always described as "he of the St. John's Wooden eye." Once, in that little room at Garlant's where Whistler and his friends often lingered in the late evening, something was said of Tadema. Miss Hensman, the manager, protested. "But I like Tadema's pictures." Whistler looked carefully round, then "Hush-sh-sh," he whispered, "I won't say anything about it." This reminds us of the man who could not quite understand what it was he liked in Japanese prints and was puzzled by Whistler's work in just the same way. What was it? colour-line-drawing-What? "Well, you know," said Whistler, "if I were you, I just wouldn't worry about it!" Poor Tadema! His fame ended with his life, while Whistler's began with his death and has increased ever since.

As time went on, although Whistler always wanted us to write the book, he did not want to be bothered about it, especially as his health made him more nervous about himself. We recognized this and bothered him as little as possible, and undoubtedly it was because we did not bother him that he gave us so much information and talked so freely and frankly. A distinct difference is seen in the notes towards the end of 1900, as he began to grow weaker and more nervous. The long talks were the exceptions. This year really marks the Beginning of the End, as we say in the Life. The Journal becomes a chronicle of his health.

Tuesday, October 3oth. A message from Whistler to say that he is just back from Paris, and is at Heinemann's, laid up with a bad cold, and will Joseph come up in the afternoon and bring The Magazine of Art and Pall Mall with him? He has just seen The Daily Chronicle and the reference to Spielmann's Protest and Halkett's note. Later on I got a telegram asking me to dinner, I98 
and we both dined there. Whistler was fairly tired by the time I arrived, but was considering the question whether the Protest was libellous or not.

The matter which now worried Whistler, though the worry should have been spared him, came from the fact that, after he had sent his own portrait, Brown and Gold, and one of Mrs. Whibley, $L ' A n d a l o u s e$, to the 1900 Exposition in Paris, Mr. Cauldwell, the American Commissioner, or some one connected with the American Section, thought it would be a good thing to add The Little White Girl to his exhibit. This he did, entirely by invitation. When the medals were awarded, the plaque stating that he won the Grand Prix, was put on the frame of The Little White Girl which was not in competition, as only works produced since the year I889 were eligible. As we have said, he won another Grand Prix for his etchings, many of which also were not eligible. A British art writer named M. H. Spielmann took the occasion to criticise the awards in the American Section with which he had nothing whatsoever to do as he was supposed to be an Englishman, and he had the impudence to suggest, in The Magazine of Art of which he was editor and in the London Graphic to which he contributed, that because the picture on which the plaque was put was not eligible, therefore the Grand Prix for painting should not be awarded to Whistler. This is the critic, now forgotten as an art authority, who had previously described Whistler's lithographs as "pencil sketches carefully reproduced," who had got hold of advance sheets of the TenO'Clock by methods he never could explain and reviewed it in The Pall Mall, who had acquired his knowledge of art, Whistler said, by running to fires and reporting them, and who was last seen by Whistler walking down Piccadilly with the nude on his arm, "trying to explain Horsley soit qui mal y pense." Whistler was rightly indignant at Spielmann's impudent interference and made him apologize for this interference, as the notes record. We cannot recall just what Halkett's note was. Halkett was then writing art criticism for The Pall Mall Gazette, and when there was question of Whistler was usually on the right side.

Thursday, November 8th. Came home at six to find Whistler here. I had been to tea at Mrs. Prothero's where I met Mrs. Z. I asked Whistler if he had ever met her. "No, I have never met her, but I understand many have!" He told us of a breakfast at Heinemann's, where there had been some very British Britons, a German 1900] 
The Whistler Journal

and himself. One of the Britons was bragging about British honesty in all things, in the Colonies, in the conduct of the late war. "The trouble is, we're too honest," he said, "we've always been stupidly honest." Whistler, who had been saying nothing, got up. "'You see,' I said to the German, 'it's now historically acknowledged: whenever there has been honesty in this country, there has been stupidity.' And with that, I left the room."

Friday, November gth. Whistler and Webb both came to dinner to talk over the Spielmann business, and there was little talk of anything else. J. had collected everything from the first note in The Graphic, the announcement really, of the Protest in The Magazine of Art, to the last comment by Halkett in The Pall Mall. Webb thought there was distinctly libel, and that Spielmann's letter of explanation in The Daily Chronicle only aggravated the case, showing he knew the facts he had suppressed. One thing Whistler told us casually is of importance in the history of his work. I stated in The Daily Chronicle that the date was plainly on The Little White Girl, so the jury of acceptance knew what they were about in hanging it. I was sure, or thought I was sure of it because of the date on the reproduction in Virtue's Paris Exhibition. But Whistler said that this was an old reproduction, and that, recently, in working on the picture he painted out the date, as he did not think there was any use of seeing those great figures sprawling there. It was decided that Webb was to write asking for an apology from the different papers-Graphic, Magazine of Art, Pall Mall, Globe-beginning with The Graphic. Whistler said that when he sent in the two full-length portraits-of himself and Mrs. Whibley-both painted within recent years, the Committee begged him to send something else, and The Little White Girl was suggested because it had never been seen in Paris. But this he did not seem to have mentioned in the affair.

Sunday, November IIth. Whistler came in very late in the afternoon. Webb is to bring the letter tomorrow when they all dine at Lavery's. I only saw him for a minute as I had to dress for dinner, the Janviers and Fishers coming, and he could not stay. 200 


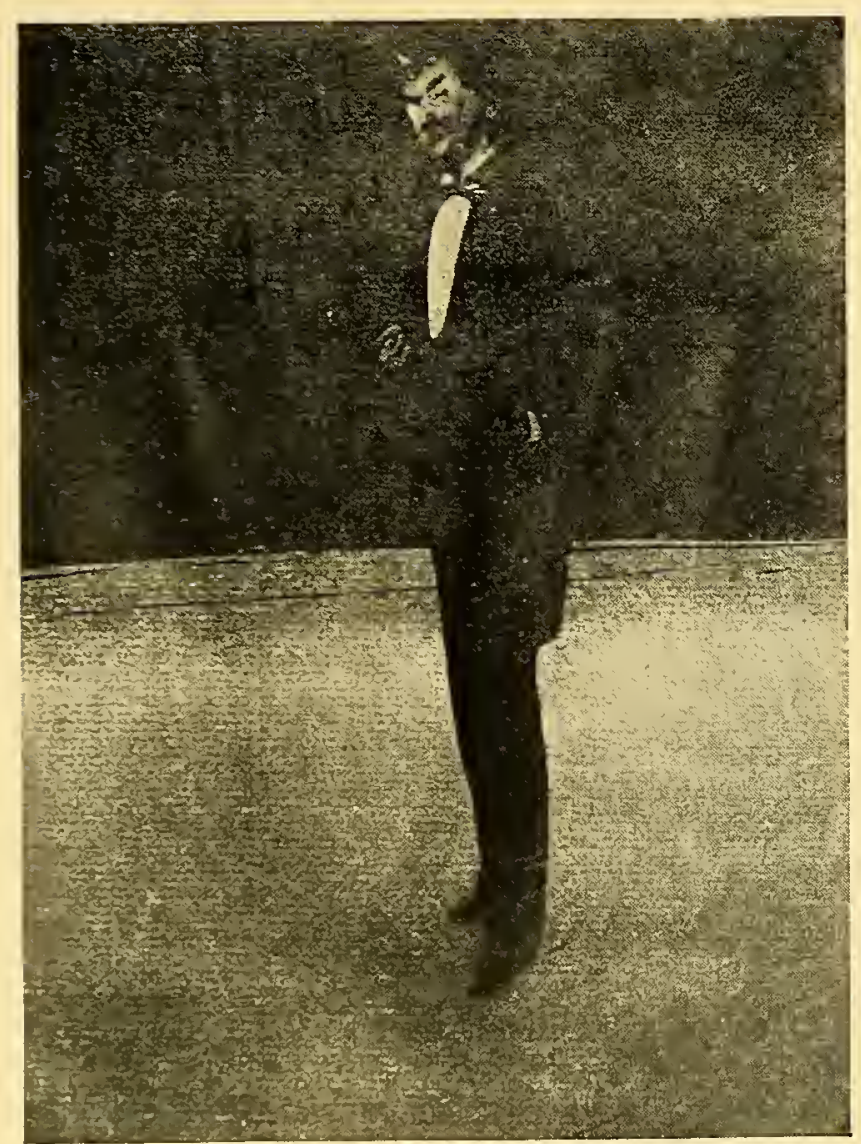

PORTRAIT OF WHISTLER

WOOD-BLOCK IN COLOUR

Drawn and cut by William Nicholson, Esq. 



\section{Failing Health and His Wanderings}

Monday, November I2th. Whistler, Webb, and J. all dined at Lavery's. The letter wouldn't do at all-too complicated and long, and Whistler is to come tomorrow morning and go into the matter with $\mathrm{J}$.

Tuesday, November I 3 th. Whistier came in a little before ten, just as I was off to the Portrait Painters. It was decided to send the letter to The Graphic only, and wait developments. Whistler wrote to Cauldwell, the American Commissioner, about it a week ago, and in answering a letter from Cauldwell yesterday, I said that $\mathrm{J}$. and I felt an official word from him would clear the air. $\mathrm{J}$. went to the South Kensington meeting in the evening. Cundall was horrified at the scheme of hanging J. suggested. "Why," he said, "if we hang the drawings like that, the Show will look just like the British Artists when Whistler was there."

Whistler dined alone with me. He wanted to know all about the Portrait Painters' show, how his picture looks, what the critics said, and because I gathered so little from the critics, I know he feels it one of the occasions when my discretion amounts to indiscretion. I told him about MacColl's scheme for presenting a Rodin-the Balzac-to South Kensington. "Well, MacColl," he said, "always gets hold of the wrong end, and, of course, admires Rodin for the things, like the Balzac, which are least admirable. It is the same with Manet about whom he has been writing of late. Manet was a student, with a sense of certain things in paint, that was all. He never understood that art was a positive science, one step leading to another. He painted his dark pictures and they looked very well when you came to them at Durand-Ruel's, after wandering through rooms full of awful blues and violets and greens. But Manet was so little in earnest in them that, midway in his career, he took to the violets and blues and greens himself. It is the same with many men. They paint in one way, with brilliant colour say, then they see something like Ribot, and think, O well, we had better try this. And, in the end, they do nothing of themselves. Look at Shannon. The Shannon at the Portrait Painters is very weak."

I 900 ] 
The Whistler Journal

Then he suggested winter vegetables, revealing a surprising knowledge of just how rice and beets, among others, were to be cooked. And after dinner, he slept-it was because he was sleeping so badly at nights - and there was a fine struggle between his sleepiness and his gallantry. And then Augustine made him a good strong grog for his cold. And then Joseph came back from South Kensington, bringing the E. J. Sullivans with him, and I was too ill from the tropical heat of the room, the big fire I kept up for him, to listen to anybody or anything.

Thursday, November I5th. Whistler again came in early, with the papers about the private view at the Portrait Painters, and why wasn't my article in? Webb has sent his letter to The Graphic, and The Graphic has written politely to say they have sent for Spielmann, and so the matter rests. It is certainly too late for this week.

Friday, November I6th. Whistler, confined to the hotel by his cold, sent for J. who went back in the afternoon, when George Vanderbilt and Sturges came in together. The latter said they were all talking about the affair at the Arts Club, and also at Rothenstein's where he had been and found the usual crowd, Steer, Tonks, Fred Brown. They were still full of Whistler's appearance at the Eden sale-he had ruined prices, they said

Saturday, November I7th. Whistler again ill in the hotel, and again sent for J. who went in the afternoon. But there is no new development.

Monday, November Igth. Whistler dined-he had been at the studio all day, but was worried about himself-his cough will not go, and he talks of Tangier. Nothing from Webb. Strange was here too, and Whistler recalled his South Kensington experiences. "I was a youngster at the time, of course, but I knew old Sir Henry Cole and the other South Kensington people of his day. I told Sir Henry that he ought to provide me with fine studios in the Museum, it would, well, you know, be an honour to the Museum. 202 


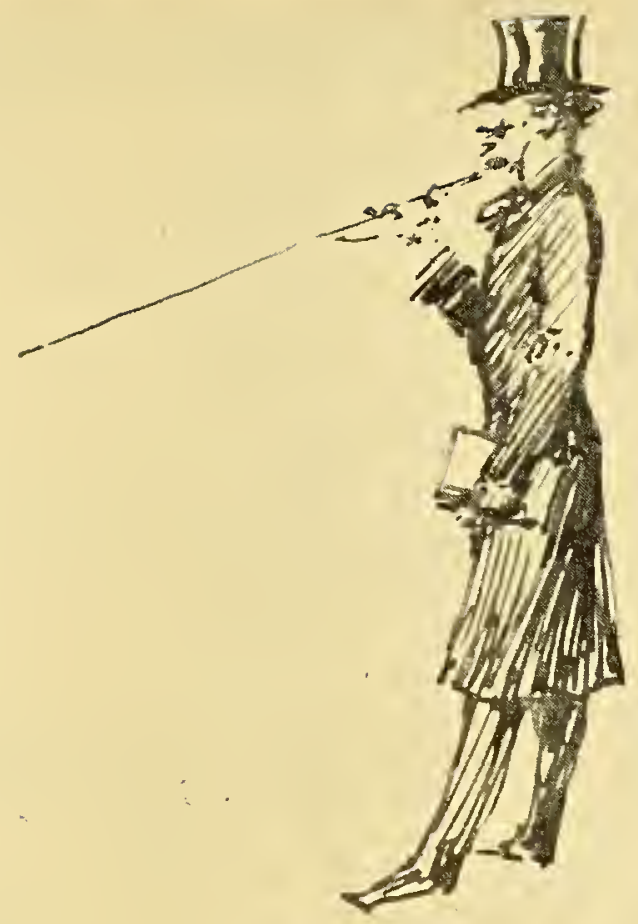

Caucus is.

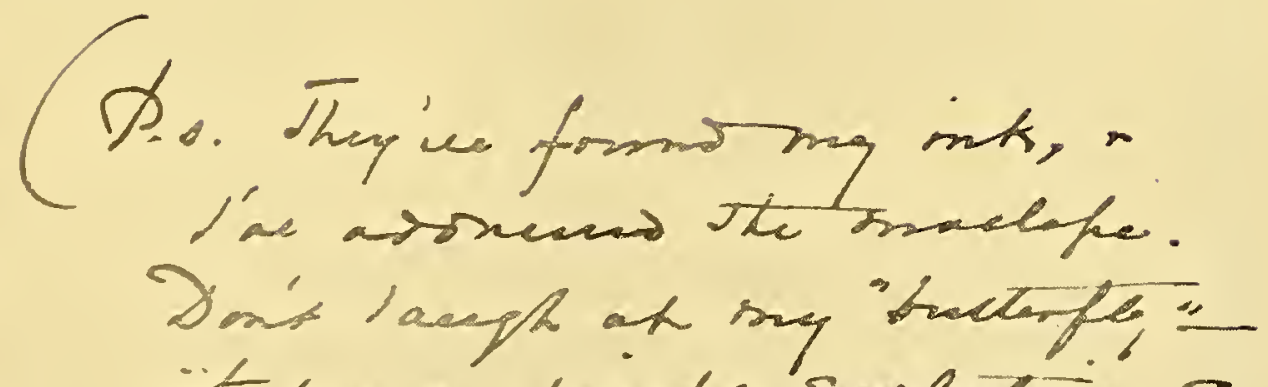
it bes a imper sedation, -

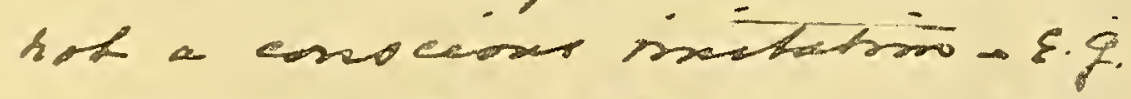

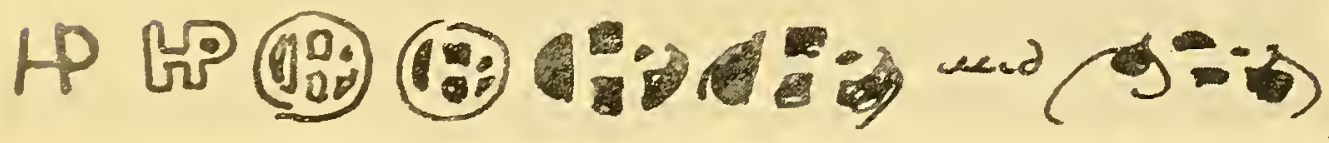

SKETCH OF WHISTLER

PEN-AND-INK

By Harper Pennington and Evolution of his Signature 


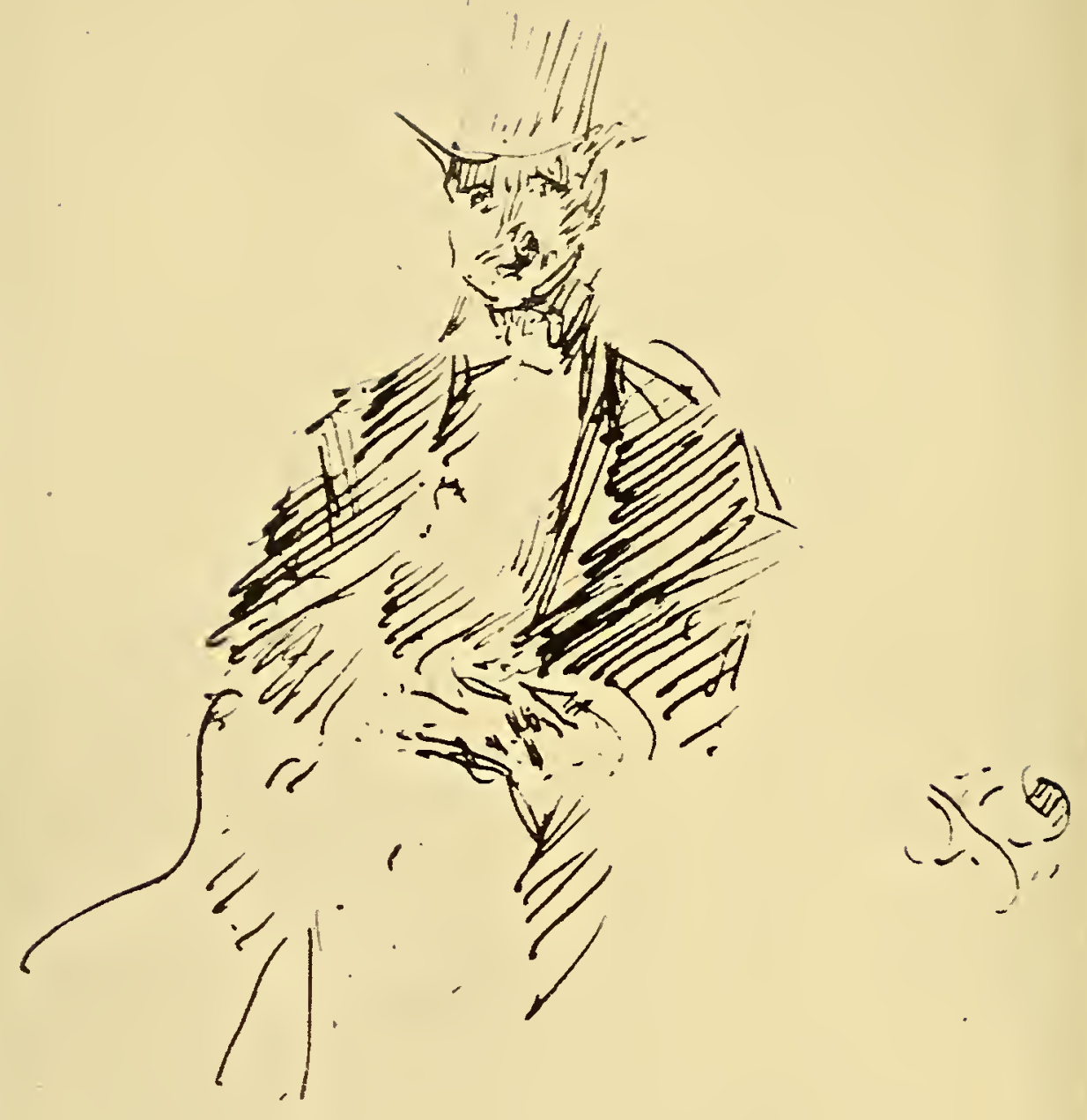

SKETCH OF HARPER PENNINGTON

PEN-AND-INK

By Whistler 


\section{Failing Health and His Wanderings}

Sir Henry always liked me. It was in the days when Haden was general practitioner, and through knowing all these people he got a post for his valet in the Library, and for his coachman's son in the Science Department." But later on he was fearfully upset because he sneezed. "That," he said, "is something new, I am sure," and it sent him home early, Strange having gone and got a cab for him.

Strange is E. F. Strange, then the Keeper of Prints and Drawings at South Kensington-the Victoria and Albert Museum. Under his able administration that Department was vastly improved.

Friday, November 23rd. Whistler called on us the first thing in the morning. Spielmann is to apologize in The Graphic; an abject apology. He was clearly wrong; he is glad to withdraw the assertion; and he apologizes. J., who had gone out before Whistler called, when he came back, thought Spielmann should be made to insert the apology in other papers and went at once to see Whistler about it. It was arranged that Whistler and Webb are to dine with us tomorrow evening to talk it over.

Saturday, November 24th. Whistler and Webb came to dinner. Webb's plan is, once the apology is published in The Graphic, then to demand that Spielmann insert it in other papers. Having admitted his mistake, he can hardly refuse. Webb has written to The Globe. Whistler wandered off in true Whistlerian style into the fact that the rules were made only to be broken in cases like his own, as Cauldwell had been ready to admit. J. warned him that it would be to his disadvantage to admit as much to the public, who would think he thus put Spielmann in the right, and the final argument between them seemed, as so often before, to have come. But, also, as often before, it blew over.

Webb referred to a paragraph in $M$. $A$. $P$. It is the same apparently as one published in International Art Notes for November: "An Art Student in Paris recently asked Mr. Whistler if he thought Nature should be painted as she saw it. The reply of the Master was, 'there is no reason why you should not paint Nature exactly I900] 


\section{The Whistler Journal}

as you see her, provided that you do not see Nature exactly as you paint her." "As usual," Whistler said, "there is some foundation, but the story is garbled. I was going round the school one morning, the students all following me, listening and breathing hard at my neck, when I came to a lady who had not been there very long. Her palette was a mess. I pointed to different little dabs of colour, and asked her if she saw anything like that in the model? $\mathrm{O}$, she said, then you want me to paint things as I see them? Well, yes, I thought, it would not be a bad idea. Excellent, excellent! A few weeks later, I was again making the round, the students again at my back, breathing and listening hard, and I came to the lady, 'I believe,' I said, 'this is the lady who wanted to know if she was to paint things as she saw them?' Yes, she said, she was. 'Excellent,' I said, 'but the shock will come the day you see them as you paint them!", J. told him of the young lady from Chicago who was here this morning, interviewing him-wanting to know everything, even whether he was born or not. Whistler interrupted him: "You should have answered, "Yes, Madam, born, not made." " The evening ended with a violent discussion about Kruger who, Whistler declares, has done the one and only right thing in coming to Europe. Webb undertook to tell us the "logic" of the South African business, and between them they kept us up till midnight. J. fought everybody about Kruger.

Sunday, November 25th. Whistler and Cauldwell, and the Heinemanns to dinner. I had little chance to talk to Whistler. He told us one story at dinner that shows how ready he is to appreciate anything in the shape of drollery, even at his own expense. It was at the Académie. "I had been talking to one of the students about her work, and half the time she seemed to pay no attention to what I said. I am afraid, I told her, you do not hear very well? 'Yes,' she said, 'I am a little deaf; not altogether an unmitigated evil!"'

Cauldwell was happy over the compliments he has received for the scheme of decoration and hanging of the American Section in Paris. He spoke of the intrigues of Dannat head of the American artists 204

[1900 
in Paris. Whistler, with characteristic unwillingness to see what he does not want to see, laughed at the idea of Dannat's having any influence at all in Paris. But Cauldwell thought he would have not a little in the coming decorations to Americans. That there might be no mistake about the official feeling anyway, he sent in three names of which the American Commission approved if decorations were to be given to any American artists.

John B. Cauldwell was the American Commissioner of Art at the Paris Exposition. He was naturally anxious to have Whistler's work a feature of his Section, but at first he scarcely knew the right way to approach Whistler. One of the first things he did on arriving in Paris was to ask Whistler to call on him at four o'clock sharp. He began to understand when, a few days afterwards, Whistler wrote, saying he never had been and never would be any place at four o'clock sharp. After that, we had several enjoyable evenings in London together. One of the decorations went to Whistler, who was made an Officer of the Legion of Honour.

Thursday, November 29th. Were both to dine with Whistler, but he was ill in bed, and so we dined with Webb alone and went with him, and without Whistler to see Herod at Her Majesty's.

Saturday, December Ist. Whistler came to dinner, was better but more depressed than I have seen him, ordered off at once by the Doctor, who wants him to go somewhere by sea. He talked of the American pictures bought for the Luxembourg. "Really," I told Bénédite the Director, "it was high time for me to take my Mummy away from his hotel!" Spielmann's apology is in The Graphic to-day. The Globe agrees to apologize-four hundred Englishmen have surrendered to the Boers-this morning brought the news of Oscar Wilde's death. "Really," little Sturges said to him, "what a week you have had!" But he was too tired to rise to it, and he slept the greater part of the evening.

M. Bénédite, lunching with us on the day of the opening of the Whistler Memorial Exhibition in London I905, in the course of much Whistler talk said it was the purchase of a Burne-Jones for the Luxembourg that caused Whistler to protest. "Really, I900] 


\section{The Whistler Journal}

after that, he did not know if he could leave his Mother in M. Bénédite's auberge."

Tuesday, December 4th. Whistler wrote to us to ask if he could come to dinner. He expects to get off on Friday of this week. He was too tired to do much but sleep.

Thursday, December 5th. Whistler and Miss Philip dined-we had asked them for the last evening but the journey is put off again. He was down about the way things were going in Paris in his dispute with the lady in the apartment above him in the Rue du Bac. She would beat her carpets out of the window into their garden, and there was no way of stopping her. He tried the law, but was told he must have disinterested witnesses, outside the family. "What can I do? I might engage a detective and a month might pass before she would do it again. But not long since, in the very act of brushing, she or her servant let a carpet fall down into my garden and my servant refused to give it up. The old lady went to law, and my lawyer advised me to give up the carpet." It depressed him hopelessly - thought he must start for Paris at once-it was always the way-people always got the better of him. But the extraordinary part of it to me was that he should bother about such trifles, or get involved in them. Then The Globe published an apology, but not exactly as he wanted it. Altogether, he saw everything blue, and for the first time, went to sleep long before dinner was over. Sullivan and Hartley came in afterwards, but it could not rouse him, he talked steamships with Joseph and left at an unusually early hour.

Monday, December Ioth. The Sauters and the Waltons to dinner, as an International Sub-Committee Meeting, with Mr. Webb, was to be held afterwards at nine. Whistler not yet gone, came in when dinner was almost over. "Lowered in tone-the Doctor says I am-well, you know, the result, no doubt, of living so long in the midst of English pictures." But he was too low, even for the usual jest with Augustine, who saw he was in no humour to be "scolded." However, a little dinner and the Spielmann affair 206 


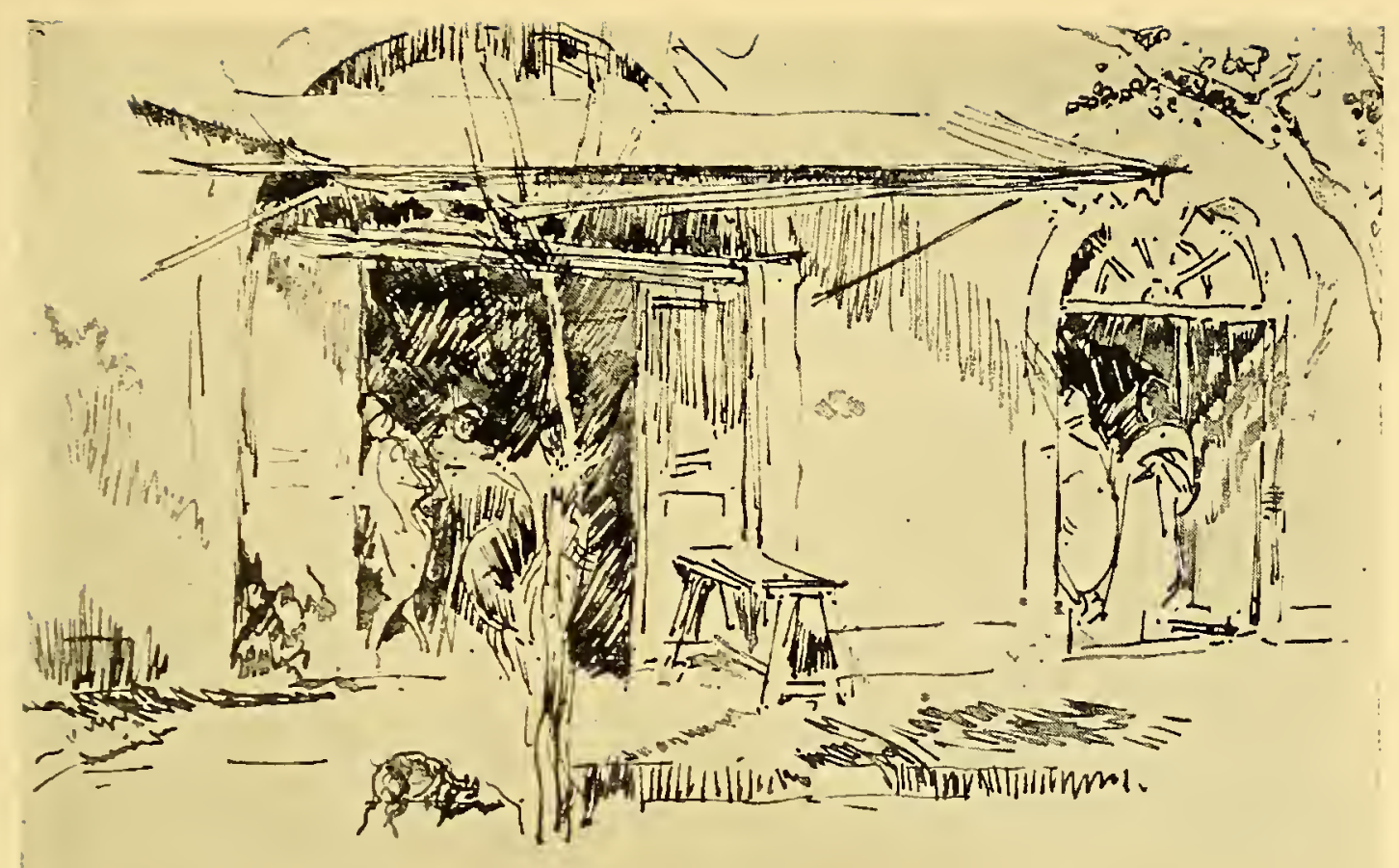

CAFÉ, CORSICA PEN-AND-INK

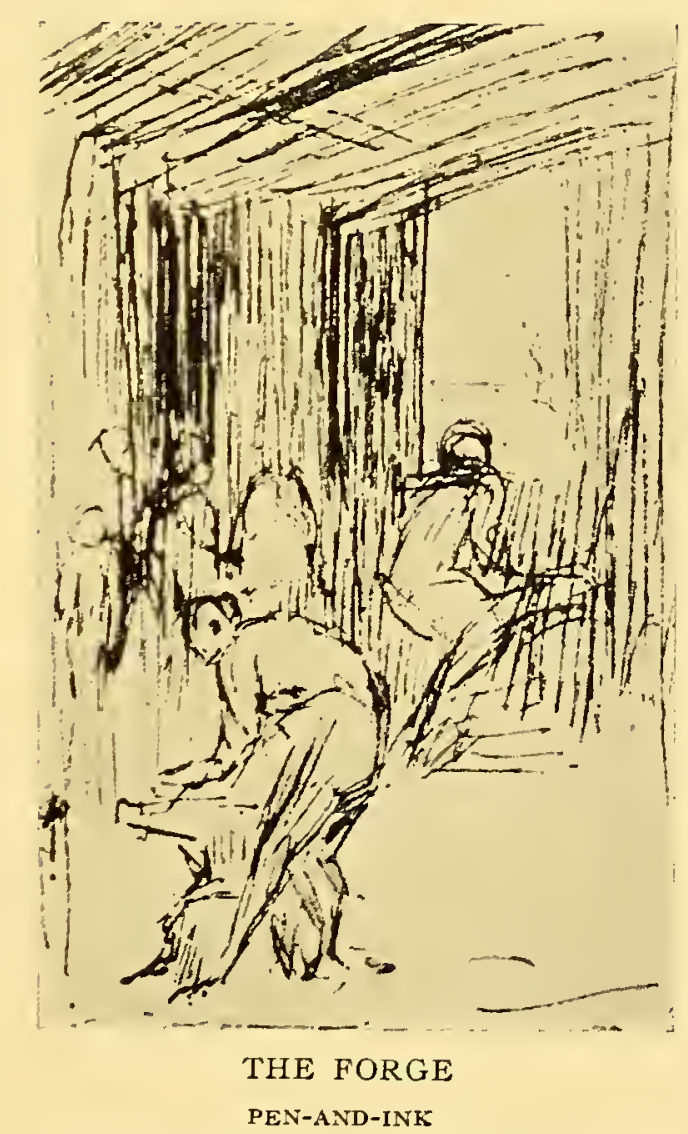

In the possession of Messrs. Knoedler and Co. 

woke him up. He went through it all for the benefit of the Sauters and Waltons-and then the Boers came next. But he left at once after the Committee Meeting and I saw little of him.

Wednesday, December Iath. Whistler telegraphed us that he would come to dinner. J. was lecturing at the Automobile Club-and he dined with me alone. He leaves on Friday. The Chairman of the P. \& O. Company, Sir Thomas Sutherland, has given him letters to the Manager and the Captain, recommending that everything should be done for him, and this, and the little attentions it implies, seemed to reconcile him to going. He sails for Gibraltar, and from there, probably to Tangier and Algiers. He slept calmly after dinner. Tried to shake it off, said it was shocking, but could not help himself, and slept again. After his grog, about half past ten, went home.

Friday, December I4th. After breakfast, J. went round to say goodbye to Whistler. Found him in all the disorder of packing, wishing he had not decided for Tangier and waiting for Mr. Philip who is to go with him. J. left him to his packing, and we now wait to see if he really gets off.

He did-get off the next morning.

One matter which $\mathrm{E}$. did not note was rather important. The day before he left, he hurriedly sent round ten or a dozen copper plates to have them grounded, wanting to take them with him the next day. J. grounded them at once as Whistler asked, and Whistler packed them up in his shirts, J. telling him, however, that the ground would probably come off as it was not properly cooled and fixed. He drew on some of them in Corsica, may be on all, and tried to bite a few. But the ground did come off, as J. warned him it would, though even then the designs could have been preserved if Whistler had only known how, as we know now. If the executrix still has the plates with the drawings on them they could easily be bitten by Sir Frank Short and printed. When Whistler returned, he blamed the whole thing on J. But J., as usual, refused to be blamed and one of the worst of all rows between them blew over like all the rest.

1900] 
CHAPTER XIII: THE RETURN FROM CORSICA AND WHISTLER'S LIFE IN ENGLAND. THE YEAR NINETEEN HUNDRED AND ONE

Friday, May roth, roor. Got back from Paris and the Salons a little after six to be met at Charing Cross Station by Augustine in a great state of excitement. M. Whistler had arrived from Corsica this morning, and had come to see me just as she was starting to the station to meet me. He walked back to Charing Cross with her, everybody staring. He had on a big overcoat, the brown one, and a little round felt hat, en voyage; she, as usual en cheveux. He asked for all the news and she invited him to dinner. Madame would not be pleased if he did not dine, and there were pigeons for dinner, just what he liked! I got home and had just changed my gown when he arrived. "Positively shocking and no possible excuse for it, but-well-here I am." He looks infinitely better, like himself again. He was full of his journey back, on a P. and O. steamer from Marseilles. "There I fell in to the midst of the Islanders, and after so many months away! Nobody but English on board. After months of not seeing them, really they were amazing. There they all were at dinner, you know, the women in low gowns, the men in dinner jackets. They might look a trifle green, they might suddenly run when the ship rolled, but what matter? There they were, men in dinner jackets, stewards behind their chairs in dinner jackets, and so, all's right with the country. And, do you know, it made the whole business clear to me down there in South Africa-what? At home, every Englishman does his duty, appears in his dinner jacket at the dinner hour, and so what difference does it make what the Boers are doing? All is well with England! You know, you might just as well dress to ride in an omnibus!"

As to himself: "I have discovered, at last, what is the matter with me. It never occurred to me before. At first, at Ajaccio, though I got through little, I never went out without a sketch book or an etching plate. I was always meaning to work, always thinking I must. Then the Curator of the Museum offered me the use of his studio. The first day I was there, he watched me, but said 208 


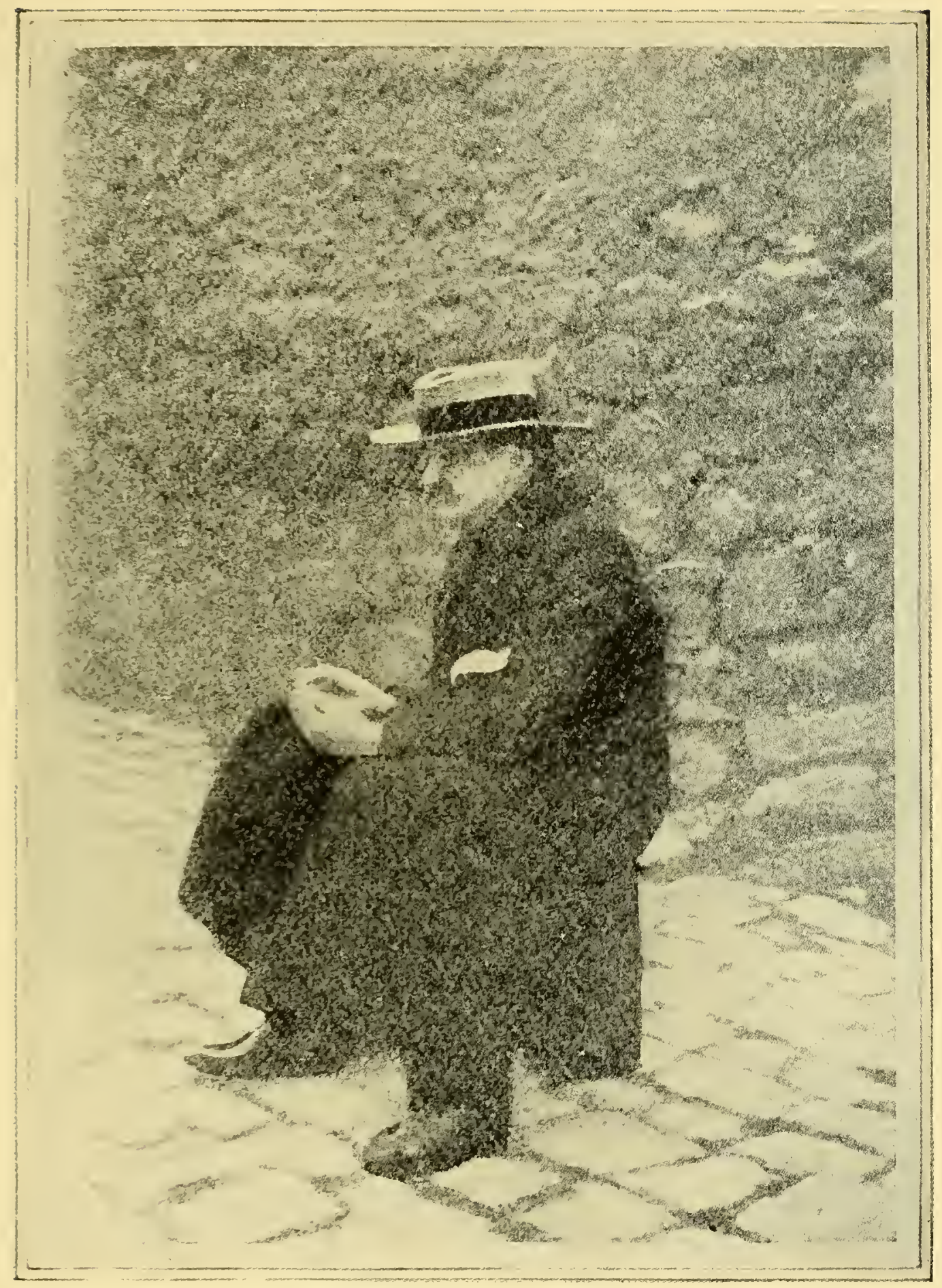

WHISTLER SKETCHING IN CORSICA

PHOTOGRAPH

By William Heinemann 


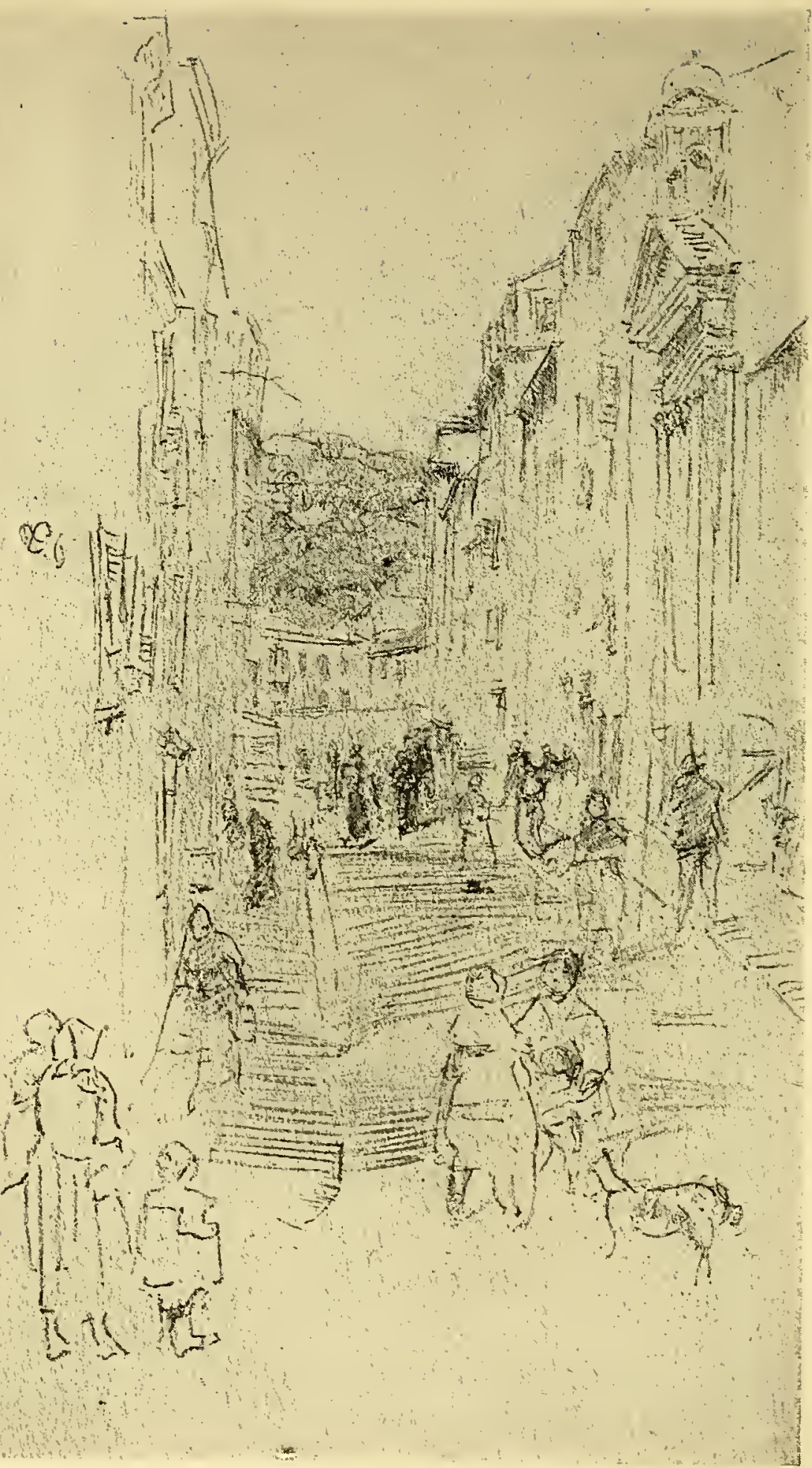

A STREET IN CORSICA

PEN-AND-PENCIL

In the possession of Messrs. Knoedler and Co. 
nothing until the afternoon. Then, 'But, Mr. Whistler, I have looked at you, I have been watching. You are all nerves. You do nothing. You try to but you cannot settle down to it. What you need is rest, to do nothing, not to try to do anything.' And then, all of a sudden, you know, it struck me I had never rested, I never had done nothing, it was the one thing I needed. And I put myself down to doing nothing-amazing, you know. No more sketch books, no more etching plates. I just sat in the sun and slept. I was cured. You know, Joseph must sit in the sun and sleep. Write and tell him so!"

After he left London in the early winter, Whistler had gone straight to Gibraltar, and then to the African coast, and zigzagged back between Tangier, Algiers and Marseilles, hunting for warm weather, which he did not find. Finally, he went to Corsica and there he did find it. He tried to work all the while and made, a mong other things, a series of little pen and pencil drawings, some of which were purchased by Richard A. Canfield. He wrote to us only once or twice. But he got Mr. Heinemann to join him in Corsica, and there they spent some time together, and he worked on one or more of his copper plates, the ground of which came off, as we have said. J. was, as usual at this time of the year, away when Whistler got back.

We were often amused at his conviction that J. must be in need of the same remedies and should be forced to take them. Once, when ill in bed at the Rue du Bac, in the hands of the Doctor, he sent E. word that J., who had nothing in the world the matter with him, must have a Doctor too, must learn there were other things besides his Yankee patent cherry drug, a tonic we had come upon at a chemist's in the Strand and patriotically invested in as our unfailing pick-me-up, while Whistler scoffed.

Sunday, May I2th. Whistler, Kennedy, and Landor came to dinner. Whistler told them too about the dinner jacket. But the talk was mostly on the Boers, and I thought every minute war would break out between him and Kennedy. The evening was spent by me chiefly in preventing it.

Landor is A. H. Savage Landor, the traveller, who at one time stayed much at Heinemann's flat. Whistler was very fond of him, as we all were. When Landor escaped from Thibet, Whistler sent I90I] 


\section{The Whistler Journal}

him a telegram of congratulations, one of the first he received at the frontier. Landor could tell stories and act them even better than he wrote, and we shall never forget the morning when, with a hearth rug for a kimono, he ate an imaginary dinner out of an inkstand with two pencils for chopsticks, and described the talk of the whole company with whom he was dining. Or, another time, when he told how in pumps he won a hare and hound race in the Scotch Highlands, and how, in the same light shoes, he climbed the Himalayas.

Friday, May I7th. Dined at Mr. Heinemann's and Whistler was there, but I had no chance for more than a word or two. There was a big party.

Monday, May 2oth. Whistler and the Sauters came to dinner. Talk all of Boers. But he told us of a wonderful cake he had eaten at Ajaccio. "After I had begun my rest cure, I used to saunter up every day to the pastry cook's, where they make wonderful cakes, buy a large supply, bring them back, and devour them all alone when I sat in the sun in the afternoon. Shocking! Well, you know, one day I saw a most beautiful cake, of a wonderful golden colour. What? It was fairly big, but it looked uncommonly good, and I bought it. I took it home, I went upstairs to my bedroom, and I began. It was crisp, fresh, but with the first mouthful, I was appalled at the flavour. Tried a second, a third, then rang the bell and presented it to the maid. The next day I told the Curator and the mystery was explained. It was a cake peculiar to Ajaccio and made there ever since the days of the old Romans, a cake of honey and oil they offered in sacrifice at their great spring festival. I was enchanted. The Roman tradition is almost as fine as the West Point tradition."

Sunday, May 26th. Dine alone with Whistler and Kennedy at Garlant's.

Monday, May 27th. Dined at Heinemann's and Whistler was there, but it was again a big dinner party, about sixteen. He was at the other end of the table, and I hardly had a chance for more than two words. 


\section{Return From Corsica and Life in England}

Sunday, June 2nd. Whistler and Kennedy both dined with me, but nothing special to record. Chiefly Boer and the old facts and arguments.

Saturday, June I5th. A visit from Whistler and Kennedy in the evening.

Wednesday, June 26th. Whistler came to dinner-no one else, but in the hurry of Helen's coming next week and the confusion of Augustine's going made no record.

This is one of the periods when the notes became brief and scanty, but they give at least a suggestion of the reason. Whistler was away now and then. J. spent the late spring and all the summer and autumn of I90I in Venice. Helen is Helen Robins, E.'s sister who came to spend a month in Buckingham Street when they were to go on together to Venice and join J. and this meant much work to be finished first and arrangements to be made with an understudy on the papers E. worked for. While Augustine's occasional and, we thanked Heaven, short journeys were the cause of such confusion for our small household which depended on her, that the wonder was not so much that E. did not just then make fuller notes of her meetings with Whistler, but rather that she made any.

Thursday, July I6th. Whistler, Landor, Rhodes, Miss Edith Pettit and Helen to dinner. Whistler indignant with the young American who shaves off his moustaches, just as he turns up his trousers, simply because it is the fashion in Piccadilly. "Well, you know," he said to Rhodes, "you would be far more distinguished with a moustache." West Point much to the front. "To try this recent hazing case in a court or by court martial-to take a cadet into court-you know-destructive to the whole morale of the place. In my time there were no laws to forbid this or that. There was the unwritten law of tradition. The boys were on their honour and nothing held them more firmly. It was such a disgrace to offend against these unwritten laws that the offender's career was ruined forever."

Rhodes is Harrison Rhodes, writer of short stories and successful plays, then living in London, just round the corner from us in IgOI] 


\section{The Whistler Journal}

York Buildings, which gave Augustine her name for him, le Monsieur du Quartier. Miss Pettit, now Mrs. Adolphe Borie, is a Philadelphian so that the party that evening was almost entirely American and therefore the more to Whistler's liking. If Whistler never went back to his own country, if he could not stand American papers, he never lost his pleasure in seeing his own countrymen.

Thursday, August Ist. Whistler and Kennedy came to dinner. A quiet evening, everybody tired. The band played Offenbach to Whistler's delight. He kept time with his foot, giving a little cancan sort of kick with it at the end. "Well, you know, there is music that really has distinction." A most wonderful essay on art in brown covers, by Arthur Haden, sent me for review by The Daily Chronicle, was lying on the table. Whistler told me what I did not know, this Arthur Haden is his nephew. He saw my note about it in The Daily Chronicle. "Ha! ha! you didn't know and I'm glad of it. As it is, you didn't hesitate to abuse it because of its absurd and wordy obscurity. Had you known, you might have hedged. You always are so polite to Seymour Haden, and I can never understand why?"

Our Buckingham Street windows overlooked the Embankment Gardens where, directly below, the County Council band played from seven to ten every evening through the summer. Its noise was often an interruption to talk, but on hot evenings when talk was an effort even Whistler could find relaxation in it. A day or two after this dinner, E. started for Venice and did not return until September.

Thursday, September I2th. The first evening and Whistler dines with me after my return from Venice. Helen still with me. The Hammonds, her friends from Memphis, Tennessee, dining with us. Whistler fine on West Point and niggers, but chiefly what I have heard before and noted. He was in his most charming mood. Explained the Ruskin case to Mr. Hammond, who is a lawyer, and read bits from The Gentle Art which I got out for him.

One of the most extraordinary things that has happened lately is that, now Whistler has come into his own, the English are again 212 
trying to re-incarnate Ruskin. The French tried years ago, and failed, but the English have returned to their prophet. Not as a literary person, however, but as an artist. A show of his work has been held at the Royal Academy, where one for Whistler was never suggested officially. Some Academicians, after his death, did make the suggestion but quite unofficially, and J. and Heinemann at once put a stop to their schemes- to the Academy's patronage of Whistler postponed until it was too late to be of advantage to him, but would bring shillings to the Academy coffers. During his life the Academicians spurned him. And it should be stated here that Whistler's name was put down at one time for membership in the Royal Academy of Arts, but he was never elected. We do not know if his name ever came up for election, according to the custom of the Academy, though we are positive that to the day of his death he would have accepted membership, just as he would have accepted the knighthood which he and everybody else thought would be given him when he was President of the Society of British Artists and obtained for it the title of Royal. But the knighthood was reserved for his successor, Wyke Bayliss, long since forgotten. And the Academy elected George H. Boughton, his contemporary, G. D. Leslie, another contemporary, and later, John S. Sargent, Edwin A. Abbey, Mark Fisher, J. J. Shannon, all Americans. These artists, had they wished, could easily have elected Whistler. But they did not, and it is to their everlasting credit, and to the loss of the Academy upon which he could have conferred honour and dignity. Had they made him their second American President, it would have vastly increased the Academy's prestige in Europe. George Boughton said, however, that he would not have elected Whistler president of an East-end boxing club, and Sargent never said anything. Facts like these must be recorded that timidity shall not prevail. Sargent, during his Academic life, has done more for poor artists than almost anybody. But it would have added to his renown had he used his great influence in securing for Whistler the official rank in England which was Whistler's due. As it is, it will be always remembered that while Sargent was a distinguished member of the Royal Academy, Whistler was kept outside and Rodin was never even represented in its exhibitions. That Whistler felt the neglect or indifference, there can be no doubt, though he was ever ready for a light jest at the expense of the Academy. One evening at a Chelsea Arts Club dinner, when something was said about the Academy exhibitions, Phil Morris reproached him: "But, Whistler, you have sent to the Academy!" And Whistler told him, "Yes, I have sent and I have been hungIgoI] 


\section{The Whistler Journal}

and, again, I have sent and I have not been hung. Well, you know, the Academy is like an omnibus-you can pay your penny-and again if there is no seat for you, you can't." Another story is of his lunching at the Cavour in Leicester Square and, not having enough money to pay, writing his name on the bill and saying he would settle when it was sent him. The waiter looked at his name, "But I do not know you," he said. "Dear me!" said Whistler, putting up his monocle staring at the waiter, then letting it drop in his hand, "you must be an R. A."!

Whistler laughed at Ruskin as he laughed at the Academy. As we wrote in the Life, he laughed away his cares. A Ruskin story that we believe has never been printed is of an old lady who met him once at dinner and was impressed at meeting an artist-she knew little of artists, having always lived in the country, she confided to him. "But," she added, "I have a cousin who is an artist. Perhaps you have heard of him-John Ruskin." Whistler leaned over sympathetically and said: "Really, Madam, you must not let it distress you too much. We all have our relations of whom we are ashamed."

His management of the International Society is the best proof of the distinction he could have given to the Royal Academy.

Monday, September I6th. A most dreadful moment-Helen and I, coming home at the dinner hour, found the McLure Hamiltons here, and I asked them to stay. Hardly had I asked them when a note came from Whistler saying, if I was quite free "of the enemy," he would like to invite himself to dinner. Had to write and say "the enemy" were in full force, and wouldn't he come tomorrow?

The McLure Hamiltons were and are our friends, but Whistler gave Hamilton a high rank among his "enemies" as he called all who ever offended him. The trouble in this case was that Hamilton, for some unknown reason, after Sheridan Ford broke with Whistler, helped Ford in many ways, and even lent him money, Whistler believed, to produce his edition of The Gentle Art which was dedicated to McLure Hamilton, though Hamilton says he refused the dedication when Ford proposed it before the book was published. This Whistler never forgave and he told McLure Hamilton what he thought of him one evening at the Hogarth Club, also in a letter, and they had not met since. E., knowing all this, knowing Whistler's feeling, could hardly have let him 


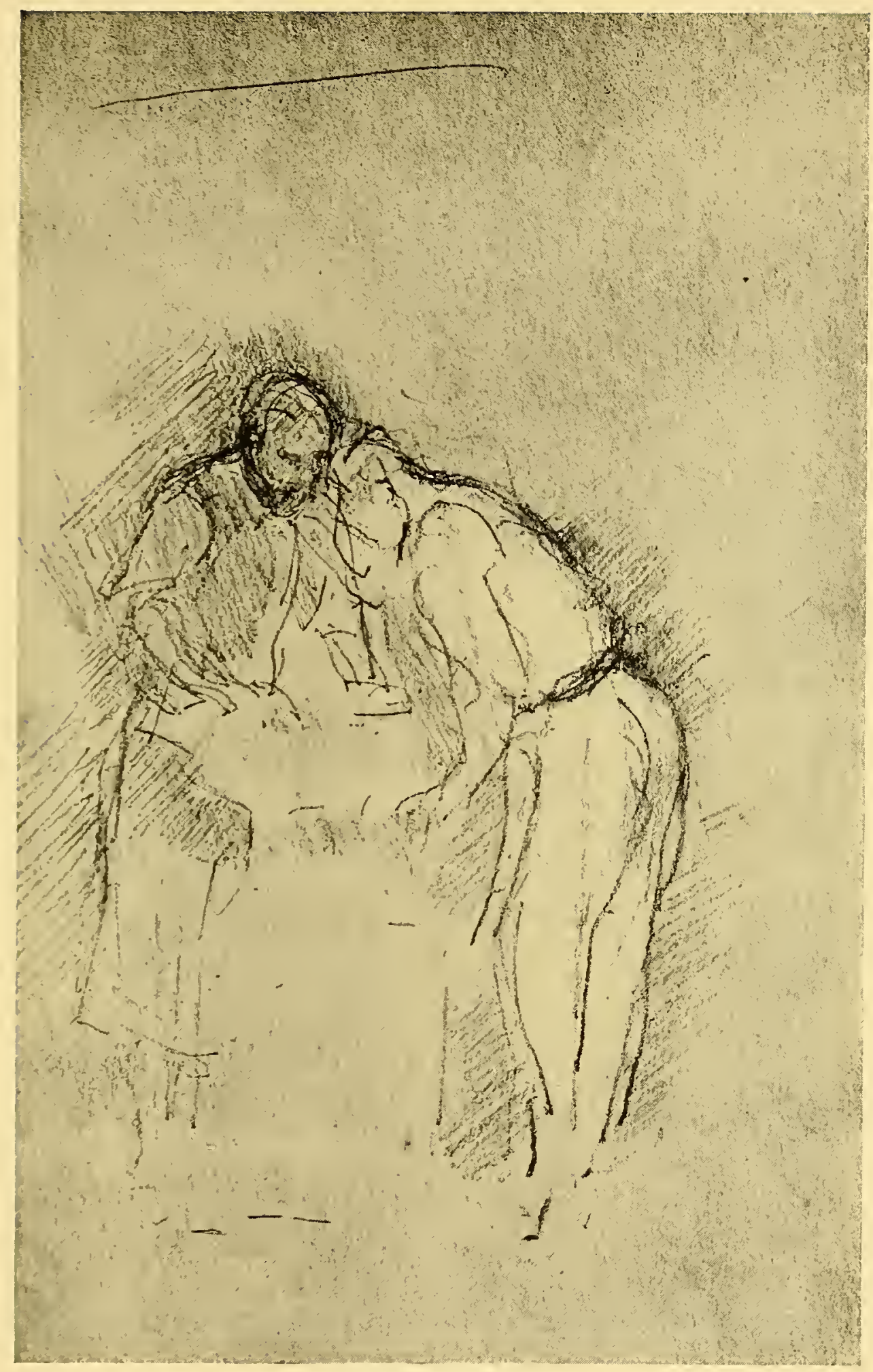

SMITHS, AJACCIO

CHALK

In the possession of Messrs. Knoedler and Co.

(See page 209) 



\section{Return From Corsica and Life in England}

come to dinner under the circumstances. It would not have been particularly agreeable to any one concerned. Hamilton wrote an account of his relations with Sheridan Ford for the Life, where it will be found. But one evening, talking the matter over with us, he denied more emphatically that he had lent Ford money to continue the work and he added a few other details.

April 28th, I905. Ford was introduced to him by John Swan and Arthur Melville as an American journalist, rather hard up, to whom he might be of use. Ford had begun work on The Gentle Art, but was in danger of being turned out of his lodgings and, as the Hamiltons were going away they put a part of their house at his disposal. Their cook was left behind, vegetables and fruit were in the garden, they thought he ought to manage. Ford and his wife seem to have had a pleasant time. He overflowed into other parts of the house, invited friends, Zorn among them. Ford had borrowed fifteen pounds of Hamilton before Whistler raised any objection to the work. When the trouble came, Ford wanted Hamilton to advance a hundred, which Hamilton refused. Ford said if he could not have his hundred, he would tell everybody of the first loan and say that it was to help him publish his edition of The Gentle Art. "And what do you think of that?" he asked. "Good-bye," said Hamilton, "that's what I think of it." If Ford carried out his threat, this would explain Whistler's belief that Ford was financed by Hamilton. There was bound to be a meeting between Whistler and Hamilton, both going to the same shows, the same private views, the same artists' receptions, and it came at a Grosvenor Gallery function presided over by royalty. Their talk was probably animated, for presently Arthur Melville joined them and whispered to Hamilton, "That's not the way to talk if you want to get on with Whistler." Hamilton laughed and suggested that it made no special difference if he got on or not. Whistler said good-bye amiably, but with a warning-"I warn you, don't have anything to do with that fellow Sheridan Ford, he'll, well, you know, take your spoons!' It was said that Arthur Melville made Ford go with him before a Notary Public and swear that Melville had lent him no money.

I90I] 
The Whistler journal

Théodore Roussel claimed that it was he who advised Whistler to publish The Gentle Art himself, pay Sheridan Ford, and get rid of him. Whistler was living at 2r Cheyne Walk, and he remembers coming in one day and finding Whistler and Mrs. Whistler almost hidden behind boxes of old papers and letters, sorting and arranging them for the book. As with everything concerning Whistler, the excitement over the Sheridan Ford episode was tense. Another incident in connection with it is worth recording. When Sheridan Ford's version was printed in Antwerp, the edition was seized by Sir George Lewis, then Whistler's solicitor. This always seemed to us one of his most remarkable performances. What it seemed to him, he once told us. We were, at the time, preparing our defence in the case Miss Philip, brought against us and Heinemann in her unsuccessful endeavour to prevent our writing and publishing the Life of Whistler. One afternoon, as we came out of the office of Sir George Radford, our solicitor, in Chancery Lane,

January Ist, I907, we ran right into Sir George Lewis. He said he hoped we were getting on with the book, and he understood we were in the hands of the lawyers. He had some letters for us, though Whistler always wrote to him in such extravagant terms of praise, he was almost ashamed to show them. Of course, he had been always glad to do what he could for Whistler, and had never charged him, and there was the affair of The Gentle Art. Yes, Joseph said, and he had always wanted to know about that, how it was done, what it all was. "Why, that," Sir George said, "I am afraid was a bit of bounce!" and with that he left us.

Tuesday, September I7th, Igor. A characteristic letter from Whistler-he could understand my joyous emotions; if he had added to them that was all right-the letter written to Helenand he would come with pleasure. Came with his pocket full of Boer clippings. Helen gave him scraps of American history that delighted him because of the parallel. He was specially charmed with the story of General Marion and the sweet potatoes and begged Helen to get it for him. Was in a state of excitement over an article in The St. James's by an officer giving a description of the shocking falling off of discipline in the army to which he, as a West Point man, knew that the whole condition of things in South Africa is due. $2 \mathrm{I} 6$ 


\section{Return From Corsica and Life in England}

Thursday, October 3 rd. Whistler and the Lungrens. came to dinner. Not a very successful evening. It was varnishing day at the International, and Lungren was disappointed at the way he had been hung, and there was a sort of feeling of restraint over the little party. The talk again of the Boers.

There was difficulty that year in securing a gallery for the International Exhibition. Owing to the death of Admiral Maxse, the Skating Rink at Knightsbridge was no longer available. In I900 no exhibition had been held. Whistler's idea was that the yearly exhibition should be an Art Congress, in which case it was useless to compete with the great International Exposition in Paris. As the notes have recorded, it was at least proposed that the homeless Society should claim the right of artists to Burlington House but this was not followed up, and as a last resource, the spring of I9OI having passed without any exhibition, the Institute was taken for the purpose in the autumn. The galleries were smaller than those in which the Society had hitherto shown, but lack of space could not induce Whistler to overcrowd and litter the walls. Decorative balance and effect were as usual respected. He sent mostly small works with, for centre, the little Phryne which he valued highly, and these were hung in a line with nothing above or below, an arrangement which, though he could not say so to Whistler, was Lungren's grievance. Why should the number of his exhibits have been limited and only a corner found for the few hung, when all that space was wasted? He was indignant, enlarged afterwards upon his treatment to E., and that evening, in her memory of him, he was silent and sulky.

Sunday, October 6th. Whistler sent young Teddy Godwin round to tell me he has a cold and is in bed, and wouldn't I come to the hotel to see him? Went round and had tea with him. My Daily Chronicle notice on the bed. "I suppose you know why I have sent for you? You know it is to reproach you for having given the International away? But why! They look to you for everything that is charming." "Haven't I said charming things about you?" I asked. "Yes, but why regret Manet and the others? Why make so little of Lavery, the Vice President? And why must you always drag in that dreadful McLure Hamilton?" I told him to wait IgOI] 


\section{The Whistler Journal}

and see what would follow, and he said he had already explained to Lavery.

E. cannot recall what crime she had committed this time in her notice of the International. But encounters of the kind were not unusual. To please herself, to please her Editor, to please Whistler, was not always an easy task. But though Whistler might object, she did not find his objection fatal. In her experience he was as ready to forgive as to take offence, and the above note reflects the gaiety with which he took it on this occasion.

Tuesday, October 8th. Called on Whistler who is still kept in bed, but very gay - approved of my notes in The Daily Chronicle Monday column and had all the other papers scattered round him over the bed.

Wednesday, October 23rd. Dined alone with Heinemann and Whistler. Whistler staying there on his return from Paris, and still afraid to go out in the evening, is looking for rooms up in that quarter. Rather a colourless evening.

Thursday, October 3Ist. Whistler and Fisher Unwin came to dinner. Nothing particular to note. Chiefly Boers.

Saturday, November 2nd. Whistler came in and he stayed on to dinner. And then-the long feared meeting. After dinner the Lungrens dropped in, and said the McLure Hamiltons, who also had been dining at the Café Roche, were to follow presently. There was nothing to do, but I wanted to run. They came. Introduced them. Whistler bowed, said he thought he had heard of Mr. McLure Hamilton, and paid no more attention to him, though he smiled upon Mrs. Hamilton. What was said, I don't know. I was occupied with the fear of what might be said, of what might happen. But I have left of the nightmare of an evening an impression of McLure Hamilton rather sad, Mrs. Hamilton distinctly nervous, Mrs. Lungren speechless, Mr. Lungren helpless, and Whistler, through it all, suave and amused. He left fairly early and said good-night to everyone but McLure Hamilton. 


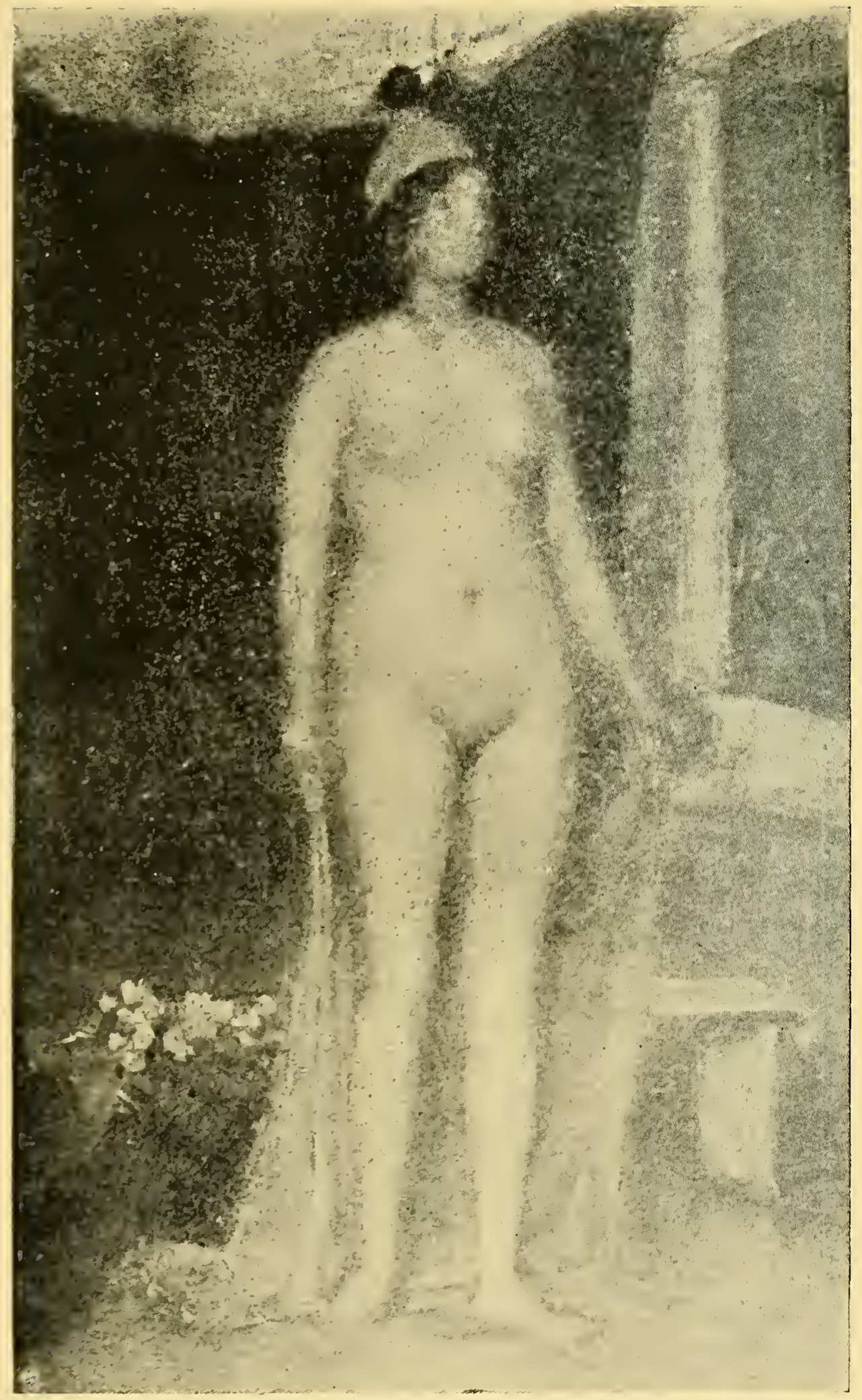

PHRYNE

OIL

International Exhibition, I9oI 



\section{Return From Corsica and Life in England}

This meeting was Whistler's second and last with McLure Hamilton after the Sheridan Ford episode. Strange meetings were always happening in Buckingham Street, or else, being avoided by the ingenious system of doors which sometimes allowed "the enemy" to foregather in three rooms without any one of them being aware of the other's presence. We might say that the rooms had been Etty's studio and apartment, and no doubt similar complications occurred among Academicians in his day, and almost certainly in Stanfield's, Humphrey Davey's and Pepys' days, who, all three, lived in the same house. And so, as Whistler would say, it was only carrying on tradition. Whistler was popularly supposed to have no consideration for anybody, to delight rather in making everybody uncomfortable. But the way he met "the enemy" in our rooms shows how considerate he could be. Nobody who did not know the circumstances could have imagined the seriousness of the situation to $\mathrm{E}$. The Lungrens were conscious of something and were embarrassed, but never gathered that Whistler and Hamilton were not exactly on terms, that the occasion was historic in the development of The Gentle Art. Mrs. Hamilton, after his death, in referring to an evening as trying to her as to any of us, recalled how quiet and dignified he was. We always felt, and never hesitated to say to Whistler, that he misjudged Hamilton who had for him and his art a profound appreciation and respect. In questions of art, no artist was in more complete sympathy with Whistler.

Saturday, November 5th. Whistler wrote to ask me to try to come and see him at Tallant's Hotel, in North Audley Street, where he is now established. A gloomy private hotel, but eminently correct. The landlady assured him she entertained royalty and nobility. "In this room, sir," as a recommendation, "Lord Ralph Kerr died." "But," said Whistler, "I told her what I wanted was a room to live in!" He is a little depressed by this correctness, the limited supplies and the high prices. I found him in trousers, white silk night shirt over them flowing loose, and a dinner jacket! Rousseau, who paints cattle, was with him. When he went, Whistler got me to dictate to him, while he wrote it, a letter he had prepared to his boot-maker in Paris who objected to send, unless prepaid, boots to London. "So unfortunate, you know, his experience with the Islanders!" Whistler's letter was one of his stateliest and he addressed it to M. - "Maître-Bottier." I90I] 
Tallant's in Mayfair was not far from Heinemann's house in Norfolk Street. In it one was conscious of what Whistler described as the "lovely respectability of the British family hotel." This autumn Whistler was so extremely worried about his health that only occasionally was he in really good form, only occasionally did he talk in the old fashion. The Journal from this time on, is more than ever the record of his health which it had begun to be the year before.

Wednesday, November r $^{\text {th }}$. Whistler and the Janviers came to dinner. Whistler made a captive of Mrs. Janvier to whom he told his story of the Roman cake in Corsica, so that after dinner she literally got him in a corner by the fire, while I talked to Janvier and Chefdeville who came in with his son. Whistler had arrived, to his horror, in a little rain that began suddenly as he was on his way here from Charing-Cross Station, and Augustine had taken him in the dining room and helped him off with his shoes and lent him her slippers which, for fear he might mind, she said were Joseph's. And in her slippers, with anything but "dandy" feet he spent the rest of the evening.

Louis Chefdeville was a most interesting French artist who, in the early Eighties, took up photo-engraving and made, during his lifetime, which was a stormy one, some of the most interesting line and half-tone blocks ever printed in France and England. He did a great deal, especially in England where he lived for years and until his death, to advance the art of photo-engraving.

Thursday, December 3rd. Whistler appeared in the afternoon just when Mrs. Mansfield was here to tea. Talked Venice to J. whom he now sees for the first time since J.'s return. He has been for the last fortnight with the Philips in Tite Street, Chelsea, where as he never invites one to come, one hesitates to go. But glad to see J. and enthusiastic about his drawings. Thinks the St. Mark's most beautiful and immensely interested in the charcoal.

Mrs. Mansfield is the wife of the man who, we believe, wrote under the name of Bowdoin, a life of Whistler which Whistler probably never saw. Mrs. Mansfield is an artist: Blanche MacManus. "The charcoal" was the new Russian compressed charcoal which 220

[I90I 


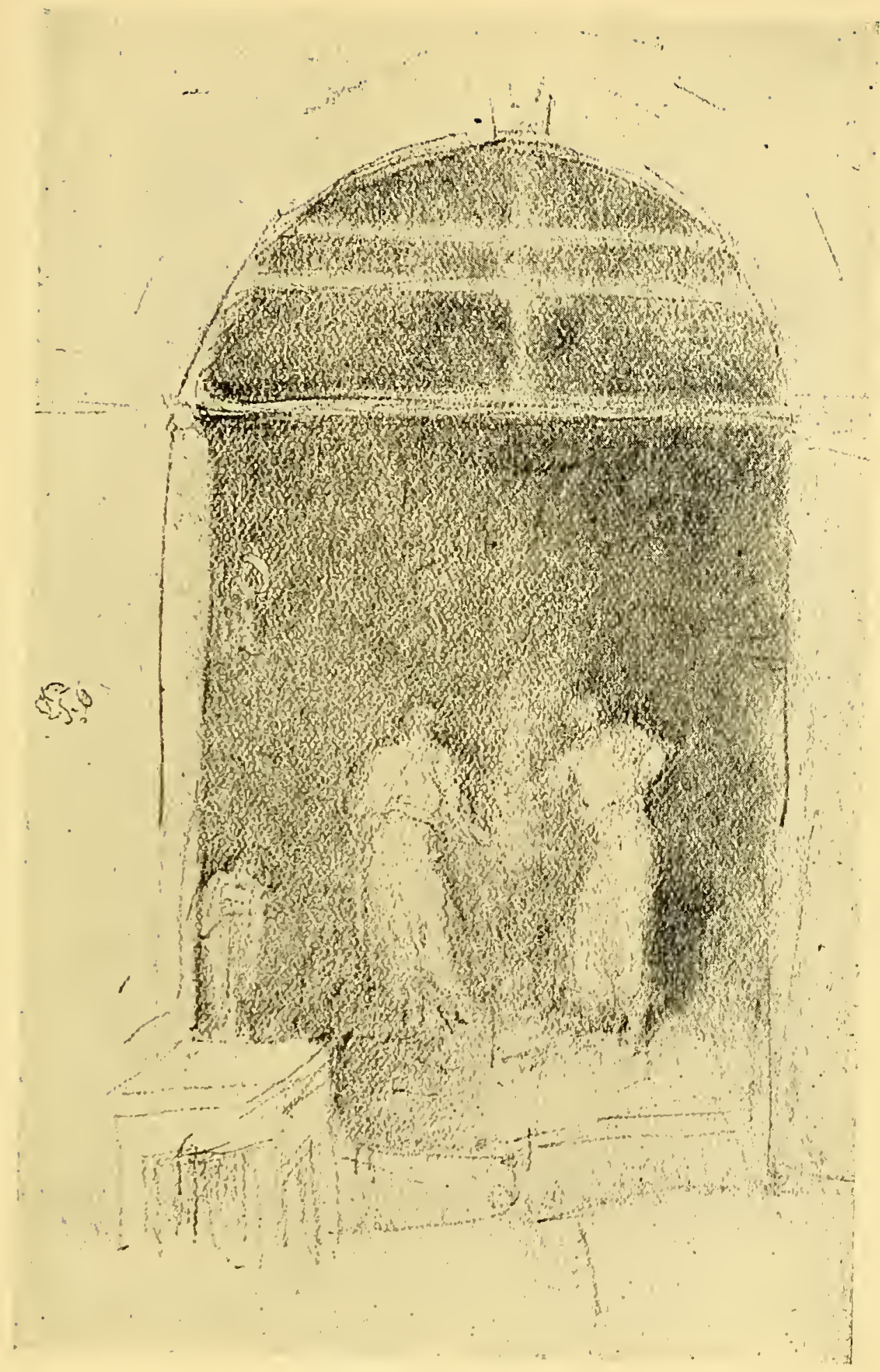

THE FORGE, AJACCIO

CHALK

In the possession of Messrs. Knoedler and Co. 



\section{Return From Corsica and Life in England}

had just been invented. J. was delighted with it and used it for his drawings in Marion Crawford's Venetian book-as usual, all illustrators at once took to it.

Saturday, December 5th. Whistler came while we were still at lunch and stayed on and lunched with us. He starts for Bath this afternoon, and it is time he gets away from London, for he looks more tired out than I have seen him yet. Had a book of American stories which he read to us, especially one about a motor, with such enthusiasm that he left so late he was afraid he would lose his train. He explained the American slang-had never heard most of it before, but understood it by instinct.

During these weeks, off and on, he was with his mother-in-law and her daughters in their Tite Street house, and when there we were never allowed to see him. After his wife's death, he was always moving from place to place. It was the same in Paris where, till he finally took his last house in Cheyne Walk, he kept his apartment in the Rue du Bac, his studio in the Rue Notre-Dame-desChamps, slept in the Hotel Chatham, dined in the Passage des Panoramas, had his studio in Fitzroy Street, his room at Heinemann's, and, as the notes show, usually dined with us when in London. No wonder he described the whole as his "collection of châteaux and pieds-a-terre."

At this time he was a sort of lion, though no one but a Frenchman is ever a real lion to Frenchmen-he is never one of them-and the longer Whistler stayed in Paris, the more he realized it. With a few old friends he dined in the Passage des Panoramas, a few friends came to the Rue du Bac, but he received no higher official recognition than is bestowed upon dry-goods men and soup makers by the French Government. For that matter, he received nothing officially from England and America-one of the penalties of expatriation, if you are an American. All sorts and conditions of men and women did their best to get at him, especially Americans who haunted the halls of the Hotel Chatham trying to carry him off to pink teas and poker parties, or, if he ventured to Lavenue's or similar haunts, stood on chairs to see him eat his dinner. As to recognizing him really as the master, they did nothing. He had no recognition. from the National Academy which acknowledged all the lesser men-J. was not made a member till after Whistler's death. If he had been, things would have been different. He has yet no niche in the American Hall of Fame, though half the famous I90I] 
The Whistler Journal

there are forgotten, and the rest mostly never have had even a national notoriety.

Whistler spent most of the winter of $190 \mathrm{I}-02$ in Bath which, with its old-fashioned stateliness and antique shops, amused him. But he was too near London to keep away altogether, and we had many unexpected visits and meetings. J. gave him introductions to some of the officials of Bath whom J. happened to know. Though they probably did not understand Whistler, he was as delighted with them as with the architecture of which he considered them a part.

Thursday, December Igth. An International Meeting held at Sauter's. J. arrives and, to his surprise, finds Whistler on the door steps. Has come up for the purpose from Bath. He and J. stay and dine after the meeting. I come for dinner, and the girl Sauter so often paints who is staying with them, and Webb. Whistler in splendid form, looking as well as he looked seedy the day he lunched with us and said good-bye. Eager to hear all the news. Full of the Boers upon whom the talk mostly ran. He left early, to spend the night as Webb's guest.

Friday, December 20th. Both Whistler and Webb came to breakfast. Supposed to be half-past nine. Got here at ten to our complete demoralization, so entirely did it revolutionize our day. They had stopped at the Charing-Cross Hotel. Whistler to go back to Bath this afternoon.

These two notes confirm the fact of Whistler's interest in the International of which we have written several times. He could not keep from the meeting, though he had been in Bath but a fortnight. He was always thinking of the welfare of his Society, sometimes in most unlooked-for ways. Later in the winter, when the Painters in Oil were about to open their exhibition at the Institute where the International had been held in the autumn, he wrote to $\mathrm{E}$. from Bath to beg her to make the most of the comparison in her notice for The Daily Chronicle. Where was the velarium? where the scientific knowledge, the perfect engineering of the light, the exquisite taste? She was to rub it in to the greater glory of the International. She hopes now that she did-thinks her article this time, anyway, must have been to his liking for she has no record of being summoned to receive his reproaches. 
From Chelsea to the Hague and Back

We had carried to London the early American hours which America no longer keeps. We breakfasted at eight on coffee and rolls, and by ten were usually well on in our morning's work. However, Augustine was wonderful in these emergencies; the Strand with its shops was close at hand; soles, eggs, marmalade and all the essentials of an English breakfast had been collected by the time Whistler and Webb appeared, and, as Whistler's visits grew rarer, we minded less and less any trouble they might put us to.

\section{CHAPTER XIV: FROM CHELSEA TO THE HAGUE AND BACK. THE YEAR NINETEEN HUNDRED AND TWO}

Saturday, January 6th, Twelfth Night, I9o2. About six, sudden appearance of Whistler. Up from Bath again, Miss Philip having to come to see her dentist. With much difficulty we persuaded him to stay and dine, sending a telegram to Tite Street. We have a galette-au-roi for Twelfth Night and we open our last two bottles of champagne in his honour, to make up for a rather poor dinner.

Champagne was a luxury we indulged in only this once, when O.K. sent us a case, and we suppose we never shall have any again. $\mathrm{O}$ thrice and four times happy those who have gone before from a world gone maudlin and dry! But galette-au-roi we always ate on Twelfth Night because Augustine made us, ordering it from the French patissier in Soho who supplied it to all the French colony in London. Whistler liked the crisp, flaky French pastry and, if we remember, E. in cutting the cake saw that he got the little king hidden in it, that brings luck for the year to whoever finds it.

Friday, January Ioth. Dine at Heinemann's. Whistler was there - going to stay all night. This sort of weather he can dine nowhere where he cannot take his bag and sleep. "Oui dine, dort," he says, "Buckingham Street at night, you know, a dangerous, if fascinating place." The Mitchells and Elizabeth Robins are the other people. He sits far from me, and I see nothing of him except for a few minutes after dinner, when I tell him that Augustine has gone to France for the event, that she has written and that she worries because she knows the Englishwoman I have as substitute will not give him the sort of petit diner he likes. "Awful," he says, "her I902] 


\section{The Whistler Journal}

interest. I am sure $I t$ will look like me-what!" This is the evening J. first suggests his idea of the Great Art Trust. Heinemann is interested. Thinks he would be willing to put five thousand in such an enterprise. Whistler is rather noncommittal, but quite ready for a meeting to consider the suggestion.

The Mitchells are the Chalmers Mitchells. Elizabeth Robins is not E., though as an authoress, is everlastingly being confounded with her. Augustine had gone to France, where the older of her two little girls was born, and where she knew she would be for a month, and, in her devotion to Whistler, she was afraid he would get nothing decent to eat without her. As for the Great Art Trust, we have forgotten entirely what J.'s immortal scheme was. It probably existed for this one night only.

Saturday, January I8th. Whistler comes in about six, but he won't stay to dinner. "Qui dine, dort," he tells us again, and we have no extra bedroom. Reads a magazine most of his visit, and is a trifle depressed. "Well-you know, there was a suspicion of a cough after I was here the last time." Then, perhaps, he is worried because he has received, like Joseph, an official notice of his medal at the Paris Exposition, and it speaks only of one. "Do you suppose that nonsense of Spielmann's could have had any influence?" he asks J. a trifle anxiously.

Thursday, January 23rd. Whistler comes in late, about six. J. not back yet from a C. T. C. Committee meeting. I tell him about T. A. Cook whom I had met a few evenings before, and who spoke of Whistler as if, at one time, he had seen him often. "I do not know him well enough to avoid him." Whistler said. I explained, it was in London, and Cook had met him at Charles Whibley's. "Oh, there," Whistler said. "I went once, some place out in the remote wilderness-you know. The room was thick with tobacco smoke and-well-I never went again." He insisted he could not stay to dinner, but J. coming back from his meeting with Archer White, persuaded him to. There could have been no greater contrast than between Whistler and White. White, growing friendly during dinner, called him Whistler once- "My 
From Chelsea to the Hague and Back

dear Whistler"-and I waited, trembling, to see what would happen next. But I noticed, he never forgot the Mr. a second time. Something was said of a story recently published about Whistler. "One thing occurring in my daily life, I cannot be responsible for," he said, "is the daily story told about me." Archer White had been lunching with Richmond who was very eager to be made Mayor of Kensington. "He ought to be," Whistler said, "it would explain the Mosaics at St. Paul's, what?"

Whistler had been to the Royal Academy and had seen the Kingston Lacy Meniñas. "Well, you know, it is full of things, only Velasquez could have done. The little heads, perhaps weak, but so much, or everything that no one else could have painted just like that. And up in a strange place they call the Diploma Gallery I saw the Spanish Phillip's copy of Las Meniñas, full of atmosphere really, and dim understanding." But it seems to me if he had not wanted not to agree with D. S. M., who thinks the Kingston Lacy picture a copy, he would not have accepted so implicitly the evidence of Phillip. He liked too the Dutch picture of the Lady Standing at a Spinet, Ochtervelt's. . . . "Have you seen any criticism beside D. S. M.'s? I would like to get them all together, and write something. But why should I trouble to write?" He told us of his offer to MacColl of the Secretaryship to Pulitzer, some years ago in Paris. "His duties, you know, would have been to drink the best champagne and cognac and to smoke the best cigars, but he would have been a slave all the same. It would have saved him though from art criticism, or art criticism from him."

The one redeeming feature of my English dinner-in Augustine's absence-was the mince pies. "Ah, well, I like them," and he was immensely pleased when we poured lighted brandy over his. A good deal of talk of the Boers. But he said little, making Archer White, who has been in South Africa, do the talking. A story on quite another subject was of the dinner given to him. After everybody was seated and before the talk was so loud that nothing could be heard, Justin McCarthy came in with Menpes on his arm. They passed just behind Whistler to get to their places. "Ha, ha! I called out to McCarthy, have you forgotten? Damien died!1902] 


\section{The Whistler Journal}

Well, I don't know how it is, but Providence sends me these little things."

Öne of J.'s many interests in those days was cycling and he was still on the Council of the C. T. C., the Cyclists' Touring Club.

T. A. Cook is Sir Theodore Andrea Cook, who is greatly interested in sport and literature, and somewhat in art. He spent a good deal of his time in Paris and, we believe, was for a while Pulitzer's Secretary there. But, tiring of it, he sought a successor one of whose duties, Whistler explained on another occasion, "would be the picking up Pulitzer's eyes that had a way of falling out and getting lost on the floor." Whistler said that Charles Whibley applied for the post and, on being summoned upstairs to the presence of the great man, stumbled into a priceless Persian pot and smashed it, and this lost him his chance. "So like the British Boulvardeer!" said Whistler. This was à propos of Whibley's invasion of Paris at that time.

Archer White is a lawyer who in those years was as enthusiastic about cycling as $\mathrm{J}$. His tendency was to be on hail-fellow-well-met terms of intimacy at once with everybody, which was something that Whistler would not countenance and knew how to put a stop to without a word. Nobody ever went further with Whistler than Whistler chose, which reminds us of another incident. Somebody, repeating to Whistler a story told of him by Chase, began, "And Chase said, Jimmie told me-." "I didn't know he was on Jimmie terms with me," Whistler interrupted.

Whistler was right as to the daily story about him. Never was there a man about whom so many stories have been told. It was after our book appeared that "the teetotal story" came to us for the first time in a version that explains it, for before this it always seemed to us rather pointless, that is for Whistler. This version we heard from Sir Bryan Donkin who said he heard it when it first began to go the rounds in London. Norman Shaw was then prominent as an architect, and Dr. Norman Kerr was no less prominent as a temperance man, and it was the two Whistler wilfully confused. He was dining in a big new house in Chelsea built by Norman Shaw who was there, and Norman Kerr also was a guest. Whistler dined well. Coming downstairs, he slipped and fell. "Well, you know," he said, "this comes of dining with these damned teetotal architects!" In some way the notion got abroad that Whistler drank excessively, he never did, yet we have a letter from Major Butt, who went down on the Titanic referring to it as a matter of unquestioned fact. It is absolutely untrue. 226

[1902 
From Chelsea to the Hague and Back

The "Why drag in Velasquez" story is another that has gone through amazing variations, the most amazing, Mrs. Edwin Edwards' solemn interpretation of it. She wrote us that conceit was Whistler's ruin: "I heard him say in our room before many artists, talking of art and artists-'Il y a moi et Velasquez'!!! This is so fearfully dreadful you ought not to mention it." To us, it was only fearfully funny. Funnier is the fashion in which Austin Dobson mixed it up with Whistler's admiration of Hogarth, which Dobson may have considered poaching on his preserves. On his seventy-fourth birthday, The Morning Post sent a representative to interview him, and inevitably Hogarth came up in the course of the interview. "Whistler compared him with Velasquez," Dobson said. "That perhaps is exaggerated praise, and in any case it is not safe to attach too much importance to Whistler's judgments."

We remember once M. Duret contrasting Whistler with Degas. Degas would prepare talk and witticisms beforehand; if he were dining, he might wait till dinner was half over before saying anything, but then when his chance came he would strike with words as sharp as a sword and they would go right through you. With Whistler, it was spontaneous, the wit of the moment. But many people, especially people who never talked to him, declared it to be manufactured and not spontaneous, all mannerism and no substance. "It's all don't you know with Whistler and nothing else," another dealer once said to Ernest Brown. Many examples are in the Life and The Journal. A few others we have not yet included which to our knowledge have not been published, are worth preserving. Mrs. Lynedoch Moncrieff was composing the music for some verses of Owen Meredith's. Whistler said he would like to illustrate them. She told him they were about the lark. "Charming," Whistler said, "but dear me, what can I do when the only larks I know anything about are larks on toast?" This immediately suggests his telegram to Madame Marchesi. She bought from him a small marine and no sooner did she get it home than she wired, "Whistler, vous êtes le plus grand mâitre au monde." As promptly he wired back, "Madame, you are the greatest lark in the world!" in which she saw only the compliment and showed it with pride to her friends, and the story got so contorted that "Madame, you are the greatest nightingale in the world," was a version of his telegram more usually quoted. Wit of another kind was in his advice to a man who couldn't sleep but walked up and down all night thinking of his creditors. "Well, you know," said Whistler, "better do as I do-let your creditors do the walking up 1902] 
and down!" As characteristic of a still different mood and manner was a story John Alexander used to tell. He was dining at the Walter Gays and Whistler was there, though at the other end of the table. Alexander was recalling another dinner some years before where he met Oscar Wilde. As usual Wilde's talk was designed to lead up to carefully prepared witticisms. In the midst of it the lady he had taken in to dinner asked, "And how did you leave the weather in London, Mr. Wilde?" and that was the end of the talk and the witticisms. Alexander had no idea that Whistler was listening or even could hear, but, at this point he heard the familiar "Ha! ha!" and Whistler leaning over said to him, "Truly a most valuable lady!" Another of Alexander's stories should have a place. He was in Whistler's studio when Lady Eden was sitting for her portrait and was very full of a Turner some Lord Somebody wanted her to buy and she was not sure if it was a real Turner, or a sham Turner, and wouldn't Whistler come and look at it and give her his opinion. "Quite impossible, my dear Lady Eden," Whistler regretted, "but, after all, isn't the distinction a very subtle one?"

Monday, January 27th. Just as we are asking each other, about six in the afternoon, whether Whistler has gone, or whether any minute he may descend upon us, we hear the familiar knock. He has come to say good-bye, as he returns to Bath to-morrow. $\mathrm{He}$ has one piece of news, and he produces an advertisement from the Paris $N . Y$. Herald, sent him by the apprentices. Walter Sickert advertises an atelier in the Boulevard Montparnasse. "Now the Atelier Carmen has come to an end, rounded out as it should be, and was always intended to be, and everything all correct after West Point models, then the Walter Sickerts, the followers who, when they come after the army, are called bushwhackers, crowd in and pick up what they can. No doubt Sickert promises to carry things much further than Whistler ever did, and to reveal, as it were, all the secrets, all the little things, all the last touches, Whistler held in reserve. What?"

London has tired him again, and he dozed off and on, but talked when awake with his usual alertness. He wants to send some old silver boxes to the doctor at Marseilles who was attentive, and to the curator at Ajaccio whose studio he shared, and, of course, was 228

$[1902$ 


\section{From Chelsea to the Hague and Back}

going about it in the most elaborate, round-about fashion, asking at the P. and O. S. S. office if they would take the parcels out in their strong room and have them delivered. The clerk said it was unusual, but he would telegraph here, there, and the other place to see if it could be done. I suggested that, in the meanwhile, it would be simpler to go to the American Express people in Waterloo Place.

Something was said about Homer Martin who, we had just been told, once painted Whistler's portrait. Whistler said no, he never had; as had been said about him, he painted vegetables not animals. He delighted in Homer Martin in the old days. He told the story of their going together to Sir Thomas Sutherland's, Chairman of the P. O. Company, one Sunday evening to have "a bit of supper" with him. "There we were, and before supper there he was showing us his pictures with all solemnity. The walls were covered. He came to a Calthorp, above the mantelpiece, a British female nude. This, he said slowly and pompously, this is Andromeda. Homer Martin looked critically and attentively for a moment: And I think very like Ann too." Whistler laughed, as I have seldom heard him laugh. Homer Martin's humour was the sort to appeal to him. He told again the story of Homer Martin spending the night in the house at Chelsea, when. Whistler lived there with his mother, and in the morning asking for the scissors for his cuffs, a story I have already written out. Martin used to dine with Albert Moore and some other men at a little French restaurant, good of its kind. "And I would go sometimes and look them up and sit there talking with them in the evening. But then, you know, the sort of Englishman who is entirely outside all these things, but likes to think he is in it, began to come too, and that ruined it. He never could make anything of Homer Martin, while I was perpetually laughing. There was one wonderful evening when Martin, fresh from the Dulwich Gallery, grew more and more fantastic as everybody looked more and more bewildered. Dullrich's Gallery he called it. He knew old Dullrich, nice old boy, somehow pictures came to him. People who had them brought them down to him, he found them in odd places, they were on his 1902] 


\section{The Whistler Journal}

walls, they overflowed into galleries. Dullrich would come and talk to him there, among the pictures, dear old boy. But he got old, feeble. He sent for Martin. I'm going, he said, I'm going, and he skipped. But there were the pictures and the gallery, and any one could see them. This was met with dead silence and bewilderment." I fancy half the absurdity was in the way Martin told it, as it was certainly in the way Whistler repeated it. "The cuff story," Whistler said, "has been twisted round in a version I can just trace to its origin. It represents me as staying at AlmaTadema's and as altogether untidy and slovenly. I!! when, if I had only an old rag to cover me, I should wear it with such neatness and propriety-with the utmost distinction." I told him the story of Gosse's horror when he took Homer Martin to the Savile Club, where, late in the evening Martin danced a breakdown on the dining-room table. "It is just like them at the Savile," he said, "they were all really butlers, afraid of the silver and china." Talking of a woman novelist he met somewhere, he wasn't sure which it was. "I don't think it was Mrs. Humphry Ward. Who was it, you know, who dined that evening at Heinemann's? Mary Ann Grand, wasn't it?"

He has been worried lately about the show at the Luxembourg. His friend, the Curator at Ajaccio, wrote to Bénédite, proposing Whistler's etchings and lithographs, and Bénédite wrote to Whistler that such a show was the desire of his heart. Whistler kept putting off answering until there came an irate letter from Bénédite, saying he must have everything in a couple of months or the exhibition would be impossible. Whistler was in despair about getting the work together. He consulted Dunthorne, who said he would be delighted. 'Then he came to J., wanting to borrow Roullier's catalogue of the Chicago exhibition, which J. refused outright. Whistler said he would never speak to J. again-to refuse in this emergency! J. suggested Colnaghi, and peace was made. Now Whistler tells us the result. MacKay at Colnaghi's would do anything. "But, Mr. Whistler, you should have let us have these things from the first." "And my answer," Whistler said, "was that I have a little way of remembering, and I remember 230

[1902 
I took my London etchings to Colnaghi's, and they said they would consider the matter. I left the prints, and, after a little, not hearing, went to ask what they were going to do. We are sorry, but we find we cannot do anything, was the answer. They, are not exactly the things for us. In fact, they are not dogs by Landseer. Ha, ha! I see," said Whistler.

On the inexhaustible Boer question, he told us that when Mrs. Philip, who naturally has no sympathy with his views, talks to him on the subject, he tells her, as he told Miss Hensman, "You would have made a very good Boer, $\mathrm{Ma}$ 'am." .A story he repeated with delight is of the American girl at the Tower, who, when shown a gun the guide said was captured at Bunker Hill, looked at it, and then, "Well, you took the gun, but I reckon we kept the hill."

Whistler's knock was as characteristic as everything else about him. In London in those days, everybody with a front door, had a knocker on it as well as a bell-a bell that pulled and a knocker that knocked. Whistler gave two violent thumps with the knocker, like the British postman for whose benefit it was there, and then gave a violent pull at the bell, and this he always did wherever he went. It was a warning and an announcement, more than once taken advantage of in getting "the enemies," if they happened to be there, out of the way. "Look out for the knock that shall announce" he would write to prepare us for his coming, and it made its announcement not only to us, but to everyone in the Buckingham Street house, from the housekceper on the ground floor to our neighbour on the top. And yet, he would express the most innocent surprise at the marvellous detective system by which we were kept informed of his visits when, by rare chance, he found nobody in our flat, not even Augustine, to open the door. In I90I Whistler, finding he was unable to visit the Académie, wrote his classic farewell from Ajaccio to the students and the school was closed. Now, new ventures were rising up out of its ashes. Of Whistler's followers, these "bushwhackers," Théodore Roussel once said to us that they always made him think of the soldier to whom Napoleon once spoke. "He spoke to me," he bragged in barracks. "What did he say?" his comrades asked. "I called 'Halte!' Napoleon said, 'Taisez-vous Imbécile!"” I902] 
The Whistler Journal

Sir Thomas Sutherland, successful business man, President of the P. and O. Steamship Company, staunch friend to Whistler through the bankruptcy, was a typical Briton in his attitude towards art. He was interested in Whistler to the end though they seldom met in later years. He was willing to tell us all he could of the earlier days of their friendship. But in his long talk with $\mathrm{E}$. his attitude towards Whistler was one of condescension, of the prosperous man of affairs to the artist whose work he does not understand. He told E.:-

November Ist, I906. After he married in I880, he went less into Bohemia, he said, he sold the old furniture, the blue-and-white china, the pictures-among them two by Whistler-with which his house as bachelor had been filled, and so, of course, was less intimate with Whistler. As a bachelor he had gone to the Sunday breakfasts - delightful - eccentric - partly American - partly French-not much to eat-but Whistler charming and carrying it off as if it were a feast. And the dinners were excellent, if original-really, he didn't know how Whistler managed them. And he went on to explain further that Whistler did not send often to regular exhibitions because he was conscious of his weakness and did not care to compete with legitimate art-such art as the art of Millais. Altogether, he spoke of Whistler amiably, but with condescending amiability as if he were an amusing child or an eccentric American, and as if it was most kind on his own part to be amused: the British attitude, the attitude that hurt Whistler, that he had "to laugh away," though he never knew it was Sutherland's.

The reference to Sutherland's collection suggests three other visits made by Whistler to great private collections. One day a rich amateur collector invited him to go through his gallery. Whistler went through it all and never opened his mouth until, at the front door, the collector got up courage enough to ask him what he thought of the collection. "There is no excuse for it," said Whistler, and, before the collector could recover, he walked out and slammed the door to after him. Another time he was inveigled into going to see another collection, and the collector kept hinting, as they passed through each room, that he proposed to make a 232 
gift of it after his death. "And to whom do you think I should give it, Mr. Whistler?" he asked at last. "To an asylum for the blind," was the reply. When he was in The Hague later in 1902, he visited Mesdag with the Sauters and Bruckman, a Dutch artist who lives in London. In the studio into which Mesdag led them to see his own work, Whistler seemed to disappear, while the others went from one picture to the next, saying what they could. When they reached the last picture, Whistler seemed to reappear, murmuring something about a fine sky and now should they not be shown Mesdag's collection of the Masters? Bruckman, our reporter of this occasion, finished the story with the lunch afterwards at the Café Riche, so good that Whistler summoned the manager to tell him so, which is characteristic. As they were leaving, a waiter asked Bruckman who the gentleman was, the manager wished to know. Bruckman refused to give Whistler's name. The manager arrived. He wanted to know only for his own pleasure, he could see the gentleman who so well liked his restaurant was one of distinction, and he was honoured. Then Bruckman told him. The next day The Hague papers published a note to say that the distinguished artist Whistler had been lunching at the Café Riche and had expressed his great approval - a regular puff.

We do not know what the little restaurant was where Whistler went to meet Homer Martin and Albert Moore, perhaps Pagani's in the days of its sanded floor and good spaghetti-not the sort of stuff Americans devour-and low prices. Both were men Whistler sincerely liked, so sincerely that it was a regret to us to hear that, though there was no break in the friendship with Homer Martin, a coolness sprang up in the end between him and Albert Moore. T. R. Way thought this was because Albert Moore criticised The Three Girls, and Whistler immediately wiped it out, and could never paint it again as well. But Whistler did not object to criticism from friends, he rubbed out and repainted this canvas many times, and it was some years after that Albert Moore was the one artist who stood by him in the Ruskin case. A more plausible reason we have from Mr. Walter Dowdeswell. At a dinner, old Mr. Dowdeswell gave to Albert Moore and Whistler at the Café Royal, Albert Moore told them that he was painting a group of flying figures, and in order to get the right movement in the draperies he had used fans and bellows, and this gave his wretched model pneumonia, and she died. "Ha! ha!" laughed Whistler, "and this is how you make consumption!" Albert Moore flew into a temper, and the quarrel could never be patched up. A pity. I902] 


\section{The Whistler Journal}

Friday, March 28th, Igo2. All this time, we have heard that Whistler is in town, but he wishes no one to know it. He is enveloped in mystery-will see no one. He answers no letters. Not even Heinemann is admitted. Sauter is once, and there is a visit from Whistler to Sauter-to be revealed to no one-when the Boer agitation is at its height, because Whistler wants to know how things are going and, of course, the subject cannot be mentioned in the presence of "the Ladies." At last we write that J. is going to Italy and Whistler asks him to come to the studio. He is living at Tite Street. J. spends the whole afternoon with him, but does not report anything to be specially noted.

"The Ladies" were his mother-in-law, Mrs. Birnie Philip, and the numerous sisters-in-law, always coming and going, fluttering about him. After his return from Bath, they literally swallowed him up for a few weeks.

Sunday, April 2oth. As Whistler is not going anywhere in the evening yet, asked him to lunch with Miss Philip. Not knowing until the last minute whether he could come or not, had time only to send round for Harrison Rhodes. Whistler in his best form, as he so often is when his audience is small and sympathetic. Has just moved into Ashbee's house in Cheyne Walk, which he has taken for a couple of years. He describes it as "The whole, you know, a successful example of the disastrous effect of art upon the British middle classes. When I look at the copper front door and all the little odd decorative touches throughout the house, I ask myself what I am doing there, anyhow? But the studio is fine, I have decorated it for myself, gone back to the old scheme of grey." Then he got launched, somehow, on West Point and after lunch went over the old familiar ground, with that ever fresh enthusiasm so marvellous in him, to Rhodes, while Miss Philip talked to me.

Thursday, April 24th. Went with Rhodes to take tea in Whistler's studio. No one else but Miss Philip. At first I thought Whistler would show nothing, but after a little while he began to bring out picture after picture: the portrait_of an American who had written 234

$[1902$ 


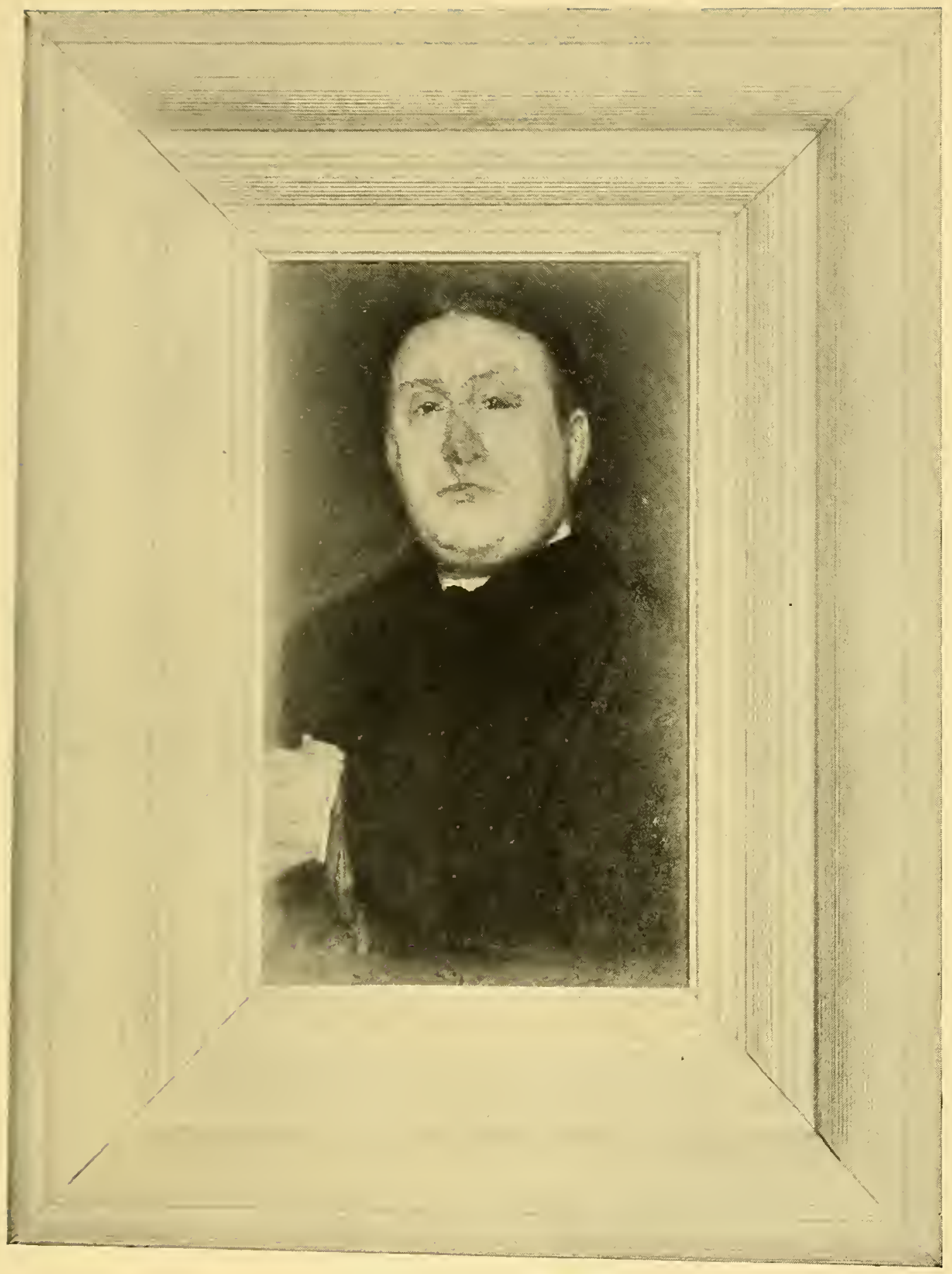

RICHARD A. CANFIELD

His Reverence

Showing Whistler Frame Finally Adopted by Him for His Oils

OIL

In the possession of Messrs. Knoedler and Co. 
to ask if Whistler would paint his portrait in some unusually short time. Whistler answered, "Well-I must see you first-andwhen he came I was so pleased with him, I went right to work." It is a small portrait, just the bust-the face, clean-shaven, round, ugly but full of shrewd character, typically American. Then, a portrait of Miss Philip; a painting of his small model, a beautiful nude-just the figure standing on vaguely suggested shore; the pastels I have seen. He seemed anxious to impress upon Rhodes, above all, the difference between what is "going on" in his studio and others nowadays. "In my pictures there is no cleverness, no brush-marks, nothing to astonish and bewilder, but simply a gradual, more perfect growth of beauty-it is this beauty my canvases reveal, not the way it is obtained."

This was the beginning of the portrait of Richard A. Canfield, gambler and Harvard graduate, who spent his time between quoting Horace, cleaning out young millionaires, and patronizing painters with the proceeds. He was forced to skip from New York, and in London he fastened himself on to Whistler and became a very good patron, if an odious character.

Saturday, May I7th. Came back from Paris and arrived home to find Whistler waiting for me. He had come just as Augustine was starting to meet me and she left him there. My train was late, the customs slow, and when we finally got to the flat, he was opening the door for the postman. He wore a light overcoat, but he was crouching over the fire-the rain had begun and he was sure he was catching cold. He came, I think, to talk over the Rodin dinner at the Café Royal of two nights before. He did not go, he is still afraid to venture out in the evening, but he wrote a letter which afterwards figured in all the papers. "Rodin was breakfasting with me today, and Tweed, the sculptor who has him in charge, and Lantéri from South Kensington. It was all very charming, Rodin distinguished in every way, the breakfast very elegant, but, well, you know, you will understand-but-of course, it is something I do not want repeated, for others might not understand. Naturally, before they came, I put all my work out I902] 


\section{The Whistler Journal}

of sight-canvases up against the wall with their backs turned, nothing about. But you know never once, not even after breakfast, did Rodin ask to see anything. Not that I wanted to show him anything, I needn't tell you, but in a man so distinguished it seemed a curious want of-well, of what West Point would have demanded under the circumstances." I could see he was hurt, though had it been a lesser man than Rodin, he would not have thought of it twice. "Well, you know, Rodin's head is a trifle turned by this sudden enthusiasm. Now he is going down to Budapest to superintend, as it were, his own show there." Then he told me, what I had not yet heard, the wild excitement at the Café Royal, afterwards the Slade students taking the horses out of the carriage and dragging it, with Tadema inside by Rodin's side, and Sargent on the box, to the Arts Club.

And the rain coming on, he began to worry at finding himself so far from home, and Augustine made him a grog, and I lent him Joseph's overcoat which he put on over his own, and he went off in a four-wheeler.

Others, besides Whistler, thought Rodin's head a little turned by the attention he received in London. He might have stood it from artists and students. But society took him up. He usually stayed with Lady Warwick or Mrs. Charles Hunter, and he was much entertained and lionized. He seemed so pleased at getting into society that he allowed the English to treat his sculpture as they chose. He was rightly particular about the way his work was shown. For instance, he always insisted to J. that his work should be placed in the light of nature, en plein air. He carried this out in his exhibition in Paris in 1900, and he even wanted later the roof taken off the sculpture hall of the New Gallery in Regent Street where the International Exhibitions were held. Therefore, his acceptance of the British treatment of his Burghers of Calais is a proof of how badly his head was turned. The group in his studio or in exhibitions, and when finally set up at Calais, was placed on a pedestal about a foot or so high, in order that one could see the whole composition and the chained feet of the figures. But some brilliant genius in England conceived the idea of sticking it upon a pedestal copied from the Colleoni in Venice, high in the air, so cutting off the feet and ruining the design. MacColl told 236 
us Rodin was delighted with it. Probably the idea was MacColl's. The story of Rodin's breakfast with Whistler went the usual rounds of everything concerning Whistler, and we had another version from Mrs. Simpson, whose husband owns Pellegrini's large, lifesize caricature of Whistler. In this version, the visit to Whistler of Rodin and another sculptor was in Paris. Whistler showed them many pictures until the other sculptor said it was time to go to breakfast. Rodin felt it an insult to think of breakfast when looking at Whistler's work, but he was the sculptor's guest and he had to go. The next time he called on Whistler, he was received in the drawing-room, Whistler said nothing of work and turned a musical box from beginning to end of the visit. A curious medley this. That Rodin went on another occasion to see Whistler we know-when Whistler's studio was in the Fulham Road, and Whistler wrote to Rodin of his pleasure in the visit. Rodin may also have gone in Paris, but Whistler's studio there was not near his house or flat or drawing-room, though the musical box is most likely the gramophone he loved and set going with inexhaustible joy for every sympathetic visitor. One record he never tired of gave an American quack's patter in praise of a patent drug, every sentence ending with "It costs a little more, but what of that?" He turned it on one afternoon when the George Vanderbilts and Heinemann were in the studio. He and Heinemann were to dine with the Vanderbilts at Foyot's that evening. But after they had gone and before he left the studio, a note came from Mrs. Vanderbilt saying, would he mind if they decided for Voisin's instead, finishing, "It costs a little more, but what of that?" which, coming from a Vanderbilt, struck him as even more humourous than in the mouth of the quack.

Sunday, May 25th. Whistler and Miss Philip, and the Sauters to breakfast. Rather a dull occasion. Whistler evidently tired, the Sauters as they always are when he is present, subdued, and as Miss Philip was with him there was no chance to talk of the Boers. He was in a state of indignation with Ashbee. "No sooner did I get into the house than building has begun on the vacant lot next door. The house is being put up by Ashbee himself, who, no doubt, went away to get out of the annoyance. It is knock, knock, knock all day long." He was full of the gossip that a knighthood for Sargent was to be included among the Birthday honours- "also, will not Abbey have to be knighted for the Coronation picture? And what of their American citizenship?" 1902] 
On several occasions, including the King's birthday, a whole basketful of titles and decorations is emptied out over the most unexpected crowd in England. None, however, came Whistler's way. There is no question of giving up citizenship. They have been showered promiscuously upon, and accepted by American officers and business men whom nobody knew, nor what they have done, and whose names have never been heard of since. Another time, the same rumour about Sargent made Whistler eager to know if Sargent had become an Englishman because of much temptation?

Sunday, June Ist. Whistler came to lunch to meet Mrs. Whitman and Miss Tuckerman. He looked tired out when he came, worse than I have seen him look for a long time. The Ashbee business has got on his nerves. And no wonder, the knocking goes on all day. There are times when in the studio you can't hear yourself speak. He told the whole story to Mrs. Whitman and Miss Tuckerman-he described the house with its decorations and explained the trick he thinks Ashbee has played. He has put the matter into the hands of Webb and hopes for legal redressthough I don't see that there is any chance of it. But it is evident that the constant knocking and indignation with Ashbee are telling on his nerves and his health. There was still time for much talk about the Boers, and he summed up the whole campaign for the benefit of his new audience.

This house, to which there have been several references, was No. 74 Cheyne Walk, into which he moved in April. There was no question that his health was failing and that he was beginning to feel the discomfort of living in a hotel and of having a studio so far from where he lived. But it is incredible in the first place that the Ashbee house was chosen for him, and, in the second, that he was not urged to leave it as soon as the building operations next door began. It had a great deal to do with shortening his life. It was a ridiculous place anyway, the studio on the ground floor, which was damp, the dining and bed rooms at the top where he had to climb to eat and to sleep until the Doctor stopped him. After that he slept in a front room on a level with the street-the model's dressing room-only one window in it, with panes so small you could hardly look out of it-more like a prison cell than a bedroom. The whole affair was tragic. 
From Chelsea to the Hague and Back

Thursday, June I2th. Whistler came to dinner to meet Harrison Morris and his wife. Sauter came too. I thought they would want to talk about the International, but the talk was chiefly of the Boers. Whistler cannot resist a new and sympathetic audience, and the amazing part of it is that, often as I have heard him on the subject, I always listen with renewed zest. He began to talk of Chase, who is now with the Morrises over here. I felt it was right to let him know that Chase was their friend, but I think the fact only made him the more anxious to go on. "Well, you know, Chase seems to think it necessary to go through the country lecturing about me and telling little anecdotes-all at second hand." But the Boers monopolized the evening.

This was the last evening Whistler dined at Buckingham Street. Mrs. Morris has kindly sent us, and allowed us to use, the note she made of this evening from her point of view. We give it because it shows how he impressed people who could understand, especially the first time they met him. We had listened with never diminishing amusement to his talk about the Boers, but E. had ceased to make detailed notes of it and many she did make were used in the Life. But it was all fresh to Mrs. Morris and stimulating in its freshness. Besides, E.'s notes were usually fullest when he dined alone with us. When there was a party she was often too preoccupied with others to hear his talk.

"June I2th, Igo2. I dined with Mr. Whistler at Mrs. Joseph Pennell's in London. Mr. Morris and Mr. Sauter, were the other guests.

"Whistler arrived very late, and kept us waiting for him at every course. He had a mustache and small imperial, his lower jaw protruded, and his white lock was noticeable. His eyes were grey, sharp and bloodshot.

"He was profoundly conscious of being the only thing in the world worth attention, so, as there was no critical influence present, he genially expanded. He mumbled, and gave parts of half a dozen sentences instead of one clear sentence, in a piercing treble voice. "He said, 'The well-meaning person is the worst kind.' "He did not allow that a nigger could ever be an equal; said 'he 1902] 


\section{The Whistler Journal}

is something between an ape and a man.' When we told him that we associate with them, he spread out his hands, smiling and saying, 'Well, you know, it depends upon the season of the year!'

"When he was telling of something unpleasant happening, I asked 'Was it in London?' And he instantly shot out the words, 'Where else?'

"He spoke of Arthur J. Eddy's knowledge, and I, supposing he had forgotten my existence, remarked, 'It's only cleverness.' $\mathrm{He}$ turned square round upon me, saying impressively, 'Very true. When a lady chooses to open her mouth, she always says what's true. That is so. It is cleverness.'

"He said, 'The English employ insolence to cover emptiness.'

"He called Wm. M. Chase 'an American bounder.'

"Eddy is more of a gentleman, because he lectured about him as an outsider; but Chase lectured about him as an intimate, a confrère, 'while the piano played an accompaniment.' Eddy ought to lecture about wine, which he knows about, instead of 'the lost art of the beautiful.'

"Whistler was delighted with Harrison's story of Buller as 'whipped cream.' He said, 'The entire English army has been captured.' "Whistler was absolutely pro-Boer. He thought the English were too dumb and too stuck-up to know when they were beaten and when they were ridiculous. Young men who know nothing about tactics, are made officers in the field. Their athletic training enabled them to run twenty miles away from the.Boers.

"He thought the training at West Point absolutely perfect, but in danger of being ruined: because wherever there is perfection, decay must begin. As soon as the West-Pointers become conscious of their isolation, then the merit of the place is lost, never to return. He remembered 'Joe Wheeler' and Professor Coppée there.

"He thought his country, America, had done some very fine things and some very stupid ones. She should have fought with the Boers. It would have been courteous to them-but mainly the Americans, with very little trouble, would have stuck their own cap full of feathers.

"He was down on American journalism. 


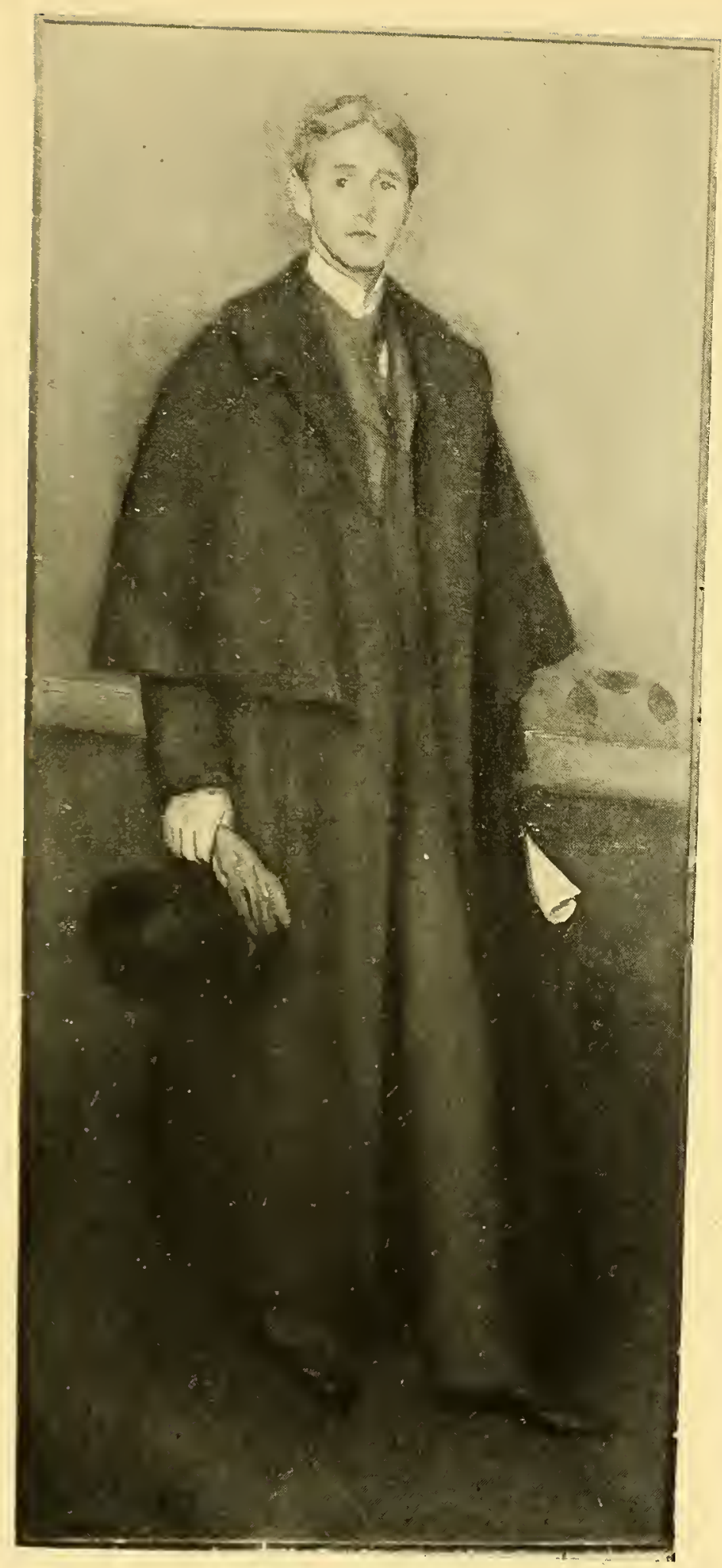

ARTHUR J. EDDY

OIL

In the possession of Mrs. Arthur J. Eddy 
- 
From Chelsea to the Hague and Back

"He considered the preparations for the coronation beneath contempt; the street decorations so bad that 'a two-year old child would not put them on its doll.'

"When asked of George Moore, he said 'George Moore? George Moore does not exist. He died many years ago!'

"He said 'One cannot be in London without one's lawyer.' When asked if he'd have whiskey, he replied, 'Well, if there's nothing else, what's one to do?'

"He sat on my right, and I observed that his profile was like the profile in the portrait of his mother. He was small, thin, grey, pink-cheeked, with crooked tie, thin ring on little finger, and little slippers. When I said I had not seen the famous eye-glass, he genially put it on.

"He said that because Alma-Tadema became an Englishman, the English have to protect all the abominable things he did.

"When I mentioned that I was treasuring some pictures of him by Menpes, he expressed incredulity of the whole business, but finally said 'I believe there was a sort of person-I mean to say, a creature, of that name. But when one allows any one to approach him, one naturally supposes that he is a gentleman. Perhaps the scoundrel did take the pictures.'

"As he left, I said, 'I am proud to have met you! and I shall keep the Menpes pictures, in spite of you!' which seemed to tickle him."

Tuesday, June I7th. Tonight dined with Whistler at the Ashbee house in Cheyne Walk. Mrs. and Miss Philip there and Mr. Freer. We did not sit down till about half past eight, or later and dinner was not over much before eleven, although it was quite simple. But Whistler had a bottle of special Burgundy which he had bought from, of all people, the French barber in Regent Street to whom he goes. It was in its cradle and the cork had to be drawn, and Mr. Freer had to help, and it was a matter of almost half an hour. And then he was showing Mr. Freer his silver and his blueand-white, about which, Mr. Freer, who collects china, knew all the correct facts. Mr. Freer, in a shop where they sell antiquities lately came across a Chinese bed, a wonderful affair, that had 1902] 
The Whistler Journal

belonged to Whistler. Whistler said he had it in the old Cheyne Walk house, but he got interested in other things and for some reason, he didn't exactly remember why, he replaced it with something else. I wondered whether it was one of the things that went at the time of the bankruptcy. After dinner, before the men joined us, Miss Philip told me the knocking was something fearful and put him in the most violent rage, the thing above all others the Doctor cautioned them must be avoided. Mr. Freer drove me home. On the way, he told me Whistler had asked him to look up his pictures and find out where they were for him.

We might as well say here that our story, printed in the Life about the dinner Whistler gave at the Café Royal to which Freer came mortally offended him. He not only never would meet us afterwards, but he did everything he could to prevent our seeing his Whistlers. This kind of opposition was not reserved for us alone. He treated Mr. Kennedy, when he was preparing the Grolier Catalogue in the same unreasonable fashion. In fact, Freer's personal likes and dislikes came near outweighing his interest in art and at times did Whistler's memory a good deal of harm. Canfield, who, as we have said, Freer introduced to Whistler, was not altogether unlike him. Another example of Freer's curious prejudices occurred at the first meeting called in London at the National Club to devise schemes and raise money for a Whistler Memorial. Freer, who had been invited to attend, calmly announced that he would either put up the Memorial with his own money or it would not go up-the attitude too often of the American patron of art. He was promptly told that, though the Committee would be glad to accept his money, the monument would be designed and erected as they wanted, and not as he demanded. Freer, after this, devoted himself to the West Point Memorial by St. Gaudens. We might also state that the money necessary to erect the Memorial (See Appendix) and the American replica was all collected. It was not erected simply because Rodin, after the site too had been secured, never finished his work, and the scheme which his executor M. Bénédite endeavoured to force in marble, when a bronze was commissioned, was rejected by the Committee as unworthy of Rodin and unworthy of Whistler. So much has been said about Whistler's always being late that we might give one reason for it, which was that he hated the stupid society fashion of breaking up a dinner party in the middle of the 


\section{From Chelsea to the Hague and Back}

evening. It is rare in this country that people dine at a civilized hour. You are asked to dinner at six or seven o'clock. The dinner is rushed through as fast as possible, everybody cackling at once. There is never any conversation, and as soon as possible the whole crowd rush off home or somewhere else. Whistler loved to potter about in the studio, to take his time getting dressed, to have his dinner never before eight except when he came to us, to sit over it, to dominate the talk, then to linger over his coffee and cognac, to talk again until he was tired, and this was usually near midnight. It was a civilized and intellectual form of existence which has disappeared from the earth. Whistler would dine only with people who interested him and who understood him. On the rare occasions when he accepted an invitation from those who did not, he took advantage of his happy faculty of sleeping, or he could be absolutely silent. He would never go again to such a house, and indeed he would not be asked. But this seldom happened. He never showed off at any time. He never could be made to show off. He was simply himself. There was nothing Johnsonian about him. He never thundered when he wanted to be heard. There was just his "Ha! ha!" and everybody stopped talking and listened. Often everybody stopped eating too.

Whistler probably asked Freer to look up his pictures because for months he had been worried and annoyed by the disappearance of much work from the studio. He had lost things before, but never in such numbers. It was doubly annoying when the missing work began to reappear for sale in Paris shops or other places where it had got without his knowledge. The apprentices had come upon many lithographs where he was surprised any should be found, paintings had turned up where they had no business to be, and "the picture robbery" as he termed it, was on too colossal a scale for him to ignore it. The apprentices, then in Paris, were set on the track "his brisk and mobile apprentices, his apprentices Envoys Extraordinary." A detective was employed. The services of Bodington and Alexander, English lawyers in Paris, were engaged. It was a moment of incessant messages and letters and wires, of cheques sent across the Channel and pictures brought back. It was hoped Carmen knew something and Whistler had her shadowed, though he must always look upon her with indulgence, he said, and would no more harm her than destroy his Phryne. He was always fond of her. She had been his model as a child, was still his model in Paris, the model for the beautiful Napolitaine, once in the Canfield collection. And she amused him. She never really grew up; was always the child. He liked to see her about the 1902] 


\section{The Whistler Journal}

studio, to laugh at her childlike nonsense. He delighted in her delight in the Académie Carmen. She was like a big baby through it all. When he advanced her two hundred pounds to start the school, "the faithful apprentice" went with her to deposit the cheque at the Crédit Lyonnais where nothing would persuade her to endorse it by any name save "Carmen," to the despair of the cashier, the irritation of the apprentice, and the amusement of Whistler when he heard of it. Then, with her first profits from the school, she bought herself a silk gown, strutted up and down in it before Whistler, boasted that it was the fashion in the Temple where she got it, was so gay that Whistler could but share in her gaiety. Most likely he would not have prosecuted her even had he suspected her. But he wanted his paintings and prints-one painting in particular because it was not finished and he did not care to have his unfinished work go before the public. He wanted also to learn the truth-to find out how these things had vanished from the studio and he thought Carmen might know. She was brought to London. "The watchful apprentice" saw her into the train in Paris, Miss Draughn, then posing for him, met her in London and secured a room for her in the same house. She was interviewed by Mr. Webb. But nothing whatever came of it. He was no nearer the truth when Carmen started back for Paris, and Whistler was more worried than ever when, going to CharingCross Station to make sure she got off, he discovered her in animated talk with a servant who looked after him in the Fitzroy Street studio, though there was some consolation in the sort of Sherlock Holmes part he found himself playing. The facts, the chances are, will never be known. What is certain is that Carmen was in possession of an interesting collection of Whistlers. Freer, who had her followed to Rome, bought some of them, and they are now in the Freer Gallery, Washington. A few months after Whistler's death, she sold the others at the Hotel Drouot in Paris, together with his letters to her, those concerning the Académie Carmen of the utmost interest. Her explanation to the manager of the Hotel Drouot was that Whistler gave her the paintings and prints, instead of money, in payment of bills he owed her. There the matter rests. Some of the missing things were not in her possession, but we heard from a Paris dealer of their being brought to him by servants of Whistler's who also explained that it was thus he paid them. All this gave Whistler in London and Bath the same anxiety he had gone through in Venice over canvases lost in the confusion of the bankruptcy, and he was now less able to bear it. Without doubt, the strain told upon his health and had something 


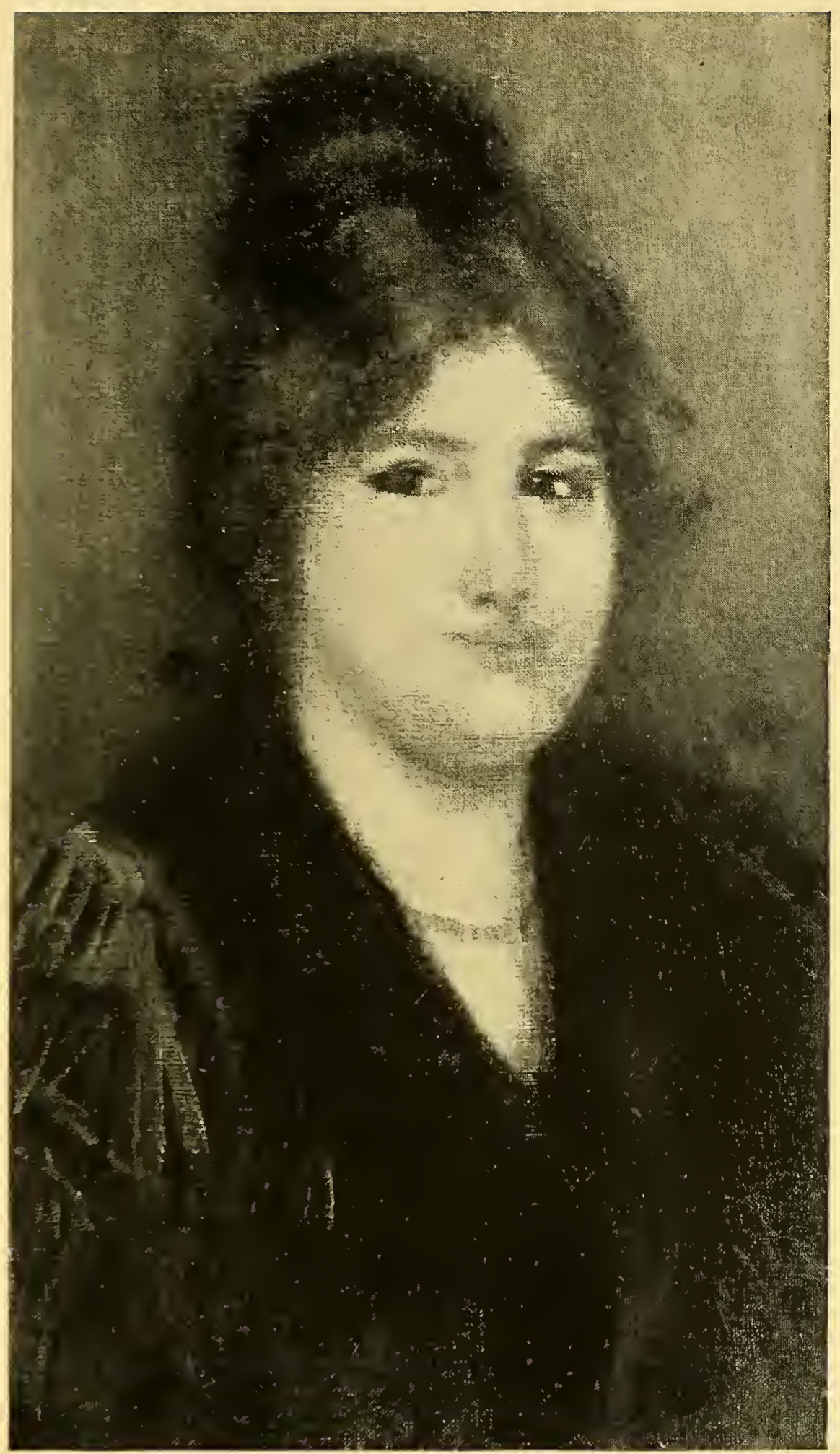

LA NAPOLITAINE, ROSE ET OR

Portrait of Carmen Rossi

oIL

In the possession of Messrs. Knoedler and Co. 

From Chelsea to the Hague and Back

to do with his rapidly increasing weakness throughout this winter and spring. It was only in his lighter moods he could make a jest of his legal adventures, though it was about this period he described them to Drouet as "la seule joie qui me reste."

September Ist. Though Miss Philip had told me how very serious was the question of the knocking next door, Whistler himself seemed in such good spirits and looked so well when I met him a week later, that it came as a shock when, just as we were wondering why he did not answer J.'s letter announcing his return, we heard that he had been sent away because of his health. Then came the alarming reports in the papers of his illness at The Hague-then the reassuring letter from Miss Philip to me, and letter and telegrams from himself. Now several weeks later, I started for Belgium and Holland.

Friday, September 5th. From Amsterdam I took the train to The Hague to see Whistler. The Saturday before, thinking I had gone straight to Haarlem, he went there with the Sauters, and drove to three hotels looking for me. Then on Tuesday in Amsterdam, I had a telegram asking me how long I was staying. I answered, till Friday. Then I heard no more. Thursday I went off for the day to the Island of Marken with the Fraleys. Walking home along the Canal from the Dam, I stopped in a shop. I suddenly saw him pass in a cab, I rushed out, but the cab had gone. Got to the hotel to find he had telegraphed he was coming, had come there at noon, and returned about five when the porter said I probably would be back.

At The Hague, found him in lodgings near the Hotel des Indesin what they call in England, a bed-sitting room. Mrs. Whibley and Miss Philip in a bedroom adjoining. In the midst of the packing, it looked rather comfortless. He was at the table, in the midst of bills and cheques, told me he was leaving for England the next day. "How could you have gone to the Island of Marken, of all places, when I had come to go with you to the Gallery! and Effie Deans, and the Rembrandts! Joseph and you are as careful as ever. It was the time of all others when you might have helped 1902] 


\section{The Whistler Journal}

me. Joseph did not know what papers had published the Ashbee story, but then why didn't he go and see? Heinemann found out and sent the papers the next day. It was a little thing I would have remembered. Now there is a little thing the other way to remember!" He had an engagement with the Doctor and left me to lunch with "the Ladies."

They told me how ill he had been, for a long while it was a question if he could get well, even now, the Doctor said he could keep well only by the greatest care and constant watchfulness-he mustn't walk up many stairs, above all he mustn't have any excitement! and how was that to be prevented? They told me how good Mr. Freer had been, staying on with him and giving up all his plans; how they were besieged by journalists and it was The $N$. Y. Herald man who had started the report; how the apprentice, Mr. Addams, came in the most extraordinary clothes, staying at a most extraordinary hotel with such a reputation for crime that the police had an eye on it, sitting up all night to paint a nocturne, though Miss Philip said even she might have told him that was not the way the Master worked. Whistler had left his cards on the Boer Generals. And then Mrs. Whibley told me how she hurried suddenly from London one day in just the clothes she had on, and how she had to pacify Charles by writing constantly that they were expecting to return, and how he had come over and she had had to conceal him, as though the meeting were most improper, and how Whistler seemed to know something was going on and had seen Charles at last from the window and had turned upon her- "Oh, Bunnie! Middle-aged and stout! It's quite unpardonable!" Whistler came in again for a few minutes before keeping his final engagement and that was all I saw of him. We were drinking whiskey and water with our lunch, for this last day, in the confusion of packing, there was nothing else. He saw it at once. "The wine of the Island, of course," he said.. I could see that he was in one of his most irritable moods.

E. had gone over to do some galleries for The Daily Chronicle in Belgium and Holland. A certain amount of attention had been 246

[1902 


\section{From Chelsea to the Hague and Back}

drawn in England to Whistler's experience in the Ashbee house, to his illness in Holland, to the knocking that was the chief cause of it. Some of the papers published articles evidently prepared for obituaries, which Whistler, whose mind had not weakened if his body had, did not fail to see. It was then he wrote from The Hague the often quoted letter to The Morning Post begging that "the ready wreath and quick biography might be put back into their pigeon-hole for later use," and apologizing for continuing to wear his "own hair and eyebrows after distinguished confrères and eminent persons have long ceased the habit;" then too that he made up for years of ill-will by paying in public gracious and generous homage to Swinburne who, however, to the end cherishing his resentment, could find no finer praise of Whistler, we have been told, than "clever, certainly very clever but a little viper."

E. has already referred to one of her visits with Whistler to the National Gallery after Mrs. Whistler's death. Sauter's visit with him to the Hals series at Haarlem is described in the Life. And now, his desire was to see with $\mathrm{E}$. in Amsterdam his painting of Effe Deans in the Rijks Museum and to study the Hals and the Rembrandts there. E. saw the Effie Deans four years later but alone. Her note is:

August 24th, 1906. An arrangement in grey and gold. A woman in long clinging grey skirt and a yellow shawl held tight round her shoulders and over her head; her face, the cheeks rose-flushed, is seen in profile; her right hand, nervously opened, is raised to it. She stands against a grey background. To the right, about midway in the canvas, is the Butterfly in the same gold and yellow as the shawl; to the left, low down, is written with a brush in the same colour, "She sunk her head upon her hand and remained standing unconscious as a statue.-(The Heart of Mid-Lothian, Walter Scott.)" The quotation is a good description of pose and feeling, but was it Whistler's writing? The picture seems scarcely finished-its charm is great.

Visits to galleries with him-and he and $\mathrm{J}$. have tramped the floors of the National Gallery and the Louvre together many times -were extremely interesting but rather sensational as, during the years we knew him intimately, the world knew him well by sight. After a discussion one evening in Buckingham Street with Timothy 1902] 


\section{The Whistler Journal}

Cole concerning Turner and Claude, the three made an appointment to meet the next morning in the National Gallery when, Whistler said, he would prove his point. Cole was working in the Gallery, perched on his high stool above the people's heads, engraving a wood block on his little stand. He came down from his perch when Whistler and J. appeared and they went to where the Claude and Turners then hung side by side as Turner wished they should. The question was of light, of sunset, and Whistler pointed out that, as J. noted,

Turner painted the sun, a great big circle, low down right in the middle of the picture, and that if it was there he could not have seen anything else or even have looked at it. And yet the picture was filled with detail from end to end instead of light, all for the benefit of the Islanders; in fact, you could not have seen anything at all, the sun would have blinded you. Claude, knowing this, veiled his sun in the same place with a thin cloud which enabled you to see the sunset without being blinded. And yet neither Turner nor Ruskin had the sense to see that the earlier artist solved the problem where they only made a mess, the one in his painting, the other in his writing. Neither had the bra ns to carry on tradition. And then the architecture. Claude painted and composed architecture. Turner's architecture would not stand up if anybody tried to build it.

But before this little demonstration was half over-it took only a few minutes-it was on the students' day-all the copyists had left their easels and gathered round, and as it was not his fashion to pose as a perambulating lecturer or docent, or to throw pearls to painters, the demonstration came to an untimely end.

Duret has memories of similar walks through the National Gallery and similar talks of Turner and Claude, and no one who ever had the privilege of visiting a gallery with Whistler did not come away with a clearer conception and understanding of all he had seen. A short-hand writer should always have been of the party, and it is the world's loss that Whistler never carried out his project of a book with the title In the National Gallery with Whistler. The idea came from his talks there in the Eighties with Mr. Malcolm Salaman, then an art critic and Whistler's ardent supporter. Mr. 248 
Salaman was to record these talks, but the trouble was, Mr. Salaman said, that when he called for Whistler, Whistler would probably be off etching the butcher's shop in Chelsea or busy with a sitter, and when Whistler called for him he would be at his newspaper office, and nothing came of the project save a few odd notes of a discussion on Veronese and Tintoretto.

As to J.'s not sending him the newspaper clippings, we have already given an idea of what Whistler sometimes expected and asked and demanded. We were ready to do anything for him, as he was for us, but there were limits. To have got these clippings would have meant one of us going to every newspaper office in London and consulting the files of the papers for a week or two. E. did make just such a search for him during the Dreyfus affair, in which his interest was keen, but he expected it always and we were too busy to do it ourselves and we had no secretaries or clerks as, we understand, the modern literary person and painter have. Whistler, in these years, usually had a secretary, and he had also "the Ladies" to attend to these things for him. But, somehow, he rarely asked them. Heinemann, however, had a large staff and Whistler's commissions gave them something useful to do, and Heinemann would let them do it. But what we wish to point out is, that there was this side to Whistler and that, if you accepted it and let him get into the habit of using you, you had to keep it up always. J. made him understand from the beginning that our friendship with him did not run to our following, fetching, carrying, collecting for him. Occasionally Whistler forgot, and occasionally there were scenes, as there was that morning at The Hague, but they were never serious. Other people were willing to fetch and to carry, but gradually they rebelled, and, with the first sign of rebellion, they were dropped, and this was the cause of a good many rows. As Mr. Walter Dowdeswell said once to J., "Whistler needed somebody always in attendance, somebody to butter his toast and black his boots-but that was the end of somebody as a friend."

The reference to the Boer Generals reminds E. that some of them were then in The Hague and that the feeling throughout Holland against England was bitter. Whistler arranged for "the Ladies" to drive her to the station by the longest and most roundabout way so as to show her the beauties of the Bosch, and as they drove along the beautiful roads, patriotic youths of The Hague, seeing them and taking them all three for hated Englanders picked up and threw great handfuls of gravel at them as they passed, which shows how strong the feeling was.

1902] 
CHAPTER XV: THE INVALID IN THE STUDIO AFTER THE RETURN TO LONDON. THE YEAR NINETEEN HUNDRED AND TWO CONTINUED

Thursday, September I8th, Igoz. Not hearing from Whistler, went out to Cheyne Walk to ask after him. Found he had been ill, and was still in his room. He sent for me to come up. His room is at the top of the Ashbee house, where the window might lock out anywhere but on the river, so little can be seen from the "artistic" place found for it. Whistler on the lounge. His Empire bed at the other end of the room, and the few things in the room beautiful of their kind-he in a white silk night shirt and a black coat over it. Some one had just sent him a New York Times Saturday Review with a notice of Sir Wyke Bayliss' recent book, a review which, as he said, showed a sense of things. It certainly was written by some one who knew Whistler and all about the British Artists. He thought it might be Julian Hawthorne. He seemed tired, the reading of the notice used up the little energy he had, and I only stayed about half an hour.

Anybody who knows anything of Whistler knows that Sir Wyke Bayliss succeeded him as President of the British Artists-a President as colourless as his own water-colours. The book was Olives, a feeble production which, if it lives, will be because the author chances to be immortalized in The Gentle Art.

Tuesday, September 23rd. Called again, and found Whistler moved down to the room adjoining the studio, the Doctor thinking, if he was strong enough to get about, the stairs would be bad for him. He was in the Empire bed, in his silk night shirt with a little knitted shawl over his shoulders, a counterpane embroidered in gold covering him, and curled up close to him a little purring kitten, white and brown and gold, in harmony with the counterpane. Whistler didn't seem as well, he said he had the "jumps" and I only saw him for a few minutes. When I asked him if I could do anything, he said, "Well you know what you can do, but you won't do it"; this being to "go" for Ashbee, Menpes, Wyke Bayliss and the others of the "enemy" generally. He doesn't 250

$[1902$ 
hear the knocking so much downstairs, but he says Ashbee should be hounded out of the Guild and everything he belongs to, and Joseph ought to be here to see that he is!

The Guild is the Art Workers' Guild to which nearly all the distinguished artists then in London belonged, or were honorary members-except Whistler. J. was an ordinary member, Sargent and Cole were honorary members. The Guild gave lectures and discussions on Whistler's work, never on the work of the others, but still he did not belong. Twice Way talked of Whistler's lithographs, the early ones. On one of these occasions he showed for the first time on the walls what Whistler had done in Lithography and brought two of the stones-The Long Bridge and a figure subject-and a press, and, without Whistler's knowledge, printed them on it and distributed the prints he pulled to the members. The appreciation of these prints was so great that they were promptly thrown on the floor or used to light pipes, a most genuine expression of British appreciation of Whistler's art at that time. It was about I 894 or 1895 .

What William Morris, long Master of the Guild, thought of Whistler, J. learned at one of the meetings some years after Whistler's death. The talk was on William Blake, a show of whose work had just opened at the Tate Gallery. In the course of the evening a story was told of William Morris who had objected when Whistler once was called an artist, saying that he wasn't. Somebody in the company could not agree, declaring that Whistler was a painter. "Any fool can see that Whistler was a great painter," said Morris. Any fool might think that a great painter must be an artist.

Monday, September 29th. Called on Mrs. Whistler to-day, as she asked. She had written to say she would be only too glad to give us any information she could about Whistler and help in any way. I explained that for the moment, owing to Whistler's illness, nothing was being done about the book but that we were collecting material. She was rather wandering in her reminiscences, dwelling particularly on Mrs. Whistler's illness, but I gathered some facts. In the first place she gave me a paper with a few dates she copied from notes made by the Doctor for an Encyclopedia. The Doctor, unfortunately, had just before he married her, destroyed all his letters, including Jimmie's, these covering the early years in Paris, I902] 
The Whistler Journal

and letters too from Swinburne, Rossetti, and others of the group. Her letters were of recent years and she would not care to show them without consulting him. He was strictly and religiously brought up by his mother. Once when Mrs. Dr. Whistler, who loved the country, succeeded in dragging the Doctor who didn't love it, there with her, and was telling him how beautiful it was, he said it was just "like Saturday afternoon." When she asked him what he meant, he told her that when he and Jimmie were boys, on Saturday afternoon their mother washed their heads, overhauled their clothes and themselves generally, put away their toys and books, and prepared them for Sunday, when they were taken to church three times. She was very pious, and would like to have had one of her sons a parson. Jimmie was her favourite, though she was never quite in sympathy with him or his work. When she lived with him in Chelsea, it was a succession of shocksonce she came up to the studio to find the parlour maid standing to him for the nude. Jimmie was devoted. When she was ill he could not, as he never could, stand the sight of illness. She was taken down to Hastings to live-toward the end, as at one or two intervals before, her mind wandered. There was one melancholy week, when Jimmie and Mrs. Dr. Whistler were the only two of the family there with her. A nurse was in charge, and they used to go on long tramps, the only thing they could do. There was a particularly melancholy afternoon, windy and wet, when they were up on the cliffs together, and Jimmie was taking himself to task for not having been kind and considerate enough-he had not written as often as he should from Venice-he fairly cried with remorse. "It would have been better," he said, "had I been a parson!"

Mrs. Whistler knew little of the Paris days, but the Chelsea days, she said, were delightful. She and the Doctor went to his Sunday morning breakfasts, and brought their silver because he hadn't enough. Jimmie's man appropriated some of it, it was not marked and the design was a very usual one, the King's pattern. He replaced it with plated things and she never discovered it till later

on. Then Godwin built the house for Whistler, and Godwin had 252

[1902 


\section{The Invalid in the Studio}

a way of always making his estimates lower than the actual expenses, and then siding entirely with the builders in case of disagreements and misunderstandings. That was the way the crash came. The woman who was living with him then-"Morals never were of any account," the Doctor used to say-went to Venice with him. It was she who later on made things so unpleasant by living in Paris when the Whistlers were at the Rue du Bac and calling herself Mrs. Whistler. "Trixie" felt it awfully, for she always was extremely jealous of Whistler's past. Then came the long story of Mrs. Whistler's illness, gone over again and again, the misery of Whistler, unwilling to admit it, his putting the case in the hands of some obscure French doctor, whom the Doctor just stopped from performing the operation, his indignation with the Doctor for not believing she could recover, and with herself for having, he said, told people it was cancer. This was the cause of the fight with the Doctor. In his indignation at the moment, Mrs. Whistler regretted, he never thought that in giving way to it he might be losing a friend, and the Doctor was the best friend he ever had. Whistler was so furious that he never let them know of Mrs. Whistler's death. They were dining at the Savoy and they heard it from friends they met there by chance. The quarrel preyed so on the Doctor's mind that it drove him into the "unfortunate habits" that were really the cause of his death. When he was ill, however, and she went round to the studio, Jimmie came at once. 'The Doctor told her then one of the valves of Whistler's heart was affected but that there was no reason why he should not outlive him, the Doctor.

The Valparaiso trip was, as far as she knew, taken just for pleasure, though she had no doubt that many things were left in confusion behind. He had always flung his money away-such extravagance -it was spent and wasted by the women who were always about him. Coming back from Valparaiso, he was kept not in irons, but in his stateroom from the time he took the "nigger" he found in his stateroom and knocked his head against the smoke stack; the story Whistler told us. At the time of Lady Haden's engagement, Whistler, then a boy of about twelve, came with his father to Eng1902] 
land. After seeing Haden for the first time, Whistler's remark to his father was, "He's just like a schoolmaster, isn't he!'

Mrs. Whistler, whom E. went to see was Mrs. Dr. William Whistler, Whistler's sister-in-law. The Mrs. Whistler to whom she referred was, of course, Whistler's wife. It was Maud Franklin who joined him in Venice, who returned with him to London, and who, as we have said, signed herself at that time Maud Whistler.

For some few years Whistler and his brother did not see each other, a grief to both. The Doctor had always been Whistler's truest friend; the Doctor's house in IVimpole Street was his home when he was ill or weary. This was their first serious difference. However, three years or so before the Doctor's death, when he was in money difficulties, Whistler, through Lady Haden, came to his aid. "It is Jimmie all over," the Doctor told his sister, "generous and open-handed as I have always known him," and he went on to say that often he remembered Whistler giving to others what he had not himself, "the pluckiest fighter against odds and the most splendid worker that I have ever known." This generous side of Whistler is the one least often dwelt upon, and two other instances might be added that we do not think have ever got into print. One we have from Mr. Alan S. Cole. In Paris an Englishman, a confirmed morphomaniac, when he was absolutely penniless came begging to Whistler. who, though Mr. Cole told him the truth, lodged the man in a decent hotel, the St. Romain we believe, clothed and fed him until at last the hopelessness of the case could no longer be denied and he had to be sent to some sort of home or sanatarium. The other instance, from Mrs. Addams, was of a student at the Académie Carmen, a girl whose father allowed her fifteen shillings a week to live on, though her brother was sent to Eton-a distinction between sons and daughters then not uncommon in England. She shared rooms with two other students, all three existing in the utmost poverty. Whistler, learning this, would send her things to eat by Carmen, sometimes would even send her gloves, seeing she had none; he had, by accident, just come upon gloves that he thought would suit her, was his message. Of his thoughtfulness for children many instances are in the Life. Of his little models, waifs and strays from the streets, he was ever careful. If he could not come to the studio at the hour appointed for them, he would notify the housekeeper at Fitzroy Street and beg her to let them wait in the kitchen where it was warm. This was the real Whistler, not the Whistler the world thought it knew. His consideration for servants was as great, though they were not 


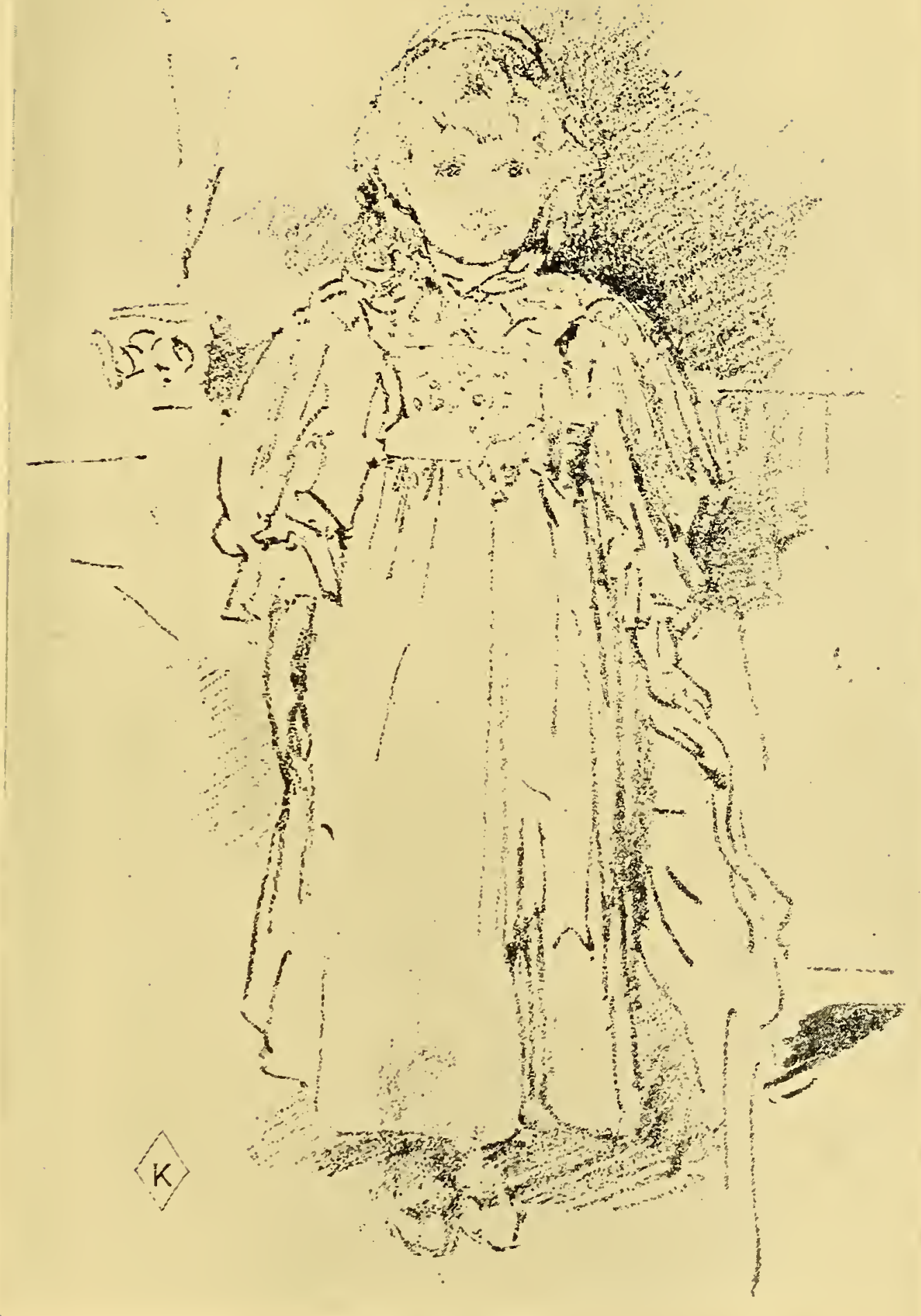

LITTLE EVELYN

Daughter of D. C. Thomson, Esq.

LITHOGRAPH. W. IIO

By permission of Kennedy and Co. 
invariably as considerate in return. To one or two robberies in the studio were traced, while in the Lindsey Row days, an amazing Mrs. Cozzens, who presided over his kitchen, repaid his kindness by drinking like a fish. He quoted Watts-Dunton as saying he always liked her best when she was very drunk, and Lord Redesdale had a funny story of her, in a state of collapse in the hall one evening when he came in late with Whistler, but with her wits enough about her to look up and smile upon them-"I-sh-shtaking care of the house for you," she said to Whistler, so that afterwards it got to be a saying with them that anybody who was drunk was taking care of the house for them.

Wednesday, October Ist. Went to call on Whistler in the afternoon. He was not ready to see me, and I sat upstairs for about half an hour with Mrs. Philip. When he sent for me, told me he had got up especially to receive me. Tea was brought in, but he dozed off almost at once, and I had not more than a dozen words with him before it was time for me to keep my engagement to take tea with Mr. Landor. Whistler struck me as weaker than when I last saw him.

During this last illness, Whistler was so weak on certain days that he hardly opened his mouth.

Monday, October I 3 th. Called on Whistler late in the afternoon after almost two weeks, but had not been able to get there sooner, because, in the meanwhile, J. has come home from Spain, very seedy. Found Whistler lying on a long steamer chair, but in the studio, which seemed an improvement. He wanted to know all about Joseph. "Well, you know, he must see a Doctor," he said, and when I said he wouldn't, he told me, "It is your duty to send for one without saying anything to Joseph about it until the Doctor appears on the scene." "But imagine," I told him, "Joseph's indignation with me for doing such a thing without consulting him." "No," Whistler said, "it will be just as it was with me. When they wanted to bring in a doctor to see me, I declared I wouldn't, but once they brought him without telling me. I just clung to him and have clung ever since. Tell Joseph that." Miss Philip left the studio, and no sooner had she gone than he promptly I902] 


\section{The Whistler Journal}

fell asleep, the cat curled up sleeping at his feet. And though Miss Philip came back and we had tea, he never woke up until just as I was going and Sauter came in to see him.

Sunday, October Igth. Coll Cooper and his wife, who to-day turned up unexpectedly, lunched with us. They talked a good deal of the Académie Carmen in Paris, "the Whistler School," of course they called it, as everybody does. They seemed under the impression that Whistler had made a good thing of it; the charge was fifty francs a month; no one was admitted for less than a quarter, and then he never came. He had written a most wonderful letter when the school came to an end. Cooper couldn't remember it, so as to do it justice, but it was very wonderful. And Addams, the apprentice, had called all the students together, made them take their hats off, and then read it to them with great solemnity. It was extraordinary, Cooper said, how all the students who had been at the school and once understood Whistler's methods, never gave them up afterward. He did not think Whistler a good master for this very reason, he impressed himself too strongly on his students.

"Coll" Cooper is Mr. Colin Campbell Cooper, and his wife, Emma Lambert Cooper. He was, all unconsciously, stating Whistler's theory of teaching, which was to carry on the old tradition of teaching-the master should teach the pupils to draw and to paint in his way, they should learn all he knew from him by precept and practise, and then they should either be able to help him in his work, as the pupils of the Old Masters did, or, having learned all they could, start out and do something for themselves. As he often said, he could teach anybody to draw or to paint in his way, and that was exactly what the Old Masters had done, but, after they had been taught, God Almighty alone could make them artists. Students went to him, however, because they thought he would turn them into artists like himself immediately, ignoring the fact that his position came from the knowledge and experience of a lifetime, and that, besides, God Almighty had made him an artist. His is the only way that art can be taught, but in this age of getting art quick, nobody is taught. The pupils get a smattering, and they get nowhere. As for the financial side of the school, 256

[I902 


\section{The Invalid in the Studio}

Whistler not only never made anything out of it, but he was careful to see that Carmen did not make too much. Mrs. Addams told us that Carmen began by asking the women twice as much as the men, and there were weeks when Mrs. Addams paid her more than a thousand francs. She asked the women one hundred francs a month. But when Whistler heard, he would not have it.

Monday, October 20th. Called on Whistler. Nobody else there but his model who was just leaving, a Miss Seton, who was rolling up her reddish hair when I came in. "Most people think she isn't pretty," Whistler said, "but I find hers a remarkable face. It reminds me of Hogarth's Shrimp Girl in the National Gallery." $\mathrm{He}$ had been working, but only a very little. He did not seem able to get back to it again. He showed me a sketch of her head, against a grey-green background, on a tiny panel. He had been pottering about looking at accumulations from the Paris studio and had found many charming things, he said, and he showed me a delicate little study in quiet greys of a house front somewhere in Touraine, just the doorway and a little window with balcony above it. Then tea came in and I gave Miss Seton tea, and he got up and emptied the stale milk out of the cat's saucer and gave it some of the fresh from the jug on the tea tray. I told him Harrison Morris was anxious to have something for this winter's show- "The man who took up with the nigger?" was his only answer. He seemed uncertain if Joseph ought to come and see him. "What if there are microbes hanging about him? I can't have any more microbes-I have had enough of them. And why have you been so kind to the British Artists? Isn't it time to rub in something about their President's book? And if you have seen Strang, did you impress it upon him that it is his duty to see that Ashbee is hounded out of the Art Workers?" I couldn't tell him that when Strang told Ashbee what he thought of the whole performance, Ashbee was abusive and said he would turn Whistler, who wasn't paying his rent, out of the house, if he were not so ill. Whistler is still wearing his extraordinary costume and, as he walked about, he looked so old and feeble and forlorn, that I hated to leave him there in the studio alone.

1902] 


\section{The Whistler Journal}

When his strength permitted that winter, he went through his canvases and prints, sorting and destroying-preparing for the end, though we doubt if he permitted himself to think that the end was within sight-he shrank from the thought of death-so much was still to be done and he was just beginning to understand. Lavery got the same impression one day when he found the big canvases in the studio stacked near Whistler, their backs turned, and the fire-place full of ashes. He had been burning things Whistler said, "To destroy is to exist, you know." He had a bad turn while Lavery was with him and Lavery helped him to the bed-he could hardly get his breath. When he sat up again, he drew his hand across his back and said almost like a child, "I don't like this at all Lavery, not at all," and Lavery thought he had begun to realize the seriousness of his illness and was trying to put things in order. Whistler's care for his little cat reminds us that he was as tender with animals as with children. To our William Penn he was charming. William had a reprehensible habit, when we were alone at dinner, of sitting at table with us under the rose-shaded lamp. He gradually became so used to seeing Whistler at dinner that he forgot his manners and jumped up all the same, and Whistler never objected. On the contrary, he even complimented William, sitting there so straight with his tail curled round his paws and the inscrutable look in his eyes: "William, you are really very beautiful." William Penn died the winter he was at the Hotel Chatham and he sent E. a special word of sympathy. He was so distressed about poor William, he said. He was long haunted by the tragedy of a green parrot in the Rue du Bac. The parrot did not like him and one day, when Whistler was trying to make it say all the things it said willingly for Carmen and never for him, it lost its temper, flew to the top of a tree in the garden, and then refused to come down, dying gradually of starvation, falling to the ground, a lean little corpse. Its death depressed Whistler for days. He felt that he was the all unwilling cause of it.

Monday, October 27th. Called on Whistler in the afternoon. Found Miss Philip there, the model just going, but he didn't know how it was, he couldn't work any more. A sketch of her head, with her hair falling on her shoulders just started on an oval canvas on one of the easels. He was exercised by a letter from Mr. Freer, enclosing copies of letters from Mrs. Arthur Bell to Mr. Freer and Mr. Freer's answer. Mrs. Bell wrote to say she had been commissioned by Messrs. Bell to write a book about Whistler: the most 


\section{The Invalid in the Studio}

important monograph on him yet published; and to ask if $\mathrm{Mr}$ Freer would allow her to reproduce some of his pictures for it and could tell her where photographs of others were to be had. Mr. Freer answered, with a politeness not unworthy of Whistler's West Point standards, to acknowledge the letter and to say he made it a rule never to allow pictures in his possession, when the artist was still living, to be reproduced without the artist's permission. He would therefore refer Mrs. Bell to Mr. Whistler himself, and for other photographs and material to dealers in London-he might name Mr. Marchant of the Goupil Gallery. Whistler was in a state of wrath and uncertain what he could do. Already, before he went to The Hague, he had received a letter from Bernhard or Oswald Sickert saying he did not see why his relations to Whistler should be disturbed by the fact of any difference between Whistler and his brother Walter. He had been commissioned by Messrs. Bell to write a book about Whistler for one of their series, and was now writing to ask. Whistler's assistance. "And I never answered the letter. And now comes this Mrs. Bell. And what redress is there?" I told him I was sure there was none as far as the book was concerned-he couldn't stop anyone writing about him-his only chance was if any of his letters were used without his authority, or any of his pictures, of which he held the copyright, reproduced without his permission. He said, "That is just what Heinemann told me about a book published in America last winter. What can I do? I might write one of my letters to the Bells, saying I have just heard through Mr. Freer of the proposed book-the honour they are prepared to do me-that I am much astonished, though no doubt they have written and the letter has not reached me-that I must ask them to submit Mrs. Bell's manuscript to me. If they refuse, why then I can write to papers like The Times and The Athenaeum to say that the book was entirely unauthorized by me and published without my approval or consent. What?" The whole affair seems to worry him, he was restless, complained of pains in his back, and could talk only of the insolence of doing a thing of this kind without the slightest reference to him and his wishes. Miss Philip, coming to the door with me, told me it had 1902] 


\section{The Whistler Journal}

upset him completely. It was the more provoking because when Mr. Freer's letter came, he was delighted and sent up for her to come and open it with him to enjoy it the more. He was too nervous for me to refer to the book we were asked to do by Heinemann. I only said it was a pity, since so many people seemed to be doing it, that he did not see that the book was at once done by the people he cared to have do it.

Tuesday, October 28 th. I called to-day on Heinemann, for it seemed to us both, in talking the matter over, that if Mrs. Bell's sheets of manuscript were sent to Whistler and he happened to be in the humour to like what she said, he might not only revise them, but give her material and his approval both, and so put an end to our book forever. Heinemann told me that one of the Bells called on him this morning about it, came to ask for the Connie Gilchrist, the copyright of which belongs to Heinemann, and anything else Heinemann might have. Heinemann told him the whole scheme was absurd, that Mrs. Bell didn't know anything about Whistler and couldn't write anything about his work of the least importance, that Whistler would object seriously, that material had been collected for some time past and was all in our hands. Then he showed Bell the photographs he had got together for our book-Whistler having let him photograph things from time to time. And immediately Bell asked him why he couldn't have them for the Mrs. Bell book. And Heinemann refused to let him have any thing at all. The thing to do, Heinemann said, was to get Whistler's consent to go on with the immediate publication of our book, that the moment was difficult because to urge the matter might make him think we were preparing to write his obituary. But he could represent that, in view of all these attempts, and of what Menpes and Sickert and others were no doubt preparing to do, it would be a great deal better to have the book done as he wanted it done, just as Sargent had been bothered so often to have his pictures photographed that, in self defense, he consented to Heinemann's making a book about him. Miss Philip had just called, she went out as I came, to ask him to go down to see Whistler tomorrow 260

[1902 


\section{The Invalid in the Studio}

afternoon at six. No doubt, it was about the Bell book. He would go, and come to us afterwards to dinner, so we could talk it all over.

Wednesday, October 20th. Heinemann came to us to dinner, straight from Whistler, whom he found still in his extraordinary costume, but gayer and more like himself than he has been for months, having managed really to get to work. He was surrounded by sheets of foolscap, preparing a letter to Bell. Heinemann persuaded him to write simply that he disapproved of the scheme and begged that it would be abandoned. Otherwise, he would have to state the circumstances and his disapproval in The Times. Heinemann told him that in Paris he managed to stave off Duret who, it seems, is writing a book too, which also is not approved of by Whistler. Duret won't give it up, feels that he must write it (and we can't help feeling that it would be interesting, Duret knowing so much of the early years in Paris) but the publisher has given it up. Then Heinemann suggested that Whistler.in self defense should allow him to announce our book which would put a stop to all these others. But Whistler turned upon him and said that he came like a Bismarck or a Machiavelli, demolishing other people's schemes that he might carry through his own. After that, Heinemann could not well say anything more on the subject. And so, the matter rests. In referring to Bell's visit he told rather a different story from the one he told me yesterday. He said he told Bell that he, Bell, could use anything if he could get Whistler's permission.

All this time, Whistler could not bear to talk about our book. As he had already told us, we were trying to make an Old Master of him before his time. His nervousness about himself is beyond belief and, much as we then wanted to go on, it was absolutely useless to discuss the matter. Duret, who is Théodore Duret, did not bring out his book until after Whistler's death. It has gone into a second edition and has been translated into English.

Whistler's "extraordinary costume" this winter was an old brown fur-lined overcoat which reached to his heels and was always well buttoned up. That he should wear it, be willing to be seen in it, seemed one of the worst signs of all, though when he was ill or I 902] 
depressed he did many astonishing things at times. We remember once when he appeared wearing one black shoe and one yellow, and his explanation was that he had a corn. Up till now his costume for the sick room had been his white silk night shirt over black trousers and his little black coat, in which $\mathrm{E}$. mentions having seen him on several occasions, and which Mrs. Dr. Whistler said he wore whenever he went to Wimpole Street to be nursed by his brother. The brown overcoat, as we look back to it, seems to mark a distinct progress in his illness.

Thursday, October 3oth. J. went down to-day to see Whistler, found him fairly well, but so many people coming and going had no chance to talk.

Saturday, November 8th. To Whistler's late in the afternoon. Mrs. Whibley there, and the household more or less upset because of the departure of the Dutch girl-Whistler giving Mrs. Whibley directions in German as to the remarks she should make. He wanted to know all about the New English, and was delighted to know that the Baronet this time was skied- "Can't be buying any more-what?" I told him of Mrs. MacMonnies' huge openair portrait of a child in a perambulator. "Oh yes, a blue baby with purple shadows sort of thing, isn't it?" Asked about the critics and was disappointed because I had seen no one but Rinder of whom he never heard before: "Rinder-pest, was it?" Altogether he was in better form than I have seen him, and looked in better form for he was dressed, the first time I have found him so since his return.

When Mrs. Whibley and Miss Philip left the studio, he told me the story of De Wet, which, he said, made him think that after all, Sauter was fortunate not to have been involved in the matter of the portrait. Constable wanted one for a frontispiece to De Wet's book, and young Meredith prevailed upon De Wet, who had no time to give sittings, to let Sargent make a sketch of him while he packed. Then Meredith jumped into a hansom and rushed off to Sargent and begged him to come and make whatever sketch he could in the time and under the circumstances. Sargent goodnaturedly agreed to do what he could, and they drove back to 262

[1902 


\section{The Invalid in the Studio}

Horrox's Hotel, and De Wet packed, and Sargent made the sketch. "And now," said De Wet, when it was finished, "what are you going to give me for it?" Meredith managed to arrange matters by saying it was his affair-Sargent got off, and the Constables settled by giving De Wet sixty pounds. Whistler was sad about it, "Well, you know, I wish it had not happened! You must not tell the story; it is sure to get out; but then it must not come from us - the reason I did not tell you before the Ladies." At this point Lavery called with a Miss L. and I came away.

Monday, November Ioth. J. went down to see Whistler-he was a wreck again. Boldini had been to see him, he had tired himself out-returned to his overcoat costume. For the first time, he struck J. as being very ill. He slept most of the time. Studd was there, Lavery came in and altogether no chance to talk.

Thursday, November I3th. A telegram from Whistler was waiting for me when I got home about six, asking me to come to tea, but, of course, it was then too late.

Friday, November I 4th. Another telegram to-day asking me to tea, and I went about five after the Walter Crane press view at Doré's. Found Sauter there. Whistler wanted to hear all about the Portrait Painters and the press view, and what everyone had said. But there was little to tell, especially as Miss Philip had been to the private view, and I hadn't. He thought I was too hard on Lavery. Why did I do it? He was full of Guthrie's election to the Presidency of the Royal Scottish Academy, he telegraphed congratulations at once and made a copy, which he read to us, and also Guthrie's answer: "Warmest thanks, my President," which pleased him immensely. Sauter and I came away together, Sauter coming home to dinner with us.

Thursday, November 2oth. To-day Wynford Dewhurst lunched with us, back from Paris where he has been showing h's pictures at the Grand Hotel and seeing all the critics. Among others he met M. Duret, who sent us a message. He had been preparing to I902] 
write a book about Whistler, but when he heard from Heinemann, through his publisher Floury, that we were doing it, he of course retired in our favour, and asked Dewhurst to tell us that all his material was at our disposal, which is certainly amiable.

I went down to Whistler's later in the afternoon. He kept me waiting upstairs for some time, sending me word that he hoped I would not get tired of waiting, he had so much to tell me. I sat in the dining-room. It is extraordinary how comfortless the house seems, his illness beginning before there was time to put things straight. His beautiful blue-and-white china was in one corner, his beautiful glass was in a cupboard in another. Brown paper in a great pile filled the settee. The cloth and the napkins were still on the table. A wooden box with Eggs printed on it, and odds and ends of parcels littered the old satinwood sideboard. Everything looked cheerless and ill-cared for.

Then downstairs-he had dressed to receive me. He was more like himself than I have seen him yet-the cause: a letter he had just been writing. "You know, Wedmore in The Standard, speaking of The Little Cardinal at the Portrait Painters referred to having seen it before-so did Claude Phillips in The Telegraph, and my letter to The Standard is to demolish them both-calling Wedmore, Podsnap-discovering Podsnap in art criticism and almost feeling the thump of Newton's apple on my head. What?" He was delighted, he read the letter aloud, then made me read it. "Heinemann, who knows the Editor of The Standard, is to take the letter to him, and, altogether, you know, the whole thing has the flavour of intrigue, and I do believe it has made me well again." Asked again about the Portrait Painters; he had heard something about Van Wisselingh having sent some Bauers to it, what did that mean? I assured him that whoever told him had got the facts crooked. Van Wisselingh has just opened a show of Bauers in his own Gallery "I knew that fool $Z$. was wrong!" When I asked him why he did not send the beautiful Mrs. Vanderbilt that was in Paris to the Portrait Painters, he said that when Vanderbilt saw it at the Salon, he seemed to think it was not quite finished, "That is, that I might like to have one or two more sittings from Mrs. Vanderbilt 264

$[1902$ 


\section{The Invalid in the Studio}

- simply an excuse for not having the picture go to other exhibitions." The reason Claude Phillips is unfriendly, he said, dates back to Paris days. "Phillips, you know, was playing le mondain and was at the house of the Comtesse de- one evening when I was dining there. Phillips was talking to her in his most impressive manner when she saw me. She called me, turned to devote herself to me. When Phillips at last walked away, she said, 'Did you ever see such hands? What a man!' And no doubt Claude Phillips heard and did not like it."

Saturday, November 2gth. In the afternoon went to Whistler's. A motor car at the door, and Heinemann in the studio with Whistler, who was dressed and looking much better. The two were deep over old letters and newspaper clippings, preparing another edition of The Gentle Art, and also a little brown paper leaflet with the Wedmore correspondence in The Standard. For Wedmore answered Whistler in last Saturday's paper, and The Standard was not willing to print Whistler's second letter. The idea is to print the two that did appear, then the unpublished Whistler letter and clippings from past notices, books, etc., by Wedmore as a proof of how for twenty years, as he says in his Standard letter, he has been praising Whistler's finer work! I was still reading Wedmore's letter when Mrs. Heinemann arrived, and there was a diversion for tea. Then, Whistler returned to the old correspondence, and read a wonderful letter to the Fine Art Society, when they complained of his failure to complete the Venice contract by pulling for them the number of prints agreed upon, though M. Duret had told them of recent proofs he had seen in a Paris gallery. Little Brown wrote, apparently, a letter from his own house and another from the Bond Street shop, and throughout Whistler, in answering, emphasized the distinction by referring to Mr. Brown of Surbiton, Mr. Brown of Virginia Water, and Mr. Brown of Bond Street, Mr. Brown expert, salesman.

Then he arranged with Mrs. Heinemann for a sitting next Tuesday, and the Heinemanns left. "Is Mr. Heinemann coming back?" I asked Whistler, thinking perhaps he had only gone to put his 1902] 


\section{The Whistler Journal}

wife in the carriage. "I hope not," Whistler said, most emphatically, "for I am so tired! Tell Joseph he must come soon, but I am tired!" And he looked it. But he went back to the letters. "I do come across extraordinary things," he said, "listen to this I have just picked up, written to Graves, I don't remember when, but it must have been at a time when they were a little sore about something." He read it. Graves seemed to have threatened the bailiffs and Whistler told them he supposed there was nothing to do but to turn on the hounds of the law. "But," he said, "what do you really think of the appearance you will make, with one hand presenting a Sir Joshua Reynolds to the nation, with the other turning the bailiffs on Whistler! Well, indeed, is it that the right hand does not always know what the left doeth." "It ought to be printed," I said, "it is too beautiful to be lost." "Yes," was his answer, "but, after all, there are things that wouldn't quite do for the public," and I suppose his being threatened with the bailiffs would not. But he thought, the Du Maurier correspondence might go into the new edition. Where was it? Miss Philip did not know. "Oh, you must, Major," but she was very severe about it. No, Ethel would probably know, she did not, she had nothing to do with it. He must ask Ethel. Something was said about Mrs. Addams and the baby. Was the baby an apprentice, I asked. Whistler laughed, "Oh, yes, of course, it was born an apprentice."

The pamphlet was never published, nor was Mrs. Heinemann's portrait finished. Whistler had a talent for inventing nicknames, and at this period, he always called Miss Philip "Major."

Tuesday, December 3rd. As J. was getting ready to go down to Whistler's, a telegram came asking us both to tea, and to bring all the Wedmore books! I could not go, so J. went alone, without any books. Whistler was dressed and in good form. J. represented that he had no books Whistler hadn't himself. Where were his copies? "Somewhere about," Whistler supposed, but he did not know just where. No one seemed to know. He wanted to heap proofs of Wedmore's appreciation upon his head. 266 


\section{The Invalid in the Studio}

Then he told J. the reason of Wedmore's irritation. It happened long ago. He had been asked to dinner at the Rawlinsons. "I arrived. In the middle of the drawing-room table was the new Fortnightly Review, wet from the press, with an article on Meryon by Wedmore, and there was Wedmore, the distinguished guestI felt the excitement over the great man and the great things he had been doing. Wedmore took the hostess in to dinner. I was on her other side. And I felt like a little devil, seeing things, bent on making the most of them. And I talked of critics, of Wedmore as though I did not know who sat opposite. And I was nudged-my foot kicked under the table. But I talked. And whenever the conversation turned on Meryon, or Wedmore's article, or other serious things, I told another story, and I laughedHa-ha! - and they couldn't help it-they all laughed with me, and Wedmore was forgotten, and I was the hero of the evening, and Wedmore has never forgiven me."

He began to talk of Raffaëlli's solid colours and was sure they were no good. His reason was personal-he did not like Raffaëlli. Raffaelli was a Jew. Then he came to London in theold White House days, with a letter of introduction to Whistler who had to be polite and ask him to Sunday breakfast. But that was all. "Then, you know, some time afterward, when I was in Paris, Durand-Ruel gave a show of my work and Manet's and others of my friends. We were all there hanging the pictures, and had been all day, and when evening came, it was a question of dining and general gaiety. Raffaëlli appeared. And he was effusive, met me like an old and intimate friend, called me 'mon cher Vistlaire, mon cher ami,' and I thought it offensive, a presumption. The next day I was again at Durand-Ruel's, in one of the rooms with a few distinguished people and critics, Mirbeau among them. Again Raffaëlli arrived, and again was familiar with 'mon cher Vistlaire' and 'mon cher ami.' I put my glass in my eye, looked him up and down, let it drop, told him that I did not know him and did not wish to, that no one had asked him there and it would be more agreeable if he were to go into another room. Raffaëlli was in a fury, naturally-said he had as good right there as anybody else 1902] 
The Whistler Journal

and would not go. Very well then, said I, as your company is not agreeable, I will go; and so I did, and all the others with me, leaving Raffaëlli alone. A week later Raffaëlli came to Mirbeau-he had been thinking it over, and had decided that Whistler's conduct was not to be accepted, would Mirbeau be his second? Mirbeau laughed. Had Raffaëlli discovered it a week ago, Mirbeau would have been charmed. After a week it was too late. He would not countenance it. And that was the last I heard of Raffaëlli and the duel."

The dinner at Mrs. Rawlinson's explains Whistler's saying that, "Well, you know, when I'm asked out to dinner, I always enjoy myself. But-well-I'm never asked to the same house twice!" Whistler loved nothing so much as chivvying people like Wedmore right to their faces, and this was one of the ways he got his reputation for malice among outsiders. He rarely went to public dinners because at them, he thought, one never dined. After an annual British Artists' dinner at the Monaco, when Wyke Bayliss began his speech by saying he had dined, "Ha! ha! Well, I haven't," Whistler interrupted. If he did go, the pleasure he failed to get in the dinner he made up for by the pleasure he got out of the people. At a dinner to Fred Brown when he was made Professor at the Slade School, or else at a New English Art Club dinner, J. cannot remember which, Whistler was put on one side of the Chairman and Wedmore on the other, and Wedmore made a speech which J. has completely forgotten. Then Whistler was called on. Even before this, he had been talking generally to the guests at the table about Wedmore as if Wedmore was not there, and, when he got up he went on in the same strain and finished by talking straight at Wedmore about himself as if he were some one else. The poor man stood it, but what else could he do?

Friday, December 5th. A letter came from Whistler, asking us to tea, and giving suggestions for a notice of the show of silver at the Fine Art Society's to which he has lent some of his. But neither of us could get to him, and when I went to the Fine Art's, there was no press view, only a private view tomorrow. I telegraphed I would come in the afternoon.

Saturday, December 6th. Went to the Fine Art's. There, Whistler's silver in a case by itself, draped with white napkins, while the 268 


\section{The Invalid in the Studio}

other cases were lined with red. There were beautiful pieces in his collection, evidently bought for use, and always a little crowd about it-people wondering to find the Butterfly on silver and linen both. Then I took a hansom and went to Chelsea. He was alone, and full of the show-wanted to know every detail-"how did the white, the beautiful napkins, look? Didn't the slight hint of blue in the Japanese stand and the few perfect plates tell? Didn't the other cases look vulgar in comparison? And didn't the simplicity of my silver, evidently for use and cared for, make the rest look like museum specimens?-What?" He examined the catalogue, found his McNeill spelt wrong, and could not understand why the entries were so few and the description so brief when it came to his case. No doubt, Percy Macquoid, who arranged the exhibition and prepared the catalogue, was indignant because he sent "the Ladies" to arrange his case. Then Miss Philip came in. Evidently "the Ladies" and Macquoid had not carried things off very amiably. When I told him Rinder was in the gallery, he said, "O, the man I called Rinder-pest the other day." He does not forget his own little sayings.

Whistler began to show me the proofs of the Wedmore-Standard correspondence, to be issued as one of the brown-paper covered pamphlets, but a musical friend of Studd's, now staying with Studd, was announced. "Damn!" said Whistler. "Take him upstairs, Major, he is one of your friends." But Miss Philip wouldn't, and the musical friend, a young German, came in, overflowing with enthusiasm. It was such a joy to play his piano in that room with the three Whistlers. Studd was so distressed that he made Whistler angry by having allowed them to be photographed by some publishers! And such pains had been taken! The photographers were almost three hours doing one of them. Studd ought to have consulted him Whistler said; other friends who had his pictures refused-the publishers did not come to him for permission, did the greater part without his knowing until he heard of it in a roundabout way-they were profiting by his work and him, and he was not getting a penny out of it. Was it the Bells? I asked. Yes, it was the Bells. The musical friend talked of the I902] 


\section{The Whistler Journal}

German Emperor. "Emperors are absurd now," Whistler said "It was all very well when they could say, cut off this man's or that man's head, and it was done at once, or as they can now if they happen to be Emperor of China or Russia. But for the others, it is nonsense." The young man stayed so long that as soon as he had gone, I had to go too. "Tell Joseph he's a humbug," Whistler said, "he never comes to see me." J. had been only three or four days before.

Thursday, December IIth. J. went down early in the afternoon before the International Meeting at Lavery's. Whistler up and dressed, but looking very ill and coughing most awfully. It was his tonsils, he said. But he coughed so he could hardly talk, once or twice wrote what he wanted to say, and seemed weaker than $\mathrm{J}$. has yet believed him to be.

Tuesday, December I 4 th. After lunching to-day at Mrs. Frankland's, went to Whistler's and found him looking again most frightfully ill. He was excited over the fact that Montesquiou had sold his portrait-"Montesquiou, the descendant of a long distinguished line of French noblemen. I painted it for a mere nothing-mon cher, you understand Montesquiou said, and it was arranged between gentlemen. And now Montesquiou has sold it, no doubt for a large sum of money! He had written to me, but his letter is feeble- he had not heard from me for so long, thought I had forgotten him-no excuse at all. Canfield has bought the pictureCanfield, an American who was here last winter and came to ask me to paint his portrait." Was that the portrait of the man with the large and rather ugly face I had seen once in his studio? I asked, and he said "Yes."

I did not stay long, he seemed so used up. But he rallied when Miss Philip came in, to tell her my menu at lunch - a kidney omelette, a beefsteak and kidney pudding, and then another pudding, a plum pudding. What an English meal! Miss Philip thought nothing so bad as a menu with repetitions. Who was it in Dickens had watched the dinner going into the neighbor's and everything was cooked with white sauce? Dickens, however, 270

[1902 


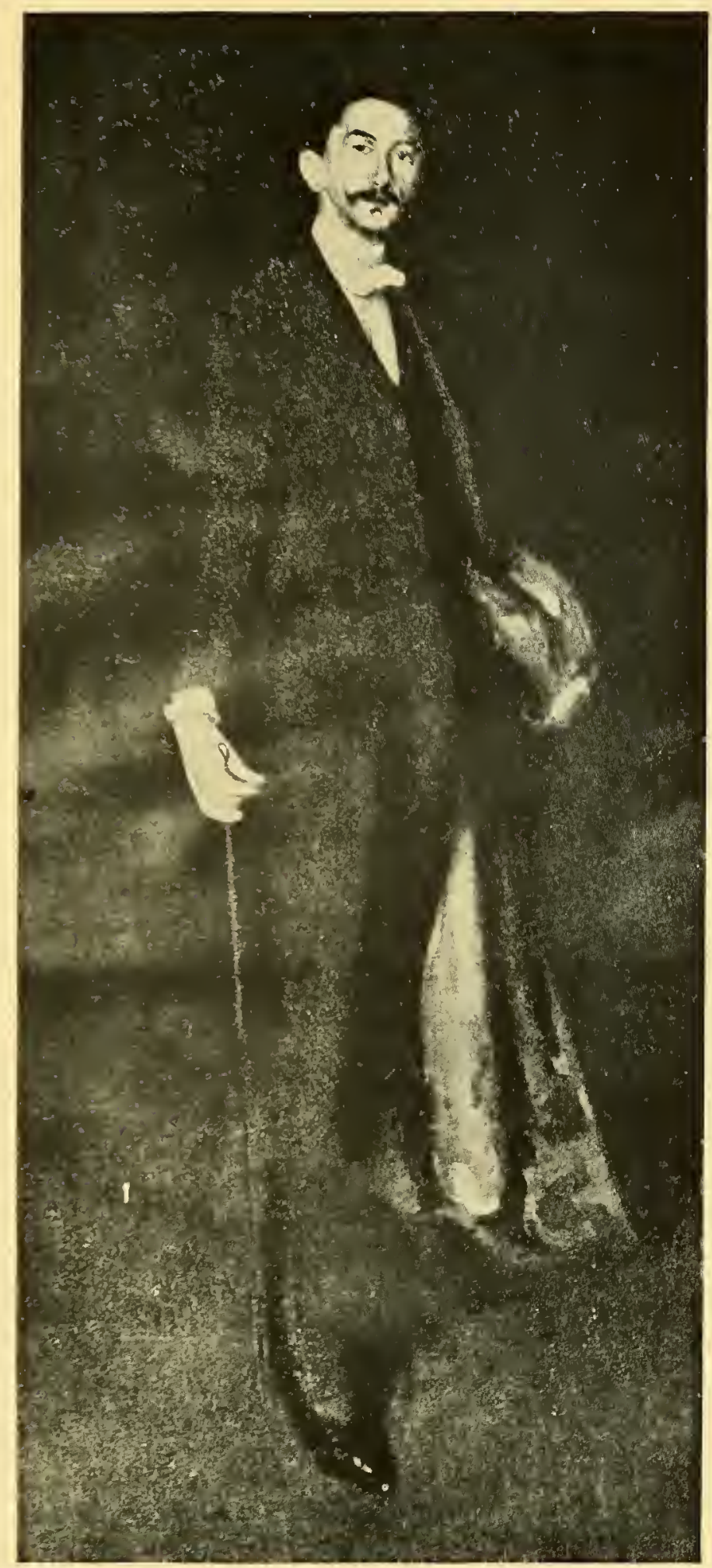

ROBERT, COMTE DE MONTESQUIOU-FEZENZAC

OIL

In the Frick Collection 
seemed to think it specially distinguished. "Ah, but that is quite another matter," Whistler said, "a dinner that aims at a certain harmony throughout. Wasn't I the first to give white and yellow lunches, an idea copied everywhere afterward with great pretense of originality?" I stayed a very short time, he looked so exhausted. When I came home, I told J. about the Montesquiou and said it was a Mr. Canfield in New York who now had it. Canfield, J. said, why that was the name of the gambler Kennedy warned Whistler against. And J. gave me the story as he heard it from Kennedy when they met at Siena last summer. I knew of a difference between. Whistler and Kennedy, but Kennedy had never explained the reason. It seems that he had come over earlier than usual that year, and with his first chance had spoken to Whistler of Canfield, thought he ought to know before getting involved with a man of that kind. Over here, no one would have heard of Canfield, and Kennedy could understand Whistler's receiving him as an American, and painting him. But the man was in every way notorious in New York, and Whistler ought to know. Whistler was furious-indignant with Kennedy for telling him. Why, Mr. Canfield had been there, had been received by him, had been introduced to "the Ladies"- that was enough to establish his respectability forever: if he had been introduced to "the Ladies" there was an end of it. And, in his indignation, he said things to Kennedy that Kennedy could not forgive. "He may say what he wants about the Boers, but he can't say things like that to me!" And Kennedy never went back, and that is the reason of the quarrel. Curiously, that very evening in The Star was a despatch from New York about the raid on Canfield's gambling place in New York with allusions to his pose as patron of art.

The Montesquiou was bought by Mr. Frick and hung upstairs in his New York house-not with the four great Whistlers in his office. Whistler was never satisfied with it, wanted to get hold of it and the Connie Gilchrist and destroy them both. The three copies, lithographs after the Montesquiou, attributed to him, we do not believe he made. He may have worked on them. If the copies are his, they are, like the etching of the Irving, which he I902] 
also attempted to copy, hopeless failures. But we have an idea they were done by Mrs. Whistler. Certainly two of them bear no resemblance whatever to his work, and we have seen references of his to two "my wife did, far more beautiful!"

Wednesday, December 24th. J. to Whistler's to report about the International Meeting the day before-Whistler better again, really in fairly good form, when $\mathrm{J}$. at last saw him. But he was first sent mysteriously upstairs to the "Green Room," was at intervals visited by the charwoman and told that "Master Whistler" would see him soon, was given the papers and a cup of tea, but it was three quarters of an hour before he was asked to come downstairs into the studio. Dunthorne was there; he had been buying etchings, and was making out a cheque for Miss Philip. Then Mr. and Mrs. Addams came in, and Whistler insisted on playing dominoes. Addams at first objected-it may have seemed to him too trivial. But he could not help himself and they played, Mrs. Addams winning everything, and J. was an hour late; for dinner.

He played only dominoes, and he loved to cheat in the most open fashion that was meant to deceive nobody, when he shuffled them getting hold of some which were marked or raised, dragging them to him. His friends understood and enjoyed the fun with him.

\section{CHAPTER XVI: THE LAST MONTHS. THE YEAR NINE- TEEN HUNDRED AND THREE}

Thursday, January Ist, I903. A card with New Year's Greetings, Butterfly and all, in the morning. In the afternoon I went down to give our greetings. Mrs. Walton was there for the same purpose. Whistler was much better, according to Miss Philip, but did not look it. He was in overcoat again, his hair flat which makes his face look as if there was nothing left of it, and he fell asleep at intervals. Mrs. Walton spoke of Benjamin Swift's lecture at Mrs. Lowrie's in Rossetti's old house. I told Mrs. Lowrie's ghost story. She saw a man on the stairs late one night on coming home, thought 


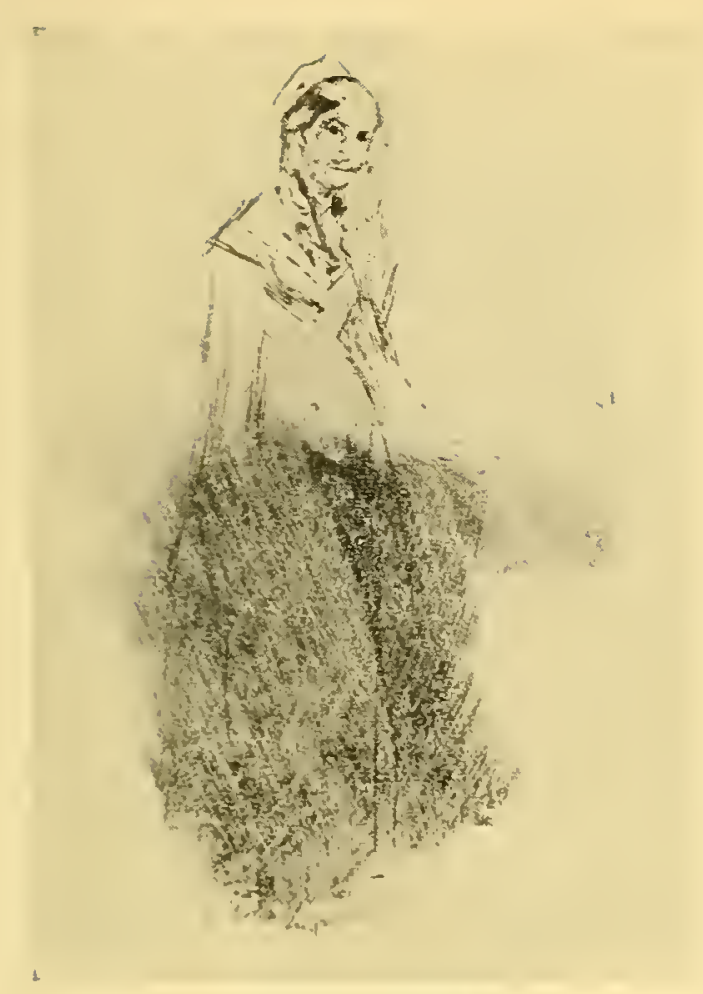

THE MOTHER

DRY-POINT. M. 97

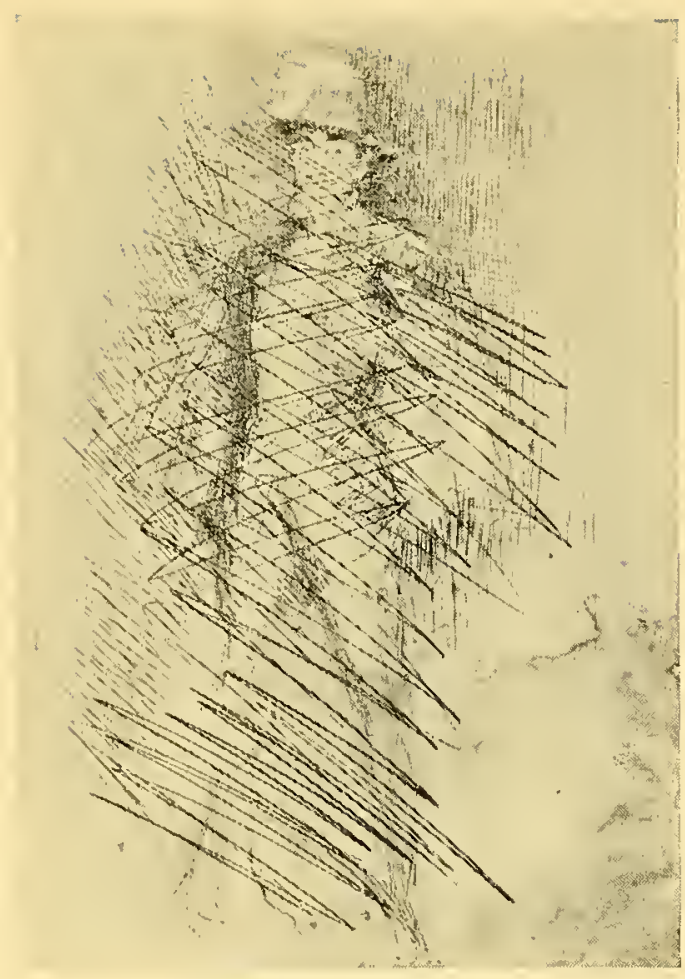

HENRY IRVING

DRY-POINT. M. I 70

From destroyed plates. Pennell Collection, Library of Congress, Washington 

it her husband, and called "Frank!" No answer, called again, "Frank, you brute, put out the light." But it was not her husband, only an unknown ghost, and I asked Whistler if there were any ghosts in Rossetti's day. Not ghosts, he said, but spirits. Wonderful things happened, wonderful things were going on in Chelsea just then, and there were evenings at Rossetti's with surprising results. Just what these results were, he did not say, but he insisted upon the difference between spirits and ghosts. He was too tired to go into detail, but kept dozing off, so I left early.

Thursday, January 8th. J. went to Whistler's to report about the International, having arranged to meet Lavery and Sauter and talk over the Howard incident. Lavery and Sauter were both there when he arrived, and a big fat man with cleanshaven face wandering about the studio. More pictures were dragged out and shown than J. had ever seen before at one time, and the table was strewn with letters. Whistler was evidently tired out and very weak. He said to J. rather with hesitation, "I want to introduce Mr. Canfield of New York," and the big man rushed forward with both hands outstretched, "Oh, Mr. Pennell, I am so delighted to meet you, I have so long known your work." In Whistler's studio there was nothing to do but to shake hands. But, with the best will in the world, it is not easy to imagine this Canfield any but the notorious gambler Canfield about whom Kennedy warned Whistler. He stayed there, in a far corner, while they talked over the International affairs, and they left him there when they went off together to Lavery's studio. Again in leaving, both J.'s hands were grasped and shaken with enthusiasm.

Monday, January I2th. J. received a letter from The Tribune correspondent here, I. N. Ford, enclosing a telegram from The Tribune, "Is Whistler painting gambler Canfield's portrait?"--so there must be some sort of scandal about it in New York. We talked it over-felt that Whistler ought to know-it does not seem right to him that he should not be told. But warned, as we have been, that he should not be excited, we are afraid to tell him I903] 


\section{The Whistler Journal}

for fear of the consequences to his health. Not willing to take the responsibility, J. went to see Webb about it, and Webb has undertaken to tell Whistler how the matter stands when he goes to the studio on Thursday before the International meeting. Webb told $\mathrm{J}$. that he ought to write the Life, and J. explained that Whistler has already asked us to do so, and Webb said he was glad to hear it.

Wednesday, January I4th. Went to see Whistler, almost wondering if it might be the last time, for Webb's interview with him may make him as indignant with us as he was with Kennedy last year. Found him amusing himself with the book about him by Elbert Hubbard, published at the Roycroft Press. "Really," he said, "with this I can be amused. I do not know how many already have used my name in this fashion and usually they only irritated me. But the intimate tone of this is something quite new." And he read bits of it, the passage about his father's courtship of his mother. "What would my dear Mummy-don't you know, as you see her with her folded hands at the Luxembourghave said to that? And our stay in Russia! Our arrival in London! Why the account of my mother and myself coming to Chelsea and finding lodgings makes you almost see us wanderers, bundles at end of long sticks over our shoulders, arriving footsore and weary in the late afternoon-amazing! It would be worth while to describe, not the book, but the effect on Whistler reading it. It would be worth while to do something about it. I must think it over." While he was still reading, Sauter and Lavery came in, and as I knew it was to talk over the International and its affairs I left at once.

Thursday, January I 5th. We dined at Sauter's and Webb came to the meeting afterwards. But when at Whistler's he did not see him alone, and was unable to say anything-and so he let the matter drop, as nothing more has been heard.

Saturday, January I7th. J. to see Whistler and report about Thursday evening's meeting. An unsatisfactory visit. The apprentices there and, for a while, not much chance for talk. 274 


\section{The Last Months}

Whistler still keen to have Lanteri on the Council of the International, "this distinguished sculptor, Master at South Kensington." He was coughing-J. could not irritate him by contradicting, and he said nothing. But Whistler is all with the Council as far as Howard goes.

Francis Howard-Francis Gassoway-Francis O'Connor-he flourished under the three names-is a young gentleman from Texas who went in for art and art dealing and art criticism. He brought together the group of artists who founded the International. These were Lavery, an Irishman, Guthrie and Walton, Scotchmen, Sauter a German, Alfred Gilbert, Ricketts, Shannon, Greiffenhagen, Englishmen. Whistler, before any meeting was held, came to J. and wished him to be a member, and also Ludovici. Howard was to be Honorary Secretary. J. was not called to the first meeting because Ricketts and Shannon and Howard strongly objected to something he had said or written, and, as Whistler insisted, Ricketts and Shannon resigned and J. attended the second or third meeting. The Society got on extremely well without them and their return to the Council, after Whistler's death, resulted in the loss of the Society's international character. It was then even proposed to make it a Royal International Society. Though both are eminent artists, they were in complete opposition to Whistler's theories and practise. They went so far as to get rid of some of Whistler's etchings which they had collected and now, they probably regret it sincerely.

Tuesday, January 27th. J. to see Whistler to give a report of the committee meeting held in our place the night before. The last Nation has a paragraph about Whistler and Canfield-some one has sent us a paper, The $N$. Y. Sun, with a long account of Canfield and his flight from New York, a leader on the subject, and a burlesque interview with Whistler about the portrait. Canfield denied that Whistler is painting him, it seems, but J. found he had been there that afternoon sitting, was still there when Sauter arrived a little earlier. Whistler asked him what brought him to London. Canfield said, no other business but to sit for his portrait. Whistler talked of $\mathrm{MacColl}$ and his visit. The Glasgow University people propose to confer a degree on Whistler and MacColl came to ask if Whistler would accept it. He first sent I903] 
MacColl upstairs and kept him waiting there a bit, of course; then, when he came down, told him he had not time just then, but would MacColl lunch on Sunday? On Sunday again MacColl was sent upstairs and given Reynolds' to amuse himself with, "the paper, you know, you always want to see but are ashamed to pick up at your club," Whistler told him. And at lunch Whistler wouldn't talk about art but insisted on talking of West Point.

Friday, February 6th. Went to Whistler's, not having been_able to get there before for some weeks. Found him, I thought, looking very ill and coughing dreadfully. He said the Doctor told him he was quite another man, stronger in every respect, his pulse good-he was wonderful. Naturally, Whistler said, but he still coughs and he can't sleep at night. "Why not?" I asked. "Well, you know," he said, "I seem to have lost the habit." Pawling was there when I arrived. When he left, Whistler spoke of his portrait of Mrs. Heinemann. "She has not come to sit and have her portrait finished, which is crime enough for anything," he said. And then, Miss Philip coming in and tea, he said little more about anything at all.

Tuesday, February Ioth. J. went to see Whistler, who was in rather bad form, talked little, and coughed a great deal. Canfield had just gone, Sauter still there. A visit with nothing to report. Joseph Gilder now writes to J. to ask in a roundabout way about the Canfield affair. Has Whistler been working in London or Paris? he asks. J. diplomatically answers that, as far as he knows, Whistler has not worked in Paris for the last three or four years. Gilder writes back that what he wants to know is whether he has been working here since January? J. answers that he is afraid he cannot give him any information on the subject.

Saturday, February IIth. A letter from Whistler asking us to come and see the Rosa Corder. It has just been bought for America and is in his studio for a few days on the way. J. is in Manchester, and I go down in the afternoon. I find Canfield in the studio-he is charmed to meet me, has already had the pleasure 276 


\section{The Last Months}

of meeting my husband. It seems it is he who has bought the picture from Graham Robertson and he wants to get it to New York in time for the spring exhibition. Whistler has been all day cleaning and varnishing it, and seems exhausted. Complains of cold and draughts, and after tea rests his forehead on the table and falls sound asleep. Miss Philip goes upstairs to see to her mother who is ill, and I am left to Canfield who plays showman and host too. Seems to be running the whole place-thinks I had better not wake up Whistler to say good-bye; he will make all my excuses both to him and Miss Philip.

Saturday, February 2Ist. J. takes Ives-back in London to see about the St. Louis Exposition-to call on Whistler. One of the Ionides is there and Canfield. There is not much talk. Whistler consents to serve as Chairman of the Committee for the selection of work by American artists in England. A more or less formal visit.

Ives was Halsey C. Ives, the distinguished Director of the Art Section at the St. Louis Exposition. J. acted as the American Secretary in England with Sargent and McLure Hamilton. Professor Ives, at this Exposition, arranged, for the first time in an international show, a proper British representation for the younger men and the younger societies.

"One of the Ionides" was Whistler's old friend Lucas, or Luke Ionides whom he had known from his Paris student days, who helped us enormously with his reminiscences of Whistler's early years both in Paris and London, and who is now reported to be preparing a book of his own.

Thursday, February 26th. J. goes down to Whistler to tell him about the Committee meeting held here last night. They play dominoes until about half past eight, and then Whistler insists on keeping $J$. to dinner. He seems in much better form, but likes dominoes more than talk. He does not approve of Ives. The one amusing story he tells $\mathrm{J}$. is of the evening, not long before his illness, when he was sitting drinking his after-dinner coffee at the Carlton and an American came up and introduced himself by saying, "You I903] 


\section{The Whistler Journal}

know, Mr. Whistler, we were both born in Lowell, Massachusetts, and at very much the same time. There is only the difference of a year-you are sixty-seven and I am sixty-eight! I put up my eye-glass, looked at him, laughed-Ha! ha!-everybody turned round-And I told him-Very charming! And so you are sixtyeight and were born at Lowell! Most interesting, no doubt, and as you please. But I shall be born when and where I want, and I do not choose to be born at Lowell, and I refuse to be sixtyseven! Ha! ha!-for the benefit of everybody in the room and the complete embarrassment of the man who was born at Lowell, Massachusetts."

The great piece of news was the birth of three small kittens, mother and family are established in the studio.

Too much has been said of Whistler's adoption of a birthplace to suit himself for us to go over it again. But we were amused when, looking through the Whistler vs. Ruskin legal documents, to discover that, preparing for the trial, Maryland was his vague choice, though a catalogue of a show of prints at the Guildhall, quoted by the lawyers, stated that he was born in Russia.

Sunday, March Ist. Whistler telegraphed us to come to see the Rosa Corder for the last time, as she starts for America on Monday, and to bring MacColl. J. don't feel especially like coming and of course there is no getting MacColl at a moment's notice, and so I go alone on a fearfully stormy afternoon. Canfield there, looking over lithographs and showing off the Rosa Corder and a little pastel of mother and child which he has also bought. No one else but Miss Philip. Whistler better and more like himself. He is not in the least sleepy-he slept eight and a half hours the night before, Miss Philip says. The kittens are shown off. But the great affair is the letter he is writing to acknowledge the honour the University of Glasgow has conferred upon him by giving him a degree. He hands to me the letter of the Principal of the University, making the formal announcement, to read, then his answer, and then the address. Is it necessary, with D.D. and other letters and honours after his name, to give him the Rev. 278 


\section{The Last Months}

before it, the Principal being a clergyman? I hesitate to give advice, as these things may be different in Scotland; anywhere else I should have thought the Rev. necessary. There is a great debate. Finally the letter is put in an envelope with a note to the Waltons next door to ask them, as Scotch themselves, what they think. Presently their answer comes back, that another still more Scotch Scotchman who happens to be there agrees with them in thinking that he is right in suggesting the use of Rev. before the name. A diplomatic answer, and the great affair is settled. We talk of little else, and there was no mistaking Whistler's honest pleasure in the degree.

Canfield left a little before I did, with a note of introduction to a lady whose name I did not hear, who owns a picture by Whistler the title of which I did not hear, but which Whistler wants Canfield to buy. What might the lady think if she knew who Canfield is? Whistler says he has worked a little on the Rosa Corder, but very little. Has washed it, however, which makes all the difference in the colour, for it was very dirty.

Canfield could not get the $V$ alparaiso he wanted. When he bought the Rosa Corder, he told J. he went to see the young man-Graham Robertson-and offered him a thousand pounds for it, which the young man refused; he then offered two thousand, and the young man jumped at it. "Damned fool!" Canfield added, "I would have offered five thousand and jumped at the chance of getting it for that."

Canfield was certainly good to Whistler during this winter. Not only did he sit for his portrait, but he purchased a number of small works and many lithographs and drawings. These were exhibited in Buffalo later by Miss Sage, and before Canfield's death they were dispersed. Not only this. Canfield's knowledge of the concoction of cocktails was as profound as Whistler's and J.'s appreciation of them. He was a curious combination of sport and culture, and, after two or three cocktails, or something stronger, was not a pleasant personality. But Whistler endured him because it was worth while and always spoke of him as "a perfect gentleman." J.'s position was difficult as all this while we were pestered by American correspondents wanting to know if Whistler was painting "gambler Canfield"-wanting also to know his whereI903] 
The Whistler Journal

abouts which were being asked for by District Attorney Jerome in New York. Finally, one day, a young newspaper man arrived in Buckingham Street and asked J. if it really was so, if Canfield was in London and was being painted by Whistler. J. advised him to go to Whistler and find out. "And do you think he would kick me downstairs?" asked the correspondent. "Well, if he did," said J., "don't you think that would add to the interest of your story?"

After the publication of our book, Canfield's interest in us suddenly ceased, as did Freer's for that matter. It is not safe to tell the truth about some American collectors. The last time J. saw Canfield was at a show in New, York where there was furniture said to be decorated by Whistler. Canfield was loudly explaining the evident fact that the paintings on the furniture were not by Whistler when he saw J. He left the room so rapidly that he forgot his hat and stick and they had to be sent for. This was our last encounter with him, though later he tried to prevent $\mathrm{J}$. from even consulting his published catalogue, while, writing to a man who is our friend and who showed us the letter, he declared us "monumental ingrates," which has amused and puzzled us ever since, as with the exception of seeing him at Whistler's, and endeavoring to get a contribution from him for the Whistler memorial, we never had anything to do with him.

Sunday, March 8th. Dining with the Fisher Unwins. Mrs. Unwin says that Whistler told her when Canfield first wanted to buy the Rosa Corder and offered fifteen hundred pounds, Graham Robertson would not hear of it. Canfield came to Whistler in despair. Whistler told him to make out a cheque for two thousand, take it with him and go back and show it to Graham Robertson, and he would see, and Canfield did. He handed the cheque to Graham Robertson who at once consented to let him have the picture. And this is the way it came into Canfield's possession.

Mrs. Unwin's story about the Rosa Corder is virtually the same as Canfield's.

Friday, March I 3 th. Down to Whistler's. He was not very well, said he was coughing and I must do the talking. Mrs. Clara Bell 280

$[1903$ 
has sent him proofs of her book and he is awfully upset over it. "It won't do at all-it is absurd and I can't have it go as it is. I suppose I must go over the proofs and correct them." "But why," I asked, "do this for her-supply her with the facts and statements that will give her book the importance she could not give it herself -you will be helping her, which is the one thing, as I understand, you do not want to do. Besides, the Bells will announce that the text has been revised by you, and, in a way, you will find yourself responsible." He was awfully worried, I could see, by the whole thing. "Well, perhaps, I will have her down to lunch and talk it over with her-I really do not know what to do,"- -then he got me to read the proof to him. He was indignant, and no wonder, because in speaking of the Little Lady Sophie, she said that as a painter of the portraits of children, it placed him with Sargent and Shannon! And also because she referred to his later work as if it were not so fine, which is against his theory that the work of the true artist is always equally good-"There is no better, no best." - she is a re-echo of the Wedmores and Humphry Wards and the others who are continually pointing out the comparative weakness and slightness of his later work. I looked over the first few chapters, then I had to go-but he said there were mistakes and endless confusion through the others, and I left him in the depths of depression.

Wednesday, March 25th. To Whistler's, but he slept the entire time I was there, and my talk was solely with Miss Philip. Nothing to report.

Wednesday, April Ist. J. went down to see Whistler. Papers from home have come in which Canfield denies that Whistler is painting him, and $J$. found Canfield there and his portrait on the easel. After Canfield had gone, J. referred to his talk with Hartley and the suggestion of an International Show at Earl's Court. Whistler would not hear of it at first. "It would be a dishonour to art - to be shown with water chutes and switchbacks as part of the entertainment!" But J. explained how fine it would be, a fine building, everything on a big scale, with Hartley to finance and 1903] 


\section{The Whistler Journal}

run it on big lines, and, at the end, Whistler not only approved but became almost enthusiastic.

Hartley is Harold Hartley, then managing the Earl's Court Exhibitions. His interest in art is keen. In every exhibition, he included an art section, and, in the course of his management, brought much work from the Continent that might otherwise never have been seen in London. His idea was to give the large galleries he reserved for art to the International, to decorate them as the Council might direct, and in every way to give this exhibition the dignity and distinction Whistler insisted upon. He knew it would be a good thing for Earl's Court and, incidentally, for the International.

Saturday, April IIth. To Whistler's-I was shown into the room upstairs and asked to wait-the Master wanted very much to see me. I suppose I waited three quarters of an hour. Then I was sent for to the studio. With his hair parted in the middle and plastered down on either side of his face, Whistler looked more forlorn than ever. He was apologetic-his French barber had been with him and, of course, he had to finish. The performance exhausted him, and I wanted to go at once, but he insisted on hearing all about A.'s wedding. So I gave him the main particulars, and hurried away, he looked too tired.

A great deal has been said about Whistler's personal appearance, especially about his hair. Over and over, J. was with him when he dressed and therefore knows, and we might as well state it once and for all, that his hair was not grey though it had grey in it. And it was not dyed. J. has seen the whole performance when it was arranged. Whistler would dip his head in the wash basin and bring it out with his hair hanging down in long locks like Louis Stevenson's, or an Indian's. In Paris, when he lived at the Hotel Chatham, a maid, or a masseuse, dried it for him. When he dried it himself, he rubbed it with a towel and ran his fingers through it, and it at once became curly again. And the white lock, last of all, was coaxed and curled into shape. He was as careful of his hair as of his work-of everything.

Friday, April I 7 th. J. to Whistler's, to submit to him the menu for the International Dinner-Whistler, after objecting to the 282 


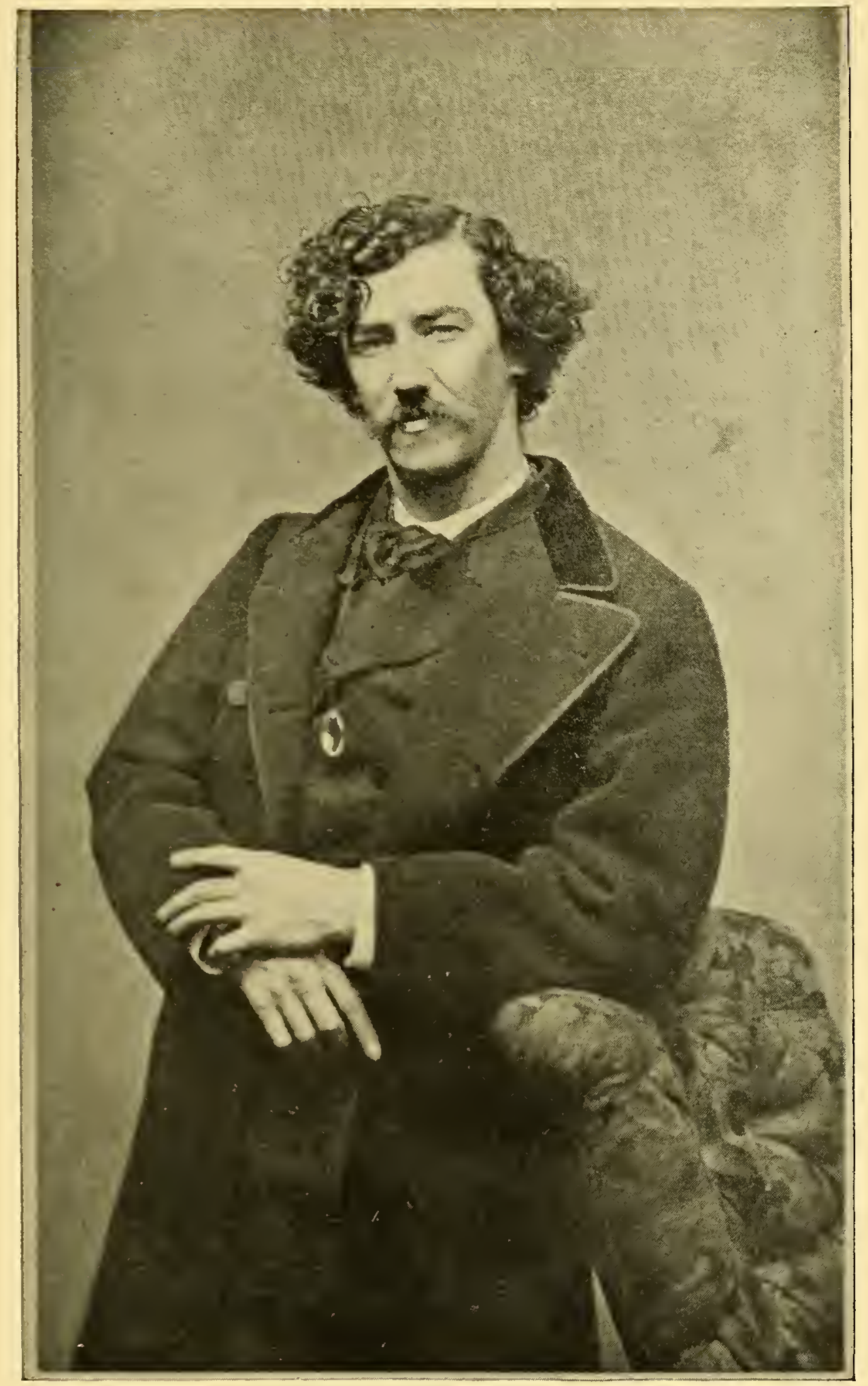

WHISTLER, ABOUT 1878

From a photograph bound in S. P. Avery's Copy of Sheridan Ford's Gentle Art of Making Enemies

Pennell Collection, Library of Congress, Washington 


\section{The Last Months}

dinner, and upsetting Council and Society, is now altogether interested. He approved of the menu-added but one suggestion which was typical: that the salad should be a Romaine, with next to no vinegar in the dressing!

This is one of the many details that show how near to him were the affairs of the International and how carefully he worked for it. It shows moreover his respect for the art of dining. If he gave a dinner he studied the menu as carefully as he studied his palette when he painted a picture. By an odd chance a proof of this turned up in the Ruskin case documents-a rough bit of paper with a note on it in his handwriting suggesting the menu for the dinner he gave his Counsel and Solicitor in the White House at the end of the trial. Here it is, a curious intimate little record: "Potage Paysanne; Turbot; Compote de Pigeons; Gigot de Mouton-haricot; Alouettes en canapé; Mince Pie; Compote de Pommes; café." The International dinner was held this year in the Café Royal, and the Austrian and Belgian Ambassadors and several other distinguished guests were invited, for the International then was the International Society it called itself. If J. remembers, Rodin attended on this occasion and speeches were made by Maurice Hewlett and men as prominent. Whistler's idea was that these annual dinners should become as important as the dinners of the Royal Academy, and they would, and the Society would have eclipsed that institution, had he lived. It happened curiously that he was never able to attend any one of the annual dinners, but his interest in them, as in all the work, great or small, of the Society, continued to the last. This year he was annoyed because nothing was made in the papers of his absence. Lavery, the Vice-President, as always when he was absent, took his place. Whistler, however, did attend many of the informal Council dinners held at the Café Royal. To one of these Sir James Guthrie came up from Edinburgh especially to express, on behalf of the Council, his belief and that of the Council in Whistler, their allegiance to him, their willingness to support him, and their faith in his art and his theories. It was one of the finest tributes, for Sir James Guthrie is an orator as well as an artist, ever paid by a body of artists to an artist whom they recognized as their master and loved as their friend.

Monday, May 4th. To Whistler's. He met me with a reproof. "Well, you know, was that your note about the International Dinner in this morning's Chronicle?" "Yes." "How could you I903] 
make no reference to the President's absence, the one fact of importance?" "No excuse," was my answer, because I did not want to tell him that Fisher complains of my forever dragging the name of Whistler into my Chronicle articles. He was tired-I always strike his bad days. He could not keep his eyes open and finally put his head down on the table, his forehead resting on it, and went to sleep. Mrs. Whibley was there and we talked on. Every now and then he waked up to say, "What was that?" just when we would rather he had not been listening. And once.it was to say, so pathetically, to Mrs. Whibley, "You are not going to leave me, Bunny. Must you really go away today?" Nothing has made me feel so much the loneliness and dulness, for him, of the life he is now forced to lead. I stayed only a short time after this, and I left him sleeping.

Fisher is W. J. Fisher, then editor of The Daily Chronicle. This question of dragging in Whistler, this objection to his very name, among so-called art critics and other outsiders was and is always recurring. Mr. Fisher was more liberal than many editors, but could not ignore his subscribers. So seldom does an artist, or any other man, happen in whom his friends and his followers absolutely believe that the average person, who never had a friend, neither understands nor knows anything about true faith, true friendship. There have been examples of this sort of faith in the world. Whistler inspired devotion and, in return, gave his friendship to those he knew, those he trusted. And because they supported and believed in him, outsiders speak of his friends as idolaters who never criticised him. These friends did criticise Whistler's work to his face and he accepted their criticism, sometimes with damaging results. But their criticism and their statements that they did not approve of all his work are ignored by a gang who cannot understand and who could not tell the truth if they did. At the time of the Whistler Memorial Exhibition in London, E. had a curious example of this determined misunderstanding on the part of the critics. Just before it opened,

February Ioth, 1905, at a press view of Le Sidaner's work in the Goupil Gallery, I ran across Humphry Ward. He wrote the Art Criticisms of the London Times and thereupon was accepted by 284

[1903 


\section{The Last Months}

the public as an authority. To him I expressed a hope that he was interested in the coming Whistler show. "Well," he said, "you have worked the press!" As if I took it personally, I said I hadn't, but the press seemed to have the sense to realize that it was something to be interested in. "I never saw anything like it," was his answer. "You all seem to look upon Whistler as God Almighty, the Three Persons of the Trinity rolled into one." "No," I told him, "we are far more interested in him than if he were God Almighty, for we look upon him simply as the most distinguished artist of recent years." The end of it was, he supposed he might give the show a little of his condescending attention. But his manner suggested disappointment that Whistler ventured to become so famous though he had never predicted it. . . . He was at the private view, on February 22nd, the one critic who stuck to his colours and remained indifferent. He bore down upon me to ask why I appeared in such sombre colours on so triumphant an occasion- "Why I expected to find you in white and garlanded!"

Another amusing meeting was with George Moore the day the Exhibition closed:

April Ist, I905. George Moore was at the show, had come over from Paris expressly for it. Scribners had asked him to write an article. But he felt he had 'written enough, though there were some things in the chapter in his book he would like to change. Now he felt more as if he might write. He had thought before coming that another look at The Piano Picture would be unendurable and that he would not be able to stand seeing those legs in the Miss Alexander again. But now he had come, the old spell was over him once more, and things seemed more wonderful than ever.

Thursday, May I4th, I903. J. to Whistler's and with his usual luck struck one of his good days. He was gay, had been workinghe showed J. the portrait of Canfield: What did he think of it? $\mathrm{J}$. thought it very fine, one of his finest portraits, but suggested that the hand was prominent, took away from the interest of the I903] 


\section{The Whistler Journal}

head in such a small half-length, or rather head and shoulders. "Oh well now! it is just like you!" But in the end, Whistler thought there might be something in it, and he would think about it. And then they played dominoes, and he kept J. to dinner, and a gooseberry tart made him apologize in the old way for "the Island," and, altogether, J. found him like himself again.

J. often hesitated to criticise details, and so did most of Whistler's friends, because Whistler never asked for criticism save from those he really wished to criticise his work, and then he had a way of taking criticism, acting on it, and getting into messes in consequence. The portrait of Canfield was at that time wonderfully fine, but when we saw it later, we think in Paris, it was ruined. It was not sold with the rest of Canfield's collection, we believe, but was bequeathed to his son. We saw it again recently at Knoedler's. E. A. Walton is one artist who felt as we did about Whistler and criticism. Talking with us over the months when he lived next door to Whistler in Chelsea, he said,

February Igth, Igo6, he was sure Miss Philip made a mistake in always praising Whistler's work and always wanting everybody else to praise it. She was indignant with him once when he happened not quite to like something Whistler had just painted. But he knew Whistler preferred to hear the truth, would rather have you say what you thought than get off the usual commonplaces. Some years ago, in Whistler's studio with Lavery, Whistler showed them a portrait he was doing and asked their opinion. Walton started to criticise, but Lavery interrupted, "Oh! Mr. Whistler, we would not venture to criticise your work!" Whistler, however, paid no attention to Lavery but made Walton say what he had begun to say, and then argued it out with him, just as any other artist would have done. We know for ourselves how little Whistler liked the "O Great Master!" attitude-the "O splendid! O wonderful!"

Another day in May, of which there is no note-E. was in ParisJ. went to Chelsea and Whistler was just like himself. He put his arm in J.'s, walked him across the studio, and then turned him round. And there on the easel was the marvellous rendering of Miss Seton with the apple. " $\mathrm{Hm}, \mathrm{hm}$, when do you think I did 286 
that?" J. said he did not know. "O, you never know. When did I do it, Major?" he asked Miss Philip. "This afternoon," she said. "And how long did I take? About two hours?" "No, it was an hour and three quarters." It was as fine as the Little Rose or any of the other small studies-a masterpiece, and J. told him so. "Hm, hm, guess we'll have a cocktail." He made them. And they played dominoes. And some of the dominoes had curious tell-tale marks on their backs, or bumps on their faces, and somehow he always got them, and somehow he always won, which delighted him and everybody else. J. does not remember if he stayed on to dinner, but he remembers too well that the next time he saw the picture, it was ruined. Whistler's everlasting desire to get something better when what he had got was perfect, was his curse and his salvation. In all these later pictures he seemed conscious of something he thought he could improve. Those to whom he showed them knew they were wonderful. But he saw something beyond, something more to add, and these last days his hand did not respond when he tried to repaint what he had done. For the work on one small spot meant, as always, working over the whole canvas to keep the skin of it right. The tragedy was, and he felt it, that he could no longer do this, and when he endeavoured to, he failed. And it saddened him. He said one day, "There is so much to do and so little tim.e to do it."

Thursday, May 28th, I903. I went to see Whistler, but had hardly got there and begun to talk and to look at a portrait of Miss Philip which he started some months ago, and is now making into the most beautiful portrait of her I have seen-a blue gown with dull yellow beads about her neck-when his barber was announced. He had been fearfully nervous about the arrival of the barberperhaps there was not time for us to have tea served in the studioperhaps there was-so I said good-bye with no talk of any kind worth remembering.

There is a big gap here, J. and E. were away. Also, at times, no notes were made or we have not used them-others have been used in the Life and we do not repeat them. And for us Cheyne Walk, Chelsea, except in a cab, was not an easy place to get to, the nearest underground was Sloane Street, the nearest bus an hour's ride, King's Road, and from both a long walk. And finally it was usually a sad, sad place to go to in the end, growing sadder every day.

1903] 
The Whistler Journal

Thursday, June 4th. J. went to see Whistler but brought me nothing special to note.

Wednesday, June Ioth. To Whistler's-he was fairly awake, listened to everything I said, but with nothing to say himself except to worry about his cough, the shut windows, the open windows, the coming of the Doctor for whom he had sent. He has never yet seemed so nervous about himself-though I thought him less tired than usual-and so there was nothing to do but make a short visit and leave him.

Thursday, June IIth. J. to Whistler's on International business. Whistler objected to Lavery's accepting the invitation from the Royal Academy to serve on the Committee for the British Art Section at St. Lou is and J. wanted to try and persuade him to change his decision. But it was one of his bad days-he didn't seem to take the least interest-and for the first time J. admitted that he was pretty bad.

Tuesday, June 23rd. J. lunched with Lavery to meet Macaulay Stevenson, who gave him three good Whistler stories that I don't think I have heard before. Some one told him of a portrait of Lord Roberts painted by Mortimer Menpes in half an hour: "Very slow exposure," said Whistler. When Stott died a friend came in to tell him the news. "Stott died at sea," was the announcement. "Where he always was," was Whistler's comment. When the authorities at Glasgow decided to buy his Carlyle, a deputation of two or three came to him with the cheque for a thousand pounds in their pocket. But they offered him eight hundred. Whistler refused. "Now think it over, Mr. Whistler, and we will be coming back again." And so they did, the next day. "And now, what have you been thinking, Mr. Whistler?" "Of nothing, gentlemen, except the pleasure of seeing you again!" And they gave him the cheque for one thousand.

The thousand, though Whistler treated it so lightly, came at a most opportune moment. He had not been married long, he was 288 
more than usually hard up, he was deep in debt again. But first he invested a large part of it in old silver for he was beginning to replace the beautiful things sold at the bankruptcy. Somehow, his creditors got wind of it, pounced upon him, and in a fortnight not a penny of the thousand pounds was left.

\section{CHAPTER XVII : THE LAST DAYS. THE YEAR NINE- TEEN HUNDRED AND THREE CONTINUED}

Wednesday, July Ist, I9o3. To Whistler's. The maid said he would see me, but Miss Philip sent word I had better not stay long as he was tired. He was in bed, distinctly worse, with a curious vague look in his eyes, all the life gone out of them. He said nothing and seemed almost in a stupor, though he must have been listening, for every now and then he interrupted to ask, "What's that?" The only two things he said were characteristic. Miss Philip told me he had not been able to eat for the last few days, and the Doctor ordered turtle soup, and they had got it at the correct place in the City-Birch's- "Shocking, shocking," said Whistler, apparently with reference to nothing in particular. But, after a minute or two, when I had almost forgotten, he added, "We all live in the City now." Then when I left, naturally in about ten.minutes, and told him I must go, he said, "No wonder you want to go from a house where they don't give you anything to eat!" I had refused when Miss Philip wanted to get tea for me. When she came to the door with me, she did not seem more alarmed than usual, though it looked to me as if he could not have more than two or three weeks at the most to live. She only said she wished they would not bother him about the International. Lavery, the last time he came, would talk business though she warned him, and Whistler was exhausted by the excitement.

All the details of these last tragic days were, in our opinion, of importance and to be recorded, and we used them in the Life. As an absurd misconstruction was put upon our use of Whistler's reference to his house as "one where they don't give you anything to eat," let us say, and be done with it, that this was pathetically characteristic of Whistler. His was the most hospitable of houses, I903] 
The Whistler Journal

and he and Miss Philip never failed in their hospitality. But at such a moment $\mathrm{E}$. would never have allowed them to trouble to get tea for her, and it touched her deeply that Whistler, ill as he was, barely conscious, could still remember what he considered his duties as host and feel that something was wanting in the welcome he gave her. It is still a keen regret to J. that work took him from London at the end of June and that he did not return until the day before Whistler's death. E. also was away off and on in June.

Monday, July 6th. To Whistler's. The Doctor was with him, and I waited almost an hour upstairs with Mrs. Whibley. Then he sent for me to the studio. He was up and dressed, had been out driving. But he looked worse than last week, his eyes vaguer and more dead, giving one the impression of a man in a stupor and he said not a word, while I did my best to interest him, describing Loubet's arrival at Victoria. Finally, Miss Philip asked him if he were tired. I had been there not more than ten minutes. He said yes, and so I told him I must go. And yet, when he said good-bye, the one thing he added was characteristic: "You are looking very nice!"

Loubet was then President of the French Republic and his arrival in London was one of the early incidents of that Entente Cordiale which the English cultivated so assiduously. From a friend's window in Victoria Street, E. had watched the ceremonial with which "the Islanders" received him, and then hurried on to Whistler's, sure that this was one of the little things that he would love to hear and ready for his never-failing ridicule of "the, Islanders" in any rôle. But he was far beyond jesting or even the glimmer of interest.

Thursday, July gth. Duret and Kennedy dined with me. Duret had been that morning to see Whistler, and, like me, he thought Whistler seemed in a stupor-he could hardly speak and found his words with difficulty; no one without a clue could have understood what he was talking about. Du ret was overcome; some of the best hours of his life, he said, were spent with Whistler. . . .

Sunday, July I2th. Kennedy came in to read me a letter from Dunthorne who was at Whistler's yesterday and reports him 290

[1903 


\section{The Last Days}

distinctly worse, hardly able to talk, unable to look at prints, his hands swollen, which in heart disease, Kennedy says, is a bad sign-a sign of the end. Miss Philip, after a little, told Dunthorne it was better to go and to come back on Monday. Dunthorne wanted him to identify certain prints, but it was useless.

Tuesday, July I4th. To Whistler's: the Doctor was with him, but he asked me to wait and I went upstairs with Mrs. Whibley, who seemed hopeful. In about ten minutes he sent for me. He was dressed, in the studio, and pictures were on the easels. He seemed distinctly better, though his face was as sunken and his eyes as vague. But he talked. When I told him lie looked better and asked him how he felt, he answered with all his old gallantry, "I only wish I felt as well as you look." He asked for news, what of Henley, had I heard anything? I spoke of the Sauters who came in to see us a few evenings before. They were in our neighborhood for a lecture which they found impossible and came to us instead, I said their energy was wonderful, they were ready to do anything, to go everywhere they were asked. "Not so much energy, perhaps," Whistler said, "as not knowing how to put in their time." The little mother cat, lately banished from the studio, was running round again, and she jumped in my lap, rubbing her face up and down against mine. "She remembers you," Whistler said. Altogether, he was like another man, or rather like himself again, especially when Miss Philip brought him a cup of chicken broth. He was in a fury at the sight of it. "I suppose I must take the damned thing-excuse the word," turning to me, "but it must be said." And he scolded in a voice as strong as ever. How did they expect him to have an appetite for his dinner? they never gave him a chance, they were always making him take something, he had no peace, every hour it was something until of course he did not want his dinner. Miss Philip looked as if her nerves were giving. She poured him out a cup of tea instead, and went in the next room for a minute. Every now and then his eyes closed, but he was interested in everything, and when Lavery was announced told the maid to show him in, and asked me why I903] 
The Whistler Journal

I was going so soon when I got up to say good-bye. But I was afraid that to have Lavery and myself both there would be too much for him. Mrs. Whibley and Miss Philip came to the door with me and they seemed encouraged. The Doctor said the heart was all right.

Henley, about whom he asked, had died but a few days before, and Whistler was anxious to know what we knew of his death, and of the funeral to which Whistler had sent a great spray of purple iris. We are afraid Whistler did not make an easy patient. His illness would not have seemed so tragic had he resented it less bitterly.

Wednesday, July I5th. Duret came in after dinner. He had been down to see Whistler again and again was shocked at Whistler's condition. He was there an hour, and he could see that Whistler wanted to talk and was struggling to find the words. Whistler showed him some of his etchings at Spithead, and was glad to have Duret recall the old days. But it was clear there were other things he wanted to say and could not, and Duret left him feeling it was the last time he would see him. Duret talked to us of those old days. . . .

Saturday, July 18 th. When I came down to breakfast, I opened a letter from Fisher: "Why did you not let me know of the death of Whistler?" He died suddenly yesterday afternoon. Fisher asked us to write an appreciation. We had hardly settled down to work when Lavery arrived. He had been to the house, had seen Miss Philip. He had suggested that all the Society should go to the funeral. She thought perhaps it would be better if only the Council went. It was not yet decided when the funeral would be. Mr. Freer was seeing to everything for them. Lavery wants a meeting called for Monday to see about sending flowers and other details. His idea is that the Society should give up next winter's Exhibition to Whistler, but this is something not even to be spoken of until later on. Then a telegram from The Star asking for an article. After lunch, Sauter came, as I was starting for Chelsea.

292

$[1903$ 


\section{The Last Days}

As I was shown in the house, Freer was coming out of the studio, wearing a rather professional air of grief. He could tell me nothing. He got to the house the afternoon before at half past three, and everything was over. Mrs. Whibley joined us-Miss Philip asked to be excused-and we sat in the hall. On Thursday, she said, he seemed so well. He went out driving with Mr. Freer. Then, after he came back he sat talking to her for a long while, and he and Miss Philip and she played dominoes together. The three dined in the studio, and she told him he was so much better, before long he would be dressing again for dinner. Anyway, she said, never at any time had he been as bad as last summer at The Hague. Friday morning Mrs. Lawson, who had sat up with him, said that he passed a fairly good night and Mrs. Whibley, who was tired, did not go down. But after lunch they called her. She saw at once the attack was serious, the Doctor was sent for, she and Miss Philip were with him, and as I understood, it was over before the Doctor got to the house. With him, it seemed to her, as with all people with whom she has been at the last, that, dying, he saw something the living could not see. The time for the funeral is not yet arranged, but the service will be held at old Chelsea Church, the church to which he used to take his mother. As I left, a brisk youth "representing the American press" made his appearance asking for information.

A cablegram from The Century saying, "Reserve Whistler reminiscences." Kennedy and little Brown came in the afternoon to find out, if possible, about the funeral, and Kennedy stayed to dinner, broken up because when, on Thursday, after more than a year, he called on Whistler, Whistler was out and Miss Philip would not see him, though she saw Dunthorne who was with him. Duret dropped in later on, tragic in his sorrow. Whistler was his last friend-all the others had gone. Now, in Paris, he is alone. If he goes out on the Boulevards, he goes by himself. He is left without friends. . . .

J. heard of Freer from another source. Back in London on the afternoon of the I7th, he went to the Art Workers' Guild in I903] 


\section{The Whistler Journal}

the evening and there met T.R.Way. The meeting is recorded in The Journal a few days later:-

Thursday, July 23rd. Uneventful, but must remember to put down what I did not at the time. When J. went to the A. W. G. on Friday, he found T. R. Way in frock coat and top hat, so unusual a sight that $\mathrm{J}$. asked him what it meant. Way said he had been lunching with Freer who wanted to see him about the lithographs-Freer had left him to go and take Whistler a drive. And so, while Whistler was dying, Freer was giving a lunch to the "enemy."

All along, J. had told Whistler he refused to fight with Way because Way was useful to both of them, just as he refused to take up Whistler's business affairs with Way, at the time of the quarrel which involved the bill for lithographs, and he advised Whistler to get Webb to see to it. The bill for merely some two hundred pounds covered an enormous amount of work. Way turned over to Webb all the stones with drawings on them, Whistler paid the bill and got the best of the bargain, but he refused to see, or have anything to do with the Ways, father and son, from then until the day of his death.

Sunday, July roth. Lavery in the evening. He wanted to know if we had heard the date of the funeral. But, like evenyone else, we know nothing. He told us Guthrie was coming up from Scotland, he was always devoted to Whistler, though, at first, Whistler distrusted him, was not sure of him. But, gradually, Whistler began to understand how genuine Guthrie was in his devotion. Guthrie got him the LL.D. in the Glasgow University, which is interesting to hear as MacColl gave us to understand that it was his doing. ...

Monday, July 20th. Began the day with a telegram from Kennedy asking when the funeral was to be-still we did not know. Heinemann sent for J., said, of course, the arrangement for the book held good. But nothing could be done until the family was consulted or it was known who were the executors, and there for the moment the matter rests. At lunch, Wilson came in, he also 


\section{The Last Days}

wanting to know when the funeral was to be. He told us of a wonderful Chinese cabinet from Whistler's studio bought by his brother-in-law at the sale. Somehow or other the top got misplaced, and long afterwards Whistler, chancing on it in some old shop, bought it no doubt for a good price, and brought it in a cab straight to Wilson's brother-in-law, that the cabinet might be complete as a thing so beautiful should be. Then Hartrick turned up. Spoke of the evening he met Whistler here and the wonderful form Whistler was in, telling stories about Rossetti, imitating Rossetti's voice. . . .

Miss Gilder called in the afternoon to ask if she could make with J. the arrangement she has made with Gosse and Archer: to use any signed article he may have in The Daily Chronicle for The Critic-she does not pay much, but as there is no copyright any one who chooses could steal the work and pay nothing. She wanted The Daily Chronicle article about Whistler for the September Critic. Then Brown, with Pollitt, called to ask about the funeral. No one knows and everybody is anxious. I learn from Brown that other people besides ourselves think the notice in Saturday's Times shocking. Abbey is indignant. Heinemann answered it but thought it best to tear up his letter. Holme of The Studio asks J. to help him find Whistlers for an "important publication" he is bringing out! which is funny, but business-like.

A Council meeting of the International, the funeral is to be on Wednesday, the service in old Chelsea Church at eleven, and interment at Chiswick. They arranged to send a wreath, write to the family, send round notices.

The cabinet is the one referred to in The Paddon Papers. We have told the story in the Life. Pollitt is Mr. A. J. Pollitt of whom Whistler painted, in the Fitzroy Street studio, a portrait which was destroyed. After E.'s call in Chelsea, we were not only not asked to the house but kept in ignorance of the arrangements for the funeral and every thing else, as were all his friends-Heinemann, Lavery, Sauter, Duret.

Tuesday, July 2Ist. Notices of the funeral at last in the papers. Dell, having written to $\mathrm{J}$. that he would like an article I903] 


\section{The Whistler Journal}

about Whistler for the September number of The Burlington, lunched with us to talk it over. He wants an appreciation of Whistler's art, so it ought not to interfere with The Century, and $\mathrm{J}$. promises to let him know, suggesting for August an article about the man by W. M. Rossetti, one of the few old friends left. In the afternoon a visit from Fisher Unwin asking about the funeralit is incessant-and after dinner Duret and Strang and David Strang. Poor Duret again told me that he had no friends left. He brought me a copy of the Matin, with the best French notice I have seen, and told me the quotations from Whistler's Propositions for the Académie were from his translation made at Whistler's request. He kept repeating his loss: first Manet, then Zola, now Whistler-all great men. Spoke of the book he was writing, said it would be entirely of Whistler's art, and he would try and reproduce in it the things that are not so well known. . . . Letter of condolence from Gosse. McLure Hamilton and Wynford Dewhurst write to ask us to send them the best notices. One would think we ran a sort of Whistler agency.

Wednesday, July 22nd. The funeral-J. went early with the International. I took Augustine. Later than I meant to be. It was five minutes to eleven when I reached the church and I expected to find it crowded, but it was perhaps not half full. Mrs. Dr. Whistler, with Mrs. Thynne and Miss Thynne in deep mourning in a pew a little in front of me. Saw various people-little Brown; D. C. Thomson; a pew of Academicians, Alma-Tadema and East among them; Mrs. Abbey; Charles Whibley, his brother-inlaw, in a pew in the side aisle; Heinemann with Dr. Chalmers Mitchell coming in later. Joseph saw Mrs. Heinemann and Mortimer Menpes - but the names are all in the papers. At last the funeral procession. The coffin was carried the short distance from the house to the church. The men staggered under it as they walked up the aisle, the purple velvet pall any which way, owing no doubt to difficulty of passing the font at the entrance; then the pall-bearers; then the Philip family - the five sisters, the brother, young Godwin, young Lawson; then Webb, the Doctor, and Studd, 296

[1903 


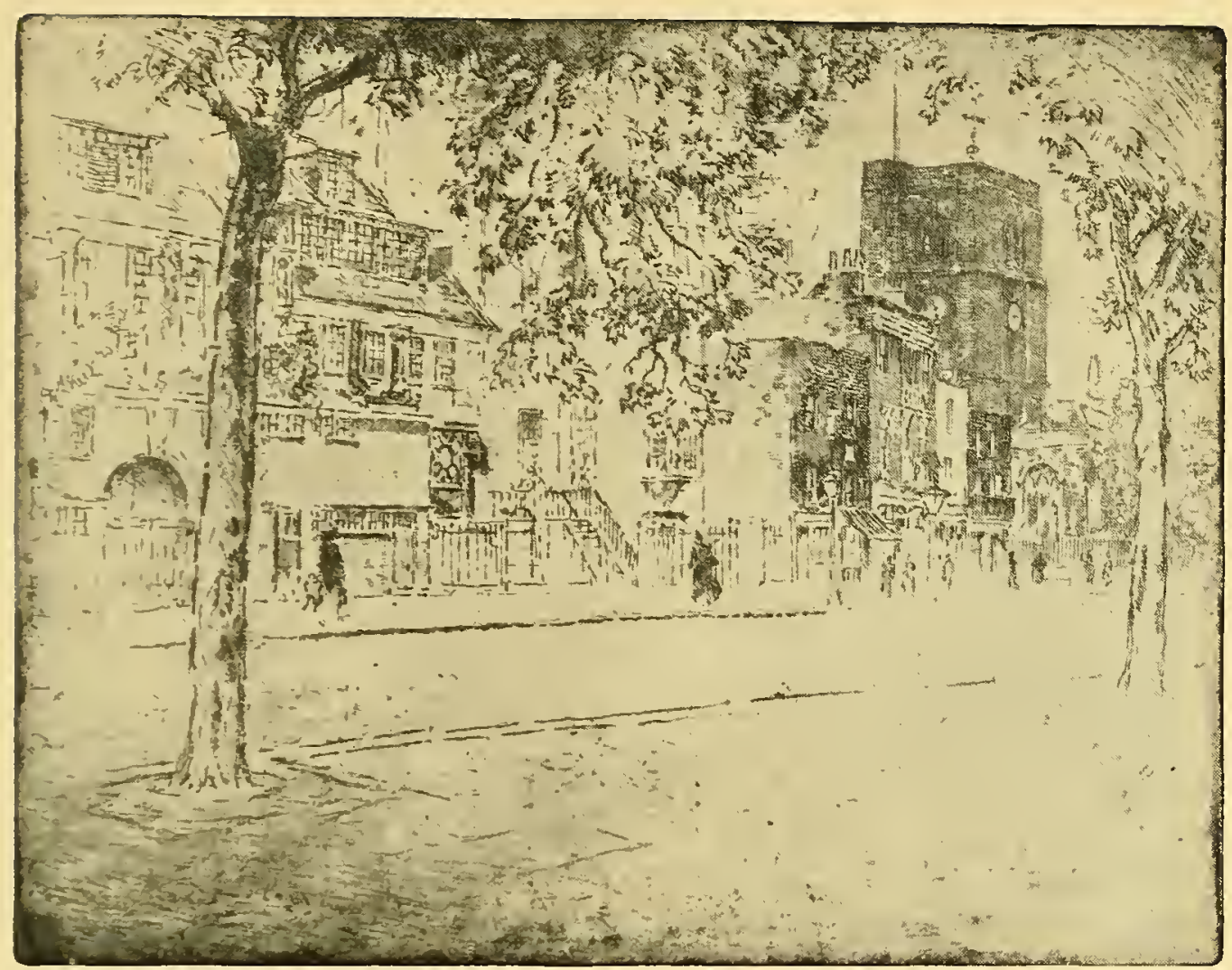

HOUSE WHERE WHISTLER DIED AND CHELSEA CHURCH FROM WHICH HE WAS BURIED ETCHING

By J. Pennell 
. 
and immediately after, as if part of the procession, Brandon Thomas and his wife, who came in the pew with me. The clergyman has a dull, emotionless voice, and as he reads lessons and prayers, the beautiful burial service is not in the least impressive, neither so simple as to be solemn in its simplicity, nor so fine in its formality as to be dignified with the dignity Whistler loved. The procession re-forms, the Council of the International fall in behind and the people follow in carriages and hansoms provided by themselves, but not many. At Chiswick, J. says a crowd evidently is expected for numbers of policemen form round the funeral party as if to protect it, but there are few people. Miss Philip walks to the grave and looks in with calm, expressionless face. The International Council are given a place close to the grave. A man in blue monocle, red coat, blue shirt, orange flower in buttonhole, fur cap, long fur edged gloves, comes leaping over the graves like some strange uncanny monster. The clergyman takes off his biretta, mumbles the prayers as if in haste to get through with them. Miss Kinsella crouches on the grass, crying audibly. And all is over. But the graveyard is calm and beautiful, the grave under a wall covered with clematis.

In the confusion of coming away, J. finds himself in a carriage with Studd, who explains how he happened to be with the family. They had asked him to be a pall-bearer, but, at the last moment, as a favour begged him to make way for Duret. It is to be noted that among the pall-bearers-George Vanderbilt, Freer, Abbey, Guthrie, Lavery, and Duret-there are three Americans, one Scotchman, one Irishman, one Frenchman, and no Englishman. It is also to be noted that not an art critic is present in the church. A wreath of gold bay leaves, one of the only two wreathes on the coffin, was sent by the International. When $\mathrm{J}$. reached the church, no arrangement had been made to reserve seats for anybody, and only by his instructions to the verger were pews reserved for the International Council and friends. He lunched at the Hyde Park Hotel with the others of the Council, to talk over a Whistler Memorial. Howard, in a moment of inspiration, suggested a gallery. Sauter was in a state of indignation because the funeral 1903] 
The Whistler Journal

was so little impressive, anywhere else it would have been an official occasion, the chief authorities represented, the military out. Indeed, all the Societies and Academies to which Whistler belonged should have been represented and they probably would be very indignant because they had not been.

This completes The Whistler Journal, from the day of our first talk after he asked us to write his Life three years before, until the day of his funeral-but only to the day of his funeral. The end is not yet, nor will be as long as we live. Whistler's fame grows with the years, and we feel it our duty to leave as full a record as we can of the great Master it was our privilege to know. His fame endures, increases. None shall prevail against it. 


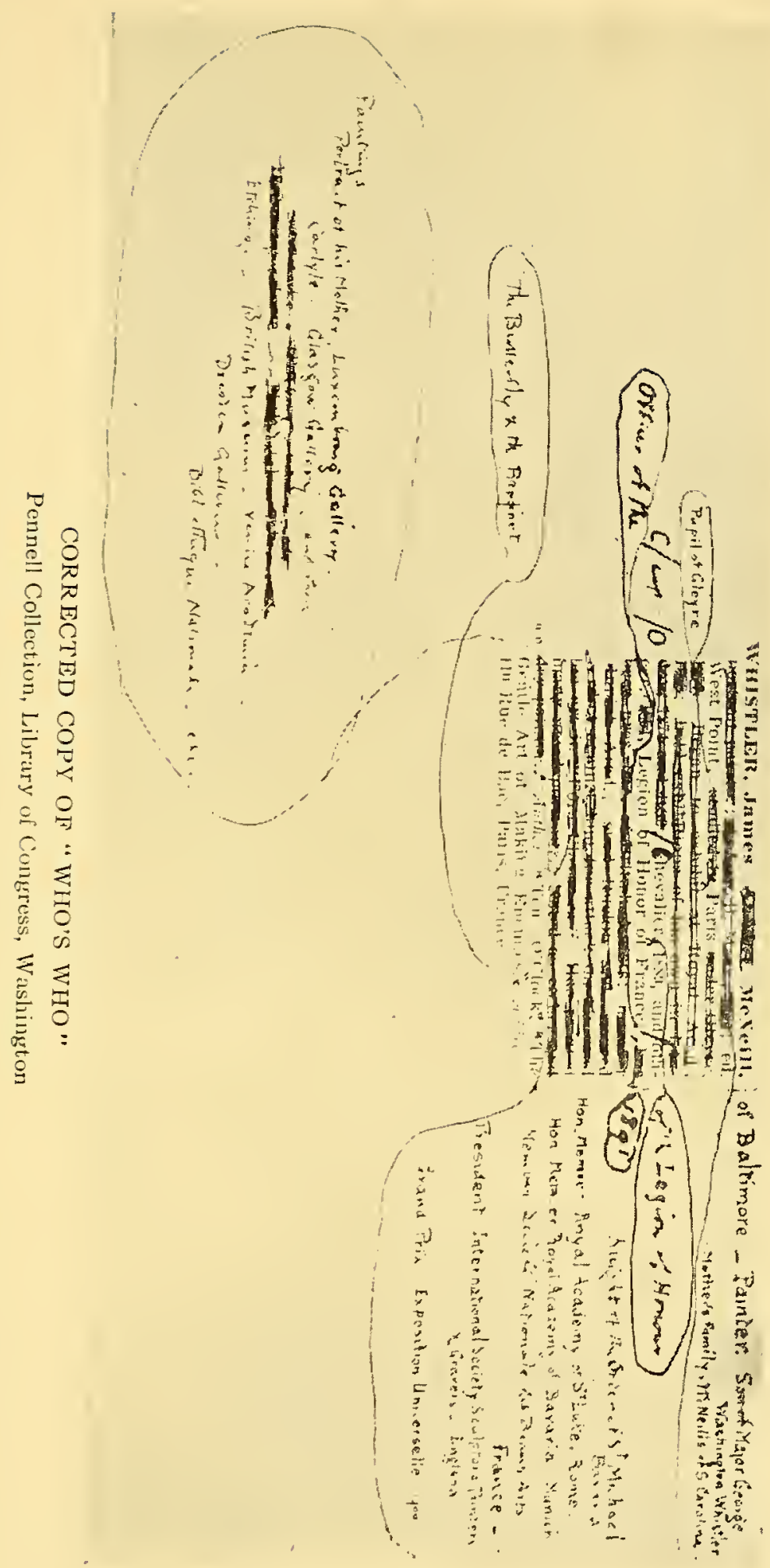




\section{APPENDIX I: WHISTLER AS A DECORATOR}

Whistler's genius as a decorator is seen in every picture, in every drawing he made, though this was not realized in his lifetime. When he came to live in London, the Pre-Raphaelites, with William Morris as their business man, had set the fashion in decoration and they maintained that their work alone was decorative because they painted as the painters before Raphael painted. But Cimabue and Giotto and the illuminators painted and drew what they thought they saw, and so were realists. The greatest decorator who ever lived, Piero della Francesca-from whom the Pre-Raphaelites might have learned had they had the brains and the ability, from whom Puvis de Chavannes did learn, from whom future artists will learn-was the greatest of realists. Whistler, who believed not in going back but in carrying on, was as intent as the early Italians upon painting what he saw as he saw it, and he relied upon the proper placing of his subject within the frame, the distribution of his spaces and his lines, to obtain perfect balance, perfect proportion, perfect repose, and so produce a Harmony, a Symphony, an Arrangement-a decoration. His titles explain his methods, the results prove that he was right, that there is as true decoration in his Falling Rocket as in Botticelli's Spring, though in this as in much of his early work he followed the Japanese. But this was not understood by his contemporaries-is hardly understood now -and he gave no help in his answer to doubters: "I am not arguing with you; I am telling you."

To complete the decoration, Whistler designed the frames for his paintings and prints. He and his assistants decorated them with patterns which, for a while, he derived from the Japanese and other Orientals. Each was different, for each was suggested by the picture it enclosed, though the same feeling ran through all. Later he gave up these painted frames and adopted one now known as "the Whistler frame," which has become a standard. It was goldgreen or red, not glaring-with reeded lines for his oils, watercolours and pastels; white, sometimes with blue or purple lines or patterns, for his etchings and lithographs. His frames and his canvases were of definite sizes, with the result that for every canvas there was always a frame that fitted. He went further. $\mathrm{He}$ insisted that the painter must also make of the wall upon which his work hung, the room containing it, the whole house, a Harmony, a Symphony, an Arrangement, as perfect as the picture or print which became a part of it. 


\section{The Whistler Journal}

This may be to us today a simple truth, but it was looked upon as a pose, an affectation, at the period when, as Whistler said, "for the flock little hamlets grew near Hammersmith," and sad people wore sad-coloured garments and sat in Early-English chairs, and ate beef and greens off sham Italian majolica, and drank British beer out of sham Venetian glass, and covered their walls with Morris tapestries or wallpapers so gorgeous that the pattern killed the Rossettis and Burne-Joneses alone considered worthy of the background, if the work was not already lost, in the gloom or glitter of Pre-Raphaelite stained glass windows. Ás we look back to out first years in England, it seems to us that we never so well understood the inappropriateness of it all as when we saw Morris in his blue flannels, a picturesque but wholly modern figure, stamping up and down the sham mediæval rooms of his real Georgian house at Hammersmith. Whistler had no sympathy with this sort of thing. He never tried to live out of his time, and he could not stand the stupidity of treating a drawing room in a small Mayfair house as if it were a hall in a great mediæval castle. He was as simple as Morris was elaborate, though he did not at once achieve simplicity in decoration any more than he at once succeeded in painting with the liquid colour of the nocturnes. There was always growth.

He took his first Chelsea house in I863 when his interest in Japanese art was at its height, and he filled his rooms with screens and lacquer, arranged his blue-and-white on shelves, hung prints, fans, kakemonos and plates on his walls. Beautiful use of the screens is made in the Princesse du Pays de la Procelaine, beautiful use of the detail in the Lange Leizen. A Japanese fan is in the hand of The Little White Girl, and Japanese pots on the mantel against which she leans. Blue-and-white fills the corner cupboard In the Studio. But though he always kept the blue-and-white in his dining room, he soon gave up this scheme of decoration, probably because he saw what it led to when borrowed by "the thing without" who stuck cheap "Japanesisms" all over their houses for no better reason than to be in what they thought the fashion. How deeply he felt the beauty of Japanese design, and how willing he was to use it, we know from the nocturnes with the spray of leaves trailing across, or out of the foreground, just where a Japanese artist would have placed it.

But he gave this up too, realizing that the Japanese were wrong, as the design did not keep within the frame. Even in the earliest days, no matter how much ornament was in his rooms, a flat wash of colour was on the walls. In his second Chelsea house, he painted the petals of flowers on the dado of the stair-case and conventional 300 
ships with sails spread on the panels of the hall. But in the rooms, pattern never disturbed the simple wall spaces delicately flushed with colour. After this, there was never pattern anywhere. $\mathrm{He}$ preferred colour that would make his rooms bright and gay, the first essential in London where often all is dark and dreary without. He kept his colour flat so that pictures and prints would tell upon it and not have to struggle with it. Distemper gave him what he wanted, but plain paper could be used. For distemper he mixed the colours himself, only too well aware that no house-painter could get the right tone though, once he had mixed it, any housepainter could put it on. He always thought and said that art has nothing to do with the people, and yet it was from the houses of the people rather than the palaces of the few, that he derived the idea of walls washed simply with simple tones, of dark-stained floors, of light or dark dados and doorways contrasting with the walls. His simple washes of distemper were the outgrowth of whitewash that the people have always used, a development of the beauty he had seen in the quiet old houses of New England, that we have seen in the houses of Friends in Philadelphia.

Morris preached art for the people and would run up a bill for five thousand dollars in decorating a room and making it so precious that the owner hardly dared to go into it. Whistler upheld the aristocracy of art, and at the cost of about five dollars would arrange a room, beautiful in its simplicity and appropriateness, that could be used without fear, since it could be done over again in a day.

He astonished artists who toiled in the complicated splendours of huge studios by creating masterpieces in a small bare room. The scheme in grey and black of No. 2 Lindsey Row was the background of the Mother, the Carlyle, the Miss Alexander. Mrs. Leyland stood in the flesh-colour and yellow drawing room and he designed her gown to harmonize with it. For this and other portraits, not only the colour scheme but the drapery, the minor details of sash and bows and rosettes, were of his designing, and the many studies in chalks on brown paper which he made for them, remain. With him it was not a question of rigging up a corner as it is with the artistic photographer and the swell portrait painter. Every room was an arrangement and every sitter had to fit in. At times, the arrangement was suggested by a visitor as when Rosa Corder, in brown dress, passed one of his black doors and he immortalized her. Eventually he suppressed the background in most of his portraits and the figures stand in the atmosphere in which he saw them. But this atmosphere was obtained not as painters usually 


\section{The Whistler Journal}

get it, by letting all the daylight they can into their studios, but by excluding it with curtains and shades. The early studios had no skylight. A figure, thus in shadow against a simple wall, takes its place in the atmosphere that surrounds it. Sometimes, to accentuate the figure, he hung behind it a piece of drapery of the colour he wanted.

Whistler liked his windows big. His curtains were sometimes of flowered chintz but oftener of white muslin without pattern. Of course there were shades in the studios. On the floor he had a few rugs, in the old days Chinese or Japanese; later matting, which he designed in harmony with the colour scheme. His furniture was simple in form. The first artists and artificers who built palaces, he said in his Ten o'Clock, "filled them with furniture beautiful in proportion." He designed a few pieces; had he been encouraged by commissions he would have done more. Besides the sideboard of The Peacock Room, we have seen only the great blue screen with the gold moon in the sky, done for Leyland and kept for himself and the cabinet with his decorations designed by E. W. Godwin for the 1878 Paris Exposition and now owned by Mr. Pickford Waller. Towards the end, Whistler's preference was for the furniture he called Empire. The white and gold went well with the room. There was little of it. He had no patience for contrivances for lounging in the drawing room. "When you wanted to lounge," he said, "the time had come to go to bed." His extravagance was in detail. He ate off the blue-and-white porcelain which he not only collected, but made drawings for. Unfortunately, Murray Marks never carried out the scheme and only the drawings exist. Whistler's beautiful silver was chosen for form, not for rarity. "The most beautiful," he used to say, "was Sheffield plate, designed by artists who were refugees from France and still clumsily copied by Britons, and you could find all these beautiful things in Wardour Street under the eyes of the Islanders who had not been taught to see them." His table linen was marked with the Butterfly. He demanded perfection in detail, and rather than be without it, would leave rooms unfurnished. "Besides," he said, "perfection is death."

When Whistler wished, and conditions justified it, he could be as gorgeous as he was usually simple. He had only one chance, The Peacock Room, but in it he showed the full measure of his powers as decorator-the wonderful room with its blue on gold and gold on blue, the peacocks flaunting their gold-and-blue plumage on walls and shutters and ceiling-the one decoration of Leyland's muchdecorated house that lives. As decoration, it is unapproached in 302 


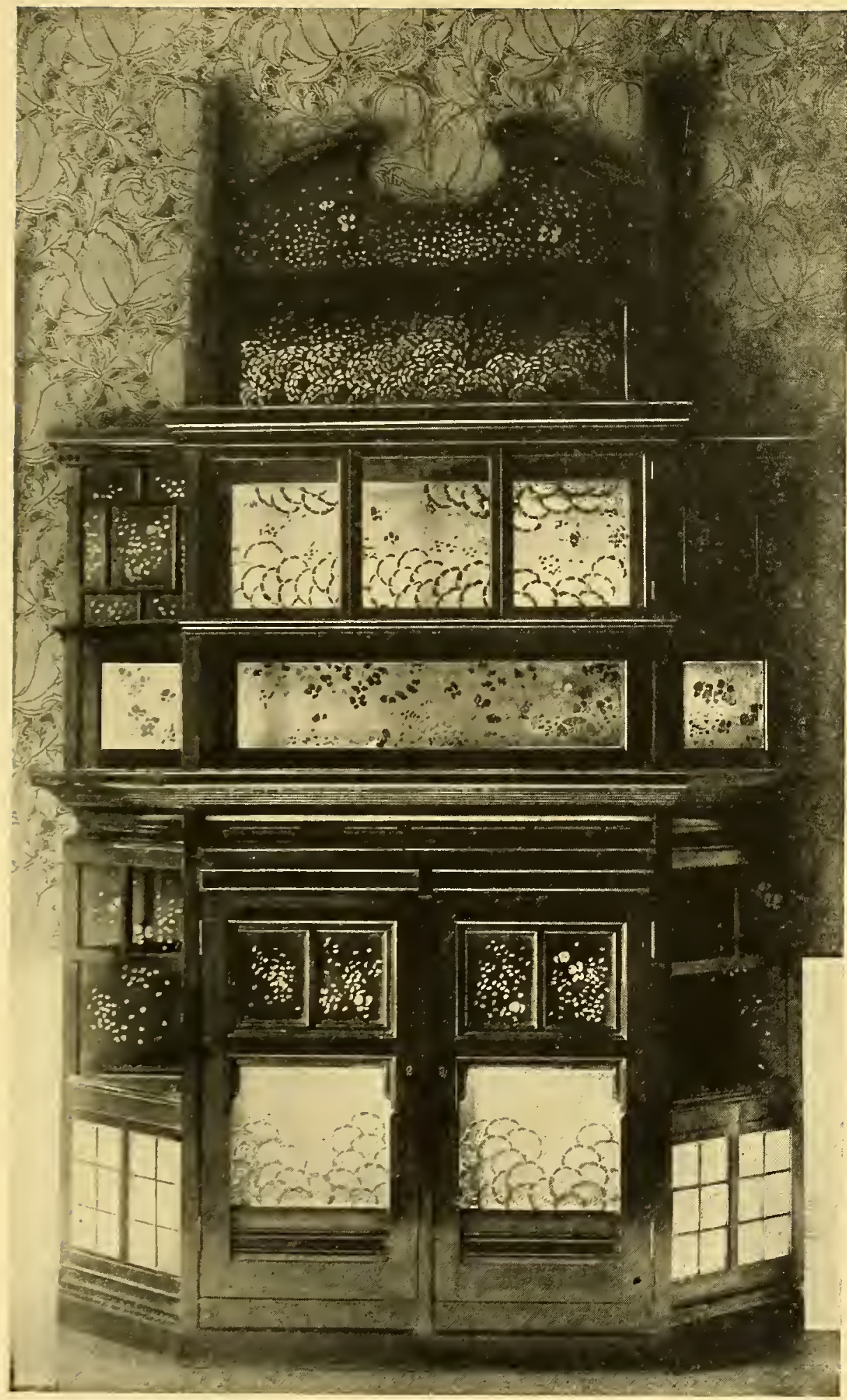

CABINET DECORATED WITH PAINTED PANELS

By Whistler

Owned by P. R. Waller, Esq. 


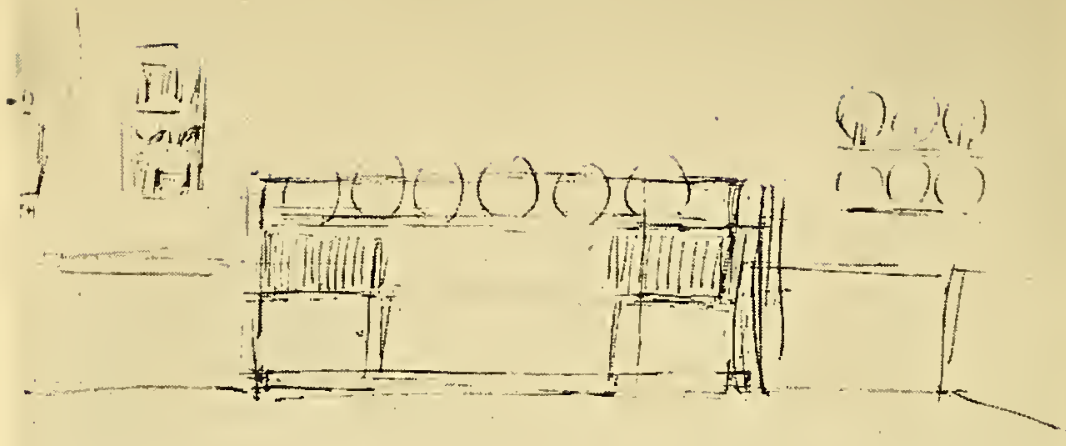

SKETCH FOR SIDEBOARD

PEN DRAIVING

Pennell Collection, Library of Congress 


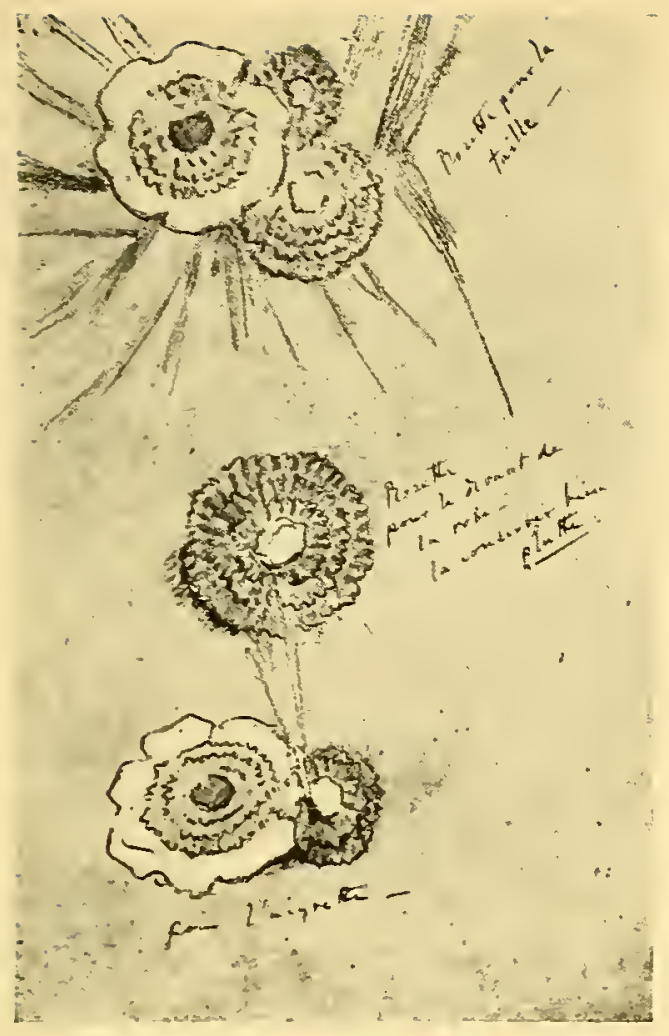

SKETCH FOR ROSETTES

CHALK

Pennell Collection, Library of Congress

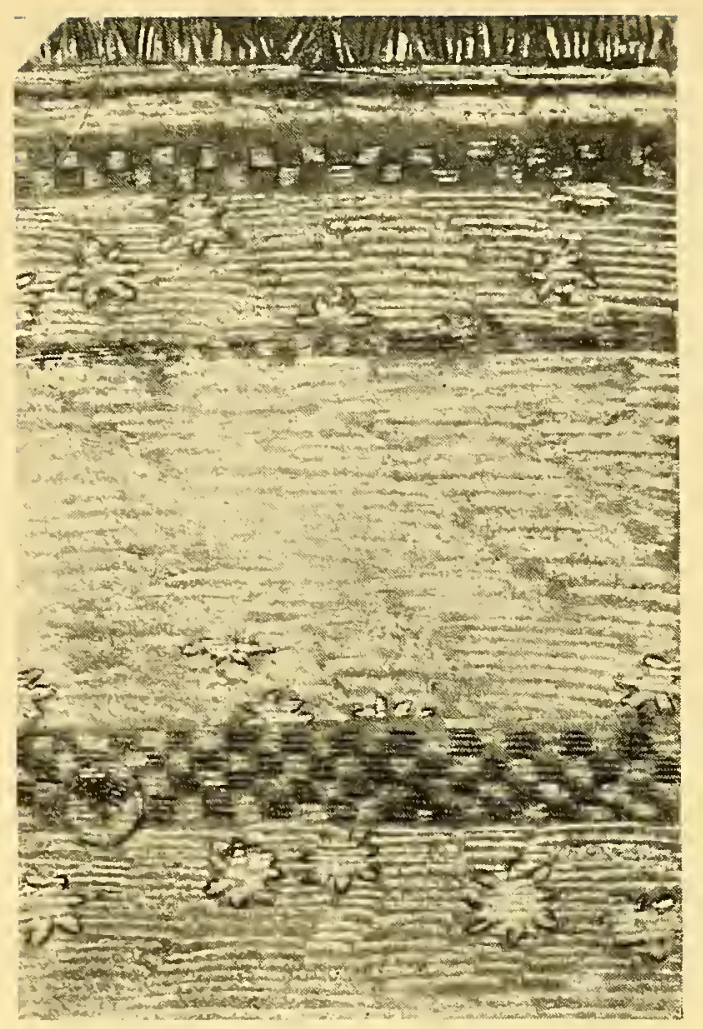

SKETCH FOR MATTING

CHALK

Pennell Collection, Library of Congress 

modern times, and yet nobody gave Whistler the opportunity to rival it. He hoped to make this opportunity for himself in the White House. Godwin was the architect but there is no doubt that Whistler was the designer, and it is the one house he ever owned. But he moved into it at the agitated moment of the Ruskin trial and moved out before a year had passed, at the more agitated moment of his bankruptcy, and when the house was bought at the sale by Harry Quilter, "history," he said, "was wiped from the face of Chelsea." Therefore, what he might have done in a house of his own designing we shall never know. The decoration of the houses he lived in grew simpler until there was nothing on the walls, except at times one of his own paintings over the mantel in the drawing-room, and in the dining room the beautiful blue-andwhite on shelves or in cupboards and, hanging from the ceiling, the Japanese bird cage above a blue-and-white stand and bowl. This is a nother crime alleged against him by artists, for by his example he has stopped intelligent people from hiding their walls behind bad pictures.

In the houses he decorated for his friends he was as restrained as in his own and as careful to mix the colours, ever distrustful of the British workman. "Why on earth should the workmen think for themselves?" he once asked Mrs. Dr. Whistler, when with two coats of yellow on white they made her walls crude and glaring, though he had ordered one coat of yellow on grey, knowing that the result then "would have been fair and at the same time soft and sweet." He kept the furniture as simple as in his own house, or simpler, using tables and cane-bottomed chairs painted in harmony with the general scheme. We remember one drawing-room in which there was a divan covered with linen of the same tint as the walls, and on the mantel, as the only ornament, a row of little white glasses for the flowers that, change as they might with the season, would never strike a discordant note.

Whistler had no factory, no shop, no staff of salesmen and workmen; he was not in the business as William Morris was. But as a decorative authority, Morris has grown old-fashioned, while Whistler has become a power. Little by little the beauty of the houses and studios he arranged for himself and his friends began to be seen, and because they were simple and beautiful, those who, seeing, could understand, knew they were right, and began to copy them, until now his scheme of simplicity in decoration has spread all over the world. Everywhere you find studios from which tapestries and armour and bric-a-brac have been banished; everywhere rooms with the walls washed or papered in a flat tint and only a few 
paintings or prints hanging upon them, with dark painted or stained floors, a few rugs or matting, with little furniture and all of it simple; the result is by no means invariably right; it is in such houses that "the something on the mantleshelf gives the whole show away." Colours mixed by Whistler are one thing; colours mixed by manufacturers and artless artists are another, and in art, as in literature, everything depends upon quality.

Whistler's influence has been as marked in picture galleries. It is not too much to say that every well-arranged artistic exhibition in Europe today owes its inspiration to him; in America, we regret, the art of picture hanging is hardly known and has hardly been practised save in two or three Whistler exhibitions held since Whistler's death, and then not altogether successfully. When he began to exhibit, galleries were decorated any how and pictures hung as close as they could be fitted from floor to ceiling, artists caring little how they were hung so long as their work was on the walls. When he sent to the Academy and other exhibitions over which he had no control, he had to accept the conditions, but in exhibitions over which he had control, he could impose them. "A beautiful picture should be shown beautifully," he said; "therefore it must be hung so it can be seen, with plenty of wallspace round it, and in a room made beautiful by colour, by sculpture judiciously placed, by furniture and decorations and hangings in harmony." In his studio he would never show more than one picture at a time, never letting it be seen until it was in its frame and on the easel. But he understood that the reason for having pictures in a gallery was to exhibit them, and he sent as many as he could, so as to produce an effect. It is well to point this out, for his practice in his studio has been misunderstood by some of his admirers and imitators. As early as 1874 , the arrangement of his first exhibition seemed revolutionary to a public debauched by the Academy. Always, the colour of the wall, either painted in a flat tone or hung with cheese cloth, gave the keynote for the harmonyYellow and White, Brown and Gold, Flesh Colour and Greywhich set the foolish public laughing. Sometimes the man at the door became part of the scheme, as at the exhibition of the second series of his Venetian etchings, when he appeared in yellow-and-white livery and was nicknamed in derision, "The Poached Egg." This was the exhibition when the public rejoiced in ridiculing Whistler's yellow socks and the assistants' yellow neckties, and when Whistler presented his friends with Butterflies of yellow silk to wear at the Private View. He adapted the ancient velarium to the modern gallery, arranging it so that the spectators were all in shadow and 304 


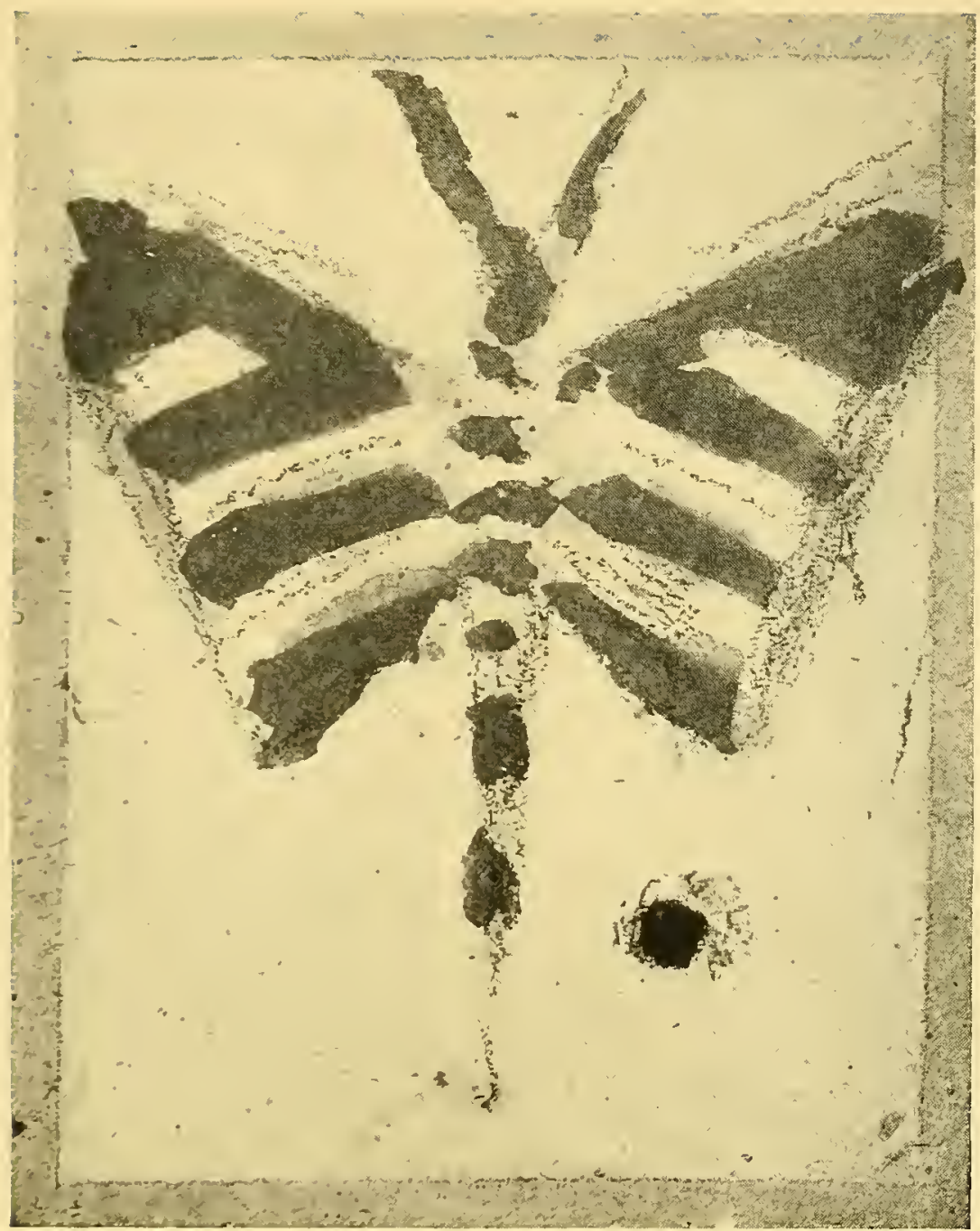

DESIGN FOR SILK BUTTERFLIES WORN AT PRIVATE VIEW In the possession of Mrs. Wickham Flower

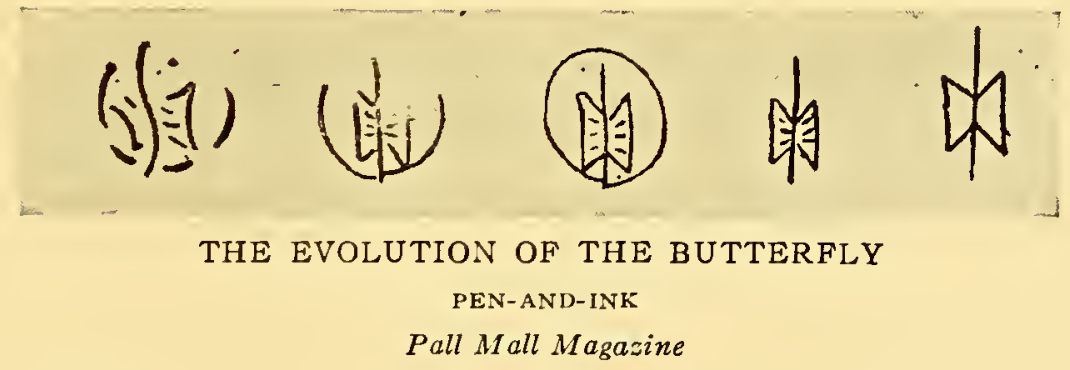

(See page 306) 


\section{Whistler as a Decorator}

the pictures all in light, the light falling upon them alone. As he said, "Picture galleries lighted at the top are very good for the spectators but not for the pictures, for the falling light is reflected up from the floor on to the pictures so that they cannot be properly seen." The velarium is a translucent screen, the edges of which are allowed to hang down, placed some two or three feet below the skylight of the gallery. The light therefore falls upon the pictures alone, and everything under the velarium is in shadow. To the British Artists it was so alarming as to be a reason for getting rid of Whistler. Ten years later it was accepted gladly by the International Society of Sculptors, Painters and Gravers. Another of Whistler's innovations was to remove the staring exhibition number from the corner of the picture, where generations of stupid painters had stuck it, to the wall beside the picture where his system of hanging left sufficient space. As a result of all this care, the gallery became a beautiful room, showing the work on the wall to the finest advantage. His arrangement of galleries has been imitated on the Continent, though not always intelligently. In many a German secession Whistler's ideas have run riot and gone mad, while when the velarium is used it is usually without understanding.

Whistler designed his invitation cards, his posters, and his catalogues. He introduced the Butterfly on the first invitation card in I874, and used the brown paper cover for the catalogue of the same exhibition. But it was with his next exhibition, in $\mathbf{I} 88 \mathbf{I}$, that he evolved the style of the catalogue to which he adhered, with increased refinement, until the last of all-the square, brown-papercovered catalogue, in size and shape like his first pamphlet, Art and Art Critics, issued in 1878, and his last, the Ten O'Clock, in 1888. The trouble he took over his pamphlets and catalogues is almost unbelievable, and he gave no less to his letters-margins ample, the division into paragraphs symmetrical, punctuation effective, the Butterfly where it told.

It is curious to compare his books with those of William Morris, who went back to the past, copying old books without considering his time. But in Whistler's books there is nothing of the past save tradition, nor are they toys for the rich, as the Kelmscott books are. Legible type and well-leaded page make easy reading, and Whistler published his books to be read, not to be hidden in bookcases. He added to the effect by the spacing, the punctuation, the Butterflies, and each Butterfly was designed to explain the text to which it referred. His title-pages, however, might have gained from the compactness in the Kelmscott books. 
The Whistler Journal

Morris thought that illustrations must be decorative and he published none that were not imitations of old wood blocks. For Whistler there could exist no form of art that was not decorative, but neither was any form of decoration to be achieved by going back. His illustrations are few and in these few he was true to his belief of carrying on tradition. In the series he contributed to Once $A W e e k$ and Good Words, he was no more subservient to the methods of other days than in his etchings. More important was his series for the Catalogue of Blue and White Nankin Porcelain, Forming the Collection of Sir Henry Thompson: drawings finer than any of similar subjects by Japanese artists or by Jacquemart, and decorative in the placing of each object on the paper, and in every touch of the brush with which they were done. Three or four drawings were made on the wood with Mrs. Whistler, but never engraved, to illustrate Little Johannes, and a few for picture shows. In his catalogues and books, save for one or two in The Baronet and the Butterfly, his only illustrations are Butterflies, and the ornament on the cover is again the Butterfly. For other books issued by William Heinemann, his publisher, he designed coverstwo for Miss Elizabeth Robins' novels, in silver with black note on blue or grey, and one for Mr. Charles Whibley's Book of Scoundrels. The portfolios to contain his etchings and the photograph of his paintings, published by the Fine Art Society and Goupil's, are in brown boards with yellow leather backs, like The Gentle Art of Making Enemies and The Baronet and the Butterfly. For the Jubilee Portfolio given to Queen Victoria as the memorial from the British Artists on the occasion of the I887 Jubilee, he drew the nitial letters, head and tail pieces in water colour, but the lettering was not his. He designed monograms for friends, usually letters in a circle or oval. One of the best was for the International Society of Sculptors, Painters and Gravers, the effect obtained by the long curves of the S's and the G's, and another was for Mr. Heinemann. But of the beauty and expression he could get from a monogram, the most delightful and famous example is the Butterfly, evolved from the simple interlacing of the letters J. M. W.

Everything Whistler designed was a work of art, and nothing in his art was unimportant. In his decorative work, as in everything else, he proved that genius is the capacity for taking pains, and he has triumphed. 


\section{APPENDIX II: THE WHISTLER MEMORIAL}

Though Whistler's work is his Memorial, the members of the Council of the International Society of Sculptors, Painters and Gravers determined to erect a Memorial as durable as bronze could make it which would testify their appreciation of their first President. They realized that other friends of the man and admirers of his work should be consulted and a meeting was called by Mr. Heinemann-Whistler's friend and publisher. It was attended by Mr. Lavery, Professor Sauter, J. and Mr. Stirling Lee as Secretary of the International. M. Théodore Duret, Mr. Freer, and Mr. George Vanderbilt-in London at the time-were also invited. Mr. Vanderbilt did not attend and Mr. Freer was scarcely favourable to the project. But instead of being disconcerted, the council appointed a Committe of the International, consisting of the members of the Society present at the meeting. Mr. William Webb was made Honorary Treasurer and Mr. Stirling Lee, Honorary Secretary. As M. Rodin had in the meanwhile been elected President of the Society, and also because of his fame as a sculptor, it was decided that he should be invited to design the Memorial. Mr. Harry Wilson and J. were asked to go to Paris and see M. Rodin. This they did after a scheme for the Memorial had been considered by the Committee. The idea was that at the western end of the Gardens on Chelsea Embankment-the little park looking towards the Chelsea in which Whistler had lived and died-there should be placed a Winged Victory symbolizing Whistler's triumph-the triumph of Art over the Enemies. Rodin agreed with the suggestion, for it gave him a splendid opportunity and besides, as he said, he had never made a portrait of Whistler and would not think of faking one. Rodin offered to undertake the commission without charge save for the casting and other technical work, the cost of which he estimated at fifty thousand francs, then ten thousand dollars. The Society had no such sum, or anything like it, and a public subscription was opened. The names of several other prominent men were added to the Committee, including Lord Plymouth, Lord Grimthorpe, Mr. George Wyndham, Mr. Harold Hartley and Mr. David Croal Thomson. It was further decided that if a sufficient sum conld be obtained, replicas should be offered to the City of Paris and to the United States. The London County Council was approached and they agreed to give the site. This was arranged by Mr. E. J. Horniman, member for Chelsea. Then Rodin came to London, went with members of the International Society and the London County Council to inspect the site, was keen about the project which developed into 


\section{The Whistler Journal}

the larger plan of cutting off the end of the Gardens and, in this space, placing a semi-circular-a Roman seat like the seat at the base of St. Gaudens' Lincoln in Chicago or those at Pompeii and in the centre above it should stand the Winged Victory. Rodin was so interested that he said he would go to work at once, though there were as yet no funds.

Subscriptions at first came in slowly, but from all sorts and conditions of men and women. At the end of two years a certain, but not sufficient, sum had been raised. Then followed the Whistler Memorial Exhibition, the most successful one-man show ever held in London-another triumph for Whistler. From the profits, the International voted a sum of five hundred pounds as their tribute to the man who made them as well as modern international art in Great Britain. The gift was announced in the press, and the public was again invited to subscribe. And it did subscribe, although in some quarters there was an attempt at opposition, it being stated that Whistler wished no memorial of himself by Rodin. Why he should object to Rodin, and even to a Memorial, before his death, it was hard to understand, though it is true he once said to J. he wished to have no portrait, like Rossetti's in the same garden, "with a tap in his tummy." Nor, we are sure, would he have cared to figure, like Carlyle, dressed in an ancient toga and seated in a modern armchair. Curiously, Sir J. E. Boehm, who did the Carlyle was the only sculptor for whom Whistler ever posed.

About this time also, the Committee was re-constituted, and William Heinemann and Joseph Pennell became joint Honorary Secretaries. They worked hard and before long the required sum was raised for the British Memorial and the American replica as well. The United States, that had mostly spurned Whistler until his fame was assured, now struggled, not only for his works, but to get the Memorial which was awarded to the City of Lowell, Massachussetts. Lowell was Whistler's birthplace. The Lowell Art Association had purchased the house in which he was born. Lowell seemed therefore the most appropriate spot in his own country. Besides, Lowell first asked for it, and raised the money to pay for it. An American Committee was appointed with Mr. Joseph A. Nesmith, Mr. Harrison S. Morris and Mr. William M. Chase among its members, and the sum necessary for the American replica was quickly subscribed in the United States. On the other hand, France showed little enthusiasm. The list of subscribers in Great Britain and the United States was extraordinary including almost every one known in art and literature, many subscriptions coming from the most unexpected quarters and rang308 

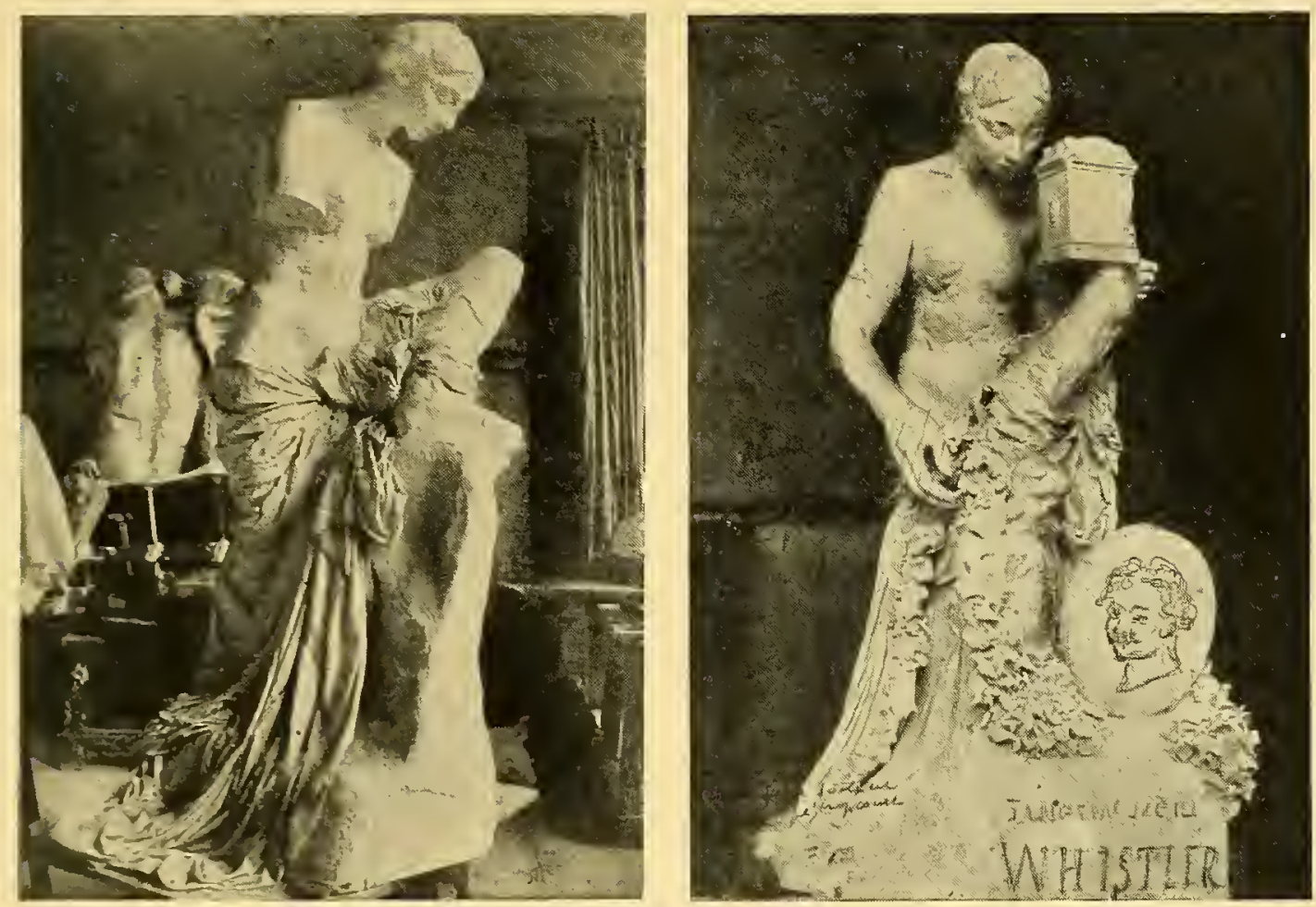

RODIN'S REJECTED MEMORIAL TO WHISTLER

ORIGINAL MODEL FOR THE MEMO- FINAL SKETCH MODEL OF MEMORIAL RIAL SHOWN IN PARIS SALON REJECTED BY THE COMMITTEE

Pennell Collection, Library of Congress, Washington 
ing from sixpence to hundreds of pounds. Among the subscribers were twenty members of the Royal Academy, a larger number than would have been necessary to elect Whistler and Rodin to that body from which they were carefully excluded. Henry James, Thomas Hardy, Maurice Hewlett, Austin Dobson, Rudyard Kipling, Bernard Shaw, H. G. Wells, Edmund Gosse and George Trevelyan were glad to honour the memory of a man for whom they had done little during his lifetime. Names of lords and persons of title, not a few, were in the first list: Sir W. Martin Conway, Lady St. Helier, Sir Hugh Bell, Lord Grimthorpe, the Rt. Hon. the Earl of Plymouth, the Viceroy of India, Count Plunkett, Lord Redesdale, Lady Archibald Campbell. Dealers there were who had believed in him and his work: D. Croal Thomson, Ernest G. Brown, Messrs. D. and P. Colnaghi, Messers. Dowdeswell, Robert Dunthorne, Messrs. Obach, Messrs. Agnew. Curiously, the American and French dealers who made more than any out of his work, were conspicuous by their absence from this first list. There were Museum Directors: Sir Charles Holroyd of the National Gallery, Mr. Lionel Cust of the National Portrait Gallery, Mr. Whitworth Wallis of the Birmingham Museum, Mr. Butler Wood of Cartwright Hall, Bradford, the only four. Now, every gallery clamours for the work of these two artists. At that time it was not wanted. There was one art critic-Mr. M. H. Spielmann, F. S. A., who just before Whistler's death had done what he could to injure him. The worm sometimes does turn. There was a parson, a professor, two ambassadors-Whitelaw Reid and Sir Rennell Rodd. But, it was from artists and art students who had always believed in him, including Whistler's and Rodin's own Society, that support really came: the American Art Association in Paris, pupils of the Royal College of Art, the London County Council Technical Schools, The National Academy of Design alone in America. Many of the Artists subscribing were of international fame which, great then, has since increased: E. A. Abbey, Paul Bartlett, J. E. Blanche, Timothy Cole, Storm Van s' Gravesande, James Guthrie, Alexander Harrison, Josef Israels, A. Lepère, John Lavery, Gari Melchers, Frederick MacMonnies, William Nicholson, Arthur Rackham, J. F. Raffaëlli, Professor Sauter, John Sargent, E. J. Sullivan, Fritz Thaulow, E. A. Walton. The list it truly international. There were even collectors: J. J. Cowan, J. P. Heseltine, H. J. Theobald, Pickford Waller, W. H. Jessop, Edmund Davis, Mrs. Potter Palmer, Howard Mansfield. It is interesting to note that the names of Charles L. Freer, George H. Vanderbilt, Richard Canfield, Henry C. Frick, and other eminent 


\section{The Whistler Journal}

American collectors, who had done much to make themselves known through Whistler, did not appear, nor those of most of the British and foreign collectors who had been extremely anxious to unload their Whistlers, and who did unload them at a phenomenal advance, when they found that the works they acquired for nothing had become too valuable to keep.

A special interest was shown in Chelsea, Whistler's home in London, a special Chelsea Committee was formed, a special meeting was held, and almost all the prominent people of Chelsea came to it on July 9, 1907. Lord Plymouth who presided said he looked back "with pride on the years Whistler spent in this country and the years he lived in Chelsea, and we desire not to be behind hand in showing future generations that Mr. Whistler's art was appreciated and that we do not forget the many years he spent in Chelsea." Lord Redesdale, who in the old Lindsey Row days lived next to Whistler, spoke and also Edmund Gosse. Lord Redesdale dwelt upon Whistler's love of Chelsea- "He was constant to Chelsea to the very end." Mr Gosse's speech was one of the best he has ever made. No one could better have explained why there should be a Memorial and why Chelsea was the place for it.

"Why should we raise a monument to Whistler? Largely, I think, because he added a sense of beauty to our world. Let no one call that a little matter. Beauty and ugliness are not indifferent to us, there is all the difference between them that lies beween health and languor, between happiness and dulness. Have you ever reflected on the positive biological value of beauty? It is stimulating, tonic, beneficent; it adds, directly, to the wealth and fulness of our physical life. But beauty does not exist till we give it optical recognition, and that has to come to us, first of all, from an interpreter. It has to come from a heaven-sent interpreter, with a temperament like Whistler's, fragile and enduring, sensitive and not sentimental, a temperament like a fine steel wire.

"He steeped London in his new-found beauty, and it is for us to return him a little cupful of London homage. When I say London, might I not say Chelsea?

"There, opposite the old church that he liked to attend, close to the brown and shining river, will be set up the memorial to James McNeill Whistler, who loved it all more intelligently than any man that lived before him, and who taught us to love it. Perhaps on blue and glassy summer nights, such as we may almost say that he created, his spirit may deign to descend for a moment and hover round it, not ill content with the ripening verdict of taste and this slight symbol of the triumph of his powerful will." 


\section{The Whistler Memorial}

Despite the enthusiasm there were complications. The London County Council demanded a sketch by Rodin. This the Committee refused to ask Rodin to make or to submit, and they told the County Council that it would be an honour to London to have the only original design it possessed by this sculptor erected in Chelsea. For at that time there was nothing by Rodin in London, though shortly after a replica of his bust of Henley was put in the crypt at St. Paul's. Rodin's only other connection with British art, outside the International, was the fact that he had been rejected when he submitted his works to the Royal Academy.

However, the money for the Memorial had all been raised, it was invested and trustees were appointed to administer the fund. The difficulty now was with the sculptor. Every once in a while, public and private inquiries were made as to what had become of the Memorial, but the Committee, recognizing Rodin's eminence, allowed him to take his time. Now and then he told them what was going on but it usually amounted to no more than he wrote in a letter to J. towards the beginning of 1906, "The Whistler monument is not yet finished."

He was always delighted with the success of the project and when the Lowell Art Association, established in Whistler's birthplace at Lowell, announced that they would raise the funds for a replica to be erected in that City, he sent the following telegram in November I908, addressing it to "Le Gouvernement de Massachusetts à Lowell." "Je m'associe à cette juste et belle réparation envers un des plus grands artistes du monde. L'cuvre de Whistler est une des premières et intégrales manifestations de l'art Américain. Je suis d'autant heureux de l'honneur qui lui est rendu que j'ai été un de ses amis et que j'ai été chargé du Monument qui s'élèvera bientot à Lowell." An amusing wire was sent a little later, February 23rd, I909:

"Le monument Whistler est le constant souci de mes journées de maintenant, d'autant que ce parfait artiste demande une sculpture réfléchie image de son ceuvre. Saluts à la Phalange de l'Internationale et Homage à Lowell, à London. Hurrah pour les bonnes nouvelles."

In 1908 the Committee asked Rodin for a photograph as they understood that he proposed to show his design in that year's Salon. What was their surprise on receiving it, and on visiting the Salon, to find the triumphal Victory transformed into a Venus climbing the mountain of fame, though, in one letter, Rodin described it as, a Muse who would hold-she had as yet no arms-or have placed near her, a medallion portrait of Whistler. She eventually held a box or a lantern, and below it a relief of Whistler's head was placed. 
The Whistler Journal

Then there was another delay. Either before or after, the Seine, rising in Paris and penetrating Rodin's studio, damaged the lower part of the figure. The Committee, however, was patient. From time to time J. received letters assuring him of the progress of the Memorial. This one, dated 7 th November, 1913 , is characteristic: "Mon cher Pennell:

Le monument Whistler marche vers sa fin. Comme sculpture il est bien. Je ne sais si il sera bien à tout point de vue.

Patientez encore, carl'hiver je.ne pense y travailler, je dois m'absenter de Paris pour ma santé qui ne supporte plus le froid.

Je suis honteuz de ne pas encore être pret et je fais mes excuses. Rodin." This was not encouraging especially as five years before, June 7 th 1908, Rodin had written Lavery that he needed but five or six months more to complete the work. On the 13th of April, 1916, he wrote $\mathrm{J}$. in reply to queries from certain subscribers then feeling the pinch of war, while the International Society had almost forgotten that Whistler was their first President, though they never forgot their five hundred pounds, and some of them were beginning their endeavours to reclaim the sum. Here is the letter, addressed to J. : "Mon cher Ami:

Le Monument Whistler était presque fait lorsque la guerre est Venue et je n'y ai plus travaillé. C'est la première chose que je vais faire, sitot que je serai un pen libre. Je ne peux repondre à vos souscripteurs en ce moment, mais six mois après la guerre terminée le monument pourra se mettre à Londres. Ces six mois, je les compte pour la fonte du bronze risque à rectifier de quelques mois. Aug. Rodin." This is the last time that J., and he believes the Memorial Committee, heard from Rodin. After his death, even shortly before it, his artistic affairs passed into the hands of $M$. Léonce Bénédite, director of the Luxembourg, who would have had the Society accept a marble version of the figure substituted by Rodin for the bronze Victory he had consented to design. The Committee, wishing to know the exact state in which Rodin had left the figure, sent three artists, Sir W. Orpen, Augustus John and Derwent Wood, to see and report upon it. With the exception of one, who was a painter, they agreed that it was "a poor thing," "quite unworthy of Rodin and the master it was supposed to perpetuate." The Whistler Memorial Committee met again, considered the three reports sent in, refused to accept the design, which was but a fragment, a sketch, not good at that, and moreover not the design originally arranged for with Rodin. This was the second grievous disappointment suffered by Rodin's admirers. The Balzac was the first. But this is the first time the story has been told. As the money collected 3 I2 


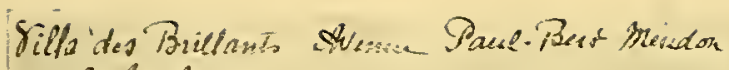
13 A thisif 1915

$$
\begin{aligned}
& \text { la fout des liowze Migque a } \\
& \text { tictifier to ipereques mois }
\end{aligned}
$$

Minchex Ams

Sug tratix

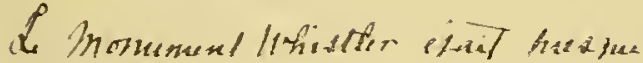

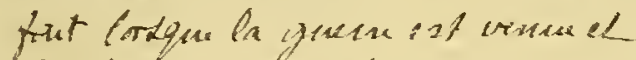
ti 11 'y ait thes hatrille'. P'ext

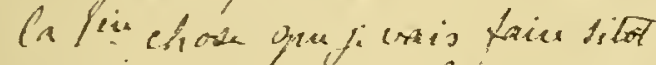

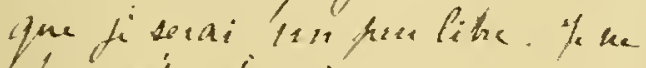

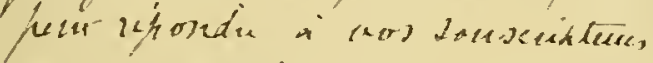

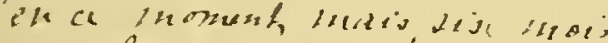
afin fa greene deninci, l' momement

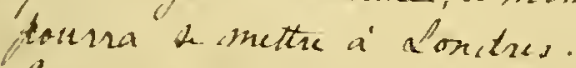
Qs if mois, $A_{i}$ fo, compte fin 



\section{The Whistler Memorial}

ten years before was given solely for the Rodin Memorial, it was returned to the subscribers in the present year. The whole affair is regrettable from every point of view. Though Rodin has now several replicas of his work in Great Britain and America, no important original was made for either of these countries. Whistler and Rodin will both live. A Memorial would have done nothing to increase Whistler's fame but it would have added to Rodin's. -Never was an artist given freer opportunity to produce a great work, work, which he himself said he delighted in. Never was there such a miserable fiasco. Never was such universal support given to a great artistic project. This can be seen in the unnumerable letters from subscribers. It is interesting to quote from them. Sargent was not sympathetic:

"I must confess to a real antipathy to the idea of artists erecting monuments to each other the moment they die. It seems to me to have no meaning at all unless it comes from the public and after a lapse of years. I also think that Whistler would have hated the idea. He never was funnier or more sarcastic than on the subject of the monument to Rossetti on Cheyne Walk. I subscribe because the work will be by Rodin."

The lithographer T. R. Way was of Sargent's opinion: "I cannot help saying that the purchase of another picture by Whistler would be more appropriate to my mind." But later, from the most unlooked-for sources came sympathy and subscriptions and tributes.' Walter Crane hoped that he "might be mentioned with those who desire to honour the memory of the artist whose true monument must, after all, be in his own works, though, as there is to be a sculptural monument, no one could be more fitting than $M$. Rodin to carry it out." Sir Alfred East sent a subscription as President of the Royal Society of British Artists-the Society Whistler had made Royal. But it was almost the only mark of appreciation. The President and Council allowed a subscription list to lie upon the table in the Suffolk Street Galleries, but feared that, as few members remembered Whistler as President, and as the times were "depressing," the response might not be as adequate as they would like. In sending his contribution, Mr. Frederick MacMonnies wrote: "I regret that St. Gaudens was not asked to undertake the work, as I do not care for Rodin's portrait statues and I recollect that Whistler was of the same opinion." In a nother letter, he asked, "Why could it not be arranged that Rodin furnishes allegory for Paris and London and St. Gaudens model a portrait statue for New York? Certainly, one could not find among modern personalities a rarer subject for a portrait statue." Storm Van s'Gravesande 


\section{The Whistler Journal}

regretted that his contribution was so little in proportion to l'admiration et la sympathie que je ressens pour le talent du grand et tant regretté Président fondateur de l'International Club. That wonderful mass of contradictions, Howard Pyle, wrote, "I am not very much interested in Whistler. If it were a question of a Whistler Memorial to Rodin instead of a Rodin Memorial to Whistler, I think it would touch me more nearly." He alone among the artists-artists of the world-sent such an answer.

Pyle, however, was equalled or surpassed by laymen, some of whose opinions are typical of the attitude of the greater public in regard to Whistler, though by this time his fame was assured. Clement K. Shorter, an editor of an English paper, could "not afford a subscription. There are too many things of this kind going round. But I shall be happy to make a note of the affair. If I could have a copy of the design, for example, we would reproduce it." It has never been reproduced before. More amusing criticisms accompanied some of the refusals. Francis James, after contributing himself, did his best to persuade friends to be as generous. But in Devon, "in this barbarous distance from any art appreciation, the eyebrow lifted of surprise could only meet any demand. The silly rich of my acquaintance absolutely refuse my most urgent and graceful appeals on their purses for the Whistler fund. The following is a specimen of the answers I get: 'I am sorry to disappoint you in the matter of contributing to a monument in Whistler's honour. I am not going to shy anything at you! but I do shy at Whistler. Of course I can recognize his genius, but the few times I met him he invariably set my bristles up by his loud and preposterous demeanor and manner of speech. I dare say that if this had not been so offensive, I might have been amused by his unbounded conceit,' etc., etc. Poor Jimmy, how little they understood him!.... I am writing to my friend Mr. George Salting to try him-but I fear these great collectors are worse than uselessthey like paint to have dimmed some hundreds of years before they honour it by loosing their purse strings. I smiled the other day when he showed me a recently acquired Corot that I tried in vain to get him to buy years ago at one-third the price he now paid, and my ardent desire to lead him toward Whistler only met with blank wonder."

Another artist, who lived in another part of England, declared that "To arouse enthusiasm for Art in our provinces is, I know, about as hopeless as kicking a dead horse." Mr Edmund A. New, who did subscribe, felt the same way about Oxford where he hardly "knew more than half a dozen people interested enough to be likely to 


\section{The Whistler Memorial}

wish to subscribe.... The only artist I know is so thoroughly a Ruskinian that I hardly think it is any use asking him. (Of course I am one too!)" But more surprising was the answer of Fred Brown, then Slade Professor, whom J. had asked to interest his students in the Memorial. Mr. Brown wrote that "the present generation of students do not know anything in an intimate sort of way of Whistler's work and genius." J. suggested to him that their ignorance or indifference could easily "be remedied by the professors and lecturers devoting some slight attention to this not altogether unimportant matter." He also found the same state of affairs in the notions of the Directors of the Art Students League, New York, where he was told Whistler was not the fashion, and fashion now bosses American Art.

Amusing protests came from Chelsea. One man was "too much out of sympathy with Whistler and Rodin to join" in the movement. A second could not say that he "appreciated the work of the late Mr. Whistler to the same extent as many of his admirers." A third was shocked at the price, double the sum needed by his Vicar to keep the Church Schools open: "I consider that the re-building of the schools is a much more important matter than the raising of a memorial to the late Mr. Whistler at a cost of two thousand pounds, which appears to me to be an enormous sum for the purpose." A writer of an anonymous letter thought it an outrage to have been asked: "Do you think the inhabitants of Chelsea propose to contribute to a monument to this scoundrel? If erected, we will destroy it." Must have been Mrs. Pankhurst. Judging from what the British vandals did to Sargent's portrait of Henry James in the Royal Academy, they very likely would. Rodin was at times the objection. An old friend of Whistler's decided "I had much rather not. Of course I think that Whistler should have public recognition, but I look upon Rodin with very incomplete satisfaction." Sculpture was the stumbling block to citizens who had not known him: "Whistler was a Bohemian of genius and some of his work will probably be more and more prized as time goes by, but I recoil from a statue. We are burdening the earth with too many statues and even Rodin's co-operation will not tempt me to join the Committee." And there was a P.S.-"My wife is of the same opinion." Or the scheme of the Memorial seemed too ambitious for a mere artist. One lord protested "I am really not in sympathy with the effort to get together so much money. An artist makes his own memorial, and something much more modest would surely be enough to record Whistler locally." Another lord was still more 


\section{The Whistler Journal}

blunt: "I did not know Whistler when he lived in Tite Street and do not propose to take any part in the Memorial."

Americans in London were not over responsive. The American Society was appealed to. The Secretary acknowledged the letter, said it would be placed before the Committee at the next meeting, a proceeding which yielded the same splendidly negative result as the List of Subscribers laid upon the table in the Galleries of the British Artists. Now they would fall over themselves to get in. The Society of American Women never answered the letter sent them. Of what Americans in America did, we have already spoken. Lowell was practical and generous, and Mr. Nesmith, President of the Lowell Association, was justified in thinking and writing that Lowell had done its part. The United States Government, though not asked directly for its support, indirectly interfered with what might have been one large and helpful subscription. Messrs. Carneigie and Rockefeller refused.

However, despite disappointments and drawbacks and refusals, the project prospered. As time went on more people of note subscribed. Among literary men now were George Meredith, William M. Rossetti, John Galsworthy, Théodore Duret, Robert Ross, and among actors, Squire Bancroft and Beerbohm Tree. Other contributors were, the Lord Provost of Glasgow, Mrs. Potter Palmer, and T. R. Way.

It must be understood that the failure of the monument was entirely Rodin's fault. He consented to carry out the design suggested by the Committee. A public site was granted. The sum he named was secured. The Society waited patiently so long as he lived. After he died the endeavour was made to induce the Committee to accept a figure that, had they accepted it, would have been refused by the London County Council. It was rejected not by a committee of laymen but by a committee of artists sent from London to Paris to see it, and the unfinished Muse still stands in the Hotel Biron. The whole failure was due to Rodin's failure to carry out what he had agreed to do, but had left undone during the fourteen years that elapsed between Whistler's death and his own.

\section{APPENDIX III: THE PAPERS IN THE WHISTLER v. RUSKIN ACTION}

While this volume was being prepared for the printers, we were presented with a series of valuable documents to add to our collection of Whistleriana in the Library of Congress. At the request of Judge E. T. Parry, of the British Bar, son of Mr. Serjeant 316 
Parry, Whistler's counsel in the Whistler v. Ruskin suit, Messrs. Walker, Martineau and Co., Ruskin's solicitors, sent us the Ruskin papers in the case which had been in their possession since the trial. These make our record complete, for, already, all the papers on Whistler's side had come into our possession.

The Whistler papers include not only the Brief, the writs, the various other legal matter for which clients pay so dear, but forty letters from Whistler to his solicitor, Mr. T. Anderson Rose. Characteristic of Whistler as these letters are, the Brief is the most important document in the history of the trial. There is much in it that never came out in Court and, supplemented as it is by the Ruskin papers, there is now not a stage in this famous law suit that cannot be followed-a record for all time.

Whistler's Brief is dull reading, so that the wonder is what Whistler thought of it, and if Serjeant Parry ever read it through. Certainly, he made no use of its strongest arguments. That Anderson Rose toiled over it we know, for we have also his first draft, full of corrections and omissions, whole paragraphs struck out, everywhere signs of the labor that went in to the finished document. Probably he worked too hard, found a draw-back in the mass of good material and the many good suggestions Whistler probably made. The material is excellent, but legal language is dry and the language is mainly the lawyers. It begins with a concise statement of who Whistler was-" "of Irish decent, American parentage, Russian birth, Parisian education, now domiciled in England"-and a short account of the work he had done. It goes on to explain the libel; the exhibition by Whistler of pictures in the first Grosvenor Gallery in the spring of 1877 , and the criticism of them by Ruskin in the July number of Fors Clavigera for the same year. The libellous paragraph is quoted, the libel contained in the last sentence:

"I have seen and heard much of cockney impudence before now, but never expected to hear a coxcomb ask two hundred guineas for flinging a pot of paint in the public's face."

Then the tables are neatly turned on Ruskin-the idea must have been Whistler's-by showing that the great man, who is so sensitive to what he considers the overcharge for work by others, is guilty of the same enormity himself. Fors Clavigera consists of only twenty-four very widely printed pages and nine pages of notes and correspondence, and yet this he sells at "the exaggerated price of tenpence, without abatement on quantity." Ruskin described its contents as "letters to the workmen and labourers of Great Britain," which is "a gross misrepresentation" for, says the 


\section{The Whistler Journal}

Brief, there are no workmen and labourers in Great Britain who could afford to pay the price. The number containing the libel is filled with "scandal and twaddle." Ruskin advertises in it "the St. George's Company," an enterprise of his own, in which he is the despot, forbidding the use of steam and machinery, determining what books members shall read and what dress women shall wear, even imposing a religion upon the tenants of his Company's estate. Libels are scattered through the pages and "without the slightest apparent connection, he drags in the names of people to cover them with abuse or insult or filth"; now dishonouring the memory of Harriet Martineau, now calling Goldwin Smith a goose, mixing him up with the adulteration of butter, flying off at a wild tangent to Isaiah VII: I 5, flying back to a nice girl waitress who described for him the adulteration of honey with carrots, again returning to Goldwin Smith, the goose, and from him wandering to Sir Henry Cole who "has corrupted the system of art teaching all over England into a state of abortion and falsehood from which it will take twenty years to recover." This is "the sort of publication Fors Clavigera is," and the sort of writer Ruskin is, and the question may be at once asked whether his attack on Mr. Whistler is in any sense art criticism, or is it not a gross libel. Then the answer:-

"Mr. Ruskin says that Mr. Whistler is 'ill-educated and conceited', and a 'wilful imposter.' He is a 'Cockney, impudent and a Coxcomb' who 'asks 200 Guineas for flinging a pot of paint in the public's face.'

"It is confidently asserted that there is not one single word of the above which has a reference to art criticism. It may be said that part of it is vulgar abuse and it may possibly be admitted that to call a man a 'Coxcomb,' a 'Cockney,' 'ill-educated' and 'impudent,' is vulgar 'abuse, but, take all these epithets together and connect them with the charge of wilful imposture and endeavouring to obtain 200 Guineas in the way described by Mr. Ruskin, it is contended is a libel and a libel of the very worst type.

"Those who know Mr. Whistler intimately would, of course, feel the deepest indignation of contempt and perhaps nothing more, not against Mr. Whistler, but against Mr. Ruskin and, but for Mr. Ruskin's age and known infirmities, a man if he has no redress at law might be tempted to avenge himself personally. An Artist lives in an atmosphere of opinion, he finds his bread slip away from him, his position as an Artist changes speedily from competence not to say affluence into indigence and poverty, a result which might be entirely brought about by the malignant abuse of Mr. Ruskin, and the certain following which Mr. Ruskin's known powers of vituperation, as well as criticism, will be sure to have from the envious and from all the cowardly part of mankind.

“Mr. Ruskin's opinions are accepted as Gospel on matters of art, not solely by the cowardly and the envious, but by many patrons of art and purchasers of pictures, and there can be no doubt that his expressed opinion in Fors Clavigera is calculated to do Mr. Whistler great pecuniary injury. The extent of Mr. Ruskin's influence is already shown in innumerable references to the article in 318 


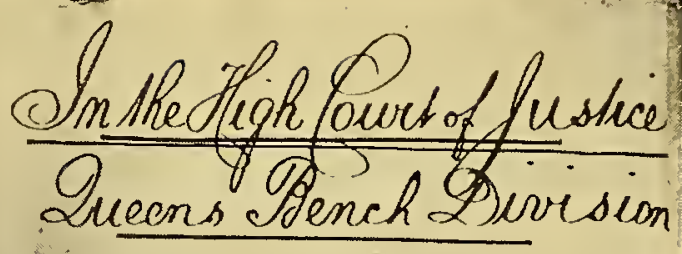

?

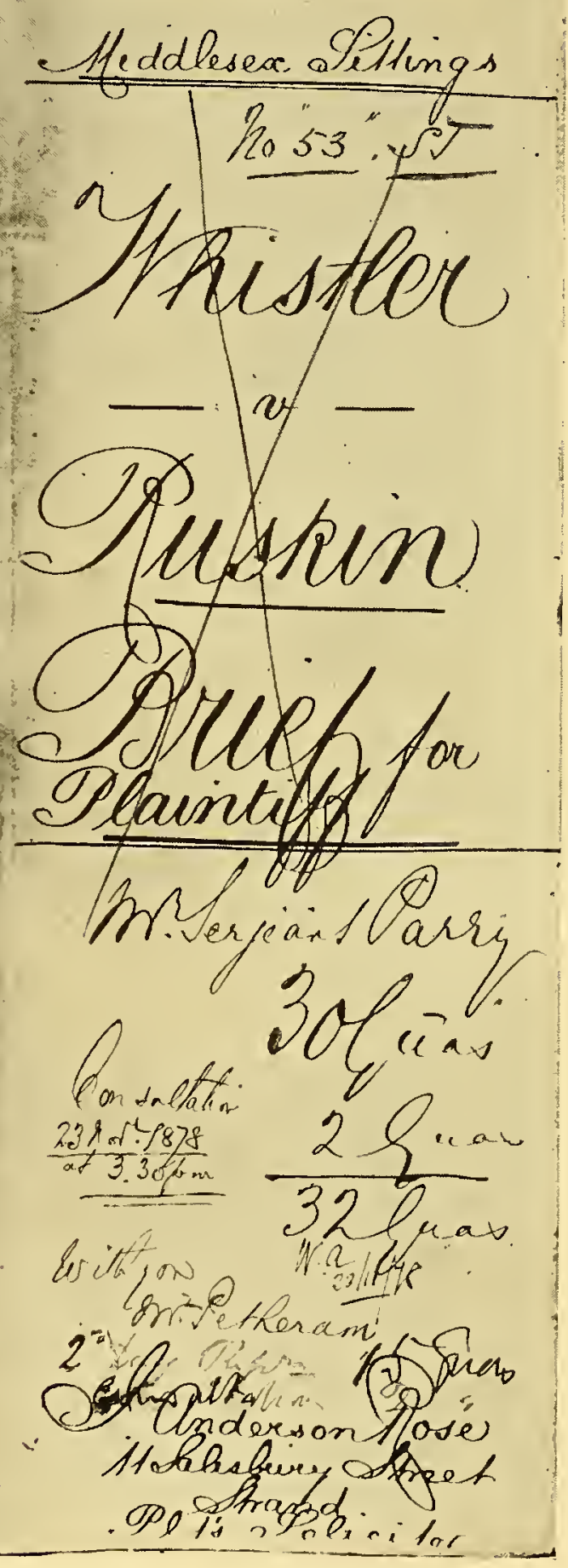

COVER OF MR. SERJEANT PARRY'S BRIEF FOR WHISTLER

Fennel Collection, Library of Congress 


\section{The Papers in Whistler v. Ruskin Action}

the newspapers, by 'the sort of newspaper sheep who follow the critic whom they consider the ram of Art Criticism.' The World thinks the paragraph about Mr. Whistler 'pleasant reading' and means to subscribe to Fors Clavigera. The Academy refrains from quoting, but suggests that a single number of Fors Clavigera can always be had for tenpence. One after another they fell in line and even when Mr. Ruskin's remarks are denounced as 'things to regret,' as in The Daily News, attention is still called to Fors Clavigera and so brings it into demand. 'There is no doubt that this particular number was more noticed and extracted from by the Press than any other number had ever been, solely because it contained this libel on Mr. Whistler' and, as a consequence, it reached a far wider audience than ever before. The passage referred to in The Daily News should not be forgotten, Whistler's champions at the time being so few. Here is a part of it :

"When Ruskin speaks of Artists and scholars as coxcombs and geese and tells the world what animal, or what critic, he would like to be at the hour of luncheon, everyone, as a rule, feels that this is only 'pretty Fanny's way.' But to mix these flowers of speech with more commercial criticism is not only to interfere with the laws of supply and demand for which Mr. Ruskin cares nothing, but to infringe on the courtesies of literature. These laws of literary courtesy have been a 'late conquest of culture,' to use an affected but useful piece of slang. .....

"Audacity and incompetence, if they exist, can still be snubbled and made to find their level without any such brave words as Mr. Ruskin employs. If Salvator Rosa had lived, even in extreme old age, to the present day he might have given his critic cause to remember that knives have edges, and that men may sleep and may have their throats about them at the same time. The time for that sort of repartee has gone by and, with the disappearance of artists as well able to take care of their reputation as Benvenuto Cellini was, the ever plain spoken criticism too, might be allowed to fall silent."

We wonder if American lawyers put such amusing asides in their Briefs.

Though Anderson Rose had not the talent to make the most of all this material, to the unlegal mind the argument running through it seems unanswerable and too valuable to be passed over. But not so to the legal mind. Ruskin was treated in court as the privileged being he believed himself. Ridicule was the: weapon reserved by the other side and for Whistler, whose counsel ignored Ruskin, the writer of nonsense and malice, to defer to Ruskin as the "gentleman," well known to us all, with perhaps the highest reputation in Europe or America as art critic, some of his work destined to immortality. Less too was made of Ruskins's unwarrantable attack upon Whistler's prices, without which there would have been no case for libel, than the unfair and ungentlemenly way in which the "gentleman" had spoken of the plaintiff. The junior counsel, Mr. Petheram, would probably have brought this point out more emphatically. His opinion, quoted in the Brief, dwelt especially upon the necessity of having: 


\section{The Whistler Journal}

"As many witnesses as possible of position and known taste in readiness, even if it should not be possible to call them to state that Whistler holds a well-known position and that his works, though they may not please some critics, are of great and recognized merit. Artists, Picture Dealers and Art Critics will be the best witnesses for this purpose."

The picture dealers could have been wanted for no other reason than to testify upon this question of price, but though many were chosen none were called. A fact the Brief discloses is that, at the eleventh hour the difficulty was to be sure of any witnesses at all, except Albert Moore who was faithful from beginning to end. Whistler tried to take it lightly, though it was no light matter. $\mathrm{He}$ wrote to Anderson Rose on the subject on November 2I, 1878, only four days before the trial, but even then he treated it as of secondary importance. For he began by stating again his view of the case and suggesting another important note for Serjeant Parry -that he is known, and always has been known, for his independent position in art and for the Academy's opposition to him - that this would account for any evidence Academicians might give against him, and for an offer Academicians seem to have made to paint one of his pictures in five minutes-that his art was something apart, for which reason he did not need a large number of witnesses. And then, at last, he gives Anderson Rose good names that occur to him: Holmes, Librarian at Windsor Castle; Reid of the British Museum Print Room; Charles Keene; Tissot and what of the Rev. Mr. Haweis who had preached the beauty of The Peacock Room? What of Prince Teck who might answer for it? Though Boehm and Albert Moore ought to be enough. The cause of this anxiety was the withdrawal at the last moment of men who had agreed to go into the witness box. We had always heard that Leighton was among those who promised, and we never knew why he failed to appear until, in the mass of the Whistler documents, we came upon Anderson Rose's "Costs." The entry is for November 23d, Saturday, and the trial was set for the following Monday:

"Attending you almost the whole day, conferring on evidence and it appeared that Mr. Leighton refused to attend as he was going to be knighted on Monday. Mr. Burton also refused.

That was the last engagement Leighton would have broken. Albert Moore, William Michael Rossetti, and W. G. Wills gave evidence for Whistler. But if one of the artists and one of the art critics, whose presence the junior counsel considered essential in the witness box, put in an appearance, not one art dealer was heard from. And yet, Mr. Algernon Graves was in court, waiting to be called. 


\section{The Papers in Whistler v. Ruskin Action}

Mr. Bernard Oswald Colnaghi's evidence had been prepared in a Plaintiff's Proof given with the others in the Brief. He was willing to swear that Whistler's Nocturne in Blue and Gold was a most extraordinary and wonderful picture; that the libellous passage in Fors Clavigera was not fair criticism but libellous and a false account of Whistler and his work; that Whistler had had a very extensive education in art both in England and France; that the libel was "calculated to do Whistler great professional damage, stop the sale of his pictures or cause them to be sold at a greatly depreciated price." This was evidence a jury could have understood from a man whose business was to buy and sell and therefore worthy of their respect. But Mr. Colnaghi was not called. The failure to emphasize this question of price may be one reason why the jury valued the damages at the farthing Whistler never got, so often described as hanging on the watch chain he never wore.

The description of the trial we do not give, for Whistler's report of it, with his comments, is in the Gentle Art of Making Enemies, and in our Life of Whistler. But the legal side has never been published before, was not known to exist.

The Brief for Ruskin is shorter and less dry for, incorporated in it, are Ruskin's and Burne-Jones' own statements. Ruskin, in his, worked out carefully for his solicitors, his theories of art upon which the libellous criticism was based and the solicitors must have known they could not improve upon it. Ruskin evidently proposed to publish this. With some additional matter in the opening paragraph, references to the farthing damage and the four hundred pounds the law suit cost his friends, and under the title My Own Article on Whistler, it was found after his death among his mss. at Brantwood. A copy of it he had sent to Charles Eliot Norton on the second morning of the trial. But, as far as we know, it was never published until Sir. E. T. Cook included it as an Appendix of the second volume of Fors Clavigera in The Library Edition of the Works of John Ruskin. There, the chances are, it remained and might have continued to remain unread, interest in Fors Clavigera having been exhausted long since though not interest in the trial, had not Judge Parry happened to see the Brief, read it with the very special interest of the son of the counsel for Whistler, and contributed an article on it to The Cornhill for January, I92I. In this he spoke of the additional interest there would be if Whistler's side had also been preserved. We wrote and told him that it had been, that the documents were in our possession. It was then he succeeded in obtaining the Ruskin papers for us that they might be preserved with the Whistler papers in the Library of Congress. 


\section{The Whistler Journal}

Ruskin's memorandum is a convincing proof that he had really worked out his defence himself, that he had summed up what he meant to say when he wrote to Burne-Jones that the trial would be "nuts and nectar" to him because, in the witness box through the newspaper reports, he could get his views before the public as he never could by writing. When the time came, however, he was not well enough to appear. Both sides wanted him. He wanted to testify. Whistler, loving an open fight and having a sense of humour, wanted so much to hear his testimony that he proposed Ruskin should be subpoenaed. There were several postponements because of his mental and physical condition. Though Whistler's writ was issued on July $28, \mathbf{1} 877$, the case did not come into court until November 25, 1878, and even then his doctor would not let Ruskin attend. In his absence this statement was not read.

The main contention in his defense is that the paragraph in Fors Clavigera was no libel but justified by facts. He pointed out that the function of the critic was to recommend Authors and by this he meant also Artists, of merit to public attention and to prevent Authors of no merit from occupying it. "All good critics delight in praising as all bad ones in blaming.." His description of Whistler's work and character was accurately, absolutely, true, so far as it reached, and so far as it was accepted was calculated to be extremely beneficial to Whistler and still more to the public.

"I have spoken of the plaintiff as ill-educated and conceited-because the very meaning of education in an artist is that he should know his true position with respect to his fellow workmen and ask from the public only a just price for his work. Had the plaintiff known either what good artists gave habitually of labour to their pictures or received contentedly of pay for them, the price he set on his own productions would not have been coxcombry, but dishonesty. I have given him the full credit of his candid conceit and supposed him to imagine his pictures to be really worth what he asked for them. And I did this with the more confidence because the titles he gave them showed a parallel want of education."

That the price an artist asks for his work is nobody's affair but his own and the purchaser's, would never have been questioned by any critic less pontifical and autocratic than Ruskin. But it should be pointed out that Whistler had been getting the prices which were so exasperating to Ruskin, that, curiously, the picture Ruskin criticized was the only one for sale, and that Burne-Jones was at this very period asking far higher prices. But how the situtation has changed!

Ruskin continues his memorandum by explaining that his standard for the estimate of the relative value of pictures depended on the justice and clearness of the ideas they contained, a fact he had 322 


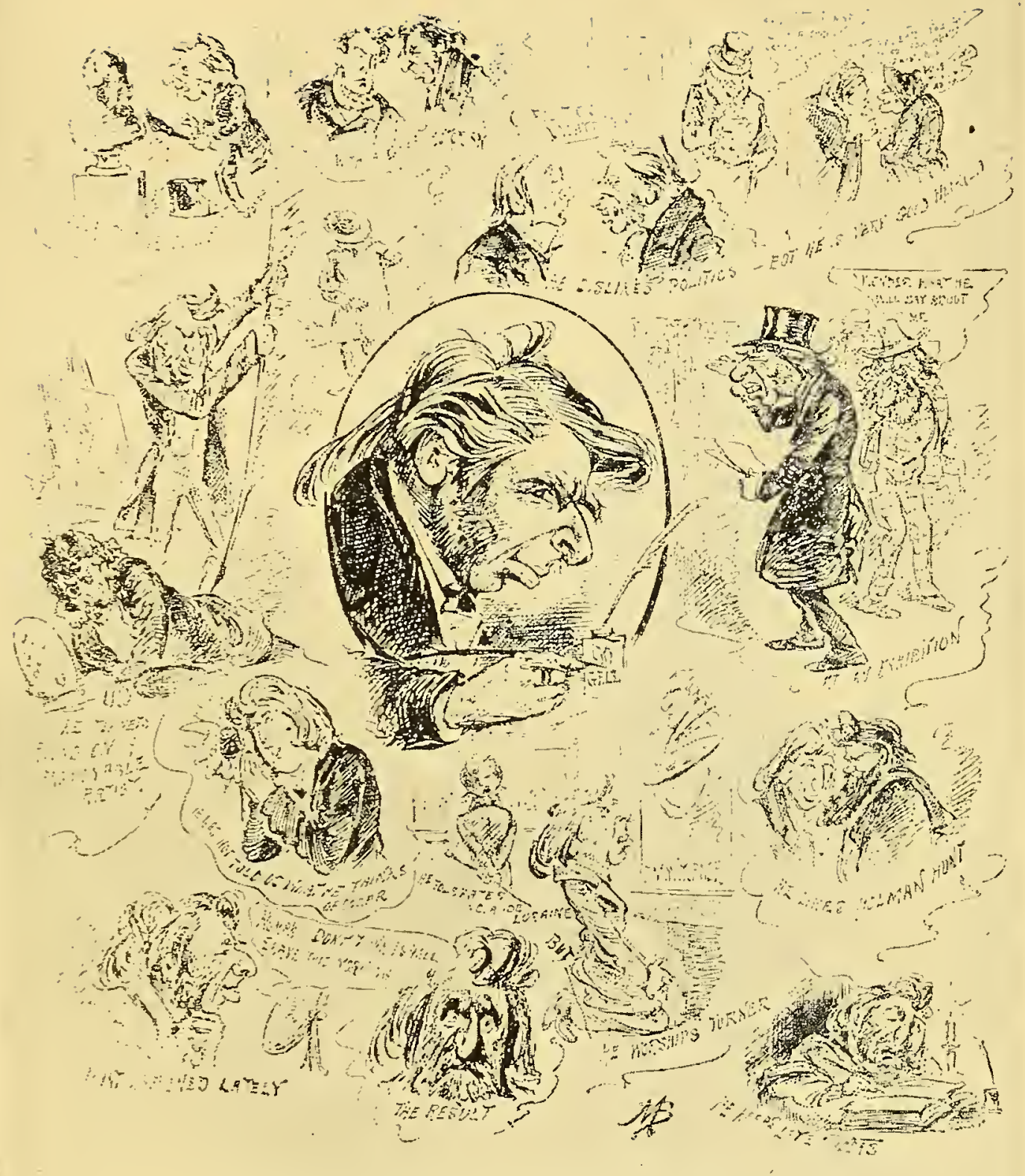

DA Y $S$ HTH CELEBEITIES. (46).

Min. Til'sklar.

TRIAL. CARICATURES OF TRIAL

PEN-AND-INK

By M. Bryan in "Judy" 



\section{The Papers in Whistler v. Ruskin Action}

especially dwelt upon lately for the benefit of the modern schools "which conceive the object of Art to be ornament rather than edification." He did not consider it unreasonable in a critic to "require of a young painter that he should show the resource of his mind no less than the dexterity of his fingers," and he thought the critic might, without libellous intentions, "recommend the spectator to value order in ideas above arrangement in tints, and to rank an attentive draughtsman's work above a speedy plasterer's." He can be agreed with when he condemns patronage of incompetent artists for charity's sake, and "the corresponding effort of large numbers of the middle classes, under existing conditions of social pressure, to maintain themselves by painting and literature without possessing the smallest natural faculties for either...." That advice might be taken very seriously in the United States today. Then he loses himself again, recalling flourishing periods, whether of trade or art, when the dignity of operative merchant and artist was held alike to consist in giving each in their several functions good value for money and a fair day's work for a fair day's wage. And he finishes by announcing his intention, whatever might be the issue of the action, to retire from public life, a retirement to which he was before sufficiently inclined by the langour of advancing age. Afterwards he wrote, in still plainer language, to Dean Liddell that it was better to refer his resignation of the Slade Professorship to its real cause "which is virtually represented by this Whistler trial." All the same, five years later he made known his willingness to accept if the post was again offered him, as it was, and he accepted, no doubt thinking that he had lived down the trial and its consequences.

In this memorandum, we have the real views upon art of the British public of the time through the mouth of its prophet. Ruskin's justification was more outrageous than the original libel. It would not be surprising for his criticism to be considered strong speaking today, the courage to express any save amiable approval amiably having long since gone out of fashion. But even at the time, when courage in criticism was more common, it was thought that Ruskin had gone too far. His junior counsel, Mr. Bowen, said so bluntly in his Opinion. Such language was, in his words, "exceedingly trenchant and contemptuous....Mr. Ruskin must not be surprised if he loses the verdict. I should rather expect him to do so." The truth is Ruskin was mad, he had been subject to intervals of madness for some years past. His friends would have been kinder had they restrained him from writing during these intervals, and he wiser had he, in his lucid moments, destroyed all the nonsense 


\section{The Whistler Journal}

he had written. His madness is the only excuse for his conduct, from his first attack upon Whistler until he accepted money to pay his costs from sentimental admirers, for his acceptance was a virtual admission that he still believed the libel justified.

It has often been said that Whistler suffered little from the neglect, misunderstanding or ill-will of his comtemporaries-that he exaggerated things. But no one can doubt the ill-will and misunderstanding after reading Ruskin's memorandum, still less after reading Burne-Jones'. The solicitors state in their Brief that they had applied to several Academicians for an opinion of Whistler, but had been refused, a refusal they attributed less to Academic appreciation of Whistler's work than to Academic disinclination to give evidence against a fellow artist no matter how bad his work might be. Burne-Jones, however, had no such scruples. He not only wrote out his opinion, but wrote it with a venom of which we would not have suspected him. Ruskin, it is true, puffed and boomed him, bought his work, paid his travelling expenses and his wife's on long journeys to delightful places, but gratitude for these favours hardly called for such an extreme of rancouragainst an artist who could in no sense be a rival. It seems the more venomous because the memorandum was for counsel alone, while, when he was in court with reporters taking down his testimony, he qualified his criticism, admitting there was still art in recent Nocturnes, recognizing Whistler's power, in the present as in the past, to suggest atmosphere and beauty of colour. His one other published opinion of Whistler is in his Life by Lady Burne-Jones, and in this he refers to Whistler an as artist whose technique was perfect and colour always good. He naturally could not foresee that his confidences to the lawyers would ever be revealed to the public in print. But his attitude was not exceptional among Whistler's contemporaries and to read Burne-Jones' memorandum, together with Ruskin's, is to discover in Whistler's defiance during the stormiest years of his life less of the mystery that has been made of it. And it might be a good thing if recent American authorities had had a little bit of knowledge of the man they were writing about, or the brains to understand what they read. Or is it the everlasting anglomania?

What Burne-Jones thought was this: that scarcely anybody regarded $\mathrm{Mr}$. Whistler as a serious person; that for years past he had so worked the art of brag as to succeed among the semi-artistic public.

"But amongst artist his varieties and eccentricities have been a matter of joke of long standing." There was at first sufficient excellence in his work to make artists look forwara to his future, but the qualities he possessed appeared to be soon 324 


\section{The Papers in Whistler v. Ruskin Action}

exhausted and it was long since further fulfillment had been expected. He was notoriously without principle or sentiment of the dignity of his art. "It is a jest but a fact that he has been ceaseless in all company for years past in depreciating the work of all artists, living or dead, and, without any shame at all, proclaiming himself as the only painter who has lived"- "he has a perfect estimate of the value of this trumpeting"- "he has never yet produced anything but sketches more or less clever, often stupid, sometimes sheerly insolent-but sketches always -not once has he committed himself to the peril of completing anything."

"That Whistler should be an incomplete artist concerns himself alone, but that for years past he should have been proclaiming this incompleteness to be the only thing worth attaining concerns art itself and all artists, and Ruskin's forty years of striving to raise his country's skill would have ended tamely if he could have quietly let pass Mr. Whistler's theory and practice." Whistler's plan has been to found a school of incapacity-his work has the merit that one sees in the work of a clever amateur-There is often not so much appearance of labour in one of his pictures as there is in a rough sketch by another artist and yet he asks as much for one of those as most artists do for pictures skillfully and conscientiously finished-Mr. Ruskin's language is justified on the grounds of the scandal that this violent puffing of what is at best a poor performance brings upon art. "If any one caring, as, Mr. Ruskin does, for the question of art could think this meaningless scribbling should be looked upon as real art, for admiration and reward, I think he might lay his pen down and never write again, for art would be at an end."

That Burne-Jones could have been guilty of such a misconception, such a misrepresentation of Whistler could hardly be believed were it not there, written out plainly, in the Brief. Whistler, who had done nothing to fulfill his first early promise, from whom further fulfillment had long ceased to be expected who had never produced anything but sketches, had then painted and exhibited the Mother, the Carlyle and the Miss Alexander, The White Girl, The Little White Girl, and the elaborate Japanese Series, to say nothing of the Nocturnes reviled by Ruskin-and several of these paintings were in the Grosvenor and shown at the trial. We knew that Burne-Jones was not in sympathy with Whistler's work, but we had not fancied him so blinded by narrow prejudice, and we wondered why he was so upset when we told him how his work interested Whistler. Nor does it seem possible that the perversion of the "Why drag in Velasquez" story could have been anything save intentional. That Whistler held himself to be the only painter who ever lived, and said so, is farcical to those who knew his reverence for the Old Masters and generous appreciation of contemporaries whose work he thought good. No less unpardonable is the representation of Whistler as notoriously without principle or sentiment for the dignity of his art. It was his care for the dignity of art that had made him force Ruskin into the law courts. Nor could Ruskin's solicitors have doubted it after one experience with him during the 
preparations for the trial. They had demanded to see the pictures he had shown at the Grosvenor. Whistler objected. He was not going to allow anybody to discuss and criticize his pictures-were the persons who asked proper experts? Was not the whole thing a question of Pure Law, not of Criticism? The Court, however, gave the solicitors for the defence an Order for Inspection, and then they demanded to have the pictures brought to Anderson Rose's office. Whistler was outraged. He might have to obey the ruling of the law, but his pictures were not to be shown in any accidental or promiscuous manner-pictures were not to be handled about like samples of butter to be inspected by chance experts in the market place, and his were to be shown properly hung as they were when first seen by Mr. Ruskin, his studio was the fit place with proper light; to his studio Messrs. Walker, Martineau could come -and to his studio, accordingly, they went, which must have given them a better idea of an artist's respect for the dignity of his art than Ruskin's preaching and Burne-Jones' malice. The same spirit of malice seems to have inspired the selection for details"circumstances" - useful for counsel in cross-examination. The story of Whistler's quarrel with Haden eleven years before in Paris was dug up, together with his expulsion from the Burlington Fine Arts Club which was the result, though nothing is said of the fact that Dante Gabriel and William Michael Rossetti were so indignant that they immediately resigned in protest. The description of the materialized spirits or figures in a London fog he painted as portraits was resurrected from the Times, probably Tom Taylor's -and TomTaylor and Frith were the only two other witnesses that Ruskin could get, though he had hoped for Leslie, Richmond and Marks. The decoration of The Peacock Room is wilfully confused with The Gold Scab-" he painted the walls with what he called Devil Peacocks, being things with Devils' heads and Peacocks' bodies, and on the tails he painted sovereigns intended, as he stated, to represent Mr. Leyland's wealth" —and of course,all that can be is made of the differences with Leyland over the question of payment. Altogether, the Ruskin Brief is an amazing document and does not present the Whistler v. Ruskin case as a creditable incident in Ruskin's career. The fact that Whistler was an American may have had something to do with the personal feeling shown. No American artist has gone to England who has not had to fight, who has not had a hard time of it. Even though West became President of the Royal Academy, it was by no means always easy for him, and members have often wished the others who have followed him into the Academy out of the way and their places 326 


\section{The Papers in Whistler v. Ruskin Action}

filled by natives. Among the papers are copies of $P$ unch, with comic reports of the trial, and it's sneers at "the Anglo-American Artist" prove what we have said completely.

The Whistler-Ruskin documents, though legal, still live with the passions and turmoil of the days long dead when the virtue of art was in the subject and its value measured by the time and labour spent upon it. Pictures were for edification, for conscientious toil the artist was given his reward. Art was lost in the maze of morality, genius could not contend with industry. When Whistler fought the false gods of his generation, it was thought he was fighting for the fun of it. How strong the enemy was, and what a good fight he made is recorded in these documents which it has been our privilege to place safely in the Library of Congress. Even at the time, unfriendly to him as was the outlook, Whistler, with his knowledge of a lifetime, won the case-though not without the farthing sneer for the victory-and the result was not "nuts and nectar" but gall and vinegar for J. R. Oxon. And now Ruskin has more fame as an artist than as an author and Burne-Jones is near forgotten, and Whistler has triumphed all over the world. 



\section{INDEX}

Аввеу, Edwin, A., 213, 295, 297, 309.

Abbey, Mrs. Edwin A., I 3, 296.

Abbott, Mrs. (See. Jo.)

Abram, Mr., 72, I 47, I68.

Académie Carmen, I 5, 32, 33, 35, 58, 7 I, $244,254,256$.

Addams, Clifford, 34, 37, 246256,272 .

Addams, Mrs. C., 26, 27, 33, 35, 37, 254, $257,266,272$.

Adler, Elmer, I 27, I 29.

Agnew, Messrs., 309.

Alexander, John. W., I64, 228.

Alexander, Dr. L. C., 158.

Alexander, Miss May, I34.

Alexander, W. C., I09, I 29, 134.

Allingham, H., 175 .

Alma-Tadema, Sir Laurence, I22, I69, I94, I97, I98, 230, 236, 241, 296.

Altman, W. R., 99.

American Hall of Fame, 22I.

Americaine, $L$ ', 163 .

Andrews, Mr., 2.

Andalouse L', I99

Andromeda, I 7 I

Ape's and Spy's cartoons, 6.

Archer, William, 295.

Architectural Review, The, 7I, 72,I47.

Armand-Dayot, Inspecteur Générale des Beaux-Arts, 16.

Armstrong, M., 29.

Armstrong, Sir Walter, 38, 39.

Art and Art Critics, 78, 305 .

Arts and Crafts Exhibition Society, 34.

Arts Club, 3, 202.

Art Journal's Paris Exhibition Number, The, I9I.

Art Journal, The, 192.

Art Nouveau, L', 73.

Art Worker's Guild, 78, 8r, 148, 25 I, 293.

Ashbee, C.R., 237, 238, 241, 246, 247, 250, 257.

Astor, W. W., 30.

Astruc, editor of L'Artiste, 91.

Atalanta in Calydon, 28.

Athenæum Club, 10, I39, 259.

Aubert, M., 9I.

Augustine, I94, 202, 206, 208, 21 I, 212, 220, 223, 225, 23 I , 235, 236, 296.

Avery, S. P., 2.

Axenfeld, M., qr.
Bacher, Otto H., I65.

Bachimont, Madame, 86.

Baden-Powell, Major-General, r6y

Balcony, The, 137.

Bal Bullier, 92.

Bargello, The, 47.

Barrie, Sir J. M., 9, I 79.

Barthe, I I 7.

Bartlett, Paul, 309.

Bartlett, Mrs. Paul W., I 56.

Barye, C., 55.

Baronet and the Butterfly, The, 19, 20. 306.

Bathers, Courbet's, r62.

Battersea, Lord, Iog.

Battersea Bridge, I20, I30, 137.

Bate, Miss Inez, (See Mrs. C. Adams)

Bayliss, Sir Wyke, 2 I 3, 250, 268.

Beardsley, A., I2.

The Wagnerites, I 2

Béarn, Comtesse de, i I I.

Beaumont, Sir George, 182, 184 .

Beaumont, Lady, I82, I84.

Beaux, Cecilia, 39 .

Becquet, 90, 9 I.

Beefsteak Club, 183 .

Beerbohm, Max, I6.

Beerbohm-Tree, Sir H., 197.

Bell, Edward, 26I, 280, $28 \mathrm{I}$.

Bell, Mrs. Arthur, 258-260, 280, 28 I.

Bell, Sir Hugh, 309.

Belleroche, Albert, I6.

Belloc, Mr. Hilaire, 76 .

Belloc, Mrs. Hilaire, 76.

Bénédite, Léonce, 83, 84, 205, 206, 230, 242, 3 I 2.

Benham, Captain, I8I, 182.

Benjamin-Constant, 49.

Berenson, B., 47.

Bernhardt, Sarah, 91.

Beurdeley, M., I I.

Biarritz, I62.

Bibi, Lalouette, 85.

Bibi, Valentin, 91, 93.

Billingsgate, $\mathbf{1} 86$.

Bismarck, Count, 57, 26r.

Blaikie, Walter B., I73, 176, 178, I96.

Blake, William, $25 \mathrm{I}$.

Life of, 7 I

Blanche, M. Jacques., I4, 84, I 5 I, 309.

Blenheim, Io.

Blue Girl, The, 134 


\section{INDEX.}

Blue Wave, The, Io, 162.

Boat Race Day, Hammersmith Bridge, Greaves', I43.

Bodington and Alexander, 243.

Boehm, Sir E. I., I85, 308.

Statue in the Chelsea Embankment, Gardens, 178.

Boldini, J., I 7, I8, 39, 263.

Bone, Muirhead, 56 .

Bonheur, Rosa, 37.

Borie, Mrs. Adolphe, 212.

Boston Library, 34, I 42 ,

Botticelli's, Spring, 299

Boughton, George, 196, 213.

Bowdoin, W. G., 220.

Brinton, Dr. Christian, I40, 145.

British Museum, 66, 74 .

Brock, Mr. Clutton, I 42, I 45.

Bronson, Mr. \& Mrs., I 65.

Brooklyn Museum, I34

Brown and Gold, 199.

Brown, Ernest G., 2, 65-67, I33, 171-172, I73, I 80, I 84, I 86, I 88, 227, 265, 295, 309.

Brown, Prof. Fred, 202, 268, 3 I 4 .

Brown, Ford Madox, 170.

Brown, Oliver, I I 4.

Bruckman, W. L., 233.

Buller, General, 54, I54, 240.

Burlington Magazine, The, 296

Burne-Jones, Sir E., 27, 62, 63, 205, 300, 322-327.

Burns, Robert, 177.

Burrell, Mr., I 84 .

Butt, Major, 226.

Campbeli, Lady Archibald, 166, 309.

Campbell, Lady Colin, 55, I66.

Canfield, Richard A., 209, 235, 242, 243, 270, 27 I, 273, 275, 28I , 285, 286, 309 . collection, 180 .

Canichon, 86.

Caran D'Ache, 38, 193.

Carfax Gallery, I83.

Carlyle, Thomas, I04, II6, II8, I19, I74, I 75, 301, 325 .

Portrait of, I0, 29, I29, I36, I37, I78, 288.

Carmen, I 52, 172, 244, 257, 258.

Carmen (See La Napolitaine), 73.

Carmen, Atelier, 228.

Carolus Duran, 7I, 72.

Cauldwell, John B., I99, 201, 203-205.

Cavour, 37, I 34

Caxton Club, I 45-149.

330
Cassatt, Miss Mary, 167.

Cassatt, Mrs., 134 .

Cellini, Benvenuto, 319.

Centenary Exhibition of Lithography, 20.

Century, The , 4, 57, 85, 293, 296.

Chambers, Miss Alice, 59, 67, 68, I 30 , I65, I66.

Champ-de-Mars Salon, 6, 155.

Chase, Wm. M., 8, 7 I, I I2, I 41, 195, I96, $226,239,240,308$.

Chefdeville, Louis, 220.

Chelsea Arts Club, 2 I, I I 4, 2 I 3.

Chetwynd, Sir George, I 93.

Child, Theodore, rog.

Christie's, 66, I68, I85.

Claghorn, James, L., 2.

Clark, Sir Charles Purdon, 4.

Clark, Irving, 3 I-33.

Claude Lorraine, 248.

Claus, Emil, 6.

Cole, Alan S., 108, 109, 112, 129, 139, I 44, I 57, 25 I, 254 .

Cole, Mrs. Alan S., 30, I03, I08, 133.

Cole, Sir Henry, 202, 318.

Portrait of, 134 .

Cole, Timothy, I7, 5 I, 53, 247, 248, 309.

Collins, General Arthur, 193 .

Colnaghi, Messrs. D. and P., 309. Bernard Oswald, 32 I.

Colvin, Sir Sidney, 64 .

Company of the Butterfly, I 5.

Connie Gilchrist Skipping-The Gold Girl, I 83, 260, 27 I.

Conway, Sir W. Martin, 309.

Cook, Sir Theodore Andrea, 177, 224, 226, 321 .

Cooper, Mr. Colin Campbell, 256.

Cooper, Mrs. C. C., 256.

Coppée, Professor, 240.

Corder, Rosa, 59-61, 70, 30I. Portrait of, 1 26, 276, 278-280.

Cormon, L., 35.

Cottier Galleries, New York, 139.

Courbet, G., 79, 90, 92, 94, I62.

Cowan, J. J., 82, 309.

Cox, Kenyon, 66, 67, I 26.

Craies, Mrs., 160.

Crane, Walter, 25, 263, 3 I3.

Crawford Marion, 22 I.

Cremorne, 134 .

Cremorne Gardens, 97, I I 7, 140.

Series, 48 .

Critic, The, 295.

Crockett, S. R., I77, 179. 
Cundall, Mr., 20r.

Curtis, Mrs., I65,

Cust, Harry, 9

Cust, Lionel, 309.

Custer, General, 57.

Custer, Mrs., 54, 57.

Daily Chronicle, The, 15, 170, 198, 200, 2 I 2,2 I 7,2 I $8,222,246,283,284,295$.

Daily Mail, The, I 38 .

Daily News, The, 319.

Daily Telegraph, The, 30.

Dannat, IV. L., 204, 205.

Darrach, Doctor, 2.

Daubigny, C. F., 55 .

Daumier, H., 55 .

Davenport Brothers, $\mathbf{I 7 7}$.

Davey, Humphrey, 2 I 9.

Davies, Rev. Mr., I 19.

Davis, Edmund, 79, 309.

Davis, Jefferson, I80.

Degas, H. G. E., 227.

Delacroix, E., 80.

Delannoy, Ernest, 43, 44, 49.

Delâtre, A., 8I, 95 .

Dell, R., 295.

Denny, Annie, portrait of, I 7 I.

Derby Day, Frith's, 78.

Deschamps, L., 85, 106.

Dewhurst, Wynford, 263, 264, 296.

De Wet, General, I 46, 262, 263.

Dickens, Charles, I97, 270.

Dixon, Miss, 33.

Dobbin, James C., I 8I.

Dobson, Austin, 227, 309 .

Don Baltasar, I20.

Donkin, Sir Bryan, 226.

Donkin, Lady, 68.

Doré, G., 263.

Douglas, Langton, 50.

Dowdeswell, Messrs., I I2, I 36, I40, I45, I $88,309$.

Dowdeswell, Walter, 125, 132, 135-137, $233,249$.

Doyle, Sir Conan, 9.

Draughn, Marion, 244.

Dreyfus Case, The, 76, 249.

Drouet, C., I I 49, 86-96, I 29, I62, 245.

Drouot, Hotel, 244.

Duke of Marlborough, I I.

Dulac, Mr. and Mrs., I60.

Dulwich Gallery, 229.

Du Maurier, G., 266.
Dunthorne, R., 148, 230, 272, 290, 29I, 293, 309.

Durand-Ruel, 201.

Duret, Théodore, I I , 33, 55, 85, 90, 9I, 96 , I1 1, 164, 165, 227, 248, 261, $263,265,290,292,293,295-297$, $307,316$.

Portrait of Whistler, I 34.

Duveneck, F., 7 .

EAST, Alfred, Sir, I43, 313.

Echoes of Whistler, $\mathrm{I} 58$.

Eddy, Arthur J., I 46, 240.

Eden, Sir William, 20, 32, 202.

Eden, Lady, 228.

Eden Case, 2 I.

Eden, Sale, 34 .

Edwards, Mrs. Edwin, 85, 227.

Efre Deans, I63, 245, 247.

Eldon, R., 123.

Elwell, Mr., 77, I67, I69, I73, I 77, 179.

Emilia in England, 25.

Ernest G. Brown and Phillips, Messrs., I73.

Etchers and Etching, I47.

Etty's studio, 2I9.

FAGAN, Mr. Louis, 74, 77.

Fagan, Mrs. Louis, 77.

Falling Rocket, The, 4.

Fantin-Latour, 83-86, 192.

Fantin, Madame, 84,85 .

Farquhar, Mrs. (Miss Peck), I55.

Faustine, 26.

Fernald, C. B., 3I.

Cat and the Cherub, The, 26.

Ferris, Gerome 2.

Ferris, Stephen, J., 2.

Fine Art Society, I 72, I 86- I 88, 265, 268

Venice show at, 182 .

Finette, 9I.

Fireworks at Vauxhall. 5.

Fisher, Mark, 213.

Fisher, W. J., 284, 292.

Flagg, James Montgomery, I 35 .

Floury, H., 264.

Flower, Cyril (see Battersea, Lord), rog.

Forain, I.L, I 53.

Ford, I. N., 273.

Ford, Paul Leicester, 193.

Ford, Sheridan, 214, $216,219$.

Fors Clavigera, 317-319, 321, 322 .

Fortnightly Review, The, 24, 267.

Fraley, Mr. J. C., 245. 


\section{INDEX}

Fraley, Mrs. J. C., 245.

Frankland, Mrs., 270.

Franklin, Maud, (see Maud).

Freer, Charles L., 46, I I2, I I3, I 34, I46, I 56, 24I, 242, 246, 258-260, 292, 294, 297, 307, 309 .

Collection, I6r.

Gallery, Washington, 244.

French Cathedrals, The, I2.

Freshfield, Douglas, 70.

French Set, The, 49, I04.

Frith, W. L., 77, 78, I2 I, 169, I 49.

Frick, H. C., 99, I I 3, 27 I, 3 IO.

Fumette, 86, 90 .

Fur Jacket, The, 4, 163, I 84 .

Furnival, Doctor, F. J., 26.

Furse, Charles, 9 .

Gabrimi, Dante, 326.

Galsworthy, John, I 50, 316.

Galsworthy, Mr. S., I 5 I.

Garlant's Hotel, I 7 .

Garrick Club, 24.

Gassoway, Francis, (See Howard, Francis) 275.

Gavarni, 87.

Gazette des Beaux-Arts, 83 .

Gay, Walter, 228.

Gentle Art of Making Enemies, The, 36, I83, 2I2, 216, 219, 250, 265, 306.

Gibson, Charles Dana, I35.

Gilbert, Alfred, 275.

Gilchrist, Mrs. Alexander, 7 I.

Gilchrist, Herbert H., 7I.

Gilder, Joseph, 276.

Ginsberg, Doctor, I 58.

Giotto, 299.

Glasgow University, 275.

Gleyre's studio, 90,172 .

Globe, The, 200, 203, 205, 206.

Godwin, Mrs., E. W., later Mrs. J. McN. Whistler, I I9, I66, I67.

Godwin, E. W., 106, I 57, 166, 252, 302, 303.

Godwin, E. I9, 21, 2 1 7, 296

Gold Scab, The, I I 3, 326.

Goncourts, the de, 82 .

Goodyear, W. H. I05.

Gosse, Edmund, 27, 192 ,230, 295, 309, 3 IO.

Goulding, Charles, I 49.

Goulding, Frederick, 80, I2 I, I22, I 48, I 49.

Goupil Gallery, I0, 8I, I36, I43, 284.

Grand, Madame Sarah, I90.
Grand Palais des Beaux-Arts, 73.

Graphic, The, I99, 200-203, 205.

Grasshopper, The, I I9.

Gravesande, Storm Van s', I I2, 309.

Graves, Messrs. H., 60, 266.

Gray, W. E., 50, I05.

Greaves, Miss Alice, I 36.

Greaves, Miss Tinnie, 97, II8, I19, I3 I, I38.

Greaves, Mrs., I23.

Greaves, Walter and Harry, 98, I06, I I4-I 45, I6I-I63, I66, I 79 . portraits, 3, I 41, I84.

Greiffenhagen, Maurice, I90, I9 I, 275.

Greiffenhagen, Mrs. M., I90, I9I.

Grimaldi, 74, I47.

Grimthorpe, Lord, 307, 309.

Grolier Catalogue, I47, 242.

Grosvenor Gallery, 2 I5, 325, 326.

Grover, Oliver D., I64.

Guthrie, Sir James, I4, 47, I50, I 5 I, 263, $275,283,297,309$.

Hague, The, 245, 247, 249, 259.

Haden, Arthur, 2 I 2.

Haden, Lady, 78, I29, 253, 254.

Haden, Sir Seymour, 2, I 5, 43, 45, 79, 80, $82, \mathrm{I} 82,203,2 \mathrm{I} 2,254$.

Halkett, G. R., I43, I98-200.

Halliday, Miss, 33 .

Hamilton, J. McLure, 82, I43, I56, 2 I4, 2I 5, 2 I 7-2 I9, 277, 296.

Hamilton, Mrs. J. McLure, I43.

Hammond, Mr. \& Mrs., 2 I 2.

Hardy, Thomas, 309.

Harmony in Blue-Gray, Greaves', I44.

Harmony in White and Gray, by Harry Greaves, I44.

Harper Brothers, Messrs., I 58, I94.

Harris, Frank, I6.

Harrison, Alexander, 72, 309.

Hartley, Harold, 206, 281, 282, 307.

Hatrick, A. S., 28, I 39, 295.

Haweis, Rev. Mr., 320

Hawthorne, Julian, 250.

Hecker, Colonel, 82.

Heffernan, Joanna (See Mrs. Abbott and Jo).

Heffernan, Patrick, I6I.

Heinemann,William, $1,15,16,27,32,34,38$, 4I, 45, 50, 53, I05, IIO, I33, I39, I42, I45, I47, 190, 197-199, 204, 209, 2 I0, $213,216,218,220,230,237,249,259-$ 26I, 264-266, 294-296, 306, 307, 308. 


\section{INDEX}

Heinemann, Mrs. William, 32, 38, 39, Israels, Josef, 309. 45, 204, 209, 2 I0, 220, 265, 276, 296. Ives, Halsey C., 277.

Henley, IV. E., I 5, 34, I77, 291, 292.

Hensman, Misses, I89, I98, 23 I.

Herbert, J., I 59.

Herkomer, Sir Hubert von, 8.

Hervier, A., 55 .

Heseltine, J. P., 309.

Hewlett, Maurice, 283, 309.

Hewlett, Mrs. Maurice, 76.

Hogarth, 227.

Shrimp Girl, 257.

Hogarth Club, 9, I06, 214.

Holme, Charles, 295.

Holmes, G. A., 6, i I 9 .

Holroyd, Sir Charles, 309.

Hommage à Delacroix, 80 .

Horne, Herbert, 45, 46.

Horniman, E. J., 307.

Hotel du Bon Lafontaine, I I.

Howard, Francis (Francis Gassoway, Francis O'Connor, 275).

Howard, George [Lord Carlisle], 59.

Howell, Charles Augustus, 58-70, I07, I I 7, I 2 I I I 30, I 33, I 34, I64, I69, I 70.

Hubbard, Elbert, 274 .

Hubbell, Captain, I 13.

Huish, Marcus B., I 88.

Hullah, Miss, I60.

Hunt, W. Holman, 26, 46, 169.

Hunter, Captain Charles H., 74-77.

Hunter, Mrs. Charles H., 74-77

Hunter, Mrs. Charles, 236.

Huth, Mrs. Louis, 102.

Hutton, Mrs., I I9, I 22.

$I d y l, A n, 8$.

International Art Notes, 203.

International Society of Sculptors, Painters and Gravers, I4, 145, I5 I, 305, $306,307$.

Dinner held in Café Royal, 283.

Exhibitions, 2, I18, I37, I40, I45, I62. (See Memorial Exhibition.)

International Exposition in Paris, (See Paris.)

In the Studio. 161, 300.

Ionides, Luke, 27, 83, I I 2, I 32, 277.

Constantine, 27.

Irish National Gallery, 39.

Irlandaises Les, Courbet's I62.

Irving, Sir Henry, I 4 I.

Etching of, 271.

Portrait of, 184 .

JACKson, Ernest G., I 78.

Jacomb-Hood, G. P., i 13 .

Jameson, Frederick, 6 .

James, Francis, 314.

James, G. P. R., I 40.

James, Henry, 309, 315.

Janvier, Thomas A., 50, $5 \mathrm{I}, 200,220$.

Janvier, Mrs. Thomas A., 50, 5 I, 200, 220.

Jekyll, 102, I 10.

Jenner, Mr. \& Mrs., 68.

Jerome, District Attorney, in New York, 280.

Jessop, W. H., 309.

Jessop Collection, 189 .

Jo (Joanna Heffernan, Mrs. Abbott), 69, II 8, I6I-163, 254 .

Johnson, Robert Underwood, 18, 99, I35.

Jones, Mrs. Cadwalader, I 55 .

Jones, Gussie, I6 I.

Jopling-Rowe, Mrs., 167.

Journal, Le, I93.

Kauffmann, Angelica, 93.

Keene, Charles, 320.

Kendall, M., I60.

Kennedy \& Co., Messrs., I 7.

Kennedy, E. G., 2, I7, 3I, 39, 41, 50, 5 I, $58,73,74,77,96,97,147,209-2$ I 2,242 , 27I, 273, 290, 291, 293, 294.

Keppel, David, I48.

Keppel, Frederick, 2, 80, 8I, 85, 86, 90, 96, I $45-147,149$.

Keppel, Messrs. Frederick \& Co., I 48.

Kerr-Lawson, J., 45, 46, 47, 140, 178, 296.

Kerr-Lawson, Mrs. J., 293.

Kerr, Dr. Norman, 226.

Kerr, Lord Ralph, 219.

Kinsella, Miss, 297.

Kipling, Rudyard, 309.

Knoedler, Messrs., I61, 286.

Konody, P. G., I38, 145.

Kruger, President, 204.

Kruger, Mrs., 54 .

Kyllman, O., 22.

Labouchere, Henty, 181-I83.

Lady Elcho, Mrs. Adeane and Mrs.Tennant, Sargent's, 39.

Lady Meux, 10. 
Lady Standing at a Spinet, Ochtervelt's, 225.

La Farge, John, I 55 , I 56.

Lalouette, 86, 93.

Lambert, John, 7I , 72, 87.

Landor, A. H., Savage, 209-2I I.

Landseer, Sir Edwin, 172.

Lane, Sir Hugh, 70, I38.

Lane, Mrs. John, 28.

Lange Leizen, 135, 300.

Lannion, 56.

Lanteri, Prof. E., 83, 235, 275.

Laurenco Marquez, I 80 .

Laus Veneris, 28.

Lavenue's, 22 I.

Lavery, Sir John, 14, 21, 46, 47, 73, 84, I 50, I 52, I 79, 194, 195, 200, 201, 217 , 2 I $8,258,263,270,273-275,283,286$, 288, 292, 294, 295, 297, 307, 309, 312.

Le Brun, Madame Vigée, 37 .

Lee, Gerald ,62.

Lee, Mrs. Gerald, 62.

Lee, Mr. Stirling, 307.

Legros, A., 79, 80, 84, 89, 16 I.

Leicester Galleries, 65.

Leighton, Sir Frederick, I22, 320.

Leland, Charles Godfrey, 3.

Lepere, A., 309.

Le Sidaner, H., 284.

Leslie, G. D., 213, 326.

Lewis and Allenby, 197 .

Lewis, Sir George, 34, 2 I6.

Leyland, Florence, I05.

Leyland, Frederick R., 54, 67, 98-1 I3, I 22, I33, I 34, 302, 326 .

Leyland, Mrs. Frederick R., 54, 97-II3, 301.

Portrait of, I20, 134 .

Liberty, Lazenby, 64.

Liddell, Dean, 323.

Lillie in Our Alley, 77.

Lindsey Row, houses in, 48, 49, 59, IOI, 102, I04, 108, I16, I 17, I21, I24, I30, I39, I6I.

Linton, Sir James, 15.

Lithography and Lithographers, II I, 147 .

Little Cardinal, The, 264.

Little Johannes, 306.

Little Lady Sophie, 77, 28I.

Little Rose of Lyme Regis, 287.

Little White Girl, The, 48, 49, 78, 126, 161, I 19I, I 99, 200, 300, 325 .

Lobsters, The Loves of the, 134

Loeser, C., 47.
London Garland, A, 15, 73.

Long Bridge, The, $25 \mathrm{I}$.

Lord Donoughmore, 20.

Louvre, the, $48,64,85,89,90,93,94,169$, I 7 I, 247.

Lowrie, Mrs., 272.

Lucas, George A., 55, 56, 85, 87, I 54, I64, 277.

Ludovici, A., 40, 275.

Lungren, Fernand, 54, 57, 58, 2 I 7-2 I9.

Lungren, Mrs. Fernand, 54, 57,58, 2 1 7-2 19.

Luxembourg, the, 84, 205, 230.

Lyme Regis, 56.

MACCol.t, D. S., 9, I3, I9I, I92, 225, 236, 237, 275, 276, 278, 294.

Mac Ewen, Walter, 197.

MacKay, A., I $72,230$.

Maclaren, Ian, I 79.

MacLaughlan, D. S., I 59-161.

MacLaughlan, Mrs. D. S., I6o.

MacManus, Blanche, 220.

Macmillan, Mrs. Maurice, 58.

MacMonnies, Frederick, 309.

MacMonnies, Mrs., 262.

Macquoid, Percy, 269.

Magazine of Art, The, 198-200.

Burlington, The, 296.

Mallarmé, Stéphane, II.

Vers et Prose, II.

Manet, E., 78, 192, 201, 21 7, 267, 296.

Mansfield, Howard, 2, 8I, I I 2, I47, 309.

Mansfield, Mrs. H., 220.

Marchant, William, I33, I36, I37, I40, I $42,143,259$.

gallery, 138 .

Marchesi, Madame, 227.

Marks, Murray, I09, I 10, 302, 326.

Martin, Dr. Benjamin Ellis, 4 .

Martin, Mrs. Bradley, 19, 20.

Martin, Henri, 88, 92.

Martin, Homer, 229, 230, 233.

Martin, J., I I 7 .

Martineau, Harriet, 3 I8.

Matin, Le, 296.

Maud (Maud Franklin), 69, I02, I05, I I8, I I9, I63, I64, I66, 254 .

Maxse, Admiral, I96, 217 .

Mazzini, I74.

McCarter, Henry, 156.

McCarthy, Justin, 225.

McCullock, George, 46, I I 3.

McIlvaine, Clarence B., I 58.

McNeill, Miss, Eliza, I04, I82. 


\section{INDEX}

McQueen, W., 48.

Melchers, Gari, 309.

Melville, Arthur, 215.

Memorial Exhibition in London, Whistler, I 905, I I3, I 22, I 45. in Paris, I905 84.

Meninas, Las, 5, 225.

Menpes, Mortimer, $5,63,65,66$, I I 5 , I4I, I 80, 225, 24I, 250, 260, 288, 296.

Mère Gérard, La, 78, 80, 93.

Meredith,George, 24, 25, 170, 262, 263,3 16.

Meredith, Owen, 227.

Merritt, Mrs. Anna Lea, 3.

Meryon, C., 267.

Metropolitan Museum, 4, I83.

Metsu, 39 .

Meyer, G., I 48 .

Meunier, Constantin, 6, 7 .

Michael, Angelo, 26, 4I, 64, I7 I, I75.

Michie, Coutts, I I 3 .

Milcendeau, Charles, I53.

Miles, Frank, I I 9 .

Millais, Sir J. E., 22, 23, 25, 29, 64, I29, 232.

Life of, 26.

Millais, Lady, 25.

Millet, Jean-François, 72, 73 .

Milner, Sir Frederick, 54.

Mirbeau, Octave, 267, 268.

Miss Alexander, Portrait of Miss Cicely H. (Mrs. Spring-Rice), Io, 69, 73, I 16, I 23, 285, 30I, 325 .

Mitchell, Dr. Chalmers, 39, 197, 223, 224, 296.

Mitcheil, Mrs. Chalmers, 38, 39, 197, 223, 224.

Moncrieff, Mrs. Lynedoch, 227.

Monna Lisa, 167 .

Montesquio, Comte Robert de, 270. Portrait of, 270, 271.

Moore, Albert, I23, I 41, 229, 233, 320.

Moore, George, 9, Io, 24I, 285.

Moran, Peter, 2.

Moreau Nelaton Collection, 80.

Morgan, J.P., 99.

Morgan, William De, I78.

Morley, John, 24.

Morning Post, The, I09, I38, 227, 247.

Morris, Harrison S., 25, I 56, 239, 247, 308.

Morris, Mrs. Harrison S., I 70, 239.

Morris, Phil, I03, IO4, I23, 213.

Morris, William, 27, 25I, 299, 300, 30I, 303,305 .

Morris, Mrs. William, 62.
Morse, Sidney, 34 .

Moscheles, Felix, 70, I 5 I.

Mother, The, 3, 66, 73, 84, I16, I20, I2I, I23, I69, I74, I84, 30I, 325 .

Moulton, Fletcher, 62.

Mount Ararat, I I3, I34.

Muller, Iwan, 30, $3 \mathrm{I}$.

Mura, Frank, 70, 7 I.

Mura, Mrs. Frank, 70.

Murray, C., Fairfax, 66.

Music Room, The, I0, $\mathbf{1 2 9 .}$

Musset, Alfred de, 86.

Napolitaine, La, 243.

National Academy of Design, 52, I 56.

National Collection, Washington, 82, I34.

National Gallery, I4, I7, 4I, 48, 49, 78, I 20.

National Liberal Club, 58.

National, Observer, The, 8, 9 .

National Portrait Gallery, I84.

Nation, The, 275.

Nesmith, Joseph A., 308, 316.

Nevill, Lady Dorothy, 184 .

Nevinson, H. W., I70.

New, Edmund A., 3 I4.

New English Art Club, 9, 20, 192, 268.

$N_{e w}$ York Herald, The, 246.

Paris Edition, 228.

$N_{\text {ew }}$ York Sun, The, 275.

New York Times Saturday Review, The, 250.

Nicholson, William, 138, 309 .

Norton, Charles Eliot, 32 I.

Northcliffe, Lord, I38.

Nocturnes, Marines and Chevalet Pieces, Io.

Nocturne in Blue and Gold, Whistler's, 32 I.

Note Blanche, I6I.

Notes, Harmonies, Nocturnes, 5 .

$\mathrm{O}_{\mathrm{CHs}}, \mathrm{Mrs} ., \mathrm{I} 97,309$.

O'Connor, Francis (see Howard).

Ohl, Mrs., 57, 58, 73, 77.

Old Battersea Bridge, IO, I38.

Olivarez, Velasquez, I 20.

Once a Week, 306.

Orpen, Sir William, I38, 3 I2.

Oulevey, M., 83, 86-90, 93-95.

Owl and the Cabinet, The, 34 .

Oxon, J. R., 327.

PADDon, S. Wreford, 6I.

Paddon Papers, The, 64, 295.

Paimpol, 56. 


\section{INDEX}

Pall Mall Gazette, The, 6, 9, 30, 134, I43, I98-200.

Palmer, Mrs. Potter, I6, 57, I25, I27, I55, 309, 316.

Panizzi, 74 .

Paris International Exposition of 1900, 40, I90, I92, I99, 200, 217.

Parry, Judge E. T., 316, 321.

Passing Under Battersea Bridge, Greaves', I37, I38, I 44 .

Paulus, Herr, I 50.

Pawling, Sydney S., 276.

Peacock Room, the, 98, 100, 103, I05IO9, I I 2, I I 3, I I 7 .

Portrait, 302, 320, 326.

Pellegrini, C., I63.

Portrait of Whistler, 237.

Penn, William, 258.

Pennsylvania Academy of the Fine Arts, $3,141,156$.

Pepys, Samuel, 219.

Petit, Georges, I I I.

Philip, R. Birnie, 207, 296.

Philip, Mrs. Birnie, I53, 220, 23I, 234, 24I, 242, 255.

Philip, Ethel Birnie (see Whibley, Mrs. Charles).

Philip, Rosalind Birnie, 40, 45, 50, 5 I, 67, 77, I34, I48, I 49, I53, I58, I66, I9I, $194,195,220,223,234,235,237,245$. $246,255-263,266,269,270,272,-76$, 277, 28 I, 286-293, 295, 296.

Phillip, John, 79, 82.

Phillips, Sir Claude, Io, 264, 265.

Phulosopher, The, II I.

Phryne, $217,243$.

Piano Prcture, The, 78, 79, 82, 95, 285.

Piero della Francesca, 299.

Plymouth, Lord, 307.

Plunkett, Count, 309.

Pollitt, A. J., 295.

Poore, Harry R., 2.

Pope, A. Atmore, I30.

Portfolio, The, 186.

Pourville, 56.

Poynter, Sir Edward, 49, 50.

Pre-Raphaelites, The, 22, 26, 27.

Pretty Nellie Brown, I73.

Prinsep, Mrs. Val, I05.

Portrait of, by Val Prinsep, Io3.

Prince, Charles, 52,53 .

Princesse du Pays de la Porcelaine, La, IOI, I26, I32, 300.

Princess Louise, I2I, I85.

Propositions, 36, 296.

Prothero, Mrs., I99.

Pulitzer, Mr., 225, 226.

Puvis, de Chavannes, 299.

Pyle, Howard, 3 I 4.

Quilter, Harry, 303.

RackHAM, Arthur, 309.

Radford, Ernest, I93, I94.

Radford, Sir George, 2 I6.

Raffaēlli, T. F., 267, 268, 309 .

Rawlinsons, W. J., I 29, $267,268$.

Redesdale, Lord, 64, 108, I 29, I33, 255, 309, 3 I0.

Redesdale, Lady, I 28, 309.

Reid, Alexander, 4 .

Reid, Whitelaw, 309.

Reinhardt, Messrs., I33, I 36.

Rembrandt, 3, 8 I, 96, I67, I87, 245.

Repplier, Agnes, 185.

Reynolds, 156.

Reynolds, Sir Joshua, $266,276$.

Rhodes, Harrison, 2 I I, 234, 235.

Ribot, T., 20I.

Ricci, C., 46.

Ricketts, Charles, 275.

Richmond, Sir William, B., 225, 326.

Rijks Museum, 247.

Rinder, Frank, 262, 269.

Ringler \& Co., Messrs., I47.

Roberts, Lord, 54 .

Robertson, Graham, 277, 279, 280.

Robins, Elizabeth, 223, 224, 306.

Robins, Helen, 2 I I.

Robinson and Fisher's, 69, 70, I 43 .

Rodd, Sir Rennell, 309.

Rodin, A., 48, 20I, 213 $, 235-237,242,283$, 307-309, 3 I I -3 I 6 .

Balzac, $20 \mathrm{I}$.

Burghers of Calais, 23.

Whistler Memorial, 307-316.

Rose, Anderson, 65, 317,3 19, 320, 326.

Rosenbach Company, The, I4I.

Ross, Mrs. Janet, 47.

Ross, Robert, 63, 64, I33, I38; I39, I43, I83, 3 I6.

Rossett1, Dante Gabriel, 7, 23-27, 34, 58, $62-64,79,84$, IоI, I04, I 10, I 19, I29, I 57, 170, I 7 I , 252, 272, 273, 295, 300, $3 \mathrm{I} 3$.

Rossetti, William Michael, 83, 8.4, 296, $316,320,326$.

Rothenstein, William, I6, I43, 202. 


\section{INDEX}

Roullier, Albert, I45-I47, 230.

Rousseau, M., 219.

Roussel, Theodore, 216, 23 I.

Rowe, Mrs. Jopling, I67.

Royal Academy, 22, 39, 49, 50, I5 I, I94I96, 2 I3.

Royal Historical Society, I58.

Roycroft Press, 274.

Ruskin, John, 7, 8, 25, 68, I03, 2 I4, 248, 283.

Ruskin, Mrs.,25.

Ruskin Case, The, 60,"164, 212, 2 13, 233, 316-327.

Russell, R. H., I46.

Russian Schube, The, I4.

SAGE, Miss, 279.

St. Anne's, Soho, 72.

St. Gaudens, A., I 56, I 74, 308.

St. Helier, Lady, 309.

St. James's, The, 2 I6.

St. Louis Exposition, 277.

Salaman, Malcolm, 248, 249.

Sala, G. A., IO.

Salting, George, 314.

Sandra Belloni, 25,26 .

Sandys Frederick, 2 I-23, I 70.

The Nightmare, 22.

Sarasate, 4.

Sargent, John S., 34, 35, 39, 46, I43, I54, 168, 2 I3 $, 236-238,251,262,263,277$, $281,309$.

Sassofera to, 62.

Saturday Review, The, 9, I4, 192.

Sauter, George, I4, I50, I5 I, I60, 206, $207,210,222,233,237,239,247,256$, $263,273-276,291,295,297,307$, 309.

Sauter, Mrs. George, I51, 160, I80, 233, $29 I, 295$.

Savile Club, I I , 230.

Scammon Lectures, I 55.

Scheffer, Ary, I 22.

Scots Observer, The, 8 .

Second Venice Set, The, 66.

Selsey Bill, 6r, I34.

Selsey Bill Sands, 65.

Seton, Miss, 257, 286.

Seule (The Coast of Brittany; Alone with the Tide), I 56.

Shannon, J. J., I5 I, I 52, 201, 213, 275, 281.

Shaw, George Bernard, 9, 309.

Shaw, Mrs. Graham, 33.
Shaw, Norman, 226.

Shadow of the Cross, The, Holman Hunt's, 26.

Short, Sir Frank, 78, 80, 81, 207.

Shorter, C. K., I6, 3 I4.

Sickert, Oswald, 259, 260.

Sickert, Walter, 9, 14, 67, 81, 143, 228.

Sickert, Mrs. Walter, I6I, I66.

Simpson, Mrs., 237.

Sir Isumbras at the Ford, Millais', 22.

Six Projects, The, I26, 161.

Smalley, George W., 84 .

Smith, G. L., 23, 318.

Society of American Artis ts, 156.

Society of Illustrators, I5.

Sotheby's, I89.

Soupe a Trois Sous, 92.

South Kensington Exhibitions, 20, 22, I37, I44.

South Kensington Museum, 175 .

Spartali, Miss, I26.

Speaker, The, 9.

Spectator, The, 9 .

Speke Hall, 54.

Spencer, Mr., I 25, I 27-I 29, I33, I36.

Spielmann, M. H., 198-200, 202, 203, 206, 309.

Spreckles, Mrs., I I 3 .

Spy and Ape, I4I, I 84.

Standard, The, 264, 265, 269.

Stansfield, James, I24, 219.

Star, The, 9, 54, 77, I42, I46, I $86,27 \mathrm{I}$, 292.

Steer, P. Wilson, 2 I, 46, 202.

Steevens, George W., 9.

Stephens, F. G., Iо.

Stevens, Mr., I I3.

Stevenson, R. A. M., (Bob), 9, 10.

Stevenson, Robert Louis, 34, I 77, 282.

Stevenson, Macaulay, 288.

Stillman, Mrs. W. J., 99, 106.

Stott, William, I66, 288.

Strang, David, 296.

Strang, William, 296.

Strange, E. F., I 38, 203, 257.

Streatham Town Hall, I I8.

Strindberg, Madame Frida, I33, 135.

Stuart, Gilbert, I 35 .

Studd, Arthur, 43, 48, 49, 59, 263, 269, 296, 297.

Studio, The, 295, 300 .

Sturges, Jonathan, 193, 202, 205.

Sullivan, E. J., I6, 2 I, I 85, 202, 206, 309. 
Sutherland, Sir Thomas, 106-109, 207, Vanderbilt, George, 193, 202, 237, 297, 229, 232.

Swan, John, 215.

Swift, Benjamin, 272.

Swinburne, A. C., 24, 26, 63, 78, 80, 170 , 247,252 .

Symons, Arthur, 38,39 .

Symphonies in White, 120.

Symphony in White, No.III, 161.

TAte Gallery, 25 I.

Taylor, Tom, I17, 326 .

Telegraph, The Daily, 10, 264.

Ten O'clock, The, 8, 31, I99, 302, 305.

Terborgh, 39.

Thames in Ice, The, 79, 82, 120.

Thames Set, The, 2, IO4.

Thaw, Mrs., I35.

Thaulow, F., I4, I I I, I 53, 309.

Theobald, K. C., Mr. H. S., I1 2, 309.

Thomas, Percy, 165.

Thompson, Sir Henry, 306.

Thomson, David Croal, Io, 65, II2, 191, 192, 196, 296, 307, 309 .

Three Girls, The, I 34, 233 .

Thynne, Mrs., I 29, 296.

Thynne, Miss, 296.

Times, The, I0, 48, 137, I39, I41, I42, I9I, I92, 259, 26I, 284, 295, 326.

Tintoretto, I 54, 249.

Titian, 26, I 54 .

Tomson, Mrs. Arthur, I 30.

Tonks, Henry, 202.

Trevelyan, George, 309.

Tribune, The, 273.

Tristan and Isolde, I 2.

Troubetzkoi, Prince, I 50.

Truth, 183, I84.

Tuckerman, Miss, 238.

Turner, J. M. W., 7, I20, 228, 248.

Tweed, J., 235.

Twenty-fifth of December, The, 79.

Ufrizi, The, $45,47$.

Untermeyer, Mrs., 4.

Unwin, Mr. T. Fisher, 76, I1 1, I12, I68, $218,280,296$.

Unwin, Mrs., T. Fisher, I68, 280.

VALE, The, II9, I65, I67.

$V$ ale of Rest, The, Millais, 70.

Valparaiso, 4I-43, 48, I I 3, 253.

Valparaiso, 134, 279.

307, 309.

Vanderbilt, Mrs. George, 237, 264.

Van Dyke, Mr. John C., 30. American Painting and Its Tradition, 31. Modern French Masters, 162.

Vela squez, 99, I 20, I 62, I93, 227.

$V e n e t i a n$ Interior, $A$., Sargent's, 39.

Venice Sets, The,2, I 88.

Venice show at Fine Art Society, 182.

Venturi Madame, I 24, I74.

Veronese, 249.

Victoria and Albert Museum, 203.

Vielé-Griffin, I 2.

$V$ iolet and Gold, 120.

WaLKer, Martineau \& Co., Messrs., $317,326$.

Waller, Pickford, 302, 309.

Wallis, Whitworth, 309 .

Walton, E. A., 206, 275, 279, 286, 309.

Walton, Mrs. E. A., 272, 279.

Wanamaker, Mr. I73.

Wapping, I I9, I22, I61.

Ward, T. Humphry, 10, 82, I92, 281, 284 .

Ward, Mrs. T. Humphry, 230.

Warr, Mrs., 70.

Warwick, Lady, 236.

Watts-Dunton, Theodore, I10, I75, I94, 255.

Way, Thomas, I06, I33, I34, I48, 294.

Way, T. R., 66, 81, 105, 106, II5, 133I35, I48, I49, 233, 25 I, 294, 313, 316.

Weary, I6I.

Webb, William, 200, 206, 222, 223, 238, $244,274,294,296,307$.

Wedmore, Sir Frederick, Io, I46, 264-269, $28 \mathrm{I}$.

Wells, H. G., 309.

Wertheimer, Asher, Sargent's, 140.

Westminster Gazette, The, I 38.

West Point, 42, 48, 74-77, I 54, I80, I8I, I95, 210-21 $2,216,228 ; 234,236,240$, $242,276$.

West Point Memoriai, 242.

Wales, Prince of, 176.

Wheeler, General Joe, 240.

Whibley, Charles, I, 9, 13, 37, 224, 226, 296. Book af Scoundrels, 306.

Whibley, Mrs. Charles, (Ethel Birnie Philip), 37, 200, 245, 262, 284, 29I, 293.

Whirlwoind, The, 148.

338 


\section{INDEX}

Whistler's House at Chelsea, 3.

Life of, 3, 13, 14, 27, 30, 32, 33, 40, 4I, $45,55,65,68,83$, I00, I I I, I 25, I 45 , I 58, I60, 165, 167, I82, 184, I88, 214 , $215,216,227,239,242,247,254,274$, $287,289,295,297$.

Whistler Thomas, 4 .

Whistler, Mrs. Thomas, I63.

Dr. William, 48, I 13, 163.

Mrs. Dr. William, 10, 31, 55, 74, I03, I04, II2, II3, II9, I23, I29, $133,134,152,154,157,163,165$, 166, 189, 247, 251-254, 262, 296, 303.

Whitefriars Club, 194.

White, Archer, 224, 225, 226.

White Girl, The, 4, 80, I34, I44, I57, I6II63, I84, I91, 325 .

White, Gleason, 26.

Whitehall Court, 29.

White House, 65, I33, I64, I86, 283.

Whitman, Mrs. Sarah, I 53, I 54, I85, 238.

Whitman, Walt, 3, 24, 7 I, I68. Leaves of Grass, 24, 26.

Wilde, Osca r, 3, I I9, 205, 228.

Williams, Captain, I7ı.

Williamson, Dr. G. C., 64 .

Wills, W. G., 32 I.

Wilson, Edgar, 30.

Wilson, Harry, 33, 34, 294, 307.

Wilstach Collection, 4.

Wimbush, W. L., 54 .

Winans, Thomas, 171.

Wisselingh, E. J. Van, 264.

Withers, Alfred, I60.

Withers, Mrs. I. Dods, I6o.

Wolseley, Lord, I 2 I.

Wood, Butler, 309.

Wood, Durwent, 312.

World, The, I83, I84, 3 I9.

Wren, Sir Christopher, 4r.

Wunderlich, Messrs., 2.

Wyndham, George, 307.

Wyndham, Mrs., Io3.

YAtes, Edmund, I83.

Yellow Buskin, The, 4 .

Zafhinsdorf, Messrs., I76.

Zola, E., 296.

Zug, George B., 73 . 


BIENTANO'S 
SMITHSONIAN INSTITUTION LIBRARIES

|| || ||||||||||||||||||||||||||||||||||||||||||||||||||||||||||||||

$\|$ 39088006596035 